Portland State University

PDXScholar

\title{
The collapse of the German army in the East in the summer of 1944 (Volume 2)
}

Stephen Ariel Veal

Portland State University

Follow this and additional works at: https://pdxscholar.library.pdx.edu/open_access_etds

Part of the European History Commons, and the Military History Commons Let us know how access to this document benefits you.

\section{Recommended Citation}

Veal, Stephen Ariel, "The collapse of the German army in the East in the summer of 1944 (Volume 2)" (1991). Dissertations and Theses. Paper 4302.

https://doi.org/10.15760/etd.6184

This Thesis is brought to you for free and open access. It has been accepted for inclusion in Dissertations and Theses by an authorized administrator of PDXScholar. Please contact us if we can make this document more accessible: pdxscholar@pdx.edu. 


\title{
THE COLLAPSE OF THE GERMAN ARMY \\ IN THE EAST IN THE SUMMER OF 1944
}

\author{
Volume 2
}

by

STEPHEN ARIEL VEAL

A thesis submitted in partial fulfillment of the requirements for the degree of

\section{MASTER OF ARTS}

in

HISTORY

Portland State University

1991 
JULY 10, 1944

\section{3rd Panzer Army}

Fortress Wilna. Strong Soviet attacks supported by artillery and mortar fire were beaten back during the night. However, the Soviets had managed to infiltrate the German lines and establish several strong points in the city equipped with light machine guns, mortars and anti-tank rifles.536 Kampfgruppe Tolsdorf west of the city was under attack from the east, south and southwest by approximately 40 Soviet tanks (see Figure 145). Rykonty was entered during the night by Soviet armor. Maj. General Heidkaempfer informed Lt. General Krebs of the threatening situation faced by Kampfgruppe Tolsdorf at $0545 \mathrm{hrs}$. The very serious situation west of Wilna was complicated by Soviet armored attacks since Kampfgruppe Tolsdorf had no anti-tank weapons to stop the armored thrust in the direction of Kauen (see Figure 145). Nevertheless, Kampfgruppe Tolsdorf was ordered by Field Marshal Model to hold the Landwarow bend (see Figure 145). Therefore, the 3rd Panzer Army requested the use of the Luftwaffe "Panzerjaeger" air support. ${ }^{537}$ Panzer Grenadier Brigade von Werthern smashed a Soviet infantry battalion east of Meyszagola, but the Soviets continued to reinforce this area constantly (see Figure 143).

"Fortress Wilna" requested supply drops especially of ammunition. A Stuka attack at 1230 hrs was reported effective and another Stuka attack was requested. The Commandant of "Fortress Wilna" reported that the Soviets inside the city were 
strong and that they had infiltrated the eastern part of the city by coming through a hole on the rail line in the south (see Figure 145). Presently, the Soviets were attacking from the north across the bridge on the right (see Figure 145). The Commandant requested that strong pressure be applied on the Soviets from the outside. Wilna was reported at $1535 \mathrm{hrs}$ under heavy attack from practically every side (see Figure 145), ${ }^{538}$ The Commandant informed the High Command that the terrain in the east must be evacuated tonight. The garrison under command of General Stahel had fought on all sides and even had to beat back an attack in hand to hand combat within the German artillery position. Despite heroic defensive efforts not all breakthroughs could be avoided so that as a result of German losses the defenders were pressed back into a tighter ring in the inner city (see Figure 145).539 "Fortress Wilna" reported heavy casualties during the day's fighting and two holes in the defensive line. One hole was at the mouth of the Wileika river and a $2 \mathrm{~km}$ wide hole in the south on both sides of the railway underpass. These penetrations allowed the Soviets to infiltrate the thin defense line and transfer the battle into the inner city. 540 The plugging of these holes was not possible because of continued combat losses. Therefore, the defense line was pulled back under the cover of darkness. The Soviets had transferred strong forces south and north of Wilna further to the west while attacks had been launched against the city all day (see Figure 144).

IX Army Corps. The 212th and 252nd Infantry Divisions occupied the new position after Grenadier Regiment 279 cleared it 
of Soviet troops. The north wing of the Corps had already been outflanked by the Soviets and Buitunai $(3.5 \mathrm{~km}$ southeast of Kuktiskes) was occupied (see Figure 146). The 3rd Panzer Army requested Army Group North to expedite the disengagement of the 225th Infantry Division. The division was ordered directly to send all its motorized elements and truck mounted infantry to Wilkomir. Tauragnai was under attack in the morning from the east and the west (see Figure 146). The Soviets had gotten behind the left wing of the IX Corps at Buitunai and were attacking south which meant that the left wing would have to be pulled back since Army Group North had failed to close the gap by attacking south.

Three battalions from the 225th Infantry Division were attacking in the hills of Alauso lake and were supposed to breakthrough to Utena. The 3rd Panzer Army hoped to employ the 225th Infantry Division on the south wing of the Corps once it had fought through to Utena. However, later in the day it became apparent that the 225th Infantry Division was bogged down at Utena and could not link up with the left wing of the IX Corps. Army Group North decided to retain the division to close the hole between 3rd Panzer Army and Army Group North on the left wing of the IX Corps. The 225th Infantry Division had reached to within 7 $\mathrm{km}$ northeast of Utena when the promised use of the Tiger Tank Battalion was withdrawn. Army Group North informed Army Group Center that approximately 7 Soviet divisions and armored formations of unknown strength were attacking and had partly outflanked the outermost right wing of Army Group North south of 
Duenaburg. Therefore, the continuation of the attack to restore contact with the north wing of the 3rd Panzer Army was no longer possible.541 The Soviets advanced without hindrance to the north and northwest between Kuktiskes and Tauragnai (see Figure 146).

The 212th Infantry Division was broken through in several positions and was pulled back to a new defensive line on the line of lakes: tip of Orinos lake - Isnarusee - southwest of Kraujaliai lake - southeast of Paseksciai (see Figure 146). Contact with the 252nd Infantry Division at this position was to be secured.

Meanwhile, the 3rd Panzer Army was preparing to stop the Soviet advance east of Kauen. Field Marshal Model was assembling Kampfgruppe Kauen consisting of the new XXVI Army Corps, the first elements of the 6th Panzer Division, one parachute battalion, 69th Infantry Division, and 93rd Infantry Division.542 The 63rd Infantry Division was also unloading in Jonava.

\section{4th Army}

Kampfgruppe Weidling. The Soviets were advancing on the rail line and road Lida-Grodno against Kampfgruppe Weidling (see Figure 144). The Soviets achieved numerous breakthroughs and forced the defensive line back to Orla -Lebioda - Pielasa (see Figure 144).

XXXIX Panzer Corps. The Corps was attacked on both flanks and threatened by Soviet forces west of Wilna attacking south into the Solcza sector and arriving in the rear of the 4th Army. The Corps withdrew to the line Radun-Eischischken. 
9th Army

Kampfgruppe von Vormann was restored to Army level status. Kampfgruppe von Vormann became the resurrected 9th Army (see Figure 147)..$^{543}$ The command authority over the units was transferred from the 2nd Army to the restored 9th Army.544

The Szczara front was broken through north of Byten and north of Slonim (see Figure 144). The 9th Army formations were forced to withdraw to the Hrwyda river. The 28th Jaeger Division was recovering behind the front line and was currently not combat effective. The division was building a second defensive line at the Zelwianka river and on both sides of Zelwa (see Figure 144). The 12th Panzer Division was on the left wing of the 9th Army.

$$
\text { JULY 11, } 1944
$$

\section{3rd Panzer Army}

Fortress Wilna. The garrison of Wilna succeeded in shortening the front during the night and closing the $1 \mathrm{~km}$ hole on the south edge of the city. 545 German troops fought throughout the night to clean up Soviet resistance inside the city. The situation had become critical in Wilna with the increasing casualties and shortage of water. Hitler issued a "Fuehrer Befehl" at 1528 hrs:

Fight your way out over the Wilja river to the left wing of Kampfgruppe Tolsdorf at the mouth of the Waka river. 546

General Stahel requested aerial reconnaissance to determine the route with the least enemy resistance. Radio communications 
to "Fortress Wilna" were heavily jammed during the entire day and completely ceased at $2130 \mathrm{hrs} .{ }^{547}$ There were no further reports for the day from "Fortress Wilna." Kampfgruppe Tolsdorf pushed the Soviets back at Woly in a counterattack. However, Soviet armor during the course of the day succeeded in cutting off the Kampfgruppe's supply road to the northwest by taking Vievis.

Kampfgruppe Tolsdorf was as a result likewise encircled since partisans were located on its western front. SS Parachute Battalion 500 with the first elements of the Panther Battalion of the Gross Deutschland Division organized a blocking position on both sides of the road to Kowno (see Figure 148).

IX Army Corps. The Soviets thrust deeply into the flank west of Dubingiai to the north which threatened the rear of the IX Corps (see Figure 149). Kuktiskes on the outermost left wing was lost after bitter fighting in the town. The north wing of the Corps was threatened by the unhindered advance of Soviet Divisions on both sides of the Utena-Wilkomir road (see Figure 149). 548 The IX Corps Command Post moved during the evening to Sventupe $(2 \mathrm{~km}$ northeast of Vidiskiai) (see Figure 149). The strength of the IX Corps divisions with the exception of the 212th Infantry Division had fallen significantly:

252nd Infantry Division: approximately 900 men Corps Detachment D: 550 men 391st Security Division: 1200 men. ${ }^{549}$ 
The left wing and center of the IX Corps were to be pulled back that night to the following line: the lakes east of Moletai - northern tip of Virinto lake - Kanjukai - Rubikai lake (see Figure 149).

Colonel General Reinhardt addressed three vital questions to Field Marshal Model:

1. The relief of Wilna.

2. The hole to Army Group North after the II Army Corps retreats up to $25 \mathrm{~km}$ northeast of Utena.

3. The preparation of a position from Kauen to the north, where no natural obstacle can be found up to the Memel river north of Kauen. 550

The answers to these questions were vital to 3rd Panzer Army's defensive preparations.

Field Marshal Model responded that the mission of the 3rd Panzer Army was to prevent a widening of the hole between the 3rd Panzer Army and Army Group North. Field Marshal Model ordered the following:

1. The Niemen front south of Kauen is to be blocked.

2. The battle at Kauen and to the northeast is to be conducted so Kauen, Janow and Wilkomir can be held. Mobile elements of engaged units are to intercept enemy armored spearheads rapidly and establish defensive lines.

3. Contact with Army Group North is to be restored. The IX Army Corps is to maintain firm contact with the west within the Army's front. The II Corps will be requested to close the hole at Utena with the 225th and 87th Infantry Divisions. The border between 3rd Panzer 
Army and 16th Army has been proposed as the rail line Svencionelai-Utena. 551

\section{4th Army}

Kampfgruppe Lt. General Floerke was attacked by the Soviets northeast of Wawiorka and broke through $10 \mathrm{~km}$ to the southwest. Kampfgruppe Weidling was forced to pull back its north wing to the line Wawiorka-Sobakinze (see Figure 150). The 5th and 7th Panzer Divisions were withdrawn under the cover of the 170th Infantry Division to the northwest (see Figure 150). The 5th Panzer Division and a reinforced Panzer Grenadier Regiment from the 7th Panzer Division attacked the Soviets entering the line Daugai-Valkininkai (see Figure 150).

\section{9th Army}

The resurrection of the 9th Army from "Kampfgruppe von Vormann" resulted in a new assignment. The 9th Army was directed to conduct the construction of a rear defensive position along the line Brest-Grodno.552 It was hoped by Army Group Center that the Soviet advance could finally be stopped on this line. The Soviets had broken through again on the 9th Army front east of the Polish border (see Figure 151). 


$$
\text { JULY 12, } 1944
$$

\section{3rd Panzer Army}

Fortress Wilna. Radio communications from "Fortress Wilna" had ceased at $2130 \mathrm{hrs}$ on July 11th and were later resumed at 0345 hrs by General Stahel. General Stahel reported that his Kampfgruppe would begin the breakout to the west along the north bank of the Wilja river tonight beginning approximately at 2230 hrs. 553 Losses were reported as lighter than in previous days. Stronger Soviet forces were reported crossing the Wilja river at Lesniki moving in a northwestern direction. The Soviets had also constructed a floating bridge east of the north bridge in Wilna with the intention of advancing north. General Stahel requested by radio that Kampfgruppe Tolsdorf assign a detachment with heavy weapons to hold the town at the junction of the Waka river with the Wilja river.

Kampfgruppe Tolsdorf reported that the Soviets succeeded in forcing their way across a bridge north of Rykonty and penetrated the wooded terrain northwest of Rykonty. Kampfgruppe Tolsdorf was ordered at $0822 \mathrm{hrs}$ to hold the southern front and the area around Woly under all circumstances. Kampfgruppe Tolsdorf and Kampfgruppe Stahel were to join together. 554 The area on the Wilja river bank in the area of Woly was to be held for the breakout of the Wilna garrison. ${ }^{555}$ Kampfgruppe Tolsdorf requested Luftwaffe air support at $1530 \mathrm{hrs}$ for the woods south of Landwarow and the hills 
northeast of Pietuchowo. Air support was requested at $2100 \mathrm{hrs}$ for the hills east of Woly and the woods south of the town.

Kampfgruppe Tolsdorf announced by radio at $2015 \mathrm{hrs}$ that relief was on the way. The 6th Panzer Division was ordered to attack in the direction of Landwarow at 0600 hrs the next morning.556 The 6th Panzer Division was to be reinforced by a Panzer battalion from the Panzer Division "GrossDeutschland," SS Parachute Battalion 500 and $11 / 2$ companies from Parachute Regiment 16.557 This attack was to assist the breakout of Kampfgruppe Tolsdorf and the garrison of Wilna to an area east of Kauen. Luftwaffe support was secured to support this attack. The 3rd Panzer Army had transferred its Command Post to Babtai, $21 \mathrm{~km}$ northwest of Kauen (see Figure 151). The further withdrawal of the 225th Infantry Division during the course of the day widened the hole between the 3rd Panzer Army and the 16th Army through which a Soviet tank brigade entered. However, the 16th Army was organizing Kampfgruppe Kleffell consisting of the 225th Infantry Division, 61st Infantry Division and SS Panzer Reconnaissance Battalion 11 for the purpose of attacking to restore contact to the north wing of the 3rd Panzer Army. 558 Olita was taken by Soviet attack during the day (see Figure 152).

Panzer Grenadier Brigade von Werthern attacked from Sirvintos to the east and destroyed 26 Soviet anti-tank guns, 2 tanks and 2 assault guns in Griedraiciai leaving the town in flames. But the Brigade was cut off from its supply elements by Soviet attacks in the rear and was forced to fight its way back to 
Sirvintos where Kampfgruppe Schmidt was located (see Figure 152).

Lt. General Krebs informed Major General Heidkaempfer that even though the second half of the 6th Panzer Division had not arrived other units would be coming. Therefore, the 3rd Panzer Army had two missions:

1. The present area was to be held.

2. The hole to Army Group North was to be bridged by offensive action after the arrival of further units. ${ }^{559}$

\section{4th Army}

Kampfgruppe Weidling was pushed back to the line SzecuzynOstryna by Soviet cavalry forces (see Figure 153). Further Soviet penetrations on the north wing of the Kampfgruppe forced another withdrawal to the line Niemen-Kotra sector (see Figure 153).

XXXIX Panzer Corps. The 5th Panzer Division attacked to the north and delayed the Soviet advance from Wiina (see Figure 152). Defensive battles raged with the focal point west of the rail line Wilna-Grodno (see Figure 152). Thirty Soviet tanks broke into Varena, but were repulsed in a counter stroke (see Figure 152). The 5th and 7th Panzer Divisions were employed on both sides of the Dugai lake against the flank of the Soviet armor that had entered Olita (see Figure 152). 
2nd Army

The withdrawal movement of the XX Corps progressed as planned. Soviet attacks on Pinsk were beaten back on the north wing of the XXIII Army Corps. A deep breakthrough was achieved on the 129th Infantry Division's sector (see Figure 153). The penetration reached the Jasiolda river north of Sielek and Smolanica whereby a wide hole was ripped to Kampfgruppe Harteneck (see Figure 153). The Soviet attack on the front of Kampfgruppe Harteneck and the LV Army Corps achieved several penetrations up to a depth of $5 \mathrm{~km}$.

$$
\text { JULY 13, } 1944
$$

\section{3rd Panzer Army}

Fortress Wilna. There were no reports since $2230 \mathrm{hrs}$ yesterday concerning the breakout of the garrison from Wilna. Kampfgruppe Tolsdorf reported combat activity coming from the direction of Wilna during the early morning hours. Colonel General Reinhardt drove to the 6th Panzer Division in the morning and ordered an attack at $0745 \mathrm{hrs}$ toward Landwarow using the present units and the artillery from Panzer Division "GrossDeutschland." 560 Finally, Kampfgruppe Tolsdorf reported at $0955 \mathrm{hrs}$ that the uneasy wait was over. The radio message read:

Stahel reached me with about 400 men initially. Stahel reports: Breakthrough with 3000 men succeeded...Enemy very quiet. 561 
The most difficult phase of freeing the garrison of Wilna appeared to be successful, but Kampfgruppe Tolsdorf still remained encircled (see Figure 154). The Soviets continued to attack Kampfgruppe Tolsdorf from the west. The location of the relieving force at $1020 \mathrm{hrs}$ was uncertain. The spearhead of the group consisted of the Panther Battalion of the Panzer Division "Grossdeutschland" and the Kampfgruppe of the 6th Panzer Division. ${ }^{562}$ Koschedoren was reported cleared of Soviets at 0840 hrs and the Panther Battalion of Panzer Division "Grossdeutschland" had passed Vievis at 1205 hrs. The Panther battalion "GD" radioed the 6th Panzer Division that contact had been made with Kampfgruppe Tolsdorf at $1300 \mathrm{hrs}$ (see Figure 155).563 The route of retreat for the group would be in the rear northeast of Ziezmuriai which was under Soviet fire. Kampfgruppe Tolsdorf reported that approximately 3000 men as of $2030 \mathrm{hrs}$ of Kampfgruppe Stahel had arrived (see Figure 155).564 They had crossed the Wilja river twice and were mostly lacking clothes. The 6th Panzer Division secured the line at Vievis and Ziezmariai for the transportation to the rear of the combat veterans of Wilna. According to Soviet sources the Battle of Wilna which ended on July 13th resulted in 8000 Germans killed and 5000 taken prisoner. ${ }^{565}$

\section{4th Army}

Kampfgruppe Weidling was outflanked on the north and the Soviets tried to take Grodno by a surprise attack which was defeated by rapidly concentrated forces (see Figure 156). Soviet 
armor that had broken into the city was destroyed. Weak police forces were holding the city against strong Soviet attacks from the north and northeast. The 5th Panzer Division was ordered to Grodno to mop up Soviet resistance. 566

The XXXIX Panzer Corps completed its withdrawal to the expanded bridgehead at Merken. Nevertheless, Soviet penetrations made it necessary to withdraw from the contracting bridgehead. Weak Soviet units succeeded in reaching the west bank of the Niemen river at Olita (see Figure 156).

\section{2nd Army}

The last units of the $X X$ and $X X I I I$ Army Corps on the right wing of the 2nd Army had crossed over the Jasiolda river. The Soviets attacked the right wing of Kampfgruppe Harteneck and broke through the front of the 129th Infantry Division at several positions and forced the division back (see Figure 156).

Kampfgruppe Harteneck and the LV Army Corps were withdrawn during the-night of July 13-14th to the line Kuklicze - east of Wolkowysk - to along the Ros river. The 12th Panzer Division on the left wing of the LV Army Corps smashed an encircling attack by two Soviet rifle divisions. 567

$$
\text { JULY 14-31, } 1944
$$

The Soviet advance began to slow down as they advanced further to the west. German resistance stiffened as German forces 
fell back toward East Prussia and Poland. German reinforcements were poured into Army Group Center to stabilize the front which had been ripped wide open. There was only one more major loss by Army Group Center which involved Corps Detachment $E$ in the encirclement of "Fortress Brest-Litovsk." Brest-Litovsk was a major rail junction and therefore was designated a "Fortress." (see Figure 157).

\section{FORTRESS BREST-LITOVSK}

\section{2nd Army}

The defense of "Fortress Brest-Litovsk" was conducted by the 203rd Security Division and Corps Detachment E (see Table XXXVII) (see Figure 158). 568 Corps Detachment $E$ consisted of three weak divisional groups: 86 th, 137 th and 251 st Infantry Divisions. ${ }^{569}$ Lt. General Felzman, Commander of Corps Detachment E was appointed Commandant of "Fortress Brest-Litovsk" on July 21, 1944.570

This "Fortress" like all the other "Fortresses" on the Eastern Front suffered the same fate. Soviet forces broke through northwest and southwest of the city cutting it off and encircling its garrison. Field Marshal Model recognized that holding "Fortress Brest-Litovsk" was pointless when it could not be given adequate supplies and sufficient troops. ${ }^{571}$ The fate of "Fortress BrestLitovsk" would not be decided by the outer or inner defensive rings, but by events north of the city and behind the city west of the Bug river. 
July 25, 1944

\section{2nd Army}

Soviet armor forces advancing south of Siedlice were beaten back during the morning by the attack of assault guns. Strong Soviet forces from the area of Lukow advancing in a northern direction arrived south of the Siedice-Miedzyrzec road (see Figure 159).

The VIII Army Corps was thrown back to the line MiedzyrzecBiala Podlaska. Soviet forces broke through the 168th Infantry Divisions sector but elements of the 3rd Cavalry Brigade succeeded in a counterattack in restoring communications between Biala Podlaska and the west front of "Fortress Brest-Litovsk" (see Figure 159). The withdrawal of the 541st Infantry Division from the Bug river line was pursued by the Soviets to the northeast.

The Soviets attacked the north wing of the 5th SS Panzer Division "Wiking" in the XXIII Army Corps sector from the northeast and southwest and forced the Division from Kleszczele to the south (see Figure 159).572 The 4th Panzer Division was unable to parry the Soviet attack by an armored thrust along the rail line to Kleszczele because of a Soviet attack from the east (see Figure 159). 
JULY 26, 1944

\section{2nd Army}

The 2nd Army was engaged by the concentrated attacks of 7 Soviet Armies and 5 Mobile Corps. ${ }^{573}$ Soviet attacks were repulsed from the west, south and southeast by the garrison of Siedlce which had been reinforced by elements of the 3rd SS Panzer Division "Totenkopf." (see Figure 160). The Soviets, however, crossed over the road east of the city and took Mordy (see Figure 160). The front from west of Miedzyrec to Brest and the continuous southern front of the 2nd Army had been broken through by Soviet armor supported attacks in numerous places (see Figure 160). Miedzyrzec and Biala Podlaska were lost (see Figure 160).574 The 3rd Cavalry Brigade counterattacked and destroyed 2 Soviet battalions northeast of Biala Podlaska and threw the advancing Soviets back over the road to the south.575 The Soviet attacks during the evening with infantry and armor achieved a deep breakthrough $20 \mathrm{~km}$ east of Biala Podlaska to the north and pushed forward on the Terespol-Janow Podlaski road (see Figure 160). Soviet cavalry from the wooded terrain north of Mielnik pressed to the southeast in the direction of Wysokie Litewski. The Soviet advance continued despite the best efforts of the German 1st Flieger Division which attempted to interdict from the air the Soviet advance in the area of Siedlce - Lukow and the area of Bialystok (see Table XXXVIII). 
The Soviets attacked the XXIII Army Corps north of Brest with armor support and achieved a partial breakthrough up to the rail line Brest-Bielsk Podlaski (see Figure 174). The 5th SS Panzer Division "Wiking" had fended off Soviet attacks from the west, north and east in the area south of Kleszczele (see Figure 160).

Fortress Brest-Litovsk. Soviet attacks on the outer defenses of "Fortress Brest-Litovsk" broke through and the Soviets entered the inner defense ring of the city which lead to an extremely threatening situation (see Figure 174).576 The breakthrough into the inner defense ring combined with the progressive encirclement from the west placed the "Fortress" in an untenable position. There was only enough ammunition for 10 days at maximum and food supplies for 14 days.577 There were also 700 wounded which could not be evacuated and Junker 52 transport aircraft were requested.578 The Commandant of "Fortress Brest-Litovsk" strived to acheive contact with the left wing of the 223rd Infantry Division Kampfgruppe by rapidly pulling out troops from the eastern front of Brest-Litovsk and transferring them to the west in the general line Dobryn Wlk. - west of of Wolka - Dobryniska - west of Dobrynka (see Figure 161). However, the disengagement of troops from the east front of "Fortress Brest-Litovsk" weakened the outer defense ring sufficiently that the Soviets achieved several penetrations in the defense line.

"Fortress Brest-Litovsk" was only connected to the west by radio. The Soviets pressed their attacks in several sectors with units up to battalion strength. The Germans managed to liquidate 
the penetrations at Kostomoloty, Zakije and Jamno. Nevertheless, the Soviets succeeded by advancing from the west and south against "Fortress Brest-Litovsk" achieving deep breakthroughs in the fortress defense line at Wolka Dobrynska.579 The 2nd Army granted permission for withdrawal to the inner defense ring of the fortress. 580

German commanders had become sensitive to the disasters that had resulted from the encirclement of Hitler's so called fortresses. Colonel General Weiss, Commander of the 2nd Army expressed his concerns about the encirclement of Brest-Litovsk at 1210 hrs to Lt. General Krebs, Chief of Staff Army Group Center. He informed Krebs that the situation was getting worse. The enemy had broken into Miedzyrzec from the south (see Figure 160). The enemy at Biala Podlaska could not be stopped after the loss of the 12th Hungarian Division and the cavalry (see Figure 160). Col. General Weiss stated:

The crisis on the south flank of the Army has intensified. Brest cannot remain standing under these circumstances. It could come any minute when a situation that is not supposed to happen will appear terribly similar to the situation of Bobruisk...Today it is necessary to pull back the garrison of Brest to the inner ring. I will order this action. Brest must be evacuated en masse as early as possible tonight. It is important that the first elements of the movement are rapid. It is important to deliver forces to the threatened positions. 581

Lt. General Krebs responded that he did not believe that the issue could be settled today. 582 Col. General Weiss responded: 
We have not lost our nerves and also the essential experience gained in previous battles. Therefore, you can believe us, that it is essential. A relief of the XXIII Corps by the 541 st Division is not possible. The 2nd Army is presently being attacked by 8 armies. ${ }^{583}$

Colonel General Weiss informed Lt. General Krebs at 1230 hrs that the Soviets were in Biala Podlaska and were advancing from there towards the west. 584 The Soviets were also forcing their way into Miedzyrzec from the south (see Figure 160). Colonel General Weiss stated that a "major decision was urgent."585 $\mathrm{He}$ requested freedom of movement to the line Siedlce-Orla. Lt. General Krebs responded that Field Marshal Model had planned for a withdrawal to the line Miedzyrzec-Kleszcze but that would soon be difficult. Col. General Weiss informed Krebs that the forces in "Fortress Brest-Litovsk" were being pulled back to the inner defense ring (see Figure 161). He further stated that the forces in Brest needed to be evacuated tonight so that the troops could be freed for further use.586 Lt. General Krebs responded that he did not believe Brest could be evacuated tonight. 587

Lt. General Krebs responded at $1250 \mathrm{hrs}$ that with the occupation of the inner defense ring Field Marshal Model had approved the release of two battalions from "Fortress BrestLitovsk" to clear the road to Biala Podlaska. ${ }^{588}$ 
JULY 27, 1944

\section{2nd Army}

Colonel Lassen, General Staff Operations Officer for the 2nd Army informed Colonel General Weiss that Corps Detachment E would be cutoff tonight. Col. General Weiss responded that the moment had not yet arrived for complete freedom of movement. Finally, Lt. General Krebs informed the 2nd Army at $0025 \mathrm{hrs}$ that Field Marshal Model had approved the objectives of the 2nd Army including the withdrawal of Corps Detachment $E$ from BrestLitovsk. 589 Colonel Lassen informed Lt. General Krebs at 0850 hrs that the Brest units would be pulled back to the following line: northwest of Biala - east of Janow Podlaski - along the Pulwa to the rail line. The order had been transmitted to the $X X$ Army Corps.

Lt. General Felzmann, Commandant of "Fortress BrestLitovsk" sent a radio message describing the breakout. Two Soviet attacks each consisting of 1000 troops from the southwest were repulsed. Then the garrison of Brest after 45 minutes of artillery preparation and the demolition of the airport commenced the breakout through the west ring of "Fortress Brest-Litovsk" at 1805 hrs through Terespol over the Bug river against 3 Soviet Divisions. ${ }^{590}$ The breakout had begun just prior to the complete and total isolation of the city had been completed by the Soviets (see Figure 162). The Commandant of "Fortress Brest-Litovsk" organized the breakout to the west based upon two assault groups. ${ }^{591}$ The assault groups encountered stiff resistance despite 
45 minutes of artillery preparation. The assault group on the right reached Krzyczew while the left group got bogged down in the Krzna sector of Beresowka. The main difficulty encountered in the fighting withdrawal of Kampfgruppe Felzmann was not frontal resistance but Soviet fire from both flanks along the route of retreat which inflicted heavy losses in men and material.592 Lt. General Felzmann reported that the last German soldier evacuated Brest shortly after midnight. 593

JULY 28, 1944

\section{2nd Army}

The garrison of Brest-Litovsk which had made its breakout was according to the last radio message engaged in heavy battle with the lead elements located at Kolosz and Zaczopki (see Figure 163). The southern assault group reported strong Soviet pressure from the south along the entire route of march. 594

The XX Army Corps formed a Kampfgruppe from the 102nd Infantry Division and the 223rd Divisional Group which was assembled for an attack on July 28, 1944 at $1300 \mathrm{hrs}$ at Wierzchlas (see Figure 163). ${ }^{595}$ The attack was to proceed through BionyZaczopki. This attack was successful and broke through the Soviet defense line and permitted the relief of Kampfgruppe Felzmann (see Figure 164).596 The first group to reach German lines was the 448th Regimental group in a column with more than 600 wounded men.597 The remnants of the 137th Infantry Divisional Group and 
the 167th Regimental Group also broke through with severe losses of men and equipment.

$$
\text { JULY 29, } 1944
$$

\section{2nd Army}

The garrison of "Fortress Brest-Litovsk" reached German lines, but had suffered severe losses in men and equipment. 598 Elements of Corps Detachment $E$ managed to reach the German defense line along the west edge of Niemojki to the west edge of Hadynow (see Figure 164).599 Elements of the 3rd Cavalry Brigade secured the retreat route of Kampfgruppe Felzmann to the west where elements of Corps Detachment E were placed back into the front (see Figure 165).

According to Soviet sources the German losses from the three divisions attempting to escape amounted to 15,000 killed and 2000 taken prisoner between July 29-30,1944.600 The 86th, 137th and 251st Infantry Divisional Groups were for the most part destroyed in the battle and subsequent retreat from "Fortress Brest-Litovsk." The 86th Infantry Divisional group was destroyed but some remnants were absorbed into the 251st Infantry Division which had also been smashed but was later reformed as the 251st Volksgrenadier Division.601 The 137th Infantry Divisional Group appears to have been disbanded. .02 


\section{THE CAUSES OF THE COLLAPSE OF ARMY GROUP CENTER} AND THE SIGNIFICANCE OF THE GERMAN LOSSES TO THE EASTERN FRONT

The causes of the collapse of Army Group Center were a result of Soviet strengths and German Weaknesses. The Soviets had changed their tactics and the Germans as a result of their weaknesses could not counter the new Soviet tactics successfully. The Soviet and German factors combined produce an explanation for the collapse of Army Group Center in the summer of 1944. There were six significant Soviet factors that contributed to the success of the Red Army in Belorussia:

1. The Soviets possessed numerical superiority in every category of combat strength: troops, tanks, trucks, artillery, aircraft and supplies.

2. The Soviets employed massive concentrations of artillery for the initial breakthrough on the Belorussian Front. The mass and numbers of artillery employed for the initial artillery barrage was unprecedented.

3. Soviet offensive tactics were developed to exploit their numerical superiority for maximum effect. The Soviets concentrated their forces on narrow frontages with closely concentrated infantry and attached armored brigades employed in the first wave to make the initial breakthrough. Soviet tank and mechanized corps strength was preserved by holding them in reserve till the hole in the German lines was made by the initial 
first wave of infantry. Then the tank and mechanized corps were deployed through the broken German line into the depth of battlefield toward distant objectives.

4. Soviet air superiority based on the 5 air armies employed was used effectively against the German front lines, directly behind the front, and in all areas where the Soviets were mounting a major breakthrough.

5. The vast quantity of ammunition supplies gave the Soviets the capability to use firepower from artillery, mortars and fighter aircraft continuously for days without pause. Artillery barrages could be maintained for days. The Soviets were not restricted like their German counterparts by the supply of ammunition.

6. The extensive motorization within the tank and mechanized corps (see Figures 166 \& 167) permitted the formations to drive great distances into the depth of the German front. They could carry more fuel and infantry to accompany the tanks because of the vast quantities of American trucks supplied to the Soviets through lend-lease. The Soviets empowered by such a high level of mobility were able to advance behind German lines without regard to their rear or flanks especially since Soviet numerical superiorty in the air permitted units operating in depth a sense of security. The Soviet deep armored penetrations permitted the Soviets to achieve certain decisive advantages: occupation of strategic terrain features, interruption of all German rearward communications, preventing supply operations to frontline troops, 
setting the stage for encirclement, and producing detrimental psychological effects on German troops. 603

7. The Soviet use of the "double pincer" maneuver such as in the case of the German 4th Army. The "outside pincer" was formed by tank armies driving towards distant objectives and the "inner pincer" by infantry armies with attached tank brigades which pressed the German 4th Army into a tighter cauldron in a process of encirclement which had aiready been completed by the breakthrough of the "outside pincer" into the rear area. This technique enabled the Soviets to successfully encircle entire German armies.

Thus, Soviet strengths were major factors causing the collapse of Army Group Center, but only provide a partial explanation of the German defeat. The most serious weakness was found within the German Army High Command.

German weakness combined with Soviet strengths provides more complete answers to the causes of the collapse of Army Group Center. Soviet strengths alone could not have caused the collapse of Army Group Center. Soviet strengths in the past had been countered by a resolute German defense such as in the failure of the Soviet winter offensive of 1943-1944 against Army Group Center. Therefore, the explanation is found in the mistakes of the German Army High Command. The German High Command made the following six grave errors:

1. There was a failure to heed the military intelligence summaries of Army Group Center which reported obvious Soviet concentrations and impending signs of a major offensive against 
Army Group Center. Colonel Gehlen and Foreign Armies East bear a major responsibility for the inaccurate intelligence assessment that predicted the major Soviet summer offensive against Army Group North Ukraine. Gehelen's inaccurate intelligence summaries lead the German High Command not to take the necessary measures in Army Group Center's sector to prevent a major collapse. Strong reserves were not brought up and early withdrawal of the overextended front to the Dnieper river covering position was not executed in time. The Army Group was forced to conduct a battle with an inadequately manned, overextended line without virtually any reserves. This alone produced a hopeless situation.

2. Hitler, however, taxed the abilities of Army Group Center to defend itself even further. He forbid the construction of rearward positions believing that such positions would weaken the resolve of the German soldiers to fight. Instead they were exposed during the retreat in Belorussia to continuous Soviet air attacks and encirclement by Soviet armor in their rear areas. The failure to construct a Berezina river defense line was an enormous mistake on the part of Hitler. It would have provided a solid secondary main defense line in Belorussia. Unfortunately, for the German soldiers of Army Group Center the Berezina river proved to be instead an obstacle to their retreat from the Soviet offensive. The Berezina river proved to be the same problem to the German Army in 1944 as it had been to Napoleon in 1812. There were not enough bridges for a large army to cross the river quickly. (see Figure 168). 
The most shocking fact during the retreat of the 4th Army to the Berezina river was that there were only two main permanent bridges between Borissow and Schatkowo (north of Bobruisk) (see Figure 168). The bridge at Beresino was a wood road bridge 560 meters long and 3.5 meters wide and a wood road bridge $15 \mathrm{~km}$ north of Beresino was 560 meters long and 4.2 meters wide.604 These were the only two large bridges on the Berezina river for hundreds of kilometers that were available for the retreat of the 4th Army. The Soviet air force consequently could concentrate on these limited crossing points and the roads leading to them. These crossings and the roads were subjected to massive bombing and strafing creating even further chaos for the retreating Germans. The bridges were subjected to concentrated air attacks which damaged them and caused even further delays in crossing the Berezina river facilitating the Soviet encirclement of the German 4th Army. Clearly the need for more bridges across the Berezina river was necessary for the retreat of the German Army as well as fortified positions along the river from which to establish a defense line. However, Hitler had forbid all of this rear area construction leaving no defensive line in depth for Army Group Center to fall back on.

3. Hitler failed to permit his generals the freedom of command to execute a flexible defense. His insistence on a doctrine of "standing fast" and the medieval notion of fortresses which he ordered with his Fuehrer Befehl Nr. 11 interfered with the local commanders decision making authority to respond to the 
changing circumstances on the battlefield. Bobruisk, Vitebsk, Orsha, Mogilev and Minsk along with others received the "Fortress" designation which meant that troops were locked into defending a fixed position instead of available to be used in a flexible manner. Generalmajor Peter von der Groeben who was a staff officer in Army Group Center stated:

Even the smallest move depended on authorization from Hitler's Field Headquarters. This, in particular pertained to withdrawal of sectors, evacuation of cities, etc. Every separate move of this type, no matter how urgent it may have been, had to be fought for almost to the point of despair. Due to Hitler's daily schedule, decisions for requests were made only once daily, late at night, and consequently if an approval was given, this usually arrived too late. Authorization for withdrawals were granted only in the rarest cases. Misjudging actualities to an almost tragic extent, Hitler believed to have found the road to victory in his principle "hold at all costs"605

4. The German weakness in the air proved a decisive factor in the collapse of Army Group Center. Previously, the German Luftwaffe on the Eastern Front had been able to supply encircled units or halt Soviet armored breakthroughs. However, German Luftflotte 6 (see Table $X X X \mid X$ ) proved unable to halt the breakthroughs of the Red Army in the summer of 1944 especially when the breakthroughs were occurring simultaneously. The lack of German fighter aircraft prevented Luftflotte 6 from interdicting the 5 Soviet air armies in the skies over Belorussia which meant that the Soviets had achieved effective air superiority. Luftflotte 
6 had only 40 combat ready fighters to oppose the massive numerical superiority of the Soviet Air Force.606

The Soviets were able as a result of their air supremacy to break the backbone of the German defense which was centered in their artillery. The German Army in Belorussia depended on artillery because of the low combat strengths of the German infantry and the shortage of tanks. Artillery positions had been sited on exposed foreward slopes or in open positions to reinforce anti-tank defenses.

Paul Carell described the situation of the German Army in Belorussia under conditions of Soviet air supremacy:

By means of well-prepared air strikes, the Russians succeeded in eliminating the previous reconnoitered or rapidly pinpointed gun positions of the German artillery. The backbone of the German defense was broken. The German infantry was helpless against any motorized or mechanized enemy. The same dilemma arose in the west. Soviet ground-support aircraft bombed the retreating columns of the German rearward services and reserve units at bridges and road bottlenecks. The effect was devastating. There was chaos on the roads. No switching of units was feasible. Faced with this sudden enemy superiority in the air, the German divisions were desperate and, in view of their defenselessness, frequently panicked. There was nothing the German could do.

Nothing revealed more strikingly the turn in the military situation on the Eastern Front than the crushing air superiority of the Soviet air force. Thanks to Eisenhower, Stalin had conquered the Russian skies. Without a protective roof overhead no front on earth could be held in the long run. The Russians had learned this in 1941 and 1942. Now this law of modern warfare 
was being proved against the German armies--in both East and West.607

5. The German High Command failed to supply their troops with adequate supplies of hand-held anti-tank weapons. The Germans had developed the Panzerfaust, a hand-held recoiless antitank grenade launcher which could be fired from 30 yards with a penetration of $200 \mathrm{~mm}$ of armor.608 The Panzerschreck or Ofenrohr was an $88 \mathrm{~mm}$ rocket launcher similar to the American Bazooka which had also been developed and had a range of 130 meters. ${ }^{609}$ Both of these weapons were the most effective hand-held anti-tank weapons in the German arsenal and if the German infantry in Belorussia had been supplied with these weapons in quantity it would have increased their anti-tank capability dramatically. However, the German infantry was supplied instead with large quantities of anti-tank mines which required the infantry to deploy the mines before their defensive positions or actually place the mine on the tank or under the tank so that it would detonate. This of course required the German infantry to expose themselves to Soviet fire. Therefore, the lack of hand-held anti-tank weapons contributed significantly to the demise of the German Army in Belorussia.

6. The last major weakness of the Germans was their hesitancy to move in reserves on time and in sufficient numbers. Hitler failed to permit the reinforcement of Army Group Center on a massive scale even after the attack against Army Group Center had been identified as the major Soviet summer offensive. 
Reinforcements only trickled into Army Group Center while it was virtually disintegrating. Eventually, the German High Command had to pour in massive reinforcements to plug the hole left by the destruction of 28 German divisions in Army Group Center.610 The total number of replacement divisions to reconstruct the front amounted to 29 divisions and 7 brigades (see Table $X X X X$ ). If only half of these formations had been available as reserves in the rear area of Army Group Center the disaster for most of Army Group Center could have been averted and the debacle of the collapse of Army Group Center avoided.

The collapse of Army Group Center constituted the most decisive defeat of the German Army in the summer of 1944 and it set the the stage for the weakening of other Army Groups on the Eastern Front because the divisions to shore up Army Group Center came mostly from Army Group North, Army Group North Ukraine and Army Group South Ukraine (see Table XXXX). The subsequent weakening of the other Eastern Front armies to reinforce Army Group Center facilitated the remaining Soviet offensives launched during the summer of 1944 against the other Army Groups. The collapse of Army Group Center resulted in the destruction of 28 German divisions and the loss of 31 generals (see Table $X X X X \mid$ ). The defeat of the German Army in Belorussia was greater than the defeat at Stalingrad and constituted one of the greatest disasters in the history of the German Army. ${ }^{611}$ 
TABLE XXXV

ARMY GROUP CENTER ORDER OF BATTLE JUNE 22, 1944

Army Group Center Formations Army Group Center And OKH Reserve

14th Motorized Infantry

Division

20th Panzer Division

60th Panzer Grenadier Division

"Feldherrnhalle"

390th Field Training Division

707th Infantry Division

White Ruthenia Military

District:

52nd Security Division

221st Security Division

391st Security Division

3rd Panzer Army

Reserves:

95th Infantry Division

201st Security Division

IX Army Corps

Corps Detachment D

(combined 56th \& 262nd

Infantry Divisions)

252nd Infantry Division

LIII Army Corps

4th Luftwaffe Field Division

6th Luftwaffe Field Division

206th Infantry Division

246th Infantry Division
Commanders

Field Marshal Busch

Chief of Staff: Lt. Gen. Krebs

Lt. Gen. Floerke

Lt. Gen. Von Kessel

Maj. Gen. Von Steinkeller

Lt. Gen. Bergen

Maj. Gen. Gihr

Maj. Gen. Newiger

Lt. Gen. Lendle

Lt. Gen. Von Monteton

Col. Gen. Reinhardt

Maj. Gen. Michaelis

Lt. Gen. Jacobi

Gen. d. Arty. Wuthmann

Maj. Gen. Pamberg

Lt. Gen. Melzer

Gen. d. Infantry Gollwitzer

Lt. Gen. Pistorius

Lt. Gen. Peschel

Lt. Gen. Hitter

Maj. Gen. Mueller-Buelow 
TABLE XXXV

ARMY GROUP CENTER ORDER OF BATTLE

JUNE 22, 1944

(continued)

\begin{tabular}{ll}
\hline Army Group Center Formations & \multicolumn{1}{c}{ Commanders } \\
\hline 3rd Panzer Army & Gen. d. Arty. Pfeiffer \\
VI Army Corps & $\begin{array}{l}\text { Col. Preu (acting) } \\
\text { 197th Infantry Division }\end{array}$ \\
256th Infantry Division & Lt. Gen. Wuestenhagen \\
299th Infantry Division & Lt. Gen. Graf Von Oriola \\
Fortress Vitebsk & Gen. d. Inf. Gollwitzer \\
4th Army & Gen. d. Inf. Tippelskirch \\
Reserves: & Lt. Gen. Oschmann \\
286th Security Division & Gen. d. Inf. Voeickers \\
XXVII Army Corps & Maj. Gen. Schuermann \\
25th Panzer Grenadier Division & Lt. Gen. Traut \\
78th Assault Division & Maj. Gen. Klammt \\
260th Infantry Division & Gen. d. Arty. Martinek \\
XXXIX Panzer Corps & Lt. Gen. Bamler \\
12th Infantry Division & Lt. Gen. Ochsner \\
31st Infantry Division & Lt. Gen. Von Kurowski \\
110th Infantry Division & Lt. Gen. Schuenemann \\
337th Infantry Division & Lt. Gen. Vincenz Mueller \\
XII Army Corps & Lt. Gen. Zutavern \\
18th Panzer Grenadier Division & Lt. Gen. Trowitz \\
57th Infantry Division & Lt. Gen. Drescher \\
267th Infantry Division & Lt. Gen. Traut \\
Fortress Orsha & Maj. Gen. Erdsmannsdorf \\
Fortress Mogilev & \\
\hline
\end{tabular}




\section{TABLE XXXV}

\section{ARMY GROUP CENTER ORDER OF BATTLE \\ JUNE 22, 1944 \\ (continued)}

\begin{tabular}{ll}
\hline Army Group Conter Formations & \multicolumn{1}{c}{ Commanders } \\
\hline 9th Army & Gen. d. Inf. Jordan \\
XXXV Army Corps & Lt. Gen. Von Luetzow \\
6th Infantry Division & Lt. Gen. Heyne \\
45th Infantry Division & Maj. Gen. Engel \\
134th Infantry Division & Lt. Gen Philipp \\
296th Infantry Division & Lt. Gen. Kullmer \\
383rd Infantry Division & Lt. Gen. Hoffmeister \\
XXXXI Panzer Corps & Gen. d. Arty. Weidling \\
35th Infantry Division & Lt. Gen. Richert \\
36th Infantry Division & Maj. Gen. Conrady \\
129th Infantry Division & Maj. Gen. Larisch \\
LV Army Corps & Gen. d. Inf. Herrlein \\
102nd Infantry Division & Lt. Gen. Von Bercken \\
292nd Infantry Division & Lt. Gen. John \\
& \\
Fortress Bobruisk & Maj. Gen. Hamann \\
2nd Army & Col. Gen. Weiss \\
Reserves: & \\
1st Hungarian Cavalry Division & \\
4th Cavalry Brigade & \\
5th Hungarian Reserve Infantry & \\
Division & \\
23rd Hungarian Reserve Infantry & \\
Division & \\
XXIII Army Corps & \\
7th Infantry Division & \\
17th Infantry Brigade & \\
203rd Security Division & Lt. Gen. Pilz \\
\hline
\end{tabular}




\section{TABLE XXXV}

ARMY GROUP CENTER ORDER OF BATTLE

JUNE 22, 1944

(continued)

\begin{tabular}{ll}
\hline Army Group Center Formations & Commanders \\
\hline 2nd Army & Gen. d. Arty. Freiherr Von Roman \\
XX Army Corps & Lt. Gen. Felzmann \\
Corps Detachment E & \\
(Combined 137th \& 251st & \\
Infantry Divisions) & \\
3rd Cavalry Brigade & \\
& Gen. d. Inf. Hoehne \\
VIII Army Corps & Lt. Gen. Thum \\
5th Jaeger Division & Lt. Gen. Eckhardt \\
211th Infantry Division & \\
12th Hungarian Reserve Infantry & \\
Division & \\
\hline
\end{tabular}

Source: Kurt Mehner, Die Geheimen Tagesberichte Der Deutschen Wehrmachtfuehrung Im Zweiten Weltkrieg 1939-1945 Vol. 10 (Osnabrueck: Biblio Verlag, 1985), pp. 502, 509-523; Gerd Niepold, Battle For White Russia: The Destruction of Army Group Centre June 1944 (London: Brassey's Defense Publisher's, 1987), pp. 29-31; Hinze, Der Zusammenbruch Der Heeresgruppe Mitte Im Osten 1944, pp. 286-288; Kriegstagebuch (KTB) Heeresgruppe Mitte, Fuehrungsabteilung, Gliederung der Grossen Verbaende, 4.6.44. NAMP T-311, Roll 228; Werner Haupt, Die Schlachten Der Heeresgruppe Mitte 1941-1944 (Friedburg: Podzun-Pallas-Verlag GmbH, 1983), p. 266. 
TABLE XXXVI

OVERVIEW OF THE COMBAT READINESS, STRENGTH AND RESERVES OF THE 4TH ARMY ON JUNE 20, 1944

\begin{tabular}{|c|c|c|c|c|c|c|c|c|c|c|}
\hline \multirow[b]{2}{*}{ UNITS } & \multirow{2}{*}{$\begin{array}{l}\text { Total } \\
\text { Combat } \\
\text { Strength }\end{array}$} & & & & & \multicolumn{5}{|c|}{ Combat Ready } \\
\hline & & $\begin{array}{l}\text { h Sector } \\
\text { in } \mathrm{Km}\end{array}$ & $\begin{array}{l}\text { Km per } \\
\text { Soldie }\end{array}$ & $\begin{array}{l}\text { Artillery } \\
\text { Light/H }\end{array}$ & & $\begin{array}{l}\text { Assault } \\
\text { Guns }\end{array}$ & II & $\begin{array}{l}\text { Panzer } \\
\text { IV }\end{array}$ & VI & $\begin{array}{l}\text { Heavy SP } \\
\text { Guns }\end{array}$ \\
\hline Corps & & & & & & 27 & 24 & & & 45 \\
\hline $\begin{array}{l}\text { 78th Sturm } \\
\text { Division }\end{array}$ & 5712 & 32 & 178 & 46 & 55 & 31 & & & & 18 \\
\hline $\begin{array}{l}\text { 25th Panzer } \\
\text { Grenadier } \\
\text { Division }\end{array}$ & 2686 & 17 & 158 & 27 & 32 & 45 & & & & 10 \\
\hline $\begin{array}{l}260 \text { th } \\
\text { Infantry } \\
\text { Division }\end{array}$ & 2554 & 32 & 80 & 46 & 13 & & & & & \\
\hline $\begin{array}{l}\text { XXXXIX } \\
\text { Panzer Corps }\end{array}$ & & & & & & 58 & & & & 43 \\
\hline $\begin{array}{l}110 \text { th } \\
\text { Infantry } \\
\text { Division }\end{array}$ & 2590 & 27 & 96 & 33 & 9 & 6 & & & & \\
\hline $\begin{array}{l}337 \text { th } \\
\text { Infantry } \\
\text { Division }\end{array}$ & 3775 & 22 & 172 & 46 & 35 & 10 & & & & \\
\hline $\begin{array}{l}12 \text { th } \\
\text { Infantry } \\
\text { Division }\end{array}$ & 3604 & 32 & 113 & 36 & 11 & 10 & & & & \\
\hline $\begin{array}{l}31 \text { st } \\
\text { Infantry } \\
\text { Division }\end{array}$ & 2488 & 23 & 108 & 30 & 12 & 10 & & & & \\
\hline $\begin{array}{l}\text { XII Army } \\
\text { Corps }\end{array}$ & & & & & & & & & & \\
\hline $\begin{array}{l}\text { 18th Panzer } \\
\text { Grenadier } \\
\text { Division }\end{array}$ & 2787 & 24 & 116 & 36 & 16 & & & & & \\
\hline $\begin{array}{l}267 \text { th } \\
\text { Infantry } \\
\text { Division }\end{array}$ & 2498 & 26 & 96 & 35 & 11 & 9 & & & & \\
\hline $\begin{array}{l}57 \text { th } \\
\text { Infantry } \\
\text { Division }\end{array}$ & 2136 & 24 & 89 & 27 & 11 & 6 & & & & \\
\hline
\end{tabular}


TABLE XXXVI

OVERVIEW OF THE COMBAT READINESS, STRENGTH AND RESERVES OF THE 4TH ARMY ON JUNE 20, 1944

(continued)

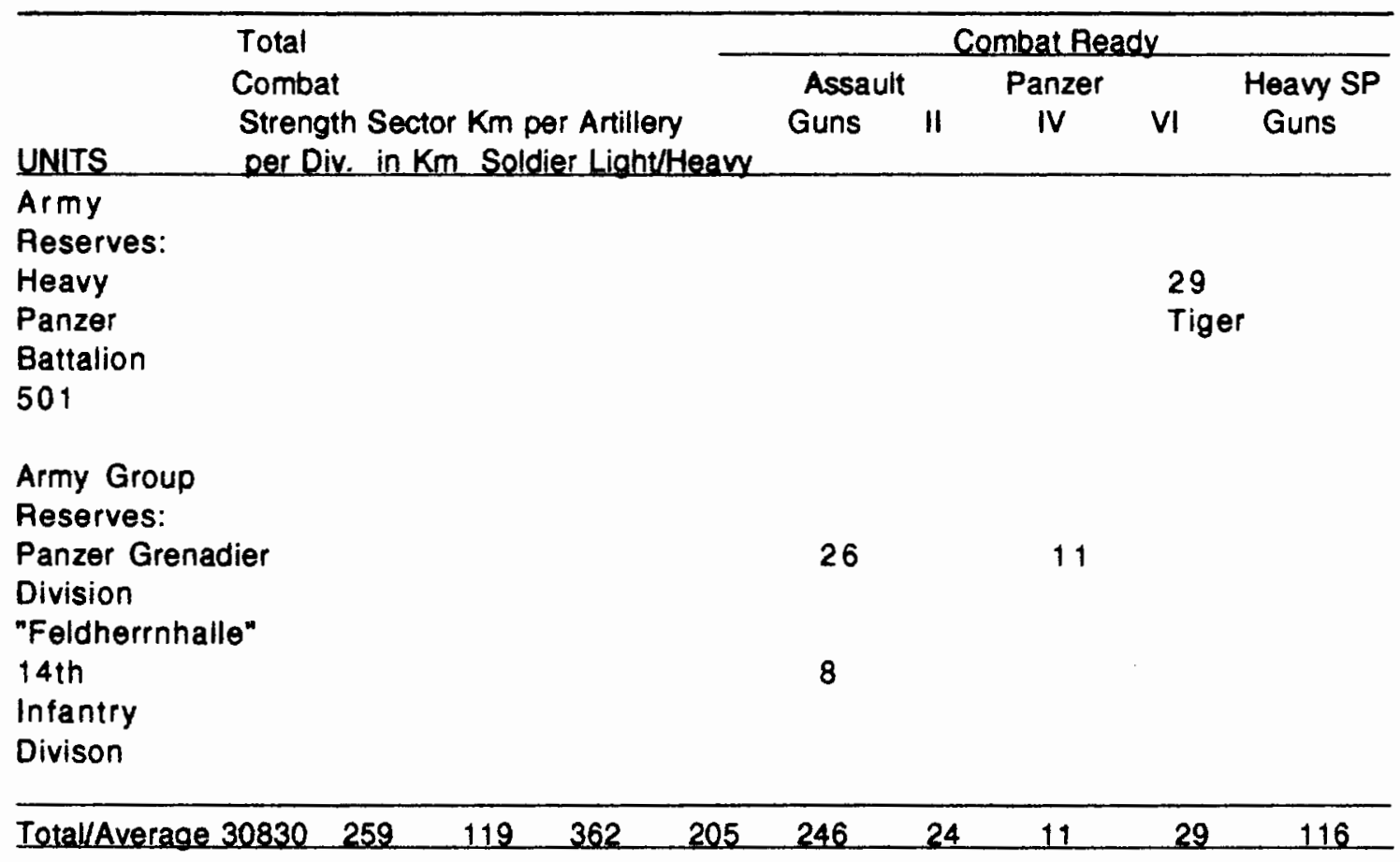

Source: Lt. Colonel Von Wienskowski, Die Entwicklung der Lage bei der 4. Armee waehrend der russischen Sommeroffensive 1944 und die Vorgaenge bei den abgesprengten Verbaenden 22.6. bis 5.7.44. National Archives Microfilm Publication T-312, Roll 1365, p. 4. 


\section{TABLE XXXVII}

BATTLE STRENGTH OF CORPS DETACHMENT E ON JULY 25, 1944

\begin{tabular}{lc}
\hline UNITS & BATTLE STRENGTH \\
\hline 203rd Security Division & 3,573 \\
137th Infantry Division & 1,563 \\
251st Infantry Divisional Group & 960 \\
86th Infantry Divisional Group & 760 \\
Miscellaneous Artillery Units & $\frac{900}{7,756}$ \\
Total Battle Strength &
\end{tabular}

Source: Armeeoberkommando 2, Gliederung der Kampfverbaende am 25.7.1944. Korps Abteilung E National Archives Microfilm Publication T-312, Roll 1318. 
TABLE XXXVIII

COMBAT REPORT OF THE 1ST FLIEGER-DIVISION

FOR JULY 26, 1944

COMBAT STRENGTH:

TOTAL AIRCRAFT:

AIRCRAFT UTILIZATION:

11 Close Support Air Attacks

6 Close Support Air Attacks

5 Anti-Tank Air Attacks

Fighter Patrols and Air Cover

for the JU 87

Reconnaissance of

2nd Army Front

TOTAL AIRCRAFT UTILIZATION: $\quad \overline{356}$ Aircraft
235 Attack Aircraft

23 Anti-Tank Aircraft

73 Fighter Aircraft

25 Reconnaissance Aircraft

356
145 FW 190

90 JU 87 "Stukas"

23 JU 87 "Anti-Tank Stukas"

44 FW 190

29 ME 109

14 ME 109

$\frac{11}{356}$ FW 189

OPERATIONAL AREA: Siedlce - Lukow and area of Bialystok

SOVIET LOSSES INFLICTED BY 1ST FLIEGER-DIVISION:

6 tanks destroyed

1 tank probably destroyed

5 tanks and 1 armored personnel carrier damaged

67 trucks destroyed

6 trucks and 1 half-track carrier destroyed by incendiary fire

5 trucks damaged

3 towed vehicles destroyed

1 automobile destroyed

4 artillery guns destroyed

1 anti-tank gun destroyed

3 anti-tank guns damaged

3 anti-tank and 1 mortar platoon effectively strafed 
TABLE XXXVIII

COMBAT REPORT OF THE 1ST FLIEGER-DIVISION

FOR JULY 26, 1944

(continued)

1 Flak gun was silenced.

2 Flak guns were put out of action

2 Soviet aircraft (1 Lagg-5 \& 1 JAK-9) were sbot down

1 JAK-9 effectively strafed

A direct hit on a position containing 4 Flak guns

Numerous infantry positions and vehicles and towns were

attacked with resulting fires and explosions

GERMAN LOSSES: 1 ME 109 failed to return

Source: A.H. Qu., 26.7.44, Einsatzmeldung der 1. Flieger-Division vom 26.7.44 National Archives Microfilm Publication T312, Roll 1318. 
TABLE $X X X \mid X$

OPERATIONAL ORDER OF BATTLE OF THE FLYING FORMATIONS OF LUFTFLOTTENKOMMANDO 6, JUNE 28, 1944

Formations

2. Staffel

IV Flieger Korps HQ

Kampfgeschwader $1 \mathrm{HQ}$ II./Kampfgeschwader 1

Kampfgeschwader $4 \mathrm{HQ}$. (Ju 88)

II./Kampfgeschwader 4

III./Kampfgeschwader 4

Kampfgeschwader $27 \mathrm{HQ}$

I./Kampfgeschwader 27

III./Kampfgeschwader 27

Kampfgeschwader $53 \mathrm{HQ}$

I./Kampfgeschwader 53

II./Kampfgeschwader 53

III./Kampfgeschwader 53

Kampfgeschwader $55 \mathrm{HQ}$

I./Kampfgeschwader 55

II./Kampfgeschwader 55

III./Kampfgeschwader 55

Transport Staffel IV Flieger Korps

1. Flieger Division Command Post

2. Staffel
Locations

Minsk-Priluki

Minsk-Priluki

Brest/Bug

Seerappen

Prowehren

Bialystok

Baranowitsche

Bialystok

Krossno

Krossno

Mielec

Radom

Radom

Piastow

Grojec

Deblin-irena

Deblin-Ulez

Deblin-Irena

Podlodowka

Warschau-Bielany

Baranowitsche

Lessna

Nahaufklaerungsgruppe 15 (AOK 2 \& 9) Baranowitsche $1.14 \quad$ (Bf 109) Baranowitsche 11./11_ (FW 189) Baranowitsche 


\section{TABLE XXXIX}

OPERATIONAL ORDER OF BATTLE OF THE FLYING FORMATIONS OF LUFTFLOTTENKOMMANDO 6, JUNE 28, 1944 (continued)

Formations

$11 . / 12$

$12 . / 12$

12.113

Schlachtgeschwader $1 \mathrm{HQ}$. (FW 190) III./Schlachtgeschwader 1 (FW 190)

II./Schlachtgeschwader 77 (FW 190)

10.(Pz.)/Schlachtgeschwader 3

10.(Pz.)/Schlachtgeschwader 77

Jagdgeschwader $53 \mathrm{HQ}$

I./Jagdgeschwader 51 (Bf 109)

III./Jagdgeschwader 51 (Bf IO9)

IV./Jagdgeschwader 54 (FW 190)

14.(rail)/Kampfgeschwader 3

I./Eins.Gr.2.FIg.Sch.Division

I./Nachtschlachtgeschwader 2

4 Flieger Division Command Post

Nahaufklaerungsgruppe 10 (AOK 4)

2./Nahaufklaerungsgruppe 4 (Bf 109)

3./Nahaufklaerungsgruppe 4 (Bf 109)

$3 . / 14$

(FW189)

Nahaufklaerungsgruppe 4 (Pz.AOK 3) 2./Nahaufklaerungsgruppe 5 (Bf 109) $4 . / 31$ (FW189)
Locations

Baranowitsche

Pinsk-Halewo

Brest/Nord

Baranowitsche

Baranowitsche

Pinsk/West

Puchowitschi

Puchowitschi

Baranowitsche

Puchowitschi

Matschulitschi

Baranowitsche

Pinsk/West

Pinsk/West

Pinsk-Halewo

Minsk

Shodino

Shodino

Shodino

Shodino

Parafjanowo

Parafjanowo

Budslaw 
TABLE XXXIX

OPERATIONAL ORDER OF BATTLE OF THE FLYING FORMATIONS OF LUFTFLOTTENKOMMANDO 6, JUNE 28, 1944

(continued)

Formations

Schlachtgeschwader $10 \mathrm{HQ}$. (FW 190)

I./Schlachtgeschwader 10 (FW 190)

III./Schlachtgeschwader 10 (FW 190)

I./Schlachtgeschwader 1

10.(Pz.)/Schlachtgeschwader I

Jagdgeschwader $51 \mathrm{HQ}$

Stabsst./Jagdgeschwader 51 (FW 190)

III./Jagdgeschwader 51 (FW 190)

IV./Jagdgeschwader 51 (Bf 109)

III./Jagdgeschwader 52 (FW 190)

4./Nachtschlachtgeschwader 2

Fliegerfuehrer 1 Command Post

Nachtschlachtgruppe $2 \mathrm{HQ}$

3./Nachtschlachtgruppe 2

Stab/Eins.Gr.2.Flg.Sch.Div

2. and 3. Staffel

Schleppgruppe $3 \mathrm{HQ}$

1.(DFS)/Schleppgruppe 3

2.(Go)/Schleppgruppe 3

3.(Go)/Schleppgruppe 3

Eins.Kdo.Schleppgruppe 3

Eins.Gr.z.b.V.7

1. and 2. Staffel
Locations

Parafjanowo

Wilna

Parafjanowo

Matschulitschi

Matschulitschi

Minsk/Sued

Minsk/Sued

Minsk/Sued

Shodino

Parafjanowo

Lida

Minsk

Lida

Lida

Chotzow

Chotzow

Bialystok

Bialystok

Bialystok

Bialystok

Bialystok

Pruzcana/Ost

PruzcanalOst 
TABLE XXXIX

OPERATIONAL ORDER OF BATTLE OF THE FLYING FORMATIONS OF LUFTFLOTTENKOMMANDO 6, JUNE 28, 1944

(continued)

Formations

I.Ostfliegerstaffel

Bildkette $12 . / 12$

Jagdfliegerfuehrer 6 Command Post

Stab I./Nachtjagdgeschwader 100

I./Nachtjagdgeschwader 100

3./Nachtjagdgeschwader 100

I.Schwarm

II.Schwarm

III.Schwarm

I.Schwarm

II.u.III.Schwarm

4./Nachtjagdgeschwader 100

Fernaufklaerungsgruppe 2

1. $(F) / 100$ (Ju 88)

4. $(F) / 11$ (Ju 188)

4. (F)/14 (Ju 188)

Eins.Kdo.I.(F)/122 (Me 410)

Nachtaufklaerungsstaffel 2 (Do 217)

Verb.Staffel Lfl.Kdo.6

Transport Staffel Lfl.Kdo.6

Stab I./Transportgeschwader 3

1. - 3./Transportgeschwader 3
Locations

Lida

Minsk/Ost

Minsk

Baranowitsche

Biala Podlaska

Baranowitsche

Pinsk/West

Radom

Baranowitsche

Radom

Biala Podlaska

Baranowitsche

Pinsk/West

Pinsk/West

Baranowitsche

Baranowitsche

Baranowitsche

Minsk/Sued

Minsk/Ost

Matschulitschi

Matschulitschi

Source: Luftflottenkommando 6, Einsatzmaessige Gliederung der fig. Verbaende des Lfl.Kdo.6. Stand 28.6.44, 00.00 Uhr National Archives Microfilm Publication T-311, Roll 228. 
TABLE $X X X X$

REINFORCEMENTS FOR ARMY GROUP CENTER

JUNE-AUGUST 1944

Reinforcements

Source

PANZER DIVISIONS:

1st Fallschirm Panzer Division Southwest Theater, Italy

"Hermann Goering"

3rd SS Panzer Division

"Totenkopf"

4th Panzer Division

5th Panzer Division

5th SS Panzer Division "Wiking"

6th Panzer Division

7th Panzer Division

12th Panzer Division

14th Panzer Division

19th Panzer Division

Panzer Division "Gross

Deutschland"

TOTAL PANZER DIVISIONS:

Army Group South Ukraine

Army Group North Ukraine

Army Group North Ukraine

OKH Reserve

OKH Reserve

Army Group North Ukraine

Army Group North

Army Group South Ukraine

Army Group North Ukraine

Army Group South Ukraine

10 Panzer Divisions

INFANTRY DIVISIONS:

1st Infantry Division

17th Infantry Division

28th Jaeger Division

50th Infantry Division

69th Infantry Division

73rd Infantry Division

131st Infantry Division

170th Infantry Division

196th Infantry Division

Army Group North Ukraine

Army Group South Ukraine

Army Group North Ukraine

Army Group South Ukraine

Army Group North

Army Group South Ukraine

Army Group North Ukraine

Army Group North

AOK Norway

212th Infantry Division

Army Group North

367th Infantry Division

541 st Volksgrenadier Division

542nd Volksgrenadier Division

547th Volksgrenadier Division

548th Volksgrenadier Division

Army Group North Ukraine

OKH Reserve

OKH Reserve

OKH Reserve

OKH Reserve 


\section{TABLE $X X X X$}

REINFORCEMENTS FOR ARMY GROUP CENTER

JUNE-AUGUST 1944

(continued)

Reinforcements

Source

INFANTRY DIVISIONS:

551st Volksgrenadier Division

OKH Reserve

558th Volksgrenadier Division

OKH Reserve

561st Volksgrenadier Division

OKH Reserve

562nd Volksgrenadier Division

OKH Reserve

TOTAL INFANTRY DIVISIONS:

19 Infantry Divisions

BRIGADES:

Panzer Grenadier Brigade Von OKH Reserve Werthern

Lehr Brigade

Panzer Brigade 102

OKH Reserve

OKH Reserve

Panzer Brigade 103

OKH Reserve

Panzer Brigade 104

OKH Reserve

Grenadier Brigade 1131

OKH Reserve

Grenadier Brigade 1132

OKH Reserve

TOTAL BRIGADES:

7 Brigades

TOTAL REINFORCEMENTS TO

ARMY GROUP CENTER:

PANZER DIVISIONS:

INFANTRY DIVISIONS:

TOTAL DIVISIONS:

10 Panzer Divisions

19 Infantry Divisions

29

BRIGADES:

7 Brigades

Source: Kurt Mehner, Geheim Tages Bericht der Deutschen

Wehrmacht Vol. 10, pp. 502-508, Vol. 11, pp. 337-338;

Kriegstagebuch (KTB) Heeresgruppe Mitte,

Fuehrungsabteilung, Kriegsgliederungen National Archives

Microfilm Publication T-311, Roll 228. 
TABLE $X X X X \mid$

THE DESTRUCTION OF ARMY GROUP CENTER

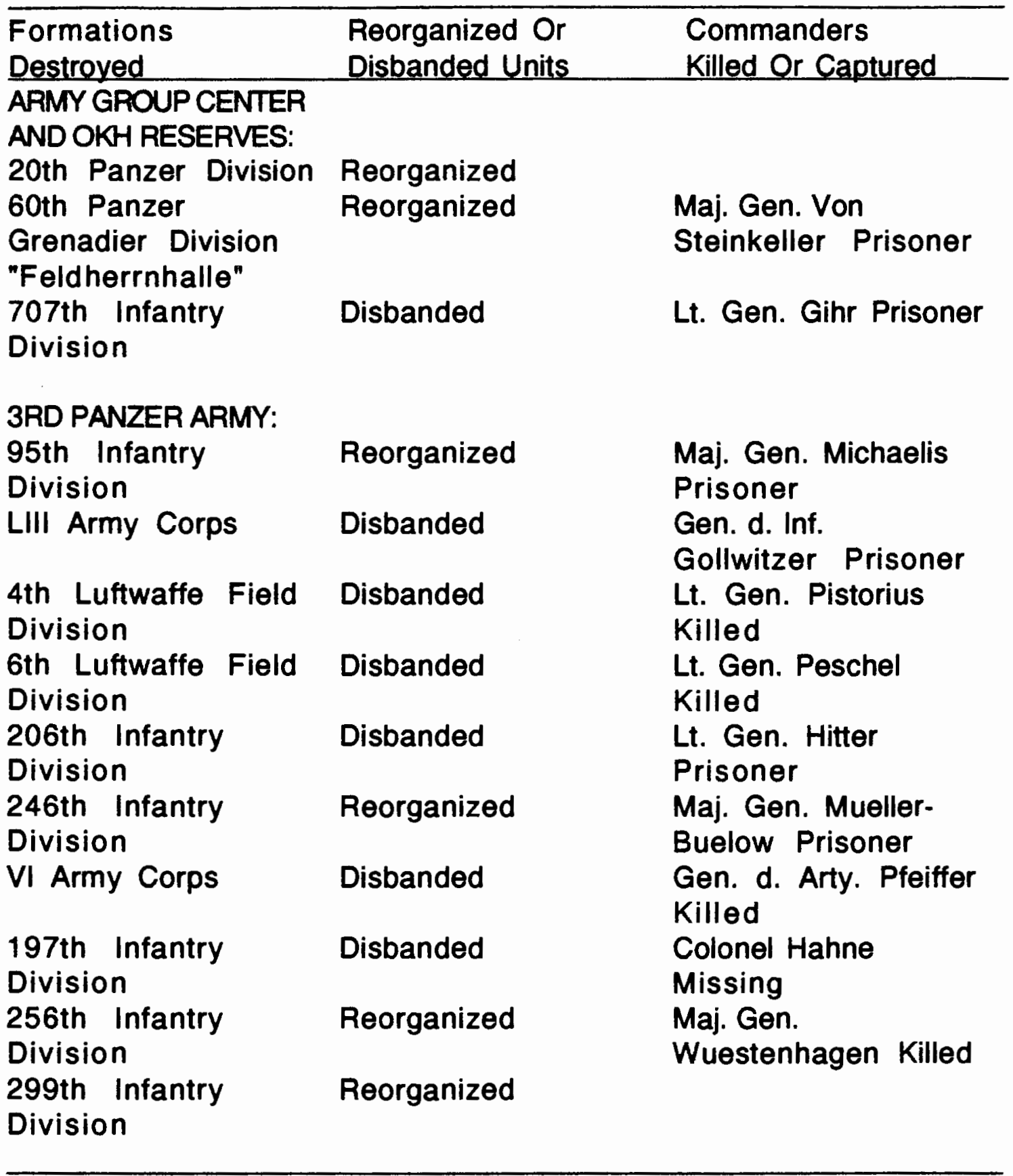


TABLE XXXXX

THE DESTRUCTION OF ARMY GROUP CENTER

(continued)

\begin{tabular}{|c|c|c|}
\hline $\begin{array}{l}\text { Formations } \\
\text { Destroyed }\end{array}$ & $\begin{array}{l}\text { Reorganized Or } \\
\text { Disbanded Units }\end{array}$ & $\begin{array}{l}\text { Commanders } \\
\text { Killed Or Captured }\end{array}$ \\
\hline $\begin{array}{l}\text { 4TH ARMY: } \\
\text { XXVII Army Corps }\end{array}$ & Reorganized & $\begin{array}{l}\text { Gen. d. Inf. Voelckers } \\
\text { Prisoner }\end{array}$ \\
\hline $\begin{array}{l}\text { 25th Panzer } \\
\text { Grenadier Division }\end{array}$ & Reorganized & \\
\hline $\begin{array}{l}\text { 78th "Sturm" } \\
\text { Division }\end{array}$ & Reorganized & $\begin{array}{l}\text { Lt. Gen. Traut } \\
\text { Prisoner }\end{array}$ \\
\hline $\begin{array}{l}\text { 260th Infantry } \\
\text { Division }\end{array}$ & Disbanded & $\begin{array}{l}\text { Maj. Gen. Klammt } \\
\text { Prisoner } \\
\text { Gen. d. Arty. } \\
\text { Martinek, Commander } \\
\text { of XXXIX Panzer } \\
\text { Corps Killed }\end{array}$ \\
\hline $\begin{array}{l}\text { 12th Infantry } \\
\text { Division }\end{array}$ & Reorganized & $\begin{array}{l}\text { Lt. Gen. Bamler } \\
\text { Prisoner }\end{array}$ \\
\hline & Reorganized & $\begin{array}{l}\text { Lt. Gen. Ochser } \\
\text { Prisoner }\end{array}$ \\
\hline & Disbanded & $\begin{array}{l}\text { Lt. Gen. Von } \\
\text { Kurowski Prisoner }\end{array}$ \\
\hline & Reorganized & $\begin{array}{l}\text { Lt. Gen. Schuenemann } \\
\text { Prisoner }\end{array}$ \\
\hline XII Army Corps & Disbanded & $\begin{array}{l}\text { Lt. Gen. Vincenz } \\
\text { Mueller Prisoner }\end{array}$ \\
\hline $\begin{array}{l}\text { 18th Panzer } \\
\text { Grenadier Division }\end{array}$ & Reorganized & $\begin{array}{l}\text { Lt. Gen. Zutavern } \\
\text { Suicide }\end{array}$ \\
\hline $\begin{array}{l}\text { 57th Infantry } \\
\text { Division }\end{array}$ & Disbanded & $\begin{array}{l}\text { Maj. Gen. Trowitz } \\
\text { Prisoner }\end{array}$ \\
\hline $\begin{array}{l}\text { 267th Infantry } \\
\text { Division }\end{array}$ & Disbanded & $\begin{array}{l}\text { Lt. Gen. Drescher } \\
\text { Killed }\end{array}$ \\
\hline
\end{tabular}




\section{TABLE $X X X X \mid$}

THE DESTRUCTION OF ARMY GROUP CENTER (continued)

\section{Formations}

Destroyed

4TH ARMY:

9TH ARMY:

XXXV Army Corps Disbanded

6th Infantry Division Reorganized

45th Infantry

Division

134th Infantry

Division

296th Infantry

Division

383rd Infantry Disbanded

Division

XXXXI Panzer Corps

36th Infantry

Division
Reorganized Or

Disbanded Units

Reorganized

Disbanded

Reorganized

Reorganized

Reorganized
Commanders Killed Or Captured

Maj. Gen. Von

Erdmannsdorff,

Commandant of

Fortress Mogilev

Prisoner

Maj. Gen. Aurel

Schmidt, Senior

Engineer Commander

Prisoner

Lt. Gen. Von Luetzow

Prisoner

Lt. Gen. Heyne

Prisoner

Maj. Gen. Engel

Prisoner

Lt. Gen. Philipp

Suicide

Lt. Gen. Hoffmeister

Prisoner

Maj. Gen. Conrady

Prisoner

Maj. Gen. Hamann,

Commandant of

Bobruisk Prisoner 
TABLE $X X X X \mid$

THE DESTRUCTION OF ARMY GROUP CENTER (continued)

\begin{tabular}{lll}
\hline $\begin{array}{l}\text { Formations } \\
\text { Destroyed }\end{array}$ & $\begin{array}{l}\text { Reorganized Or } \\
\text { Disbanded Units }\end{array}$ & $\begin{array}{l}\text { Commanders } \\
\text { Killed Or Captured }\end{array}$ \\
\hline $\begin{array}{l}\text { 2ND ARMY: } \\
\text { Corps Detachment E }\end{array}$ & Disbanded & \\
& & 6 CORPS \\
TOTAL CORPS DESTROYED: & 28 DIVISIONS \\
TOTAL DIVISIONS DESTROYED: & 32 COMMANDERS \\
TOTAL COMMANDERS KILLED OR CAPTURED: & \\
\hline
\end{tabular}

Source: Carell, pp. 508-509, Kurt Mehner, Die Geheimen Tagesberichte Der Deutschen Wehrmachtfuehrung Im Zweiten Weltkrieg 1939-1945 Vol. 10, pp. 502, 509-523; Mehner, GHTBDW Vol. 11, pp. 337-338; Kriegstagebuch (KTB) Heeresgruppe Mitte, Fuehrungsabteilung, Kriegsgliederung NAMP T-311, Roll 228; Rolf Hinze, Das Ostfront Drama 1944: Rueckzugskaempfe Heeresgruppe Mitte, p. 426; Teske, p. 216; OKW/Org. Abt. und Heerespersonalabt., Zusammenstellung der in diesem Kriege gefallenen, toetlich, verungluecten, verstorbenen, vermissten und im Gefangenschaft geratenen Generale Flensburg 5 June 1945 NAMP T-77, Roll 785; Generalstab des Heeres, Organisationabteilung, Uebersicht ueber die grossen Verbaende des Heeres, der Waffen-SS und der Fallschirm-truppen, Stand 30.7.44 NAMP T-78, Roll 413; Generalstab des Heeres, Organisationabteilung, Uebersicht ueber Aufgeloeste Division 1944 NAMP T-78, Roll 410; Burkhart Mueller-Hillebrand, Das Heer 1933-1945 Vol. 3, p. 241; Mitcham, pp. 41-471; OKH Allgemeines Heeresamt, Abwicklungsstab, $\mathrm{H}$ 41/7-H 41/12 NAMP T-78, Roll 139. German Army files $H \quad 41 / 7-H \quad 41 / 12$ contain the reports of units destroyed in the Soviet summer offensive of 1944 against Army Group Center. 


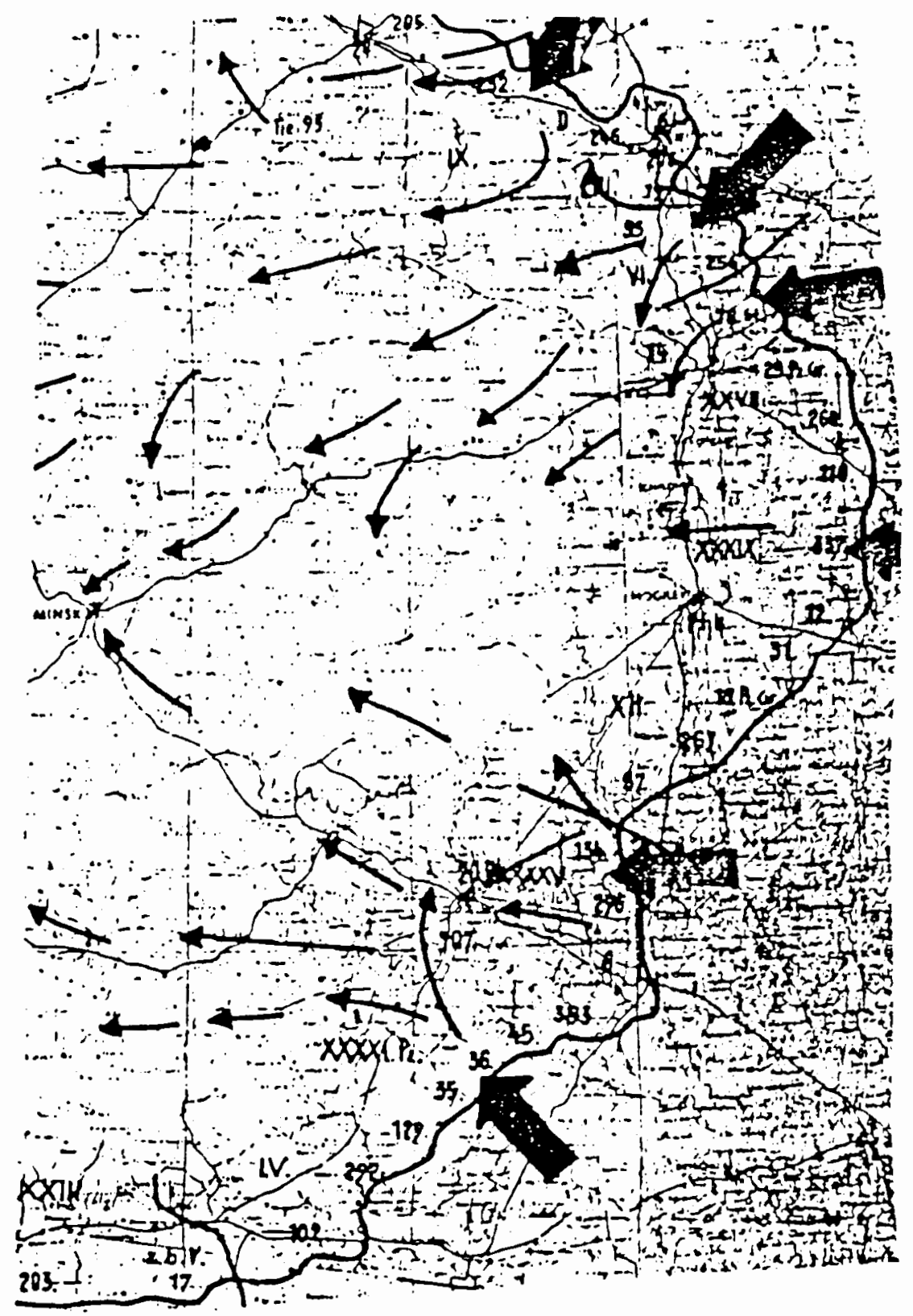

Figure 63. The Six Staggered Offensives Of The Red Army During "Operation Bagration." Source: AOK 4, Beibringung Von Unterlagen ueber die Vorgaenge bei den Abgesprengten Verbaenden im Sommer 1944 National Archives Microfilm Publication T-312, Roll 244. 


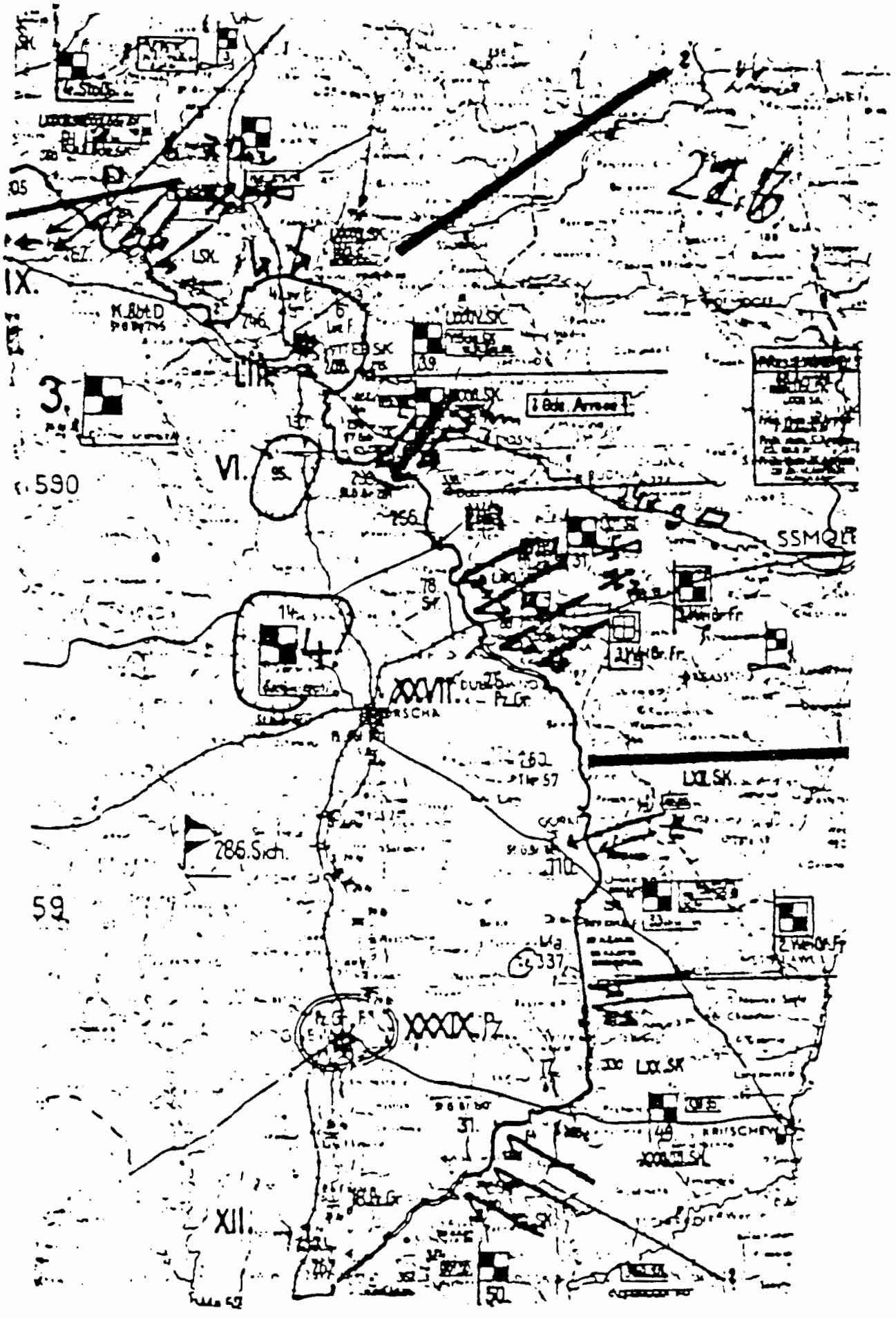

Figure 64. Army Group Center Under Attack, June 22, 1944. Source: OKH, Der Grosse Durchbruch Bei Hgr. Mitte Von 21.6.-10.8.44., National Archives Microfilm Publication T-78, Roll 136. 


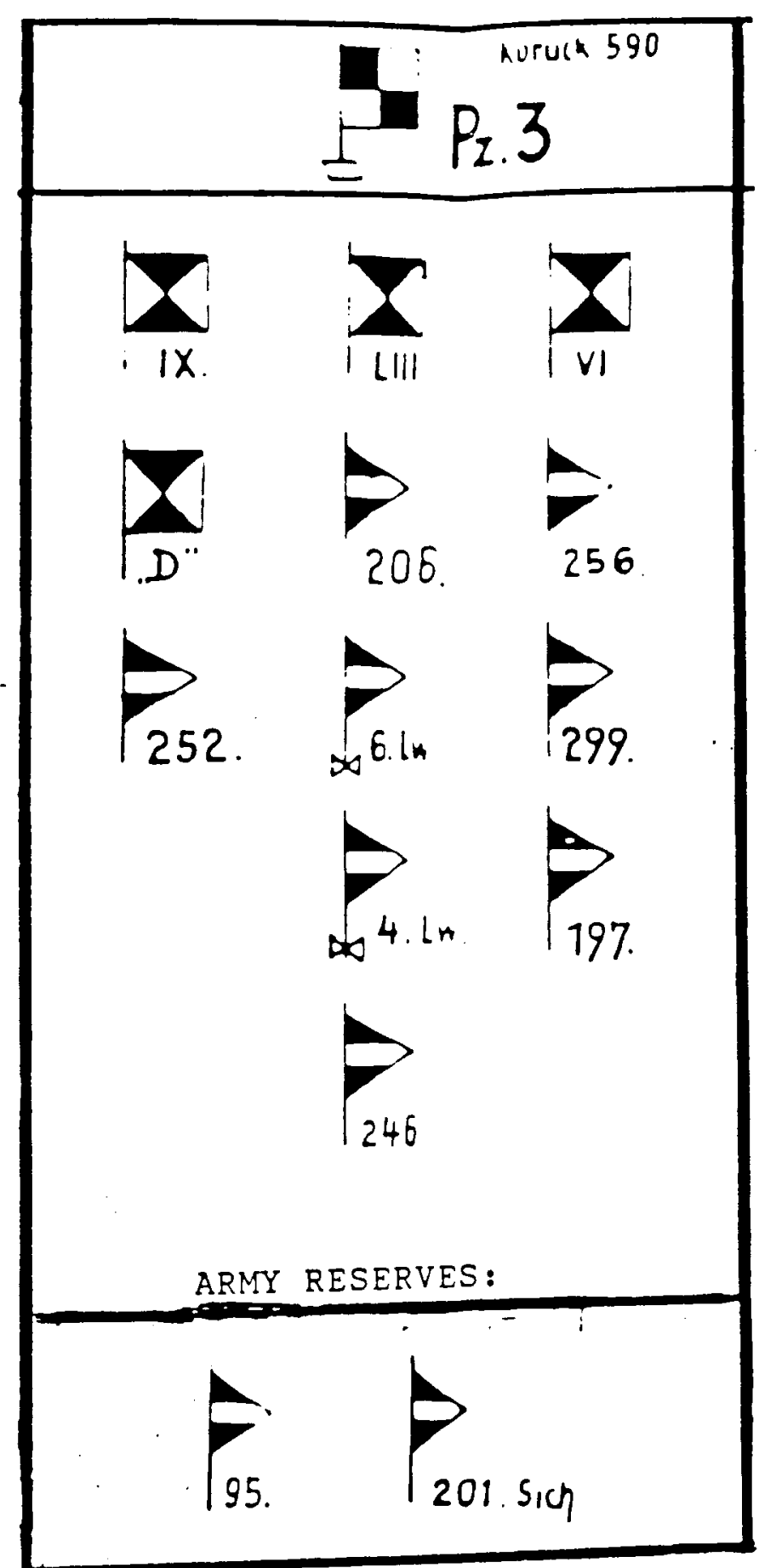

Figure 65. 3rd Panzer Army Order Of Battle, June 1944. Source: Kriegstagebuch der Heeresgruppe Mitte Fuehrungsabteilung, Gliederung der Grossen Verbaende 4.6.44., National Archives Microfilm Publication T-311, Roll 228. 


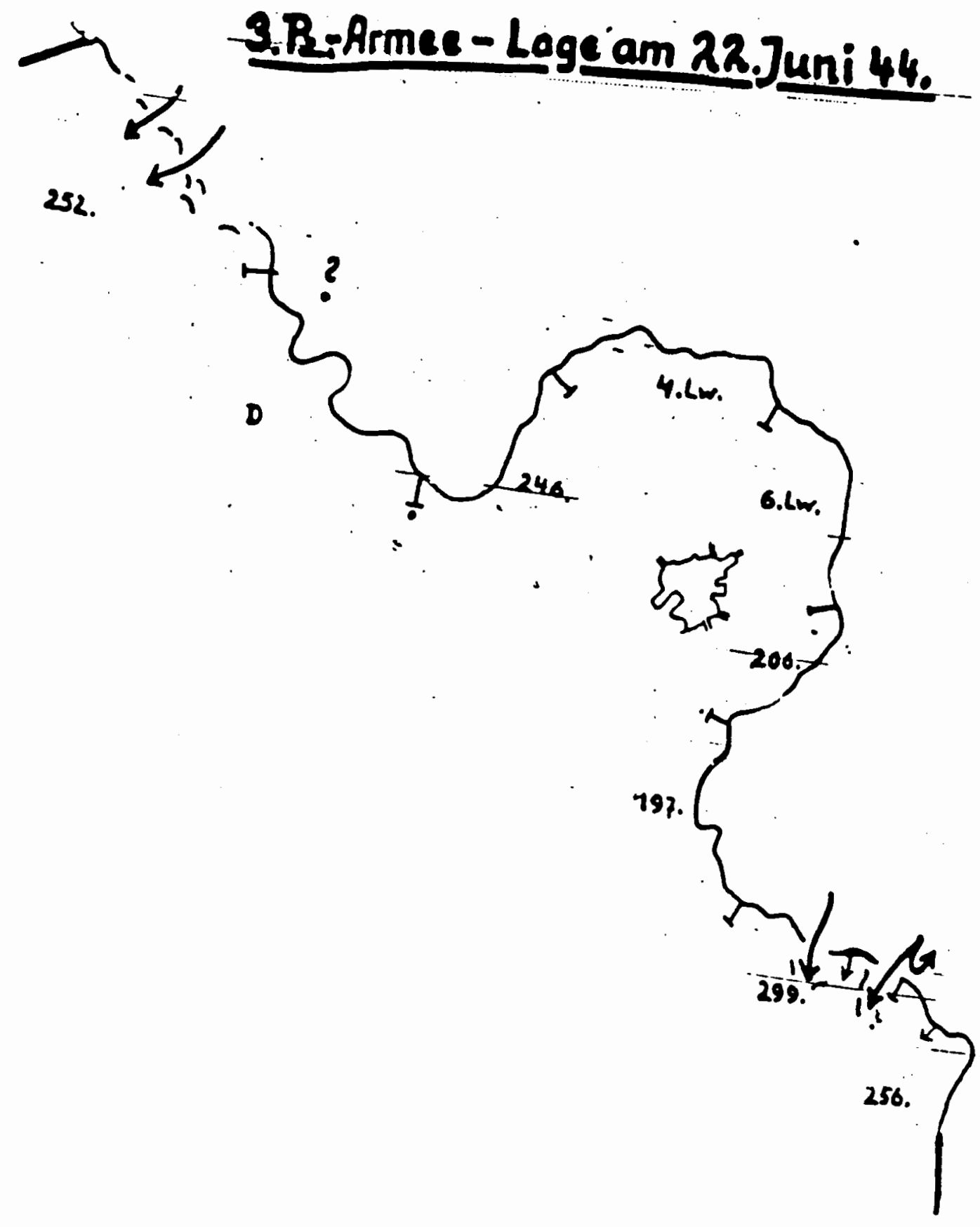

Figure 66. 3rd Panzer Army - Situation On June 22, 1944. Source: Heeresgruppe Mitte, 3 Panzer ArmeeLage am 22. Juni 44. National Archives Microfilm Publication T-311, Roll 219. 


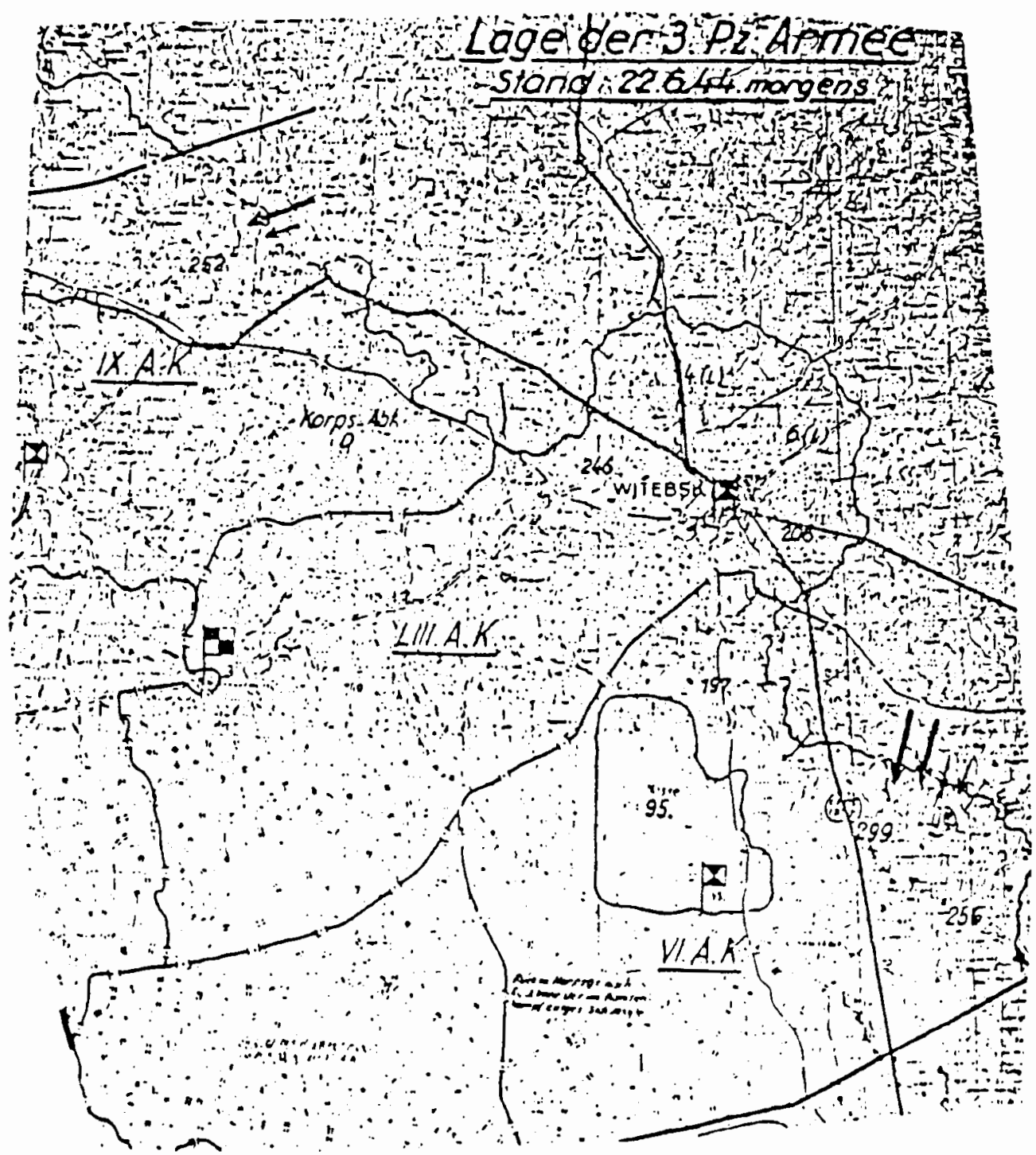

Figure 67. The Situation Of The 3rd Panzer Army On June 22, 1944. Source: Pz.A.O.K. 3, Lage der 3. Pz. Armee, Stand: 23.6.44. morgens National Archives Microfilm Publication T-313, Roll 318. 


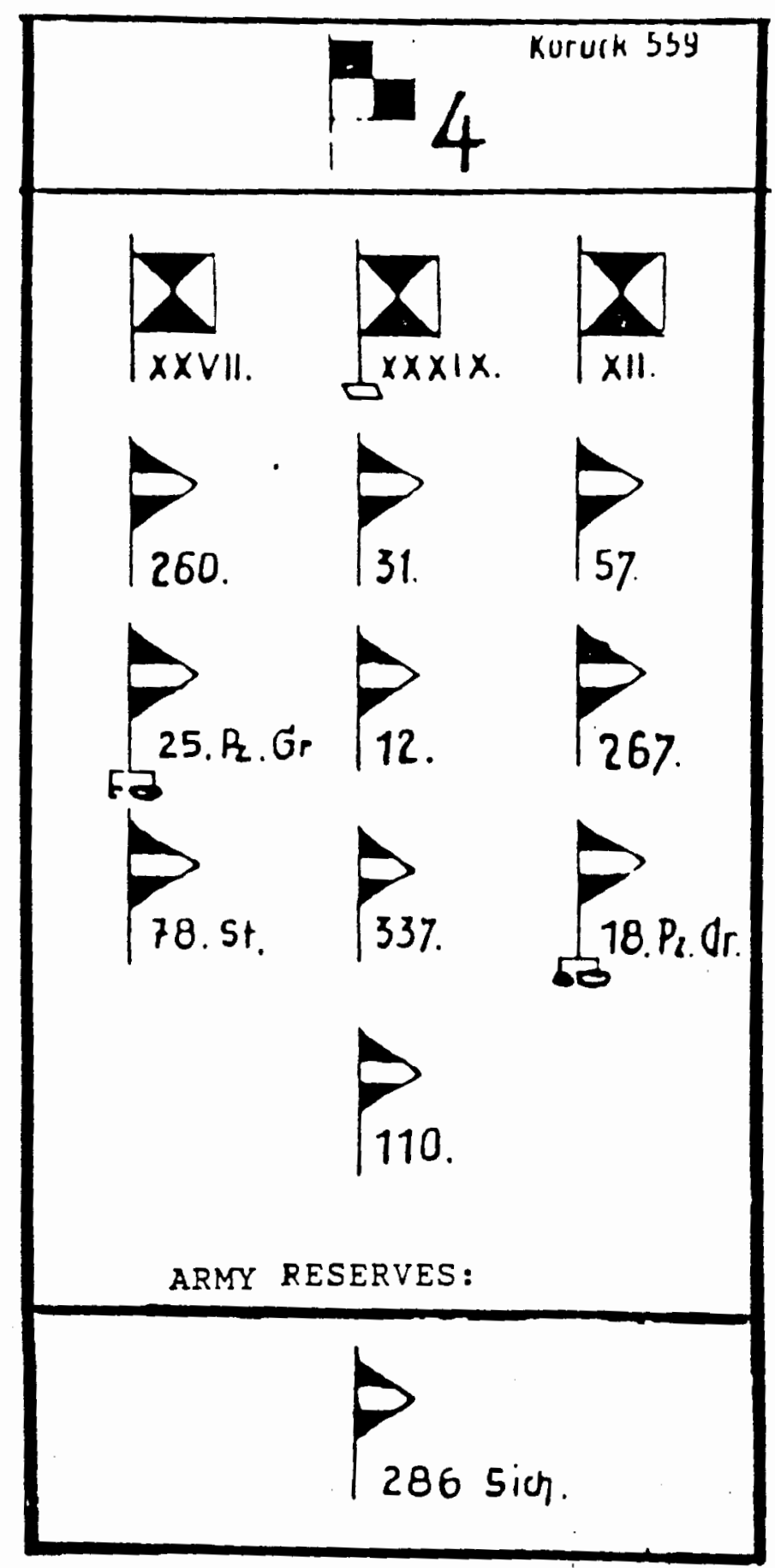

Figure 68. 4th Army Order Of Battle, June 1944. Source: Kriegstagebuch der Heeresgruppe Mitte Fuehrungsabteilung, Gliederung der Grossen Verbaende 4.6.44., National Archives Microfilm Publication T-311, Roll 228. 


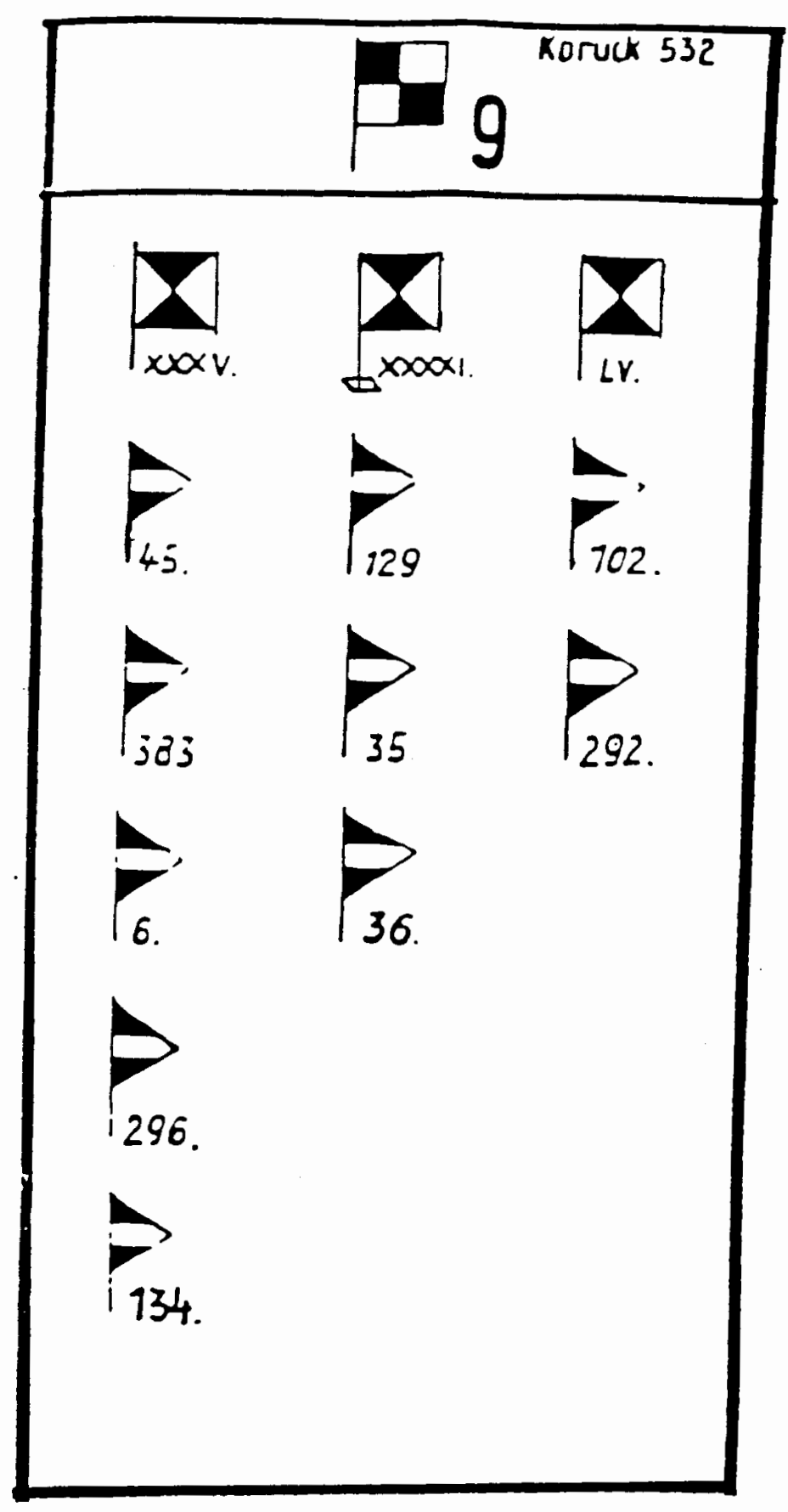

Figure 69. 9th Army Order Of Battle, June 1944. Source: Kriegstagebuch der Heeresgruppe Mitte Fuehrungsabteilung, Gliederung der Grossen Verbaende 4.6.44., National Archives Microfilm Publication T-311, Roll 228. 


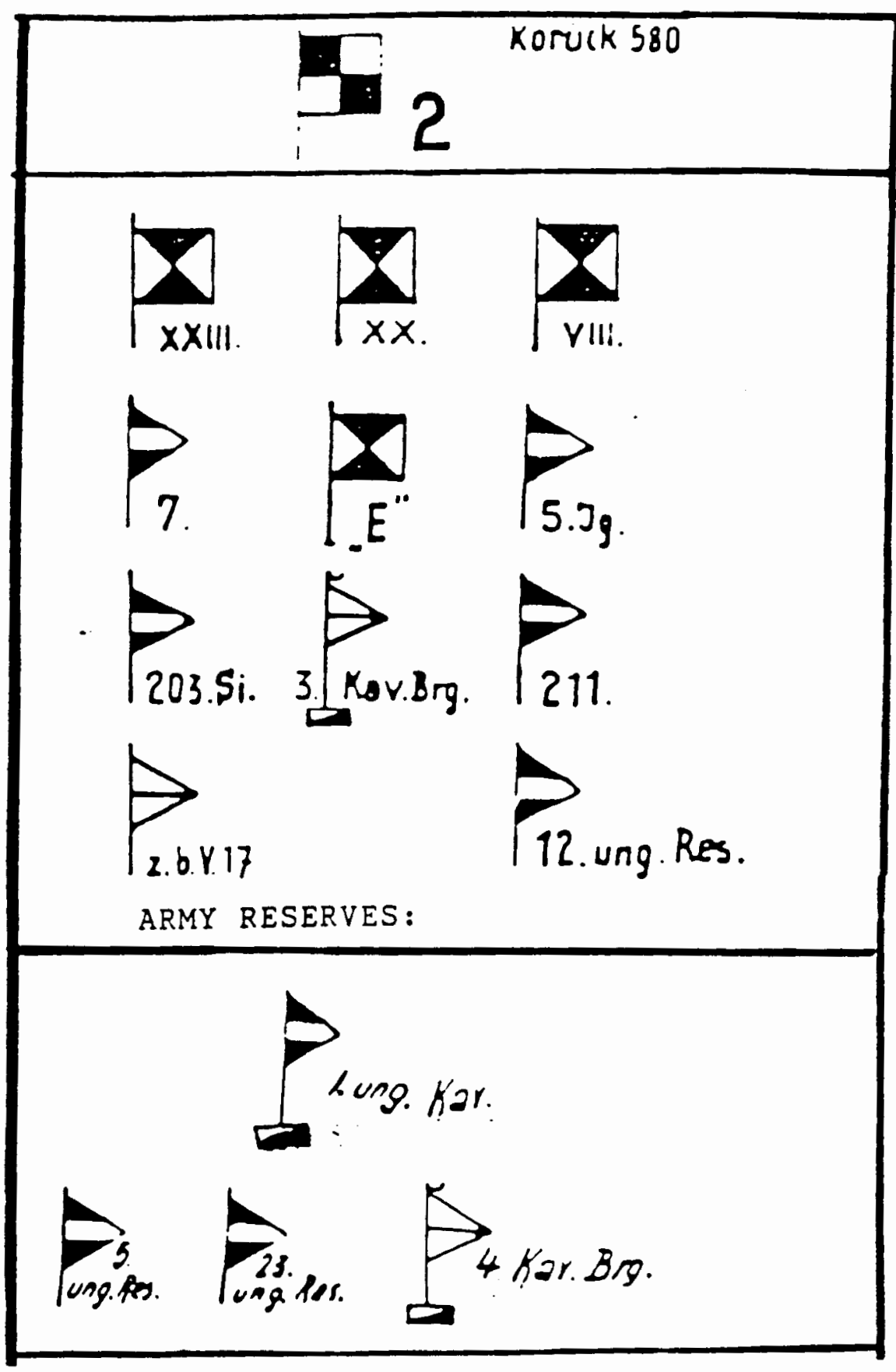

Figure 70. 2nd Army Order Of Battle, June 1944. Source: Kriegstagebuch der Heeresgruppe Mitte Fuehrungsabteilung, Gliederung der Grossen Verbaende 4.6.44. National Archives Microfilm Publication T-311, Roll 228. 


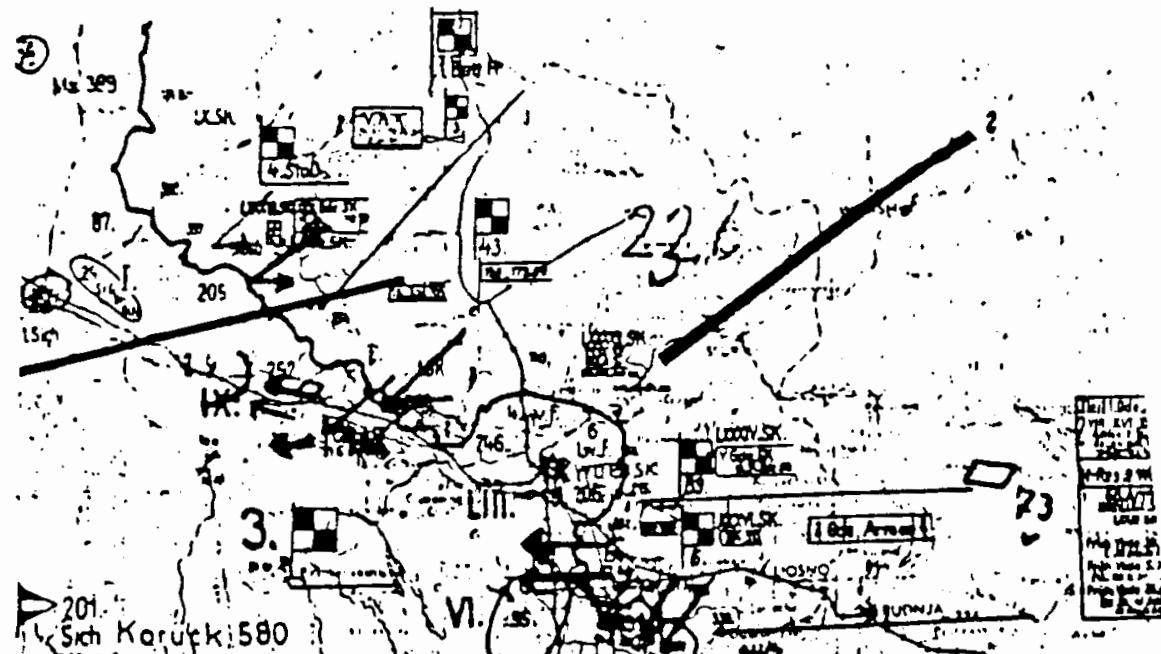

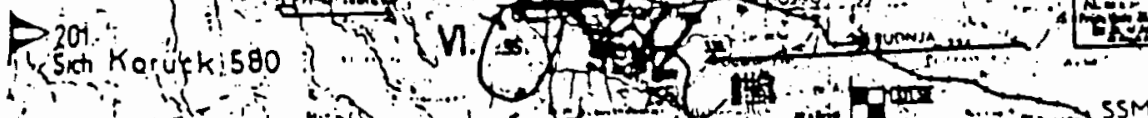

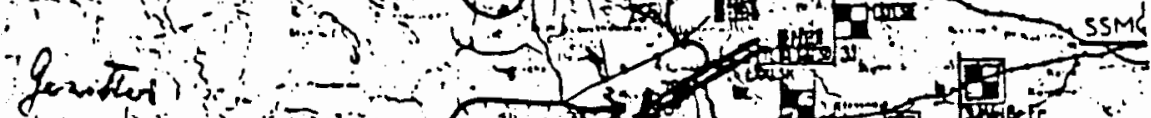
6.

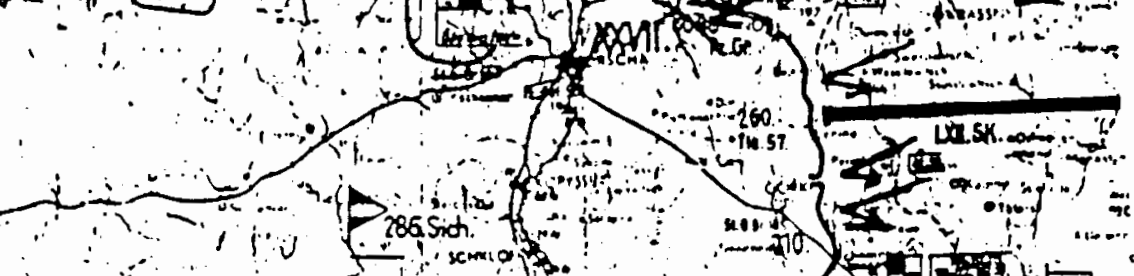
Kor $i^{2}-1$ if

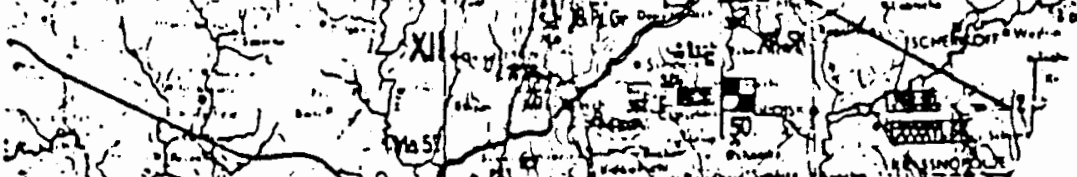
1 320 \%

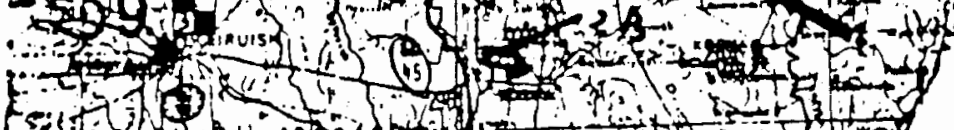
sit

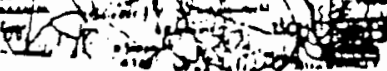

Figure 71. Army Group Center, June 23, 1944. Source: $\mathrm{OKH}$, Der Grosse Durchbruch Bei Hgr. Mitte Von 21.6.10.8.44., National Archives Microfilm Publication T-78, Roll 136. 


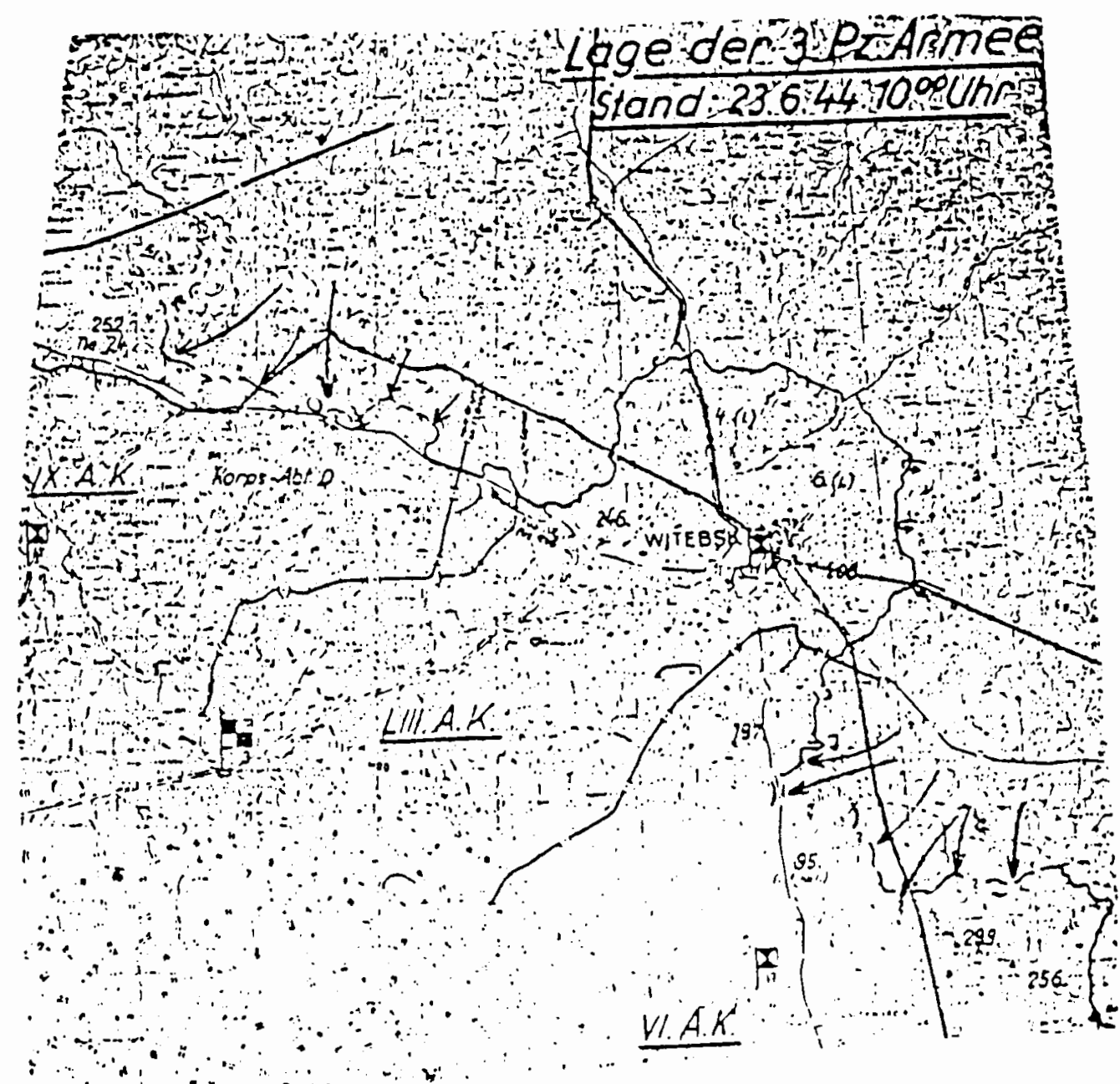

Figure 72. The Situation Of The 3rd Panzer Army On June 23, 1944 At 1000 hrs. Source: Pz.A.O.K. 3, Lage der 3. Pz. Armee, Stand: 23.6.44. 1000 Uhr National Archives Microfilm Publication T-313, Roll 318. 


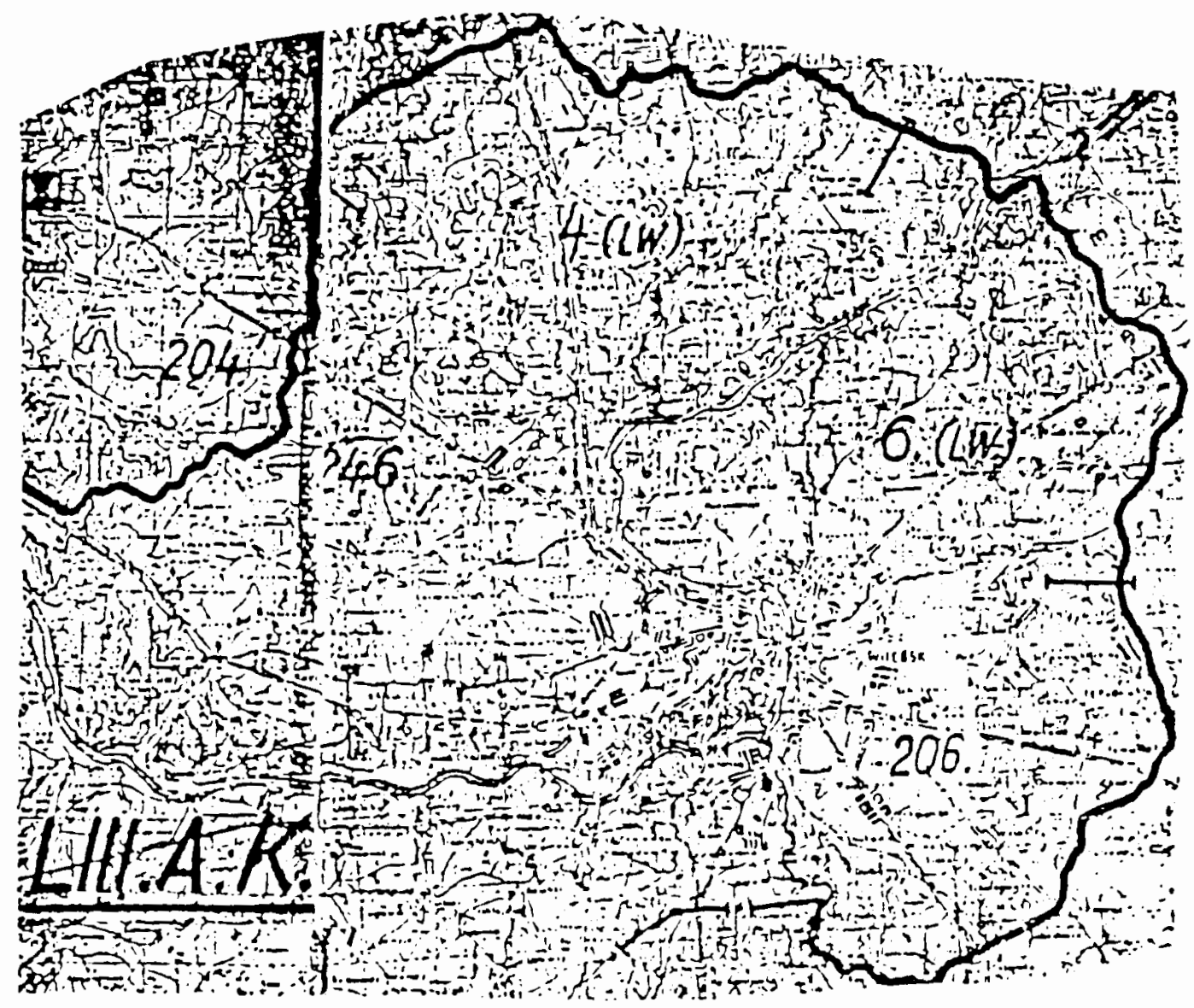

Figure 73. Vitebsk, June 23, 1944. Source: Pz.A.O.K. 3, Witebsk. Juni 23, 1944 National Archives Microfilm Publication T-313, Roll 309. 
507

$\downarrow$ 3.P2.-Armee-Logeam 23.Juni.44.

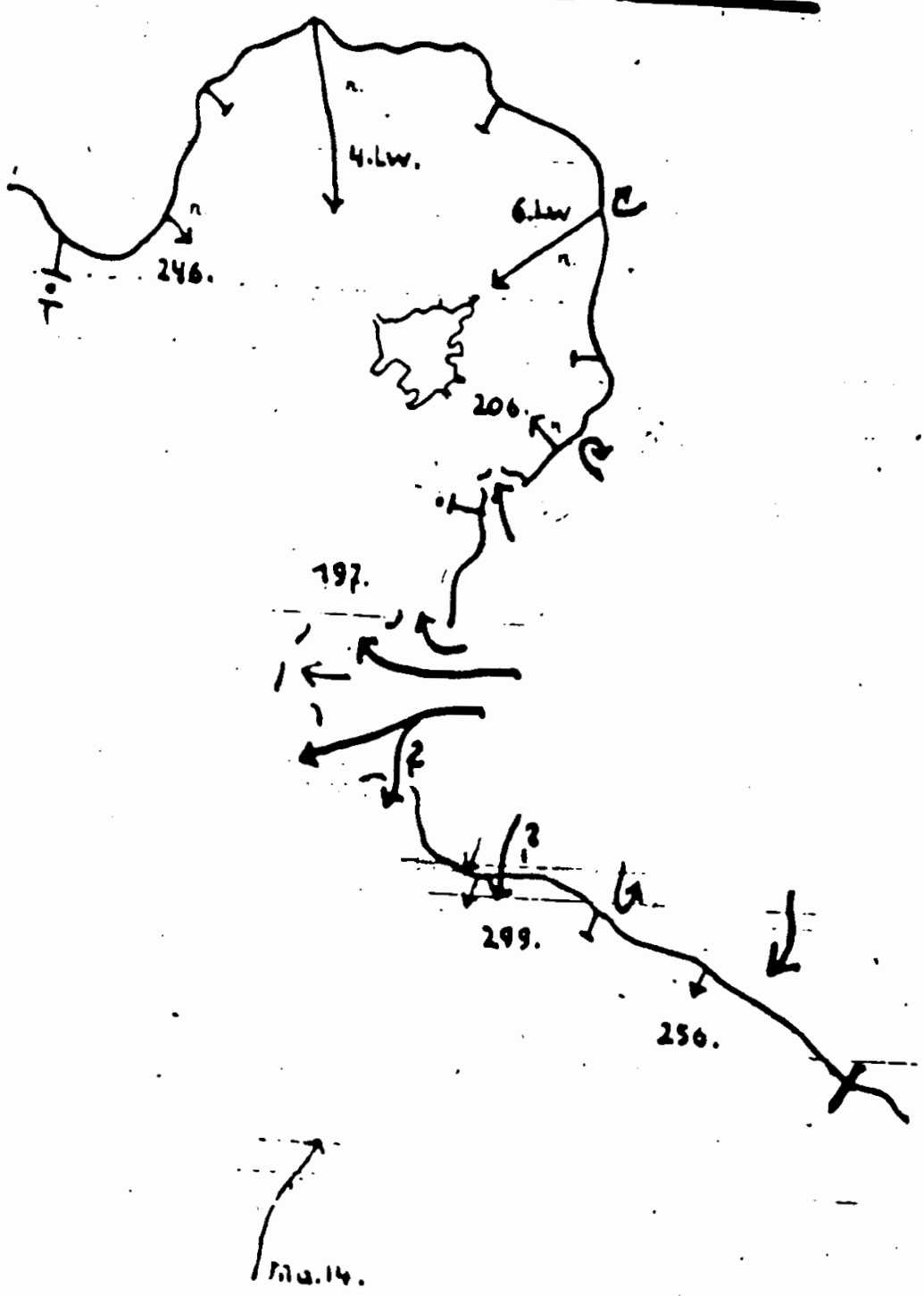

Figure 74. 3rd Panzer Army - Situation On June 23, 1944. Source: Heeresgruppe Mitte, 3 Panzer ArmeeLage am 23. Juni 44. National Archives Microfilm Publication T-311, Roll 219. 


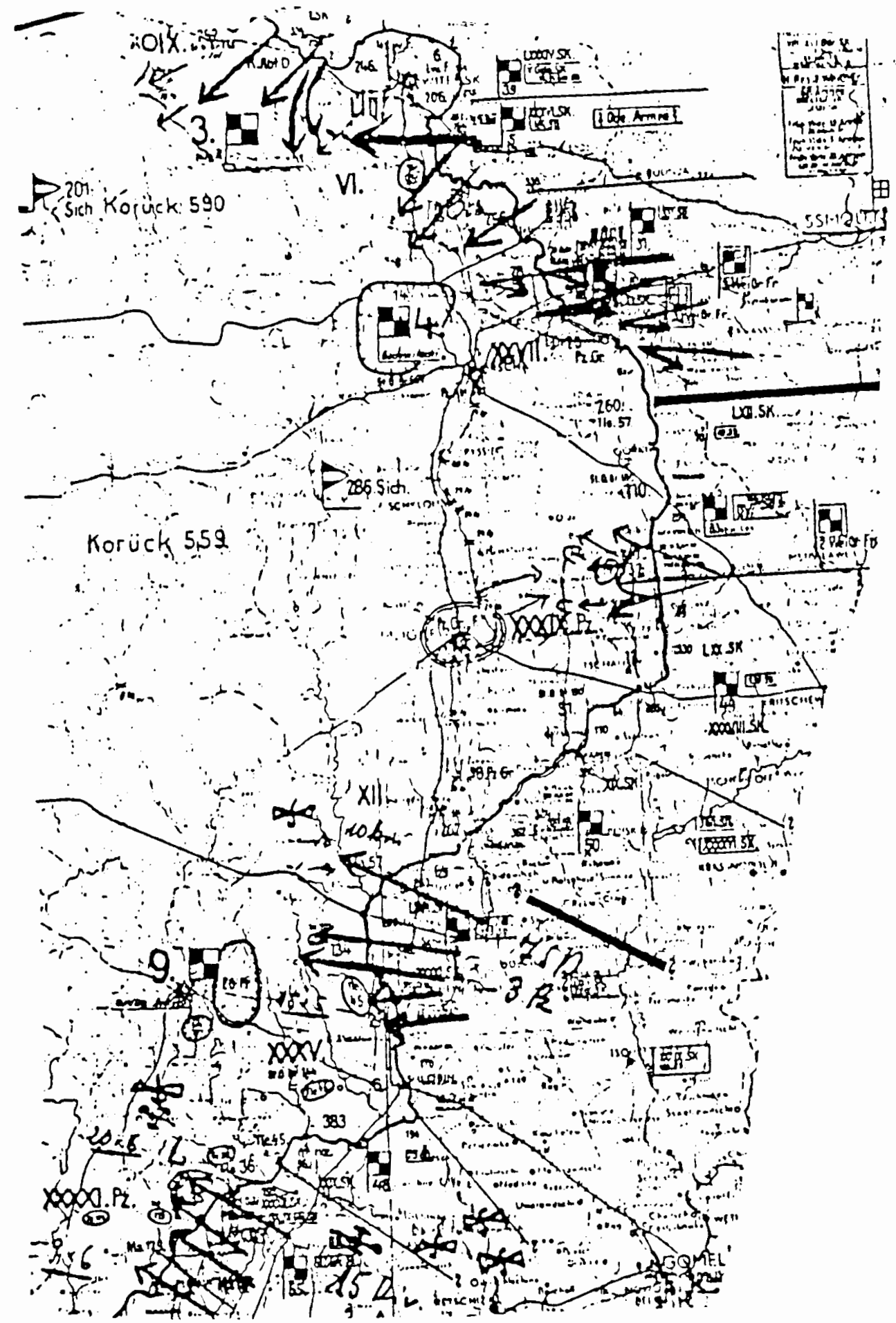

Figure 75. Army Group Center, June 24, 1944. Source: $\mathrm{OKH}$, Der Grosse Durchbruch Bei Hgr. Mitte Von 21.6.10.8.44., National Archives Microfilm Publication T-78, Roll 136. 


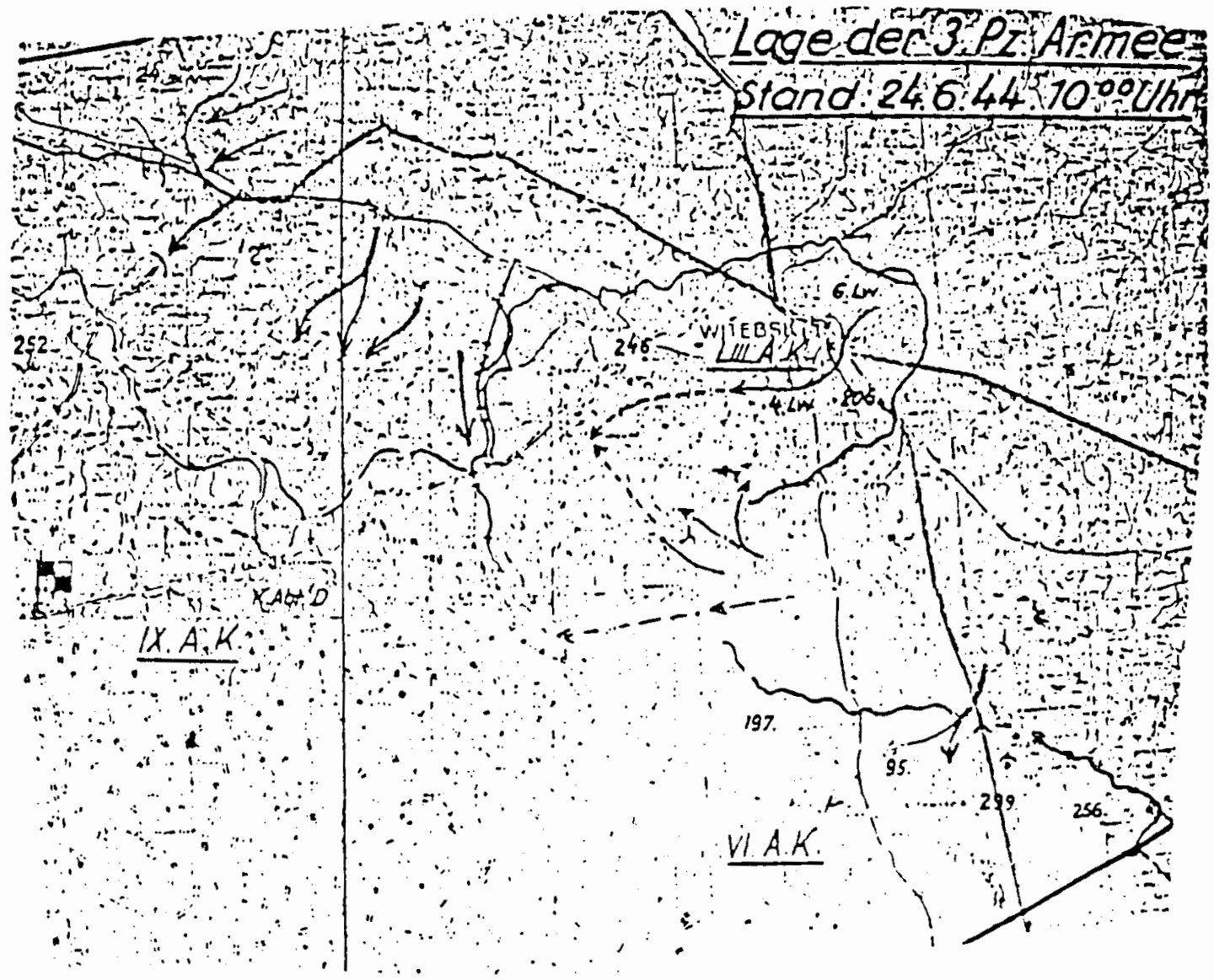

Figure 76. The Situation Of The 3rd Panzer Army On June 24, 1944 At 1000 hrs. Source: Pz.A.O.K. 3, Lage der 3. Pz. Armee, Stand: 24.6.44. 1000 Uhr National Archives Microfilm Publication T-313, Roll 318. 
510

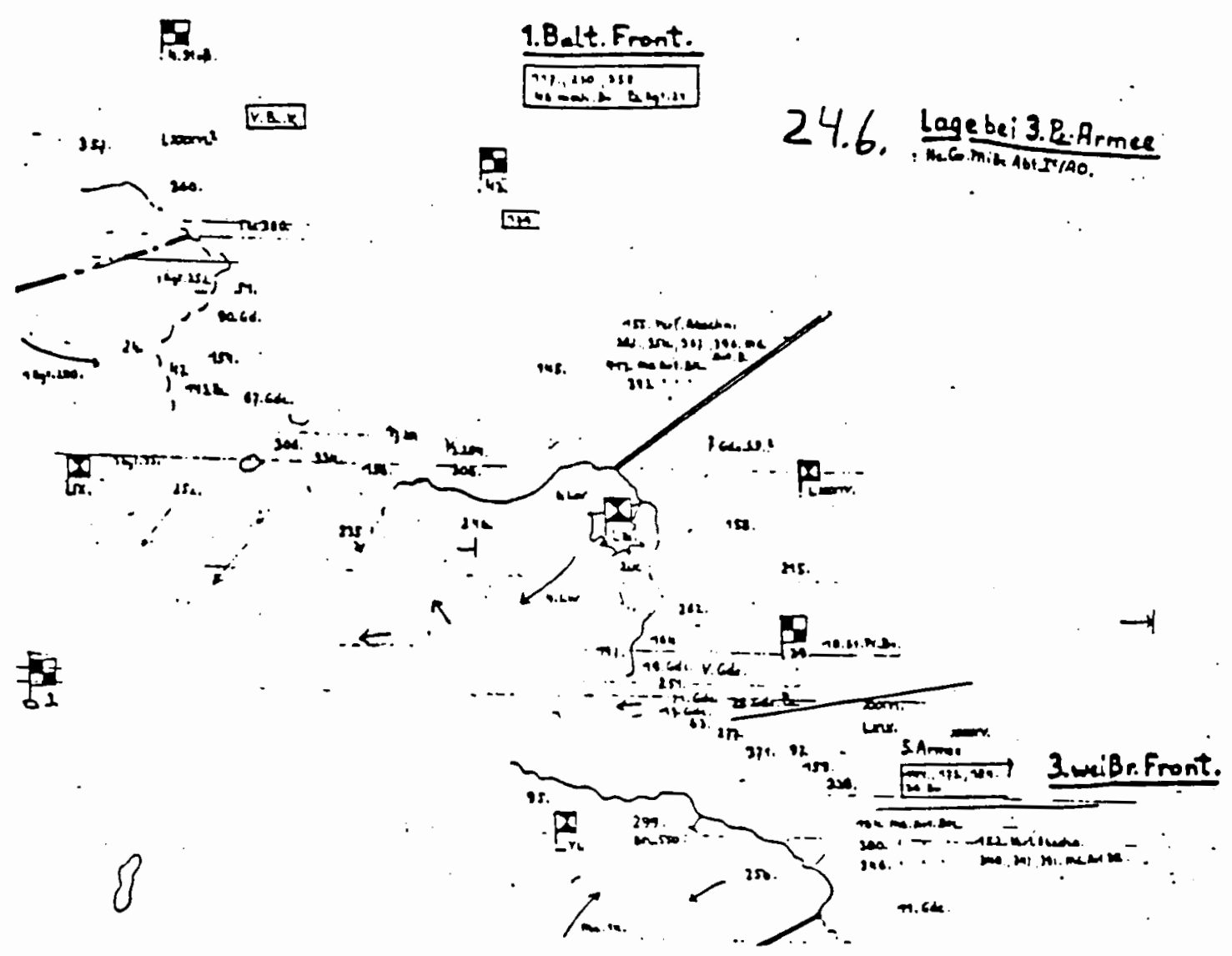

Figure 77. The Hole Between LIII And VI Army Corps, June 24, 1944. Source: Heeresgruppe Mate, Lade bel 3. Panzer Armed, 24.6.44., National Archives Microfilm Publication T-311, Roll 219. 


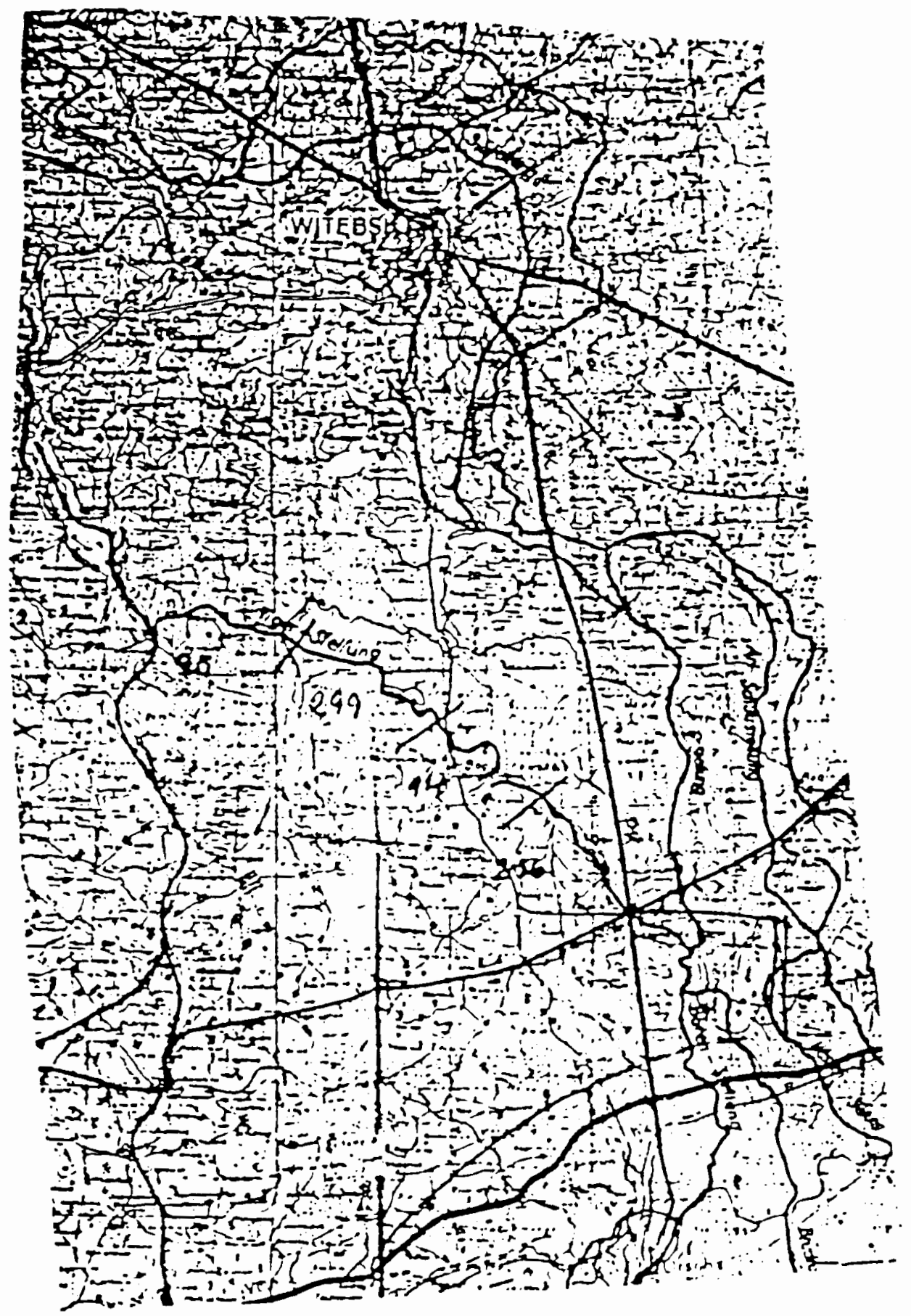

Figure 78. The Tiger Line South Of Vitebsk. Source: A.O.K. 4, la. Kartenband 1, Anlagen zum KTB Nr. 24 National Archives Microfilm Publication T-312, Roll 252. 


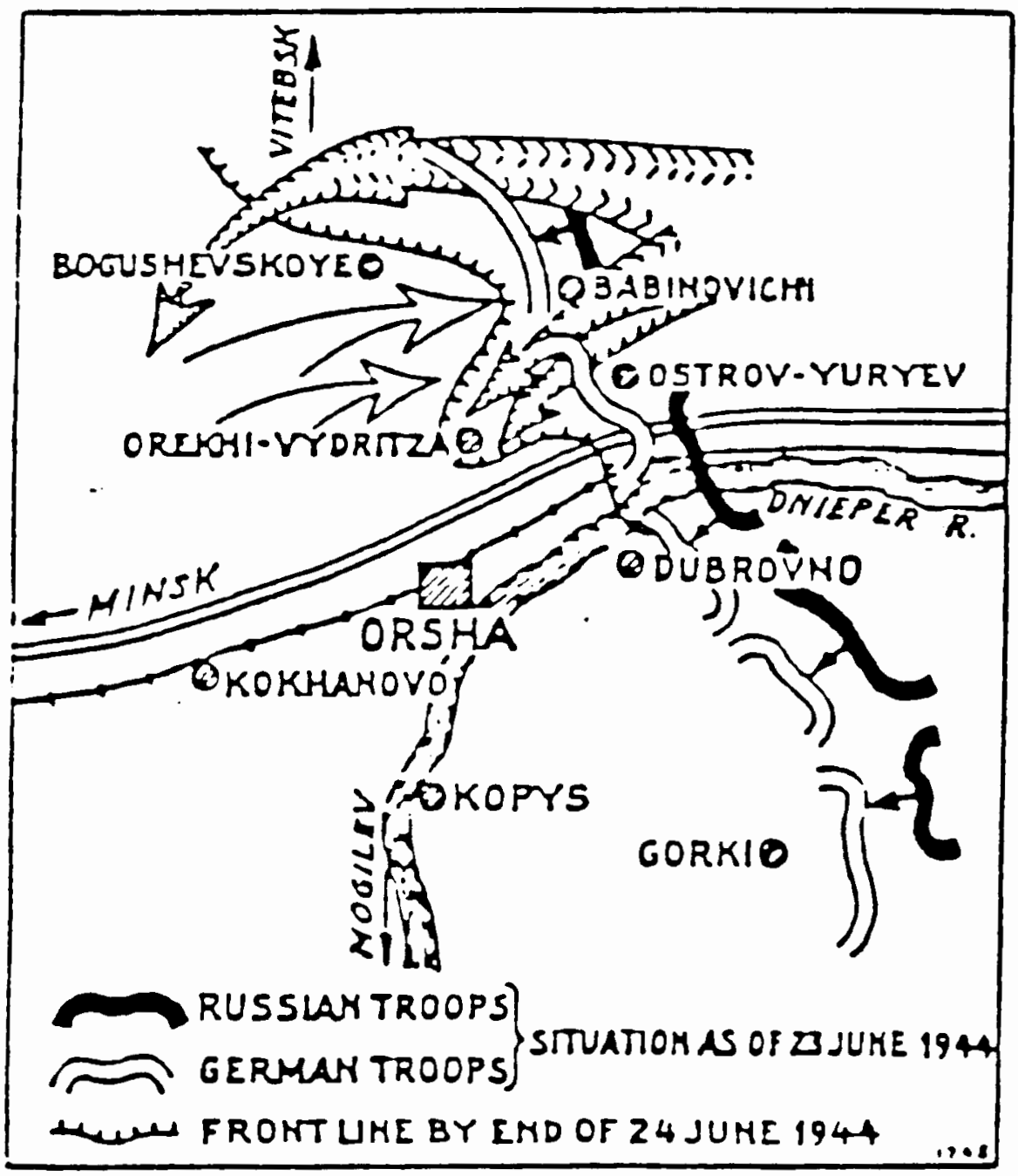

Figure 79. The Soviet Breakthrough On The Left Flank Of The 4th Army, June 24, 1944. Source: Major D. Saulin, "The Battle of Orsha," Krasnaia Zvezda (Red Star) 11 October 1944 as translated in Military Review Vol. 25, No. 2, May 1945, p. 122. 


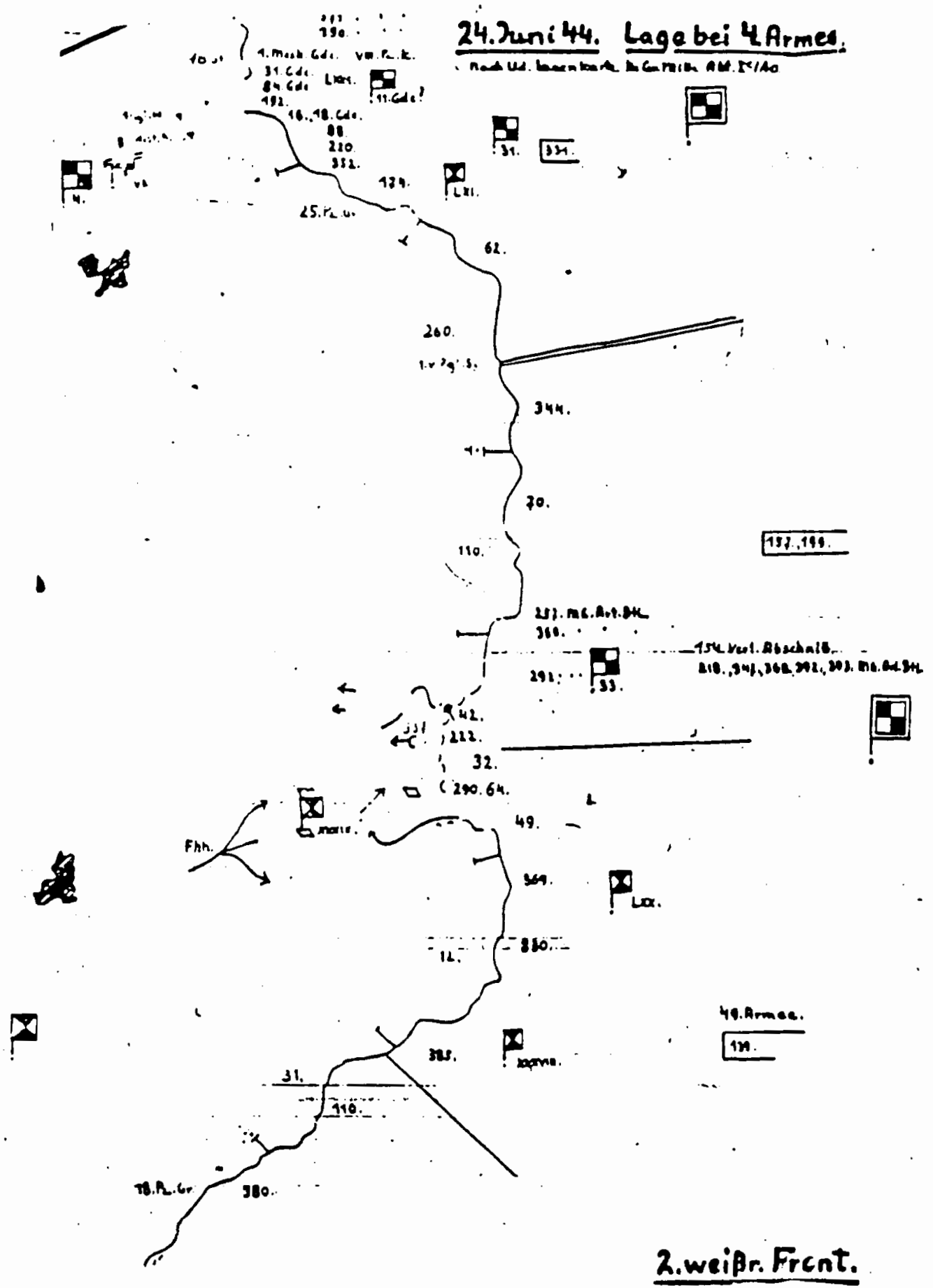

Figure 80. The Hole Between The 337th And 12th Infantry Divisions, June 24, 1944. Source: Heeresgruppe Mitte, Lage bei 4. Armee, 24 Juni 44. National Archives Microfilm Publication T-311, Roll 219. 


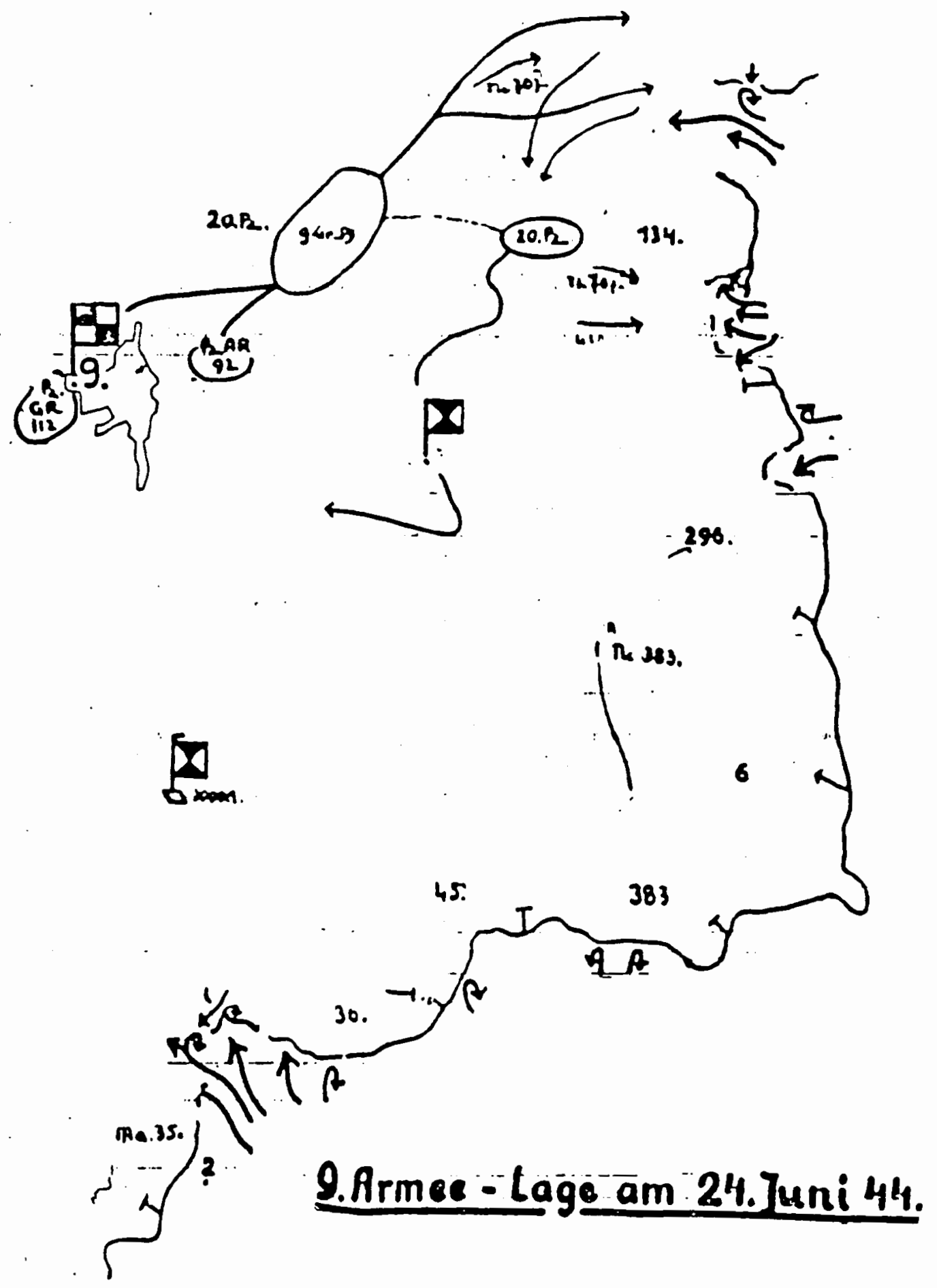

Figure 81. The Soviet Breakthroughs On The 9th Army Front, June 24, 1944. Source: Heeresgruppe Mitte, 9 . Armee - Lage am 24.Juni 44. National Archives Microfilm Publication T-311, Roll 219. 


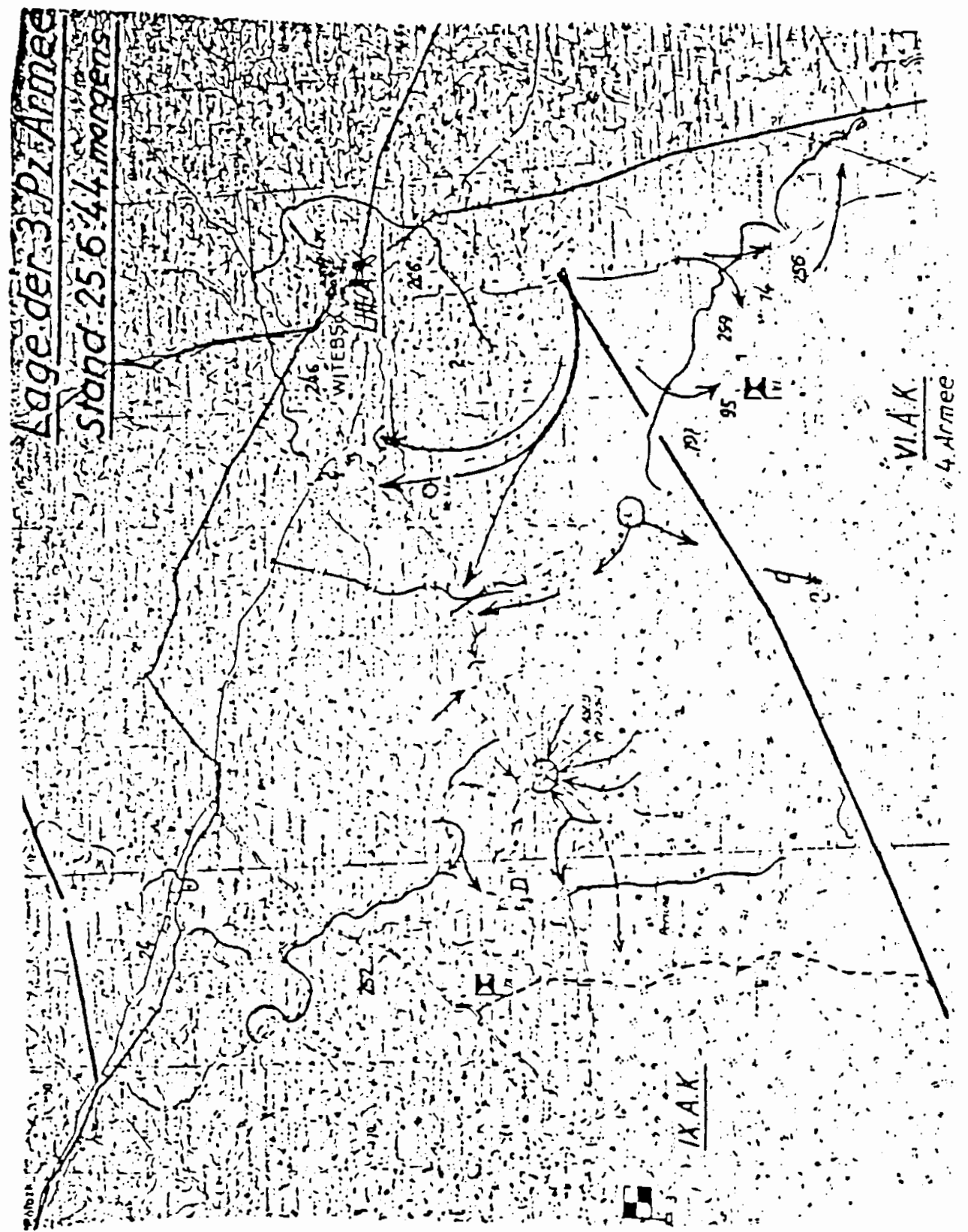

Figure 82. The Situation Of The 3rd Panzer Army On June 22, 1944. Source: Pz.A.O.K. 3, Lage der 3. Pz. Armee, Stand: 25.6.44. 1000 morgens National Archives Microfilm Publication T-313, Roll 318. 


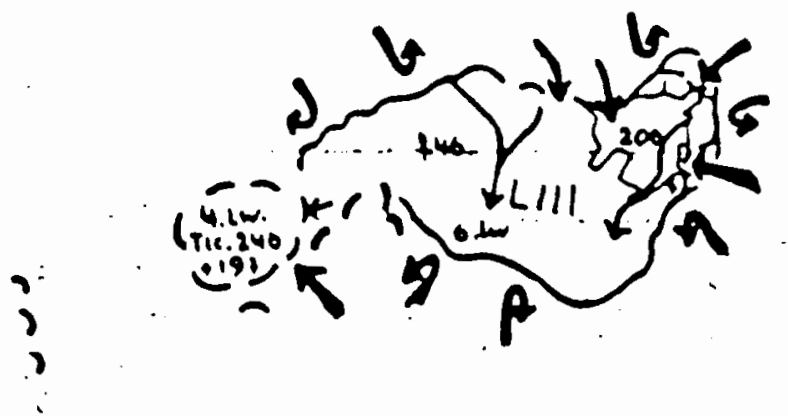

$?$

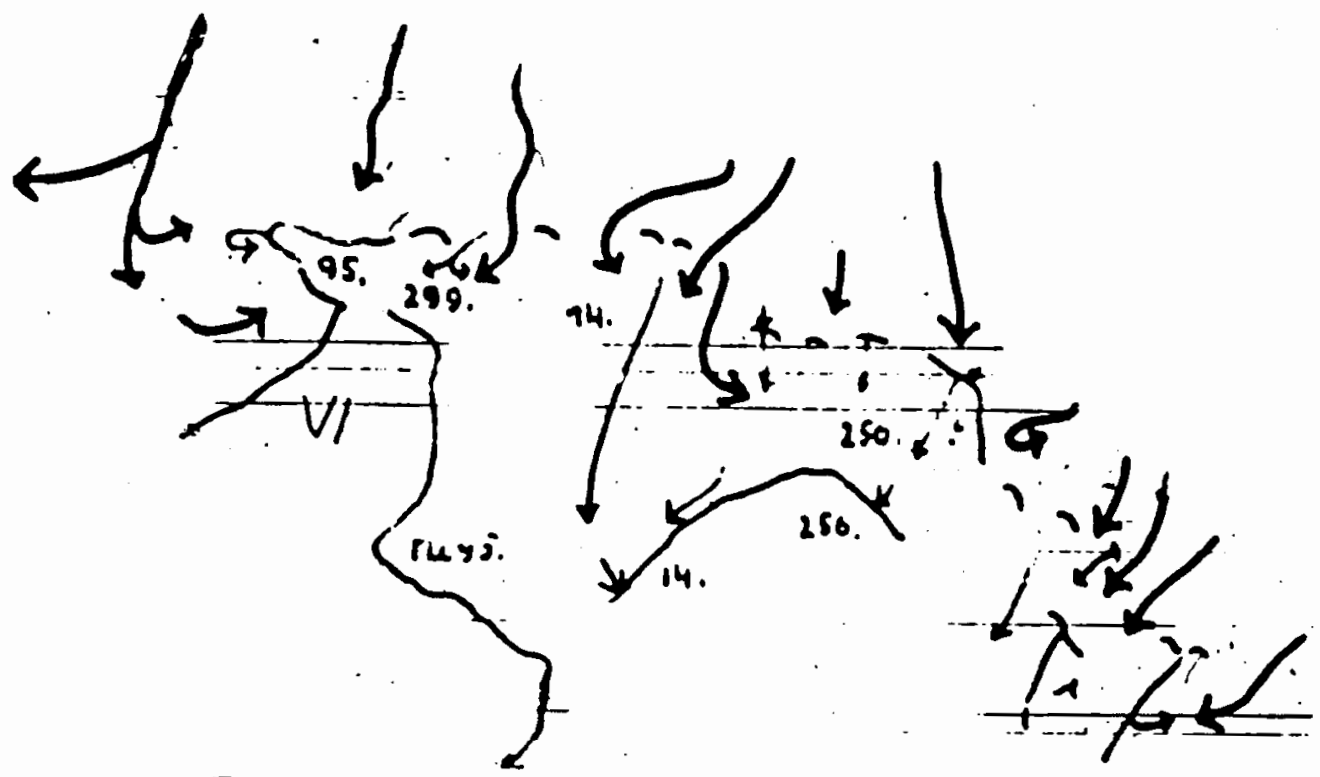

\section{P2.-Armee -Lage am 25.]uni 44.}

Figure 83. The Encirclement Of The LIII Army Corps, June 25, 1944. Source: Heeresgruppe Mitte, 3. Panzer Armee - Lage am 25.Juni 44. National Archives Microfilm Publication T-311, Roll 219. 


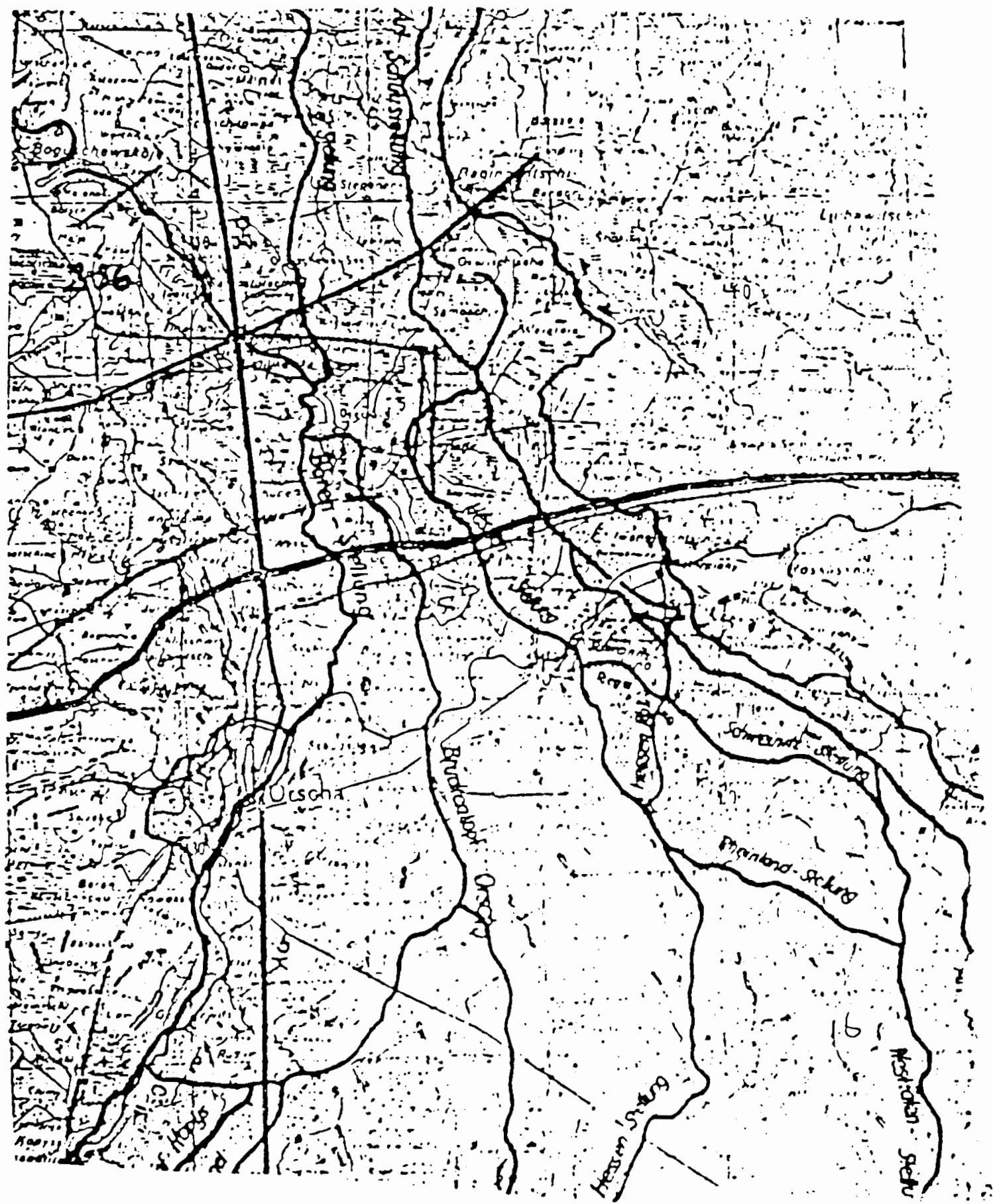

Figure 84. The Hessen and Bear Defensive Lines. Source: A.O.K. 4, la. Kartenband 1. Anlagen zum KTB Nr. 24 National Archives Microfilm Publication T-312, Roll 252. 
ailec.

For kolskiso
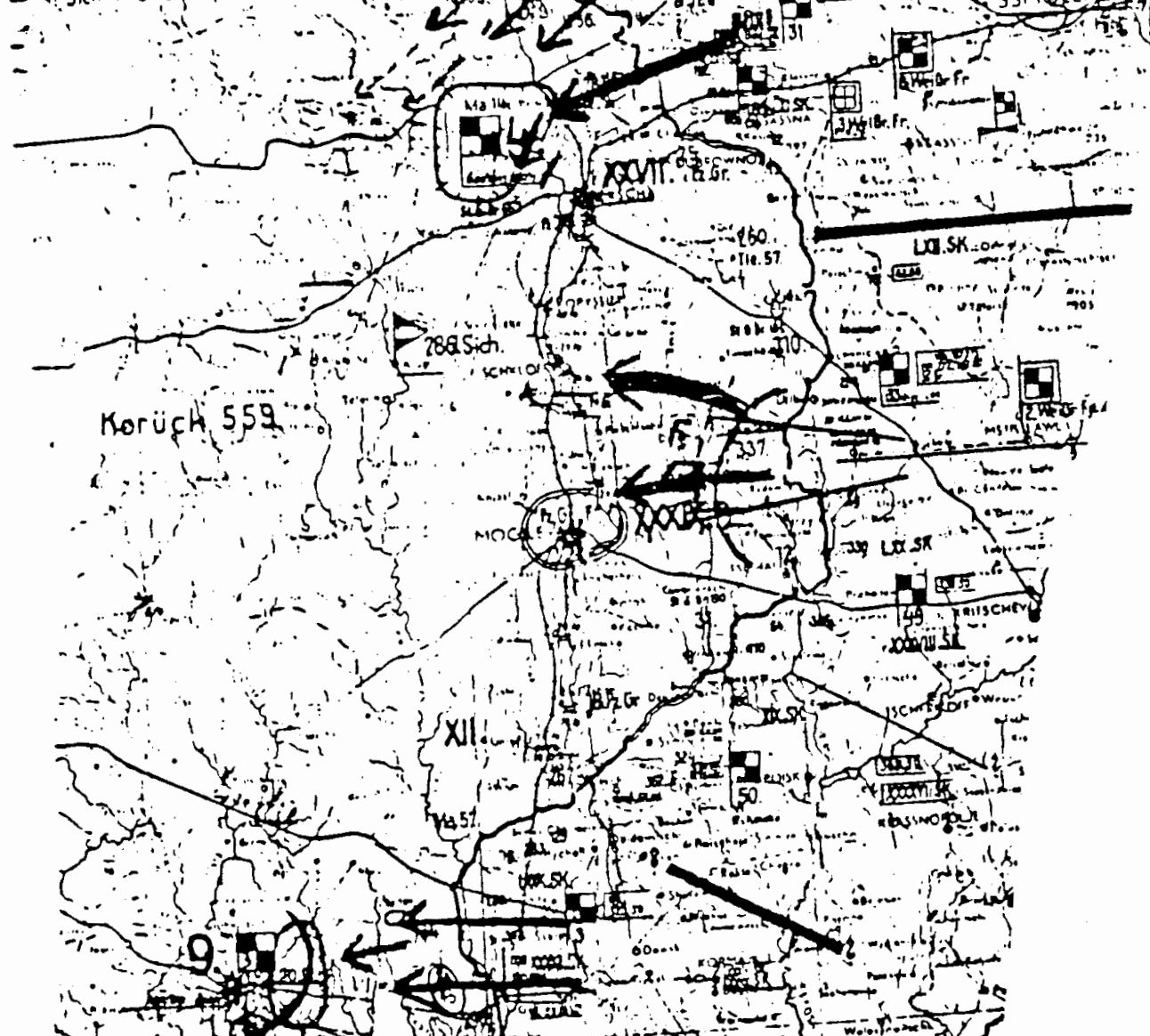

i 0 of

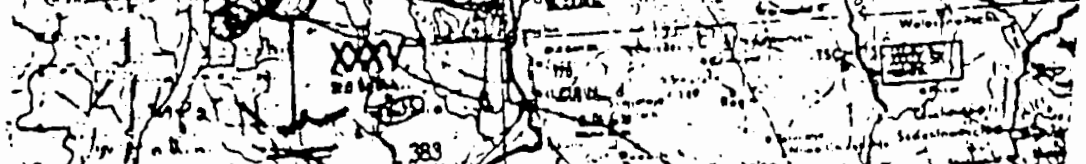

-2.

Wo6

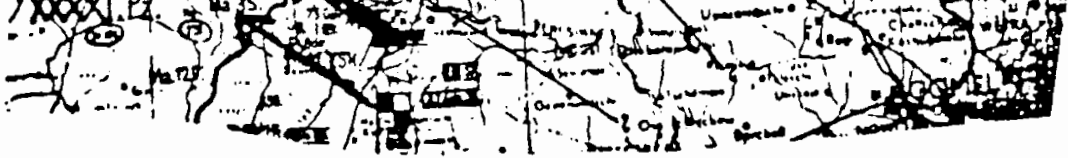

Figure 85. Army Group Center, June 25, 1944. Source:

$\mathrm{OKH}$, Der Grosse Durchbruch Bei Hgr. Mitte Von 21.6.-

10.8.44., National Archives Microfilm Publication T-78,

Roll 136. 


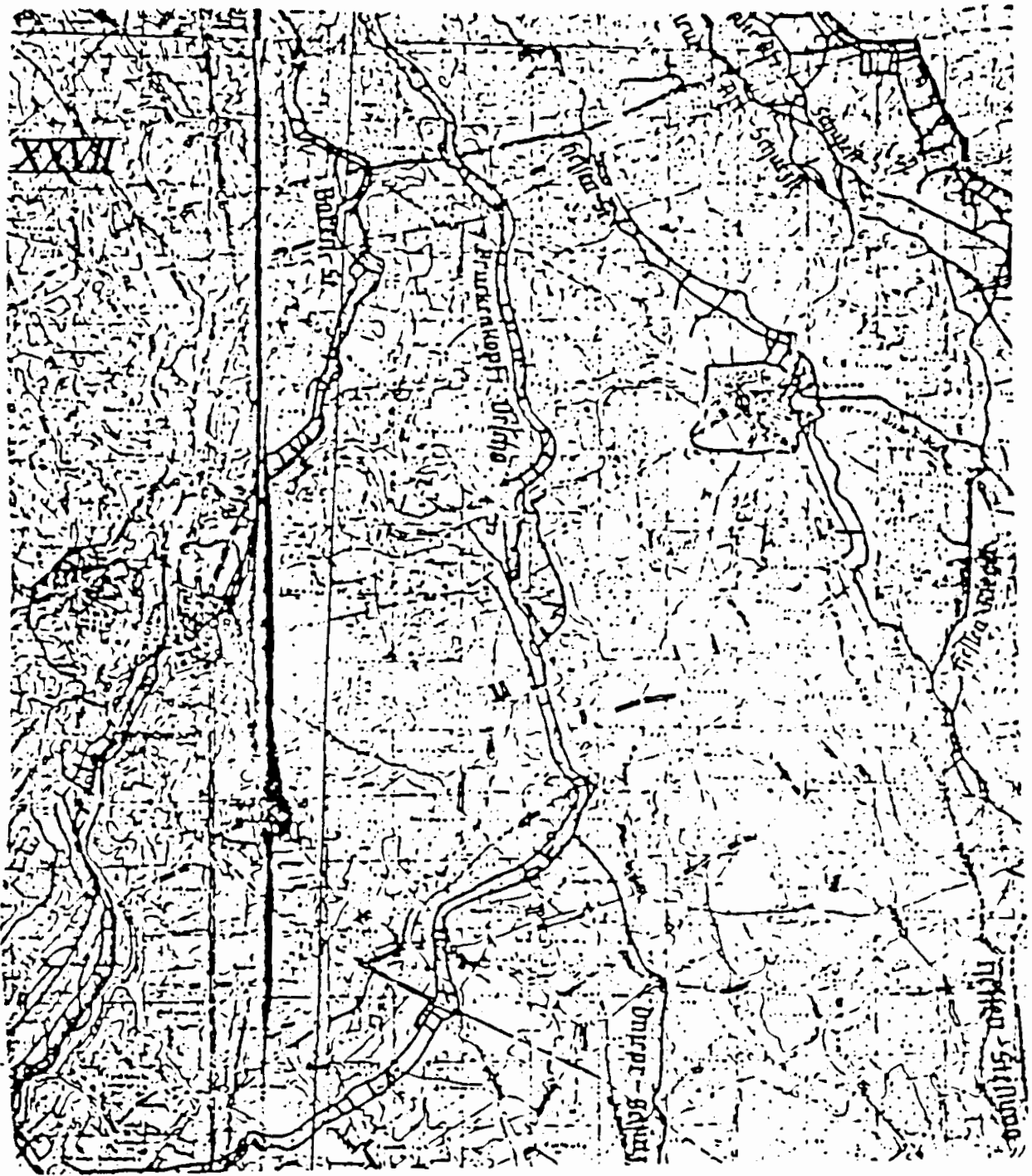

Figure 86. Bridgehead Orsha, Dnieper Covering Position, Hessen and Bear Lines. Source: A.O.K. 4, la. Kartenband 1. Anlagen zum KTB Nr. 24 National Archives Microfilm Publication T-312, Roll 252. 


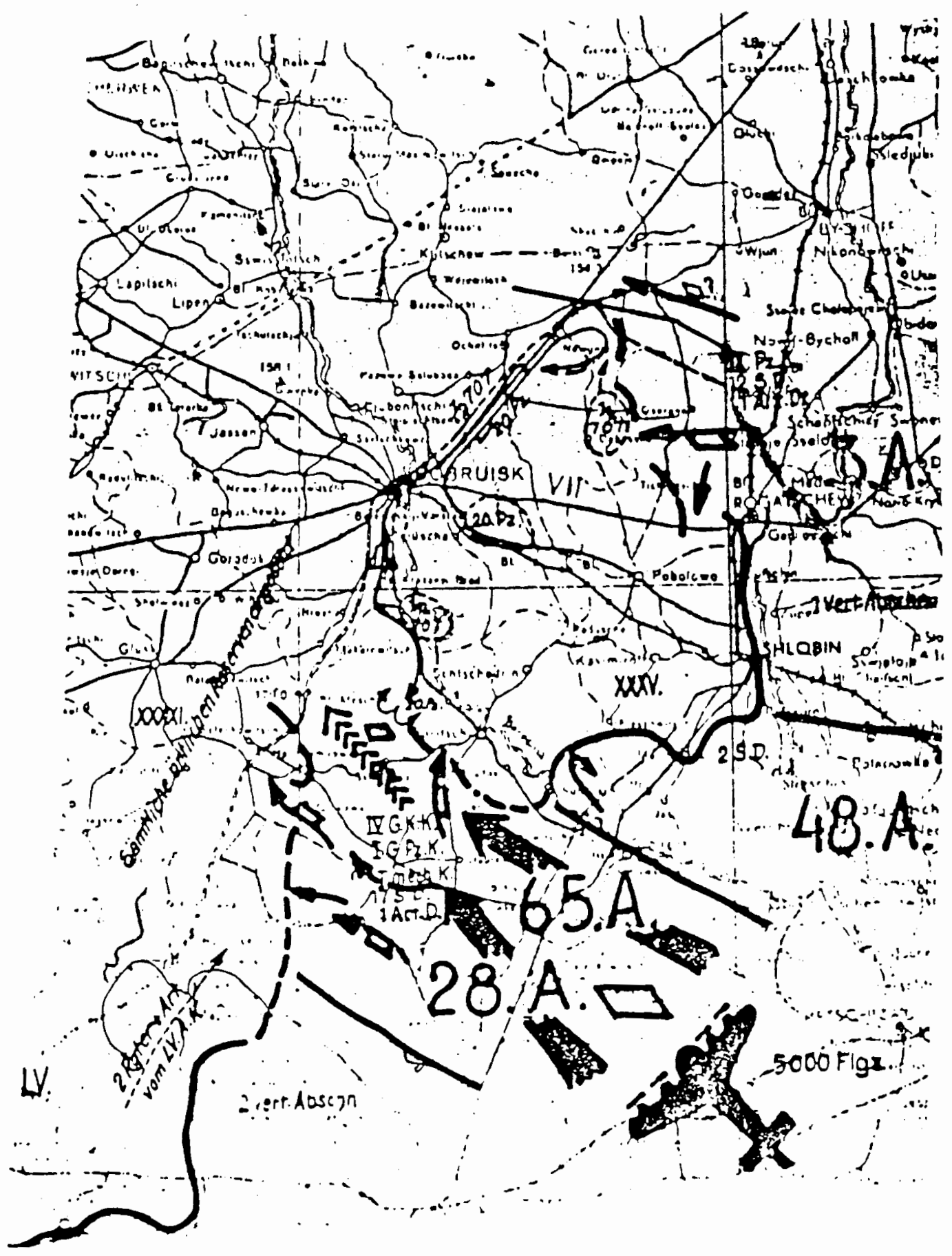

Figure 87. Soviet Advance On Bobruisk, June 24-25, 1944. Source: Armeeoberkommando 9, Der Grossangriff auf die 9. Armee, der Einsatz der Reserven und der Durchbruch Suedl. d. Beresina, 24. U. 25.6.44. National Archives Microfilm Publication T-312, Roll 339. 


\section{Rrmee-Lage am 25. Juni 44.}

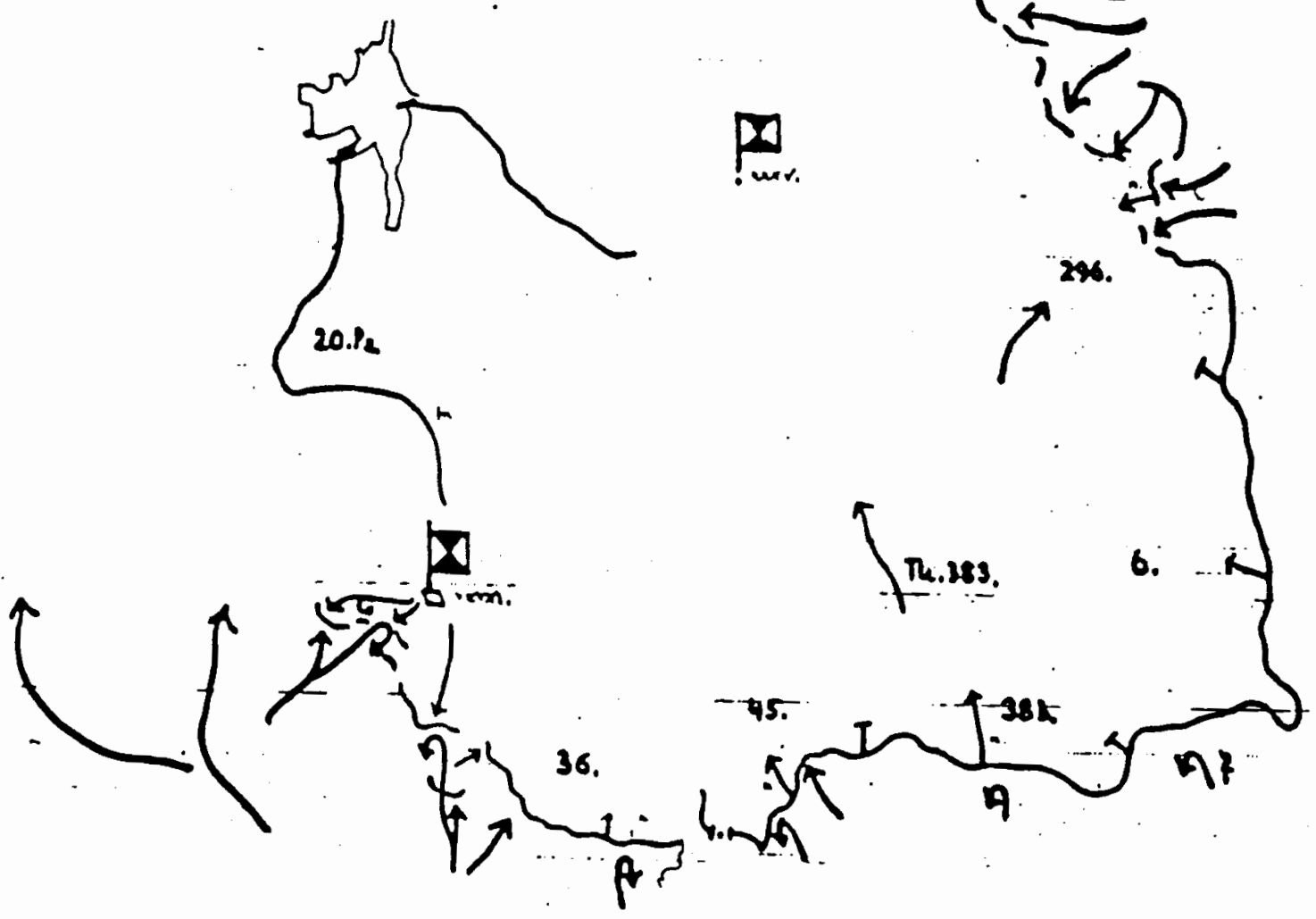

Figure 88. The 9th Army Situation On June 25, 1944. Source: Heeresgruppe Mitte, 9. Armee - Lage am 25.Juni 44. National Archives Microfilm Publication T-311, Roll 219. 


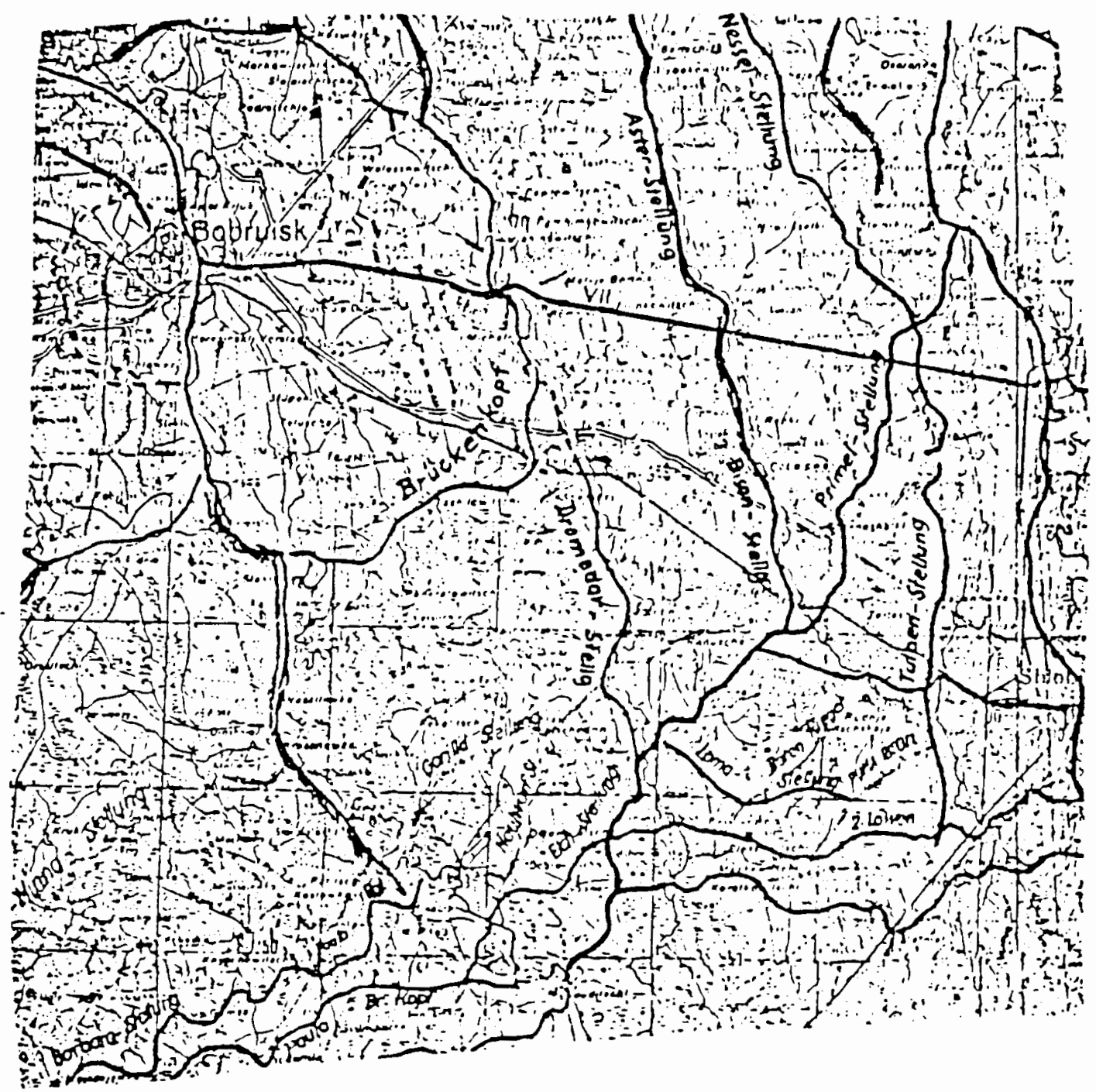

Figure 89. Bobruisk Bridgehead And 9th Army Defensive Lines. Source: A.O.K. 4, Ia, Kartenband 1, Anlagen zum KTB Nr. 24 National Archives Microfilm Publication T312, Roll 252. 


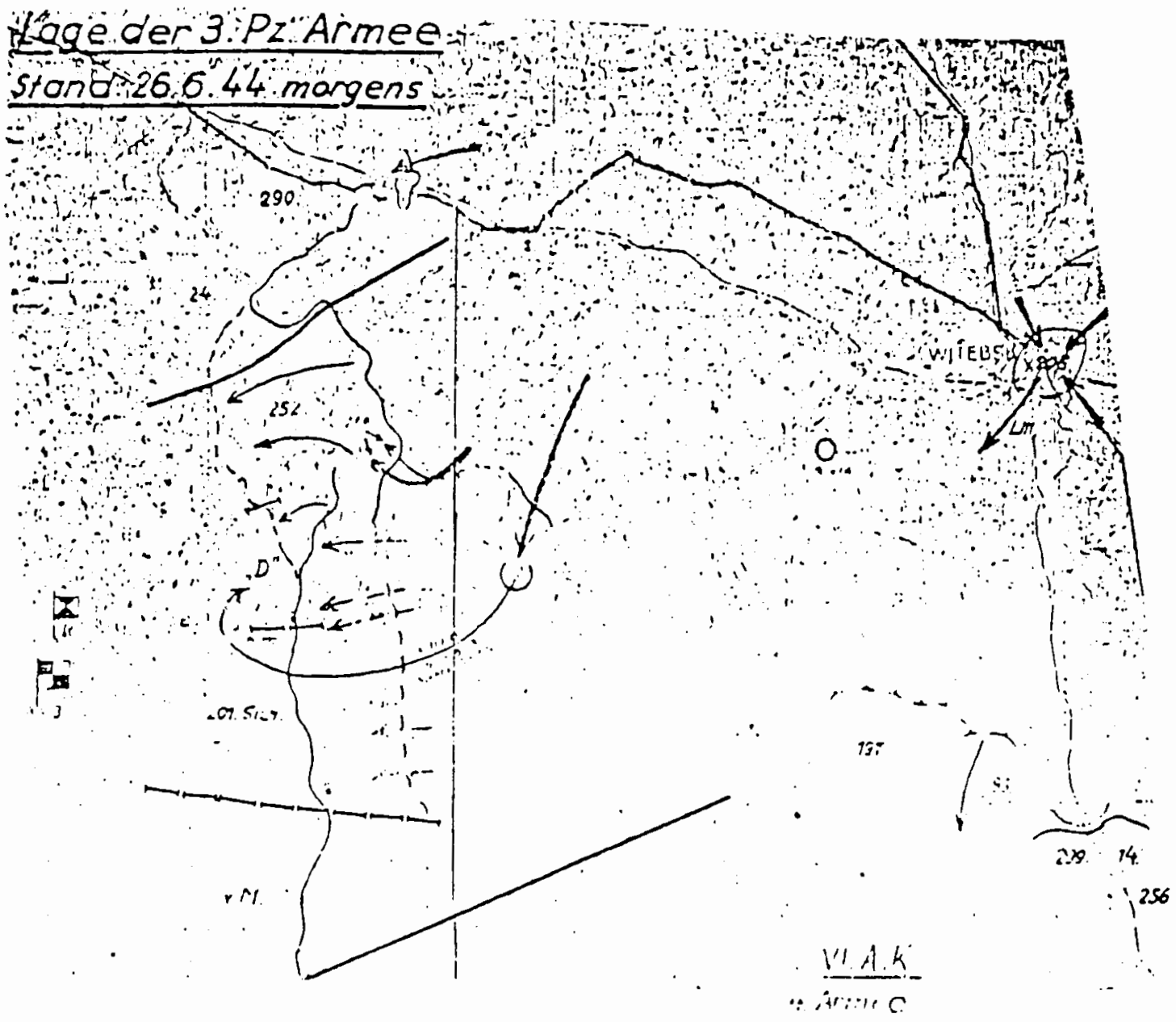

Figure 90. The Situation Of The 3rd Panzer Army On June 26, 1944. Source: PZ.A.O.K. 3, Lage der 3. PZ. Armee. Stand: 26.6.44.morgens National Archives Microfilm Publication T-313, Roll 318. 


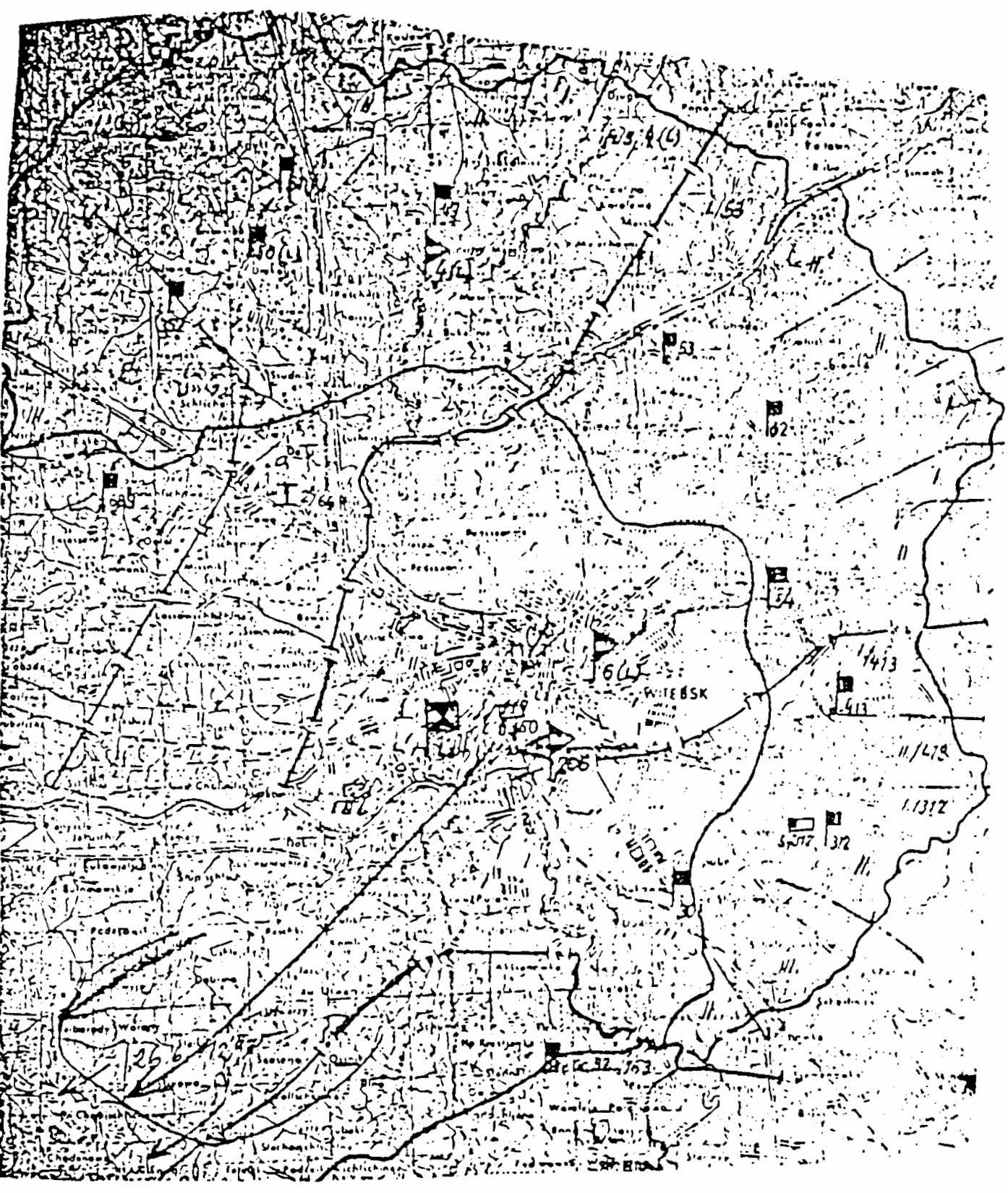

Figure 91. Breakout From Vitebsk. Source: Pz.A.O.K. 3, Witebsk, 26.6.1215 National Archives Microfilm Publication T-313, Roll 318. 


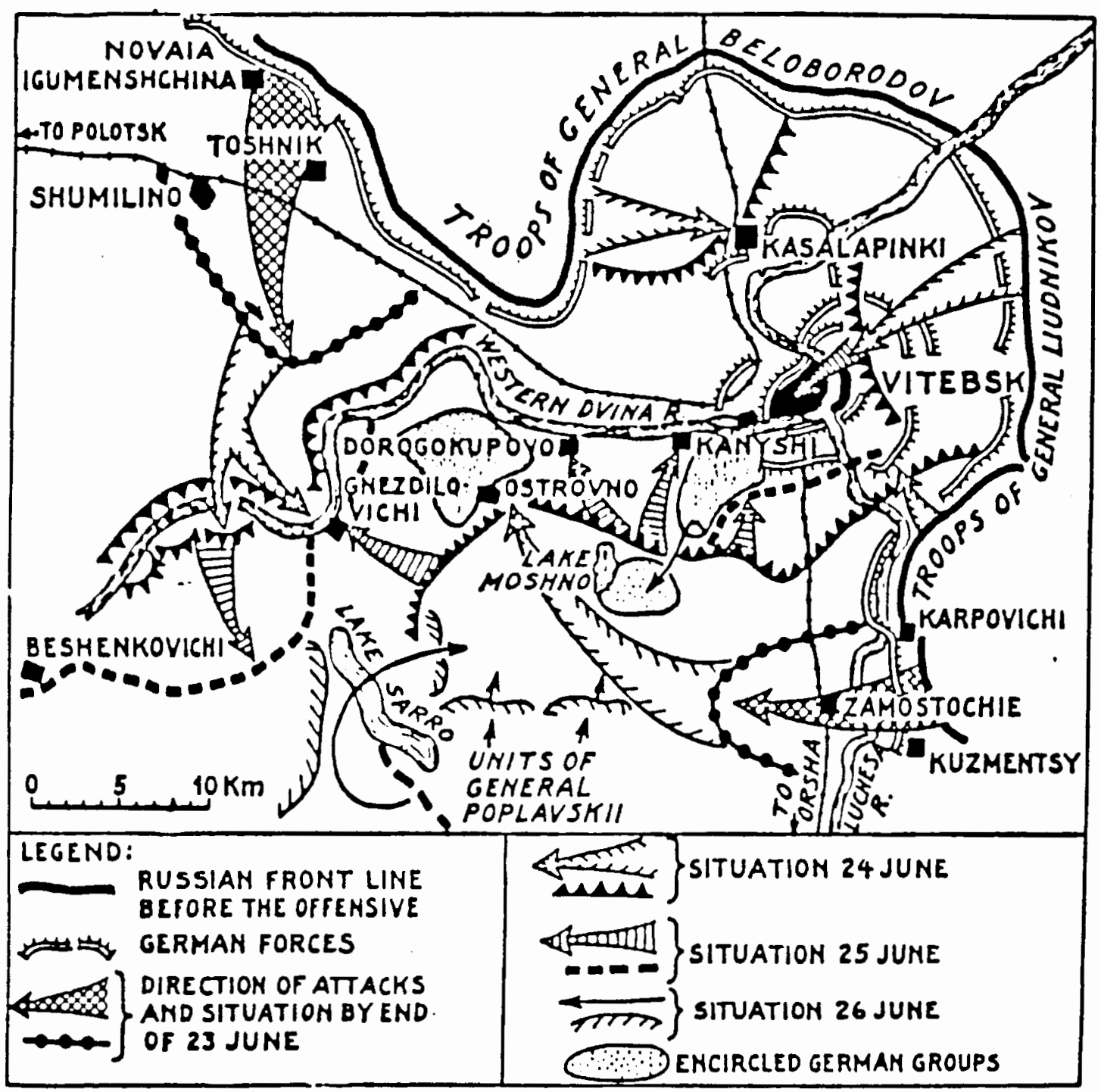

Figure 92. Soviet Encirclement Of Vitebsk. Source:

Colonel S. Shishkin, "The Vitebsk Operation," Krasnaia Zvezda (Red Star) 25 October 1944 as translated in Military Review Vol. 25, No. 4, July 1945, p. 95. 


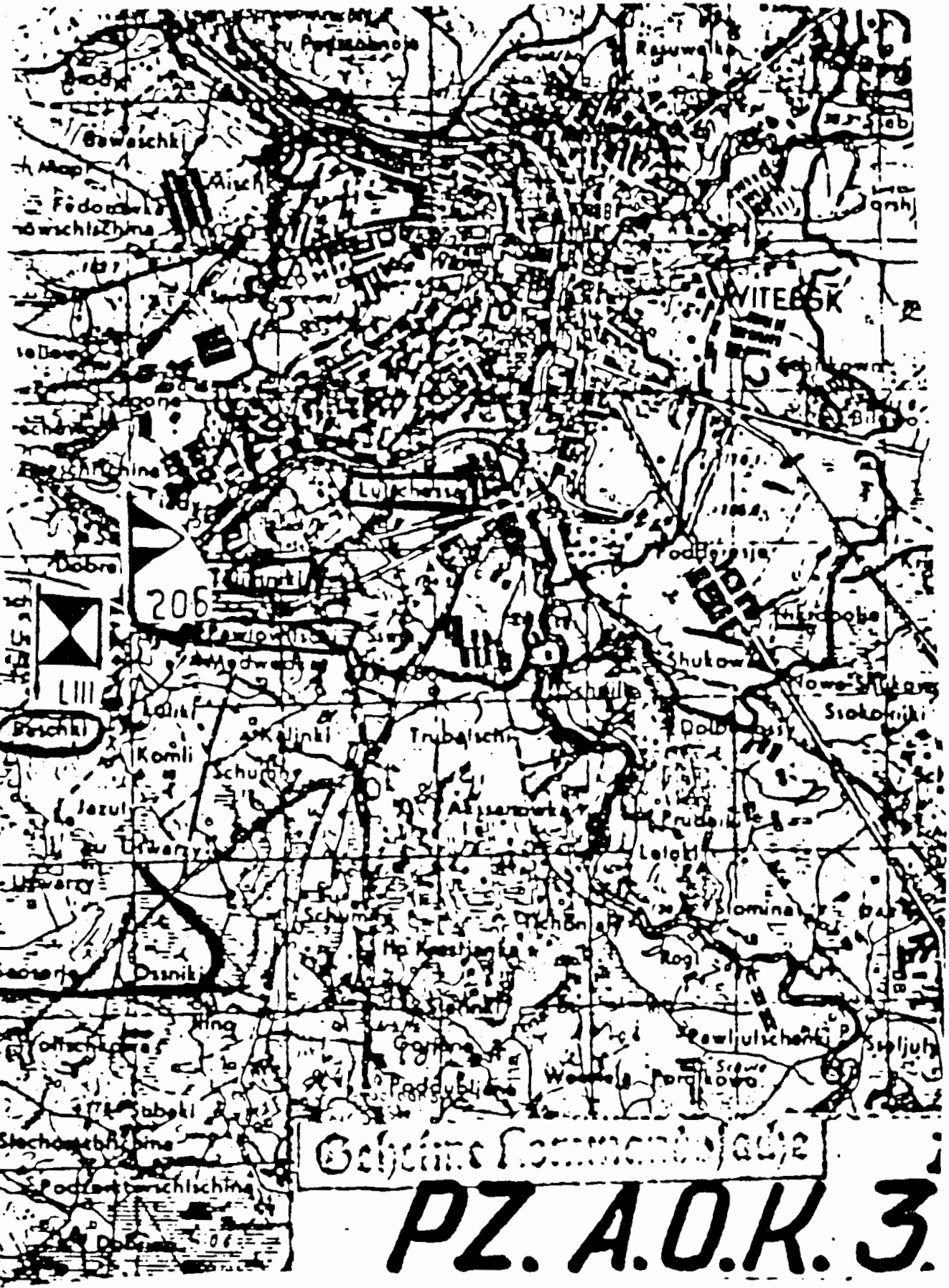

Figure 93. LIII Army Corps And 206th Infantry Division On June 26, 1944. Source: Oberkommando Heeresgruppe Mitte, Fester Platz Witebsk 21.6.44. National Archives Microfilm Publication T-311, Roll 218. 


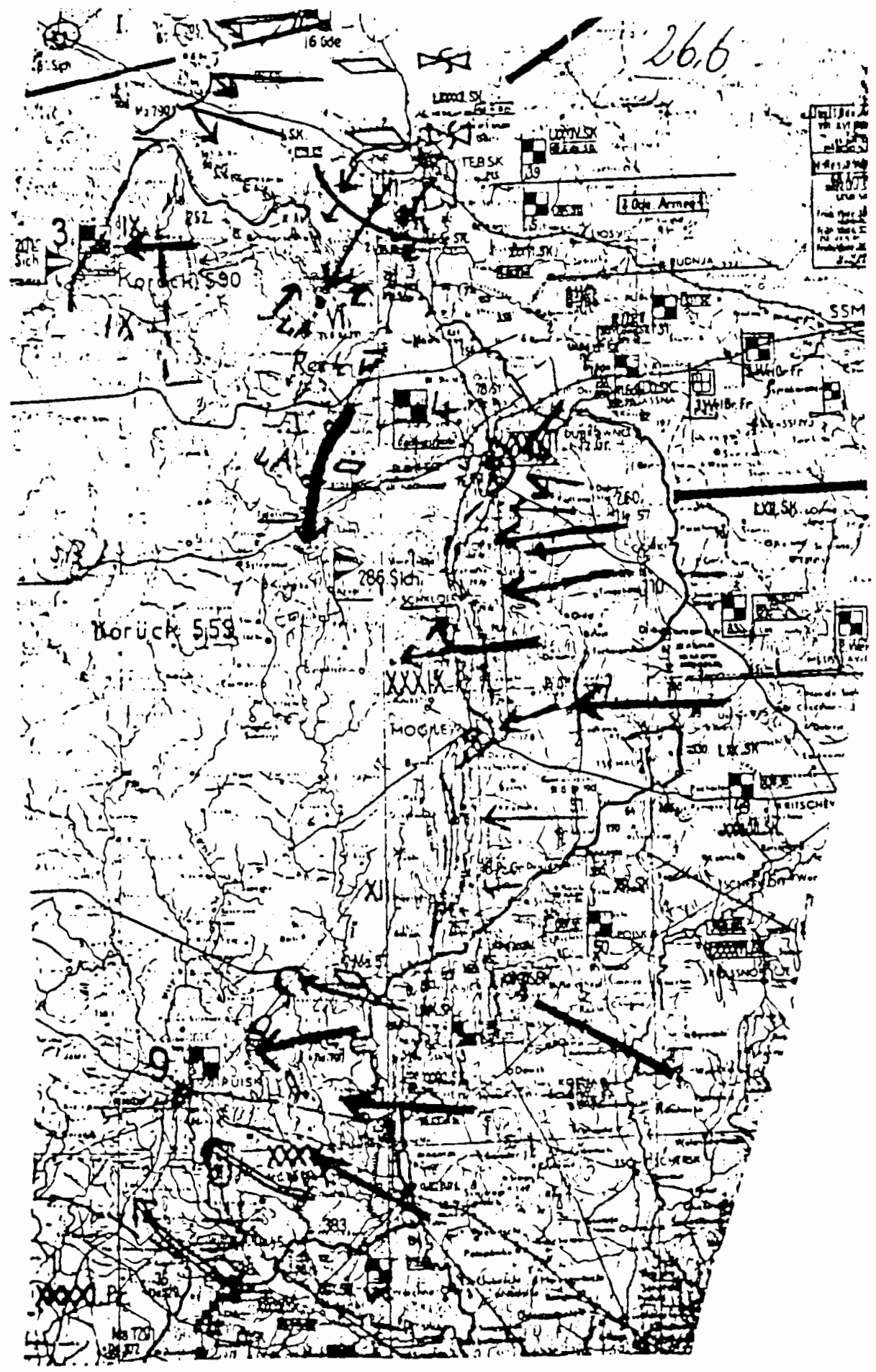

Figure 94. Army Group Center, June 26, 1944. Source: $\mathrm{OKH}$, Der Grosse Durchbruch Bei Hgr. Mitte Von 21.6.10.8.44., National Archives Microfilm Publication T-78, Roll 136. 
Divisions-A6schnitt der 25. A. Gren.Div.

\section{om 22. 6. 7944 \\ sogstab 1:100000}

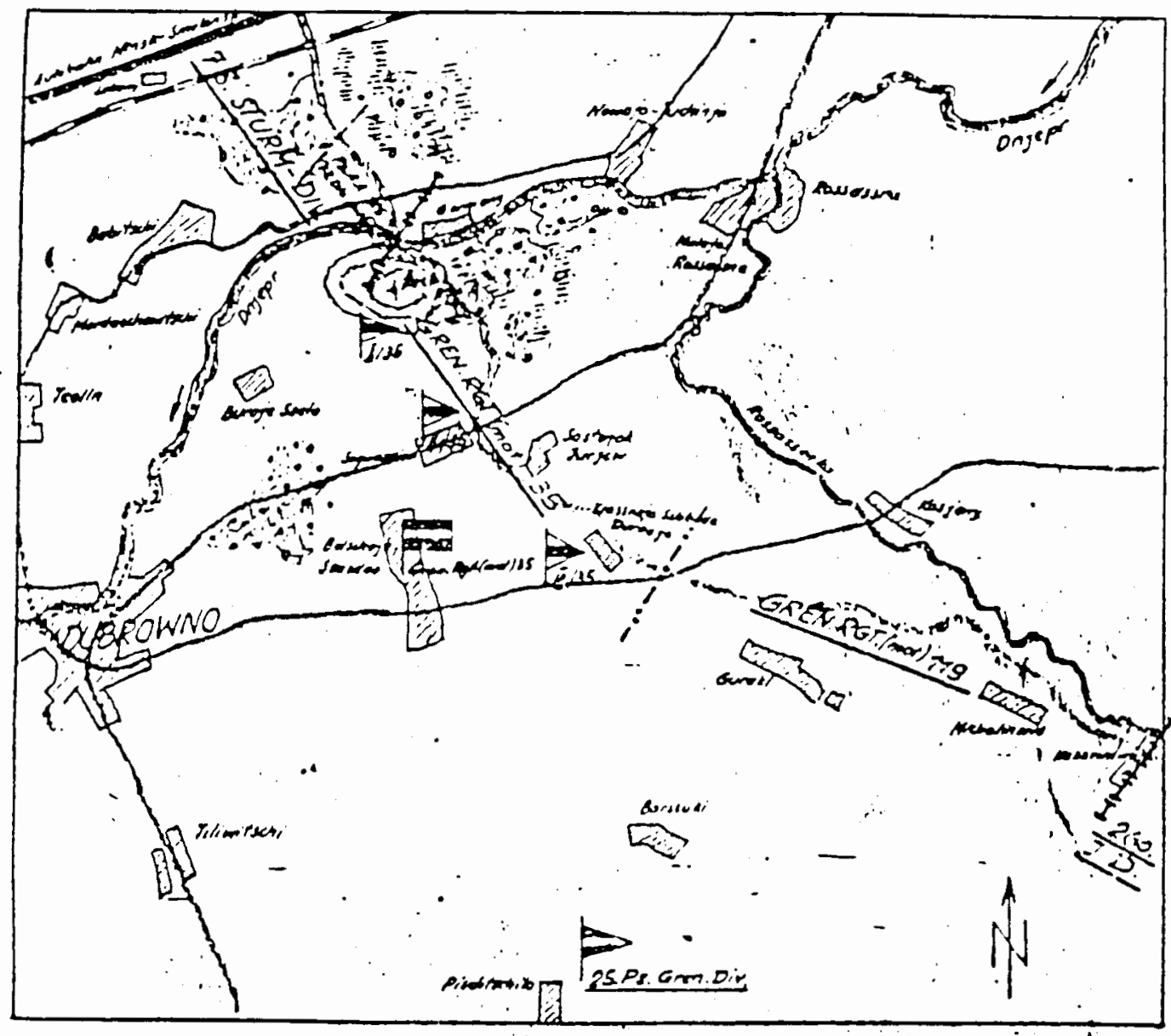

Figure 95. The 25th Panzer Grenadier Division's Sector On June 22, 1944. Source: Abwicklungsstab Heeresgruppe Mitte, Bericht ueber den Anteil der 25. PZ. Gre. Div. an den Kaempfen der Heeresgr. Mitte ab 20.6. 1944, 12.9.1944 National Archives Microfilm Publication T-78, Roll 139. 


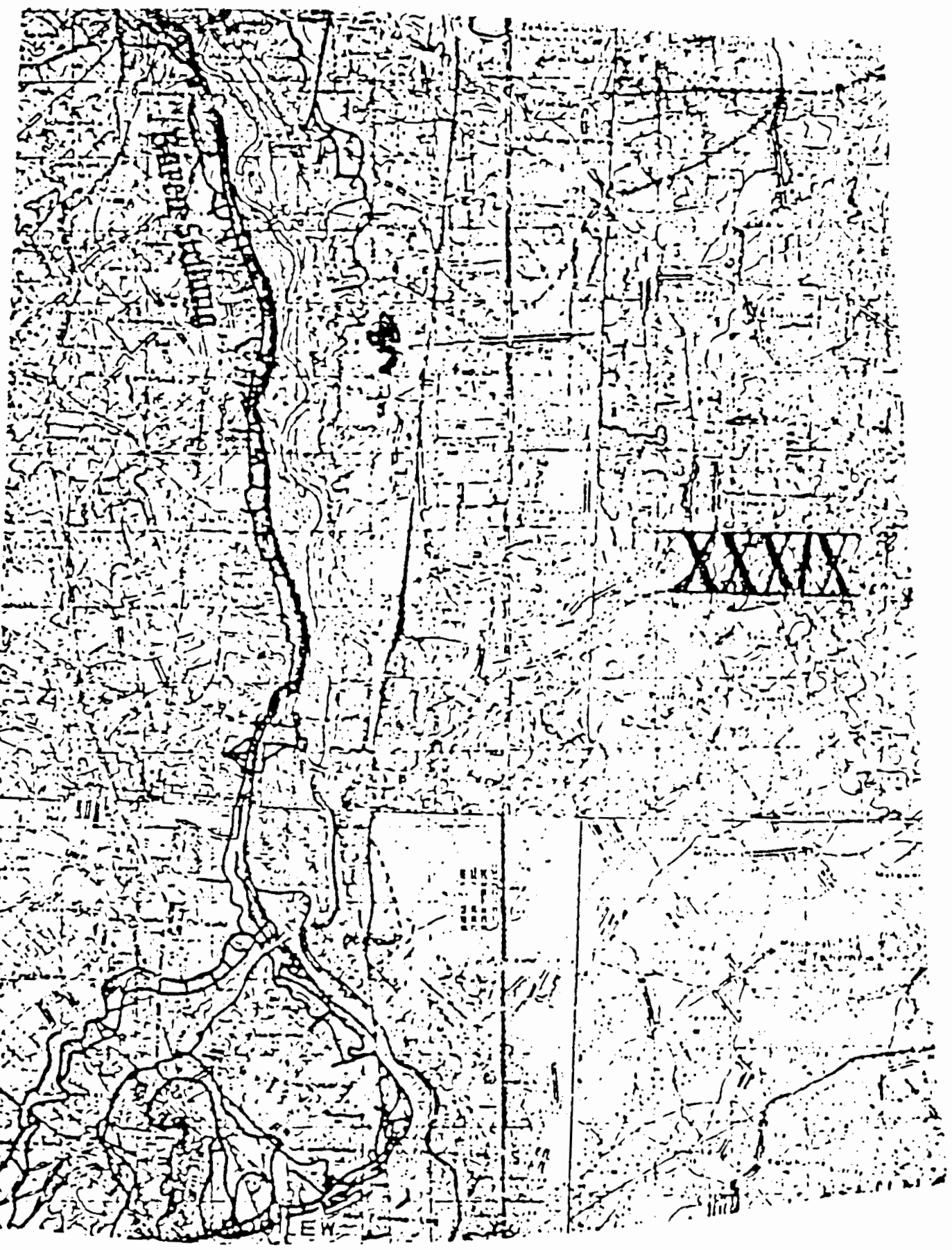

Figure 96. The Bear Line. Source: A.O.K. 4, la. Kartenband 1. Anlagen zum KTB Nr. 24 National Archives Microfilm Publication T-312, Roll 252. 


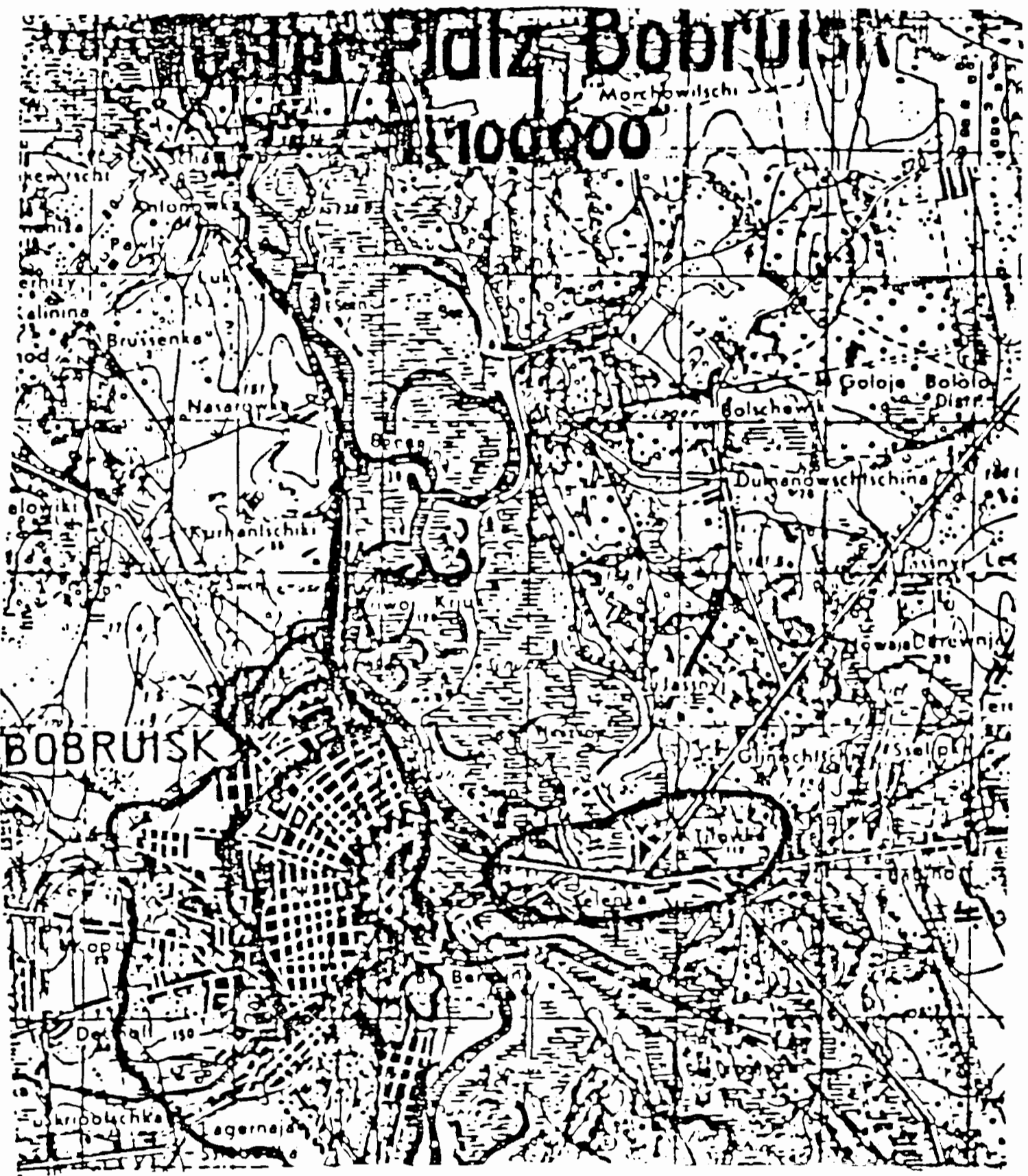

Figure 97. Soviet Control Of Titowka Road Junction. Source: Oberkommando Heeresgruppe Mitte, Fester Platz Bobruisk 21.6.44. National Archives Microfilm Publication T-311, Roll 218. 


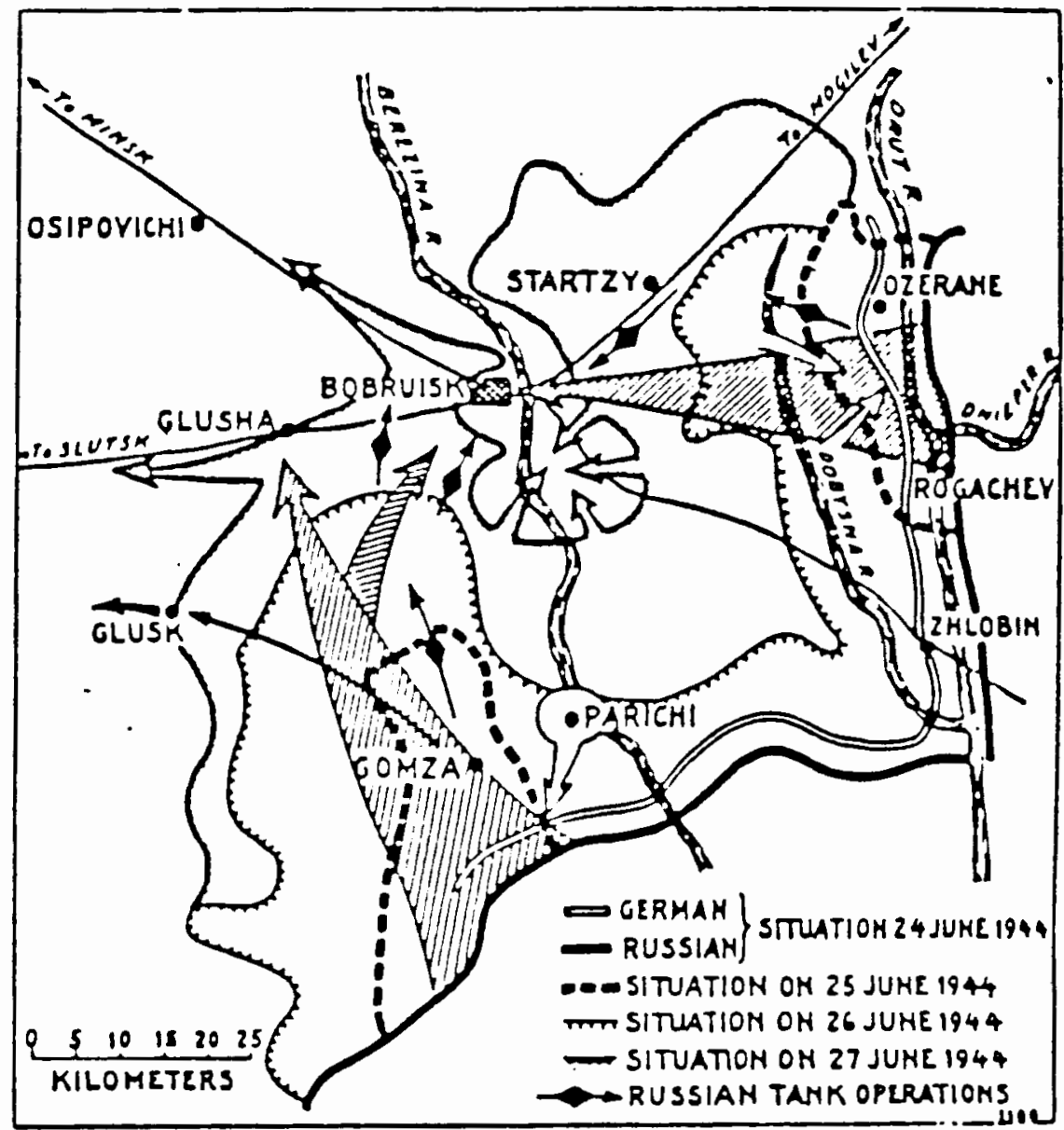

Figure 98. Soviet Operations Against The 9th Army, June 24-27, 1944. Source: Colonel P. Boldyrev, "The Bobruisk Operation," Krasnaya Zvezda (Red Star) 28 September 1944 as translated in Military Review Vol. 24, No. 12, March 1945, p. 107. 


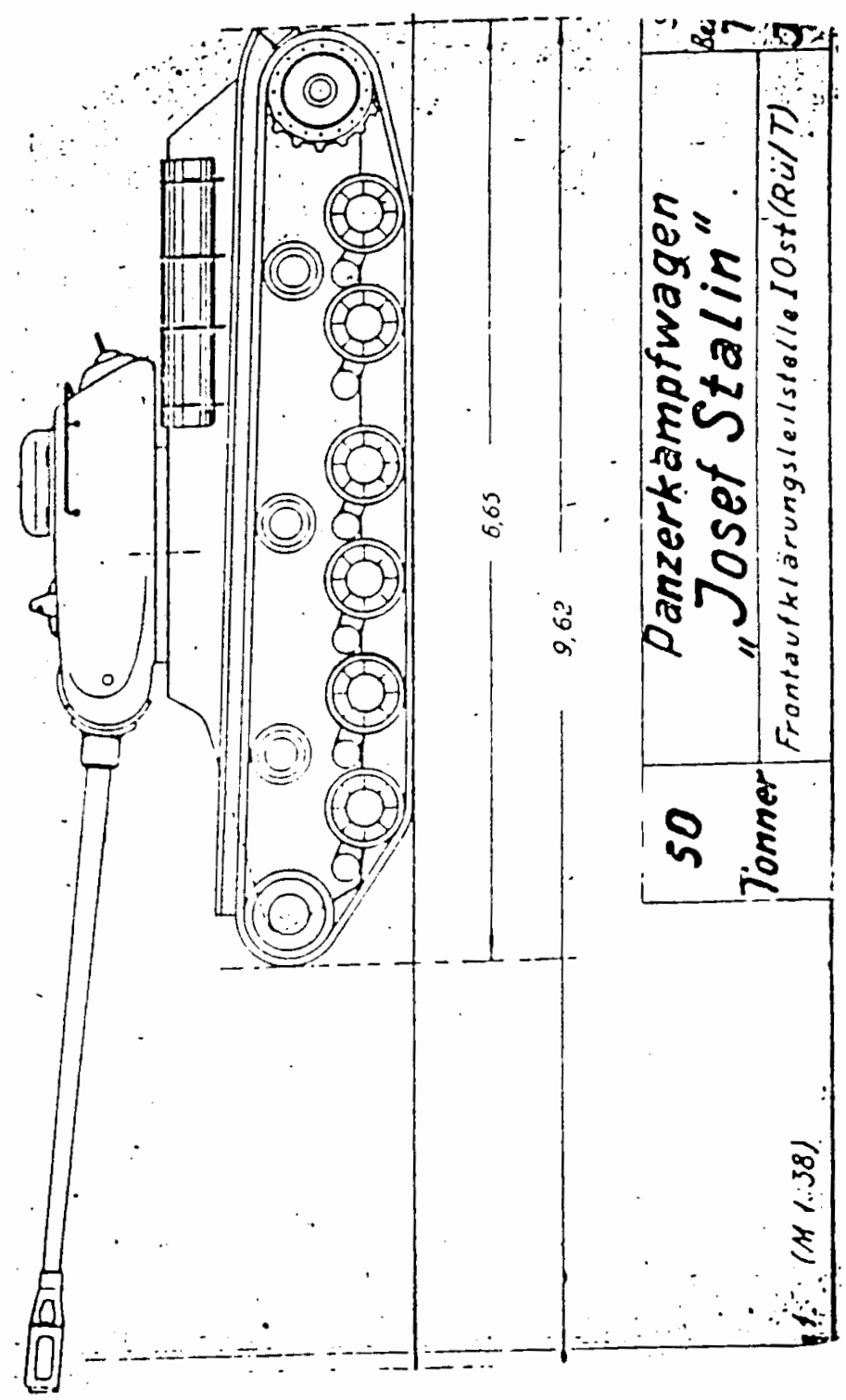

Fiqure 99. JS-122 Joseph Stalin. Source: Frontaufklaerungsleitstelle I Ost (Rue/T), Panzerkampfwagen "Joseph Stalin" National Archives Microfilm Publication T-78, Roll 579. 

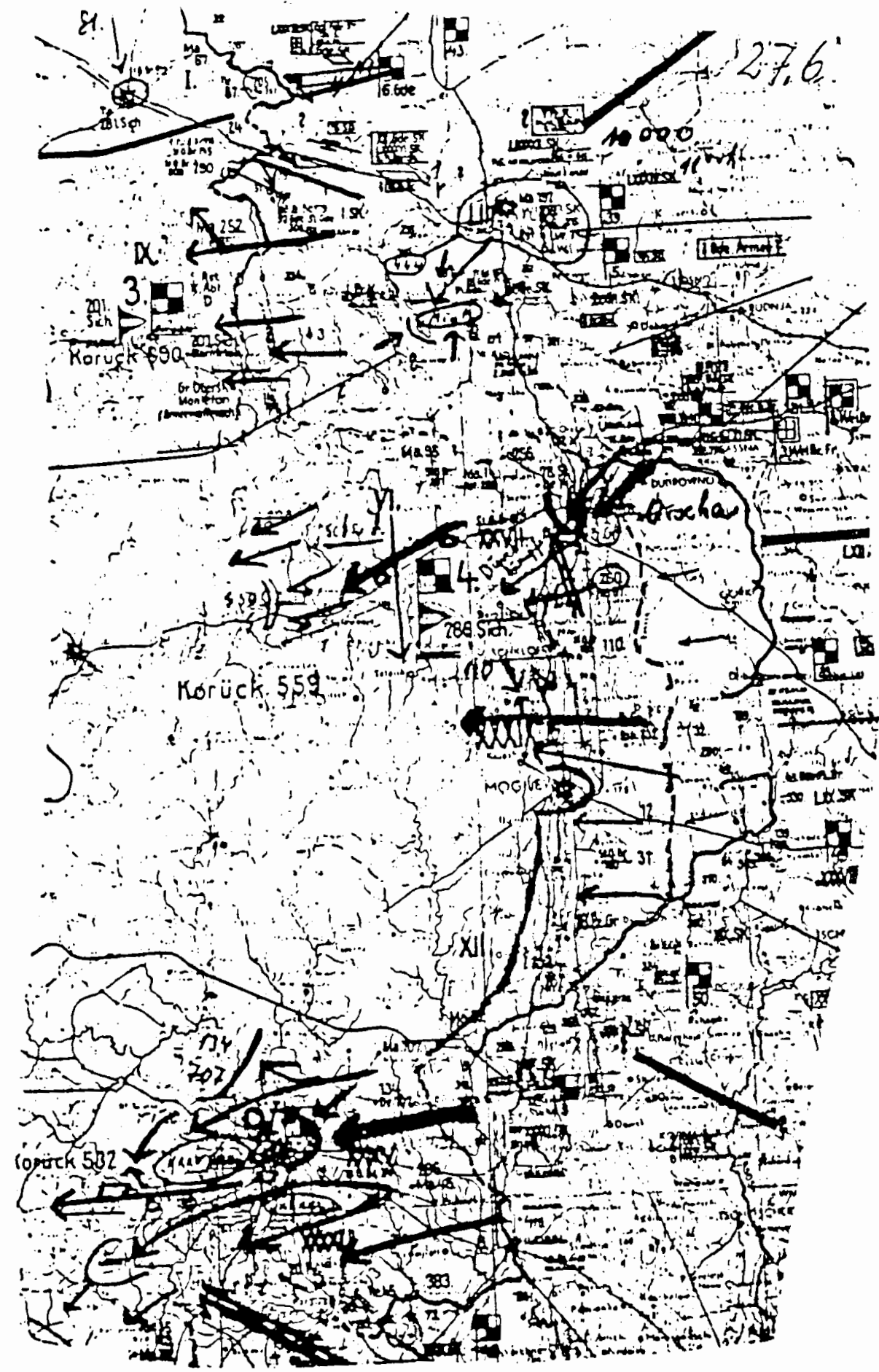

Figure 100. Army Group Center, June 27, 1944. Source: $\mathrm{OKH}$, Der Grosse Durchbruch Bei Hgr. Mitte Von 21.6.10.8.44., National Archives Microfilm Publication T.78, Roll 136. 


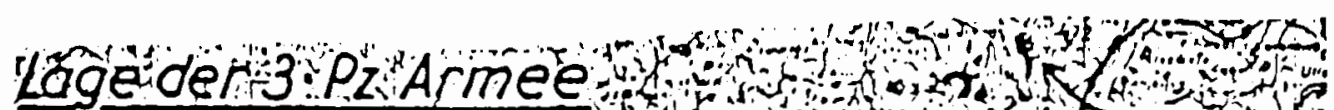
sforoto-27.44-morgens (20)

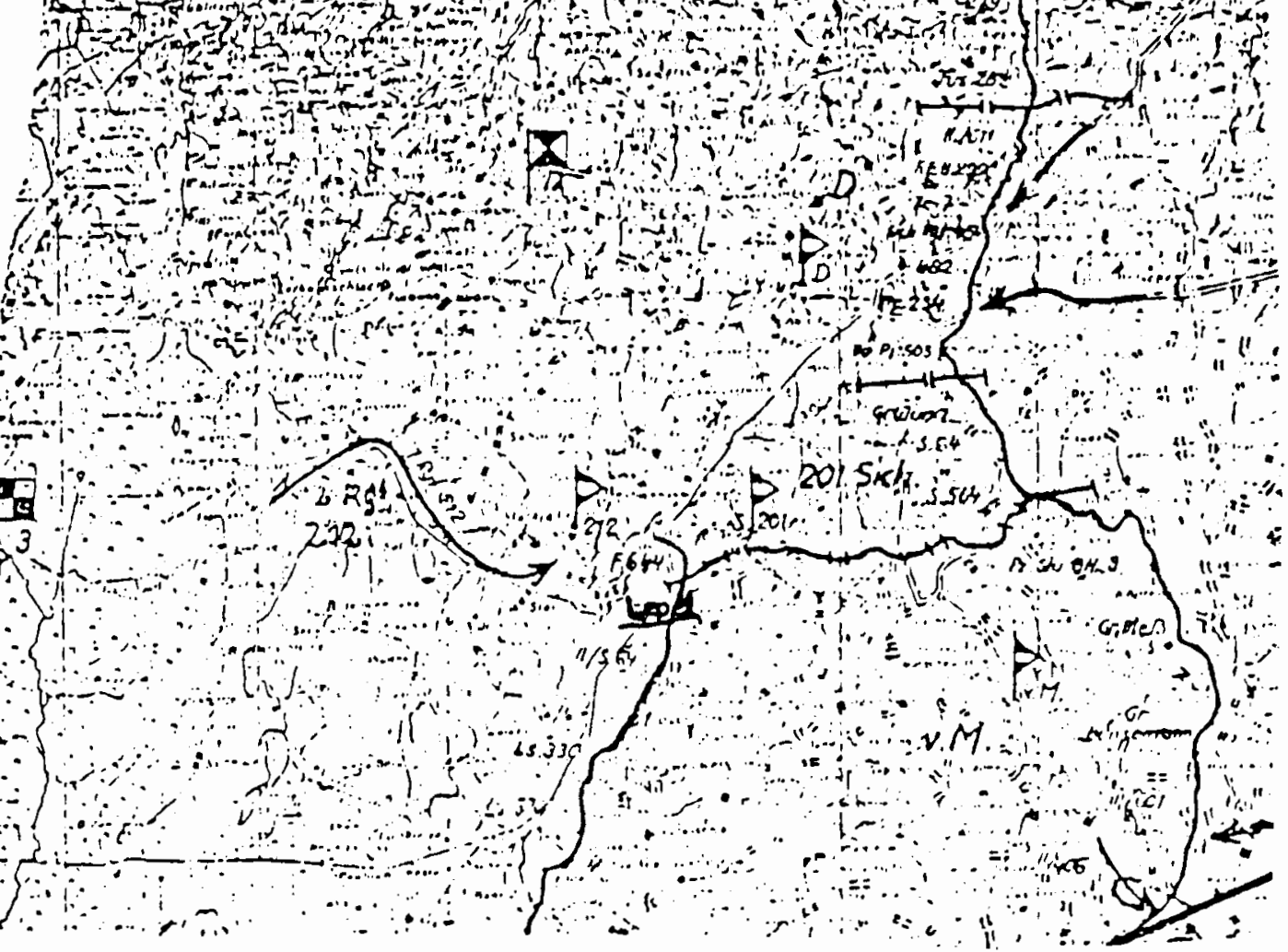

Figure 101. The Situation Of The 3rd Panzer Army On June 27, 1944. Source: Pz.A.O.K. 3, Lage der 3. Pz. Armee, Stand: 27.6.44.morgens National Archives Microfilm Publication T-313, Roll 318. 


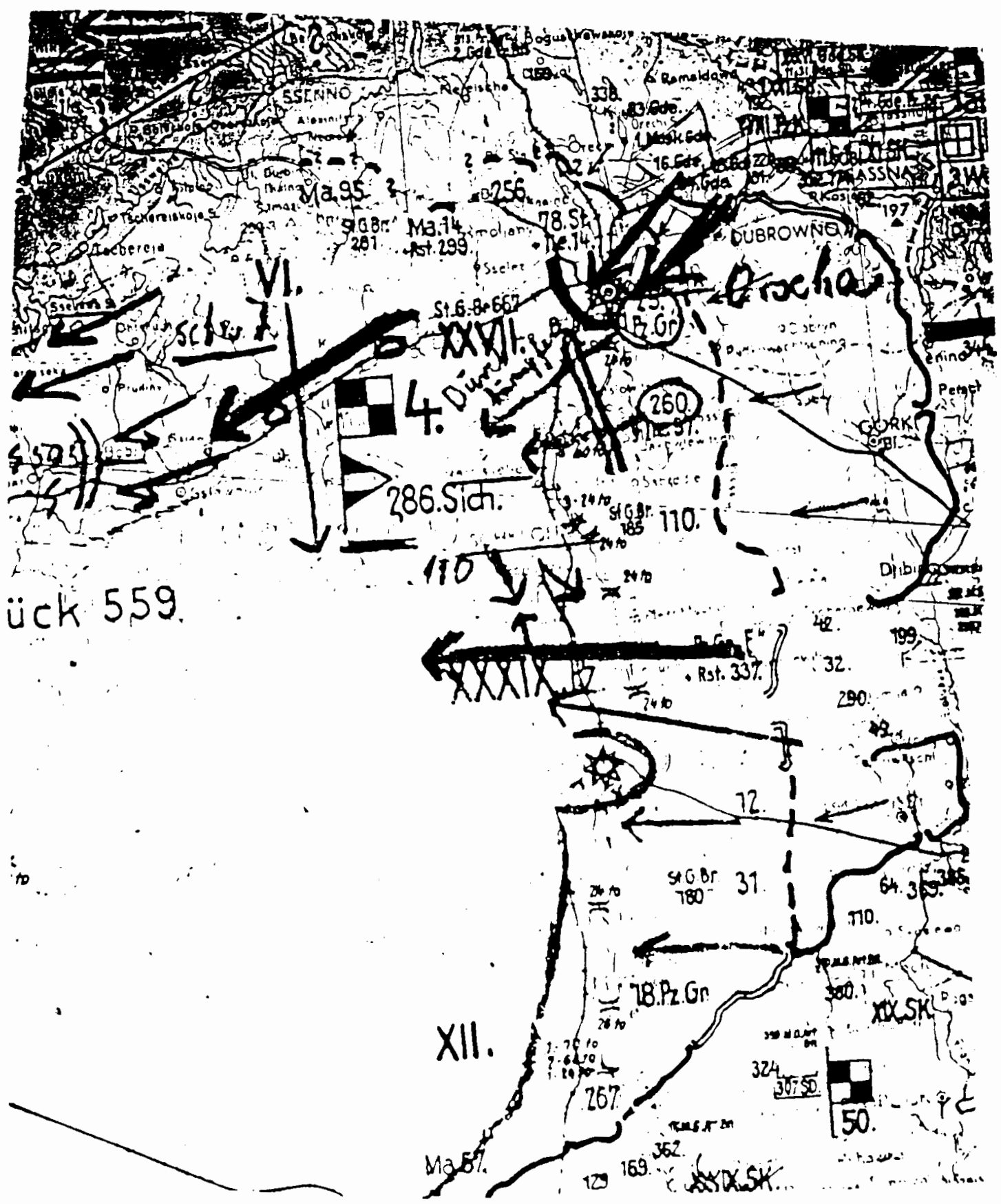

Figure 102. Soviet Breakthrough Into Rear Of 4th Army, June 27, 1944. Source: OKH, Der Grosse Durchbruch Bei Hgr. Mitte Von 21.6.-10.8.44., National Archives Microfilm Publication T-78, Roll 136. 


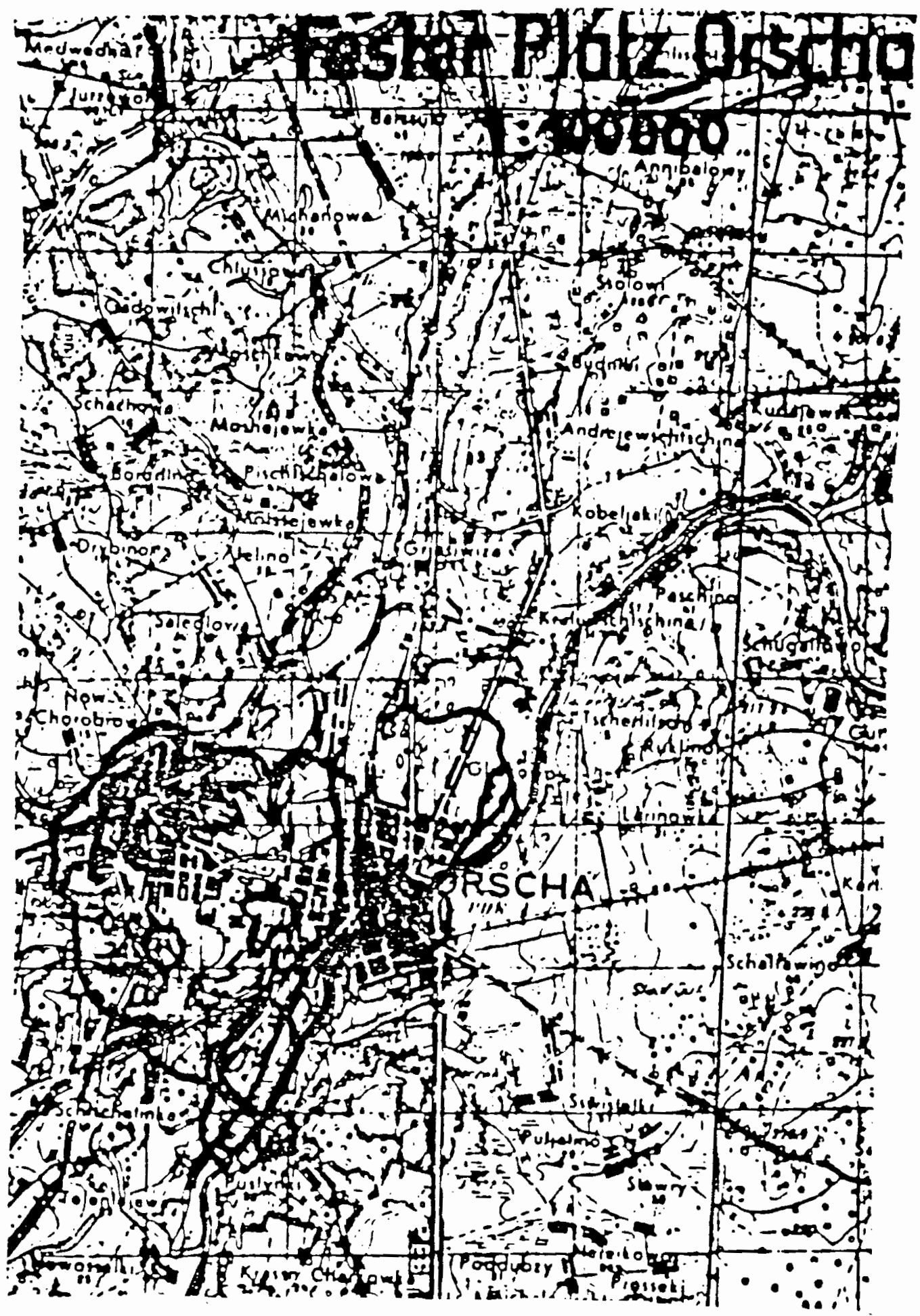

Figure 103. Fortress Orsha. Source: Oberkommando Heeresgruppe Mitte, Fester Platz Orscha 29.6.44. National Archives Microfilm Publication T-311, Roll 218. 


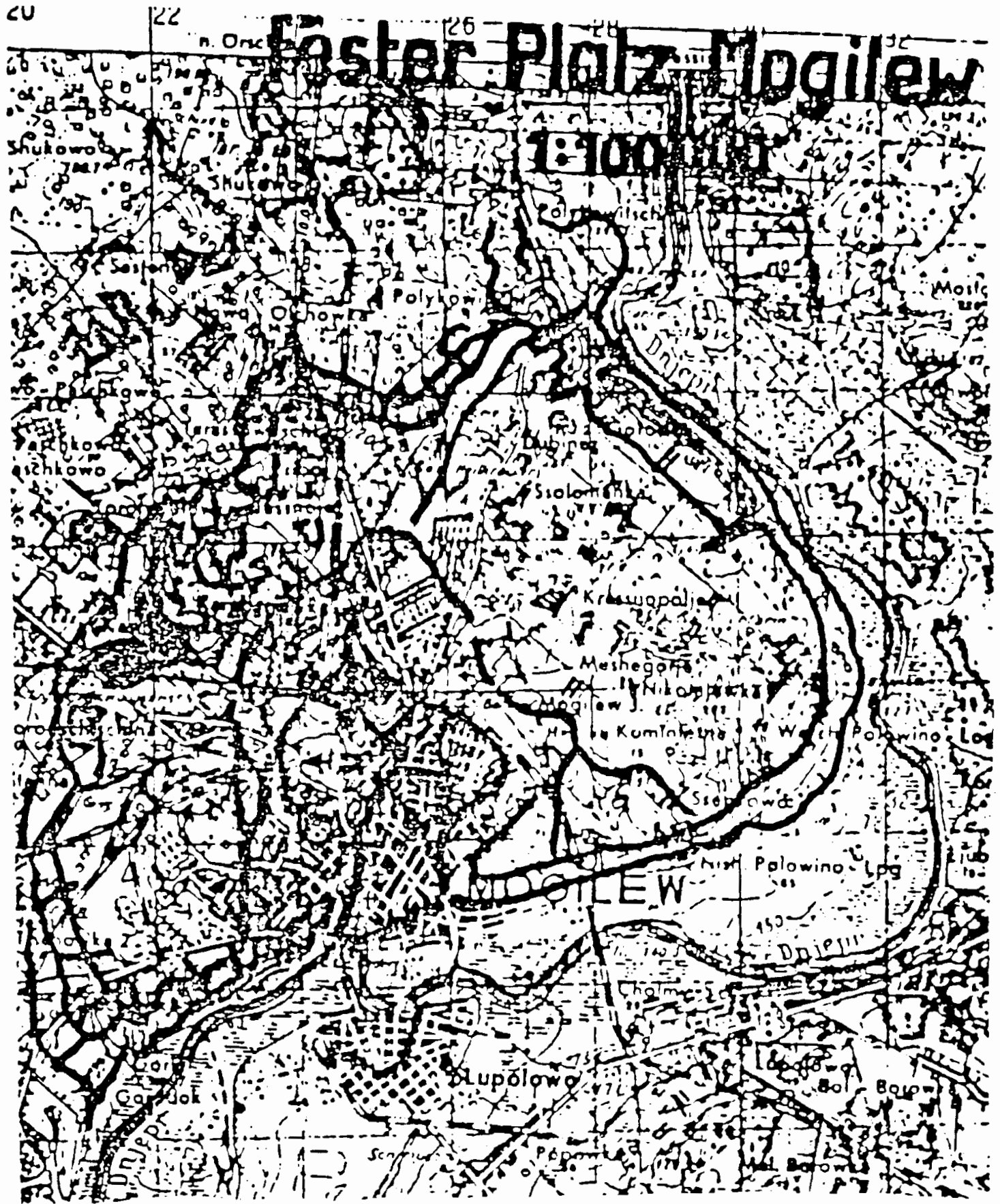

Fiqure 104. Fortress Mogilev. Source: Oberkommando Heeresgruppe Mitte, Fester Platz Mogilew 21.6.44. National Archives Microfilm Publication T-311, Roll 218. 


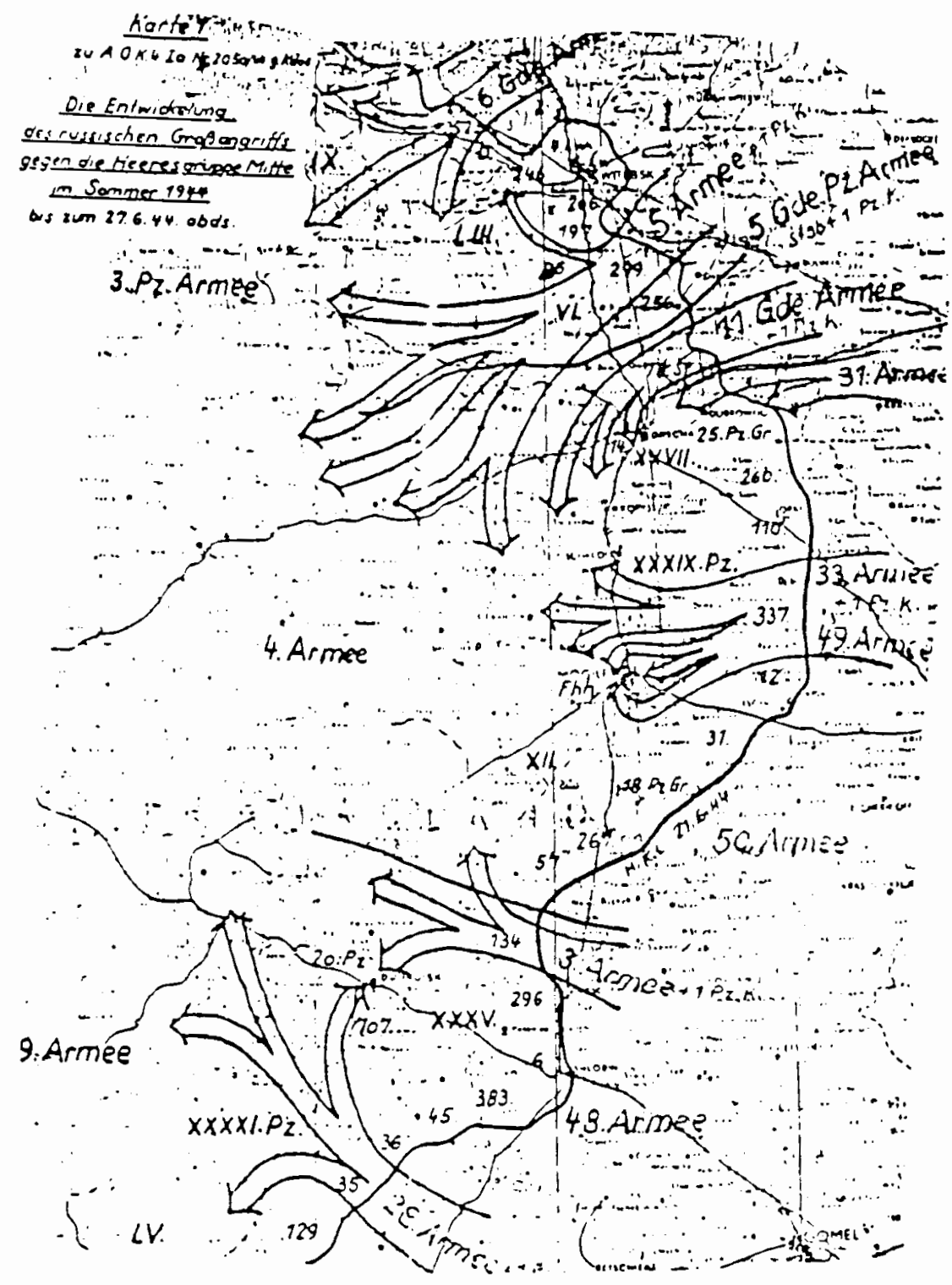

Fiqure 105. The Impending Encirclement Of The 4th Army, June 27, 1944. Source: Armeeoberkommando 4, Die Entwicklung des russischen Grossangriffs gegen die Heeresgruppe Mitte Im Sommer 1944, Karte 1 National Archives Microfilm Publication T-312, Roll 1365. 


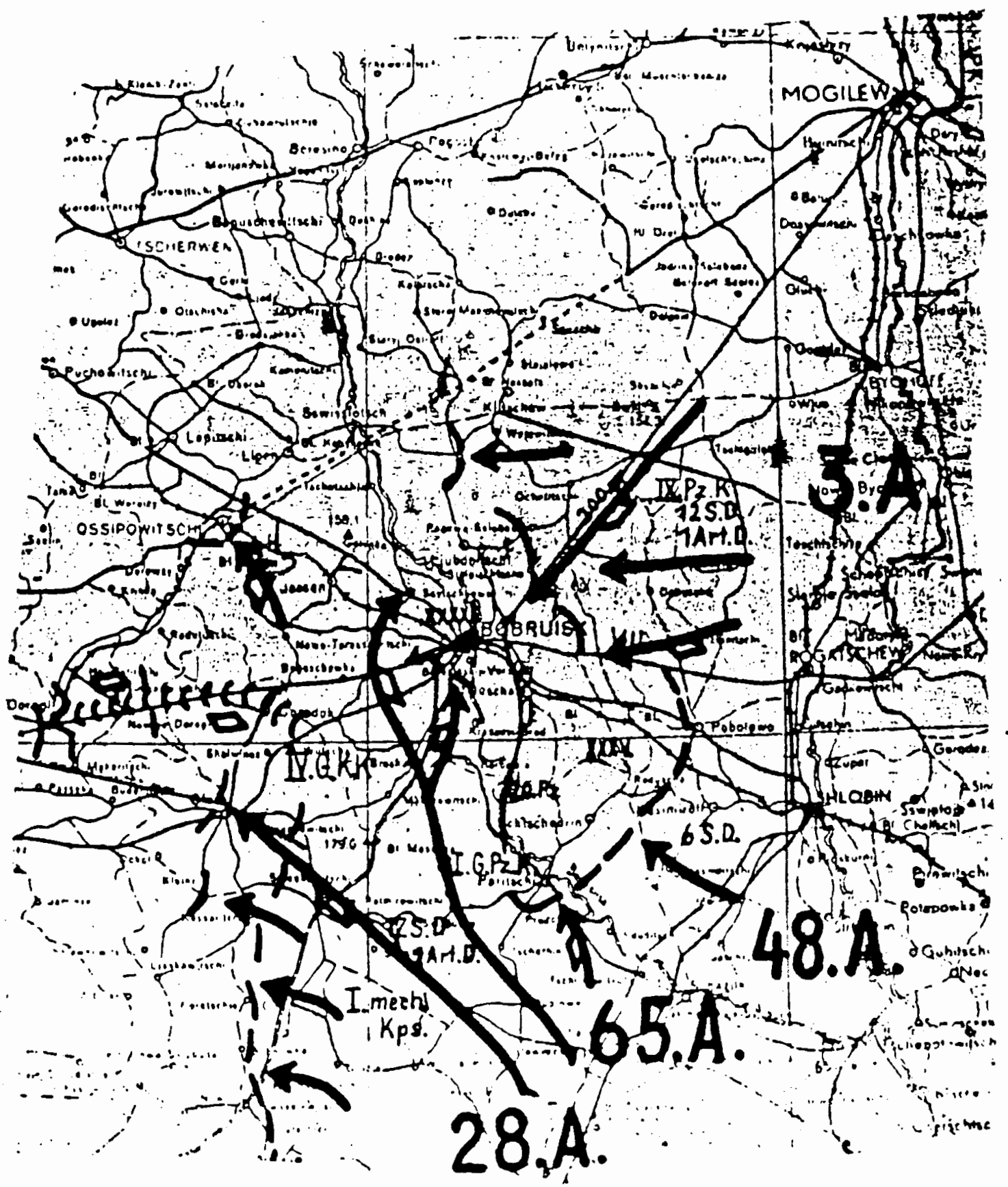

Figure 106. The Soviet Encirclement Of Bobruisk, June 27, 1944. Source: Armeeoberkommando 9, Die Einschliessung Von Bobruisk 26. U. 27.6.44. National Archives Microfilm Publication T-312, Roll 339. 


\section{Armee-loge am 27: Juni44.}

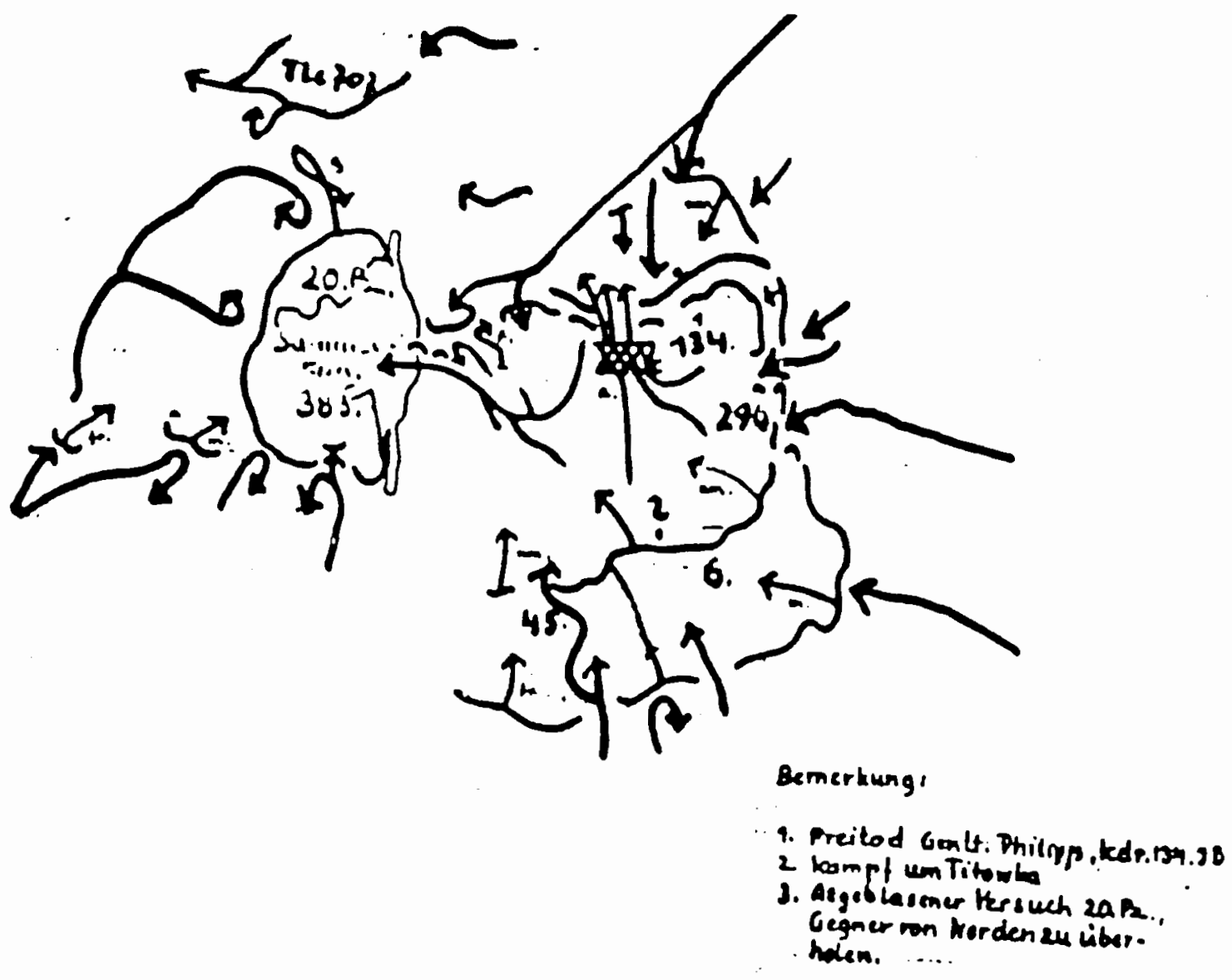

Figure 107. The 9th Army Situation On June 27, 1944.

Source: Heeresgruppe Mitte, 9. Armee - Lage am 27.Juni 44. National Archives Microfilm Publication T-311, Roll 219. 


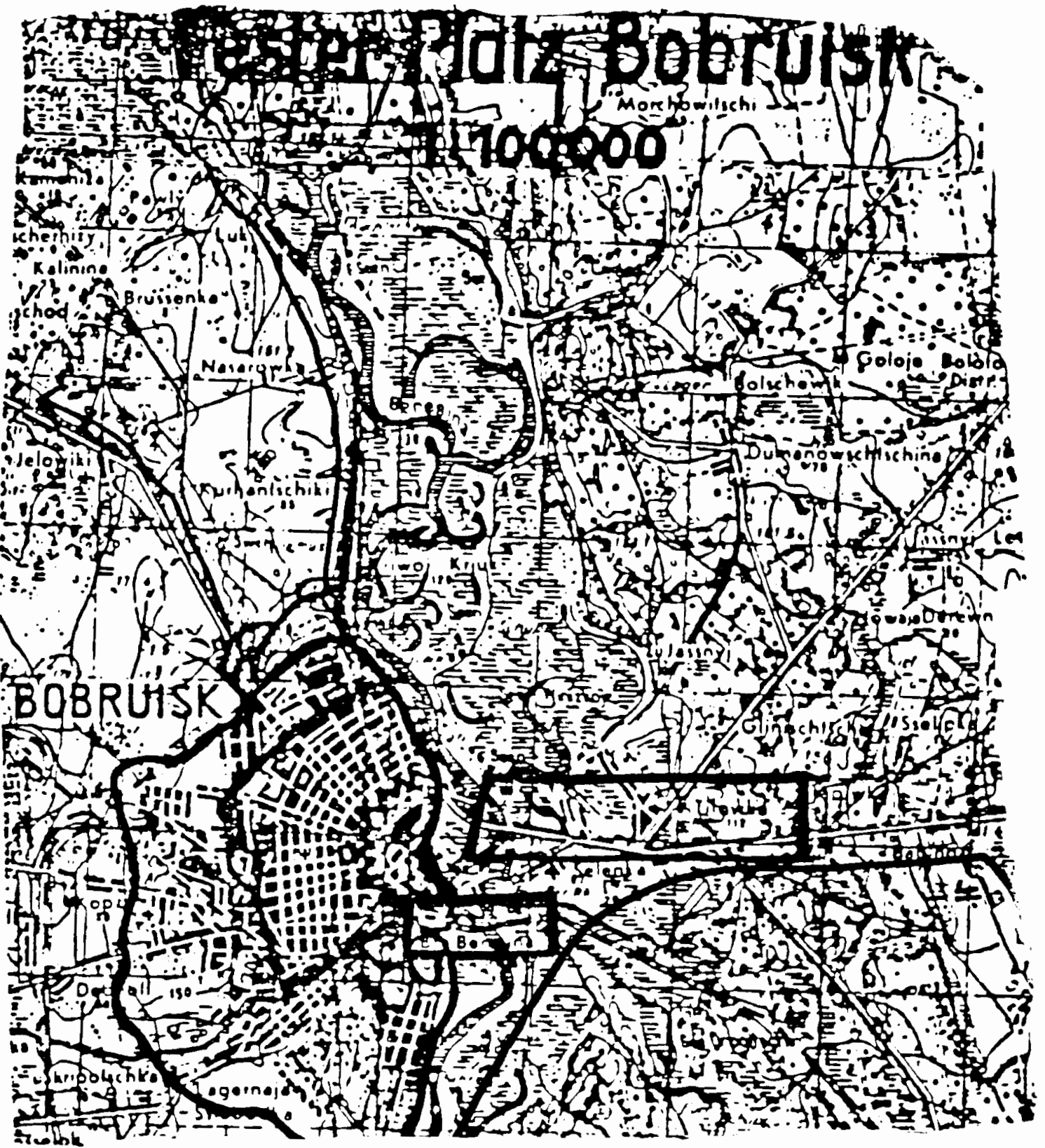

Figure 108. The Eastern Acess Into Bobruisk: The Road And Railway Bridges Across The Berezina River. Source: Oberkommando Heeresgruppe Mitte, Fester Platz Bobruisk 21.6.44. National Archives Microfilm Publication T-311, Roll 218. 


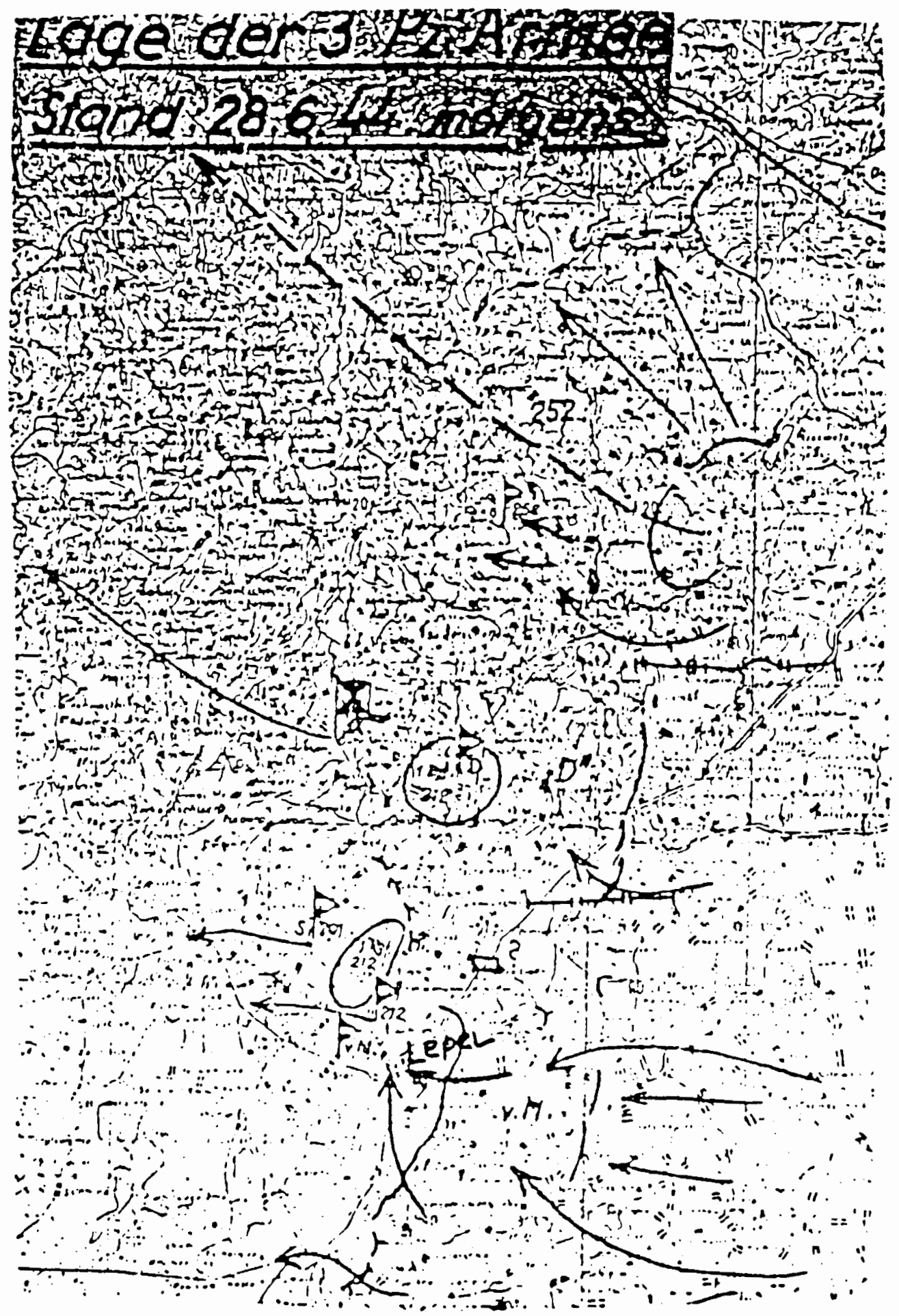

Figure 109. The Situation Of The 3rd Panzer Army On June 28, 1944. Source: Pz.A.O.K. 3, Lage der 3. Pz. Armee, Stand: 28.6.44.morgens National Archives Microfilm Publication T-313, Roll 318. 


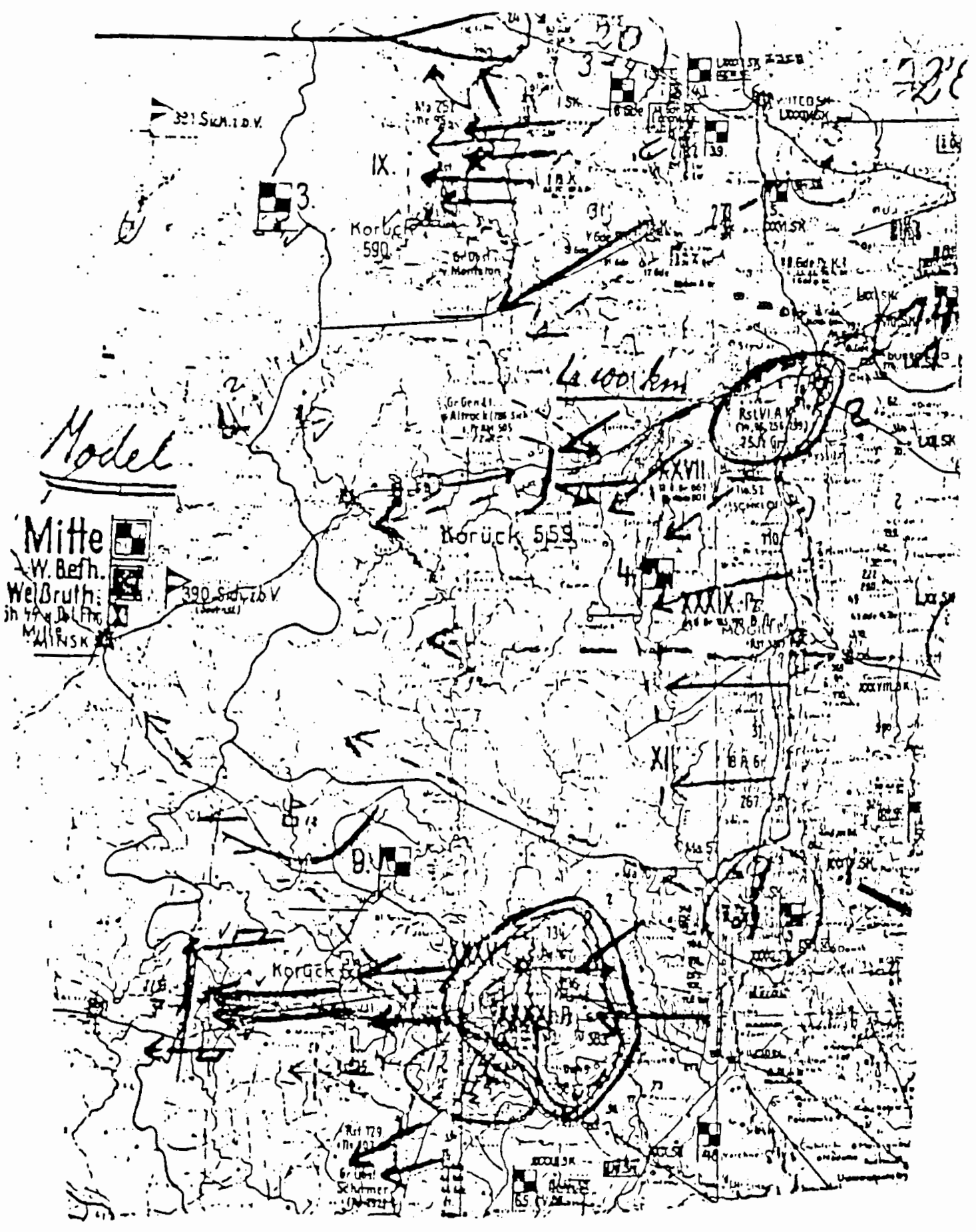

Figure 110. Army Group Center, June 28, 1944. Source: $\mathrm{OKH}$, Der Grosse Durchbruch Bei Hgr. Mitte Von 21.6.10.8.44., National Archives Microfilm Publication T-78, Roll 136. 


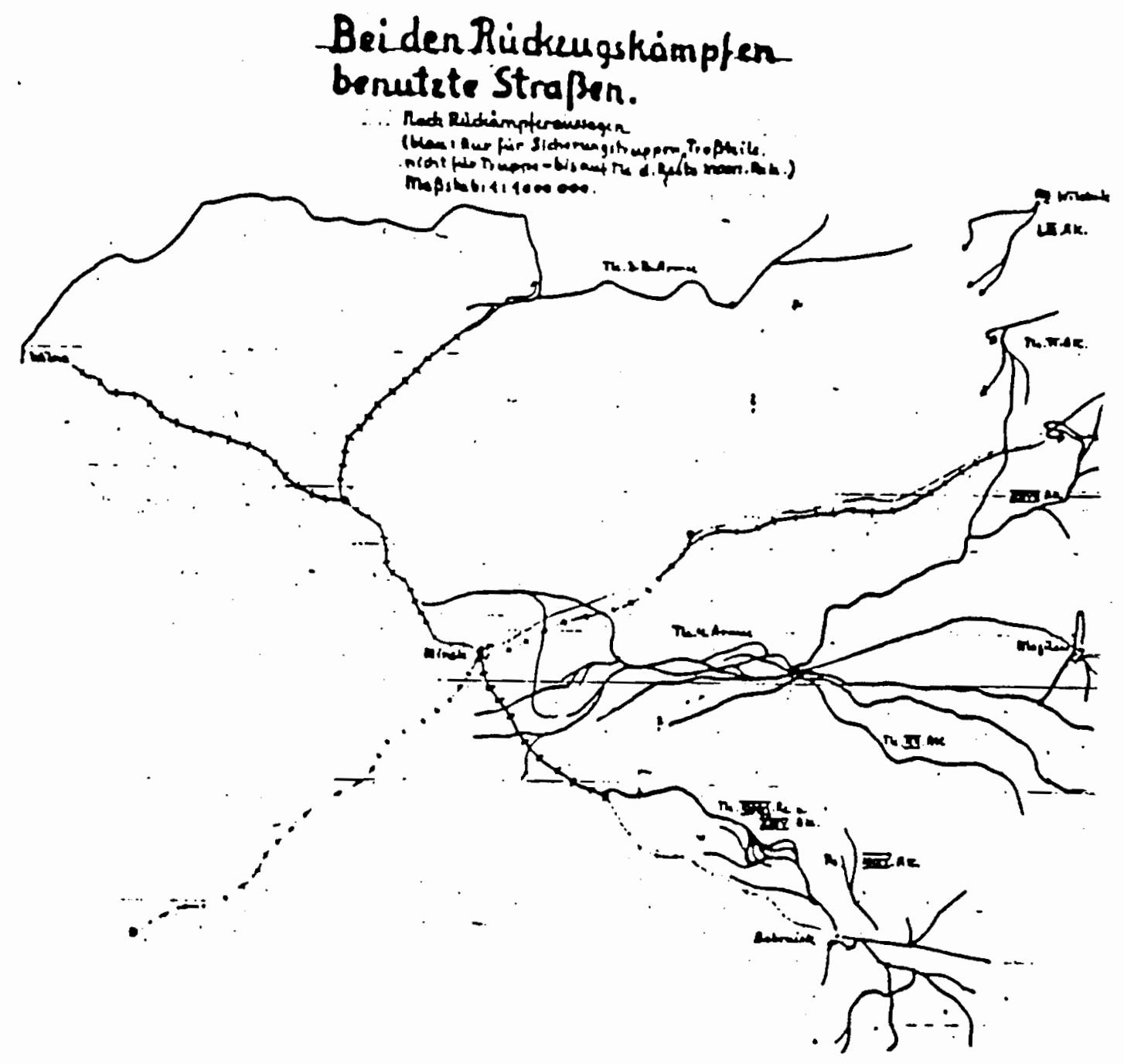

Figure 111. The Principal Roads Used In The Retreat Of Army Group Center. Source: Heeresgruppe Mitte, Bei den Rueckzuaskaempfen benutzte Strassen National Archives Microfilm Publication T-311, Roll 219. 


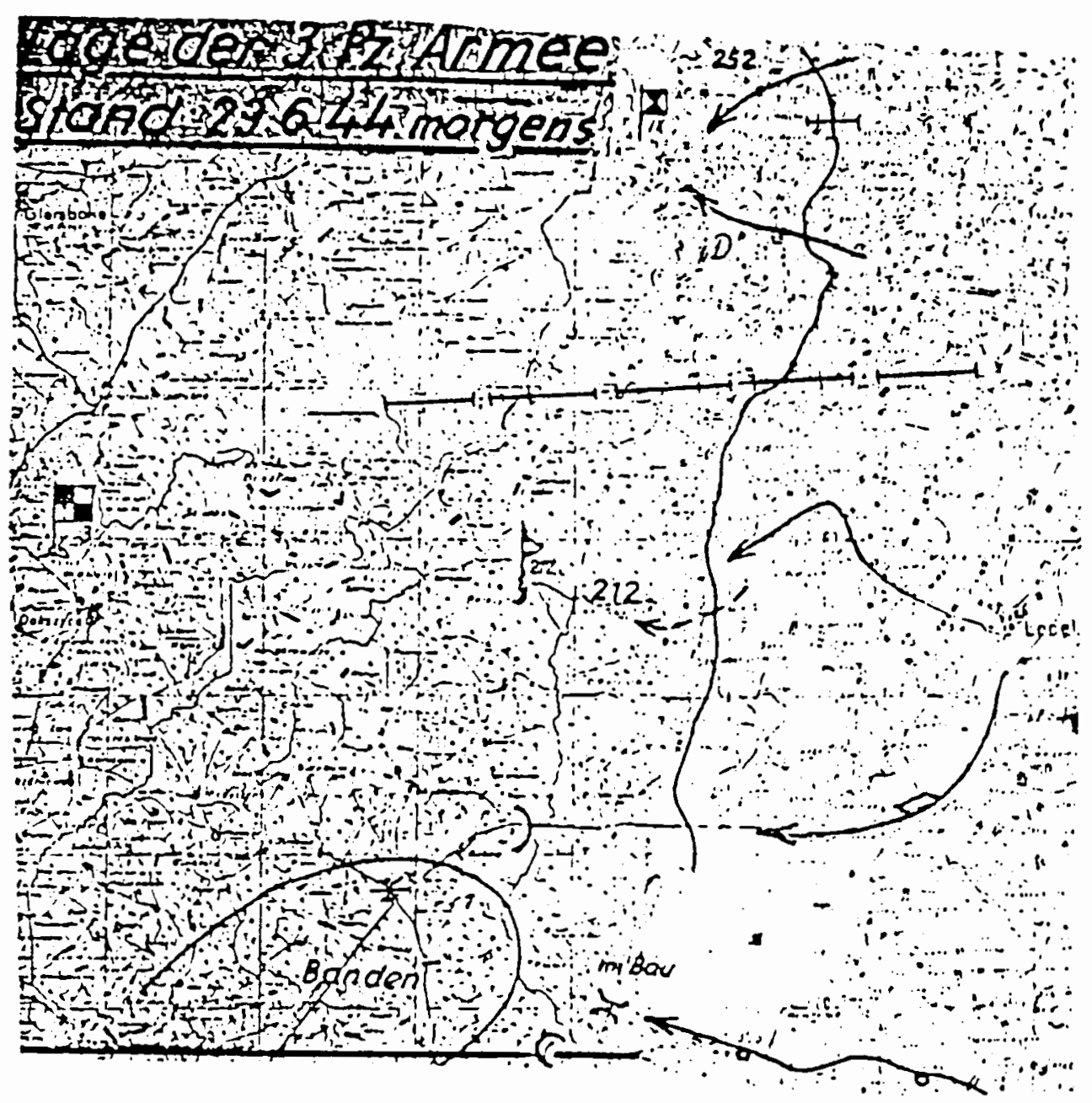

Figure 112. The Situation Of The 3rd Panzer Army On June 29, 1944. Source: Pz.A.O.K. 3, Lage der 3.Pz. Armee, Stand: 29.6.44.morgens National Archives Microfilm Publication T-313, Roll 318. 


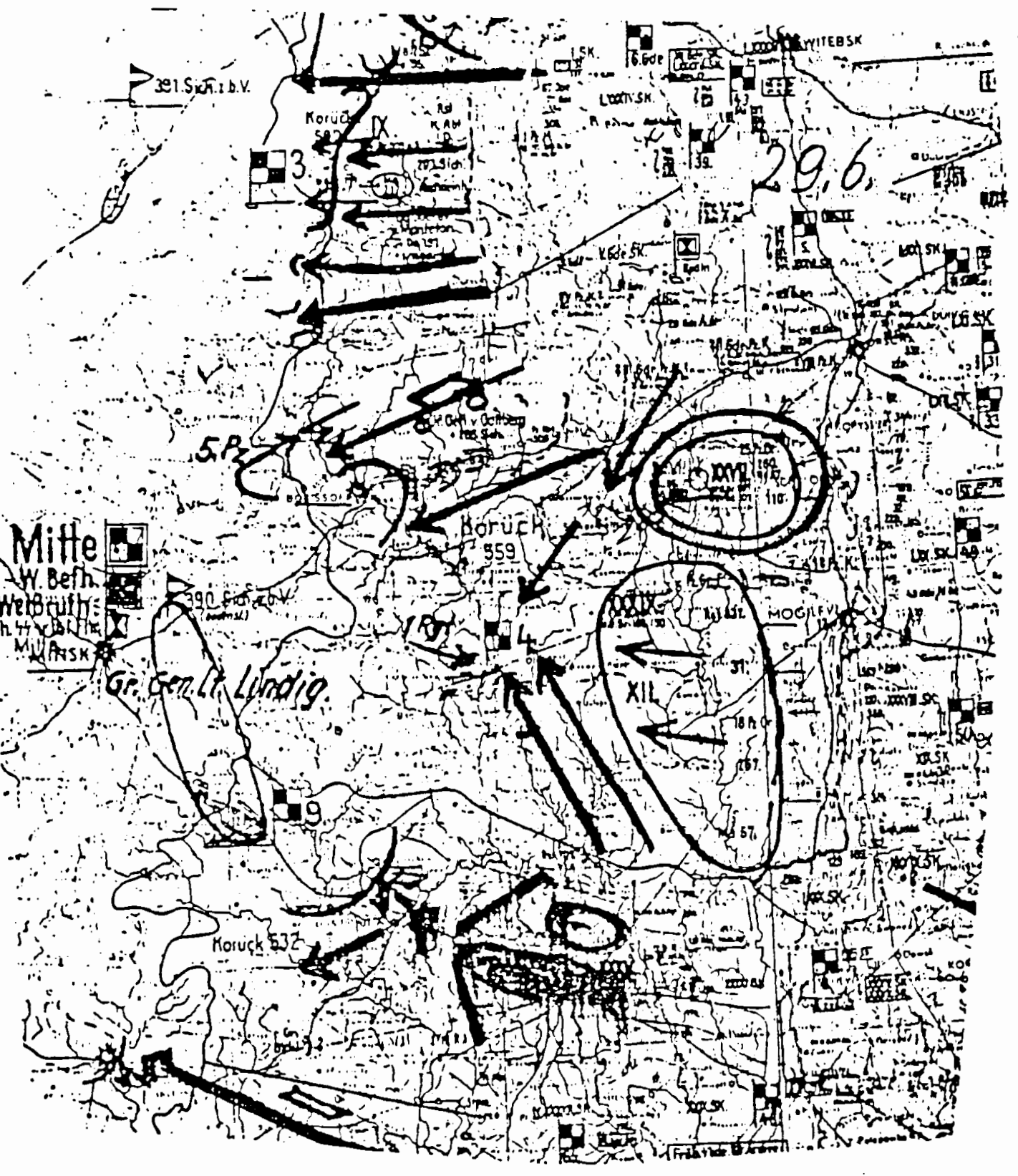

Figure 113. Army Group Center, June 29, 1944. Source: OKH, Der Grosse Durchbruch Bei Hgr. Mitte Von 21.6.10.8.44., National Archives Microfilm Publication T-78, Roll 136. 


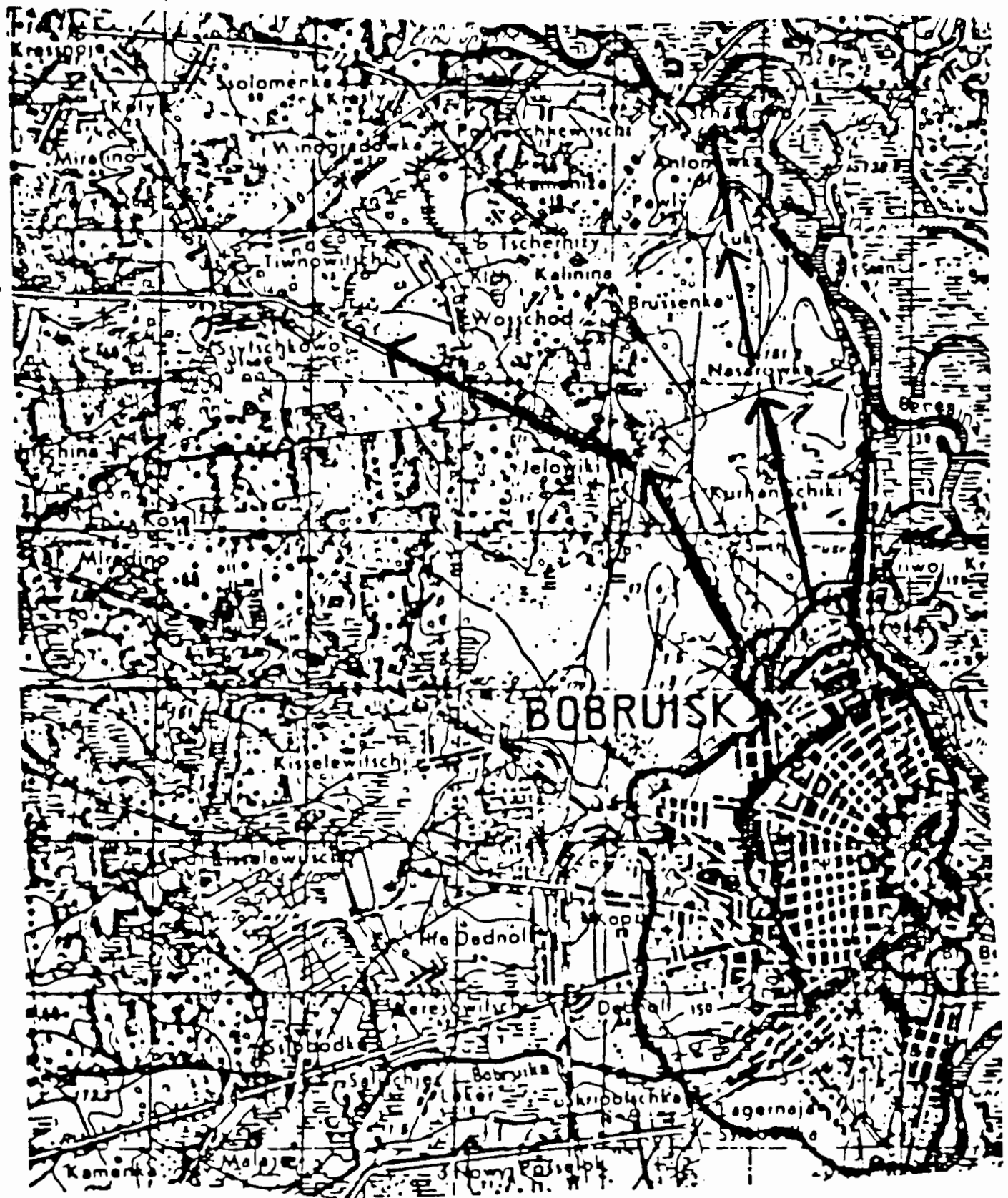

Figure 114. The Breakout From Bobruisk. Source: Oberkommando Heeresgruppe Mitte, Fester Platz Bobruisk 21.6.44. National Archives Microfilm Publication T-311, Roll 218. 


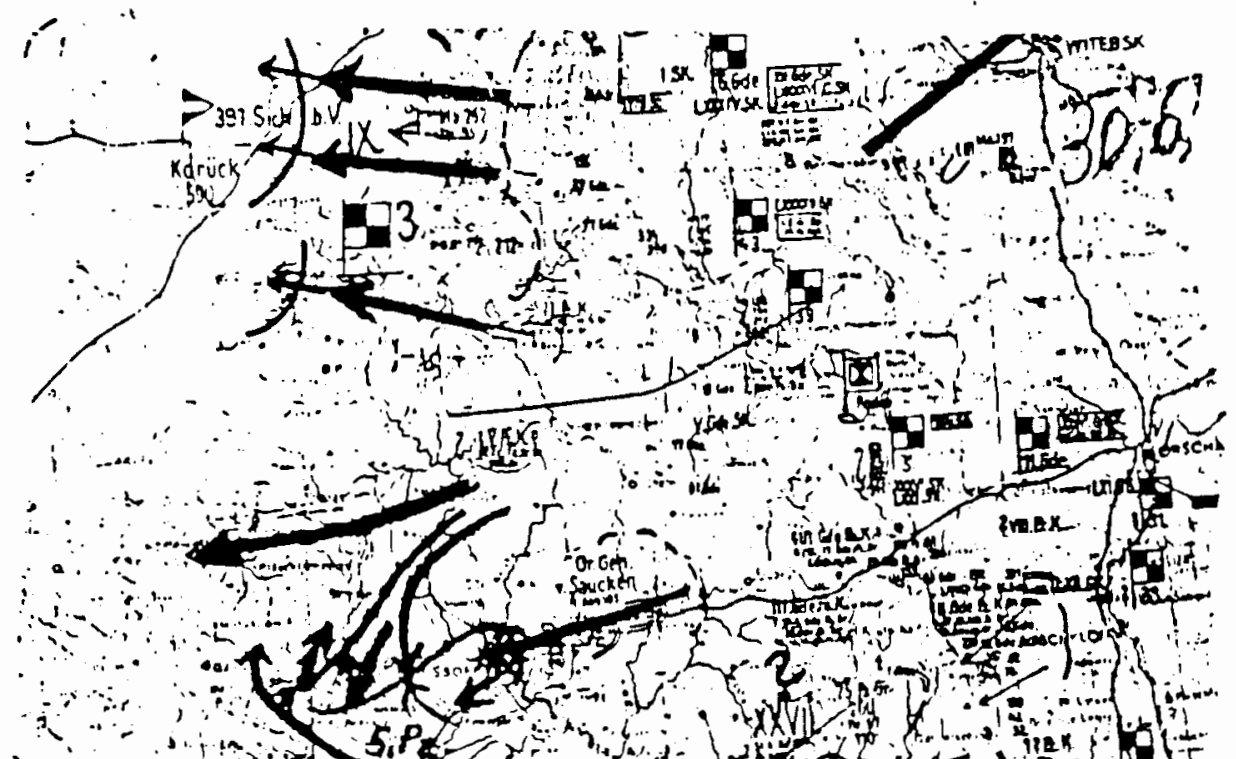

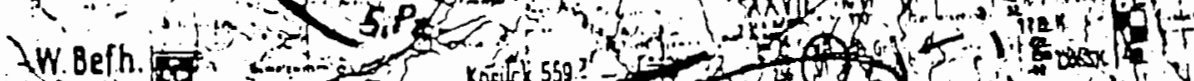
WelButh 4 .

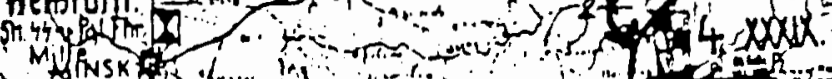

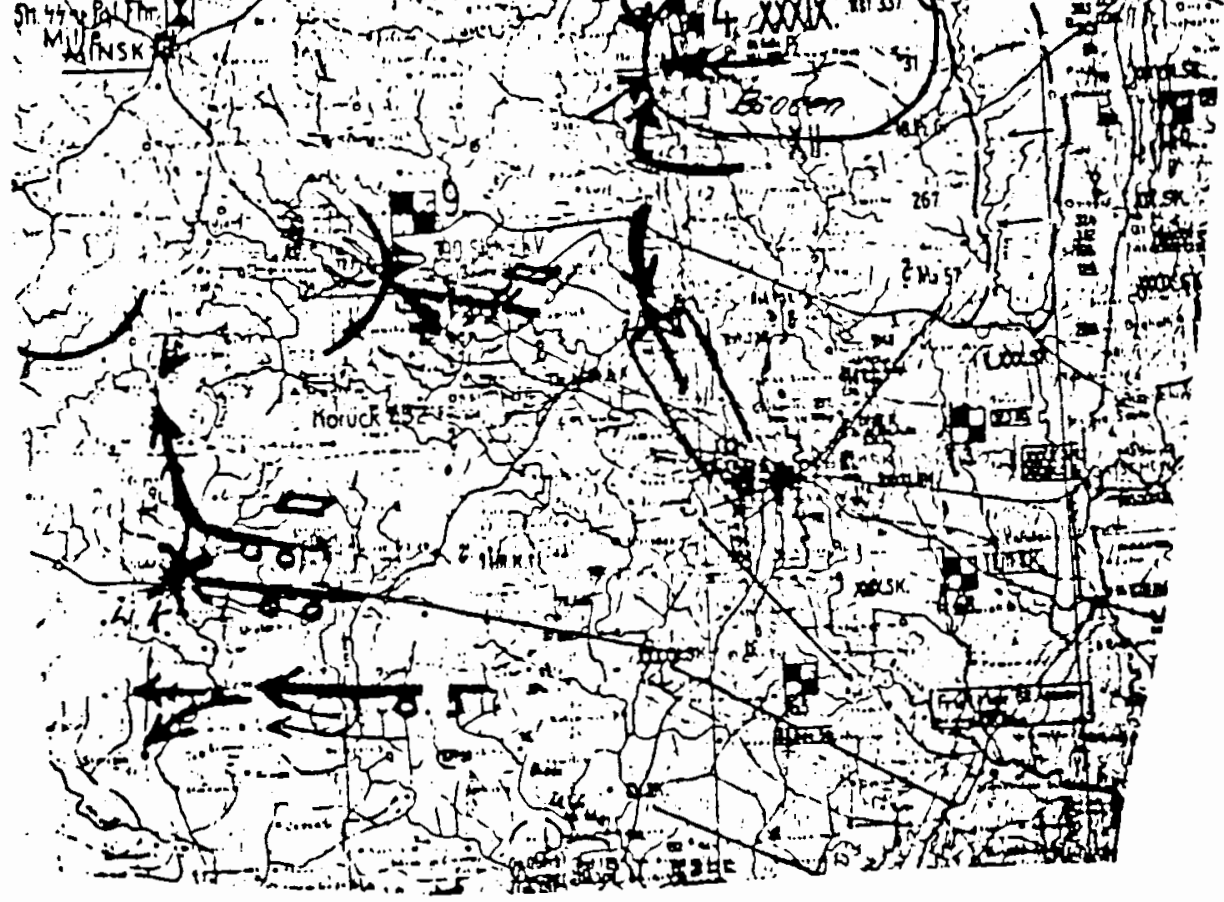

Figure 115. Army Group Center, June 30, 1944. Source: OKH, Der Grosse Durchbruch Bei Hgr. Mitte Von 21.6.10.8.44., National Archives Microfilm Publication T-78, Roll 136. 


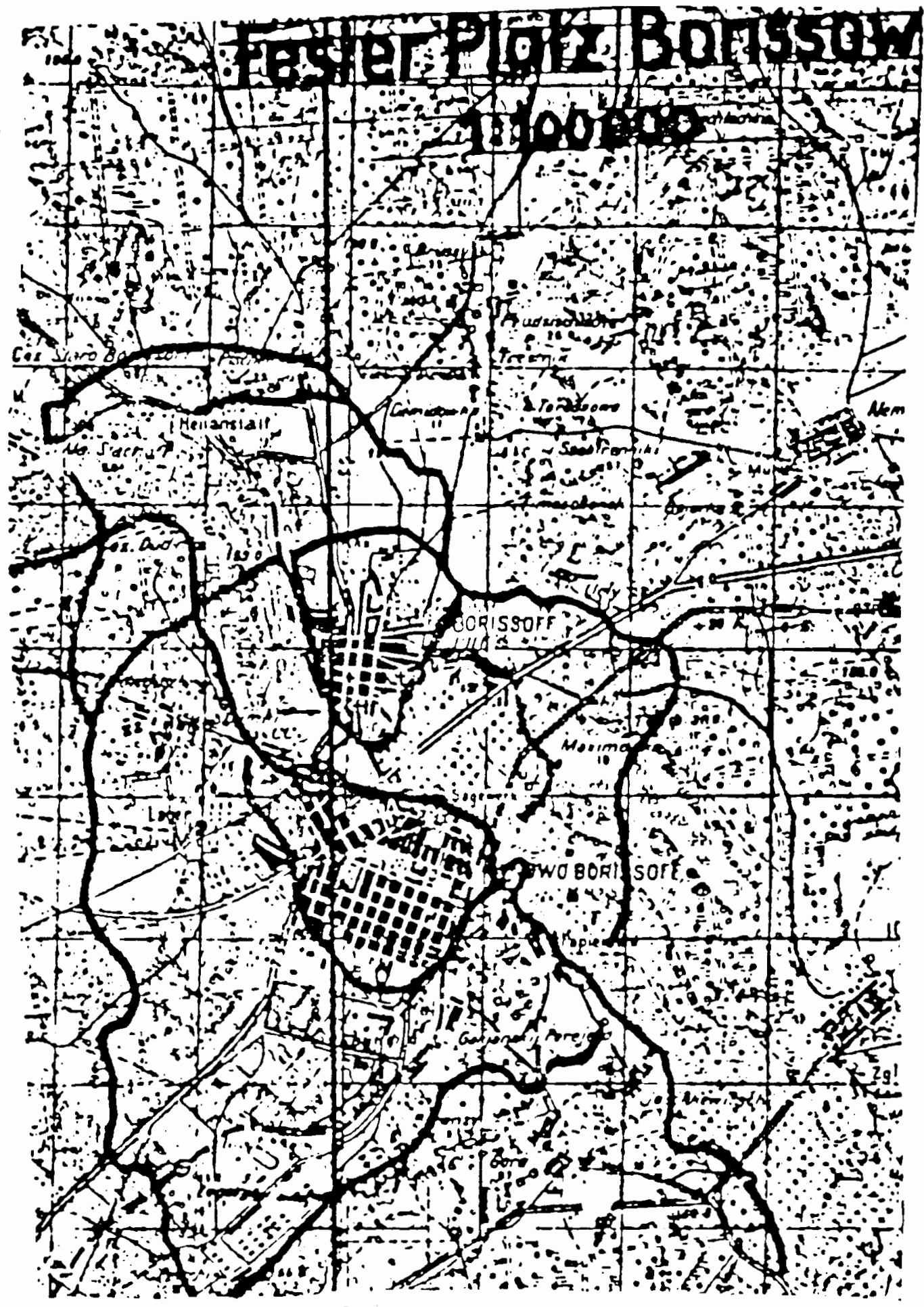

Figure 116. Fortress Borisov. Source: Oberkommando Heeresgruppe Mitte, Fester Platz Borissow 21.6.44. National Archives Microfilm Publication T-311, Roll 218. 


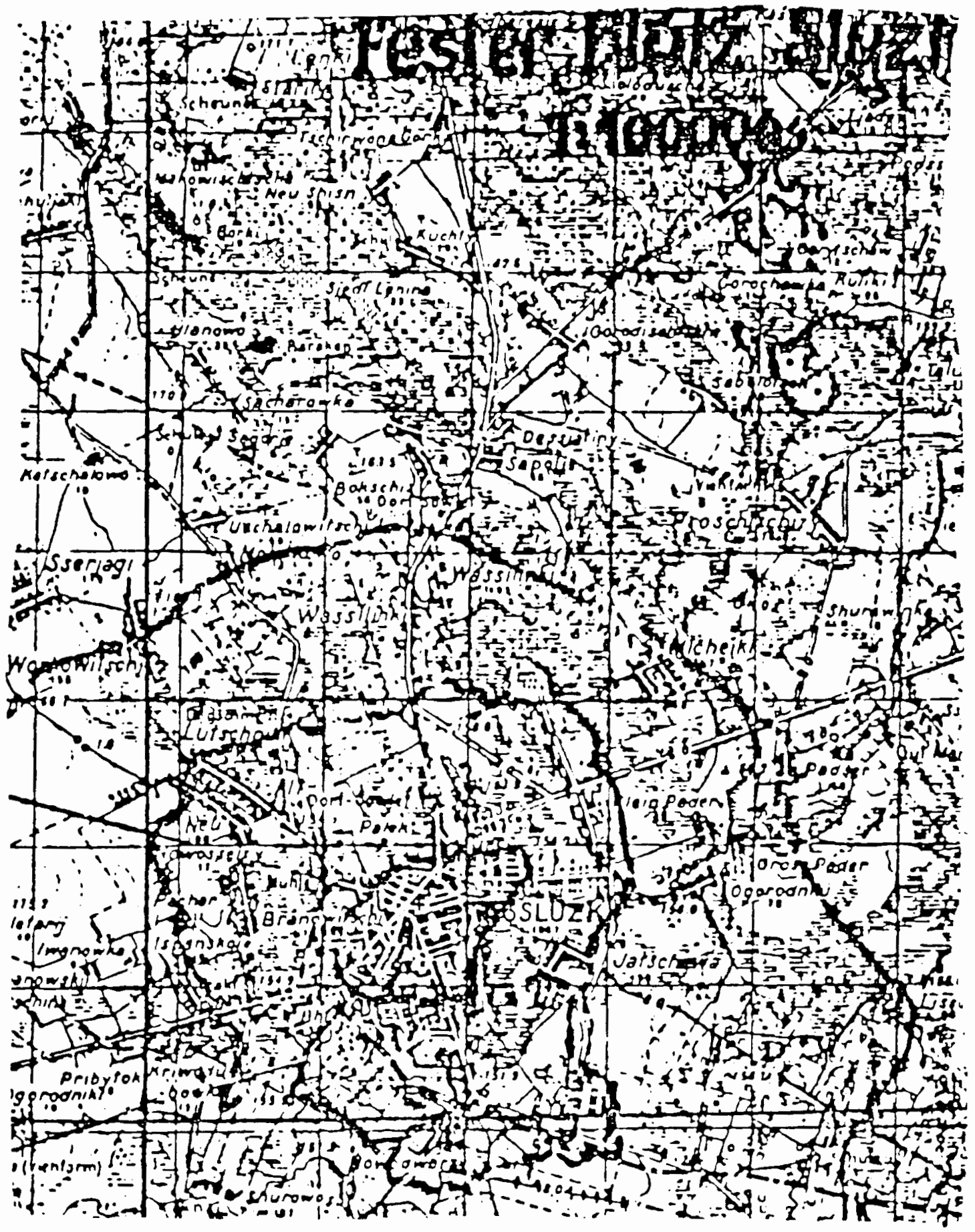

Figure 117. Fortress Ssluzk. Source: Oberkommando Heeresgruppe Mitte, Fester Platz Ssluzk 21.6.44. National Archives Microfilm Publication T-311, Roll 218. 


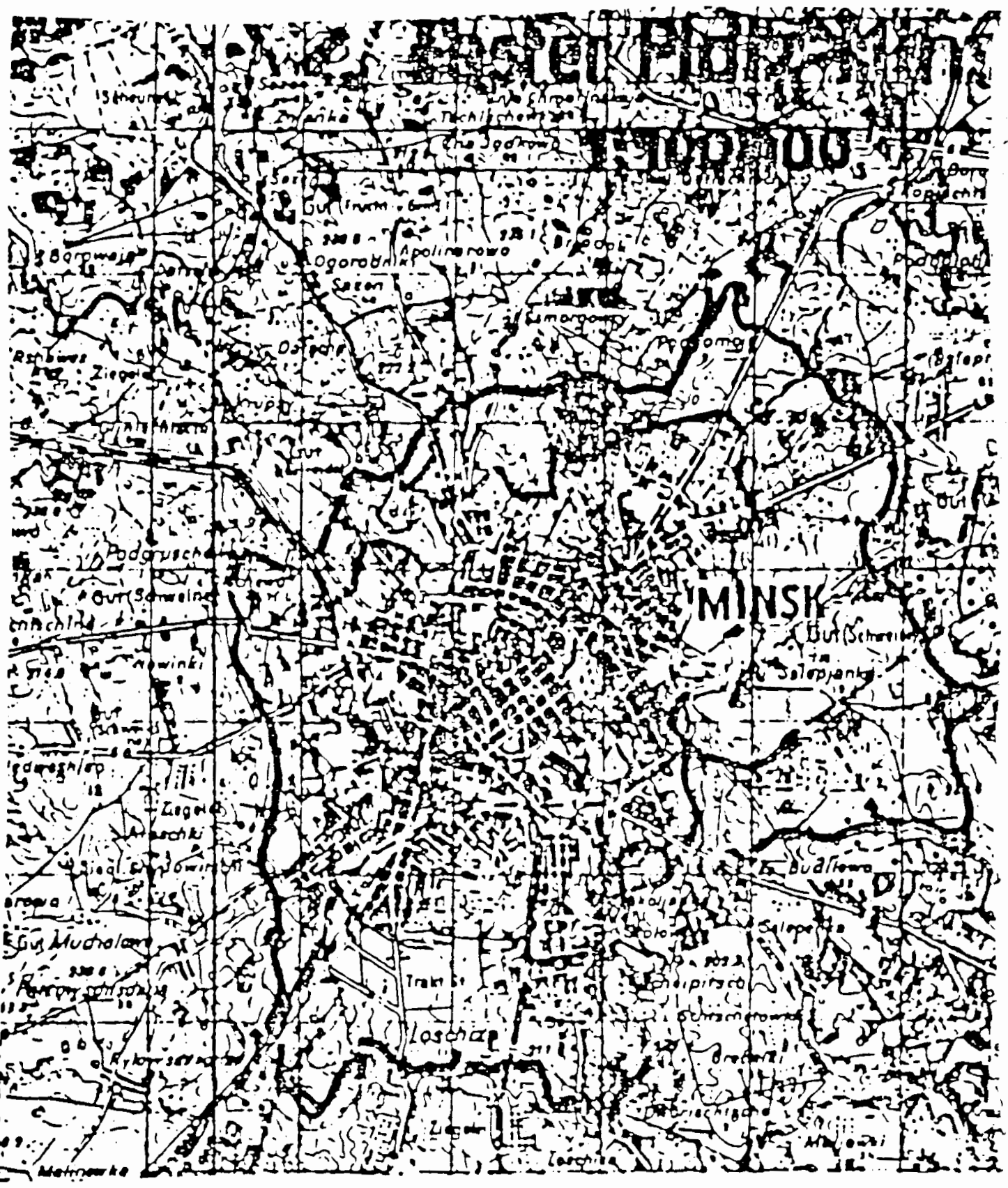

Figure 118. Fortress Minsk. Source: Oberkommando Heeresgruppe Mitte, Fester Platz Minsk 21.6.44. National Archives Microfilm Publication T-311, Roll 218. 


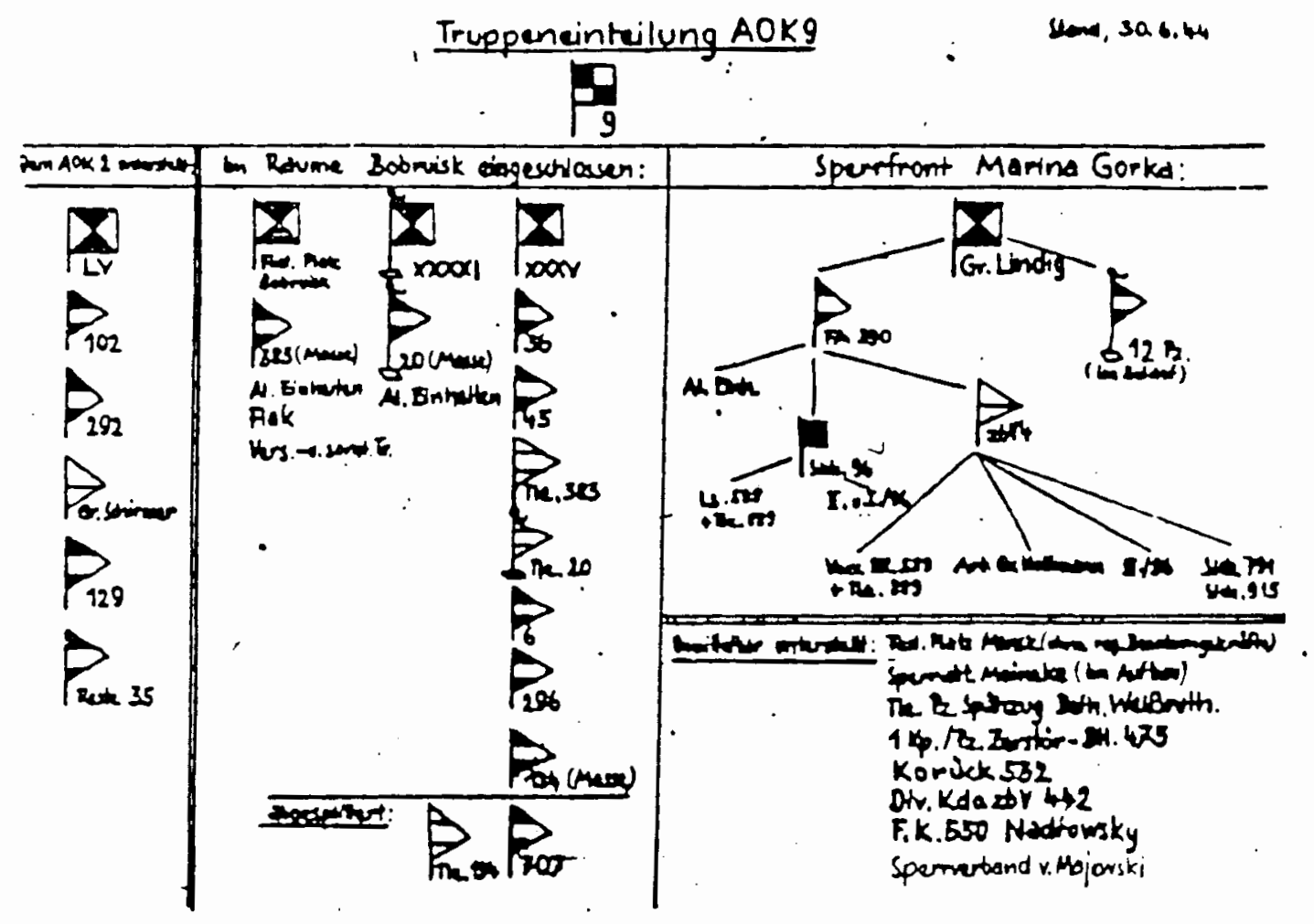

Figure 119. 9th Army Order Of Battle, June 30, 1944. Source: Lt. Weller, Gefechtsbericht der 9. Armee ueber die Schlacht in Weissruthenien 24.6.-10.7.1944 National Archives Microfilm Publication T-312, Roll 339. 


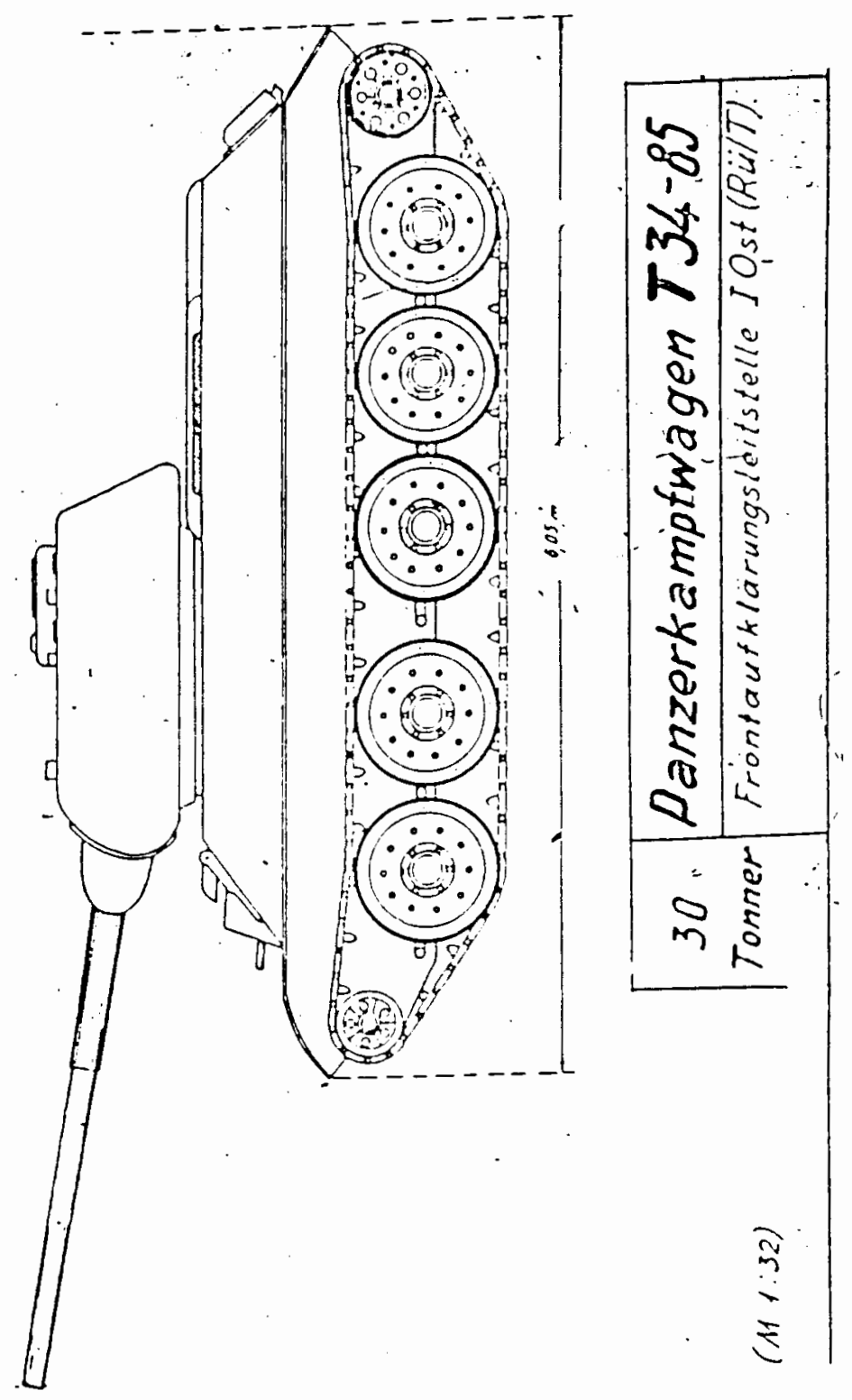

Figure 120. T34-85. Source:

Frontaufklaerungsleitstelle | Ost (Rue/T),

Panzerkampfwagen T34-85 National Archives Microfilm Publication T-78, Roll 579. 


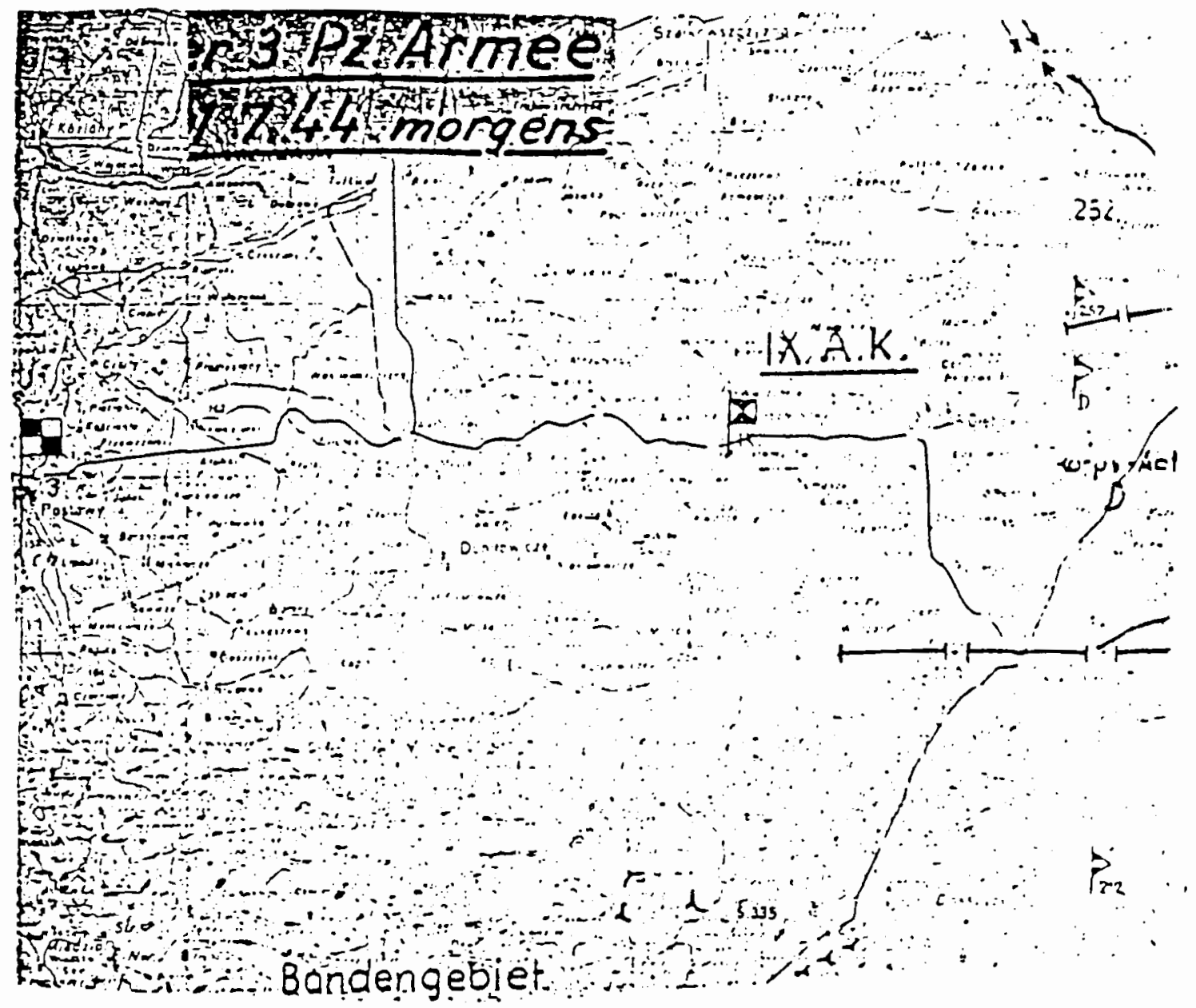

Figure 121. The Situation Of The 3rd Panzer Army On July 1, 1944. Source: Pz.A.O.K. 3, Lage der 3. Pz. Armee, Stand: 1.7.44.morgens National Archives Microfilm Publication T-313, Roll 318. 


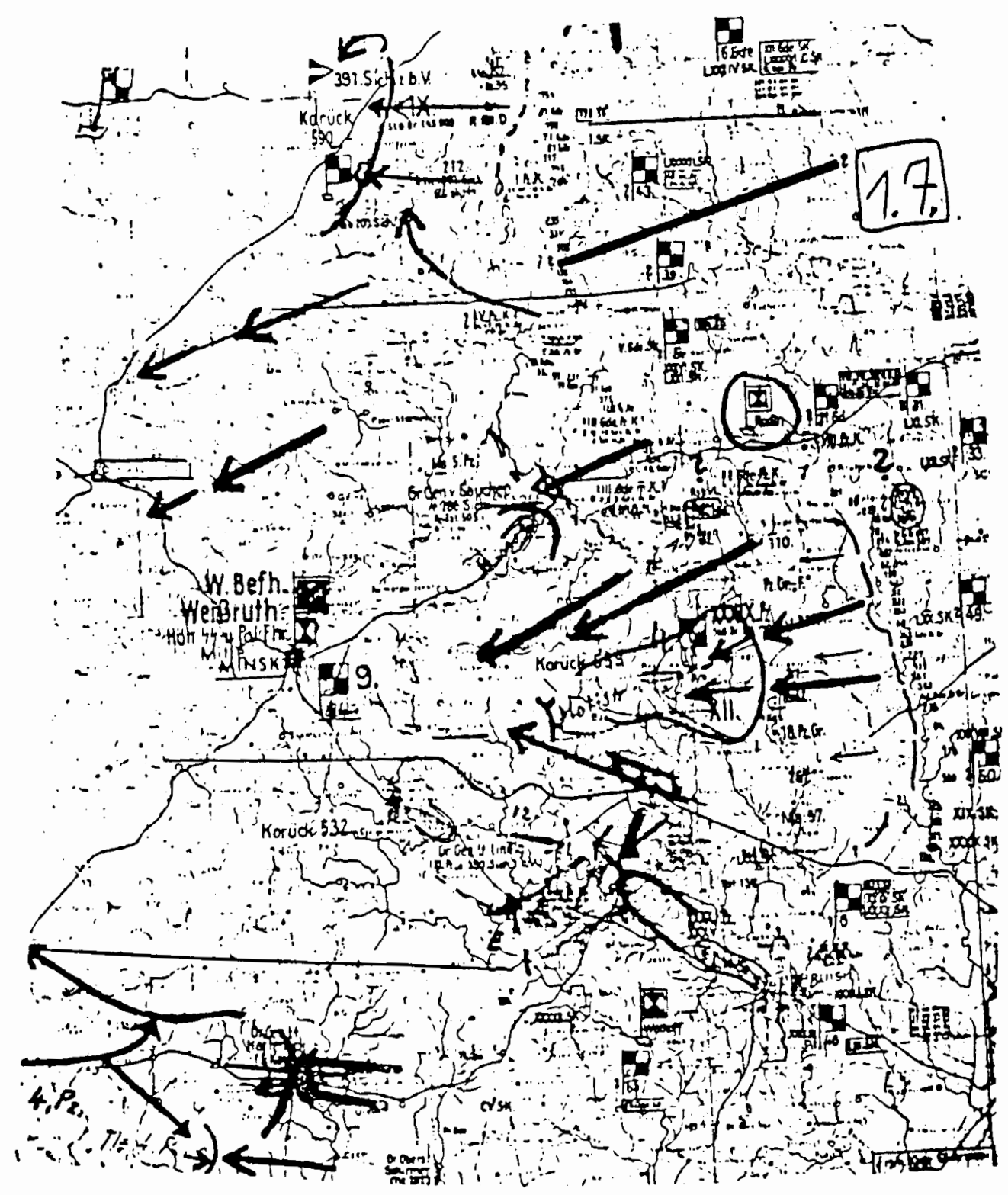

Figure 122. Army Group Center, July 1, 1944. Source: OKH, Der Grosse Durchbruch Bei Hgr. Mitte Von 21.6.10.8.44., National Archives Microfilm Publication T-78, Roll 136. 


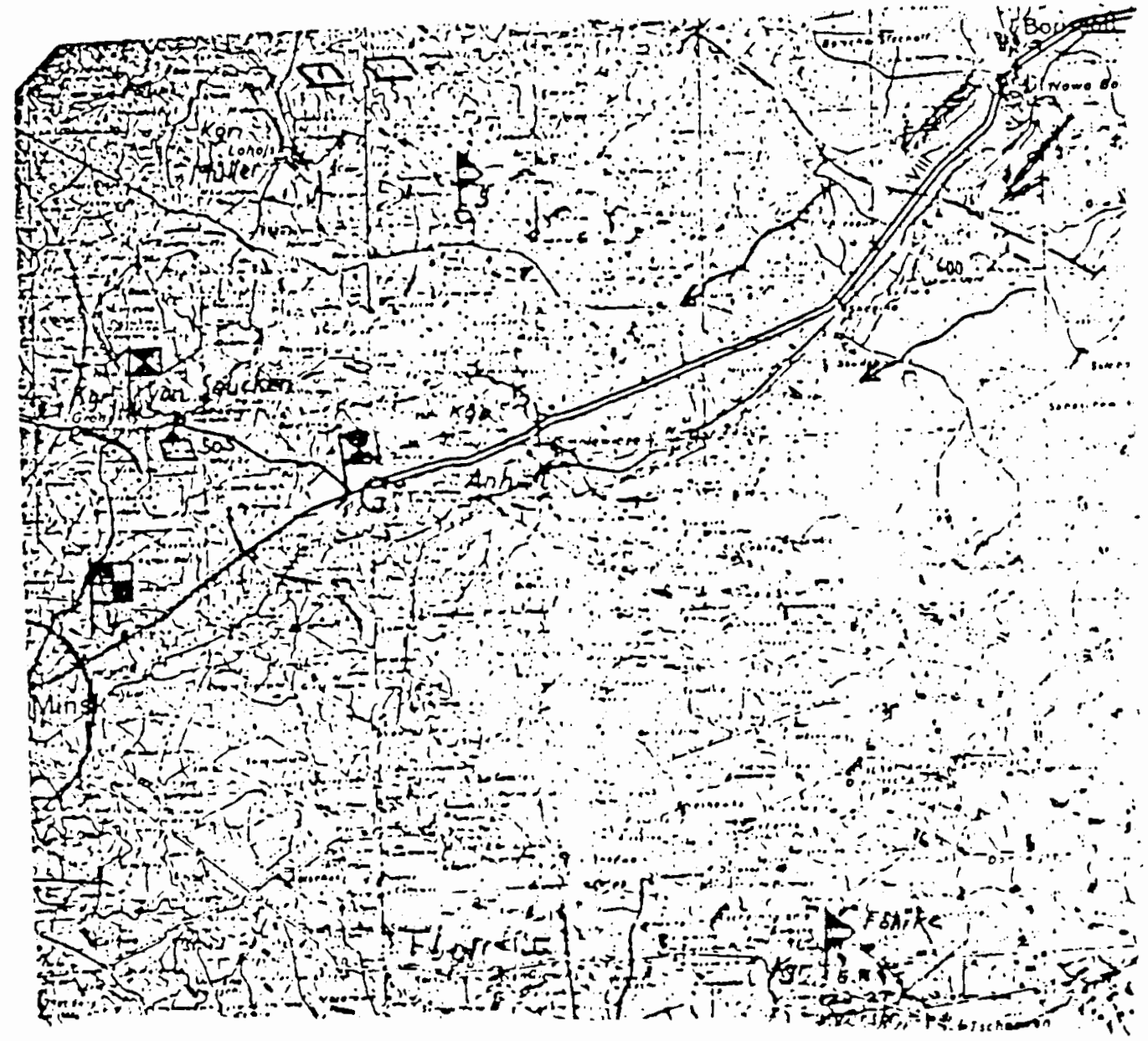

Figure 123. Soviet Eastern Advance Toward Minsk On July 1, 1944. Source: A.O.K. 4, 12. Kartenband 1. Anlagen zum KTB Nr. 24 National Archives Microfilm Publication T-312, Roll 252. 


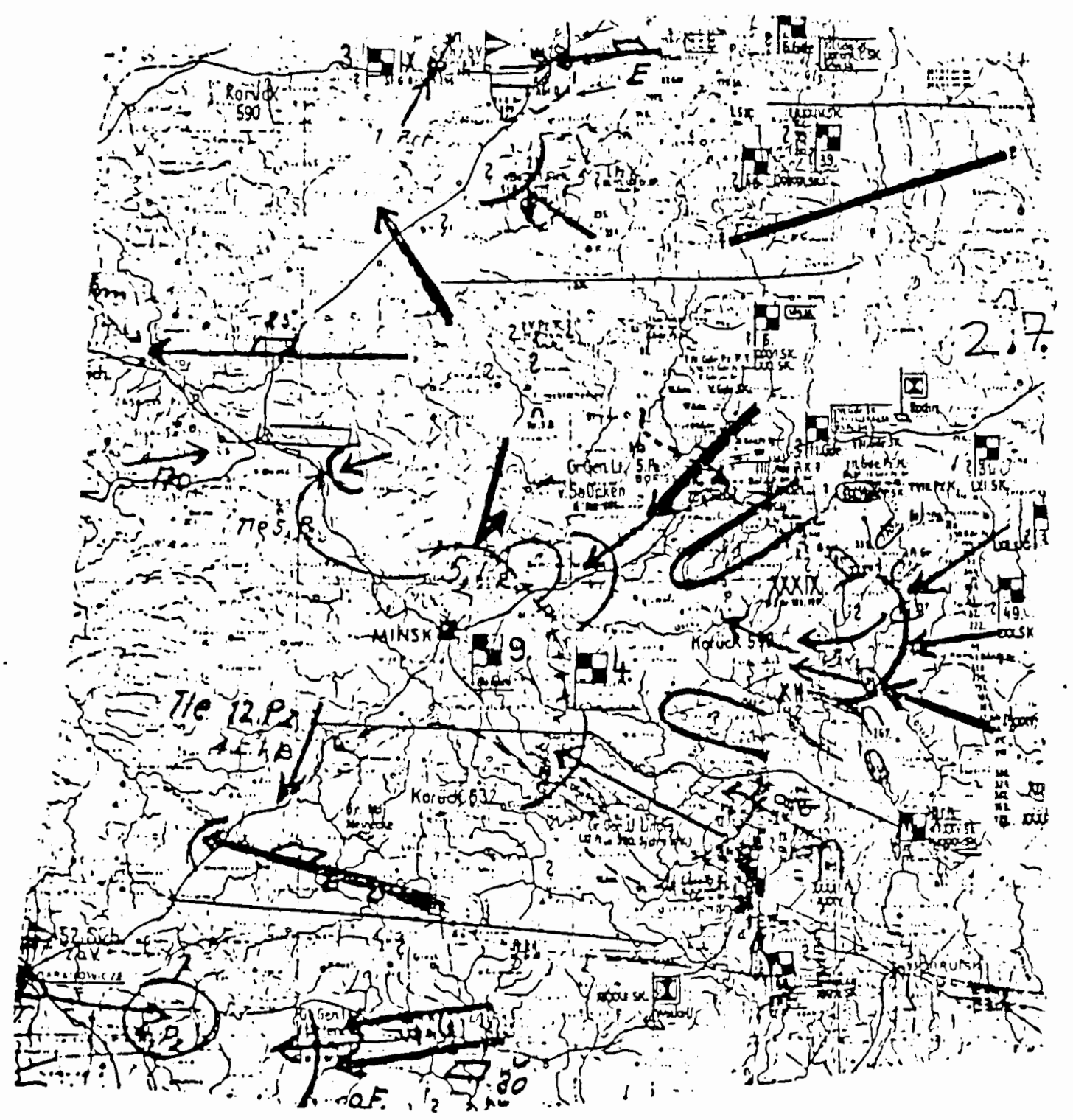

Figure 124. Army Group Center, July 2, 1944. Source: $\mathrm{OKH}$, Der Grosse Durchbruch Bei Hgr. Mitte Von 21.6.10.8.44., National Archives Microfilm Publication T-78, Roll 136. 


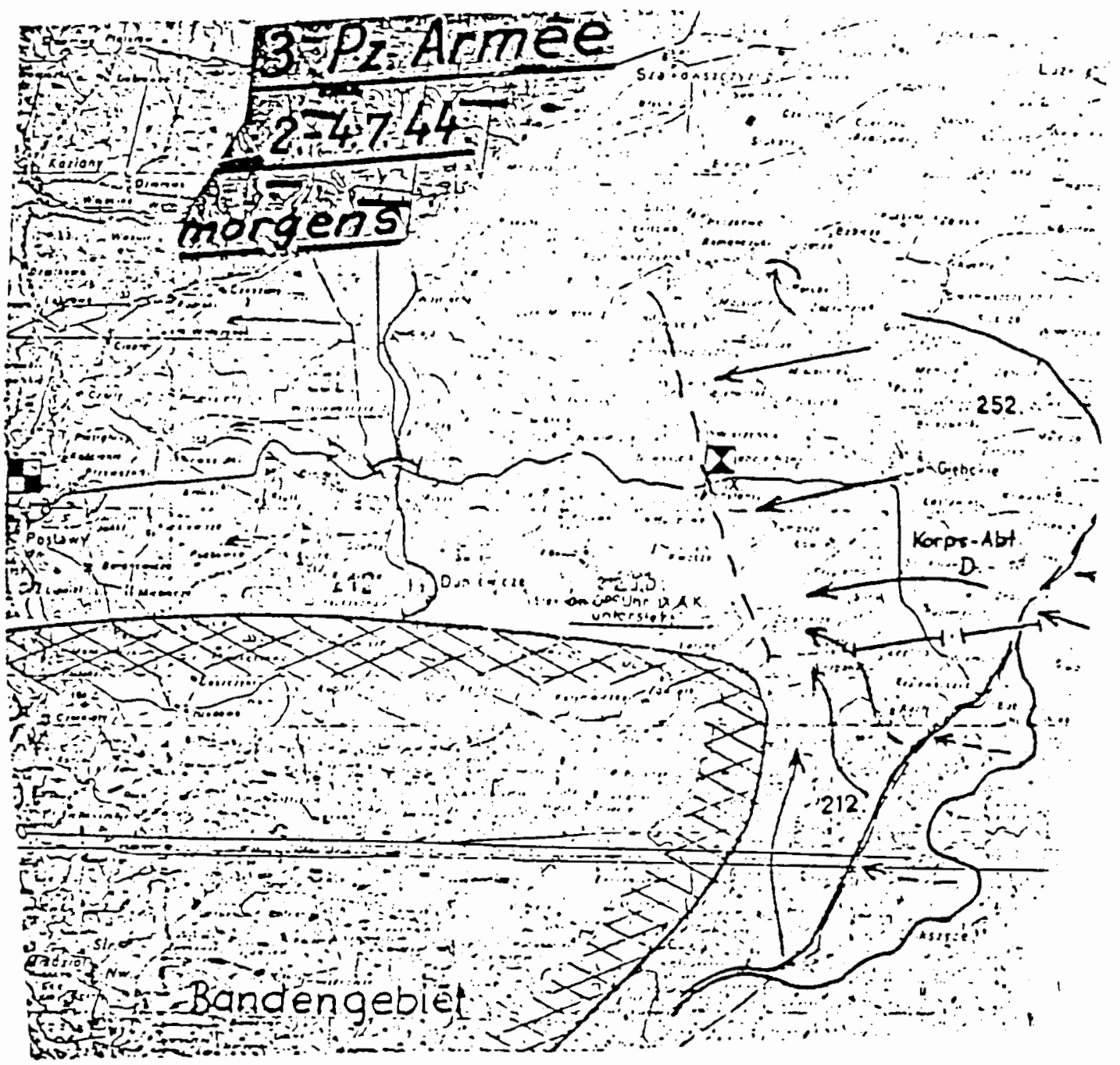

Figure 125. The Situation Of The 3rd Panzer Army On July 2-4, 1944. Source: Pz.A.O.K. 3, Lage der 3. Pz. Armee, Stand: 2.-4.7.44.morgens National Archives Microfilm Publication T-313, Roll 318. 


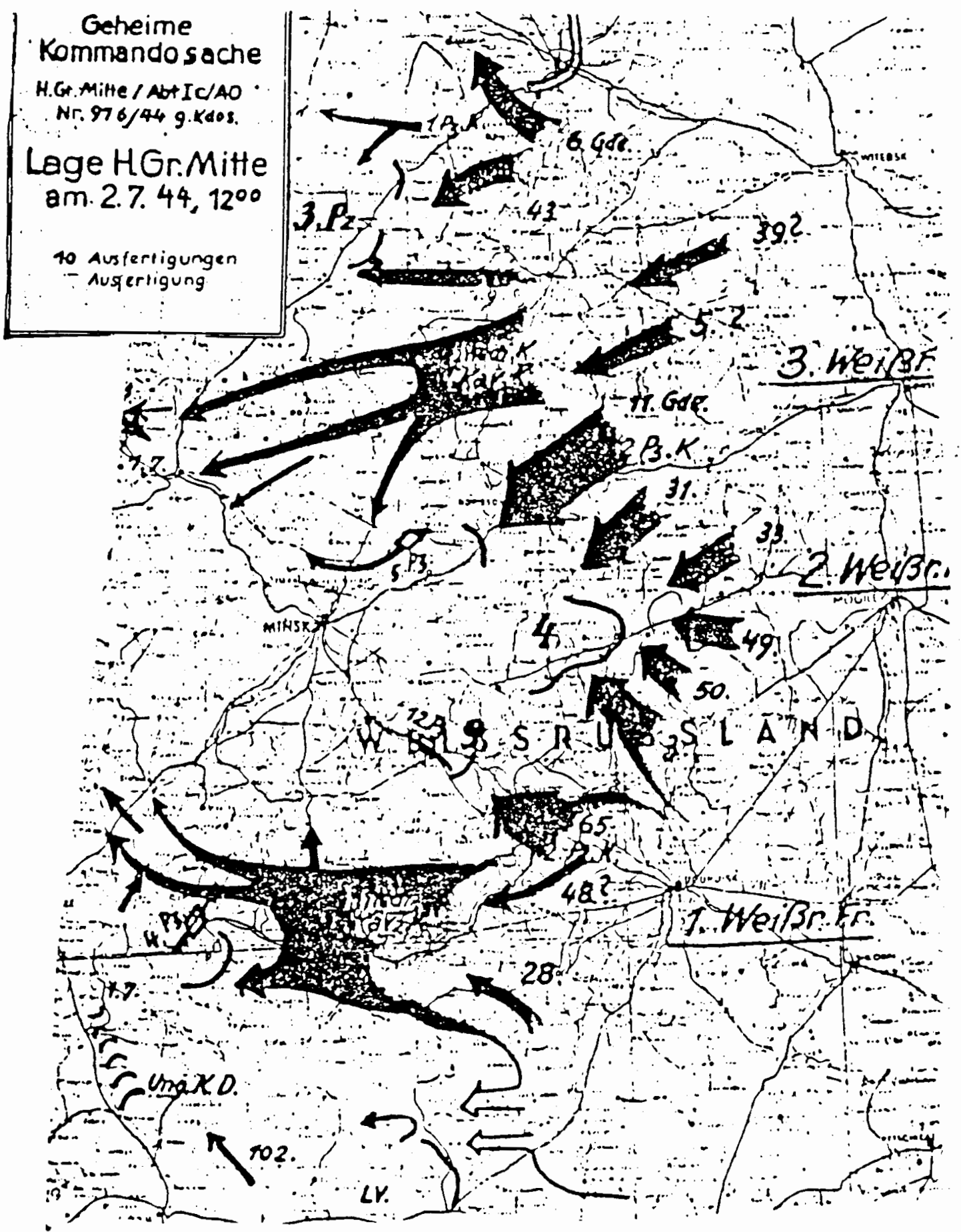

Figure 126. The Position Of Army Group Center On July 2, 1944 At 1200 Hrs. Source: Heeresgruppe Mitte, Lage H.Gr.Mitte am 2.7.44, 1200 National Archives Microfilm Publication T-311, Roll 234. 


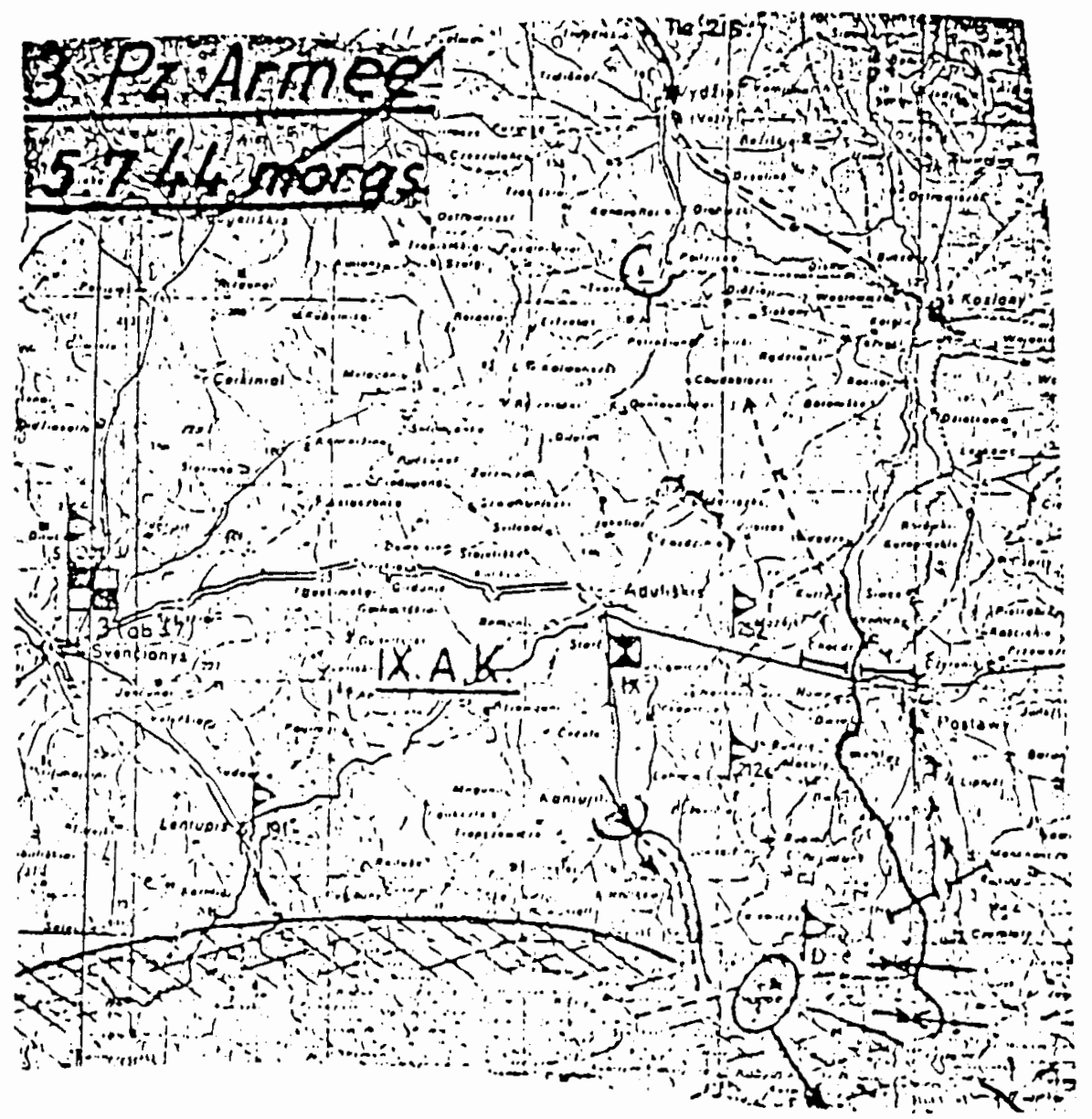

Figure 127. The Situation Of The 3rd Panzer Army On July 5, 1944. Source: Pz.A.O.K. 3, Lage der 3. Pz. Armee, Stand: 5.7.44.morgens National Archives Microfilm Publication T-313, Roll 318. 


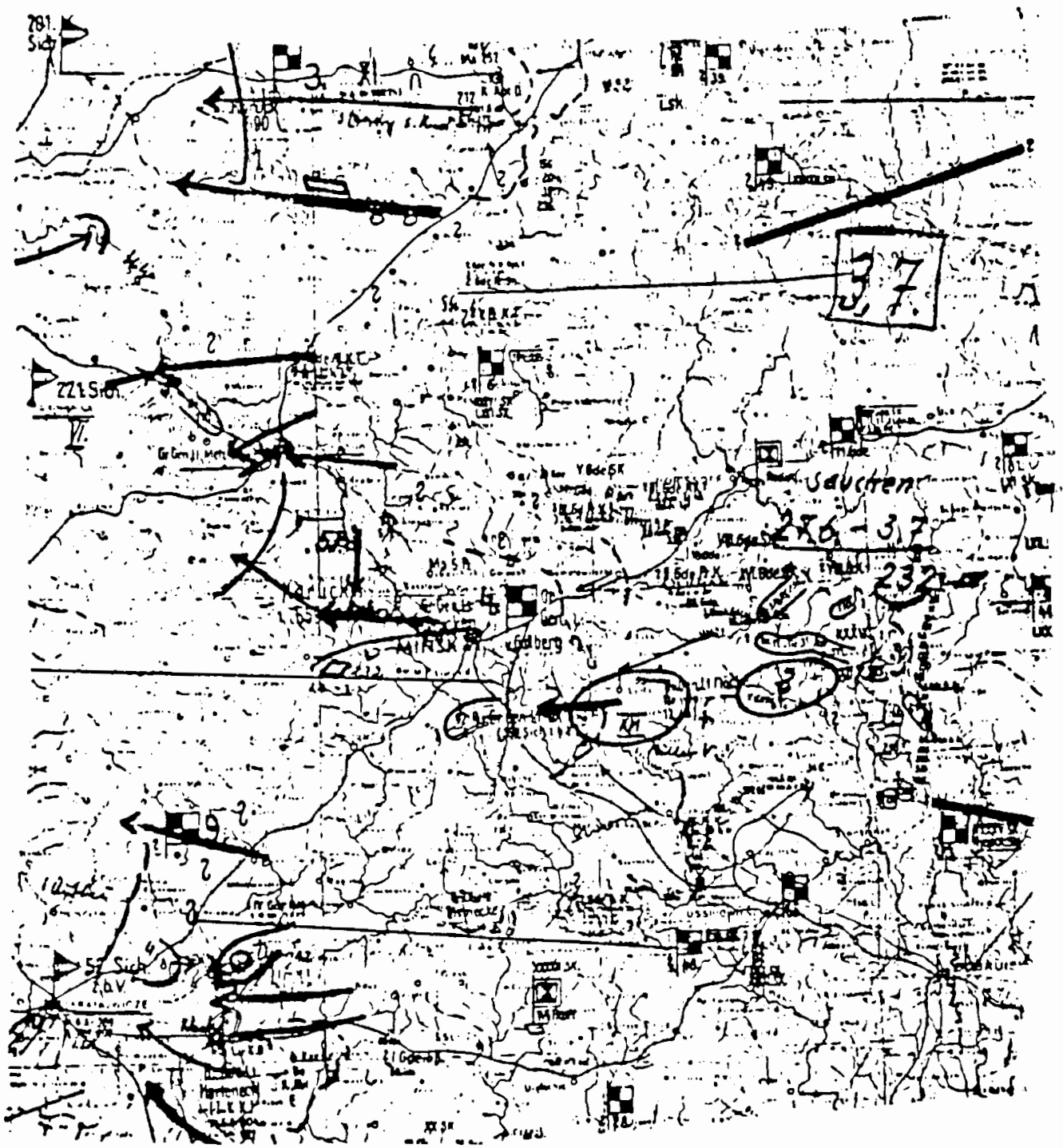

Figure 128. Army Group Center, July 3, 1944. Source: $\mathrm{OKH}$, Der Grosse Durchbruch Bei Hgr. Mitte Von 21.6.10.8.44., National Archives Microfilm Publication T-78, Roll 136. 


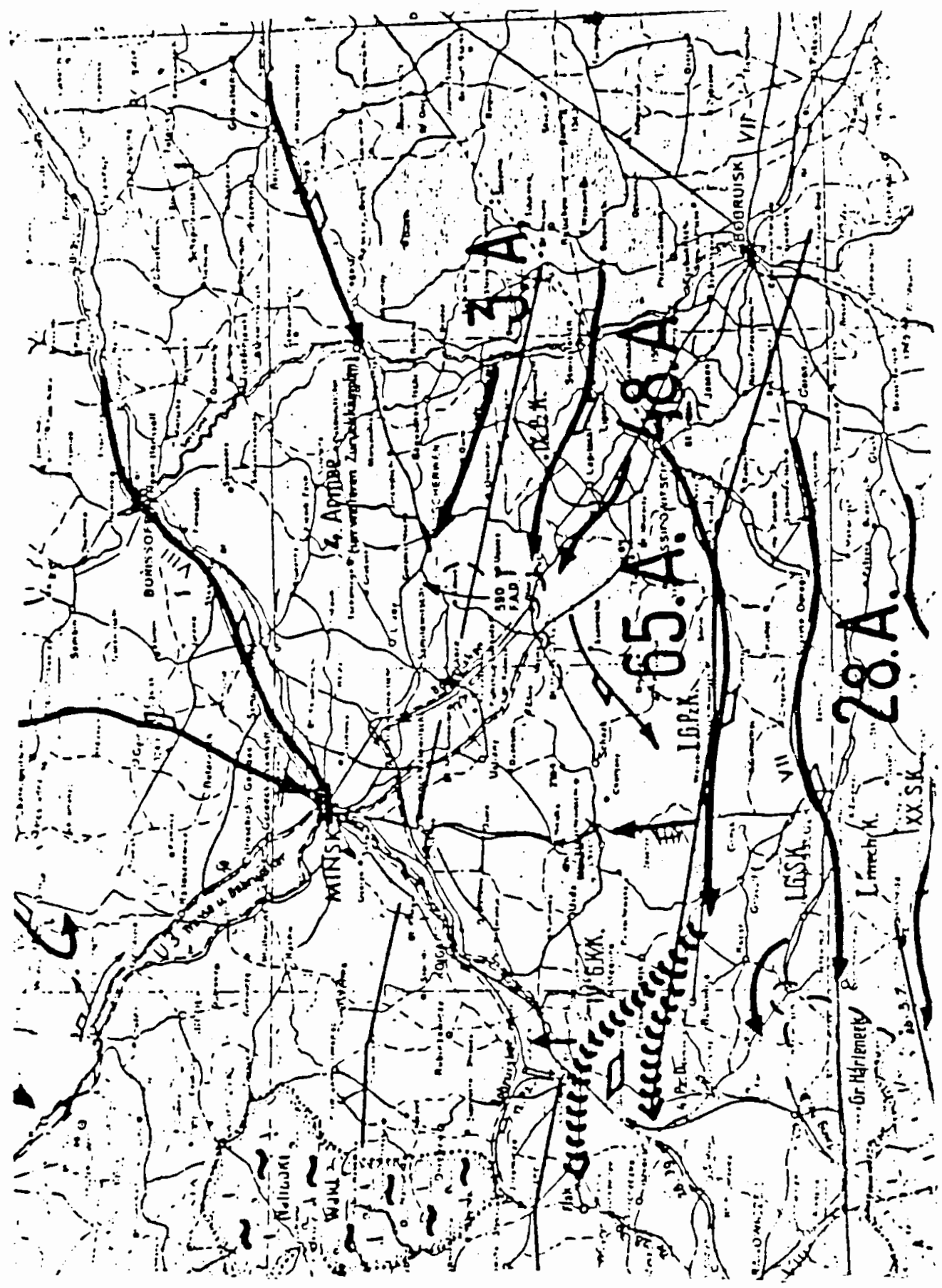

Figure 129. The Retreat Of The 4th Army And 9th Army Towards Minsk. Source: Armeeoberkommando 9, Die Leerung des Minsker Kessels 2.-3.7.44. National Archives Microfilm Publication T-312, Roll 339. 


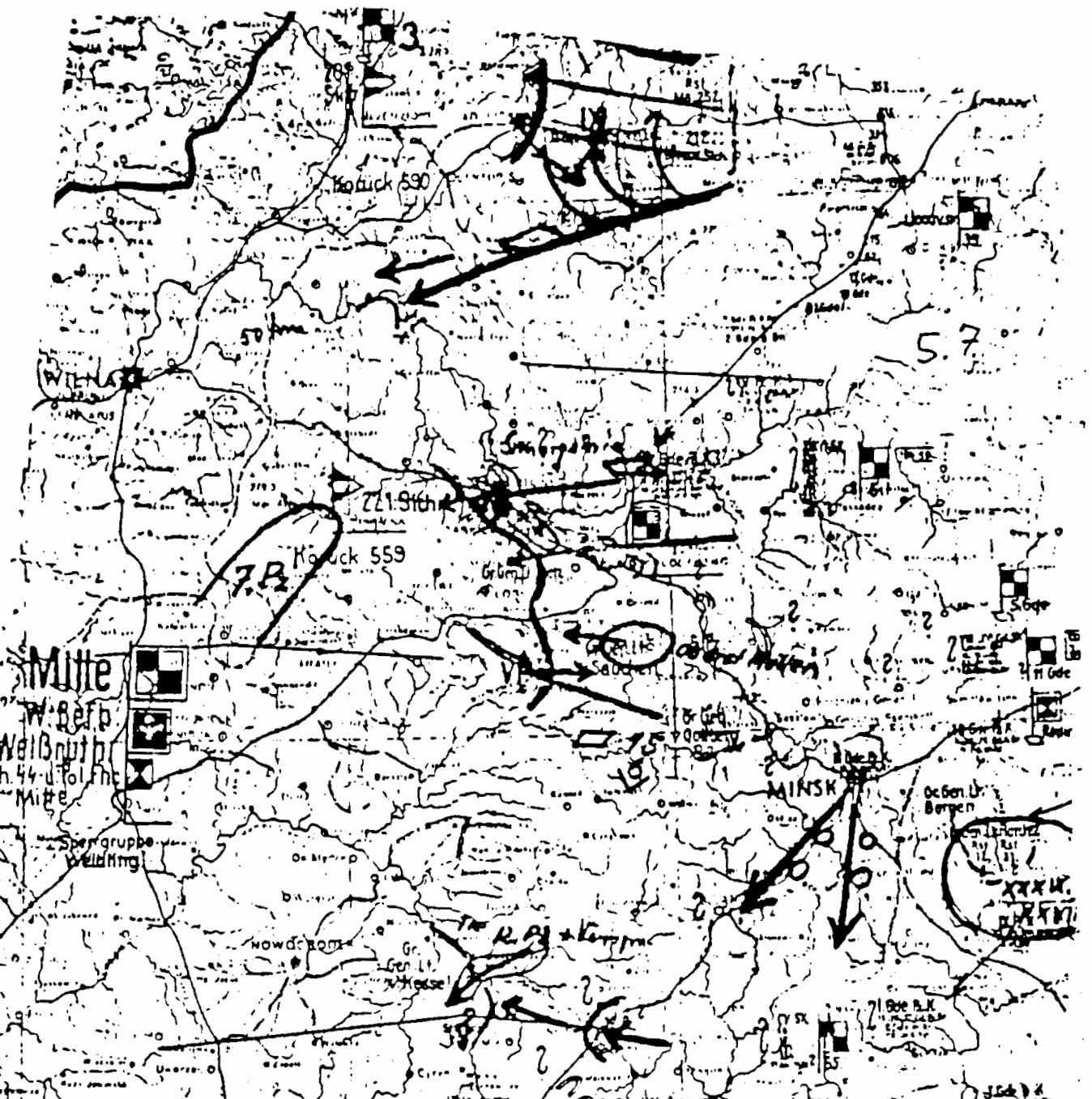

1t 3.

Figure 130. Army Group Center, July 5, 1944. Source: OKH, Der Grosse Durchbruch Bei Hgr. Mitte Von 21.6.10.8.44., National Archives Microfilm Publication T-78, Roll 136. 


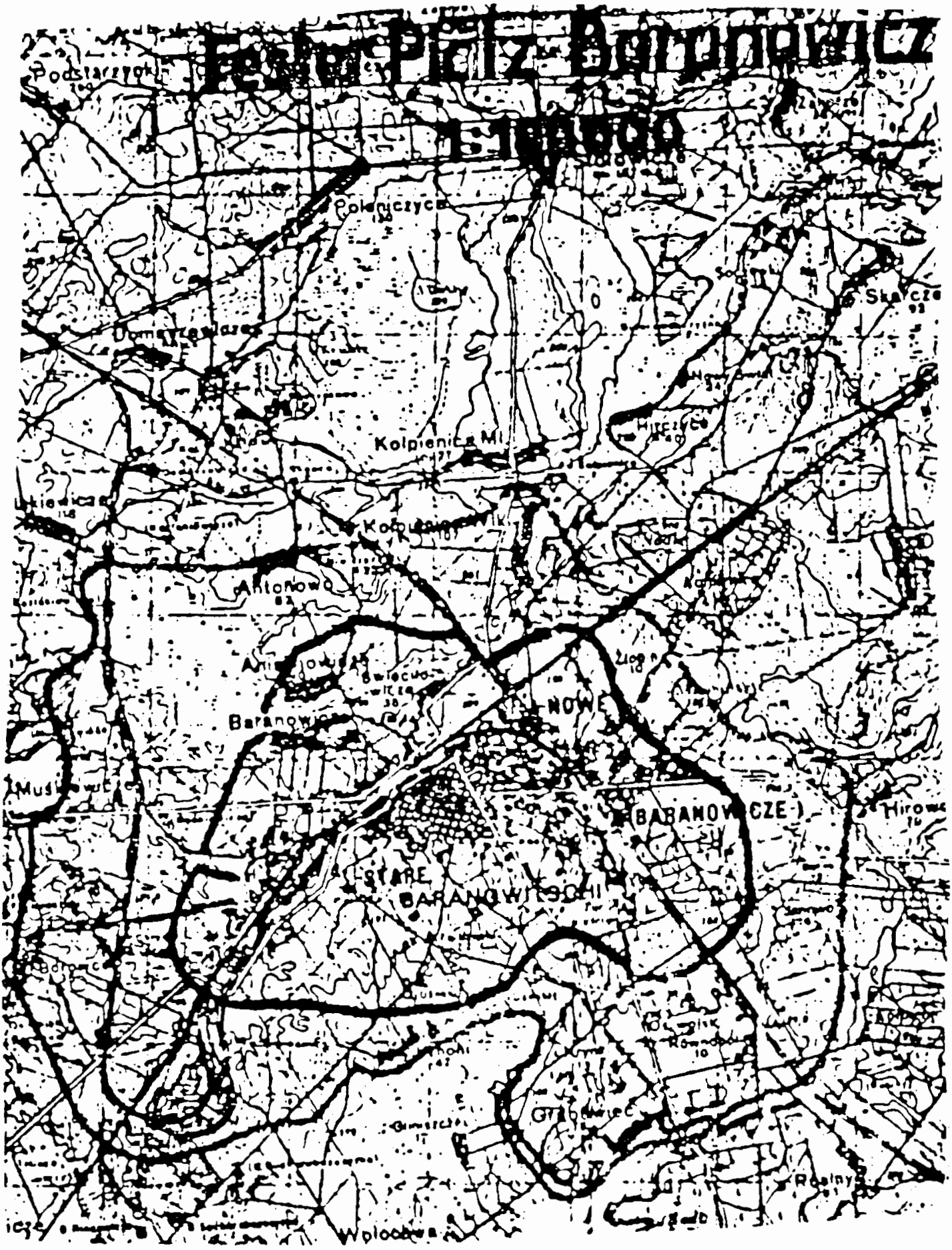

Fiqure 131. Fortress Baranowicze. Source:

Oberkommando Heeresgruppe Mitte, Fester Platz

Baranowicze 21.6.44. National Archives Microfilm

Publication T-311, Roll 218. 


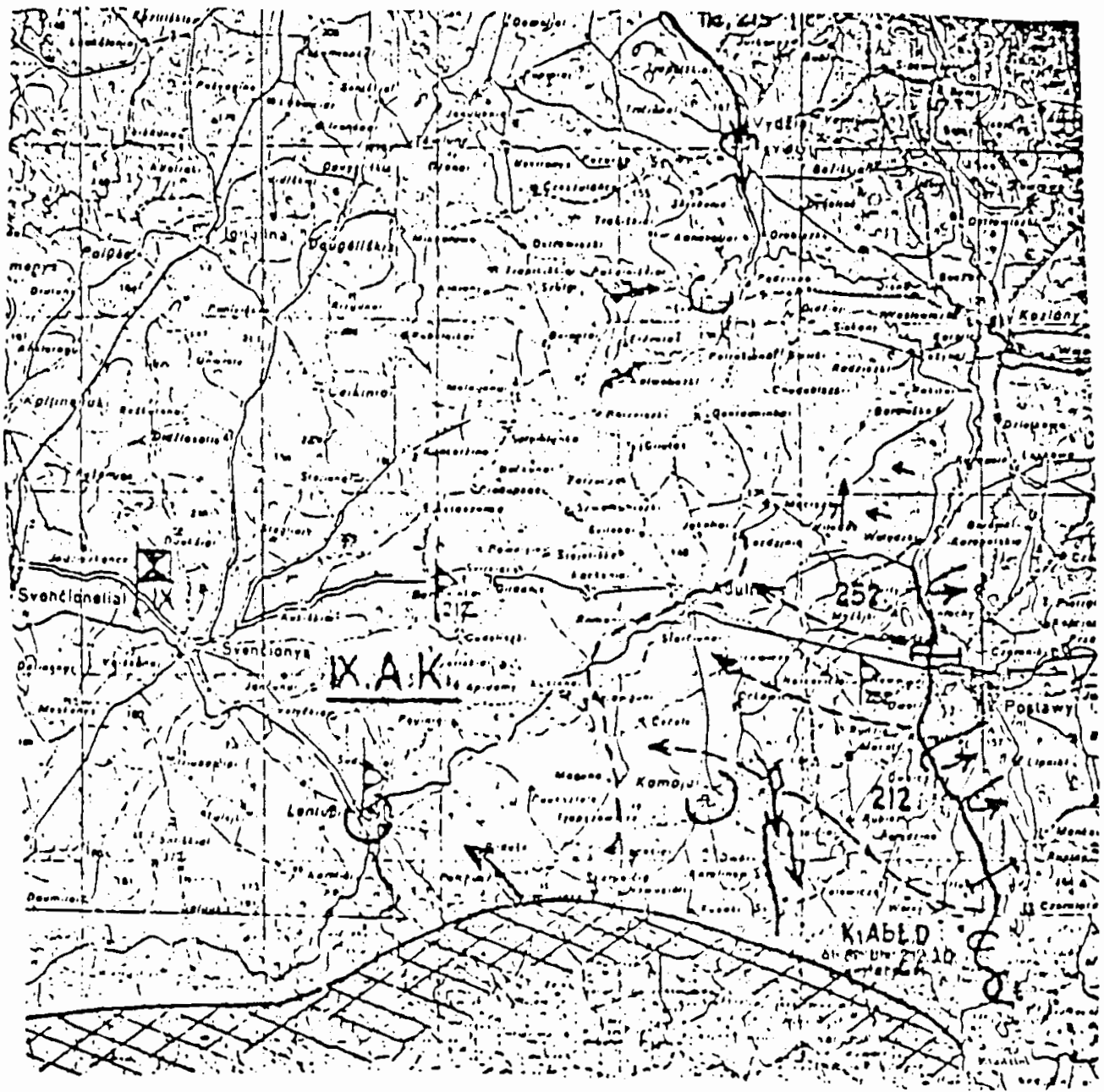

Figure 132. The Situation Of The 3rd Panzer Army On July 5, 1944 In The Evening. Source: Pz.A.O.K. 3, Lage der 3. Pz. Armee, Stand: 5.7.44.Abends National Archives Microfilm Publication T-313, Roll 318. 


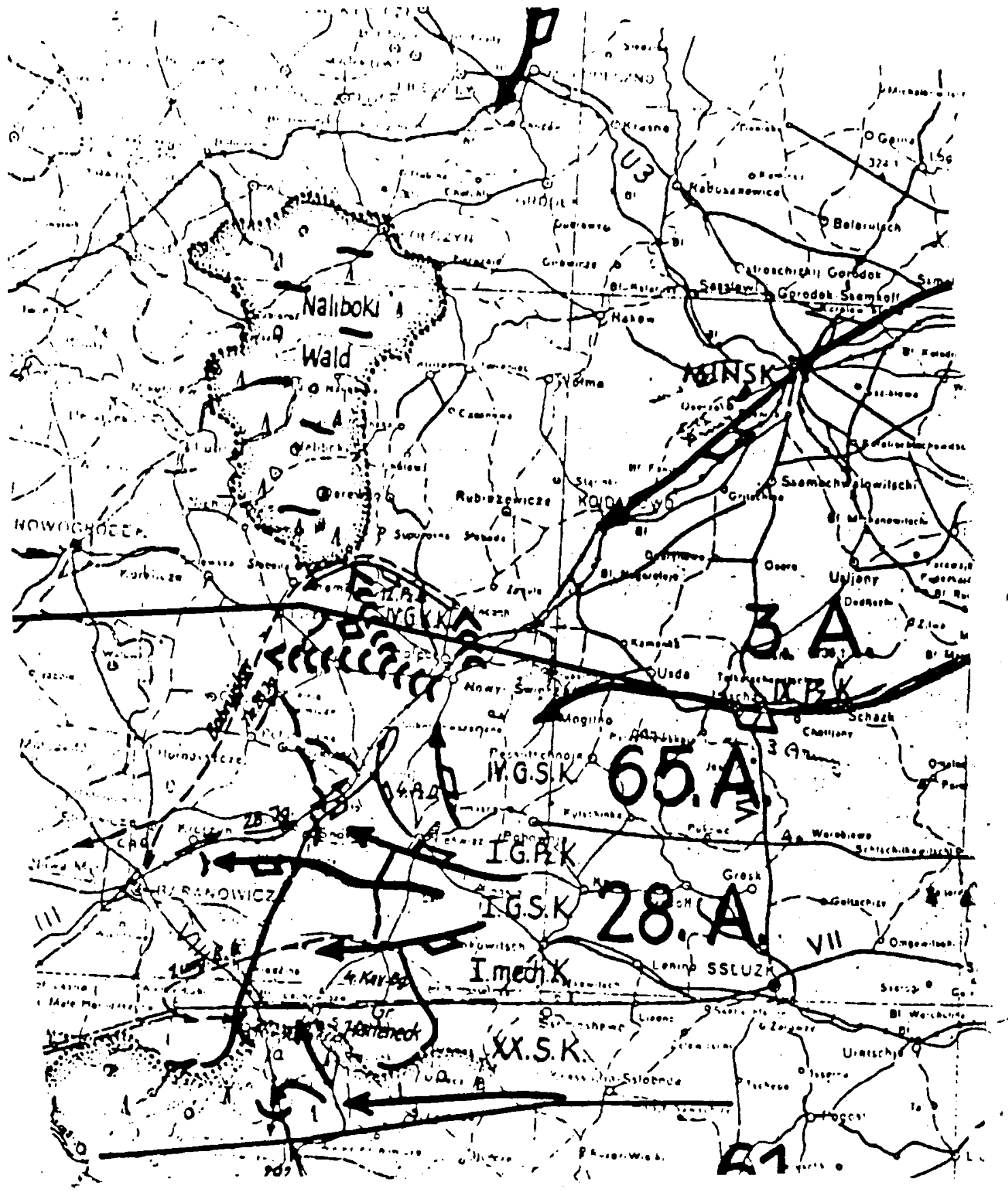

Figure 133. The 4th Panzer Division, 12th Panzer Division And The 28th Jaeger Division On July 5, 1944. Source: Armeeoberkommando 9, Der Kampf um die Landenge von Baranowicze 4. U. 5.7.44. National Archives Microfilm Publication T-312, Roll 339. 


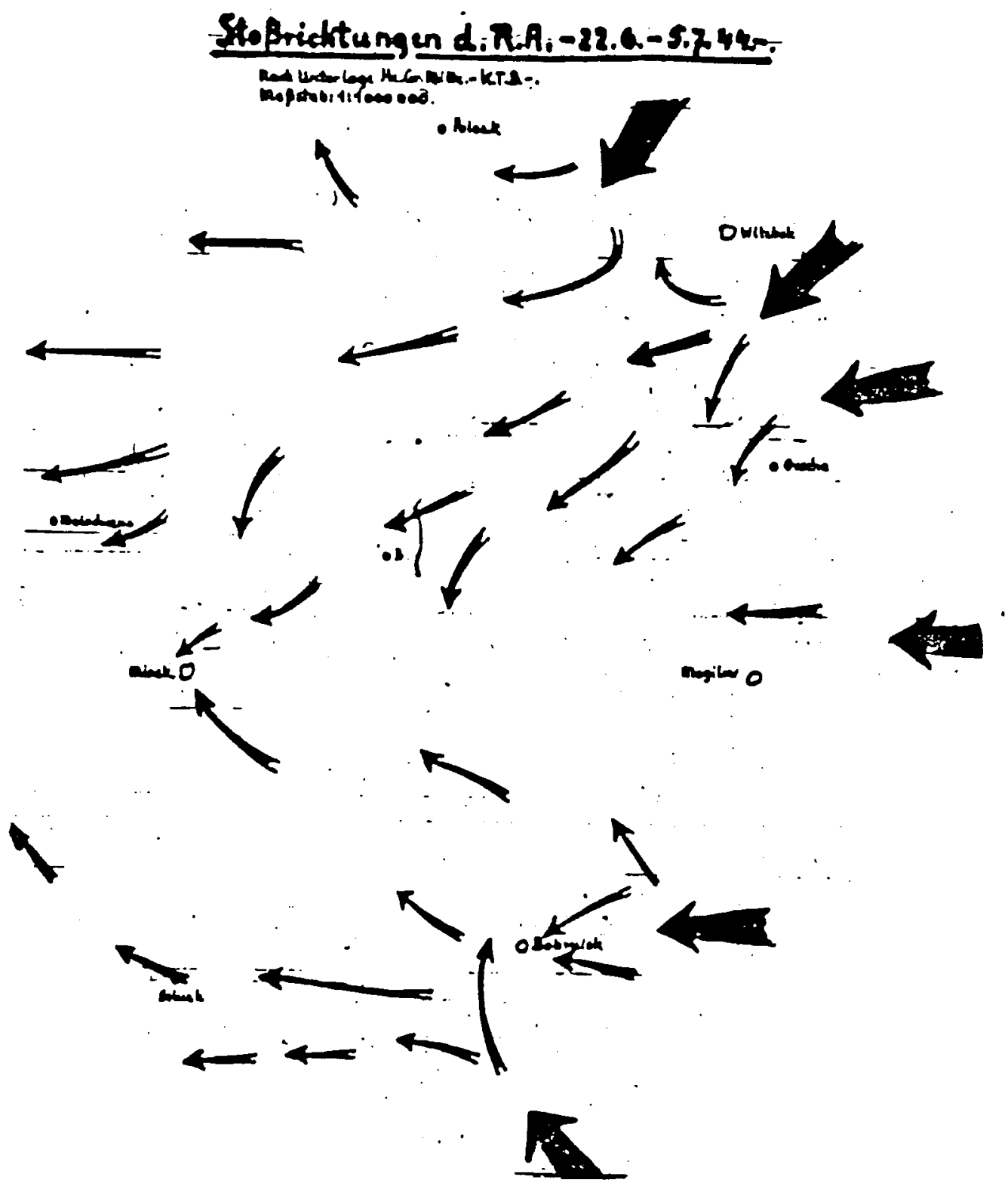

Figure 134. The Red Army's Offensive Thrusts, June 22July 5, 1944. Source: Oberkommando Heeresgruppe Mitte, Stossrichtungen d. R.A.-22.6.-5.7.44. National Archives Microfilm Publication T-311, Roll 219. 


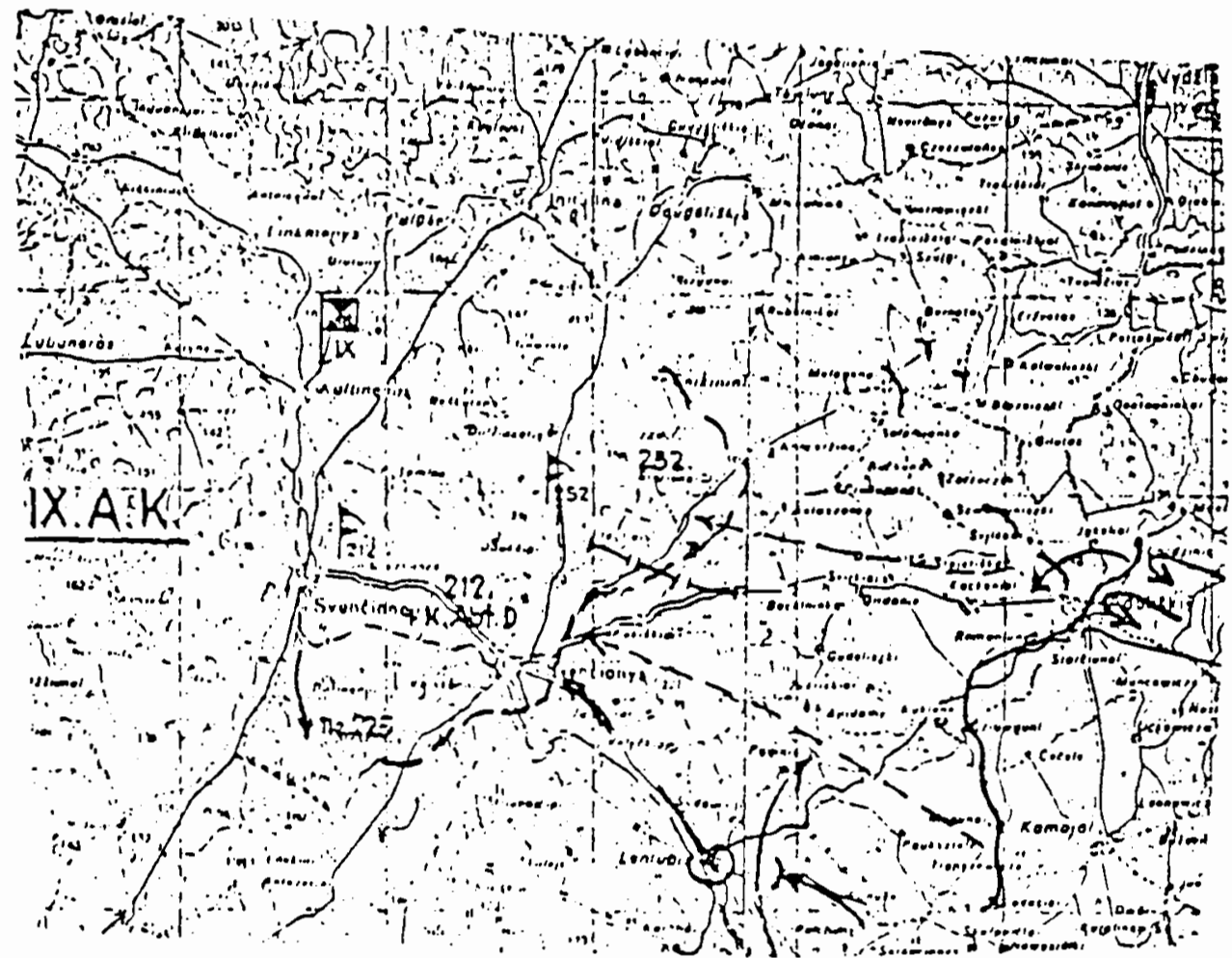

Figure 135. The Situation Of The 3rd Panzer Army On July 6, 1944 In The Evening. Source: Pz.A.O.K. 3, Lage der 3. Pz. Armee, Stand: 6.7.44.Abends National Archives Microfilm Publication T-313, Roll 318. 


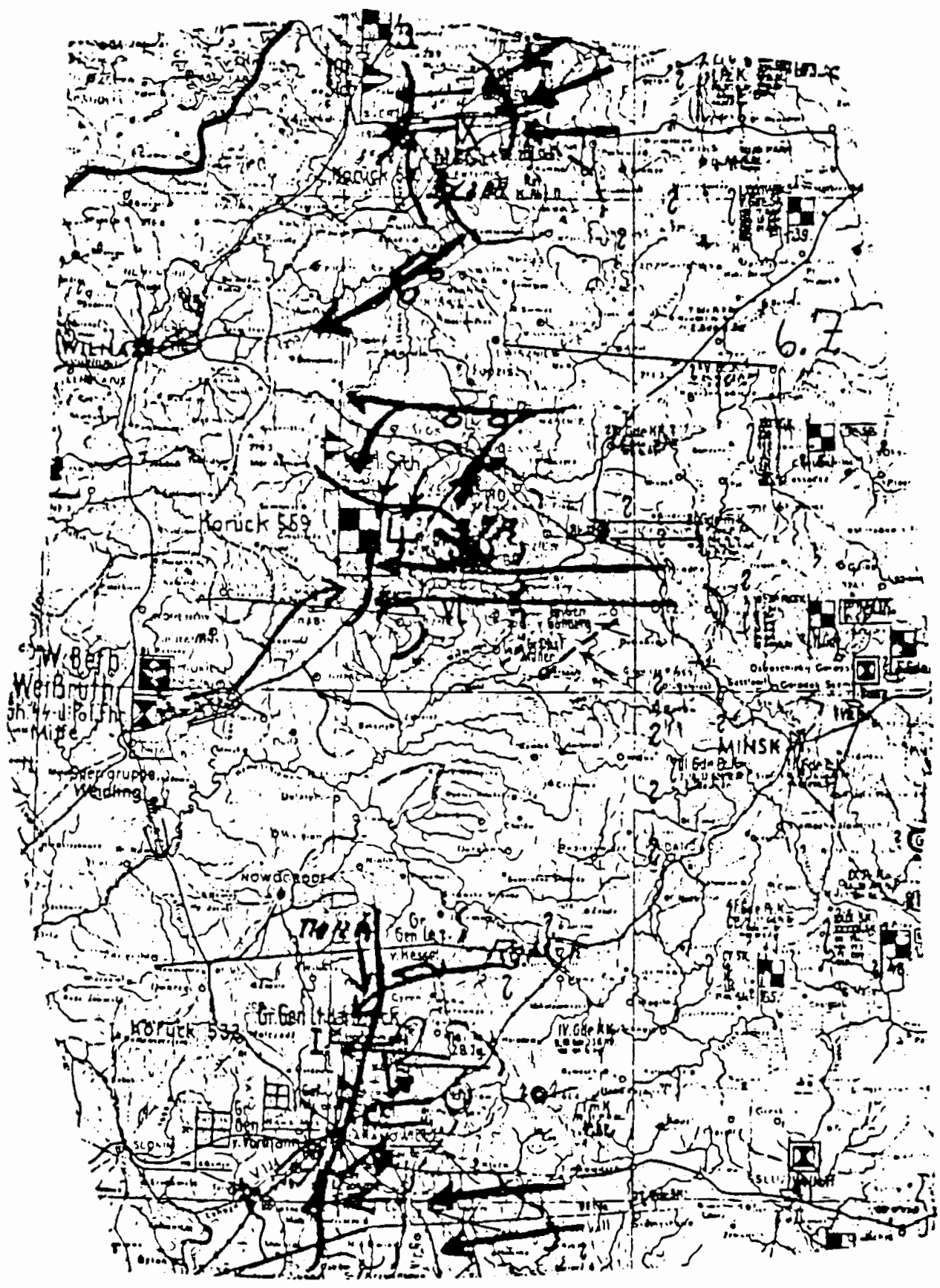

Figure 136. Army Group Center, July 6, 1944. Source: OKH, Der Grosse Durchbruch Bei Hgr. Mitte Von 21.6.10.8.44., National Archives Microfilm Publication T-78, Roll 136. 


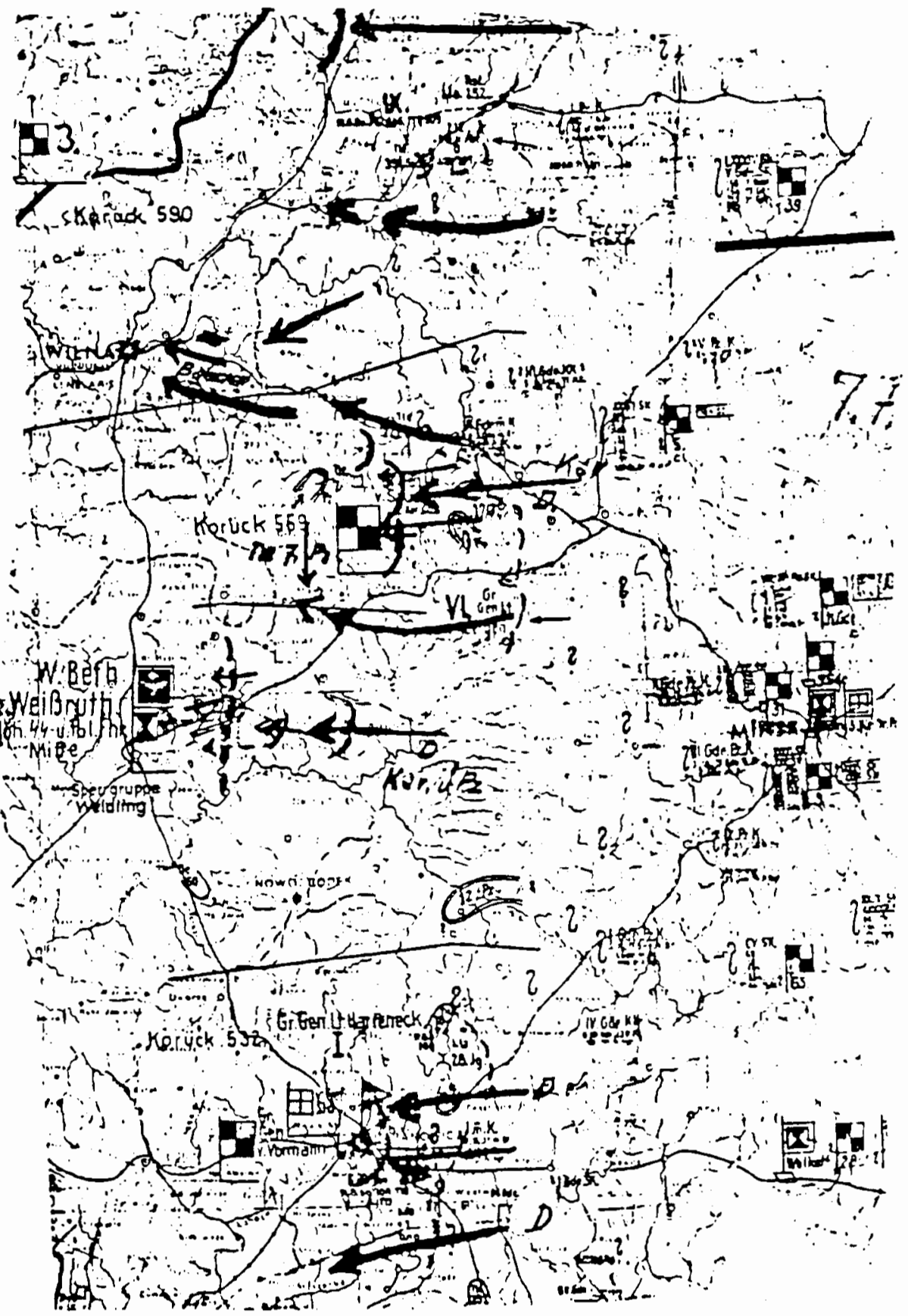

Figure 137. Army Group Center, July 7, 1944. Source: $\mathrm{OKH}$, Der Grosse Durchbruch Bei Hgr. Mitte Von 21.6.10.8.44., National Archives Microfilm Publication T-78, Roll 136. 


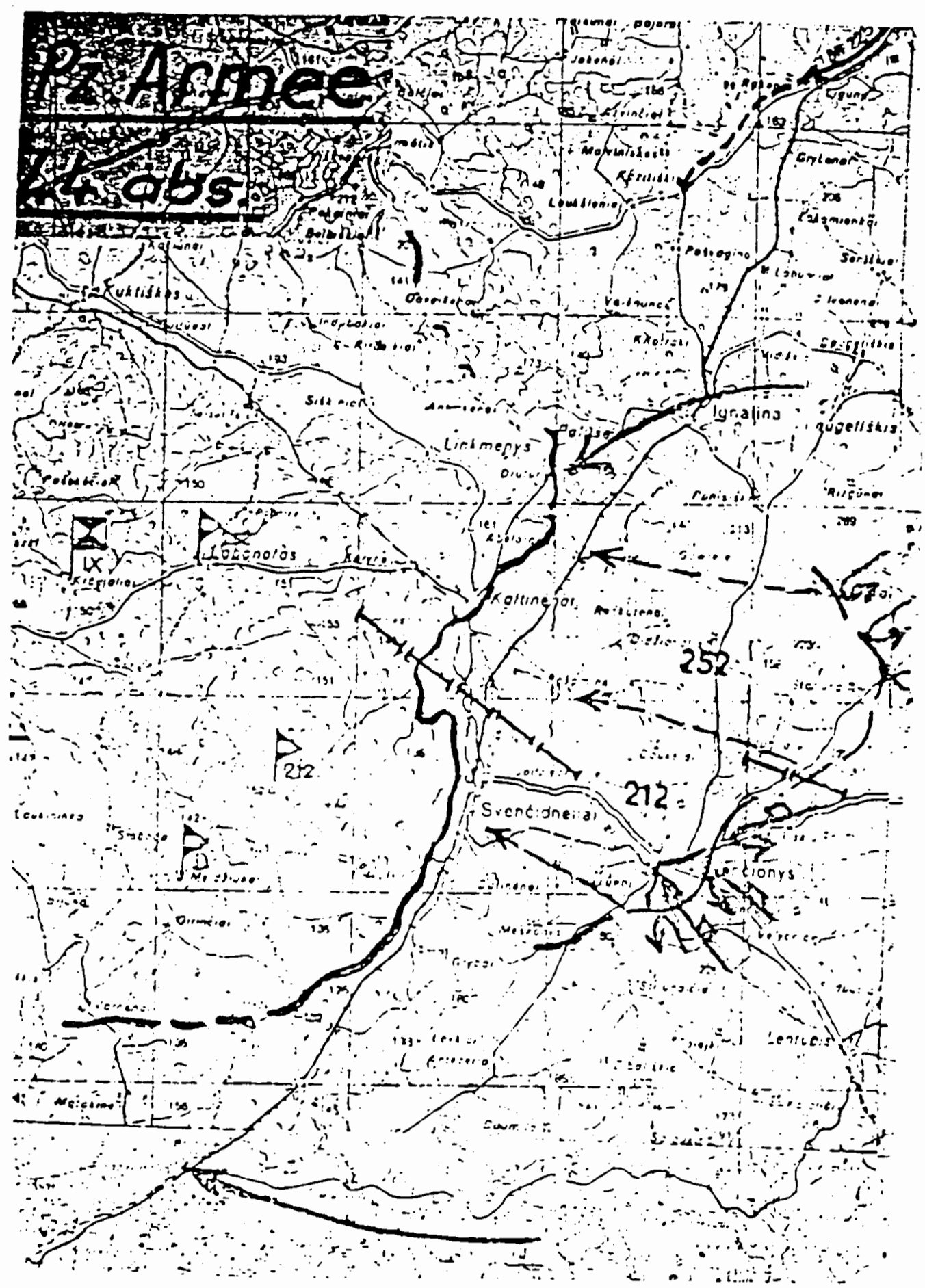

Figure 138. 3rd Panzer Army's IX Army Corps On July 7, 1944 In The Evening. Source: Pz.A.O.K. 3, Lage der 3. Pz. Armee, Stand: 7.7.44.Abs. National Archives Microfilm Publication T-313, Roll 318. 


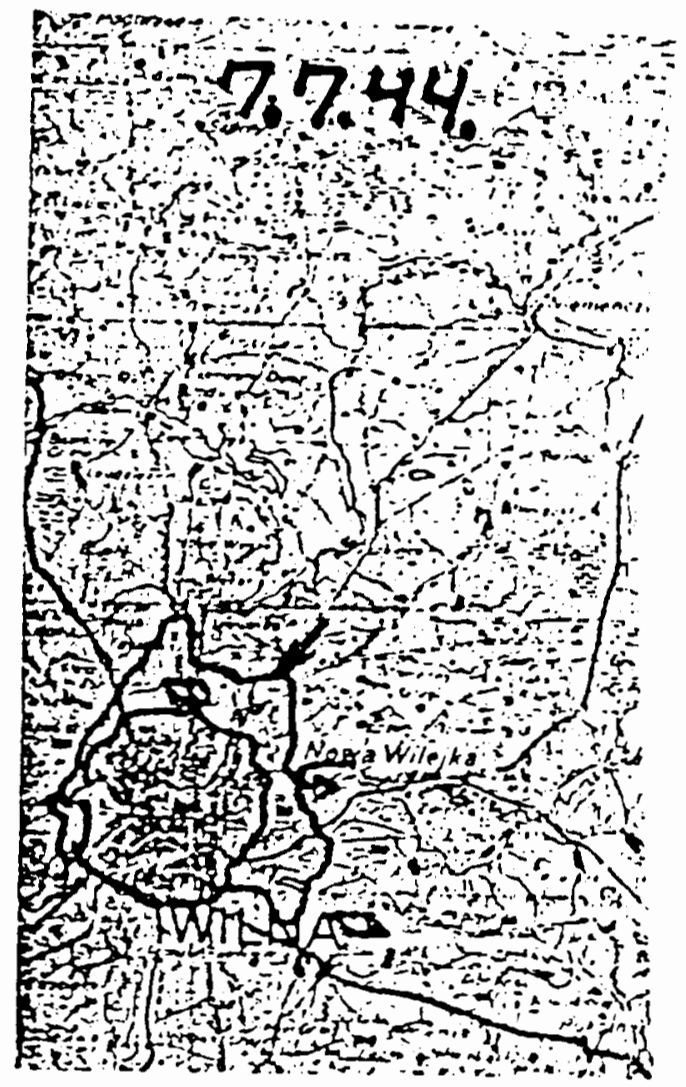

Figure 139. Fortress Wilna, July 7, 1944 In The Evening. Source: Pz.A.O.K. 3, Lage der 3. PZ. Armee, Stand: 7.7.44.Abs. National Archives Microfilm Publication T-313, Roll 318. 


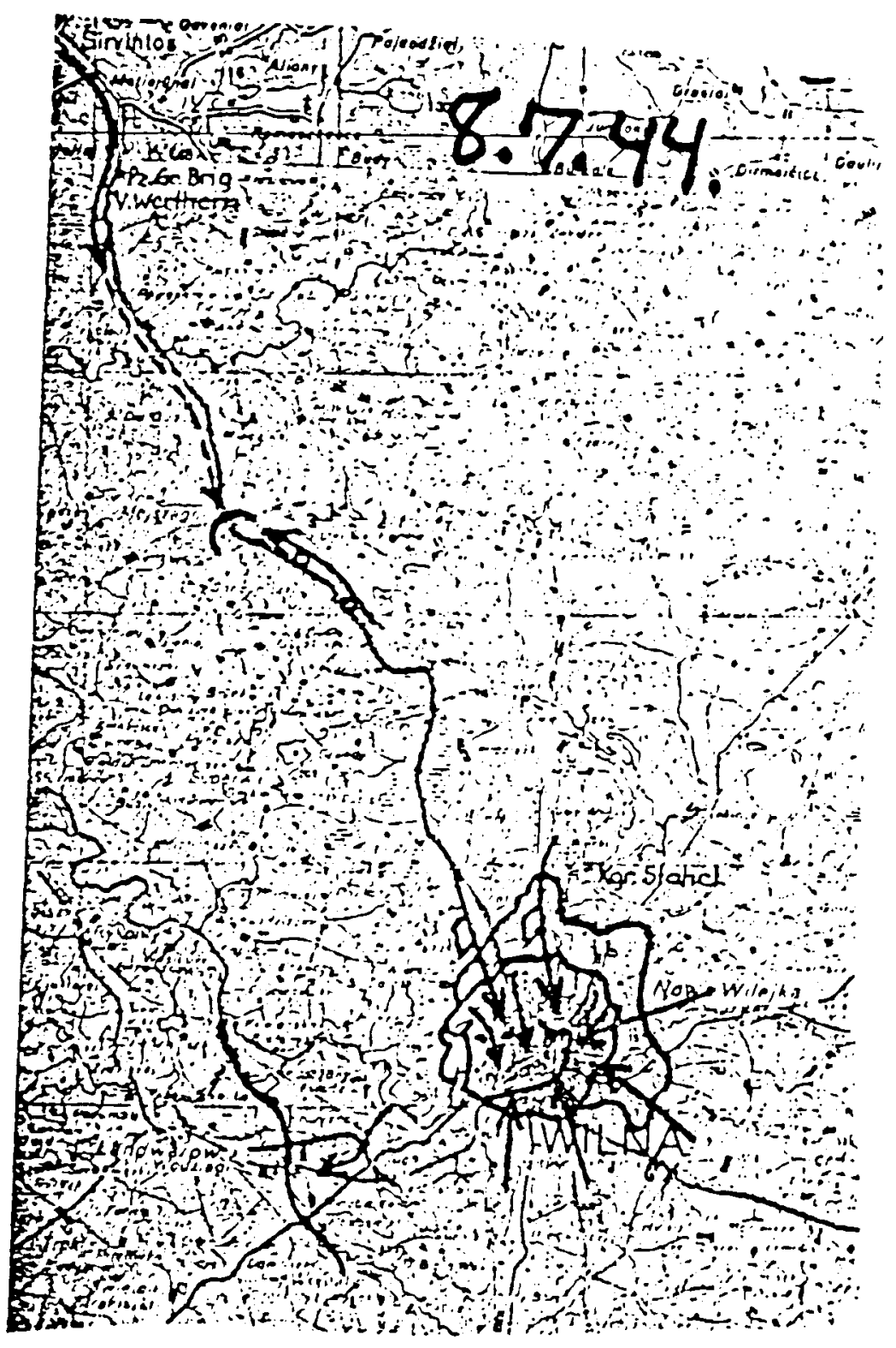

Figure 140. Soviet Encirclement Of Wilna, July 8, 1944. Source: Pz.A.O.K. 3, Lage der 3. Pz. Armee. Stand: 8.7.44. National Archives Microfilm Publication T-313, Roll 318. 


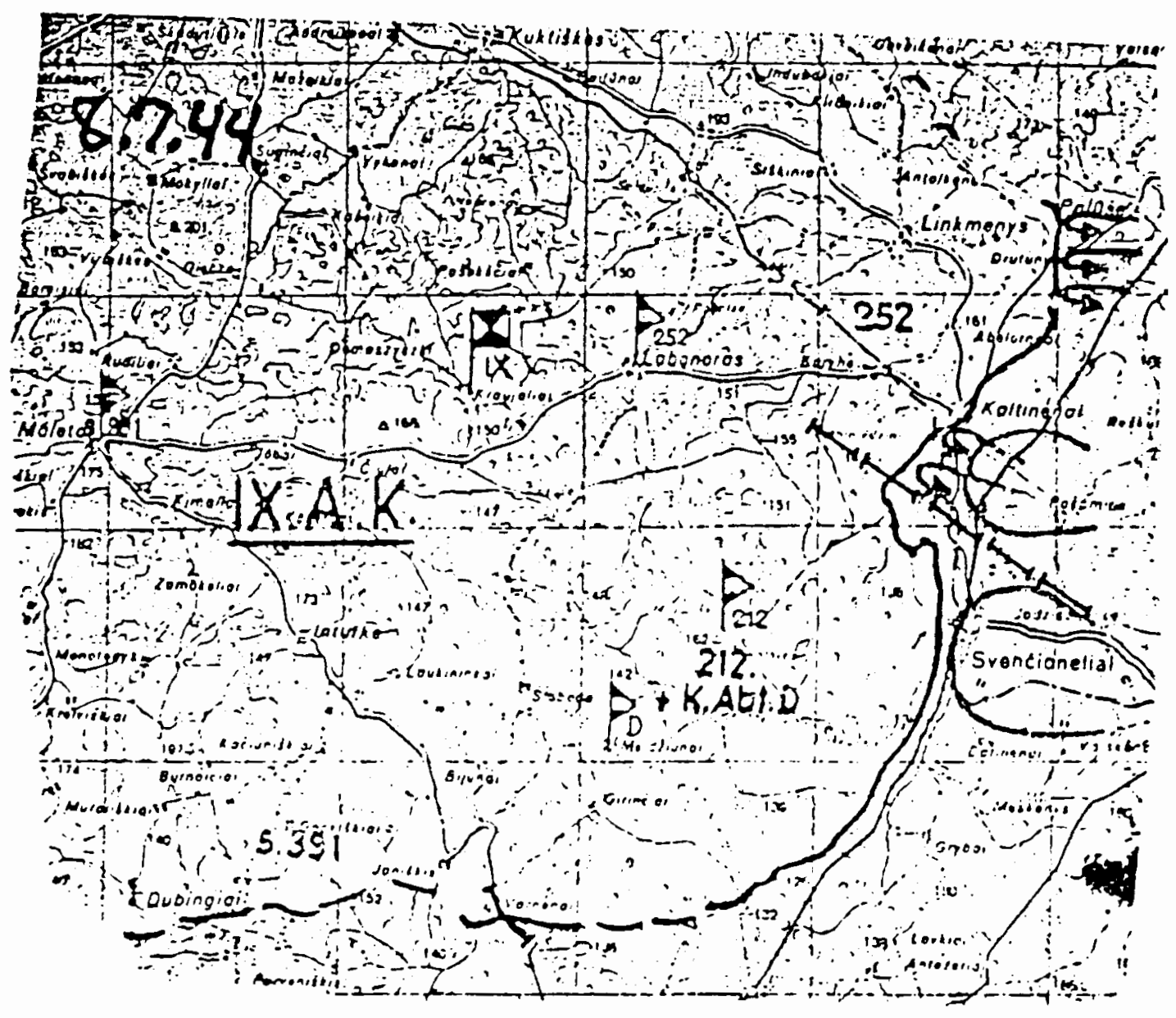

Figure 141. IX Army Corps, July 8, 1944. Source:

Pz.A.O.K. 3, Lage der 3. Pz. Armee, Stand: 8.7.44. National Archives Microfilm Publication T-313, Roll 318. 


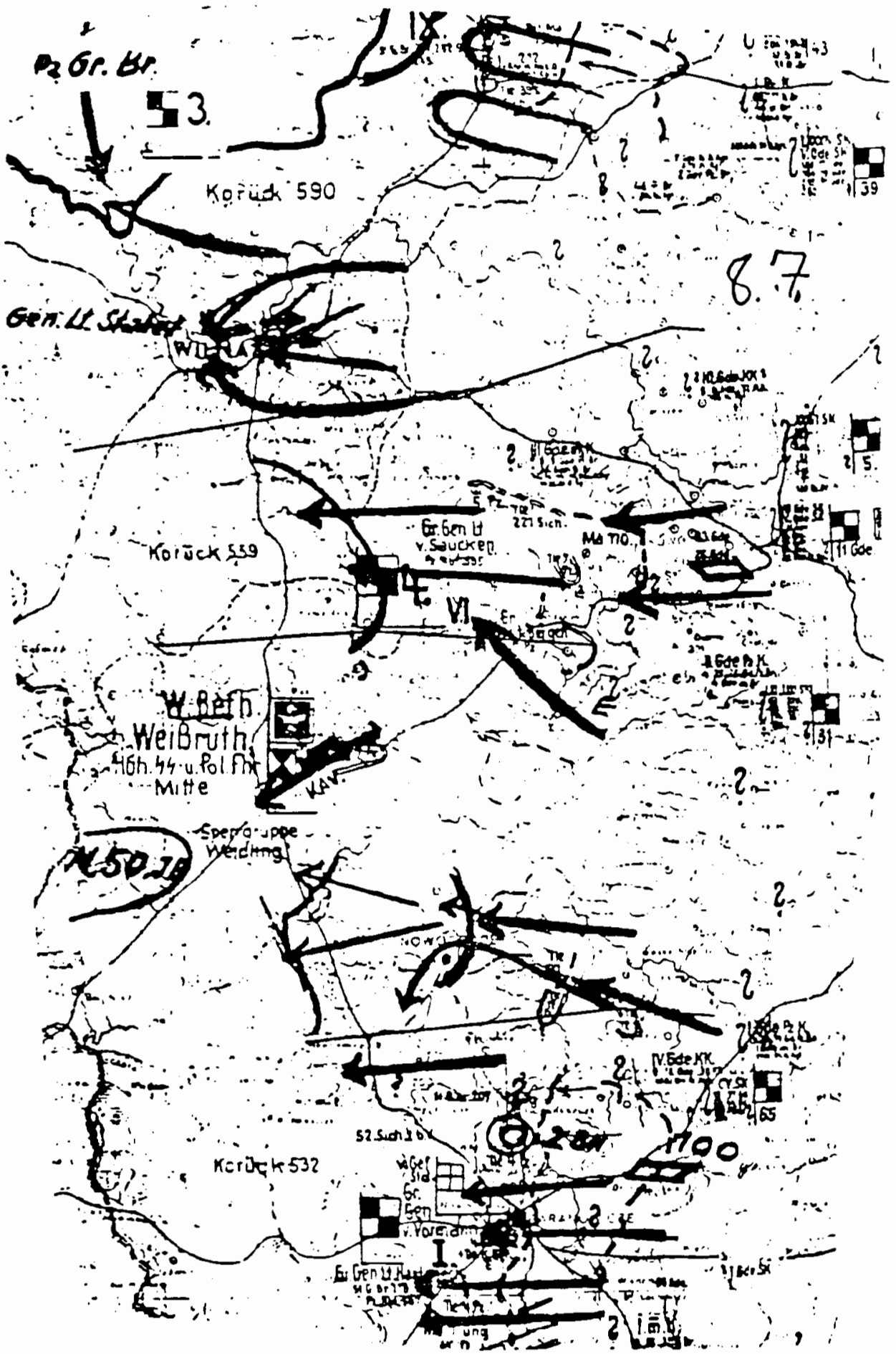

Figure 142. Army Group Center, July 8, 1944. Source: $\mathrm{OKH}$, Der Grosse Durchbruch Bei Hgr. Mitte Von 21.6.10.8.44., National Archives Microfilm Publication T-78, Roll 136. 


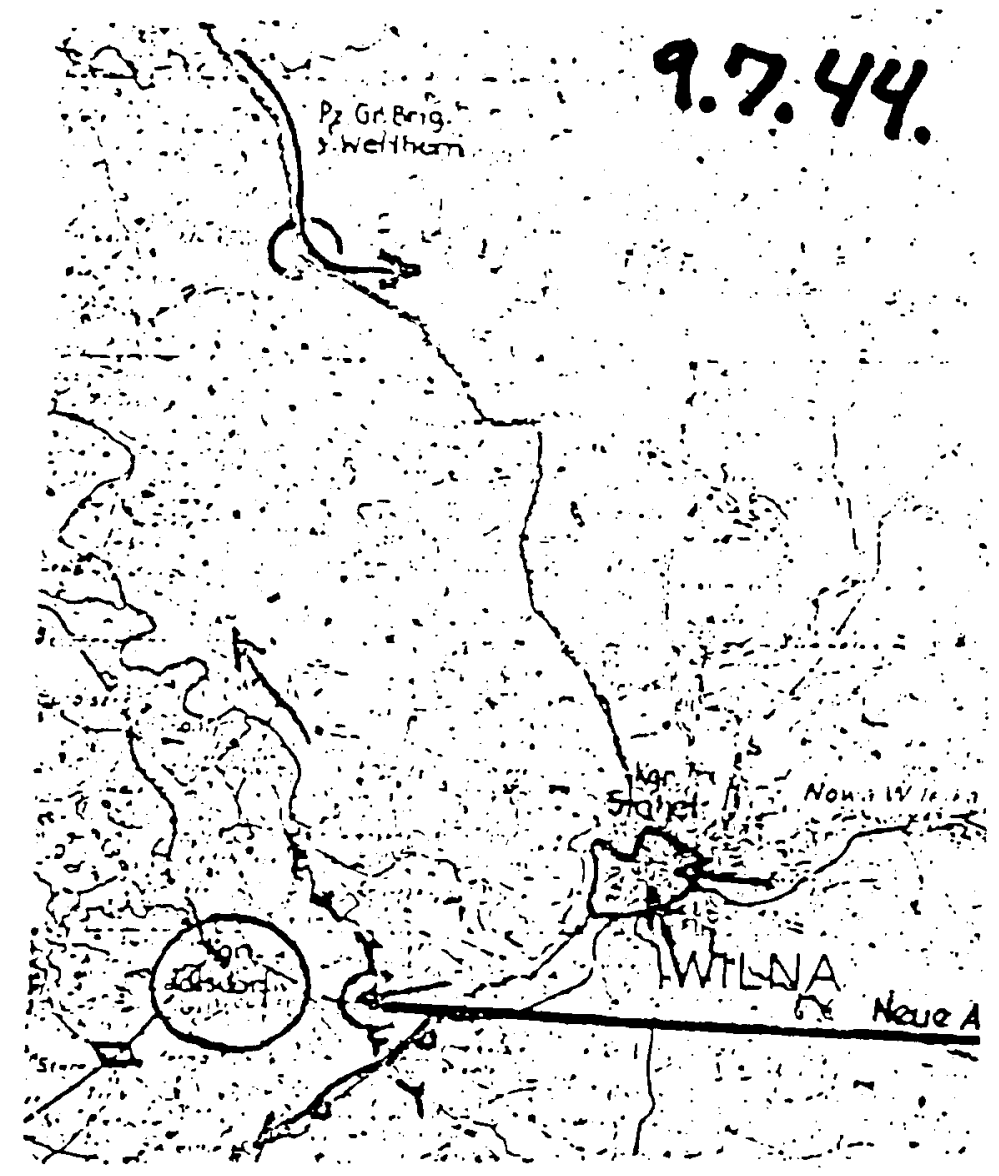

Figure 143. Fortress Wilna, Kampfgruppe Tolsdorf And Panzer Grenadier Brigade Von Werthern, July 9, 1944. Source: Pz.A.O.K. 3, Lage der 3. Pz. Amee, Stand: 9.7.44. National Archives Microfilm Publication T-313, Roll 318. 


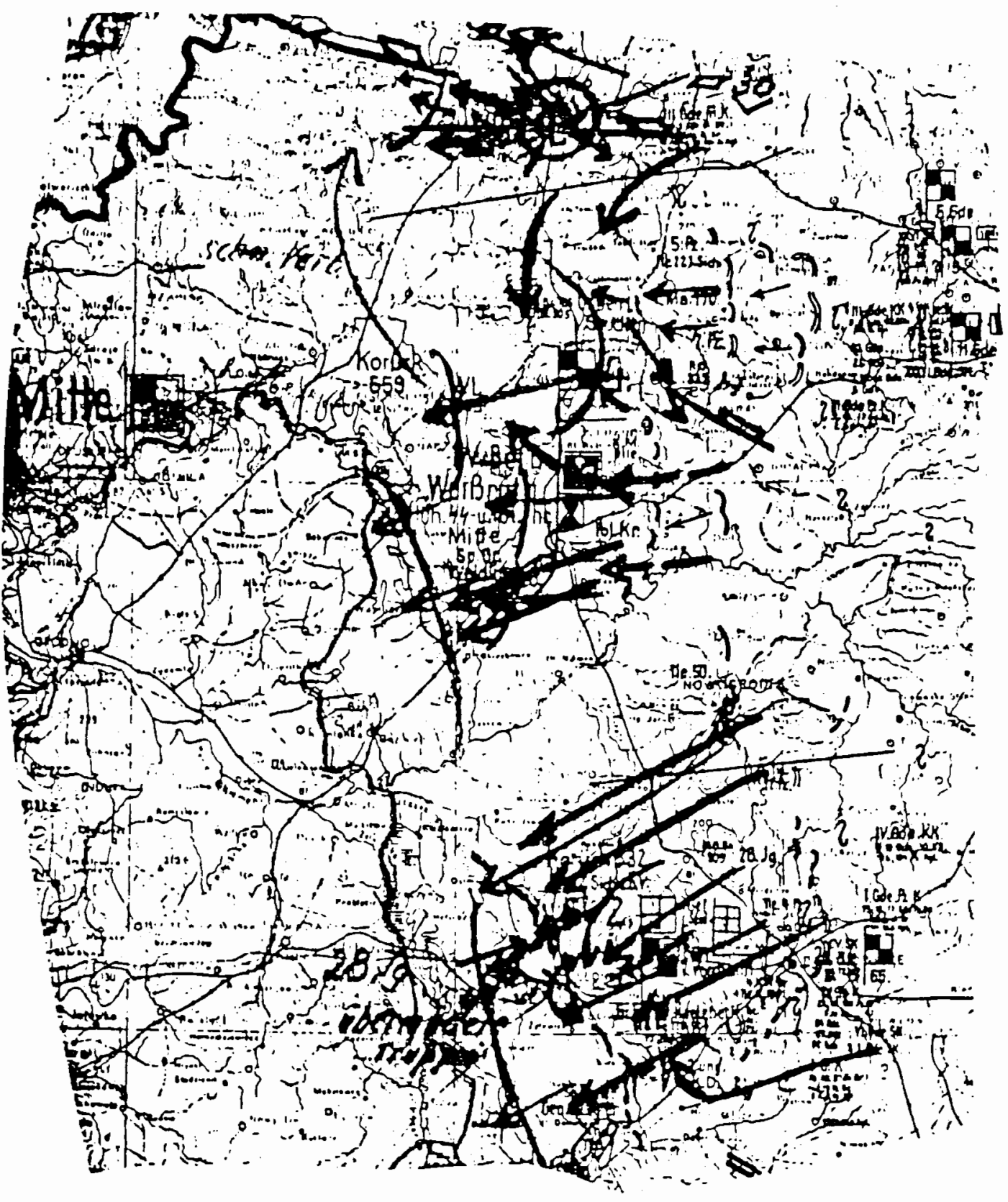

Figure 144. Army Group Center, July 9-10, 1944. Source: OKH, Der Grosse Durchbruch Bei Hgr. Mitte Von 21.6.-10.8.44., National Archives Microfilm Publication T-78, Roll 136. 


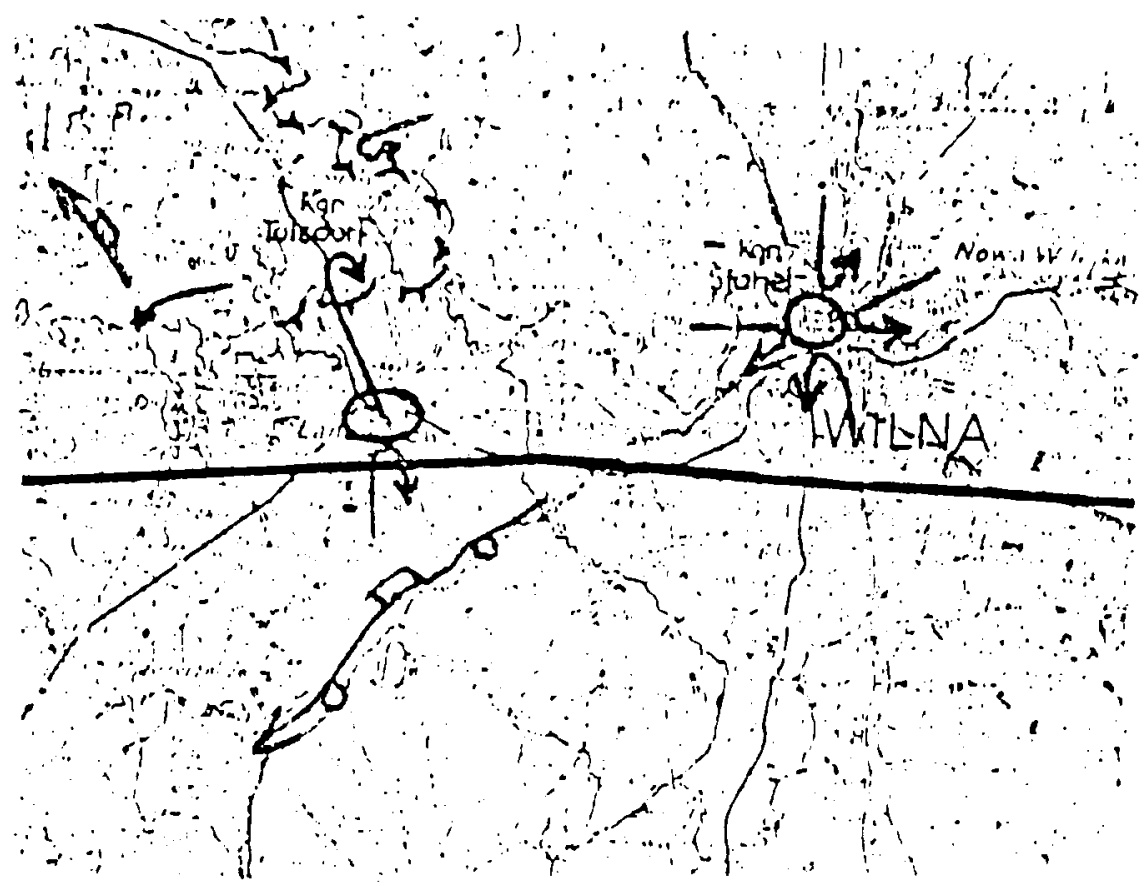

Figure 145. Fortress Wilna And Kampfgruppe Tolsdorf, July 10, 1944. Source: Pz.A.O.K. 3, Lage der 3. Pz. Armee. Stand: 10.7.44. National Archives Microfilm Publication T-313, Roll 318. 


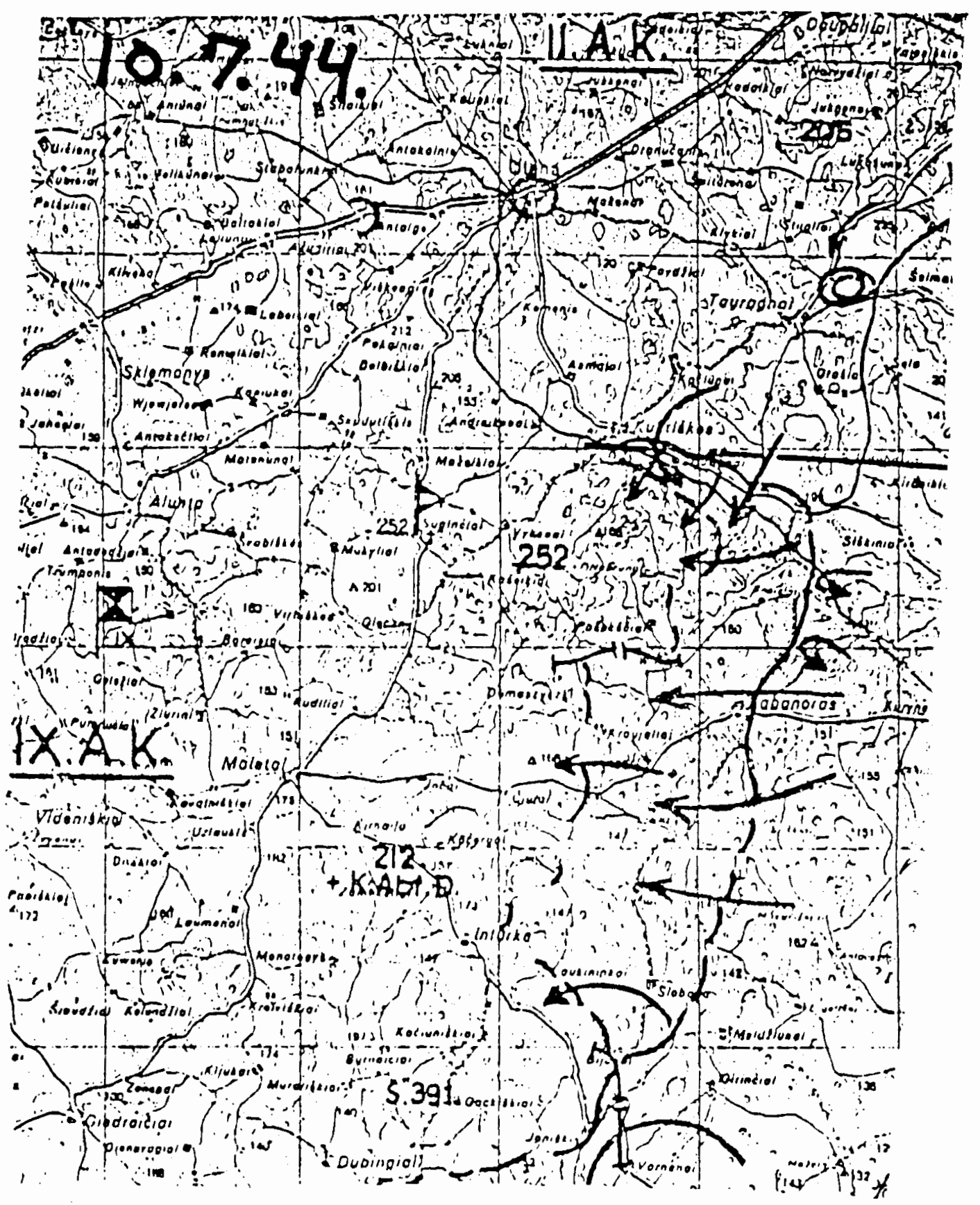

Figure 146. IX Army Corps, July 10, 1944. Source: Pz.A.O.K. 3, Lage der 3. Pz. Armee, Stand: 10.7.44. National Archives Microfilm Publication T-313, Roll 318. 
Truppensinteilung 6r.v.Vormaim

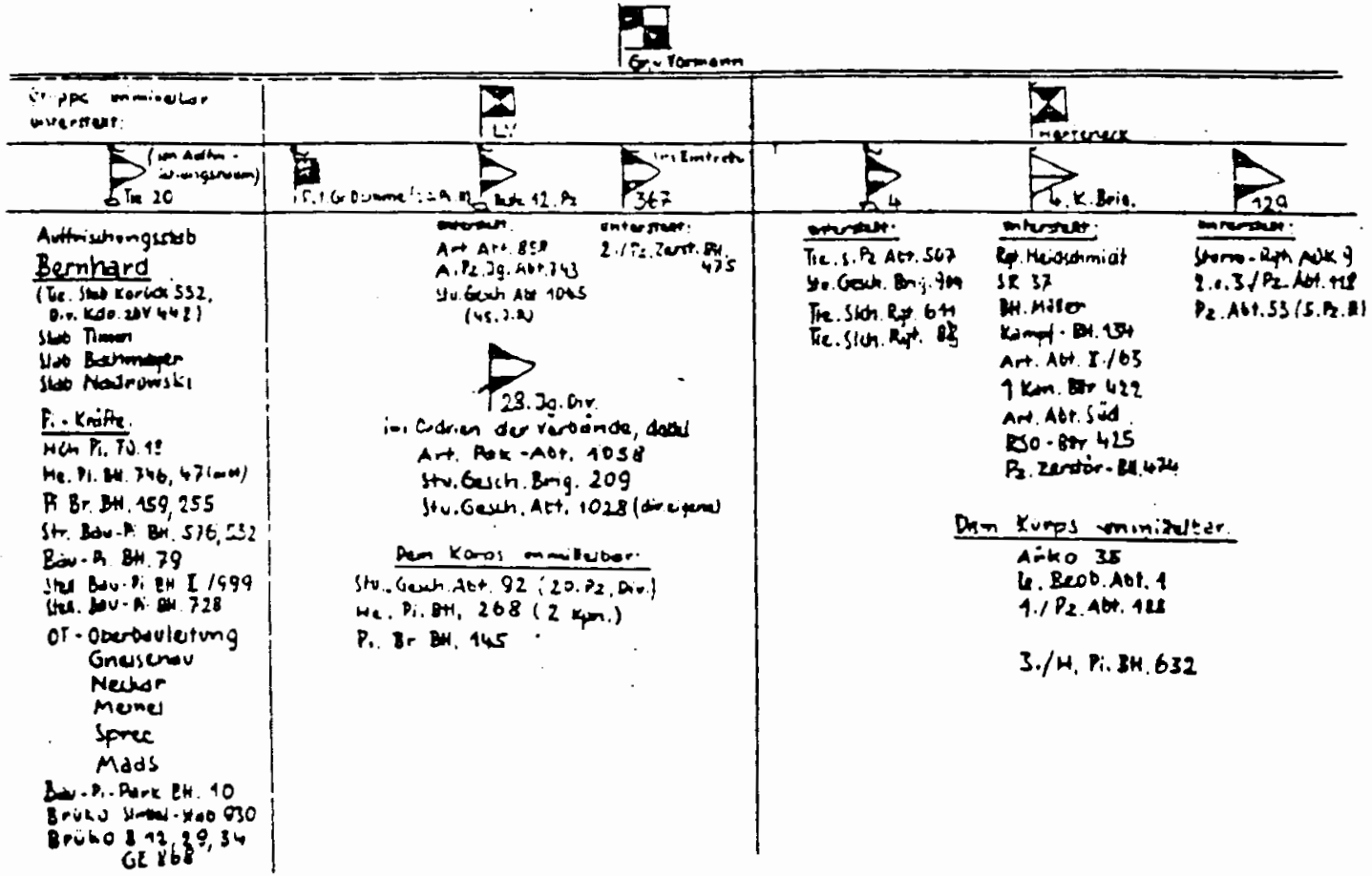

Figure 147. Gruppe Von Vormann, Order Of Battle, July 10, 1944. Source: Lt. Weller, Gefechtsbericht der 9. Armee veber die Schlacht in Weissruthenien 24.6.10.7.1944 National Archives Microfilm Publication $T$ 312, Roll 339. 


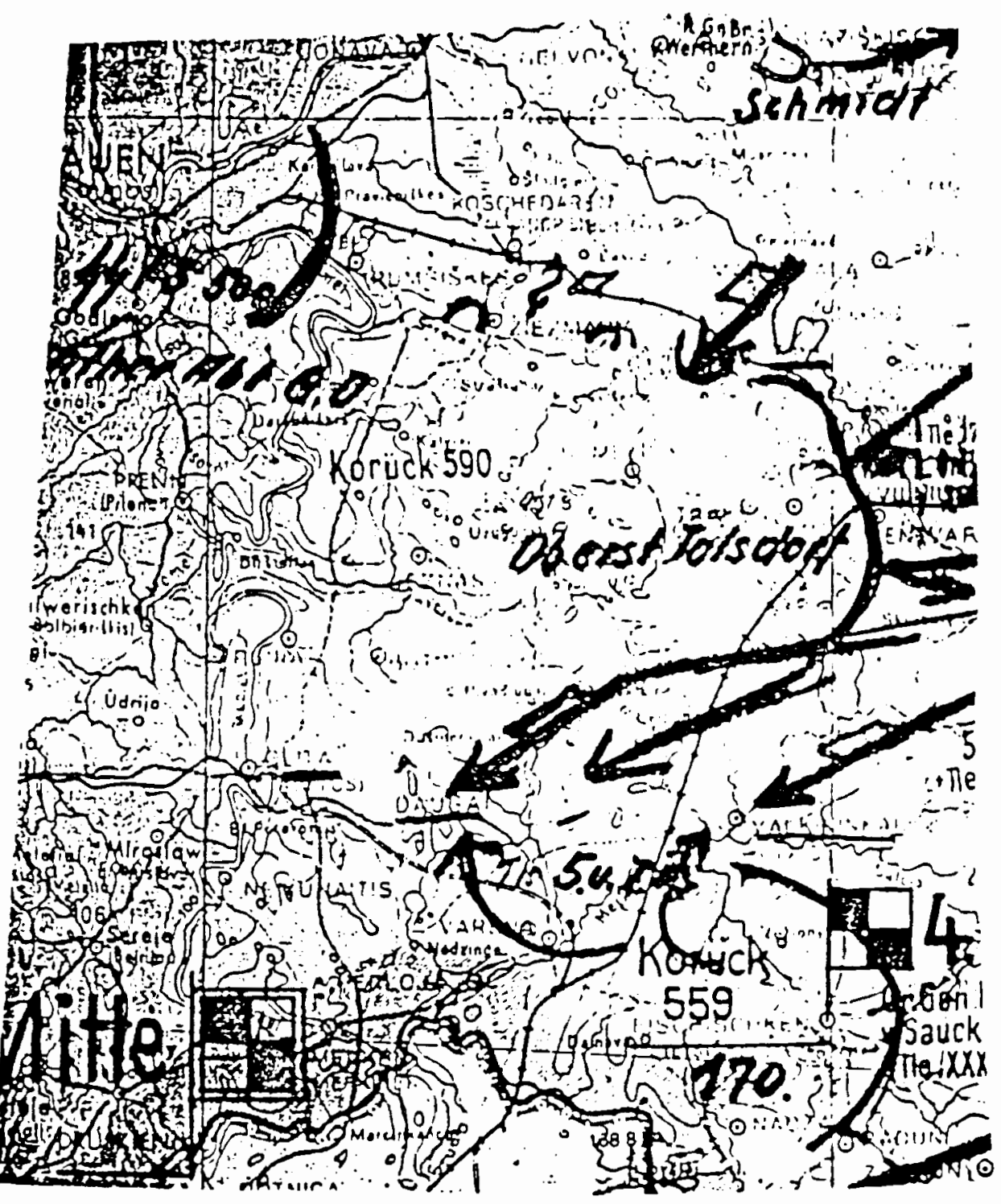

Figure 148. SS Parachute Battalion 500 And Panther Battalion Of The Panzer Division "Gross Deutschland." Source: OKH, Der Grosse Durchbruch Bei Hgr. Mitte Von 21.6.-10.8.44., National Archives Microfilm Publication $\mathrm{T}-78$, Roll 136. 


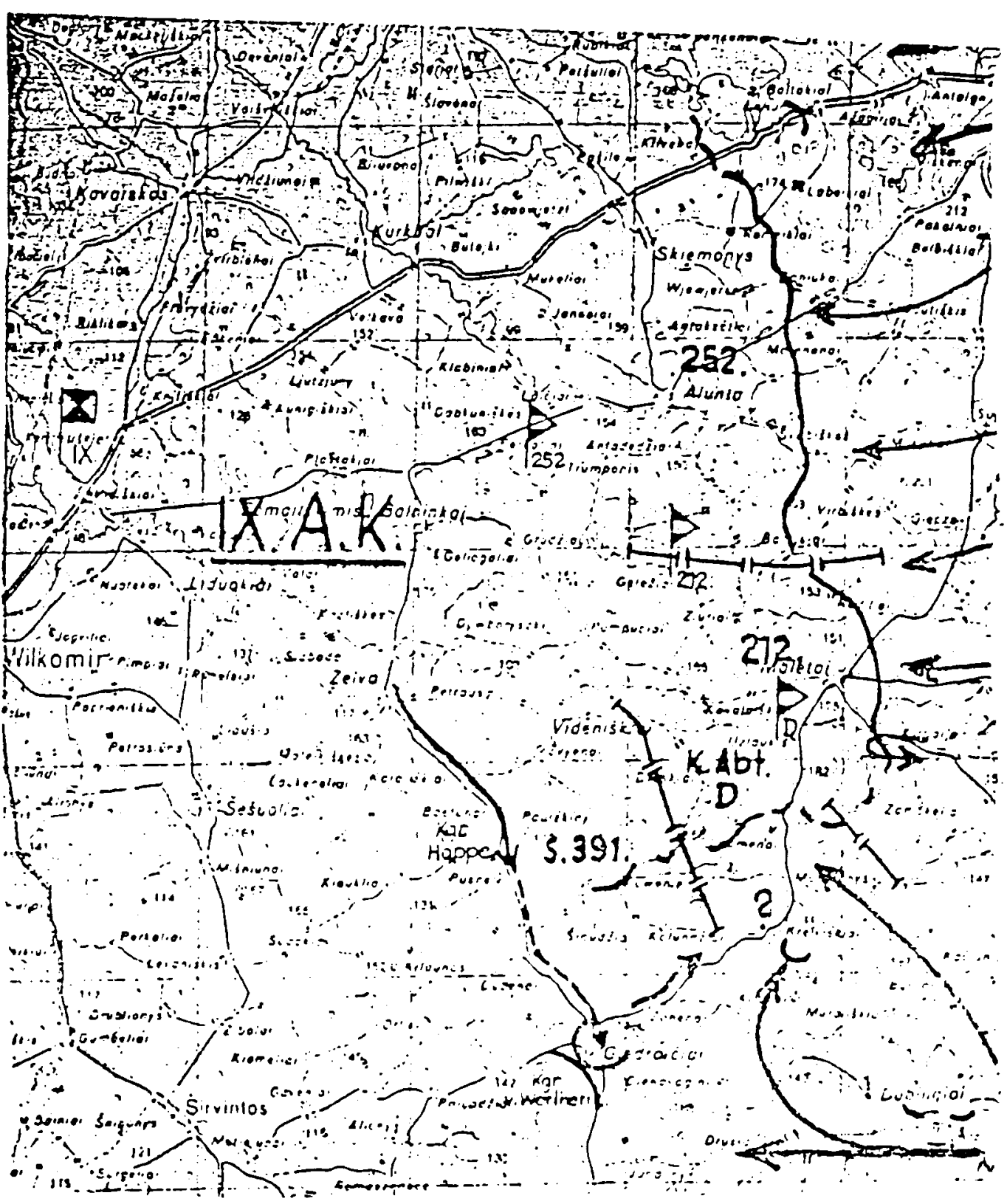

Figure 149. IX Army Corps, July 11, 1944. Source:

Pz.A.O.K. 3, Lage der 3. PZ. Armee, Stand: 11.7.44. National Archives Microfilm Publication T-313, Roll 318. 


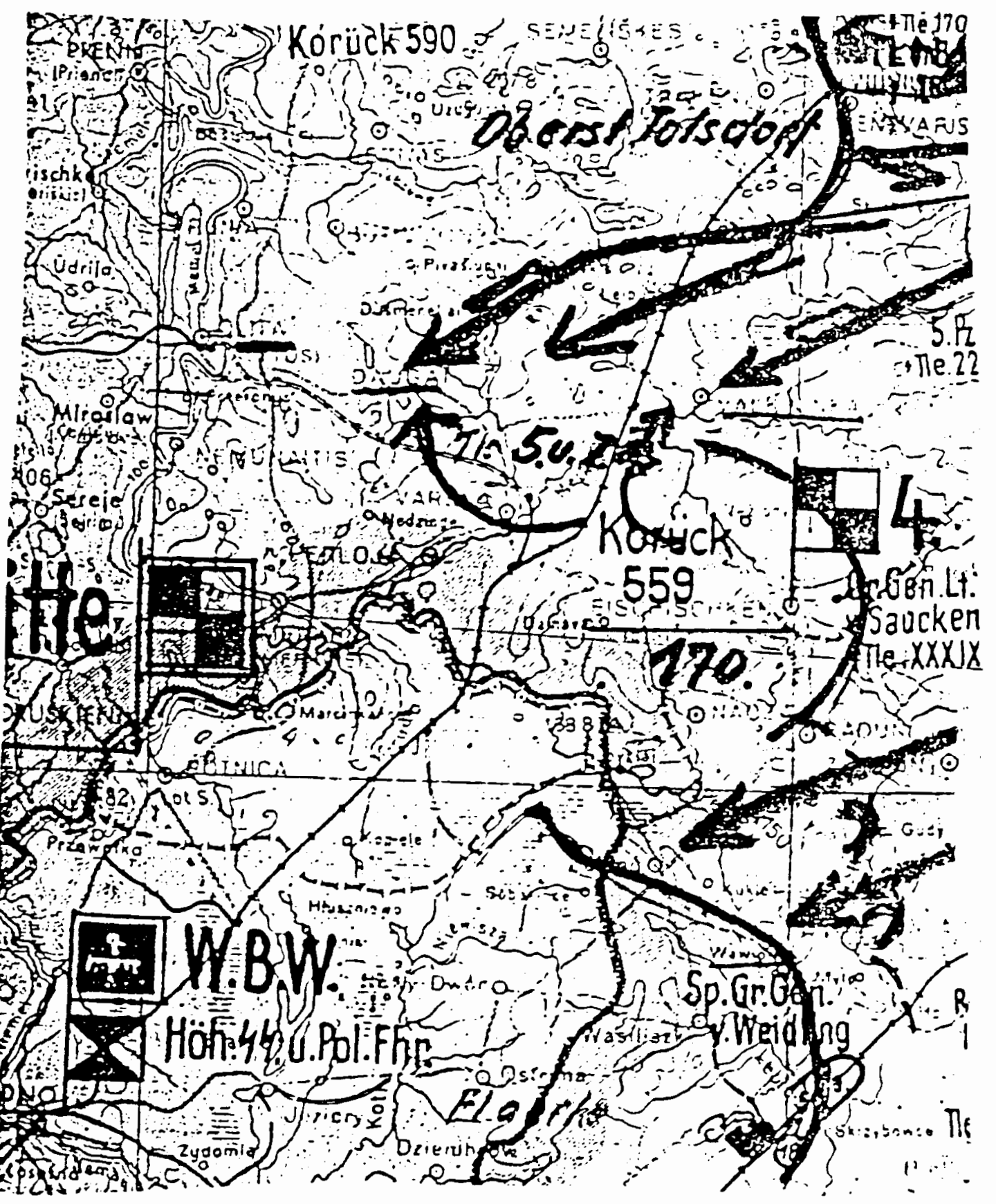

Figure 150. 4th Army, July 11, 1944. Source: OKH, Der Grosse Durchbruch Bei Hgr. Mitte Von 21.6.-10.8.44., National Archives Microfilm Publication T-78, Roll 136. 


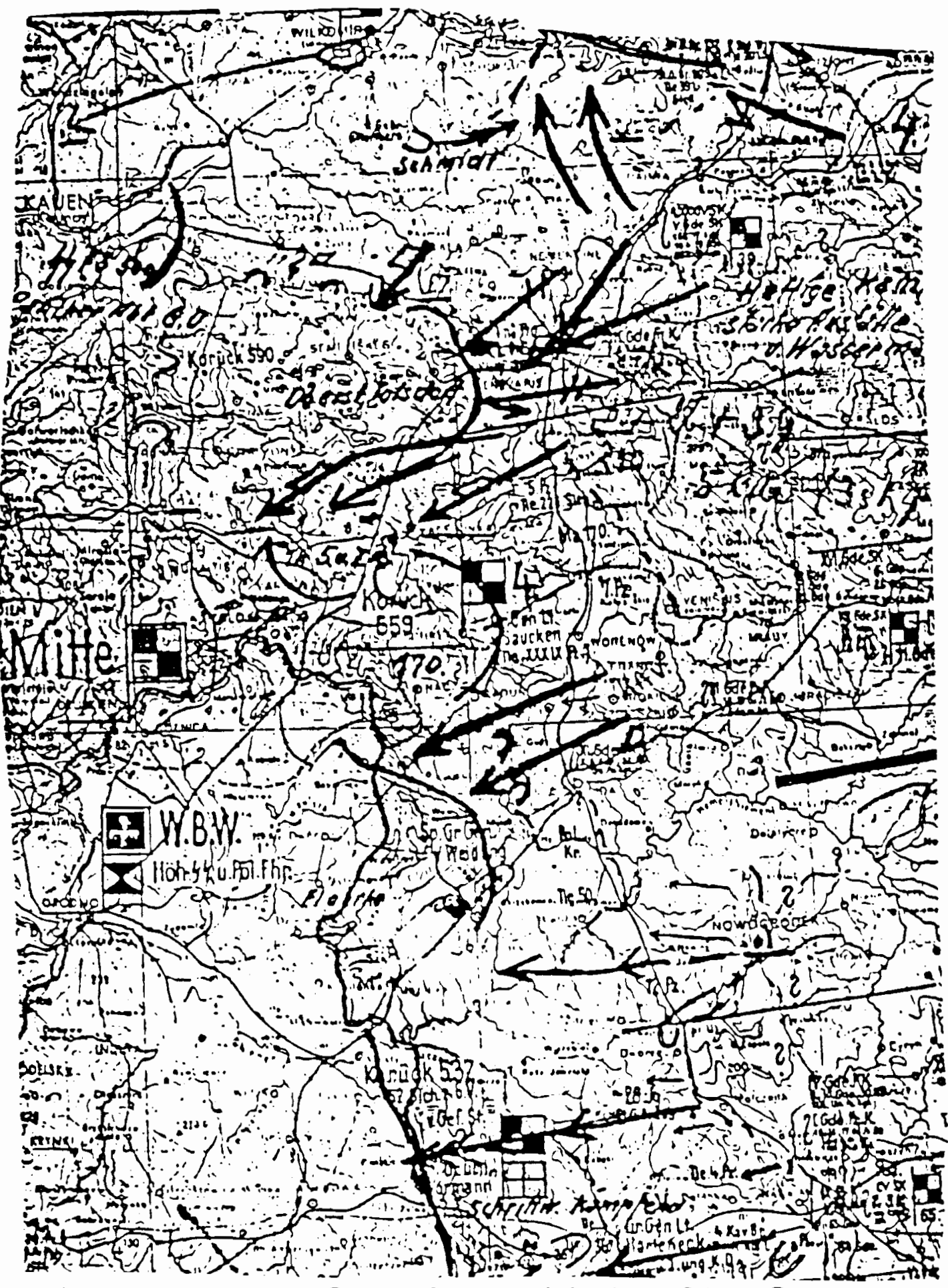

Figure 151. Army Group Center, July 11, 1944. Source:

OKH, Der Grosse Durchbruch Bei Hgr. Mitte Von 21.6.-

10.8.44., National Archives Microfilm Publication T-78,

Roll 136. 


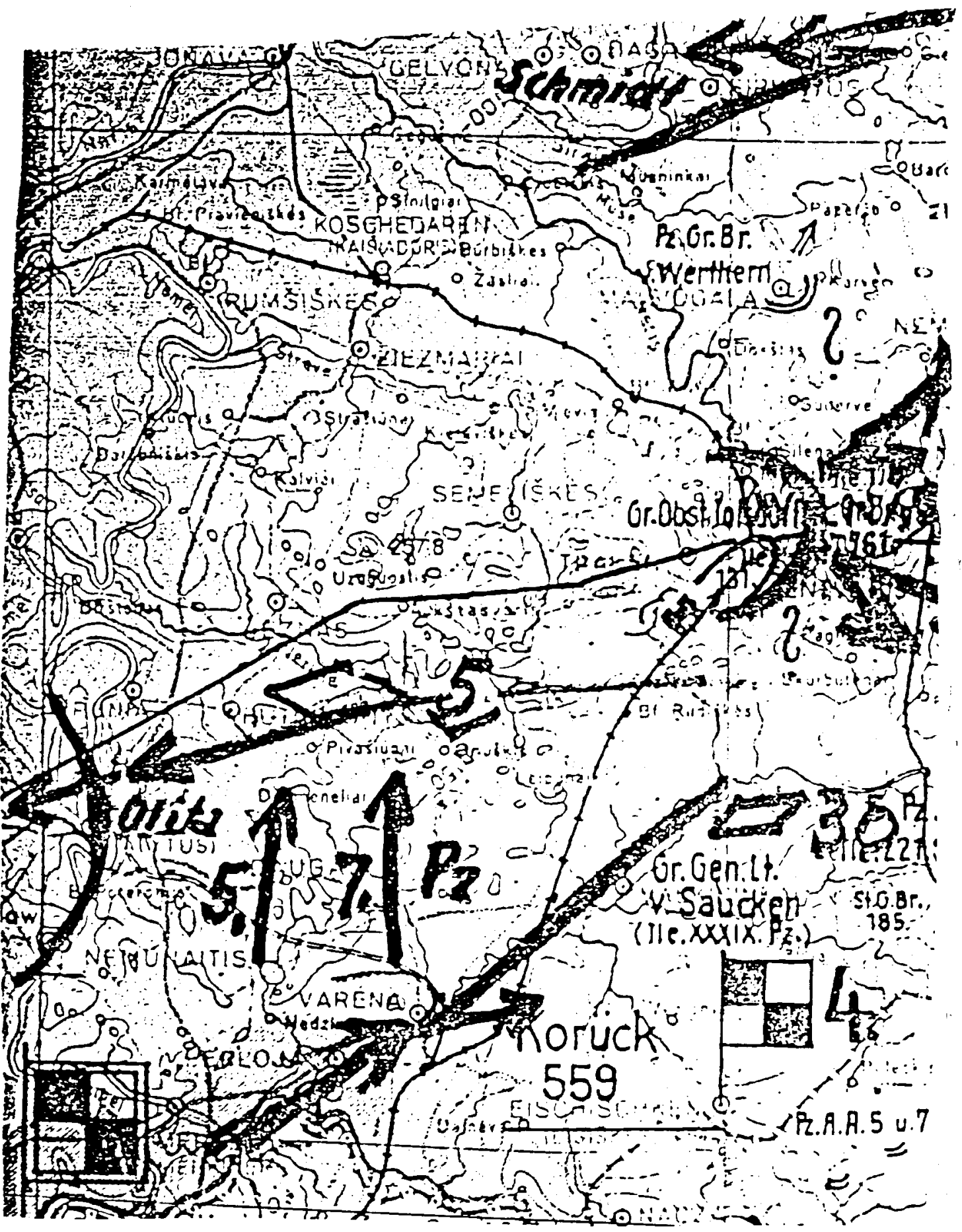

Figure 152. Panzer Grenadier Brigade Von Werthern's Attack On Griedraiciai And The Soviet Advance To Olita, July 12, 1944. Source: OKH, Der Grosse Durchbruch Bei Har. Mitte Von 21.6.-10.8.44., National Archives Microfilm Publication T.78, Roll 136. 


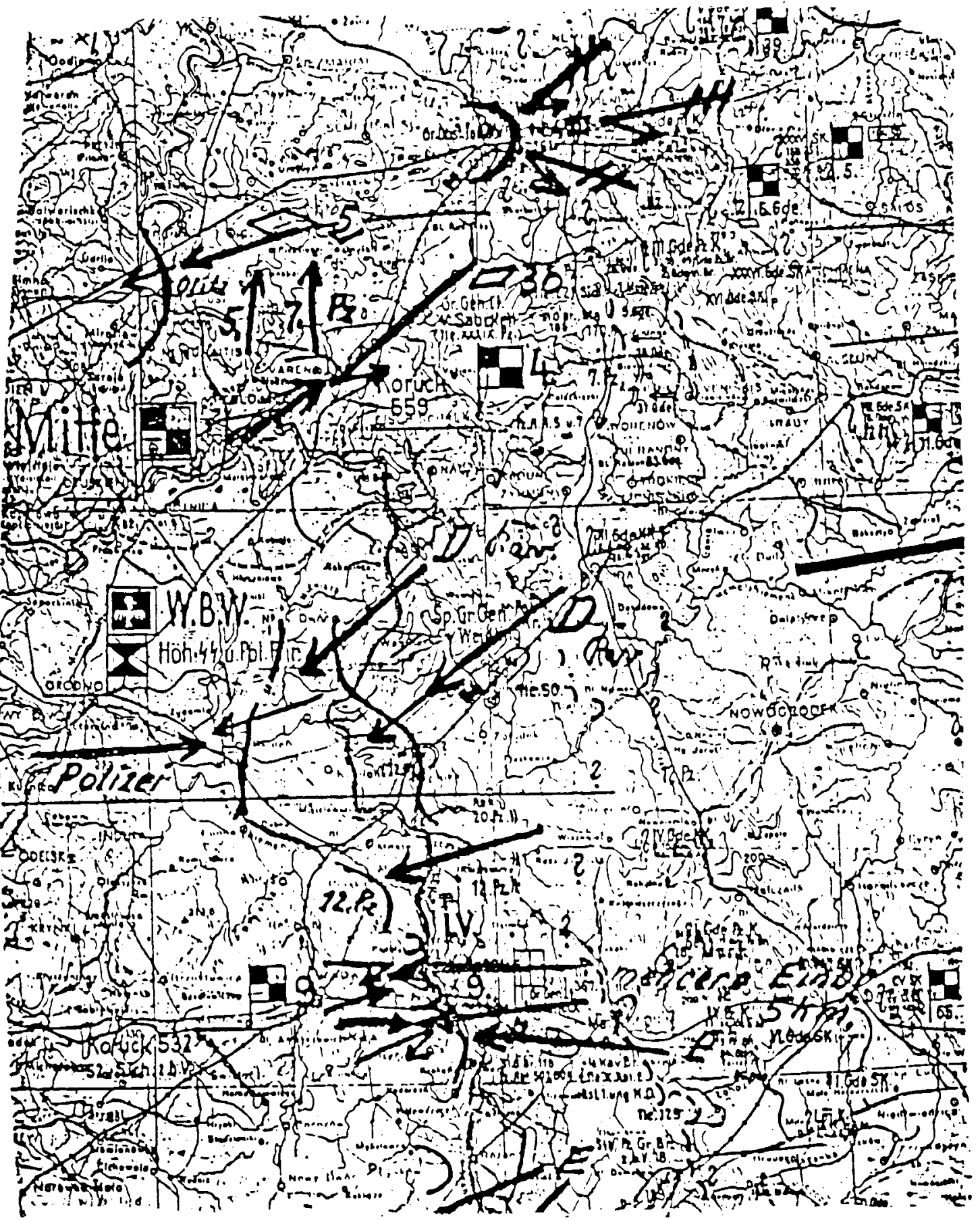

Figure 153. Army Group Center, July 12, 1944. Source: $\mathrm{OKH}$, Der Grosse Durchbruch Bei Hgr. Mitte Von 21.6.10.8.44., National Archives Microfilm Publication T-78, Roll 136. 


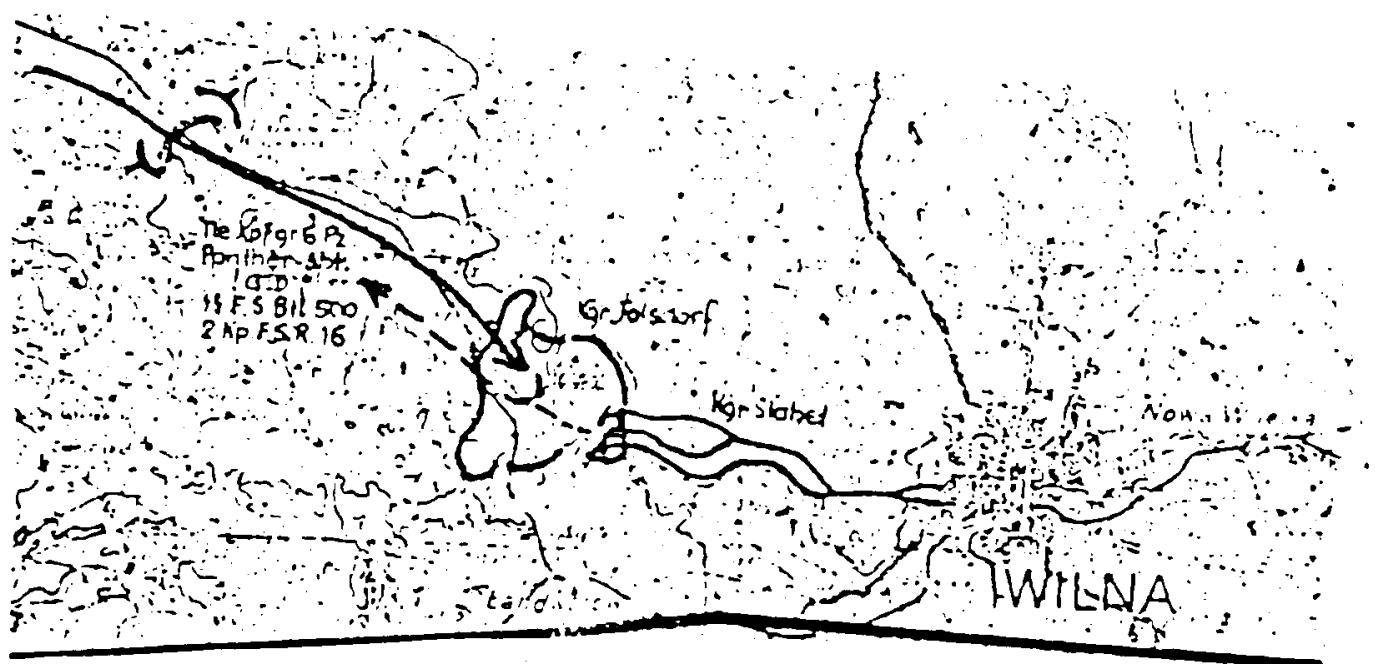

Figure 154. Kampfgruppe Tolsdorf, July 13, 1944. Source: Pz.A.O.K. 3, Lage der 3. Pz. Armee, Stand: 13.7.44. National Archives Microfilm Publication T-313, Roll 318. 


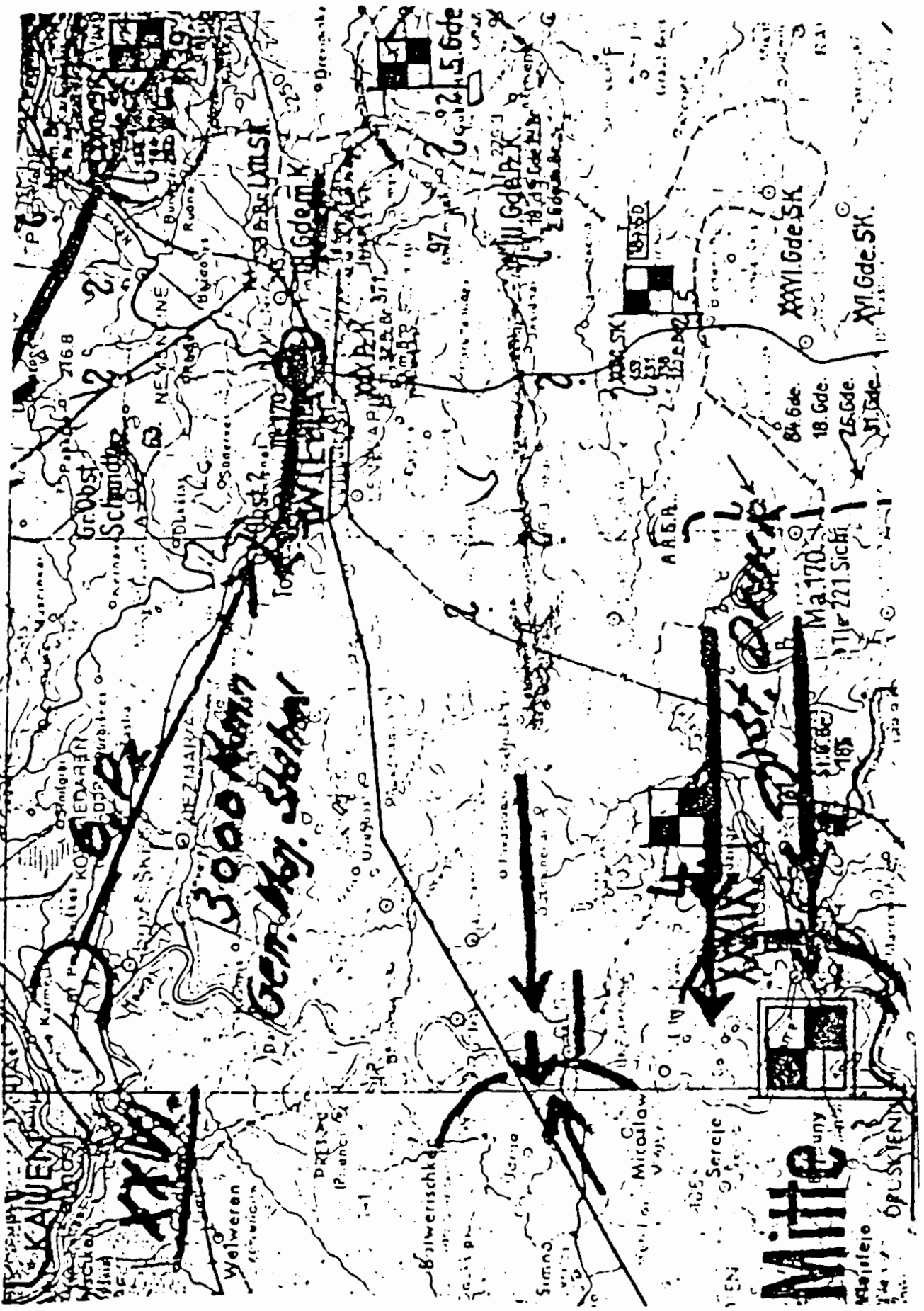

Figure 155. The Breakout Of The Garrison Of Fortress Wilna, July 13, 1944. Source: OKH, Der Grosse Durchbruch Bei Hgr. Mitte Von 21.6.-10.8.44., National Archives Microfilm Publication T-78, Roll 136. 

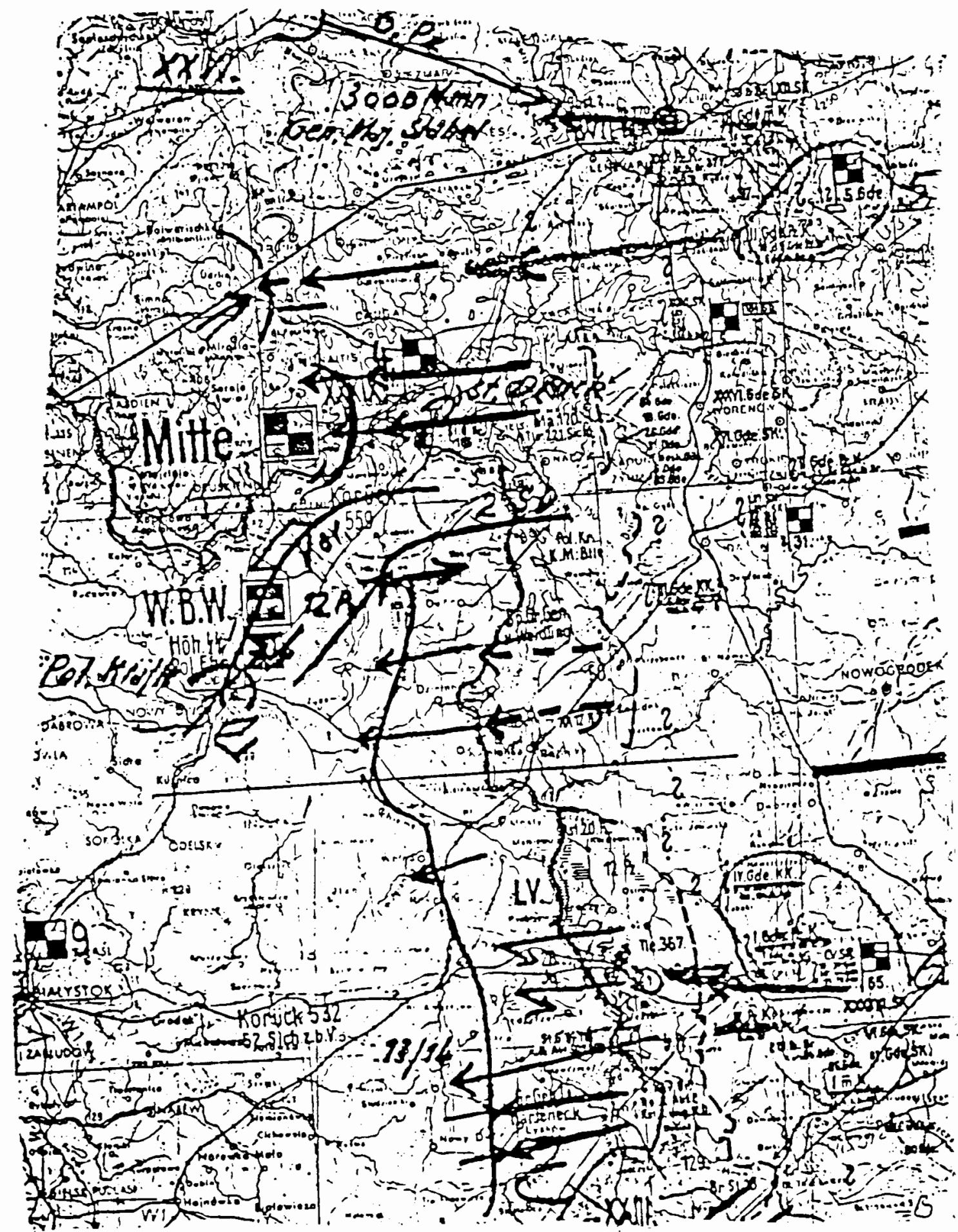

Figure 156. Army Group Center, July 13, 1944. Source: $\mathrm{OKH}$, Der Grosse Durchbruch Bei Hgr. Mitte Von 21.6.10.8.44., National Archives Microfilm Publication T-78, Roll 136. 


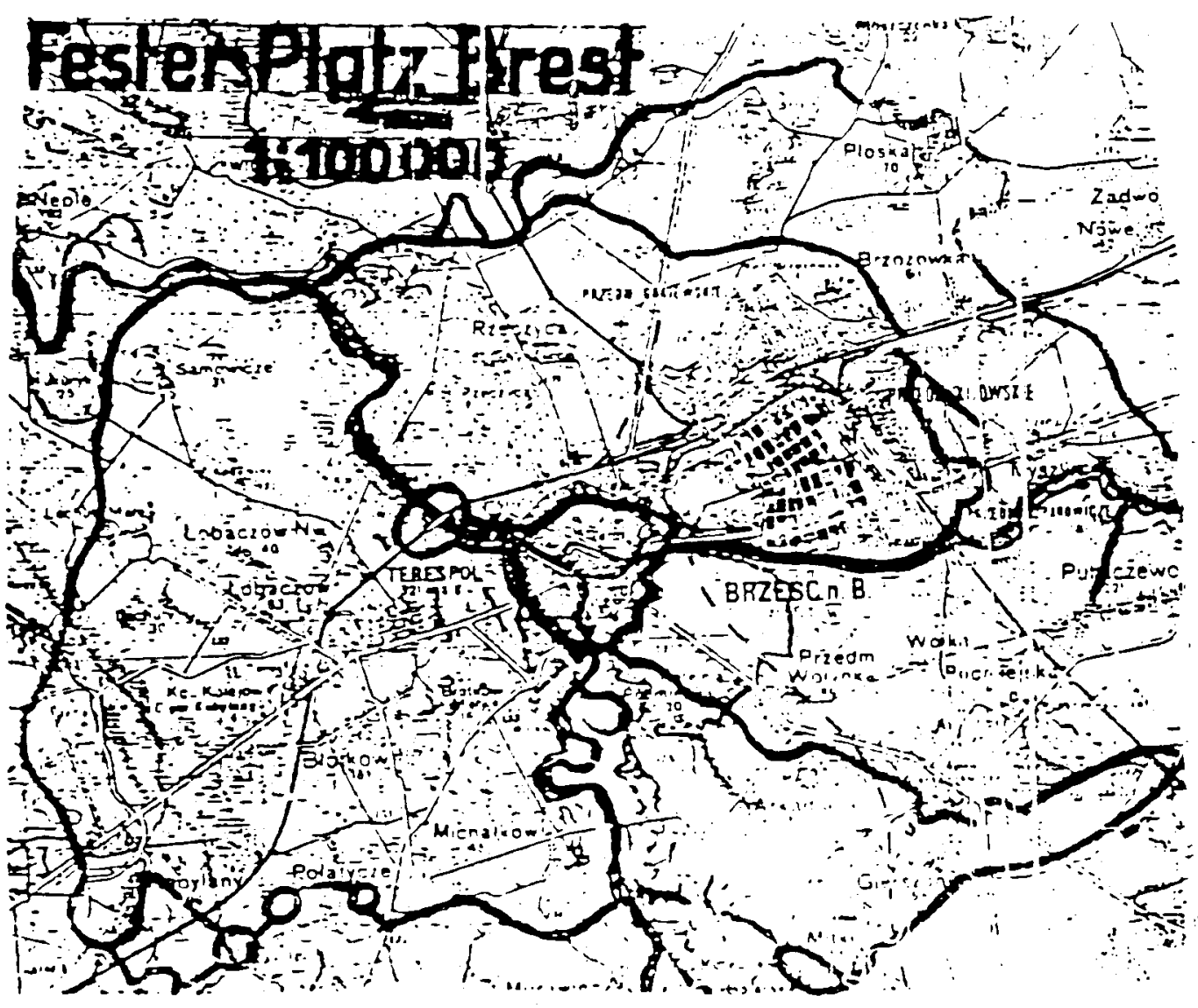

Figure 157. Fortress Brest-Litovsk. Source: Oberkommando Heeresgruppe Mitte, Fester Platz Brest National Archives Microfilm Publication T-311, Roll 228. 


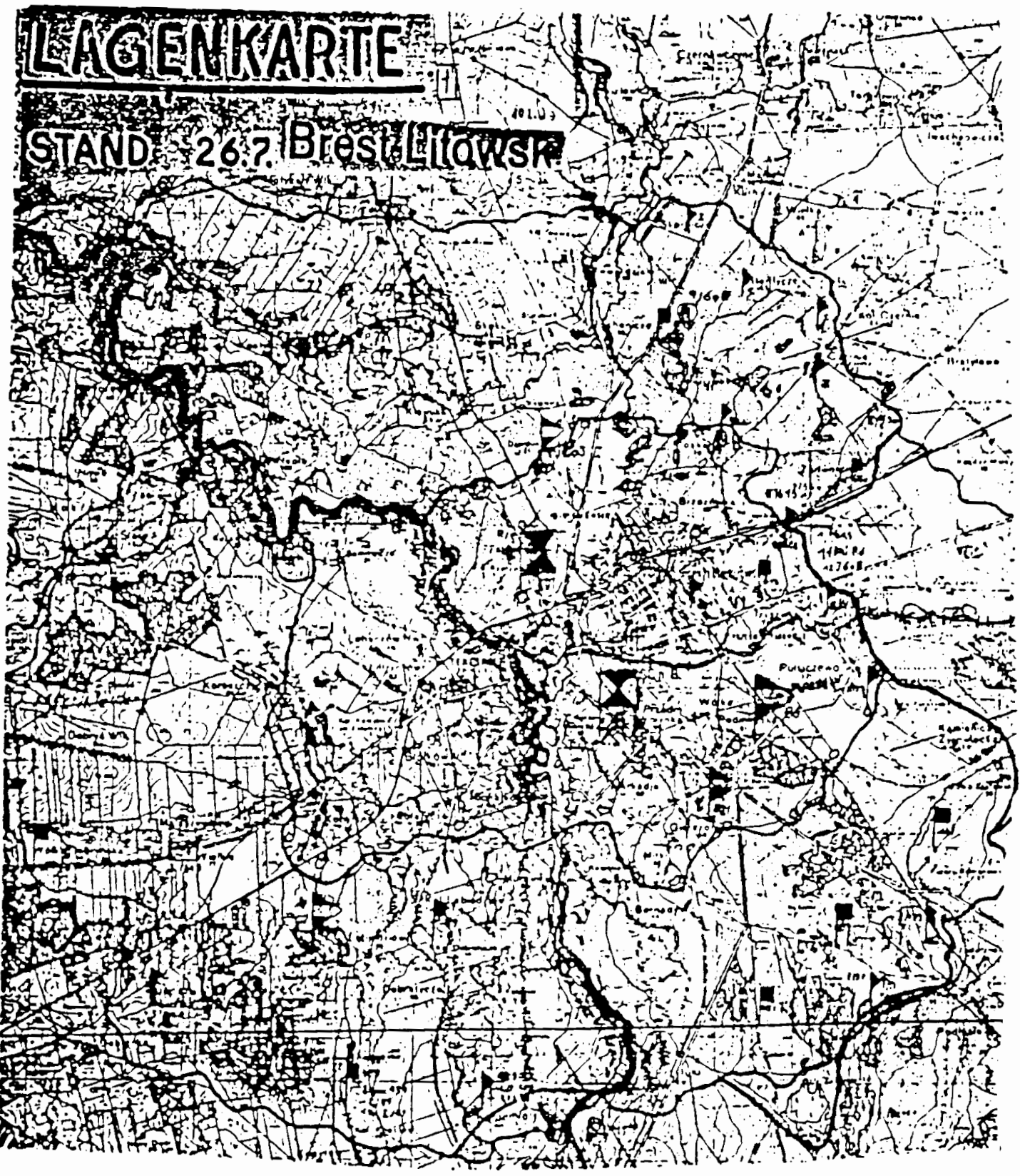

Figure 158. The Garrison Of Fortress Brest-Litovsk.

Source: Armeeoberkommando 2, Lagenkarte BrestLitowsk Stand 26.7.44. 9 Uhr. National Archives Microfilm Publication T-312, Roll 1318. 


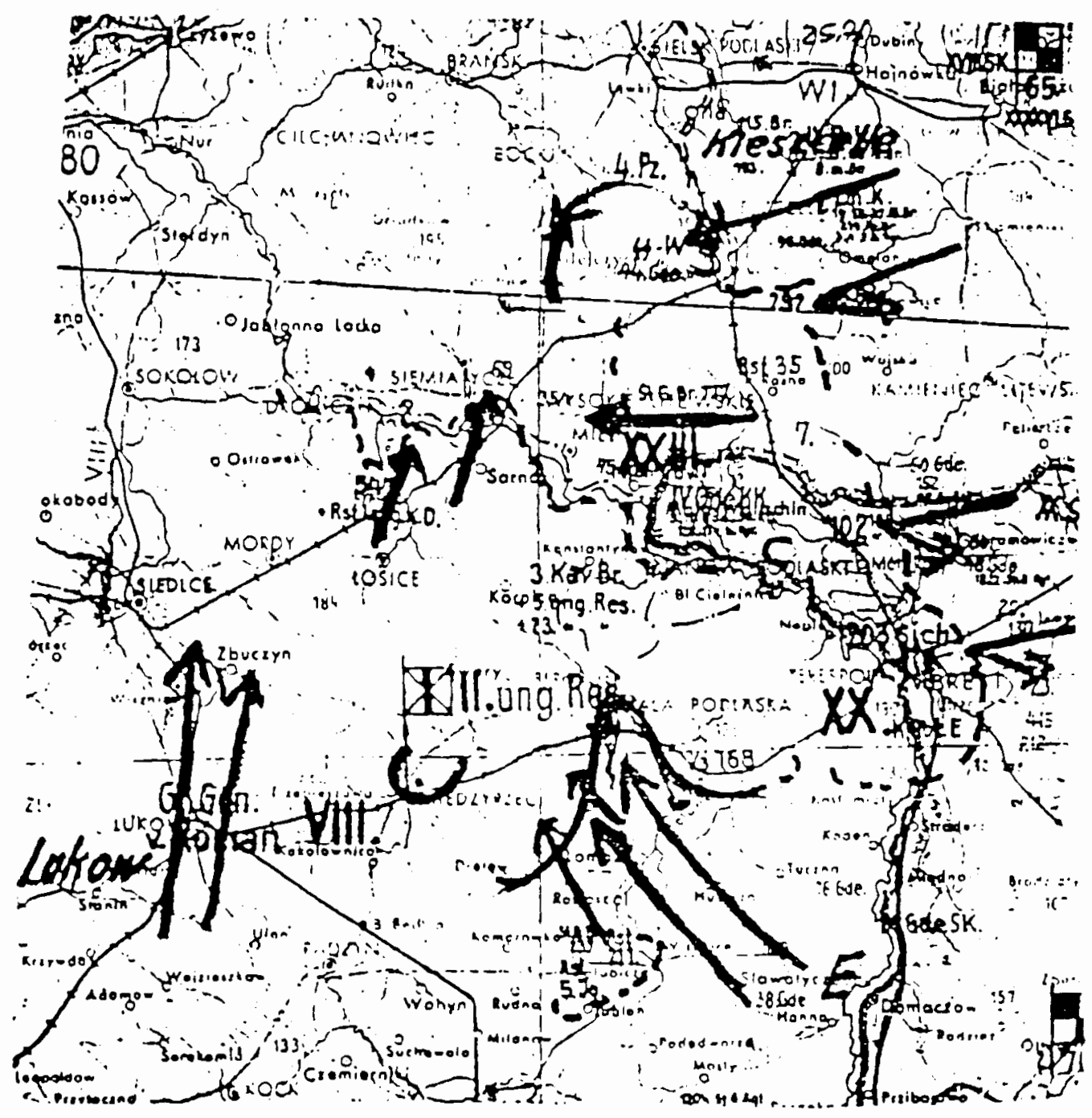

Figure 159. Soviet Attacks Southwest And Northwest Of Fortress Brest-Litovsk, July 25, 1944. Source: OKH, Der Grosse Durchbruch Bei Hgr. Mitte Von 21.6.-10.8.44., National Archives Microfilm Publication T-78, Roll 136. 


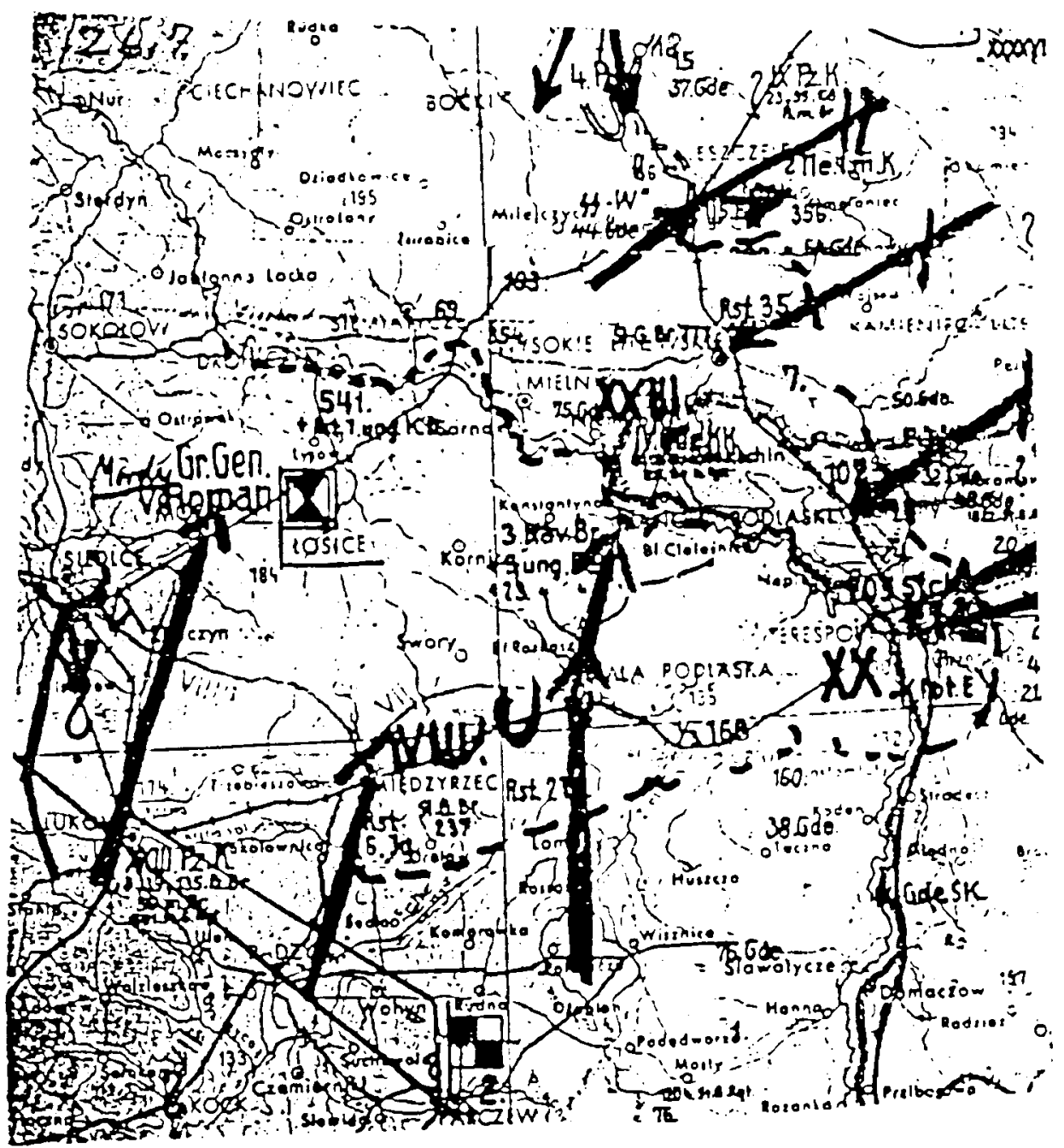

Figure 160. Soviet Attacks Southwest, Northwest And East Of Fortress Brest-Litovsk, July 26, 1944. Source: OKH, Der Grosse Durchbruch Bei Hgr. Mitte Von 21.6.10.8.44., National Archives Microfilm Publication T-78, Roll 136. 


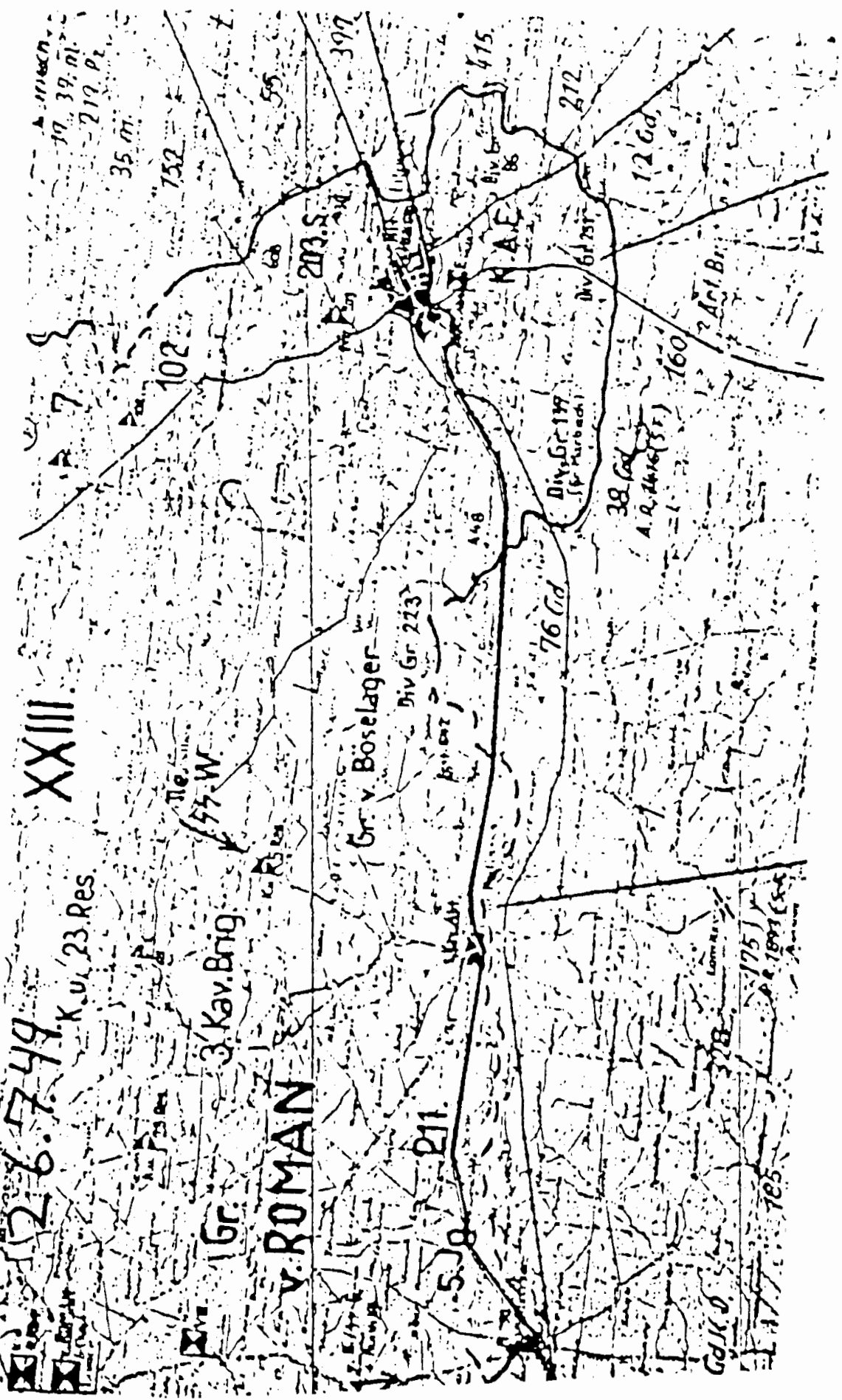

Figure 161. The Situation Of Fortress Brest-Litovsk On The Morning Of July 26, 1944. Source: Armeeoberkommando 2, Lagekarten A.O.K. 2 National Archives Microfilm Publication T-312, Roll 1325. 


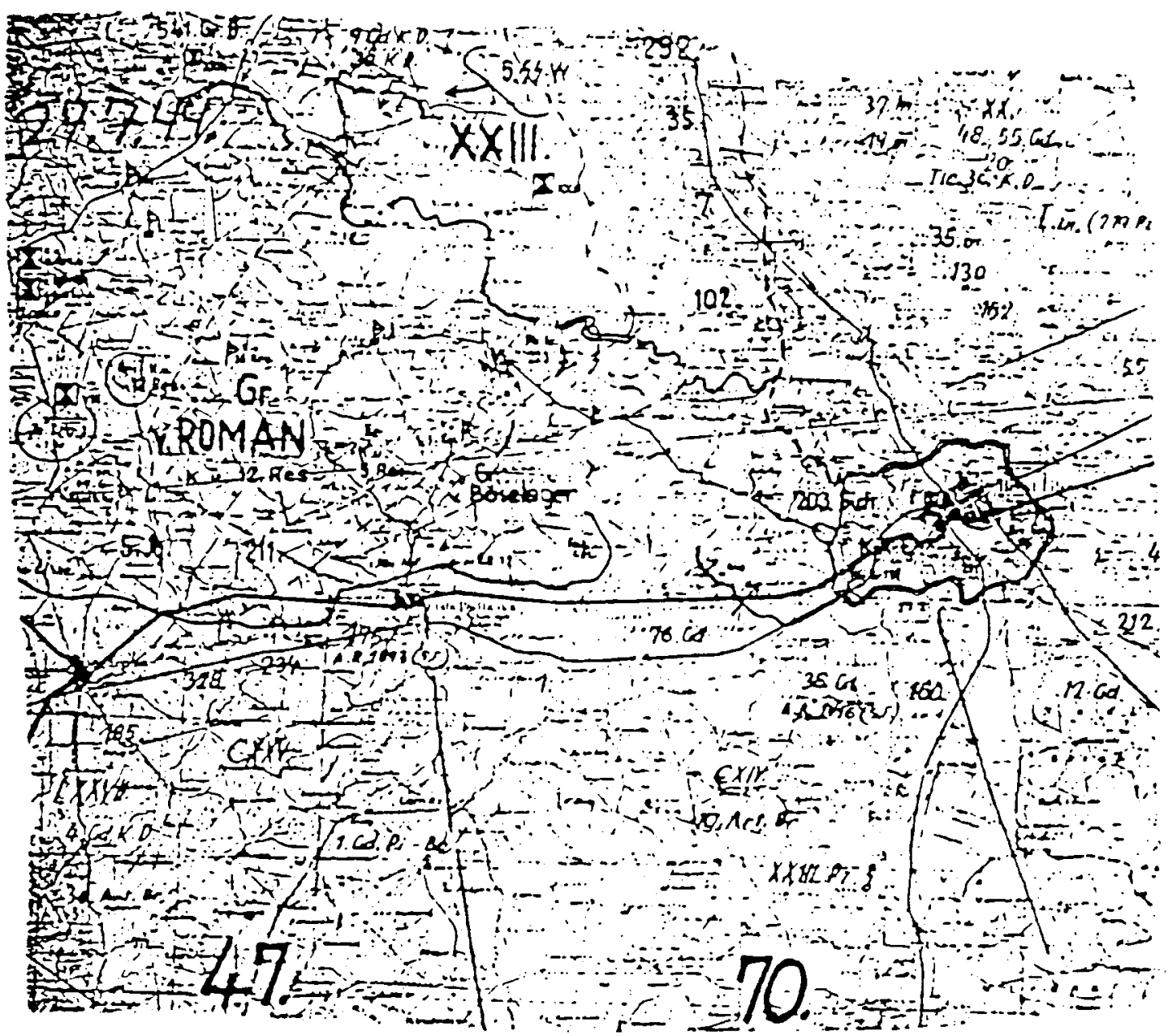

Figure 162. The Encirclement Of Fortress BrestLitovsk On July 27, 1944. Source: Armeeoberkommando 2, Lagekarten A.O.K. 2 National Archives Microfilm Publication T-312, Roll 1325. 


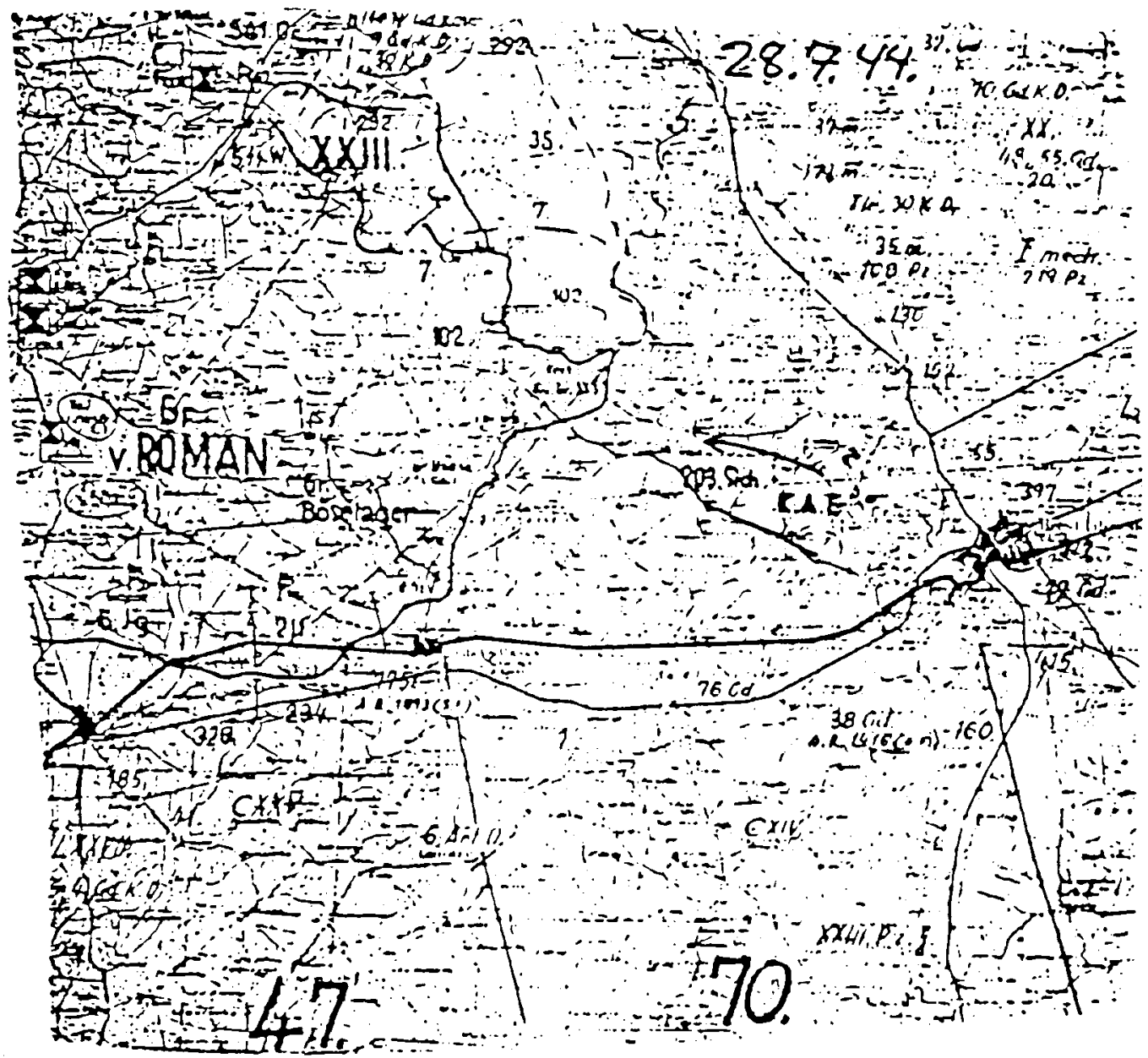

Figure 163. The Breakout Of The Garrison Of Fortress Brest-Litovsk On July 28, 1944. Source: Armeeoberkommando 2, Lagekarten.A.O.K. 2 National Archives Microfilm Publication T-312, Roll 1325. 


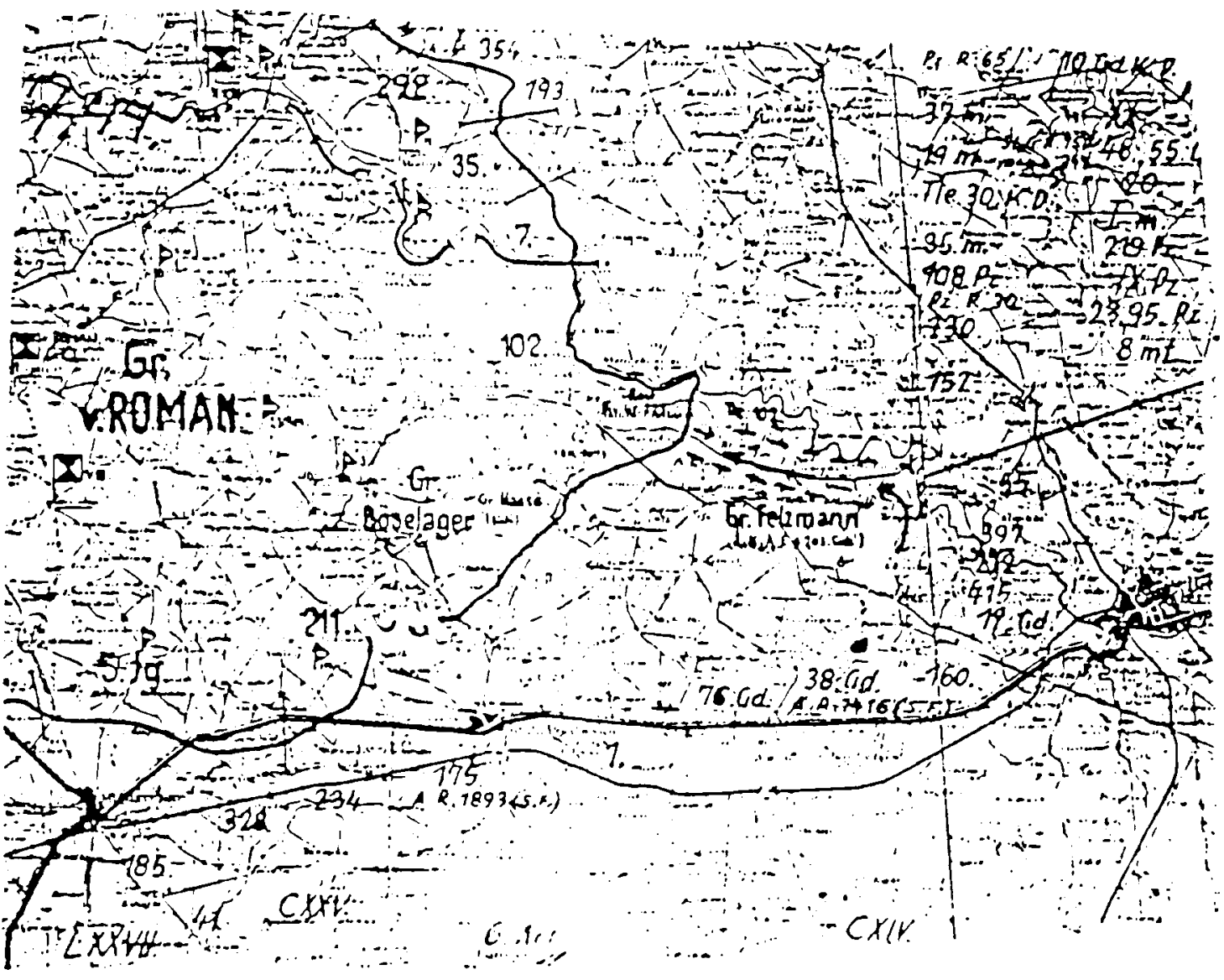

Figure 164. The Relief And Arrival Of Kampfgruppe

Felzmann At The German Western Defense Line, July 28, 1944. Source: Armeeoberkommando 2, Lagekarten A.O.K. 2 National Archives Microfilm Publication T-312, Roll 1325. 


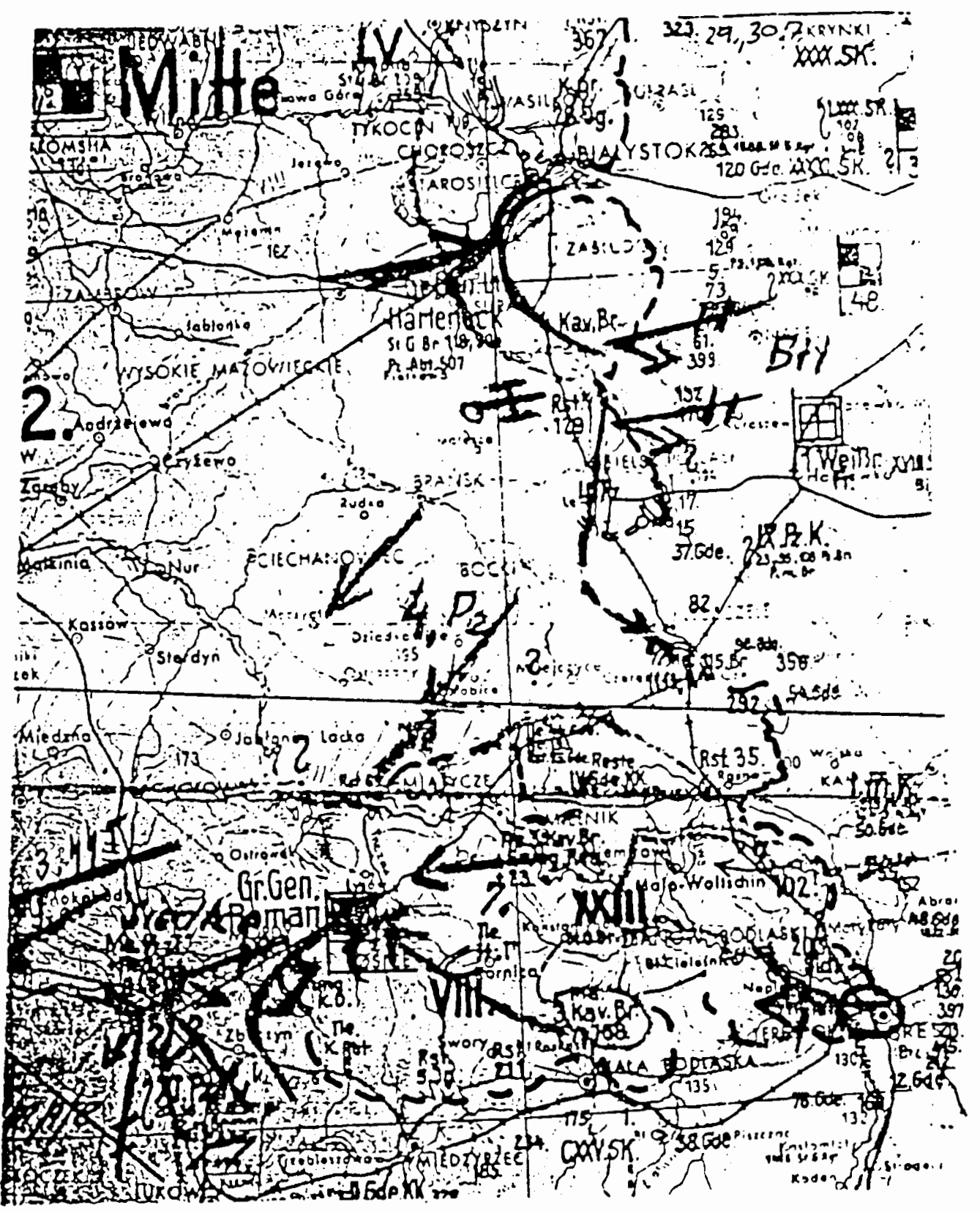

Figure 165. The 2nd Army, July 29-30, 1944. Source: OKH, Der Grosse Durchbruch Bei Hgr. Mitte Von 21.6.10.8.44., National Archives Microfilm Publication T-78, Roll 136. 
Stand März 1944

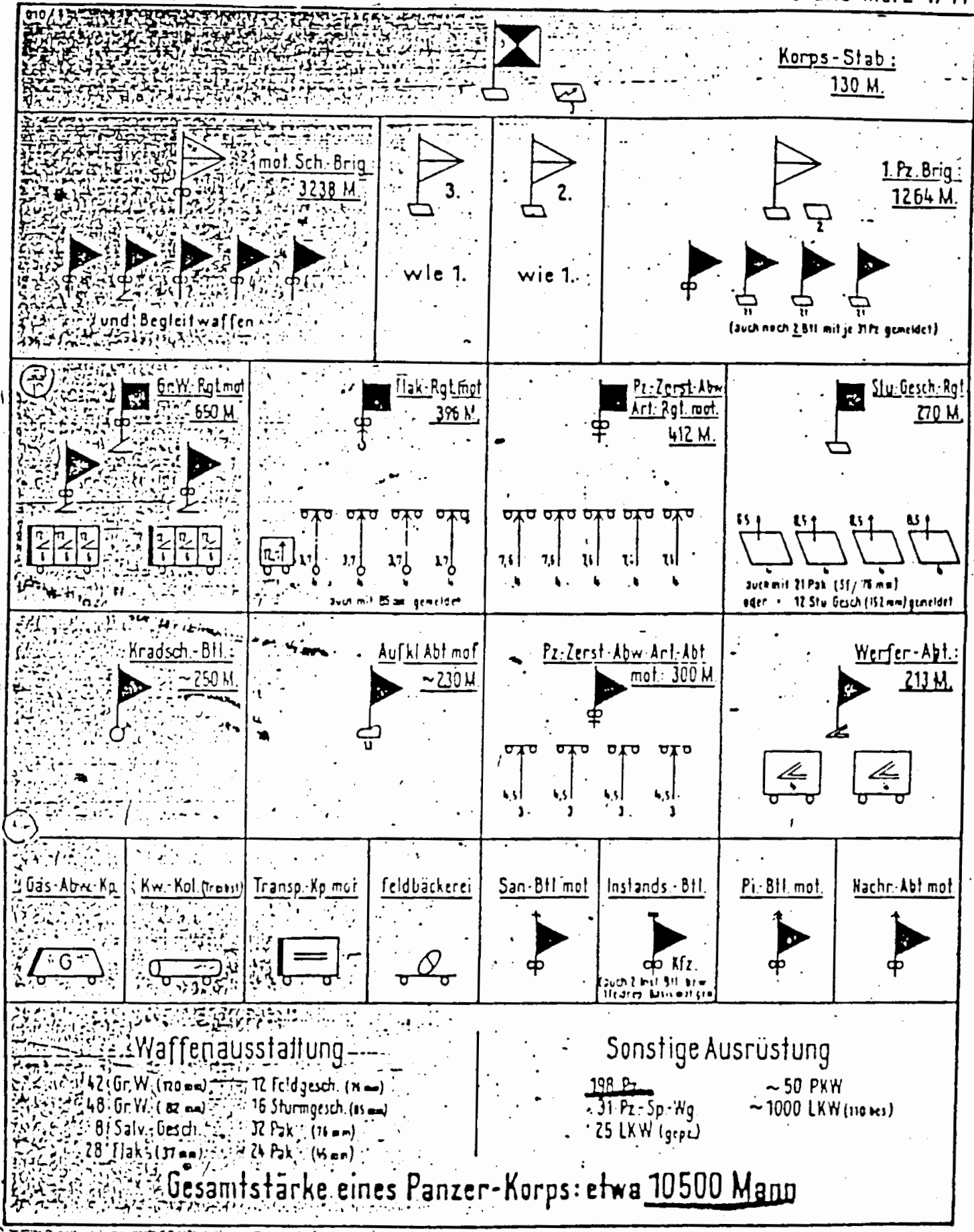

Figure 166. Soviet Tank Corps. Source: Oberkommando

H.Gr. Mitte, Beispiel fuer Kriegsgliederung eines Panzer-Korps. Stand Maerz 1944 National Archives Microfilm Publication T-311, Roll 230. 


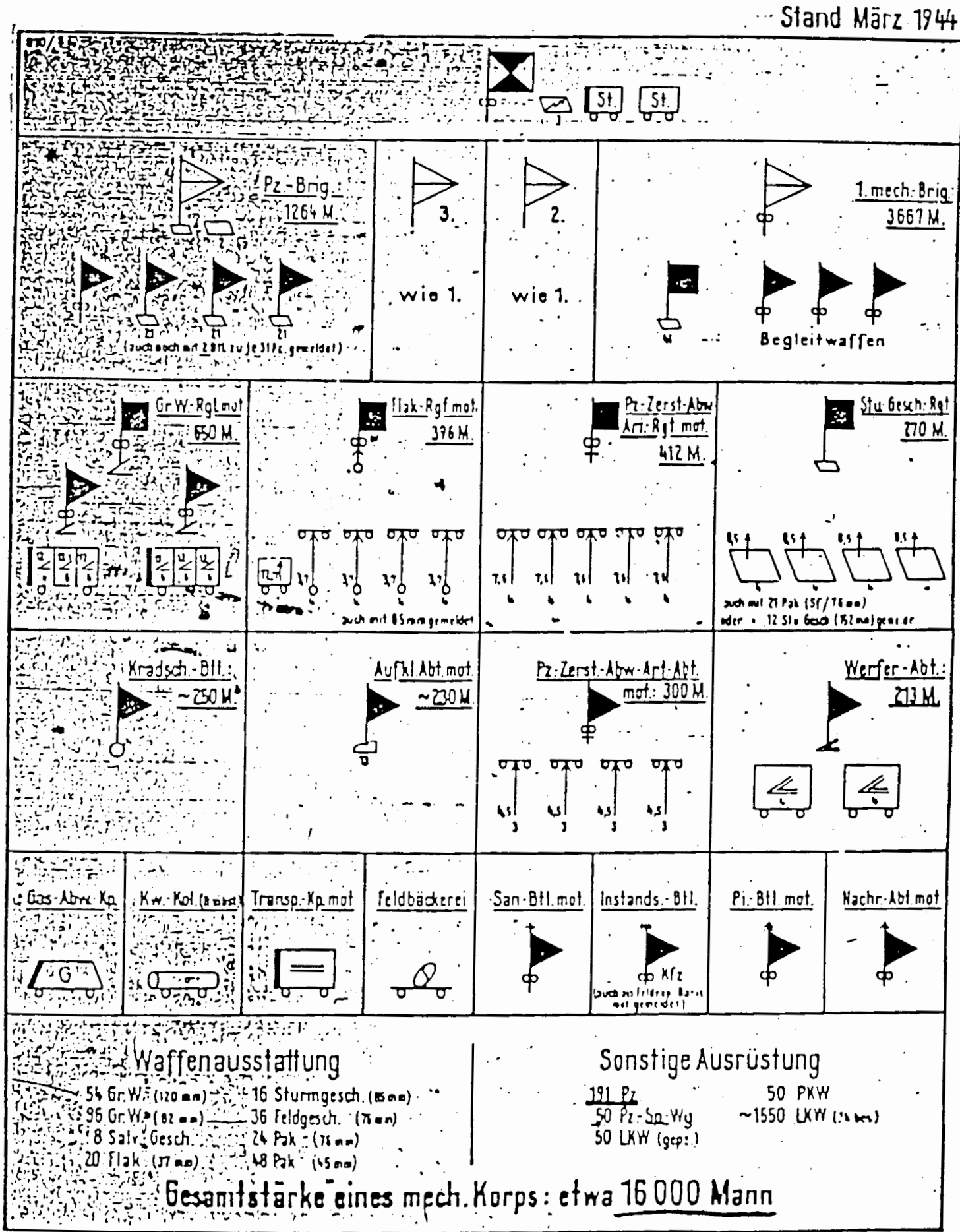

Figure 167. Soviet Mechanized Corps. Source:

Oberkommando H.Gr. Mitte, Beispiel fuer Kriegsgliederung eines Mech Korps, Stand Maerz 1944 National Archives Microfilm Publication T-311, Roll 230. 


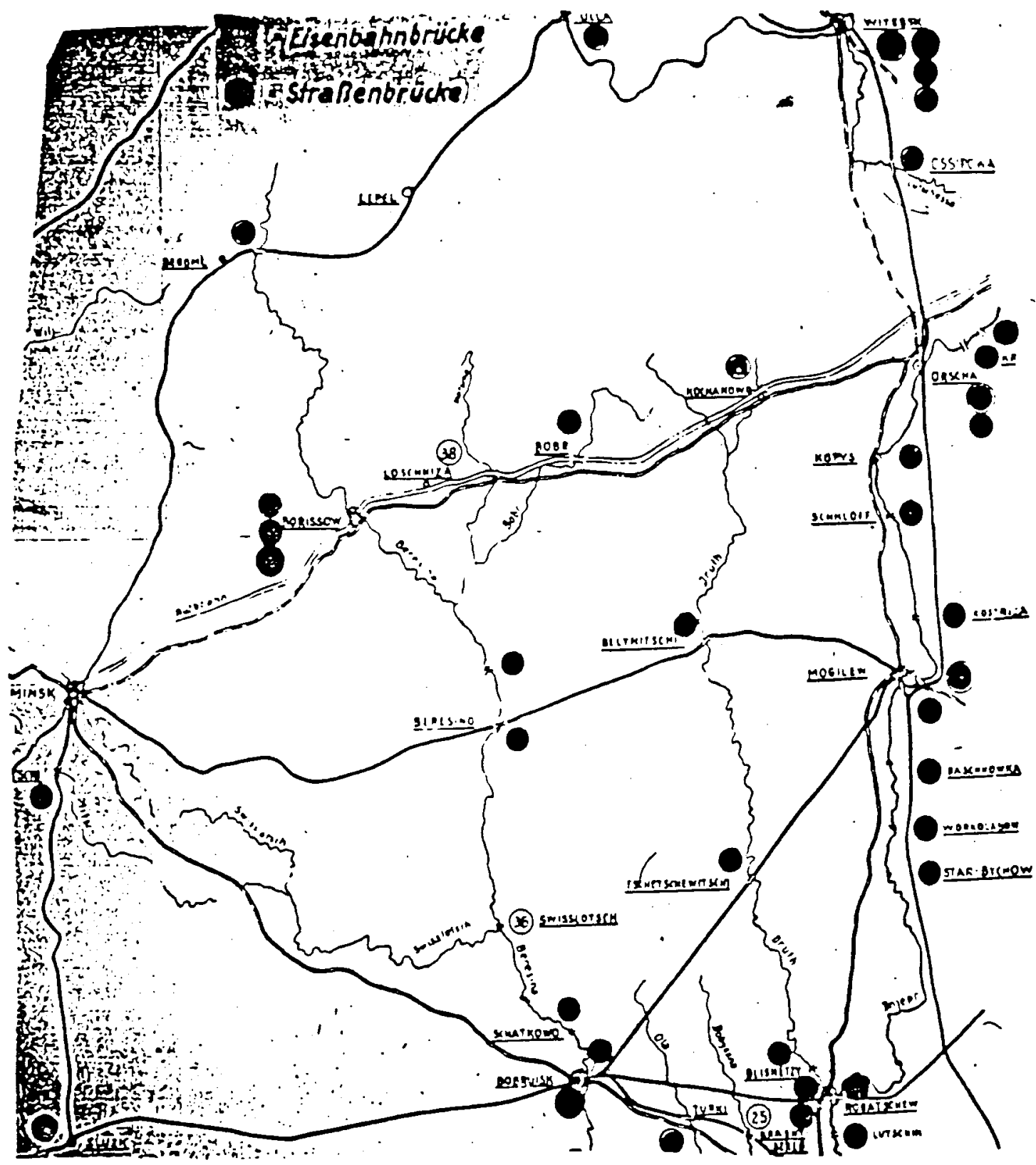

Figure 168. Rail And Road Bridges In Belorussia.

Source: Luftgaukommando XXVII, LSOK Uebersichtskante

Eisenbahn U. Strassenbruecken im Bereich Luftflotte 6

Stand 12.2.1944 National Archives Microfilm

Publication T-311, Roll 225. 


\section{NOTES TO CHAPTER IX}

${ }^{1}$ Wolfgang Schuman and Olaf Groehler, Deutschiand Im Zweiten Weltkrieg Vol. 6 (Berlin: Akademie Verlag, 1988), p. 52.

2Hermann Gackenholz, "The Collapse of Army Group Centre in 1944," Decisive Battles of World War II: The German View Ed. H.A. Jacobsen and J. Rohwer (New York: G.P. Putnam's Sons, 1965), p. 382.; Hermann Gackenholz, "Zum Zusammenbruch Der Heeresgruppe Mitte Im Sommer 1944," Vierteljahrshefte fuer Zeitgeschichte Vol. 3, July 1955, p. 317.

3lbid.

${ }^{4}$ Walter Goerlitz, "The Battle for Stalingrad 1942-3," Decisive Battles of World War II: The German View Ed. H.A. Jacobsen and J. Rohwer (New York: G.P. Putnam's Sons, 1965), p. 243.

5 lbid.

6lbid.

7Paul Carell, Scorched Earth Vol. 2 (London: George G. Harrap \& Co. Ltd, 1970), p. 508.

8Organisationsabteilung, Verluste der Heeresgruppe Mitte in der Zeit von 22.6. bis 15.7.1944 NAMP T-78, Roll 421.

9lbid.

${ }^{10}$ lbid.

11 William B. Breuer, Hitler's Fortress Cherbourg (New York: Stein And Day Publishers, 1984), p. 252.

12lbid., p. 248.

13 William B. Breuer, Death Of A Nazi Army (New York: Stein And Day Publishers, 1985), p. 289.

14 lbid., p. 294.

15John Keegan, The Second World War (New York: Viking Penguin, Inc., 1989), p. 410. 
${ }^{16}$ Rolf Hinze, Der Zusammenbruch Der Heeresgruppe Mitte Im Osten 1944 (Stuttgart: Motorbuch Verlag, 1980), p. 42; Gackenholz, "The Collapse of Army Group Centre in 1944," p.366; Gerd Niepold, Mittlere Ostfront Juni'44 (Herford: Verlag E.S. Mittler \& Sohn, 1985), p. 72; Carell, p. 492.

${ }^{17}$ P.N. Pospelov et al, History Of The Great Patriotic War Of The Soviet Union 1941-1945 Vol. 4 translated by the Foreign Technology Division, Air Force Systems Command, (Moscow: Publishing House "Voyennoye," 1962), p. 320; G. Zhukov, Marshal of the Soviet Union G. Zhukov: Reminiscences And Reflections (Moscow:

Progress Publishers, 1974), p. 275; S.M. Shtemenko, The Soviet General Staff At War 1941-1945 Vol. 1 (Moscow: Progress Publishers, 1985), p. 332.

${ }_{18}$ P.N. Pospelov et al, p. 320; G. Zhukov, Marshal of the Soviet Union G. Zhukov: Reminiscences And Reflections, p. 274; Marshal Ivan K.H. Bagramian, "The Liberation of Byelorussia (Operation Bagration")," Soviet Generals Recall World War II Ed. Igor Vitukhin (New York: Sphinx Press, Inc., 1981), p. 298.

${ }^{19}$ P.N. Pospelov et al, p. 320.

20 Ibid., Kriegstagebuch der Panzerarmeeoberkommando 3, 22.6.44., NAMP T313, Roll 316, p. 2.

${ }^{21}$ Kriegstagebuch der Panzerarmeeoberkommando 3. 22.6.44., NAMP T-313, Roll 316, p. 3.

22ibid., p. 2.

${ }^{23}$ Kriegstagebuch der Panzerarmeeoberkommando 3, 22.6.44., NAMP T-313, Roll 316, p. 9.

$$
\begin{aligned}
& 24 \text { Ibid., p. } 6 . \\
& 25 \text { Ibid. } \\
& 26 \text { Ibid. } \\
& 27 \text { Ibid., p. } 10 . \\
& 28 \text { Niepold, Battle For White Russia: The Destruction of Army Group Centre, } p \text {. }
\end{aligned}
$$
73.

${ }^{29}$ Kriegstagebuch der Panzerarmeeoberkommando 3, 22.6.44., NAMP T-313, Roll 316, p. 10. 
30Lt. Colonel Von Wienskowski, Die Entwicklung der Lage dei der 4. Armee waehrend dedr Russischen Sommeroffensive 1944 und die Vorgaenge bei den abgesprengten Verbaenden 22.6. bis 5.7.44. NAMP T-312, Roll 1365, p. 4; Niepold, Battle For White Russia: The Destruction of Army Group Centre, p. 75.

${ }^{31}$ Kurt Mehner, Die Geheimtagesberichte Der Deutschen Wehrmachtfuehrung Im Zweiten Weltkrieg 1939-1945, (hereafter GHTBDW) VOL. 10, P. 286. 1944," p. 323.

${ }^{32}$ Gackenholz, "Zum Zusammenbruch Der Heeresgruppe Mitte Im Sommer

33Mehner, GHTBDW Vol. 10, p. 286.

${ }^{34}$ Kriegstagebuch der Panzerarmeeoberkommando 3, 23.6.44., NAMP T-313, Roll 316, p. 1.

35!bid.

36 lbid., p. 3.

37lbid., pp. 4-5.

38 Ibid., p. 5.

${ }^{39}$ lbid.

40 lbid., p. 9.

41 lbid., pp. 9-10.

42Ibid., pp. 6-7.

43 ibid., p. 7.

${ }^{44}$ Ibid.

45 lbid., p. 8.

46/bid., p. 10.

47/bid., p. 11.

48 Ibid.

49 Wienskowski, p. 3. 
50Mehner, GHTBDW VOL. 10, P.289.

${ }^{51}$ Wienskowski, pp. 5-6.

52|bid., p. 6.

53 lbid.

${ }^{54}$ Ibid.

55 bid.

56 Ibid., p. 4.

${ }^{57}$ Kriegstagebuch der Panzerarmeeoberkommando 3, 24.6.44., NAMP T-313, Roll 316, p. 1.

58 Ibid., p. 5.

59lbid., p. 7.

60Ibid., p. 11

61 lbid., p. 5.

62Ibid., P. 7.

63ibid.

64 Ibid.

65 Ibid.

66/bid., p. 8.

67Ibid.

68 Ibid.

${ }^{69}$ |bid., p. 9.

70/bid., p. 10.

71 Ibid.

72/bid., p. 12. 
73/bid., pp. 13-14.

74 lbid., p. 14.

75Wienskowski, p. 6.

76/bid., p. 7.

77/bid., p. 8.

78 ibid., p. 7.

79/bid., p. 8.

80 lbid.

81 lbid., p. 10 .

${ }^{82}$ Ibid.

83Mehner, GHTBDW VOL. 10, P. 292.

${ }^{84} \mathrm{Lt}$. Weller, Gefechtsbericht Der 9. Armee Ueber Die Schiacht In Weissruthenien 24.6.-10.7.1944. NAMP T-312, Roll 339, p. 4.

85 lbid., p. 5.

86KTB der Panzerarmeeoberkommando 3, (PAOK 3) 25.6.44. NAMP T-313, Roll 316, p. 1.

87 Ibid.

88 lbid., p. 5.

89 lbid., p. 8.

90/bid., p. 9

91 lbid.

92 Ibid., p. 5.

93Pospelov et al, pp. 320-321.

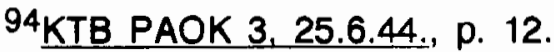


95 Ibid.

96/bid., p. 8.

97 Ibid.

98/bid., p.12.

99 Niepold, Battle For White Russia: The Destruction Of Army Group Centre June 1944, p. 103.

100KTB PAOK 3. 25.6.44., p. 12.

101 Ibid.

102/bid., p. 13.

103/bid.

${ }^{104}$ Wienskowski, p.12.

105 Ibid., p. 11.

106 ibid.

107/bid., p. 13.

108 Ibid.

109/bid.

${ }^{110}$ lbid.

111 Ibid.

112 Ibid.

113/bid.

${ }^{114}$ Weller, p. 6.

${ }^{115}$ |bid.

116|bid., p. 5. 
117|bid., p. 6.

118/bid.

119 Niepold, Battle For White Russia: The Destruction Of Army Group Centre June 1944, p. 110.

120KTB PAOK 3, 26.6.44., p. 1.

121 Ibid., p. 7.

122Ibid., p. 1.

123 Ibid., p.2.

124Ibid.

125 Ibid., p. 4.

126 Ibid., p. 6.

${ }^{127}$ Ibid.

${ }^{128}$ Colonel S. Shishkin, "The Vitebsk Operation" Krasnaia Zvezda (Red Star) 25 October 1944 as translated in Mllitary Review Vol. 25, No. 4 July 1945, p. 96.

129 Ibid.; Hinze, Der Zusammenbruch Der Heeresgruppe Mitte Im Osten 1944. p. 65 .

${ }^{130}$ Shishkin, p. 97.

${ }^{131}$ Hinze, Der Zusammenbruch Der Heeresgruppe Mitte Im Osten 1944, p. 61.

${ }^{132}$ Rueckkaempter Major Willi Voss, Vernehmung 6.9.1944. NAMP T-78, Roll 141, p. 3.

133 Ibid.

${ }^{134}$ Ibid.

135 Ibid.

136|bid., p. 4.

137/bid. 
138Wienskowski, p. 15.

139 Ibid., p. 16.

140 lbid., pp. 16-17.

${ }^{141}$ Lt. Thedor Deutscherr, Auszugsweise Von Abschritt 7.9.44. NAMP T-78, Roll 141

142 Wienskowski, p. 17.

143/bid., p. 20.

144 Ibid.

${ }^{145}$ Ibid.

146 Major D. Saulin, "The Battle of Orsha" Krasnaya Zvezda (Red Star) 11 October 1944 as translated in Military Review Vol. 25, No. 2, May 1945, p. 123.

147Wienskowski, p. 18.

148 Ibid., p. 19.

149 lbid., p. 20.

150 lbid.

151 Weller, p. 7.

${ }^{152}$ Rolf Hinze, Hitze. Frost und Pulverdampf: Der Schicksalsweg der 20.

Panzer Division (Bochum: Heinrich Poeppinghaus Verlag, 1981), p. 291.

$153_{\text {Ibid. }}$

${ }^{154}$ Ibid., p. 292.

155 Weller, p. 7.

${ }^{156}$ Ibid.

157/bid.

158 |bid., p. 8. 
159Niepold, Battle For White Russia: The Destruction Of Army Group Centre June 1944, p. 120.

160Mehner, GHTBDW Vol. 10, p. 297.

${ }^{161}$ Niepold, Battle For White Russia: The Destruction Of Army Group Centre June 1944, p. 124.

162Pospelov et al, pp. 330-331.

163Major Klassen, Erfahrungsbericht 6.7.44. NAMP T-311, Roll 217.

164 Ibid.

165 ibid.

${ }^{166}$ KTB PAOK 3, 27.6.44., p. 1.

167Ibid., p. 3.

168 bid., p. 7.

169 ibid., p. 9.

170 Ibid., p. 11.

$171_{\text {Ibid., p. } 2 .}$

172Hinze, Der Zusammenbruch Der Heeresgruppe Mitte Im Osten 1944, p. 64; Carell, Scorched Earth: Hitler's War on Russia, p. 508.

173Hinze, Der Zusammenbruch Der Heeresgruppe Mitte Im Osten 1944, p. 65; OKW/Org. Abt. und Heerespersonalabt., Zusammenstellung der in diesem Kriege gefallenen, toetlich verunglueckten, verstorbenen, vermissten und im Gefangenschaft geratenen Generale, Flensburg 5 June 1945, NAMP T-77, Roll 785.

${ }^{174}$ Pospelov et al, p. 325

${ }^{175}$ Carell, Scorched Earth: Hitler's War on Russia, p. 508; OKW/Org. Abt. und Heerespersonalabt., Zusammenstellung der in diesem Kriege gefallenen, toetlich verunglueckten, verstorbenen, vermissten und im Gefangenschaft geratenen Generale. Flensburg 5 June 1945, NAMP T-77, Roll 785.

${ }^{176}$ Carell, Scorched Earth: Hitler's War on Russia, p. 499. 
177Ibid., p. 508; OKW/Org. Abt. und Heerespersonalabt., Zusammenstellung der in diesem Kriege gefallenen, toetlich verunglueckten, verstorbenen, vermissten und im Gefangenschaft geratenen Generale, Flensburg 5 June 1945, NAMP T-77, Roll 785 .

${ }^{178}$ Carell, Scorched Earth: Hitler's War on Russia, p. 508; Hinze, Der Zusammenbruch Der Heeresgruppe Mitte Im Osten 1944, p. 68.

179Hermann Teske, Die Silbernen Spiegel (Heidelberg: Kurt Vowinckel Verlag, 1952), p. 216; Rolf Hinze, Das Ostfront-Drama 1944 (Stuttgart: Motorbuch Verlag, 1987), pp. 425-426; KTB der Heeresgruppe Mitte Fuehrungsabteilung, Gliederung der grossen Verbaende 15.7.44. NAMP T-311, Roll 228; Generalstab des Heeres, Organisationabteilung, Uebersicht ueber Aufgeloeste Divisionen 1944 NAMP T-78, Roll 410; Generalstab des Heeres, Organisationabteilung, Uebersicht ueber die grossen Verbaende des Heeres der Waffen-SS und der Fallschirm-Truppen. Stand 30.7.44. NAMP T-78, Roll 413; Samuel W. Mitcham, Jr., Hitler's Legions: The German Army Order of Battle. World War II (New York: Stein And Day, 1985), pp. 157, 162, 181, 429; Burkhart Mueller-Hillebrand, Das Heer 1933-1945 Vol. 3 (Frankfurt am Main: Verlag E.S. Mittler \& Sohn GMBH, 1969), p. 241.

180Wienskowski, p. 22.

181 lbid.

182/bid., p. 23; Pospelov et al, p. 327.

${ }^{183}$ Wienskowski, pp. 27-28.

${ }^{184}$ /bid; Lt. Colonel Von Wienskowski, Bekundungen des Generalmajors Schuermann, Kommandeurs der 25. Pz. Gr. Div. 27.8.1944, NAMP T-78, Roll 141, p. 3.

185Lt. Colonel Von Wienskowski, Die Entwicklung der Lage dei der 4. Armee waehrend dedr Russischen Sommeroffensive 1944 und die Vorgaenge bei den abgesprengten Verbaenden 22.6. bis 5.7.44. (hereafter: Entwicklung der 4. Armee), p. 28.

186 Ibid., p. 23.

187/bid., p. 24.

188 Ibid.

189 Ibid., p. 26.

190 lbid. 
191 Ibid., p. 29.

192ibid.

${ }^{193}$ Weller, p. 8.

${ }^{194}$ Niepold, Battle For White Russia: The Destruction Of Army Group Centre June 1944, p. 133.

195 Ibid.

196/bid.

197Marshal G. Zhukov, Marshal of the Soviet Union G. Zhukov Reminiscenes And Reflections (Moscow: Progress Publishers, 1985), p. 277.

198Marshal K. Rokossovsky, A Soldier's Duty (Moscow: Progress Publishers, 1985), p. 277.

199/bid., pp. 242-243.

200 Ibid., pp. 243-244.

201 Ibid., p. 244.

202 Ibid.

203Weller, p. 12; Heeresgruppe Mitte, Bemerkung: 9. Armee-Lage am 27. Juni 44. NAMP T-311, Roll 219; OKW/Org. Abt. und Heerespersonalabt., Zusammenstellung der in diesem Kriege gefallenen, toetlich verunglueckten. verstorbenen, vermissten und im Gefangenschaft geratenen Generale. Flensburg 5 June 1945, NAMP T-77, Roll 785; Carell, p. 509.

${ }^{204}$ Zhukov, Marshal of the Soviet Union G. Zhukov Reminiscenes And Reflections, p. 277.

205 Weller, p. 9.

206 lbid.

207 Ibid.

208KTB PAOK 3, 28.6.44., p. 3.

209/bid. 
210 ibid., p. 9.

211 ibid.

212Wienskowski, Entwicklung der 4. Armee, p. 37.

213 bid., p. 33.

${ }^{214}$ bid., p. 31.

215 lbid., p. 33.

216 Ibid., p. 34.

217/bid., pp. 33-34.

218 Ibid., p. 35.

219 bid., p. 36.

220 bid., p. 31.

221 Ibid., p. 33.

222Ibid., p. 35

223!bid, p. 34.

224 /bid.

225/bid.

${ }^{226}$ lbid.

${ }^{227}$ Ibid.

228Ibid., p. 36.

229 Weller, p. 12.

230/bid.

${ }^{231}$ Major Klassen, 383rd Infantry Division, Erfahrungsbericht 6.7.44. NAMP T-311, Roll 217, p. 5. 
232 Ibid.

233Niepold, Battle For White Russia: The Destruction Of Army Group Centre June 1944, p. 143.

234 Ibid.

235 weller, p. 17.

236Niepold, Battle For White Russia: The Destruction Of Army Group Centre June 1944, pp. 145-146.

237Rokossovsky, A Soldier's Duty, p. 244.

238 Mehner, GHTBDW VOL. 10, P. 305.

${ }^{239}{ }_{\text {KTB PAOK } 3,29.6 .44 .,}$ p. 8.

240Wienskowski, Entwicklung der 4. Armee, p. 38.

241 Ibid., p. 43.

242 Ibid., p. 38.

243Ibid., p. 40 .

244 Ibid., p. 39.

245 Ibid.

246 lbid.

247Ibid., p. 43.

248 Ibid.

249 Ibid.

250/bid., p. 41.

251 lbid., p. 37.

252/bid., p. 42.

253/bid. 
254 Ibid., p. 43.

255 Ibid., p. 44.

256 Ibid.

257|bid.

258 Mehner, GHTBDW Vol. 10, p. 305.

259 Ibid.

260Hinze, Der Zusammenbruch Der Heeresgruppe Mitte Im Osten 1944, p. 197.

${ }^{261}$ Colonel P. Boldyrev, "The Bobruisk Operation," Krasnaya Zvezda (Red Star) 28 September 1944 as translated in Military Review Vol. 24, No. 12, March 1945, p. 107.

262।bid.

263 Ibid.

264 Ibid.

265 Major Wurdak, Bericht ueber die Durchbruchskaempte bei Bobruisk 13.10.1944. NAMP T-78 Roll 139.

266 Niepold, Battle For White Russia: The Destruction Of Army Group Centre June 1944, p. 159.

267Major Wurdak, Bericht ueber die Durchbruchskaempfe bei Bobruisk 13.10.1944. NAMP T-78 Roll 139.

268Boldyrev, p. 108.

269Weller, p. 13.

270Mehner, GHTBDW Vol. 10, p. 305.

271 Ibid.

${ }^{272}$ KTB PAOK 3, 30.6.44., p. 1.

273 lbid., p. 3. 
274 Ibid., p. 4.

275Mehner, GHTBDW Vol. 10, p. 307.

276Wienskowski, Entwicklung der 4. Armee, p. 44.

277 Ibid.

278 lbid.

279 Ibid.

280 lbid.

${ }^{281}$ Ibid., pp. $44-45$.

282 Ibid., p. 46.

283/bid.

284 Ibid., p. 47.

285 Ibid

286lbid.

287/bid., pp. 47-48.

288 Ibid., p. 48 .

289/bid., p. 49.

290 lbid.

291 lbid., pp. 50-51.

292/bid., p. 51.

293/bid.

294 Ibid.

295/bid., p. 45.

296 Ibid. 
297/bid., p. 49 .

298 ibid.

299 Ibid., p. 52.

300 Ibid., p. 48.

301 Hinze, Der Zusammenbruch Der Heeresgruppe Mitte Im Osten 1944, p. 200 .

302Ibid., p. 201.

303 Ibid.

304 Niepold, Battle For White Russia: The Destruction of Army Group Centre June 1944, pp. 168-169.

305lbid., p. 169.

306 lbid.

307/bid.

308 Ibid.

309 Ibid., p. 169.

310 lbid.

311 Hinze, Der Zusammenbruch Der Heeresgruppe Mitte Im Osten 1944, p. 202.

312 Ibid., p. 204.

$313_{\text {Ibid., p. } 203 .}$

${ }^{314}$ Carell, p. 509; OKW/Org. Abt. und Heerespersonalabt., Zusammenstellung der in diesem Kriege gefallenen, toetlich verunglueckten, verstorbenen, vermissten und im Gefangenschaft geratenen Generale. Flensburg 5 June 1945, NAMP T-77, Roll 785.

315Niepold, Battle For White Russia: The Destruction Of Army Group Centre June 1944, p. 172.

316KTB PAOK 3, 1.7.44., pp. 2-3.

317lbid., p. 3. 
318 Ibid.

319 lbid., p. 4.

320 |bid., p. 5.

321 Ibid., p. 7.

${ }^{322}$ Wienskowski, Entwicklung der 4. Armee, p. 52.

323lbid., p. 53.

324 Ibid.

325 Ibid.

326/bid.

327ıbid., p. 54.

${ }^{328}$ Ibid.

${ }^{329}$ Ibid.

330 lbid., p. 55.

331 Ibid.

${ }^{332}$ Ibid.

333 Ibid.

334Ibid., p. 56.

335 Ibid., pp. 56-57.

336 Ibid., p. 57.

337/bid., p. 59.

${ }^{338} \mathrm{Ibid}$.

${ }^{339} \mathrm{Ibid}$.

340 lbid., p. 60. 
$341 \mathrm{lbid}$.

342/bid.

343/bid.

${ }^{344}$ Ibid.

345 Ibid., p. 61

346/bid., p. 58.

347/bid., p. 61.

348 Ibid., pp. $58-59$

${ }^{349}$ Hinze, Hitze, Frost und Pulverdampf: Der Schicksalsweg der 20. Panzer Division ,p. 297.

350 lbid.

351 Weller, p. 13.

352Niepold, Battle For White Russia: The Destruction Of Army Group Centre June 1944, p. 178.

353 Weller, p. 13.

${ }^{354}$ AOK 9, Fernspruch nach Heeresgruppe Mitte 3.7.1330. NAMP T-311, Roll 217. German text: Aus Bobruisk bisher aufgenommen: Etwa 25,000 Soldaten aller teile 9. Armee. Einzelheiten nicht festzustellen.

355Mehner, GHTBDW Vol. 10, p. 312.

356KTB PAOK 3, 2.7.44., p. 5.

357|bid., p. 8.

358 Ibid.

${ }^{359}$ Wienskowski, Entwicklung der 4. Armee, p. 62.

360 Ibid.

${ }^{361}$ Ibid., p. 63. 
362 Ibid.

363/bid.

364 Ibid., p. 65.

365 Ibid., p. 66.

${ }^{366}$ lbid.

367/bid.

368 ibid.

${ }^{369} \mathrm{lbid}$

$370 \mathrm{Ibid}$

371 lbid., p. 67.

372 ibid.

373weller, p. 15.

${ }^{374}$ Wienskowski, Entwicklung der 4. Armee, p. 65.

375 Mehner, GHTBDW Vol. 10, p. 312.

376 Weller, p. 16.

$377_{\text {Ibid. }}$

378 KTB PAOK 3, 3.7.44, p. 1.

379 lbid.

380 ibid., p. 2.

381 Ibid.

382 Ibid., p.3.

383 Ibid., p. 5.

${ }^{384}$ Wienskowski, Entwicklung der 4. Armee, p. 68. 
385Pospelov et al, p. 341.

386 Ibid.

387Wienskowski, Entwicklung der 4. Armee, p. 68.

388 Pospelov et al, p. 342.

389 |bid., p. 341.

${ }^{390}$ Wienskowski, Entwicklung der 4. Armee, p. 68.

$39{ }^{1}$ Ibid., p. 69.

392।bid., p. 70.

393Wienskowski, Bekundungen des Generalmajors Schuermann der 25.Pz.Gr.Div., 27.8.1944 NAMP T-78, Roll 141.

${ }^{394}$ Ibid.

395 Ibid.

${ }^{396}$ Ibid.

${ }^{397}$ Ibid.

${ }^{398}$ Ibid.

${ }^{399}$ Ibid.

400 Wienskowski, Entwicklung der 4. Armee, p. 71.

401/bid., p. 72; Field Marshal Model, Obkdo H.Gr. Mitte, Fuer die weitere Kampffuehrung der 4. Armee, 3.7.44 NAMP T-311, Roll 299.

402Wienskowski, Entwicklung der 4. Armee, p. 72.

403/bid., p. 73.

404/bid.

405 Ibid.

406/bid. 
407Ibid.

408Luftwaffenverbindungskommando beim Obkdo.H.Gr.Mitte,

Kampferfahrungen im Bereich Lfl.-Kdo. 2, 12.6.44 NAMP T-311, Roll 229.

${ }^{409}$ Von der Groeben, Obkdo H.Gr. Mitte, Flugabwehr mit Handwaffen auf Eisenbahnzuegen NAMP T-311, Roll 229.

410Weller, p. 19.

411 lbid., p. 20.

412ibid., p. 18; Field Marshal Model, Fernschreiben An A.O.K. 2, Kgr. 9. Armee, 3.7.1944 1020 Uhr NAMP T-311, Roll 230.

413Niepold, Battle For White Russia: The Destruction Of Army Group Centre June 1944, p. 200.

414 Weller, p. 18.

415A.O.K. 9, Fernspruch Nr. 522, An Heeresgruppe Mitte, 3.7.44. 1330 Uhr NAMP T-311, Roll 217.

${ }^{416}$ KTB PAOK 3, 4.7.44., p. 1.

417/bid.

418 |bid., p. 3.

${ }^{419}$ lbid.

420 lbid., p. 5.

421/bid.

422Wienskowski, Entwicklung der 4. Armee, p. 75.

423/bid.

424Ibid.

425Ibid.

426Wienskowski, Bekundungen des Generalmajors Schuermann der 25.Pz.Gr.Div.. 27.8.1944 NAMP T-78, Roll 141. 
${ }^{427}$ Abwicklungstab, Heeresgr.Mitte, Bericht ueber den Anteil der 25. Pz. Gren. Div. an den Kaempfen der Heeresgr.Mitte ab 20.6.1944, 12.9.1944 NAMP T-78, Roll 139.

428Wienskowski, Bekundungen des Generalmajors Schuermann der 25.PZ.Gr.Div.. 27.8.1944 NAMP T-78, Roll 141.

429/bid.

${ }^{430}$ Weller, p. 20.

431 Niepold, Battle For White Russia: The Destruction Of Army Group Centre June 1944, p. 212.

432 Ibid.

433KTB PAOK 3, 5.7.44., p. 1.

${ }^{434}$ Ibid., p.4.

435 Ibid.

436|bid., p. 5.

437Ibid.

438 Ibid.

439 Ibid., p. 6.

440 Ibid.

${ }^{441}$ Mehner, GHTBDW Vol. 10, p. 318.

442Wienskowski, Entwicklung der 4. Armee, p. 75.

443lbid., p. 76.

444Ibid.

445Field Marshal Model, Fernschreiben an A.O.K. 4, 5.7.44., NAMP T-311, Roll 229.

446/bid. 
447Wienskowski, Bekundungen des Generalmajors Schuermann der 25.Pz.Gr.Div. 27.8.1944 NAMP T-78, Roll 141.

448 Ibid.

${ }^{449}$ Ibid.

450 lbid.

451 lbid.

452 Ibid.

453 lbid.

${ }^{454}$ Ibid.

455 Ibid.

456 lbid.

457/bid.

458 Pospelov et al, p. 348 .

459 Ibid.

460Mehner, GHTBDW Vol. 10, p. 318.

461 Ibid.

462 Weller, p. 21.

${ }^{463}$ KTB PAOK 3,6.7.44., p. 1.

464/bid., p. 2.

465 Ibid.

${ }^{466}$ Ibid.

467 Ibid

468 lbid., p. 3.

${ }^{469}$ lbid. 
470 lbid., p. 5.

${ }^{471}$ lbid., p. 6.

472 ibid., p. 7.

473Wienskowski, Entwicklung der 4. Armee, p. 76.

474Mehner, GHTBDW Vol. 10, p. 321.

475Wienskowski, Bekundungen des Generalmajors Schuermann der 25.Pz.Gr.Div., 27.8.1944 NAMP T-78, Roll 141.

${ }^{476}$ Abwicklungstab, Heeresgr.Mitte, Bericht ueber den Anteil der 25. Pz. Gren. Div. an den Kaempfen der Heeresgr. Mitte ab 20.6.1944, 12.9.1944 NAMP T-78, Roll 139.

477Wienskowski, Bekundungen des Generalmajors Schuermann der 25.Pz.Gr.Div., 27.8.1944 NAMP T-78, Roll 141.

478 Ibid.

479 Ibid.

480 ibid.

${ }^{481}$ Pospelov et al, p. 348.

482Oberleutnant Janetzko, Auszug aus Vernehmung Rueckkaempfer OberGefreiter Karl Augner 20.9.1944 NAMP T-78, Roll 141.

483 /bid.

484Wienskowski, Bekundungen des Generalmajors Schuermann der 25.Pz.Gr.Div.. 27.8.1944 NAMP T-78, Roll 141.

485Mehner,GHTBDW Vol. 10, p. 321.

486 KTB PAOK 3,7.7.44., p. 1.

${ }^{487}$ Ibid., p. 3.

488/bid.

489/bid., p. 4. 
490Ibid.

${ }^{491}$ Ibid., p. 6.

492 Ibid.

493/bid.

${ }^{494}$ Ibid.

495 Ibid., p. 9.

496/bid.

497Ibid.

498 Ibid., p. 10.

${ }^{499}$ Wienskowski, Entwicklung der 4. Armee, p. 77.

500 lbid.

501 Ibid., pp. 111-112.

${ }^{502}$ Field Marshal Model, Oberkommando H. Gr. Mitte, Fernschreiben An Kgr. A.0.K. 4. 7.7.1944 NAMP T-311, Roll 230.

503Mehner,GHTBDW Vol. 10, p. 323.

${ }^{504}$ KTB PAOK 3, 8.7.44., p. 1.

505 pospelov et al, p. 355.

${ }^{506}$ KTB PAOK 3, 8.7.44., p. 1.

507 lbid., p. 3.

508 Ibid.

509 Ibid.

510 lbid., p. 5.

511 ibid. 
512Mehner,GHTBDW Vol. 10, p. 326.

513 Pospelov et al, p. 355.

514 Ibid.

515/bid., p.349.

516 Weller, p.21

517Mehner,GHTBDW Vol. 10, p. 326.

518 KTB PAOK 3, 9.7.44., p. 1.

519 Ibid.

520 lbid., p.2.

521 Ibid.

522 Ibid.

523 ibid., p. 3.

524 Ibid., p. 4.

525Mehner,GHTBDW Vol. 10, p. 328.

526 KTB PAOK 3, 9.7.44., p. 9.

527Ibid.

528 bid., p. 10.

529 |bid., p. 8.

530|bid., p. 11.

${ }^{531}$ Niepold, Battle For White Russia: The Destruction Of Army Group Centre June 1944, p. 253.

532 Wienskowski, Entwicklung der 4. Armee, p. 78.

533 lbid. 
${ }^{534}$ Field Marshal Model, Fernspruch an 2. Armee, 4. Armee, 9. Armee, 3. Pz. Armee 9.7.1944 2100 Uhr NAMP T-311 Roll 229.

535Mehner,GHTBDW Vol. 10, p. 328.

536KTB PAOK 3, 10.7.44., p. 1.

537 Ibid.

538|bid., p. 4.

539 lbid., p. 7.

540 lbid.

541 Ibid.

542 |bid., p. 3.

543 Weller, p. 22.

544 bid.

545 Kriegstagebuch der Panzerarmeeoberkommando $3,11.7 .44$., NAMP T-313, Roll 317, p. 1.

546 Ibid.

547 Ibid., p. 2.

${ }^{548}$ KTB PAOK 3, 11.7.44., p. 3.

549 lbid., p. 4.

550 lbid., p. 6.

551 Field Marshal Model, Fernschreiben an Pz. A.O.K. 3, 11.7.44. NAMP T311, Roll 230.

552Weller, Kriegstagebuch 9. Armee Nr. 11, 11.7.44. NAMP T-312, Roll 343 , p. 1.

553 KTB PAOK 3, 12.7.44., p. 1.

554 Ibid. 
555 Ibid.

556 lbid., p. 3.

557 Ibid.

558 Ibid., p. 5.

559 lbid., p. 6.

560KTB PAOK 3, 13.7.44., p. 1.

561 lbid.

562 Ibid.

563ibid.

564 Ibid., p. 3.

565W.E.D. Allen and Paul Muratoff, The Russian Campaigns Of 1944-45 (New York: Penguin Books, 1946), p. 120.

566 Mehner,GHTBDW Vol. 10 , p. 340.

567/bid.

568 Armeeoberkommando 2, Gliederung der Kamptverbaende am 25.7.1944. Korps Abteilung E NAMP T-312, Roll 1318; Rolf Hinze, Das Ostfront Drama 1944: Rueckzugskaempfe Heeresgruppe Mitte (Stuttgart: Motorbuch Verlag, 1987), p. 371.

569Hinze, Das Ostfront Drama 1944: Rueckzugskaempfe Heeresgruppe Mitte, p. 365 .

570 Ibid., p. 370 .

571 Ibid., p. 374.

572 Mehner,GHTBDW Vol. 10, p. 380.

573 Ibid.

574 Ibid.

575 Ibid. 
576 Mehner,GHTBDW Vol. 10, p. 380.

${ }^{577}$ Armeeoberkommando 2, Versorgungslage des Festen Platzes Brest am 26.7.1944. NAMP T-312, Roll 1318.

578 ibid.

579Hinze, Das Ostfront Drama 1944: Rueckzugskaempfe Heeresgruppe Mitte, p. 374. Roll 1318.

$580 \mathrm{Gen}$. Oberst Weiss, Ferngespraeche vom 26.7.44, 12,30 NAMP T-312,

$581 \mathrm{Gen}$. Oberst Weiss, Ferngespraeche vom $26.7 .44,12.10$ NAMP T-312, Roll 1318.

582 Ibid.

583 Ibid.

${ }^{584} \mathrm{Gen}$. Oberst Weiss, Ferngespraeche vom $26.7 .44,12,30$ NAMP T-312, Roll 1318.

585 Ibid.

586 Ibid.

587 ibid.

$588 \mathrm{Gen}$. Oberst Weiss, Ferngespraeche vom 26.7.44, 12.50 NAMP T-312, Roll 1318.

589 Generalleutnant Krebs, Ferngespraeche vom 27.7.44, 00,25 NAMP T-312, Roll 1318.

590Oberkommando der Heeresgruppe Mitte, Tagesmeldung 27.7.1944 NAMP T312, Roll 1318.

591Hinze, Das Ostfront Drama 1944: Rueckzugskaempfe Heeresgruppe Mitte, p. 376.

592 Ibid.

593Oberkommando der Heeresgruppe Mitte, Tagesmeldung 27.7.1944 NAMP T312, Roll 1318. 
${ }^{594}$ Menner,GHTBDW Vol. 10, p. 386.

595Hinze, Das Osttront Drama 1944: Rueckzugskaempfe Heeresgruppe Mitte, p. 377.

596 ibid.

597/bid.

598 |bid., p. 390.

599 lbid., p. 377.

600 W.E.D. Allen and Paul Muratoff, p. 140.

601 Samuel W. Mitchum, Jr., Hitler's Legions: The German Army Order of Battle, World War II (New York: Stein And Day Publishers, 1985), pp. 102-103, 183-184.

602 ibid., p. 127.

603Generalmajor Peter von der Groeben, "Collapse Of Army Group Center: And Its Combat Activity Until Stabilization Of The Front (22 June to September 1944), " World War II German Military Studies Vol. 16 Ed. Donald S. Detwiler, Charles B. Burdick and Juergen Rohwer (New York: Garland Publishing, Inc., 1979), p. 47.

${ }^{604}$ Luftgaukommando XXVII, Feldgaukommando XXVII ueberreicht in der Anlage Objektive und Planpause der Eisenbahn und Strassenbruecken im Bereich der Lufttlotte 6. 12.2.1944 NAMP T-311, Roll 225.

605Von der Groeben, p. 49.

606Franz Kurowski, Luftwaffe ueber Russland (Rastaft: Verlag Arthur Moewig $\mathrm{GmbH}, 1987)$, p. 286; Williamson Murray, Strategy For Defeat The Luftwaffe 19331945 (Washington, D.C.: U.S. Government Printing Office, 1983), p. 286; Kurt Von Tippelskirch, Geschichte Des Zweiten Weltkriegs (Bonn: Athenaeum-Verlag, 1956), p. 462.

607Carell, pp. 502-503.

608United States War Department, Handbook On German Military Forces (Washington, D.C.: U.S. Government Printing Office, 1945), pp. VII-11-12. 609 ibid. 
610Carell, p. 508; Gackenholz, "The Collapse of Army Group Centre in 1944," Decisive Battles of World War II: The German View, p. 382; Gackenholz, "Zum Zusammenbruch Der Heeresgruppe Mitte Im Sommer 1944," Viertaljahreshefte fuer Zeitgeschichte, Vol. 3, p. 317.

611 Lieutenant-General Siegfried Westphal, "The End Draws Near," The Fatal Decisions Ed. Willaim Richardson and Seymour Freidin (London: Michael Joseph LTD, 1956), p. 211; Gackenholz, "The Collapse of Army Group Centre in 1944," Decisive Battles of World War Il: The German View, p. 382; Gackenholz, "Zum Zusammenbruch Der Heeresgruppe Mitte Im Sommer 1944," Viertaljahreshefte fuer Zeitgeschichte, Vol. 3, p. 317. 


\section{CHAPTER $X$}

\section{ARMY GROUP NORTH UKRAINE AND THE DESTRUCTION OF THE XIII ARMY CORPS, JULY 13-23, 1944}

Marshal Ivan Koniev launched the Lvov-Sandomierz Offensive against Army Group North Ukraine on July 13, 1944.1 The Soviets had concentrated sufficent forces on the 1st Ukrainian Front to achieve their objectives of reoccupying the Ukraine and in taking southern Poland. The First Ukrainian Front consisted of 7 infantry armies, 3 tank armies, 2 cavalry-mechanized groups, and 2 air armies (see Table XXXXII). ${ }^{2}$ This force gave Marshal Koniev a total of 80 divisions, 10 tank and mechanized corps, 4 independent tank brigades, and the 1st Czechoslovak Corps. ${ }^{3}$ The strength of the 1st Ukrainain Front amounted to 843,000 men, 2,200 tanks and selfpropelled guns, 14,000 artillery guns and mortars, and 2,806 aircraft. ${ }^{4}$ This gave the Soviets a margin of superiority of approximately 1.4:1 in combat troops, 2.2:1 in artillery and mortars, 2.2:1 in tanks and assault guns and 4.4:1 in combat aircraft (see Table XXXXIII).

Army Group North Ukraine under the command of Colonel Josef Harpe contained the 4th Panzer Army, 1st Panzer Army, and the 1st Hungarian Army (see Table XXXXIV) Army Group North Ukraine 
possessed 36 Infantry Divisions, 5 panzer divisions, two Panzer Grenadier divisions, and 2 infantry brigades (see Table XXXXIV). ${ }^{5}$ These forces amounted to 600,000 combat troops, 6,300 artillery guns and mortars, 900 tanks and assault guns, and 700 aircraft. 6 Army Group North Ukraine, therefore, despite the transfer of 3 panzer divisions to Army Group Center remained very strong. ${ }^{7}$

Marshal Koniev's plan to break up Army Group North Ukraine was based on the concept of two main blows and one secondary blow. Stalin had argued for one main blow from the center of the front toward Lvov. 8 However, Marshal Koniev was persistent and received permission for his own plan, but if it failed Stalin would hold him personally responsible. ${ }^{9}$ Koniev's plan called for one main blow on the right flank on the axis toward Rava Ruska and the other main blow centered on Lvov with a secondary attack in the south on the left flank toward Stanislav.10 The following Soviet formations were deployed for the attack toward Rava Ruska on July 13, 1944: 3rd Guards Army; 13th Army; 1st Guards Tank Army; Baranov's Cavalry-Mechanized Group consisting of the 1st Guards Cavalry Corps and the 25th Tank Corps. ${ }^{11}$

The attack in the center toward Lvov on July 14, 1944 employed the following Soviet formations: 16th Army; 38th Army; 3rd Guards Tank Army; 4th Guards Tank Army; S.V. Sokolov's Cavalry-Mechanized Group consisting of the 6th Guards Cavalry Corps and the 31 st Tank Corps. ${ }^{12}$ 
The secondary attack toward Stanislav on July 21, 1944 employed fewer Soviet formations: 1st Guards Army and 18th Army. ${ }^{13}$

The Germans had established strong defensive positions in depth. There were 3 defensive belts. The infantry was deployed in the first two defensive lines and the armor was held in reserve approximately 10 miles from the forward positions. ${ }^{14}$ Nevertheless, a general lack of reserves weakened the German defense in depth. The Soviets had become masters of breakthrough operations employing concentration of forces against narrow attack sectors to achieve breakthroughs in depth. Thus, the Germans were faced again with a battle to avoid encirclement.

The Germans had studied the new Soviet style of offensive operations and reached some conclusions about countermeasures to be employed to counteract Soviet operational measures. The 4th Panzer Army Headquarters noted some characteristics of the Soviet attack based on the experiences of Army Group Center. The Soviet attack groups consisted on an average of 12-15 rifle divisions and 1-2 tank corps. ${ }^{15}$ Four major Soviet characteristics were noted:

(1) Considerable improvement in the employment of artillery; New concentrated employment of ground attack aircraft; (3) New method of armor employment; (4) Operational extension. ${ }^{16}$

The Germans observed that the Soviets had concentrated their artillery on the point of their planned breakthrough with the objectives of eliminating German artillery as the main firepower and backbone of the defense, engaging the reserves, and covering 
the flanks of the attack. ${ }^{17}$ The artillery commanders had also responded flexibly and rapidly to the development of the situation. The German countermeasures adopted were: (1) frequent artillery changes of location before the beginning of the offensive; (2) Employ numerous dummy positions; (3) camouflage; (4) When the attack is finally recognized change all earlier positions. ${ }^{18}$

The Soviets had employed the Anglo-American model of air attack in groups of often more than 100 aircraft working together with Soviet artillery. 19 The objectives were the the elimination of German artillery during the day, pinning down of reserves, and the preventing of their movement. German countermeasures were proposed: (1) employment of twilight and darkness for combat and movement; (2) Use of all weapons for anti-aircraft defense including rifles; (3) Good camouflage and cover in the front lines as well as for the reserves, assembly areas, fire positions, and command posts; (4) slit trenches were needed on both sides of the roads and tracks, at command posts, and assembly areas; (5) Radios were to be in seperate locations from the command posts; (6) Frequent changes of command post were necessary; (7) Fire positions were to be layed out so they could not be knocked out by a carpet bombing attack; (8) Light Flak artillery was to be redeployed from already destroyed and unimportant objects to important positions; (9) Combat vehicles in the rear areas were to maintain large intervals; (10) Tracked vehicles were to disperse; (11) Main roads were to be bypassed; and (12) Roads were to be cleared of damaged vehicles. ${ }^{20}$ 
The Soviet attack in the beginning was characterized by small numbers of tanks. However, after the breakthrough had been achieved on the battlefield Soviet armor was employed en masse with far ranging objectives. German countermeasures recommended were: (1) Organization of an armor defense in depth in the main battle line; (2) Mobile armor defense in the depth of the battlefield; (3) Passive armor defense (obstacles, mines, trenches, etc.) in depth with concentrations on the roads and not in the terrain. 21

The Soviet operational expansion with far ranging objectives in depth posed a challenge to the German defense. Soviet forces previously were used on a limited short range scale. Currently, Soviet forces instead had objectives deep in the German rear area and pursued these objectives without regard to threats on the flanks. Combined operations of the operational groups in the depth of the battlefield was paramount. This action denied the German Command sufficient time to rebuild the front. The only German countermeasures available remained foresight and planning ahead for the employment of German reserves. ${ }^{22}$

The effect of the Soviet artillery in the major offensive against Army Group Center was noted in the report Grosskampfgliederung 4.7.1944 by the 4th Panzer Army.23 The extremely heavy barrage fire during the beginning of the Soviet offensive against Army Group Center was directed against the forward trenches inflicting high losses of personnel and material which was decisive in the defense of the main battle line. 
Therefore, in order to preserve defensive capabilities new countermeasures were developed based on the experiences of Army Group Center. The structure of the battle area was to be organized with lines in depth. The defense was to be transferred to the lines in depth shortly before a major Soviet attack. The attack was then to be smashed in the depths of the defense and the old main battle line retaken. If the beginning of a major attack was not recognized in time and barrage fire had already begun then the defense was to be conducted from the old main battle line.

The enlarged battle area was to consist of a main battle line which was located behind the most forward trench or the second trench. Behind the enlarged battle area the main line of a new battlefield was to be established. The previous main battle line was to be held with the first trench containing only a light security line manned with combat ouposts. Soviet forces that got into the first trench prior to the actual attack were to be thrown out by a counterattack. The purposes of the enlarged battlefield concept could only be realized if the approaches to the obstacles before the main battle line remained under German control so the Soviets could be deceived as to the real intentions of the Germans prior to the major attack. The enlarged battlefield area was to be prepared so that all command posts, the majority of observation posts and heavy weapons possessed communications to the rear and could be transferred behind the new main battle line. When an alert was sounded the infantry were to occupy the enlarged battlefield positions before dawn. The most forward trench of the previous 
main battle line was to remain manned by only a weak security line. These combat outposts were assigned the mission to repulse the Soviet reconnaisance troops. Complete observation of the battlefield was to be maintained from under cover before and during Soviet barrage fire and when there was an unequivocal sign that the Soviet infantry and armored formations were attacking then these troops could withndraw to the new main battle line. 24

The new tactics adopted by the German Army may have increased its tenacity and ability to resist the new Soviet offensive measures. However, the overwhelming superiority exerted by the Soviets along the designated narrow attack sectors on the battlefield continued to achieve outstanding results in breaking open the German defenses.

$$
\text { JULY 13, } 1944
$$

\section{4th Panzer Army}

The Soviets attacked during the morning hours on a wide front and broke through the main battle line and took Horochow and Cechow (6 km south of Horochow). ${ }^{25}$ Battalions from the 16th and 17th Panzer Divisions were used in a counterattack to liquidate this breakthrough (see Figure 169). The Soviets advanced into the woods west of the main battle line on the northern sector of the 291st Infantry Division and were brought to a halt before the German artillery position (see Figure 169). The 214th Infantry Division was busy clearing out the Soviet penetration into the 
combat outpost positions (see Figure 169). The Soviet breakthrough north of Dolsk was met by a counterattack from the LVI Panzer Corps. However, the counterattack ran into heavy Soviet artillery barrage fire and was halted. 26

$$
\text { JULY 14, } 1944
$$

\section{4th Panzer Army}

XXXXII Army Corps And XXXXVI Panzer Corps. The Soviets attempted to expand their breakthrough areas in both corps sectors to the southwest and west. The Soviets broke through on the left sector of the 340th Infantry Division in several places. ${ }^{27}$ The 17 th Panzer Division was locked into battle all day east of the Druzkopol-Horochow road and repulsed the Soviets in a successful counterattack. ${ }^{28}$ The 291st Infantry Division established a blocking position west of Horochow. The 16th Panzer Division forced the Soviet spearheads back in the region $8 \mathrm{~km}$ southeast of Zawidow in a counterattack. The $40-50$ Soviet tanks which had broken through were mostly destroyed. Thirty Soviet tanks were confirmed as destroyed and contact to the right wing of the 88th Infantry Division was restored (see Figure 169).29 Strong Soviet attacks were mostly repulsed on the right and left wing of the 88th Infantry Division and the entire sector of the 72nd Infantry Division. However, the bridgehead at Lokacze was evacuated and the left wing of the 72nd Infantry Division's forward security on the main battle line was pushed back to the Turja sector (see 
Figure 169). 30 The Soviets established a bridgehead over the Turja river in the center of the 214th Infantry Division's sector.

\section{1st Panzer Army}

XXXXVIII Panzer Corps. The Soviet major offensive began at $0345 \mathrm{hrs}$ with an extremely massive artillery barrage on the German lines from 0400-0930 hrs. ${ }^{31}$ The attack hit the 357th Infantry Division's sector and the south wing and center of the 349th Infantry Division. 32 The Soviet attack pushed the entire front of the 337th Infantry Division back to the artillery covering position. The Soviet breakthrough of $3 \mathrm{~km}$ behind the main battle line during the afternoon was sealed off. But the Soviets renewed their attack in the afternoon against the 357th Infantry Division and after heavy artillery preparation with strong tactical air support failed to achieve further success. The attack was launched again in the evening against the left wing of the division with approximately 90 tanks in the direction of Zborow. The 349th Infantry Division after liquidating a deep breakthrough had its right wing pushed back $6 \mathrm{~km}$ west of the previous main battle line.

III Panzer Corps. The III Panzer Corps counterattacked with the 1st Panzer Division and the 8th Panzer Division. ${ }^{33}$ The 1st Panzer Division was employed at $1100 \mathrm{hrs}$ south of Zloczow. Panzer Grenadier Regiment 113 and the reinforced Panzer Grenadier Regiment 1 formed Kampfgruppe Neumeister under the command Colonel Neumeister and advanced along the Tarnopol-Lemberg road to the area northwest of Zborow. ${ }^{34}$ The Soviets had achieved on the 
southern edge of their breakthrough a penetration $1-3 \mathrm{~km}$ west of the old main battle line. The Soviets had taken the town of Mszana, but Kampfgruppe Neumeister stormed the town and retook it and forced the Soviets back out of the German lines. ${ }^{35}$ The 8th Panzer Division counterattacking from the northwest was delayed by strong Soviet tactical air attacks.

$$
\text { JULY 15, } 1944
$$

\section{4th Panzer Army}

XXXXVI Panzer Corps. The 340th Infantry Division was forced back to the south bank of the Sudolowka river despite tenacious resistance and Soljanow was lost (see Figure 170). ${ }^{36}$ The 16th and 17th Panzer Divisions held the newly established main battle line from the west edge of Druzkopol to the north against heavy Soviet pressure. However, local penetrations could not be prevented.

XXXXII Army Corps. The Soviets also attacked the southern wing of the Corps with armored support and broke through the front of the 88th Infantry Division in several places. The Soviets penetrated $12 \mathrm{~km}$ behind the main battle line. However, a concentrated counterattack by 20 German tanks pushed the Soviets back, but the 88th Infantry Division's southern wing still remained $4 \mathrm{~km}$ behind the main battle line (see Figure 170). ${ }^{37}$ All other attacks in the corps sector were repulsed except for the battle underway in a breakthrough area on the boundary between the 72 nd and 214th Infantry Divisions (see Figure 171). 
1st Panzer Army

XXXXVIII Panzer Corps. Fierce Soviet attacks were launched against Jezierna and to the north of the town, but were repulsed and the penetration liquidated with the knocking out of 6 Soviet tanks. 38

III Panzer Corps. The counterattack by the III Panzer Corps gained ground in the south and stopped on the line Jezierna to 15 km east of Zloczow. ${ }^{39}$ The 1st Panzer Division succeeded during the counterattack in taking Olegjow and halting the Soviet attack. 40 The 8th Panzer Division to the north got bogged down using the main rail line in its advance and was subjected to continuous Soviet air attacks which caused heavy losses (see Figure 170). ${ }^{41}$ The situation became even worse when the Soviets broke through on the left wing of the III Panzer Corps and forced the right wing of the 349th Infantry Division back which permitted the Soviets to advance further to the west. 42

$$
\text { JULY 16, } 1944
$$

\section{4th Panzer Army}

XXXXVI Panzer Corps. Soviet attacks from the northeast and north resulted in the loss of Radziechow (see Figure 172). 43 The 340th Infantry Division was thrown back to the west in the region $6 \mathrm{~km}$ southeast of Radziechow. The 20th Panzer Grenadier Division rapidly occupied the elevated terrain $6 \mathrm{~km}$ northeast of Cholojow and Witkow Nowy to cover the assembly of the 340th Infantry 
Division (see Figure 172).44 The Soviets advanced with infantry and armor forces through the hole between the 340th Infantry Division and the 17th Panzer Division and occupied Pawlow $(4 \mathrm{~km}$ north of Cholojow) during the evening. The Soviets now posed a threat to the Bug River bridges. The bridges at Rudasielecka $(6 \mathrm{~km}$ northeast of Kamionka Strumilowa) and Dobrotwor (13 km north of Kamionka Strumilowa) were blocked. The Soviet forces supported by armor attacked the front of the 17th Panzer Division, 291st Infantry Division, and the 16th Panzer Division throughout the day. The Germans were pushed back to the line $6 \mathrm{~km}$ west of Druzkopol $6 \mathrm{~km}$ northwest of Druzkopol - $5 \mathrm{~km}$ southeast of Zawidow (see Figure 172). 45

XXXXX\|I Army Corps. The 88th Infantry Division's front was ripped apart on the right by approximately 100 Soviet tanks advancing in a western and northwestern direction. ${ }^{46} \mathrm{~A}$ counterattack was launched with a heavy tank battalion from the area of Poryck (see Figure 172). The 72nd and 214th Infantry Divisions repulsed most of the breakthroughs in their respective sectors.

\section{1st Panzer Army}

XXIV Panzer Corps. The 100th Jaeger Division liquidated a local breakthrough at Kupczynce (see Figure 173).

XXXXVIII Panzer Corps. The III Panzer Corps was placed under the command of the XXXXVIII Panzer Corps. A successful defense was conducted throughout the day by the north wing of the 96th 
Infantry Division, 1st Panzer Division, 357th Infantry Division and 8th Panzer Division (see Figure 173). ${ }^{47}$ The 8th Panzer Division launched an attack to the north, but was halted by tenacious Soviet resistance. A blocking position was established by the 8th Panzer Division on its left wing west of Zloczow. Nevertheless, the Soviets made a hole in the front between the left wing of the 8th Panzer Division and the right wing of the 349th Infantry Division at Kottow and were able to attack Zloczow with armor and infantry (see Figure 172).48 Soviet forces north of Zloczow had crossed the Zloczow-Sasow road to the west and were advancing against a village $6 \mathrm{~km}$ northwest of Zloczow.

XIII Army Corps. The 349th Infantry Division which had its right wing pushed back to Kottow was now placed under the command of the XIII Army Corps.49 The XIII Army Corps received the order to withdraw to the Prinz Eugen position as a result of the deteriorating situation along its flanks. 50

Corps Detachment $C$ received the following orders:

The Division was to disengage during the night of July 16-17, 1944 beginning at $00.00 \mathrm{hrs}$ to the Prinz Eugen position. The junction point on the right to the 14th SS Volunteer Division "Galizien" was at the tip of the woods $1.5 \mathrm{~km}$ southwest of Wolochy and on the left to the 361st Infantry Division on the rail line $1.5 \mathrm{~km}$ northeast of the white church at Zablotce. The Divisional Group 217 would be deployed on the right and the Divisional Group 183 on the left. The Divisional Group 339 minus the 691st Grenadier Regiment was held in the corps reserve and was assembled in Konty. Fusilier Battalion Corps Detachment $\mathrm{C}$ was transferred to the disposal of Corps Detachment $C$ in the area 
southwest of Podhorce. Combat elements of all units were to remain as rearguards till July 17th at $1000 \mathrm{hrs}$ in the old positions and when the first Soviet pressure was encountered they were to conduct a fighting withdrawal to the new line. Artillery Regiment 219 was to provide artillery support for the rearguards with individual batteries. The 1 st Engineer battalion of Engineer Regiment 219 was to destroy the bridges at Ponikwa, Boratyn, Suchodoly and Holoskowics once the last units had passed them. The command post for Corps Detachment $C$ on July 17th was to be in the woods east of Brachowka. 51

According to the army records the Soviets had lost 123 tanks since the offensive began in the area northwest of Tarnopol.52

$$
\text { JULY 17, } 1944
$$

\section{4th Panzer Army}

XXXXVI Panzer Corps. The 20th Panzer Grenadier Division held the Bug River bridgehead northeast of Kamionka Strumilowa against heavy assaults by Soviet mounted infantry attacking from the northeast and north (see Figure 174). 53 The Soviet attacks were repulsed and 25 Soviet tanks were destroyed. Soviet armor and infantry forces attacked the right flank of the 17th Panzer Division. The attack was repulsed southeast of Tartakow and 10 Soviet tanks were knocked out. However, approximately 20 Soviet tanks broke through to Krystynopol and crossed the Bug river north of the town (see Figure 174). ${ }^{54}$ Soviet attacks against the east front of the 17th Panzer Division were weak and repulsed with only local losses of terrain. 
XXXXII Army Corps. The 88th Infantry Division's line was attacked by the Soviets with 40 tanks at Poryck (see Figure 174). The 214th Infantry Division was also under attack east of Wlodzimierz and local penetrations were achieved by Soviet armor (see Figure 174).

VIII Army Corps. The 12th Hungarian Reserve Division was broken through in several locations which required a counterattack by a battalion from the 211th Infantry Division and 168th Infantry Division to shore up the 12th Hungarian Reserve Infantry Division's line (see Figure 175).

\section{1st Panzer Division}

XXXXVIII Panzer Corps. The Soviets pursued the German withdrawal movement into the Prinz Eugen position south of Zborow slowly. A massive Soviet attack north of Zborow forced a local withdrawal from the main battle line. Both the 1st and 8th Panzer Divisions launched a counterattack and reached the region 9 $\mathrm{km}$ southeast of Kottow by midday despite unfavorable weather and tenacious Soviet resistance.55 However, Soviet defensive fire from tanks, artillery and anti-tank guns from the northeast and east as well as a regimental attack on the right flank brought the attack to a halt and the Panzer Divisions regrouped.56 A renewed attack by the 8th Panzer Division gained $3 \mathrm{~km}$ to the north. But Soviet infantry, armor and artillery formations moved through the hole between the XXXXVIII Panzer Corps and XIII Army Corps and reached the line Busk-Gliniany. 57 
XIII Army Corps. The 340th Infantry Division was pushed back by the Soviets to the south on the line Hutaszklana-Ohladow. Babinie (9 km northwest of Toporow). 58 The withdrawal of Corps Detachment $C$ to the Prinz Eugen position was completed without Soviet pressure.

The threatening situation that had developed from the southeastern direction in the area of Busk caused the XIII Army Corps in the early morning hours of July 17 th to assemble the Divisional Group 339 in the area of Olesko which was brought forward by motor transport to hold open the highway toward Busk. 59 The increasing threat to the rear of the XIII Army Corps at Busk caused the corps to establish a defensive line at Wierzblany east of Czuczmany - Humniska with the Engineer Battalion 219 and a heavy anti-tank platoon from the Panzerjaeger Battalion 219. Soviet armor was already $1 \mathrm{~km}$ east of Busk. Divisional Group 339 received the order to reconnoiter through Bialy-Kamien. Corps Detachment $\mathrm{C}$ was ordered around midday by the XIII Army Corps to transfer the Fusilier Battalion to secure the highway in the area of Jasionowce against the Soviets advancing in the direction of Majdan Pieniakkie and this position was occupied at 1400 hrs. The SS Field Replacement Battalion 14 stationed near Busk was caught between the Soviet spearheads advancing toward Busk and was mauled. 60 The remnants managed to retreat to the west. 
JULY 18,1944

The Soviet forces advancing through the existing holes in the German line at Zloczow and between the 4th Panzer and 1st Panzer Armies advanced deeper into the breakthrough areas. The Soviets reached the region west of Busk with strong armored forces and made contact with the Soviet forces from the north that had broken through on both sides of Kamionka Strumilowa and completed the encirclement of the XIII Army Corps (see Figure 176). ${ }^{61}$

\section{4th Panzer Army}

The 20th Panzer Grenadier Division repulsed Soviet attacks supported by armor against Kamionka Strumilowa from the north, east and southeast throughout the day (See Figure 176).62 The Germans withdrew north of Kamionka Strumilowa to Mosty-Wielkie and held this town against numerous attacks from the north (see Figure 176).

XXXXVI Panzer Corps. Soviet armor was crossing the Bug river at Krystynopol and north of the town. German forces knocked out at least 25 Soviet tanks halting the advance and Krystynopol was retaken by German forces (see Figure 176).63

XXXX\|l Army Corps. Poryck was lost and the Germans were thrown back to the woods west of the town (see Figure 176).64 The new main battle line followed the west bank of the Bug river and along the course of the rail line. 
LVI Panzer Corps. The Soviets launched their anticipated attack after very heavy artillery preparation combined with tactical air support. The 342 nd and 26 th Infantry Divisions were broken through on a wide front despite tenacious resistance (see Figure 176). 65 The Soviets advanced on both sides of the rail line Kowel-Luboml and southwest of Maciejow $10 \mathrm{~km}$ to the west (see Figure 176). The Soviets then assembled for a renewed attack south of the rail line against the secondary defense line of the 253rd Infantry Division.66 The units of the 342nd and 26th Infantry Divisions continued to conduct defensive battles in the depth of the defensive postions (see Figure 176).

\section{1st Panzer Army}

XXXXVIII Panzer Corps. The Soviets attacked Glinna with armor and achieved a $3 \mathrm{~km}$ wide and approximately $1 \mathrm{~km}$ deep bridgehead over the Strypa river which was sealed off temporarily, but during the evening the Soviets broke through again in a southwestern direction (see Figure 176). 67 Several Soviet attacks supported by armor were repulsed north of Zborow.

The German counterattack to the north to close the hole between the XXXXVIII Panzer Corps and the XIII Army Corps gained little ground against Soviet artillery barrage fire and had to be halted. Army reports indicated that 18 Soviet tanks had been knocked out. 
III Panzer Corps. The Soviets pushed the German line back to the west. The 101st Jaeger Division was brought up and employed in the line Gliniany to the northwest.

XIII Army Corps. Busk was lost to a heavy Soviet armored attack and 50-60 Soviet tanks had already advanced $10 \mathrm{~km}$ west of Busk (see Figure 176). 68 The German line held against repeated attacks from the south against Bialy Kamien, but Sasow was lost to a Soviet armored attack from the south (see Figure 176). 69 The 349th Infantry Division attacked from the area northeast of Zloczow and forced its way into the woods south of Kottow. Meanwhile, the Soviets achieved a breakthrough on the eastern front of the XIII Army Corps on the Sasow-Brody road. The German withdrawal movement in the north was followed by a Soviet advance toward Toporow which continued past the town to the west $10 \mathrm{~km}$ north of Busk. 70

The previous orders of Divisional Group 339 were changed during the night of July 17-18, 1944 and it was ordered to advance toward Ruda Koltowska beginning at $0200 \mathrm{hrs}$. There it was to combine with the 349th Infantry Division along with 6 assault guns for an attack to the south to take Obertasow. ${ }^{71}$ The junction with the 8th Panzer Division attacking to the north was to be accomplished in the area of Obertasow. 72 Divisional group 339 advanced out of the area of Chmielowa at 1400 hrs toward Obertasow and reached the hills north of Obertasow during the afternoon without the support of artillery from the 349th Infantry Division. The attack by the 8th Panzer Division, however, failed to 
breakthrough and the pocket remained close. ${ }^{73}$ Strong Soviet forces advancing mostly on the Lemberg-Brody highway and on both sides of the Holoskowice-Wysoko road were partially repulsed in hand to hand combat with extremely high casualties. The northern and southern Soviet pincers met just north of Busk and completed the encirclement of the XIII Army Corps (see Figure 176). Meanwhile, the 340th Infantry Division attempted to breakthrough to Kamionka-Strumilowa which was still in German hands.

The XIII Army Corps decided on the afternoon of July 18th to make a thrust to the south in the hills of the Lemberg-Zloczow road to breakout of the Soviet encirclement and establish a connection with the XXXXVIII Panzer Corps. ${ }^{74}$ The XIII Army Corps gave the following orders to Corps Detachment C:

Corps Detachment $C$ was to disengage from the front during the night of July 18-19th and assemble on July 19 th in the woods on both sides of the road to Bialy Kamien. Corps Detachment C's sector was to be assumed by the 14th SS Volunteer Division "Galizien" and the 361st Infantry Division by a simultaneous withdrawal to the line Zahorce-Czyski-Czechy-hills northeast of Gaje Konteckie. 75

Corps Detachment $C$ responded with orders for the deployment of its units for the breakout:

Divisional Group 217 will withdraw during the night of July 18-19th with Grenadier Regiment 311 to the line Zahorce-Czyski-Czechy and wait to be relieved by the 14th SS Volunteer Division "Galizien". All remaining units of the Divisional Group were to asemble in the area of Gawareczyzna. 
Divisional Group 183 will be relieved by units of the 361 st Infantry Division and assemble in the woods south of Ozydow; The Fusilier Battalion will assemble in the area of Gorna.

Ski-Jagd Kommando with the T-34 armor platoon will go to the new division command post at the forester's house $1 \mathrm{~km}$ northwest of Gorna.

Artillery Regiment 219 is to move into position in the area north of Bialy-Kamien so that it can provide effective artillery support for the planned attack over the Bug river.

Supply troops will transfer to the woods south of Ozydow. 76

The breakout of the XIII Army Corps to reach the 1st and 8th Panzer Divisions in the southwest would have to cover $24-32 \mathrm{~km}$ of heavily wooded and swampy terrain, and the Bug river would also have to be forded. 77

$$
\text { JULY 19, } 1944
$$

\section{4th Panzer Army}

Gruppe Major General v.d. Meden was pushed back by the Soviets to the line Przemyslow (north of Belz) - Wojslawice $(6 \mathrm{~km}$ west of Olwowek) where it was on the defense against attacks on the right wing (see Figure 177). ${ }^{78}$ Belz was occupied by the Soviets after losing 17 tanks. ${ }^{79}$

XXXXII Army Corps. The Soviets achieved a breakthrough on the right wing against the 88 th and $72 n d$ Infantry Divisions. The 
Soviets continued their advance to the west from their breakthrough area engaging the German forces.

LVI Panzer Corps. The Soviets pushed the defensive front back to the Bug river on a wide front and pursued the withdrawal of the corps closely (see Figure 177). 80

VIII Army Corps. Soviet attacks supported by armor were repulsed at Holowno and Zgorany. The 168th Infantry Division held the line north of Mokrany against Soviet company strength attacks.

\section{1st Panzer Army}

XXXXVIII Panzer Corps. The Soviets penetrated the thin defensive line southwest of Glinna and were then pushed back in a counterattack. Soviet infantry breached the main battle line southwest of Zborow.81 The 96th and 357th Infantry Divisions were attacked by Soviet forces supported by armor throughout the day. The Soviets achieved only local gains north of Gologory loosing 4 tanks.

III Panzer Corps. The 101st Jaeger Division repulsed a Soviet attack supported by armor east of Dziedzilow (see Figure 178) 82 The 68th Infantry Division staged a local withdrawal $4 \mathrm{~km}$ southwest of Zoltance after conducting a defense against Soviet attacks supported by armor.

XIII Army Corps. The relief of Divisional group 183 went according to plan. Divisional Group 183 reached the woods south of Ozydow by noon. The German Army official report on the 
destruction of the XIII Army Corps criticized the fighting ability of the 14th SS Volunteer Division "Galizien" severely stating:

The 14th SS Volunteer Division "Galizien" had already shown with their first actions only an exceptionally inferior ability to standfast. The Galicians proved in no way to be the fanatical defenders of their homeland against Bolshevism, as one had supposed, so that their first-rate equipment and armament had hardly any impact and was finally only in the hands of a completely undisciplined, disordered mass on which the small number of German command personnel despite their utmost efforts had hardly any control over. ${ }^{83}$

Furthermore, the numerous supply vehicles of the 14th SS Volunteer Division "Galizien" alerted the Soviets to the direction of the breakout of the XIII Army Corps by their movement in the direction of Bialy Kamien in the daylight. ${ }^{84}$ The Soviet responded by obstructing all the roads and paths so that decisive troop movements were seriously delayed.

The XIII Army Corps faced the danger of having the current pocket in which they were located being split in half with the loss of Podhorce and Chwatow. The XIII Army Corps assigned the Grenadier Regiment 311 and the Fusilier Battalion of Corps Detachment $C$ to clear up the situation. However, before the assigned units could be deployed both Podhorce and Chwatow were retaken by the 14th SS Volunteer Division "Galizien" with the support of assault guns.85 Apparently, the Galician SS were not as much of a disordered mob as the German Army claimed.

General Hauffe, Commander of the XIII Army Corps and his Chief of Staff, Colonel von Hammerstein on the morning of July 
19th at the Corps Command Post issued the orders for a breakout of the XIII Army Corps to reach the XXXXVIII Panzer Corps in a three day operation. 86 The main burden of the attack was assigned to Corps Detachment $\mathrm{C}$ which the most combat worthy formation. 87 Corps Detachment $C$ was to advance on July 20th at dawn on both sides of Bialy Kamien over the Bug river and after crossing the Zloczowka sector occupy and hold the land between Skwarzawa and Chilozyce with a strong defense line to the southeast. 88 The Fusilier battalion 361 and Assault Gun Brigade 249 were placed under the command of Corps Detachment $C$ for the breakout. Engineer Battalion 219 was also brought up for the assault.

The 349th Infantry Division was ordered to protect the east flank of Corps Detachment $C$ and also take hill 334 and the hills southwest of it. The 14th SS Volunteer Division "Galizien", 361st Infantry Division and 454th Security Division were to provide the rear cover for the withdrawal and breakout. 89

On July 21, 1944, the XIII Army Corps plan called for making solid contact with the XXXXVIII Panzer Corps by Corps Detachment $C$ between Lackie and Jasionowce and at Zloczow with the 349th Infantry Division. 90 This would open the cauldron for the escape of the XIII Army Corps.

On July 22, 1944, the plan provided for the rear echelon, supply troops and wounded to be sent out of the cauldron through the openings made by Corps Detachment $C$ and the 349th Infantry Division. The remaining order of withdrawal from the pocket was to be the 14th SS Volunteer Division "Galizien", 361st Infantry 
Division followed by the 454th Security Division. 91 This order of withdrawal was to be followed as long as Corps Detachment $C$ and the 349th Infantry Division with the support of opposite units from the XXXXVIII Panzer Corps could hold open the cauldron. Corps Detachment $C$ was assigned to assemble later in the area of Wisniowozik-Gologory.

Corps Detachment C's adjutant received the orders for the attack on July 20th at noon. Divisional Group 183 and Fusilier Battalion 361 on the right of Corps Detachment $C$ were to advance from the area of Bialy Kamien and take Belzce and Poczapy along with the hills south of the town and hold them.92 Divisional Group 217 was to advance from the area of Czeremosnia over hill 366.1 and Zulice to reach Chilozyoe on the left flank of Corps Detachment C. Assault Gun Brigade 249, Corps Detachment C's armored platoon and the motorized 1st Engineer Battalion of Regiment 219 were to asemble in Bialy Kamien. They were to cross the Bug river and occupy the hills south of the river with infantry. This armored group was then to advance on both sides of the highway to Poczapy and seize the crossings and block the Zloczow-Busk road. 93

The Soviet pressure on the XIII Army Corps continued throughout the day as it withdrew to the south. The corps assumed a new defense line of Olesko-Sokolowka. The 340th Infantry Division and 454th Security Division were closely pursued by the Soviets and separated by the Soviets from the rest of the XIII Army Corps (see Figure 178). ${ }^{94}$ Both divisions fought their way through to the west at Kamionka Strumilowa (see Figure 178). ${ }^{95}$ 
XXXXVI Panzer Corps. The 20th Panzer Grenadier Division was engaged the entire day in defensive battles against Soviet armor from the northeast and north (see Figure 178). The 168th Infantry Division's line southeast of Turyzka held against a Soviet attack supported by armor.96 The 16th Panzer Division was at Kulikow ( 9 $\mathrm{km}$ southeast of Zolkiew).

JULY 20, 1944

\section{4th Panzer Division}

A hole in the front emerged between the 1st and 4th Panzer Armies through which the Soviets advanced to the west and took Rawa Ruska and Uhnow and then proceeded further to the west and southwest (see Figure 179). ${ }^{97}$ Soviet armor engaged German units at Lubycza Krolewska and attacked Tomaszow during the evening (see Figure 179). 98

XXXXII Army Corps. The Soviets attacked this corps on a wide front with overwhelming infantry and armor achieving several breakthroughs and pushing the entire front back $3 \mathrm{~km}$ (see Figure 179). ${ }^{99}$ The corps was forced to withdraw to the line LaszcowKrylow-to $4 \mathrm{~km}$ northwest of Horodlo.

LVI Panzer Corps. The Soviets pursued the withdrawal of the corps to the west bank of the Bug river and attacked the newly occupied defense line on the Bug river (see Figure 179). The Soviets despite firm German resistance forced a crossing over the Bug river on both sides of the Kowel-Lublin rail line (see Figure 
179). ${ }^{100}$ Once the Soviets had established their bridgehead they attacked the remnants of the German 253rd and 26th Infantry Divisions. The Soviet advance was halted here after the Germans employed every available man in the battle.

VIII Army Corps. The 5th Jaeger Division was engaged in heavy combat at Zberez, but could not prevent the Soviets from crossing the Bug river. ${ }^{101}$ The corps withdrew its eastern front during the night to the Zlota-Lipa sector.

\section{1st Panzer Army}

XXXXVIII Panzer Corps. The Soviets broke through the sector held by the 254th Infantry Division and were met with a counterattack by the 1st Panzer Division. The 8th Panzer Division attacked to the north through wooded terrain south of Zloczow (see Figure 180).

XIII Army Corps. The beginning of the breakout attack of the XIII Army Corps had been set for 0330 hrs. ${ }^{102}$ However, the supply vehicles of the 14th SS Volunteer Division "Galizien" clogged the road and combined with rainy weather delayed the deployment of certain units into their attack positions. Grenadier Regiment 311 and the Fusilier Battalion from Corps Detachment $C$ had not reached their start positions by $0330 \mathrm{hrs}$. Divisional Group 183 reported at $0435 \mathrm{hrs}$ movement difficulties and requested that the beginning of the attack be postponed. The quartermaster of Corps Detachment $\mathrm{C}$ took charge of traffic at $0500 \mathrm{hrs}$ in an attempt to restore some order. 
Nevertheless, the attack of Corps Detachment C commenced at 0500 hrs. ${ }^{103}$ Divisional Group 183 with Grenadier Regiment 351 on the right and Grenadier Regiment 330 on the left overcame Soviet resistance and were north of Hill 247 at 0545 hrs. The northwest edge of Belzec was reached at 0725 hrs. 104 Divisional Group 217 minus Grenadier Regiment 311 along with the Fusilier Battalion of Corps Detachment C ran into stiff Soviet resistance at Hill 366.1 and the attack was brought to a standstill as of 0900 hrs. ${ }^{105}$ The armored task force consisting of Assault Gun Brigade 249 and the captured Soviet T-34 tanks of Corps Detachment C were delayed in advancing from their attack positions till 0800 hrs as a result of strong Soviet anti-tank fire from Hill 366.1.106 It was needed to advance against Poczapy since Grenadier Regiment 351 of Divisional Group 183 had already advance through Belzec to the southeast and was encountering strong Soviet resistance from the direction of Poczapy.

The armored task force reached the bridge at Poczapy at 1200 hrs. after engaging in a heavy battle with Soviet armor and selfpropelled guns in which 20 were destroyed. The 3rd Engineer Company of Engineer Battalion 219 and elements of Grenadier Regiment $\mathbf{3 3 0}$ had to take Poczapy in a bitter house to house battle and the town was finally secured at $1500 \mathrm{hrs.}{ }^{107}$ Grenadier Regiment 351 had occupied Hill $2513 \mathrm{~km}$ southwest of Poczapy and Divisional Group 217 arrived in the area of Zulice. Divisional Group 339 under the command of the 349th Infantry Division took Hill 334 at dawn and was fighting for Hill 234 at noon. 
The attack objectives had almost all been reached. Three batteries of Artillery Regiment 219 of Corps Detachment $C$ were pulled back over the Bug river during the morning hours. They were deployed into a position east of the road to Poczapy to provide a screen to the southeast.

The favorable conditions set the stage for a further advance. Divisional Group 183 received the order to advance and take Kniaze at $1300 \mathrm{hrs}$ and establish a screen to the west and southwest. Divisional Group 217 received orders at $1200 \mathrm{hrs}$ to take Chilozyoe with Grenadier Regiment 389 as well as Hill 274.4 and occupy the area northeast of it and establish a defense to the east and southeast. Corps Detachment C moved its command post at 1255 hrs to the woods $1.5 \mathrm{~km}$ southeast of Bialy-Kamien. ${ }^{108}$

The course of the battle began to change during the afternoon when increased Soviet air attacks brought the advance to a halt. Roads, artillery positions and the battlefield were subjected to continuous attack by Soviet bombers and attack aircraft which dropped bombs and strafed continuously. ${ }^{109}$ Heavy losses in men and material developed especially among the rear echelon troops. The German Luftwaffe did not even appear over the battlefield. The 1st Battalion of Artillery Regiment 217 shot down one Soviet aircraft with rifles. Three armored flak guns from Jaeger Battalion 219 shot down three Soviet aircraft.

Nevertheless, Divisional Group 217 entered Chilczyce at 1309 hrs and with a unit of the armored task force and the motorized 1st Company of Engineer Battalion 219 and took the town and the hills 
to the southwest by 1600 hrs. Divisional Group 183 encountered major difficulties at Kniaze as a result of terrain and the Soviet defense. The Division Command Post was transferred to the woods north of Kniaze at $2200 \mathrm{hrs}$.

A serious threat to the entire breakout emerged during the afternoon on the eastern flank. The 349th Infantry Division managed to occupy Hills 289 and 274.4 but the defensive screen to the east and southeast was too weak and the Soviets captured Hill 334 which then changed hands several times before it was finally lost to the Soviets during the evening. Corps Detachment $C$ dispatched the Fusilier Battalion to the heavy fighting around Zulice. However, the Fusilier Battalion was stopped by a Soviet air attack on the west edge of Zulice. Later in the afternoon Zulice had to be abandoned. ${ }^{110} \mathrm{~A}$ Soviet battalion advancing through Zulice to the north attempted to take Hill 268, but was brought under direct fire by the 8th Battalion of Artillery Regiment 219 and shot to pieces. The Germans, however, counterattacked throughout the night and managed to retake a portion of Zulice as far as the church by $0700 \mathrm{hrs}$ the next morning. 111

The breakout of the XIII Army Corps had been opposed by strong Soviet forces north and northwest of Zloczow. The breakout attempt had destroyed at least 32 Soviet tanks and numerous artillery guns, but had not yet succeeded.112 The entire front of the XIII Army Corps was compressed into an even tighter ring of encirclement with about 85,000 men encircled north and west of Zloczow (see Figure 180). ${ }^{113}$ 
III Panzer Corps. The defensive line on the Zloczow-Lemberg road was pushed back to the west by Soviet armor. The 1st Panzer Division withdrew toward the west in the direction of Pomercany and Wicyn. ${ }^{114}$ The retreating elements of the 1st Panzer Division were subjected to repeated heavy bombing by the Soviet Air Force.115 The 1st Panzer Division's Reconnaissance Battalion reported at noon that the Soviets had occupied Przemyslany, Zaszkow and Zukow (see Figure 179). ${ }^{116}$ Meanwhile, the 8th Panzer Division was attacking to the north to relieve the encircled XIII Army Corps in the area north and west of Zloczow (see Figure 179). ${ }^{117}$ The 101st Jaeger Division and 68th Infantry Division repulsed weak attacks against the northern front of the corps knocking out 5 Soviet tanks (see Figure 180).118

XXXXVI Panzer Corps. The corps repulsed repeated attacks against Kulikow, but could not prevent the Soviet advance on the road south of the town to the west. ${ }^{119}$ The integration of the 20th Panzer Grenadier Division and elements of the 340th Infantry Division were completed today. The 168th Infantry Division and 16th Panzer Division suffered heavy losses.

$$
\text { JULY 21, } 1944
$$

\section{4th Panzer Army}

Colonel Hoffman's unit holding Tomaszow was attacked by strong Soviet infantry and armor and pushed out of the town to the hills south of Tarnawatka (see Figure 181). ${ }^{120}$ 
XXXXII Army Corps. Soviet attacks against the right wing of Corps Group Major General v.d. Meden were repulsed. However, the Soviets broke into Krylow and made several penetrations to the north of the town (see Figure 181).121 German counterattacks blocked the penetrations north of the town inflicting severe losses on the Soviets.

LVI Panzer Corps. The Soviets achieved penetrations on a wide front which could barely be sealed off (see Figure 181). The 26th Infantry Division which had reached a state of exhaustion by continuous fighting over the last few days could not prevent the Soviet advance to Sawin (see Figure 181).122

VIII Army Corps. The Soviets on the south wing of the corps advanced out of their bridgehead Zabuze-Zberez to the west and crossed over the Cholm-Wlcdawa road. The 5th Jaeger Division was engaged in battle on its right wing at Osowa and Soviet pressure forced it to withdraw to the Bug river. ${ }^{123}$ The Soviets pushed back the 211th Infantry Divisions's sector at Piszcza to the southwest and were advancing on Wlodawa. The 12th Hungarian Reserve Division on the left wing of the corps was retreating with the Soviets in close pursuit. The Soviets reached the Bug river occupying the east bank at Slawatycze and proceeded to cross the river $6 \mathrm{~km}$ northeast of the town. ${ }^{124}$

\section{1st Panzer Army}

XXXXVIII Panzer Corps and XIII Army Corps. The combined attack on both sides of the cauldron from the south and north 
restored contact between the XXXXVIII Panzer Corps and the XIII Army Corps (see Figure 181).125 Soviet attacks continued against the eastern front of the XIII Army Corps. A breakthrough was achieved against the 96th Infantry Division north of Pomorzany requiring a local withdrawal of the main battle line.

XIII Army Corps. The XIII Army Corps gave Corps Detachment $C$ and the 349th Infantry Division the following order:

8th Panzer Division has reached Wereniaki. Advance at night through Zloczow further to the north. 1st Panzer Division advancing from the area of Gologory early in the morning to the north. The spearhead of Corps Detachment $C$ and the 349th Infantry Division are to continue their flank attack at night. Attack objectives for Corps Detachment $C$ the area Lackie-Jasionowce; 349th Infantry Division, Zloczow. ${ }^{126}$

The beginning of the night attack for Corps Detachment $C$ was set for 0100 hrs. ${ }^{127}$ Divisional Group 183 was to attack Lackie and Divisional Group 217 was to attack Jasionowce. Both divisional groups were to seek contact with the formations of the XXXXVIII Panzer Corps. The new command post for Corps Detachment $C$ was to move to the woods north of Kniaze at $0300 \mathrm{hrs}$, but was delayed by terrible road congestion. The traffic on the roads was rendered near impossible by the numerous supply vehicles plugging up the roads. Artillery Regiment 219 managed to cross the Zloczowka stream by traveling along byways during the early morning hours. Corps Detachment $C$ Headquarters arrived in Poczapy at 0500 hrs. 128 Major Pacher, Commander of Grenadier Regiment 330 secured the town with the assistance of a few assault guns. Major 
Pacher reported that Divisional Group 183 in the battle for Kniaze during the night had been thrown back to the north by a Soviet counterattack. ${ }^{129}$ The command post of Divisional Group 183 was now located on Hill 257 southwest of Poczapy. Radio communications had apparently been lost to Divisional Group 217. Grenadier Regiment 311 and 389 assembled for the attack during the night southwest of Chilczyce. The attack was delayed till $0400 \mathrm{hrs}$ and was reinforced by various units from other divisions and two assault guns. The main assault was launched directly east of Jasionowcze and the town was taken from the south. ${ }^{130}$ The attack progressed and the hills were taken and the attack objectives accomplished. However, the 8th Panzer Division was not located. Both regimental commanders decided to seek contact further to the south. The terrain was unsuitable for vehicles and they had to be abandoned. The 1st Panzer Division was finally reached after numerous battles around midday at Zukow. ${ }^{131}$ The entire fate of the XIII Army Corps hung in the balance based upon the changing situation of the XXXXVIII Panzer Corps.

The 1st Panzer Division took command of Grenadier Regiments 311 and 389. Divisional Group 217, elements of Assault Gun Brigade 249 and the 1st Company of Engineer Battalion 219 which had advanced through Boniszyn made contact with the 1st Panzer Division. Kampfgruppe Neumeister of the 1st Panzer Division had launched a relieve effort during the early morning hours and succeeded in opening a small hole on the western side of the cauldron. This opening permitted 400 men of the 14th SS 
Volunteer Division "Galizien" and about 3000 troops from various other XIII Army Corps units to escape.132 The 1st and 8th Panzer Divisions restored contact with the XIII Army Corps west of Zloczow at $1400 \mathrm{hrs}$ (see Figure 181). ${ }^{133}$ German forces captured Prezemyslany in an attack from the south and east after a difficult battle.

The battle for the survival of the XIII Army Corps was waged during the day to the south. Corps Detachment $C$ moved its headquarters after arriving in Poczapy to the woods east of Belzec. Divisional Group 183 was employed again against Kniaze without success. Divisional Group 217 had also been locked into battle around the town most of the day. Major Von Bonin, Commander of Divisional Group 217, even became separated from his staff in the course of the battle. The 2nd and 3rd Companies of Engineer Battalion 219 were subjected to severe bombing attacks in Poczapy. The 2nd Engineer Company despite the bombing participated in the renewed attack of Divisional Group 183 against Kniaze and managed to breakout of the ring of encirclement and advanced to the south. These elements made contact with the 8th Panzer Division in the area of Gologorky. ${ }^{134}$ Grenadier Regiment 330 after a repeated effort to take and occupy Kniaze withdrew with the onset of darkness to the east of the town. Elements of Corps Detachment C's Fusilier Battalion remained in heavy defensive battles at Zulice. Divisional Group 339 under the command of the 349th Infantry Division secured Hill 274.4 on the left flank of the XIII Army Corps. Corps Detachment C assumed 
command of the 454th Security Division at noon. It was pulled out of the northern front and was assigned to relieve Fusilier Battalion 361 in the area of Belzec-Skwarzawa.

The XIII Army Corps on the afternoon of July 21, 1944 gave the following order to Corps Detachment $\mathrm{C}$ and its subordinate units:

The division was to assemble with 3 assault groups after the onset of darkness:

Right Flank: Fusilier Battalion 361 in the area of Skwarzawa is to advance over the rail line ZloczowLemberg to Lackie and to the south to occupy the hill terrain.

454th Security Division follows as right flank security for the corps.

Center: Divisional Group 183 with Engineer Battalion 219 and Ski-Jagd Kommando in the area of Kniaze-Completely capture the town with a further advance in the direction directly east of Lackie and pass by on the southeast side of the town's high terrain--the middle assault group shall contain Corps Detachment C's Headquarters with Felders Battalion 219 and the division's combat school.

Left Flank: Divisional Group 217 with Fusilier Battalion of Corps Detachment $C$ was to move from the area southwest of Chilczyce to capture Boniszyn and the high terrain south of the town. Artillery Regiment 219 was to provide close support.

The 349th Infantry Division east of Corps Detachment C was to thrust toward Zloczow.

The supply troops were to be transferred during the course of the day to the area of Belzec and would 
follow Corps Detachment C Headquarters to the assembly area.

The assembly area of Corps Detachment C after breaking through the ring of encirclement was to be Wisniowszyk and Gologory for the 454th Security Division. ${ }^{135}$

This order was given by the XIII Army Corps based upon the belief that the Corps would make contact with the armored spearheads of the XXXXVIII Panzer Corps directly south of the Zloczow-Lemberg road. ${ }^{136}$ The Corps Detachment C Headquarters assembled at $2100 \mathrm{hrs}$ near Hill 257 southwest of Poczapy. Lt. General Lange, Commander of Corps Detachment C and Major General Nettwig, Commander of the 454th Security Division had a conference at the command post of the 454th Security Division in Belzec during the afternoon. ${ }^{137}$ General of the Infantry Hauffe, Commander of the XIII Army Corps, also appeared with his staff at this meeting. ${ }^{138}$ The plans were laid out for the breakout of the XIII Army Corps that night.

The departure to the assembly areas occurred just before the onset of darkness. Reconnaissance had determined that Kniaze was again completely occupied by the Soviets. Therefore, Lt. General Lange assembled his group directly northwest of Boniszyn along with Major Pacher, Commander of Grenadier Regiment 330.139 -Major Pacher informed Lt. General Lange that based upon his experience a repeated attack on Kniaze would not guarantee success. Boniszyn on the other hand was already occupied by German troops. Therefore, Lt. General Lange decided to attack to 
the south with Grenadier Regiment 330 through Boniszyn. ${ }^{140}$ Boniszyn was reached by $0100 \mathrm{hrs}$. Grenadier Regiment 330, the division's combat school and the Felders Battalion of Corps Detachment $\mathrm{C}$ assembled on the railway embankment south of Bonisyn.

The 349th Infantry Division along with most of the subordinate Divisional Group 339 and Grenadier Regiment 912 had also selected the route through Boniszyn and joined the assembly area to the east. The attack through Zloczow had, therefore, been abandoned since it would have been necessary to occupy the town for the vehicles to get through following in the rear. ${ }^{141}$

The assembly area was not noticed by the Soviets until 0300 hrs. The assault group of Corps Detachment $C$ and the 349th Infantry Division with the subordinate Divisional Group 339 began to attack shortly after $0300 \mathrm{hrs} .{ }^{142}$ Lt. General Lange described the attack:

The enemy which had remained completely silent suddenly opened up heavy fire from their well prepared positions in the hills. Armor, anti-tank guns, selfpropelled guns, anti-aircraft guns, mortars and machine gun fire attempted to pin down the attacking German troops. A battle commenced which was rivaled by only few examples in the history of war and was comparable with the assault of our grandfathers, fathers and brothers on the Spieherner hills and at Langemark... ${ }^{143}$

The officers and grenadiers lead by their two Generals, Lt. General Lasch and Lt. General Lange assaulted the Soviet positions with unheard of bravery and fearless defiance of death with ringing yells of "Hurra" and the force of pounding waves which broke through regardless 
of numerous casualties and like the raging elements themselves advanced to the highway. Several blocking tanks were destroyed in close combat and the increasing artillery fire from the west and east and later the northern direction into the flanks and rear of the attacking troops was not capable of damming up the force of the assault. Wave after wave surged through the enemy positions. The hills south and west of Jasionowce were taken at $0500 \mathrm{hrs}$. The town itself and also Zalesie were taken by German troops. The officers and men honored their two generals with a ringing "Sieg Heil" on the edge of the woods south of Zalesie. The anticipated contact with units of the XXXXVIII Panzer Corps was not established. ${ }^{144}$

The left assault group of Corps Detachment $C$ and the 349th Infantry Division punctured the encirclement ring at Jasionowce and directly west of the town which proved decisive. ${ }^{145}$ However, the middle and right assault groups failed to breakout of the Soviet encirclement. The middle assault group of Corps Detachment C contained the commanding general of the XIII Army Corps, General of the Infantry Hauffe, along with his staff, and units of the 361 st Infantry Division. ${ }^{146}$

The middle assault group's assembly area was $1 \mathrm{~km}$ east of Kniaze and deployment into the assembly area was completed by 0100 hrs. Major Schliep, Commander of Engineer Battalion 219, received the order personally to attack at $0200 \mathrm{hrs}$ directly from General Hauffe. ${ }^{147}$ The attack was supported by 4 assault guns, 3 captured T-34 tanks and 6 armored personnel carriers. The armored assault group broke into Kniaze and advanced further into swampy terrain while the Soviets sealed off the breakthrough behind the assault group with armor and mounted infantry. ${ }^{148}$ The 
units following the assault group could not breakthrough and the assembly area east of Kniaze and between Boniszyn was brought under artillery barrage fire.

Major Schliep advanced with the 3rd company of Engineer Battalion 219 during the attack along a railway embankment bridge built further to the east and managed to enter the breakthrough area of the left assault group and advanced to the southwest. However, the whereabouts of the the Headquarters of XIII Army Corps and its staff are uncertain after the failure of the middle assault group. 149

Essentially, the fate of the right assault group remains unkown. It appears to have been deflected from its route of attack in the same way as the attack on Kniaze. The 454th Security Division's Headquarters with Major General Nettwig was probably annihilated. ${ }^{150}$ There was no trace of the Major General and Fusilier Battalion 361.

The Soviets responded rapidly and tightened the ring around the XIII Army Corps during the night of July 21-22, 1944. The Soviets closed the ring again at Jasionowce with strong armored forces during the early morning hours. ${ }^{151}$ The Soviets were even attacking Boniszyn in strength by noon. Poczapy in the north was lost. 152 Vehicles and heavy weapons were no longer able to get through and the swamp south of Boniszyn could not be traversed. Various assorted units managed to pry open the Soviet ring a third time west of Jasionowce and others managed to successfully 
defend the woods west of Boniszyn till the end of July 23rd and then later broke out in small groups. ${ }^{153}$

XXXXVIII Panzer Corps and III Panzer Corps. The Soviets advance with strong armored forces through the hole between the XXXXVIII Panzer Corps and the III Panzer Corps past Bobrka and reached the region of Dawidow with armored spearheads where the German line finally halted the Soviet advance (see Figure 181). ${ }^{154}$ Weak Soviet attacks against the 101st Jaeger Division and the 168th Infantry Division were repulsed. Soviet units which had managed to infiltrate between the 168th Infantry Division and the 16th Panzer Division southwest of Kulikow were in the process of being destroyed by a counterattack of the 68th Infantry Division from the northeast and the 16th Panzer Division from the south (see Figure 181). ${ }^{155}$

XXXXVI Panzer Corps. The corps repulsed Soviet attacks supported by armor against Turynka. The Soviets advanced through the hole between the 1st and 4th Panzer Armies in the direction of Jaroslau on the San river (see Figure 181). ${ }^{156}$ Soviet armored spearheads were reported $5 \mathrm{~km}$ east of Jaroslau by aerial reconnaissance.

$$
\text { JULY 22, } 1944
$$

The Soviets advanced rapidly through the hole between the 1st and 4th Panzer Armies as well as between the LVI Panzer Corps 
and the VIII Army Corps to reach the San and Weichsel rivers. The most forward Soviet units reached the San river at Jaroslau and Lublin as well as the region $15 \mathrm{~km}$ northwest of Lublin (see Figure 182). ${ }^{157}$ The 1st Panzer Army was broken through again southeast of Lemberg (see Figure 183). ${ }^{158}$ There were only a few units of the XIII Army Corps which had broken out of the Soviet encirclement while the majority of the XIII Army Corps remained within the Soviet encirclement (see Figure 183).

\section{4th Panzer Army}

XXXXII Army Corps and LVI Panzer Corps. Soviet attacks against the XXXXII Army Corps were repulsed (see Figure 182). The right wing of the LVI Panzer Corps was pressed back to the Teratyn-Cholm road. Cholm was lost to the Soviets and they achieved a $50 \mathrm{~km}$ wide breakthrough advancing to Lublin (see Figure 182). ${ }^{159}$ The Soviets forced their way into the eastern portion of Lublin and reached the region $15 \mathrm{~km}$ northwest of the city (see Figure 182). ${ }^{160}$ The 26th Infantry Division as a result was cutoff $30 \mathrm{~km}$ northwest of Cholm and had to fight its way back to the southwest (see Figure 182).

VIII Army Corps. Soviet armor and cavalry forces pushed the right wing of the corps back southwest of Wlodawa. The Soviets then advanced to the north and occupied Parczew. 


\section{1st Panzer Army}

XXXXVIII Panzer Corps. Soviet attacks from the east and northeast achieved deep breakthroughs forcing the 8th Panzer Division back to the southwest and northwest of Zukow. ${ }^{161}$ Contact with the XIII Army Corps was completely severed as a result (see Figure 183). ${ }^{162} 1000$ men from the XIII Army Corps were rescued before contact with the XIII Army Corps was lost (see Figure 183). ${ }^{163}$

XIII Army Corps. The XIII Army Corps ceased to exist as an effective combat formation on July 22, $1944 .{ }^{164}$ Assault groups broke through individually without heavy weapons and advanced toward their ordered assembly areas. The assault group of Corps Detachment $C$ under the command of Lt. General Lange along with numerous dispersed units from other divisions split into two groups in the woods south of Zalesie ${ }^{165}$ The command of the second group was assumed by Lt. Colonel I.G. von Prittwitz. The various small assault groups gained an awareness of the hard facts during the day that units of the XXXXVIII Panzer Corps could not be expected to meet them in the breakout. In fact, the assigned assembly areas were occupied by the Soviets during the evening. Therefore, the troops of the XIII Army Corps organized in various assault groups fought their way out of the Soviet encirclement to the southwest under unprecedented difficulties without support from outside of the cauldron. Lt. General Lange's assault group was almost entirely annihilated. ${ }^{166}$ 
A successful breach was made in the Soviet encirclement which allowed other units of the XIII Army Corps to escape. A corridor was opened between Kniaze and lasenivtsi. 167 The narrow escape corridor was only 137 to 205 meters wide and was defended as long as possible to allow as many German troops to escape as possible.168 The 14th SS Volunteer Division "Galizien" defended Pochapy, Belzets and Skvariava with the assistance of assault guns from the 8th Panzer Division which had broken into the cauldron from the outside. ${ }^{169}$ General Lindemann, Commander of the 361st Infantry Division apparently was responsible for the successful breakout of this portion of the XIII Army Corps. ${ }^{170}$ Brigadefuehrer Freitag with his staff and 800 troops of the 14th SS Volunteer Division "Galizien" along with the 361st Infantry Division escaped from the pocket.171 Unfortunately, General Lindemann failed to breakout with the elements of the 361st Infantry Division and was captured along with General Nedtwig, Commander of the 454th Security Division. ${ }^{172}$ General Hauffe, Commander of the XIII Army Corps, was killed during the course of the breakout on July 22 , 1944.173

III Panzer Corps. The Germans launched attacks from the east and west to attempt to close the hole on the III Panzer Corps front. Meanwhile, the right wing of the III Panzer Corps had been penetrated and the Soviets had reached the east and southeast edge of Lemberg (see Figure 183). Bobrka was lost to the Soviets.

XXXXVI Panzer Corps. The corps had closed the hole to the III Panzer Corps by an attack of the 16th Panzer Division to the 
south. 174 The Soviets advanced through the hole between the 1st and 4th Panzer Armies to the San river on both sides of Jaroslau (see Figure 182). ${ }^{175}$ Crossings over the San river were in progress.

$$
\text { July 23, } 1944
$$

\section{4th Panzer Army}

XXXXII Army Corps. The Soviets during the early morning hours took Krasnobrod on the right wing of the corps and advanced further to the northwest and were attacking Rudka (18 km northwest of Krasnobrod) by evening. 176 Soviet attacks north of Tomaszow were smashed. The 17th Panzer Division launched a rapid thrust to the north from Krasnystaw and advanced over the Cholm-Lublin rail line to Pawlow engaging Soviet armored and motorized columns advancing to the west.

LVI Panzer Corps. The garrison of Lublin repulsed numerous Soviet attacks from the north and south knocking out 38 Soviet tanks (see Figure 184). ${ }^{177}$ The Soviets advanced from Lublin to the northwest to the Weichsel river and reached Kurow. ${ }^{178}$

\section{1st Panzer Army}

Soviet attacks supported by armor and tactical air power pushed the front of the the XXIV Panzer Corps and the right wing of the XXXXVIII Panzer Corps back along the entire front (see Figure 184). The 8th Panzer Division picked up approximately 10,000 troops from the XIII Army Corps equipped with only hand-held 
weapons since the heavy weapons had to be abandoned during the breakout from the cauldron. 179 The 1st Panzer Division and the 75th Infantry Division's attack on Przemyslany gained little ground.

XIII Army Corps. The mass of the units which had broken through during July 22-23, 1944 made contact with units of the XXXXVIII Panzer Corps on the Zlota-Lipa river at Wiesniowczyk or on the Gnila-Lipa river at Wolkow. ${ }^{180}$ The troops coming out of the pocket were completely exhausted and were sent to Chodorow. Grenadier Regiment 311 of Corps Detachment $C$ under the command of Knights Cross holder, Captain Loer was placed under the command of the 1st Panzer Division and arrived later on July 28th at the new assembly area in Synowodsko Wyzne. A total of approximately 5,000 troops of Corps Detachment $C$ had survived the encirclement battle and had brought out their light infantry weapons, but heavy equipment, vehicles and horses had been lost. ${ }^{181}$ The part of the supply troops of Corps Detachment $C$ which were fortunate to have been outside the cauldron were almost totally intact. Corps Detachment $C$ reported the loss of the following commanders: Lt. Colonel Simons, Commander of Divisional Group 183 was missing; Major Kaupert, Commander of Artillery Regiment 219 was missing; and Captain Zinge, Commander of Fusilier Battalion Corps Detachment C was missing. ${ }^{182}$ There were another 78 officers and 4,059 non-commissioned officers and troops reported killed or missing. ${ }^{183}$

III Panzer Corps and XXXXVI Panzer Corps. The hole between these two corps was closed (see Figure 184). ${ }^{184}$ 
XXXXVIII Panzer Corps and III Panzer Corps. The Soviets advancing through the hole between these two corps broke into Lemberg from the east, southeast and west and the German garrison was forced back to the defense of the city center (see Figure 184). ${ }^{185}$ Soviet reconnaissance forces attempted to establish a small bridgehead across the San river in the sector of Gruppe Lt. General Freiher von Edelsheim (see Figure 184). The Germans, however, managed to partially eliminate the bridgehead. Soviet units further to the east blocked the Lemberg-Przemysl road at Sadowa Wisznia.

\section{GERMAN LOSSES IN THE BATTLE OF BRODY, JULY 13-23, 1944}

The Germans lost five divisions in the encirclement of the XIII Army Corps at Brody (see Table XXXXV). ${ }^{186}$ Soviet sources claim that the German losses were 8 divisions destroyed, 38,000 killed, and 17,175 captured. 187 The discrepancy between Soviet claims of 8 divisions destroyed and actual German losses results because the Soviets claim the actual divisional groups within Corps Detachment $C$ as divisions destroyed. Corps Detachment $C$ contained the 183rd, 217th and 339th Divisional Groups. The Soviets apparently also counted the 349th Infantry Division which was also encircled with the XIII Army Corps, but achieved a successful breakout with heavy losses. 
Major General Lindemann, Commander 361st Infantry Division and Major General Nedtwig, Commander 454th Security Division were captured.188 However, Soviet and German sources disagree about the fate of General d. Inf. Hauffe, Commander of the XIII Army Corps. Soviet sources reported him captured and German sources reported him killed. ${ }^{189}$ Soviet claims about German losses appear to be exaggerated since according to German sources the XIII Army Corps contained between 32,000 and 35,000 troops. ${ }^{190}$ German losses appear to be more like 20,000 troops in the Brody pocket since 5,000 men of Corps Detachment $C$ escaped along with 3000 troops of the 14th SS Grenadier Division "Galizien". Nevertheless, there was an overall loss of 25,000 to 30,000 troops in the Battle of Brody. 191 The losses of Army Group North Ukraine were mostly replaced by transfers of divisions from Army Group South Ukraine (see Table XXXXVI) which weakened this Army Group for the next major Soviet offensive. Thus, the Battle of Brody constituted a significant defeat in the chain of defeats that resulted in the collapse of the German Army in the East in the summer of 1944. 
TABLE XXXXII

SOVIET ORDER OF BATTLE, JULY 13, 1944

\section{Soviet Formations}

1st Ukrainain Front:

1st Guards Army
3rd Guards Army
5th Guards Army
13th Combined Arms Army
18th Combined Arms Army
38th Combined Arms Army
60th Combined Arms Army

Mobile Formations:

1st Guards Tank Army

3rd Guards Tank Army

4th Tank Army

Baranov's Cavalry Mechanized Group:

1st Guards Cavalry Corps

25th Tank Corps

S.V. Sokolov's Cavalry Mechanized Group:

6th Guards Cavalry Corps

31st Tank Corps

Front Reserves:

XLVII Rifle Corps

Source: Colonel T.N. Dupuy \& Paul Martell, Great Battles on the Eastern Front: The Soviet-German War 1941-1945 (New York: The Bobbs-Merrill Company, Inc., 1982), p. 171. 
TABLE XXXXIII

SOVIET NUMERICAL SUPERIORITY

\begin{tabular}{lll}
\hline $\begin{array}{l}\text { Men and Equipment } \\
\text { Ratios }\end{array}$ & $\begin{array}{l}\text { 1st Ukrainian } \\
\text { Front }\end{array}$ & $\begin{array}{l}\text { Army Group } \\
\text { North Ukraine }\end{array}$ \\
\hline $\begin{array}{l}\text { Personnel (combat) } \\
\begin{array}{l}1.4: 1 \\
\text { Guns and Mortars }\end{array}\end{array}$ & 843,000 & 600,000 \\
$\begin{array}{l}\text { 2.2:1 } \\
\text { Tanks and Assault Guns }\end{array}$ & 13,825 & 6,300 \\
$\begin{array}{l}2.2: 1 \\
\text { Combat Aircraft }\end{array}$ & 1,979 & 900 \\
$4.4: 1$ & 3,052 & 700 \\
\hline
\end{tabular}

Source: Colonel T.N. Dupuy \& Paul Martell, Great Battles on the Eastern Front: The Soviet-German War 1941-1945 (New York: The Bobbs-Merrill Company, Inc., 1982), p. 178. 
TABLE XXXXIV

\section{ARMY GROUP NORTH UKRAINE, ORDER OF BATTLE, JULY 15, 1944}

\begin{tabular}{ll}
\hline Axis Formations & Commanders \\
\hline $\begin{array}{l}\text { Army Group North Ukraine } \\
\text { 4th Panzer Army }\end{array}$ & Col. Gen. Harpe \\
Reserves: & Col. Gen. Harpe \\
168th Infantry Division & Maj. Gen. Schmidt-Hammer \\
213th Security Division & Lt. Gen. Lendle \\
253rd Infantry Division & Lt. Gen. Becker \\
XXXXVI Panzer Corps & Gen. d. Inf. Schulz \\
16th Panzer Division & Maj. Gen. Back \\
17th Panzer Division & Maj. Gen. v.d. Meden \\
291st Infantry Division & Maj. Gen. Eckholt \\
340th Infantry Division & Maj. Gen. Ehrig \\
& \\
XXXXII Army Corps & Lt. Gen. Recknagel \\
72nd Infantry Division & Col. Arning \\
88th Infantry Division & Maj. Gen. Graf v. Rittberg \\
214th Infantry Division & Maj. Gen. V. Kirchbach \\
$\begin{array}{l}\text { LVI Panzer Corps } \\
\text { 1st Ski Jaeger Division }\end{array}$ & Gen. d. Inf. Hossbach \\
26th Infantry Division & Col. Berg \\
342nd Infantry Division & Lt. Gen. de Boer \\
VIII Army Corps & Maj. Gen. Nickel \\
5th Jaeger Division & Gen. d. Inf. Hoehne \\
12th Hungarian Reserve Division & Lt. Gen. Thumm \\
211th Infantry Division & Lt. Gen. Eckhardt \\
\hline
\end{tabular}


TABLE XXXXIV

ARMY GROUP NORTH UKRAINE,

ORDER OF BATTLE,

JULY 15, 1944

(continued)

Axis Formations

1st Panzer Army

Reserves:

14th SS Grenadier Division

"Galizien"

20th Panzer Grenadier Division

LIX Army Corps

1st Infantry Division

20th Hungarian Division

208th Infantry Division

XXIV Panzer Corps

75th Infantry Division

100th Jaeger Division

254th Infantry Division

371st Infantry Division

XXXXVIII Panzer Corps

96th Infantry Division

349th Infantry Division

359th Infantry Division

III Panzer Corps

1st Panzer Division

8th Panzer Division
Commanders

Gen. d. Pz. Tr. Raus

Brigadefuehrer Freitag

Lt. Gen. Fries

Lt. Gen. Roehricht

Lt. Gen. v. Krosigk

Lt. Gen. Piekenbrock

Gen. d. Pz. Tr. Nehring

Lt. Gen. Beukemann

Lt. Gen. Utz

Maj. Gen. Thielmann

Lt. Gen. Niehoff

Gen. d. Pz. Tr. Balck

Lt. Gen. Wirtz

Lt. Gen. Lasch

Lt. Gen. Arndt

Gen. d. Pz. Tr. Breith

Maj. Gen. Marcks

Maj. Gen. Friebe 
TABLE XXXXIV

ARMY GROUP NORTH UKRAINE,

ORDER OF BATTLE,

JULY 15, 1944

(continued)

\begin{tabular}{ll}
\hline Axis Formations & Commanders \\
\hline XIII Army Corps & Gen. d. Inf. Hauffe \\
Corps Detachment C: & Maj. Gen. Lange \\
183rd Infantry Divisional Group & \\
217th Infantry Divisional Group & \\
339th Infantry Divisional Group & Lt. Gen. Lindemann \\
361st Infantry Division & Maj. Gen. Nedtwig \\
454th Security Division & \\
1st Hungarian Army & \\
Reserves: & \\
1st Hungarian Infantry Division & \\
2nd Hungarian Panzer Division & \\
1st Hungarian Moutain Brigade & \\
2nd Hungarian Moutain Brigade & \\
19th Hungarian Reserve Division & \\
18th SS Panzer Grenadier Division & \\
"Horst Wessel" & \\
VI Hungarian Corps & \\
27th Hungarian Light Division & \\
XI Army Corps & \\
18th Hungarian Reserve Division & \\
24th Hungarian Infantry Division & \\
25th Hungarian Infantry Division & \\
101st Jaeger Division & \\
16th Hungarian Infantry Division & \\
68th Infantry Division & \\
\hline
\end{tabular}


TABLE XXXXIV

ARMY GROUP NORTH UKRAINE,

ORDER OF BATTLE,

JULY 15, 1944

(continued)

Axis Formations

Commanders

TOTAL FORMATIONS:

PANZER DIVISIONS

PANZER GRENADIER DIVISIONS

INFANTRY DIVISIONS

INFANTRY BRIGADES
5 Panzer Divisions

2 Pz. Gren. Divisions

36 Infantry Divisions

2 Infantry Brigades

Source: Kurt Mehner, Die Geheimen Tagesberichte Der Deutschen Wehrmachtfuehrung Im Zweiten Weltkrieg 1939-1945 Vol. 10, p. 504. 
TABLE XXXXV

ARMY GROUP NORTH UKRAINE

LOSSES AT THE BATTLE OF BRODY

\begin{tabular}{lll}
\hline Formations & $\begin{array}{l}\text { Reorganized } \\
\text { Disbanded }\end{array}$ & $\begin{array}{l}\text { Commanders } \\
\text { XIII Army Corps }\end{array}$ \\
$\begin{array}{l}\text { 14th SS Division } \\
\text { "Galizien" }\end{array}$ & $\begin{array}{l}\text { Gen. d. Inf. Hauffe } \\
\text { killed }\end{array}$ \\
$\begin{array}{l}\text { 340th Infantry Division } \\
\text { 361st Infantry Division }\end{array}$ & $\begin{array}{l}\text { Reorganized } \\
\text { Reorganized }\end{array}$ & $\begin{array}{l}\text { Maj. Gen. Lindemann } \\
\text { prisoner } \\
\text { Maj. Gen. Nedtwig } \\
\text { prisoner }\end{array}$ \\
Corps Detachment C & Disbanded & \\
TOTAL DIVISIONS DESTROYED: & 5 Divisions \\
\hline
\end{tabular}

Source: Generalstab des Heeres, Organisationabteilung, Uebersicht ueber Aufgeloeste Division 1944 NAMP T-78 Roll 410; OKW/Org. Abt. und Heerespersonalabt., Zusammenstellung. der in diesem Kriege gefallen, toetlich verunglueckten. verstorbenen, vermissten und im Gefangenschaft geratenen Generale Flensburg 5 Juni 1945 NAMP T-77 Roll 785. 
TABLE XXXXVI

ARMY GROUP NORTH UKRAINE REINFORCEMENTS

FROM AUGUST 1-31, 1944

\begin{tabular}{ll}
\hline Formations & Source \\
\hline 3rd Panzer Division & Army Group South Ukraine \\
23rd Panzer Division & Army Group South Ukraine \\
24th Panzer Division & Army Group South Ukraine \\
78th Volkssturm Division & OKH Reserve \\
97th Jaeger Division & Army Group South Ukraine \\
154th Reserve Division & OKH Reserve \\
304th Infantry Division & Army Group South Ukraine \\
544th Volksgrenadier Division & OKH Reserve \\
545th Volksgrenadier Division & OKH Reserve \\
& \\
TOTAL REINFORCEMENTS: & 9 Divisions: \\
& 6 Infantry Divisions \\
& 3 Panzer Divisions \\
\hline
\end{tabular}

Source: Kurt Mehner, Die Geheimen Tagesberichte Der Deutschen Wehrmachtfuehrung Im Zweiten Weltkrieg 1939-1945 Vol. 10, pp. 504-507; Vol. 11, p. 337. 


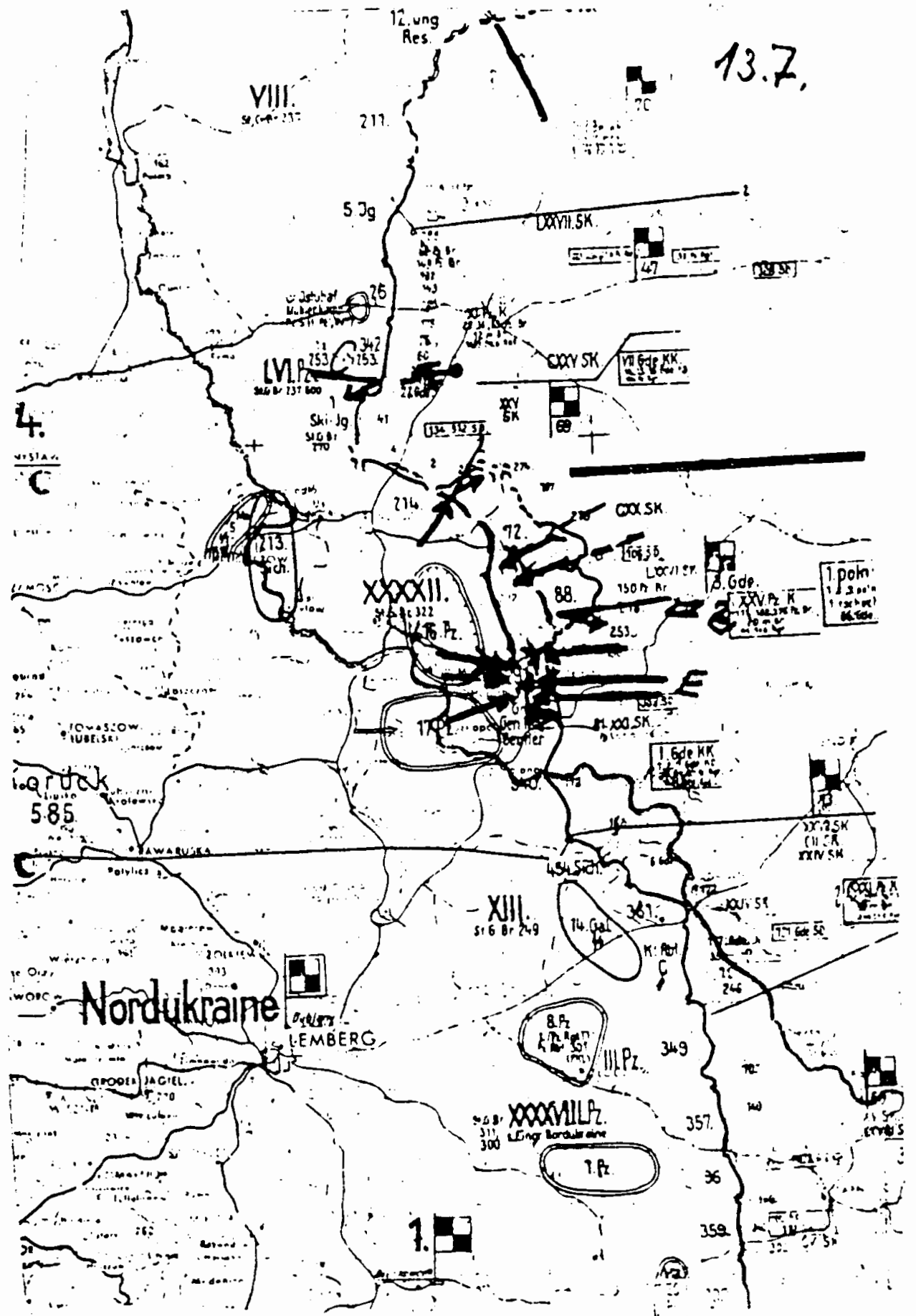

Figure 169. Army Group North Ukraine, July 13, 1944.

Source: OKH, Der Grosse Durchbruch Bei Hgr.

Nordukraine u. Kaempfe am grossen Weichsel-

Brueckenkopf v. 8.7. - 29.8.44 National Archives

Microfilm Publication T-78, Roll 136. 


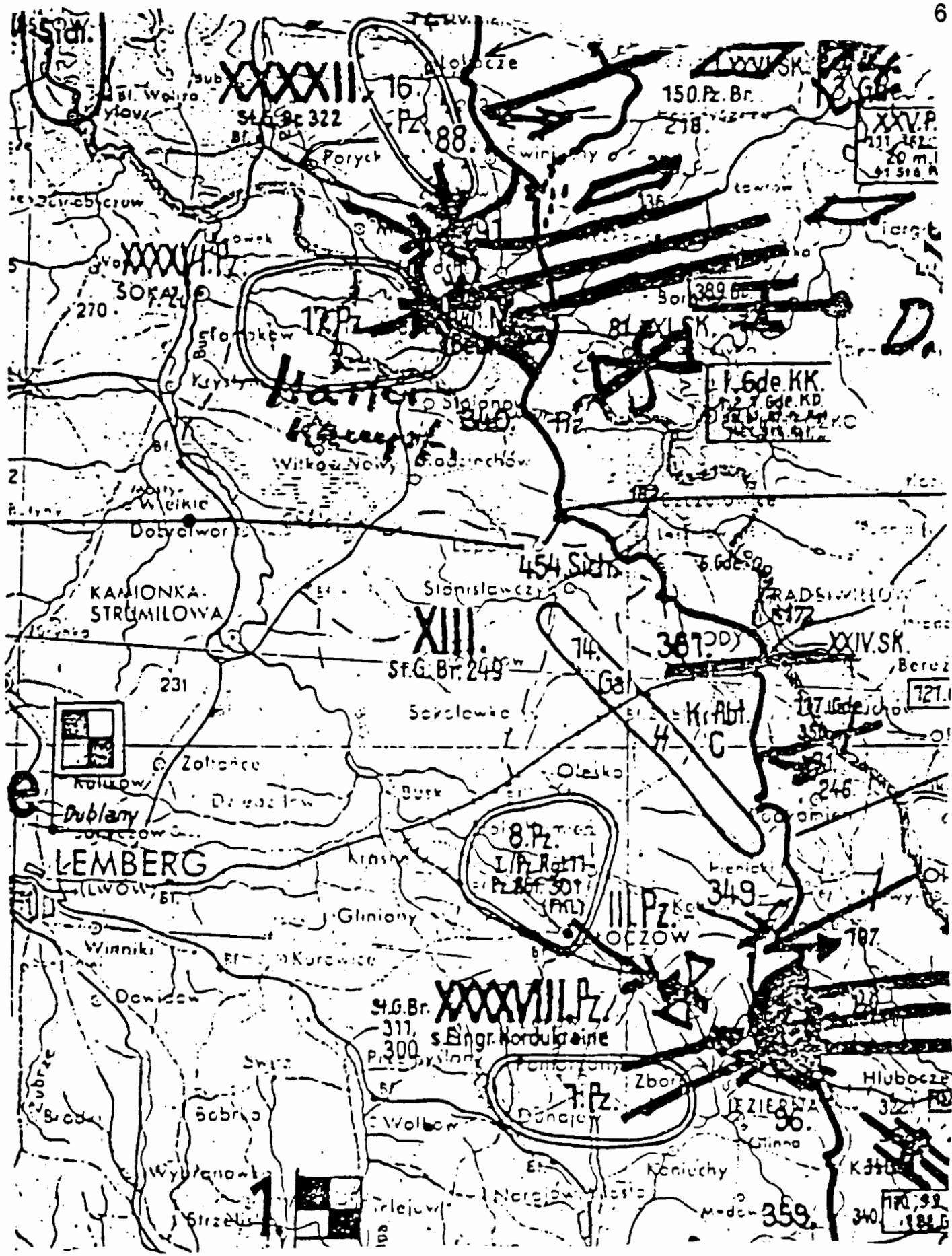

Figure 170. Army Group North Ukraine Under Attack On

The Flanks Of The XIII Army Corps, July 15, 1944.

Source: OKH, Der Grosse Durchbruch Bei Hgr.

Nordukraine $u$. Kaempfe am grossen Weichsel-

Brueckenkopf v. 8.7. - 29.8.44 National Archives

Microfilm Publication T-78, Roll 136. 


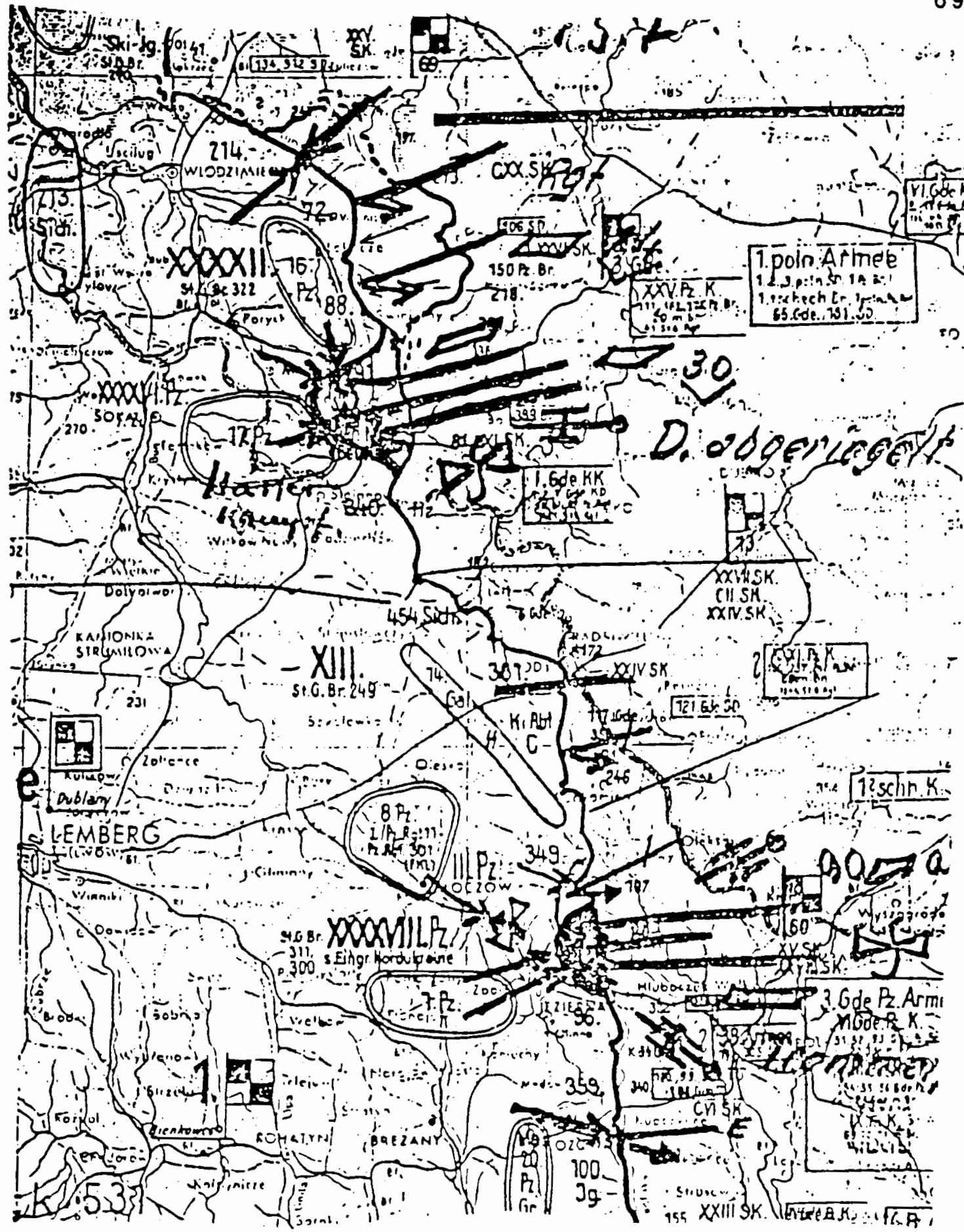

Figure 171. Army Group North Ukraine, July 15, 1944.

Source: OKH, Der Grosse Durchbruch Bei Har.

Nordukraine u. Kaemote am grossen Weichsel-

Brueckenkopf v. 8.7. - 29.8.44 National Archives

Microfilm Publication T-78, Roll 136. 


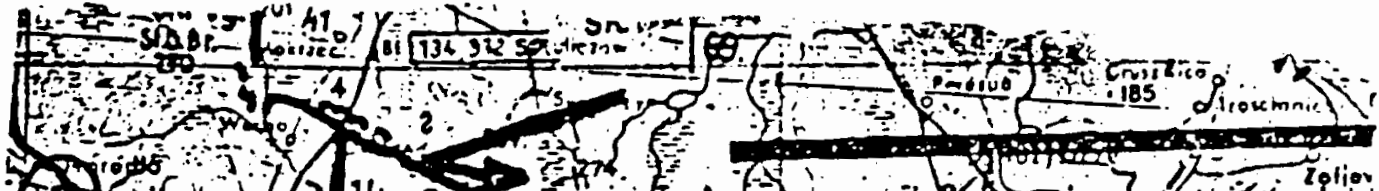

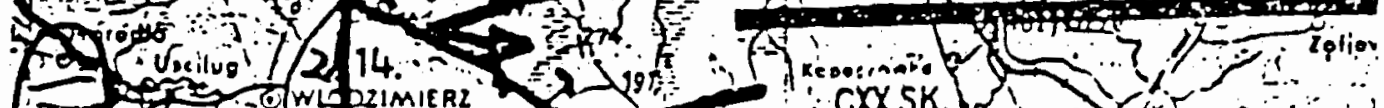

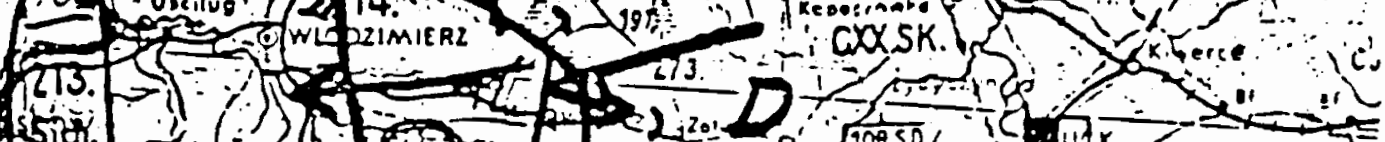

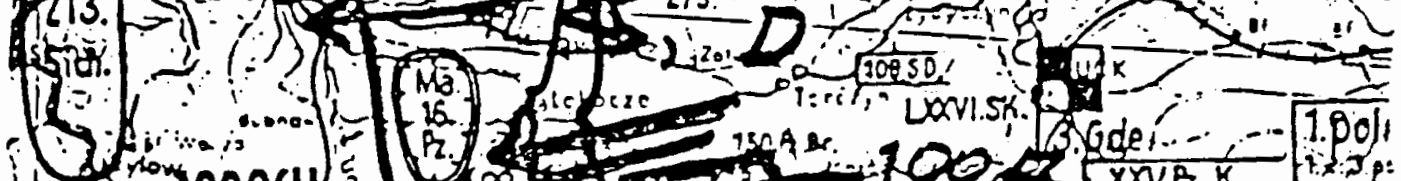

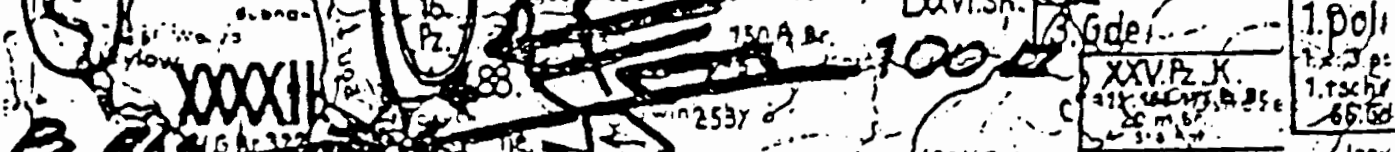
3 (2)

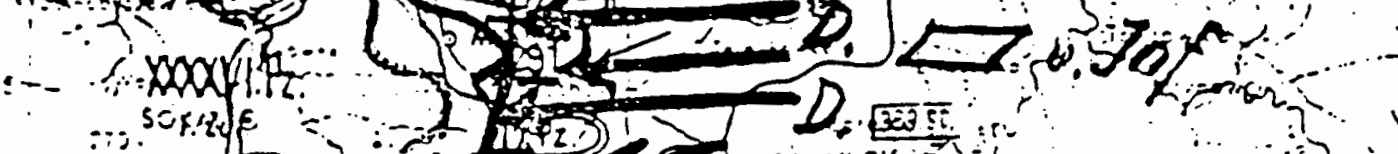

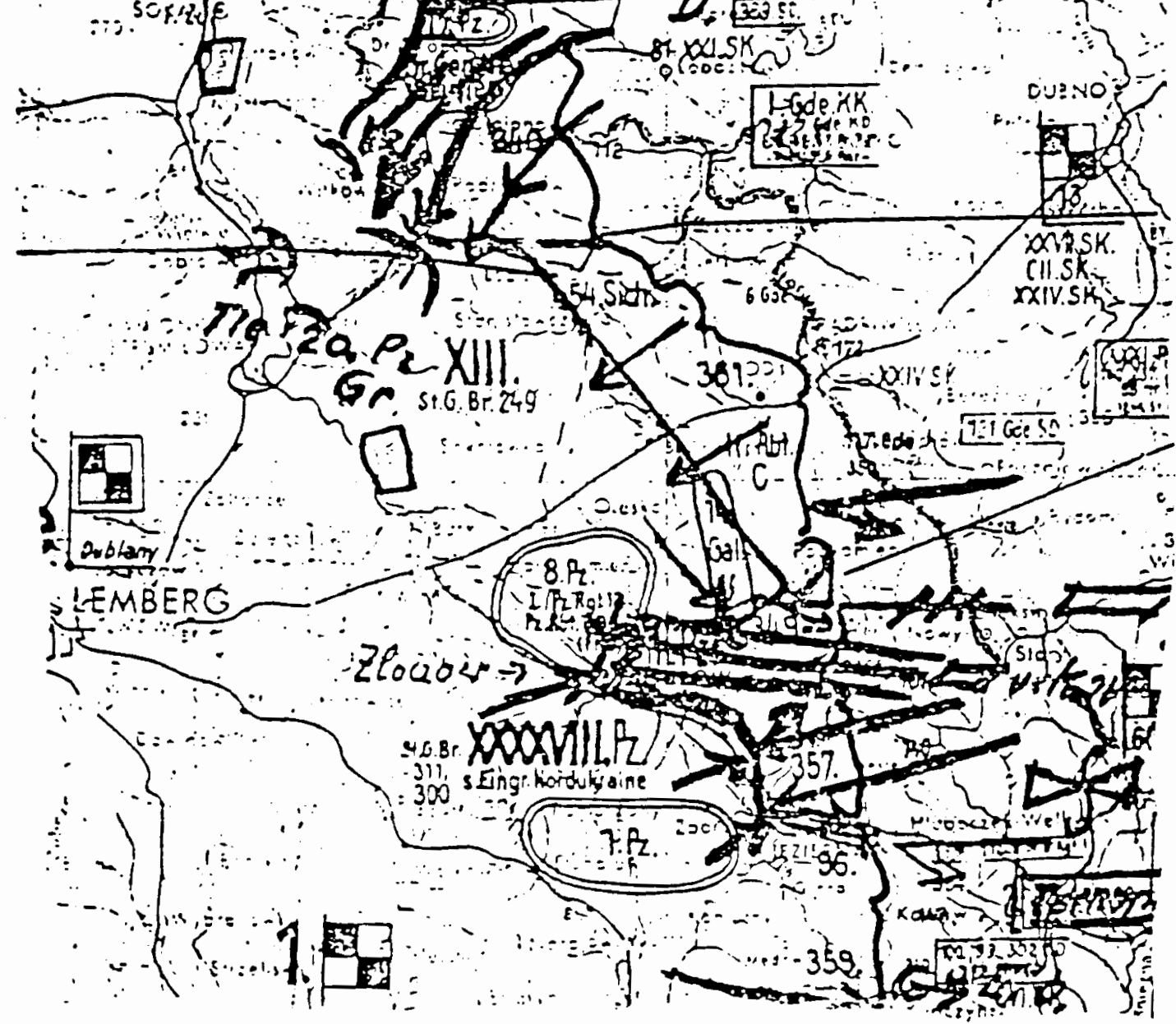

Fiqure 172. Soviet Attacks On The Flanks Of The XIII Army Corps, July 16, 1944. Source: OKH, Der Grosse Durchbruch Bei Har. Nordukraine u. Kaemofe am grossen Weichsel-Brueckenkopf v. 8.7. - 29.8.44 National Archives Microfilm Publication T-78, Roll 136. 


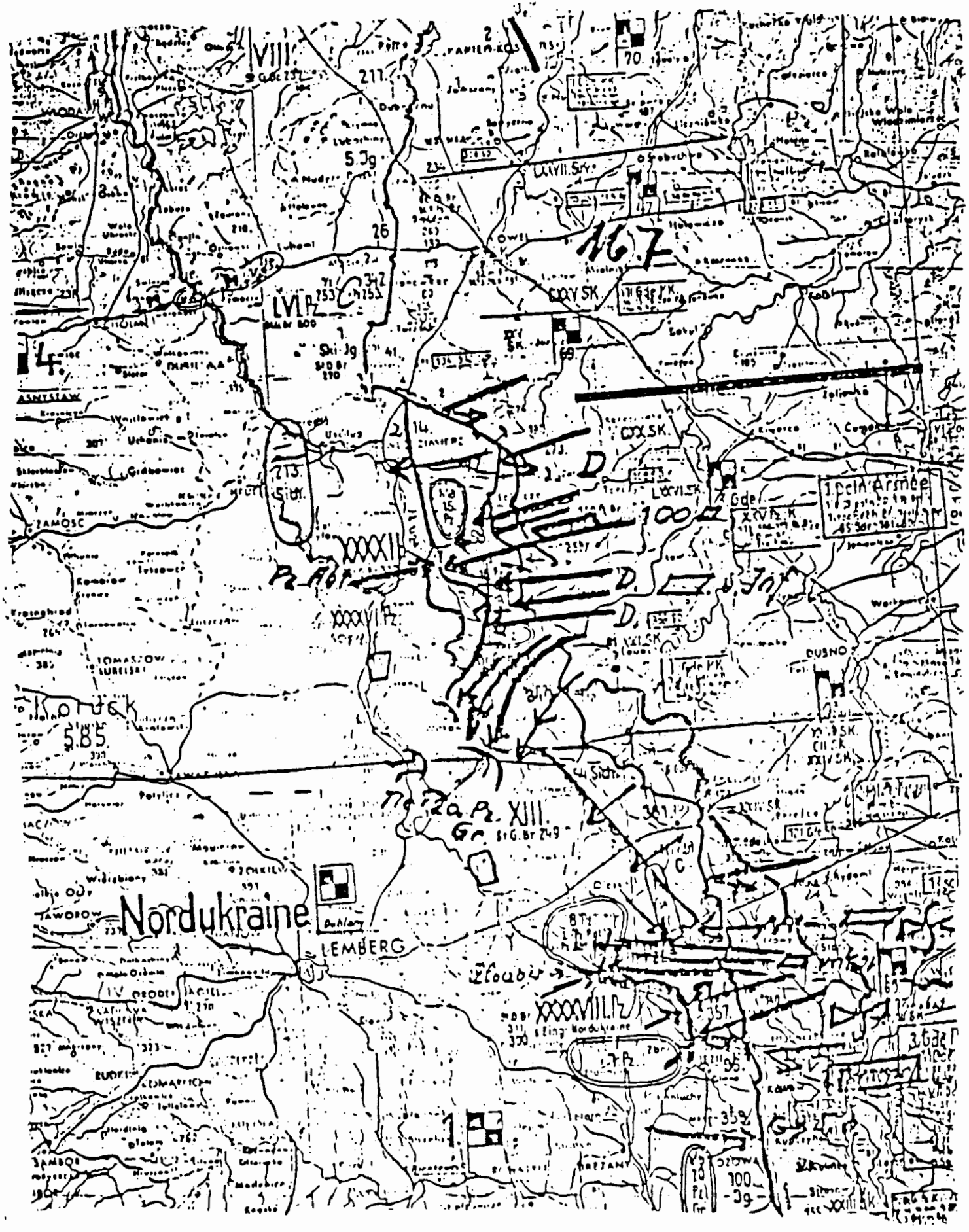

Figure 173. Army Group North Ukraine, July 16, 1944.

Source: $\mathrm{OKH}$, Der Grosse Durchbruch Bei Har.

Nordukraine U. Kaempfe am grossen Weichsel-

Brueckenkopf v. 8.7. - 29.8.44 National Archives

Microfilm Publication T-78, Roll 136. 


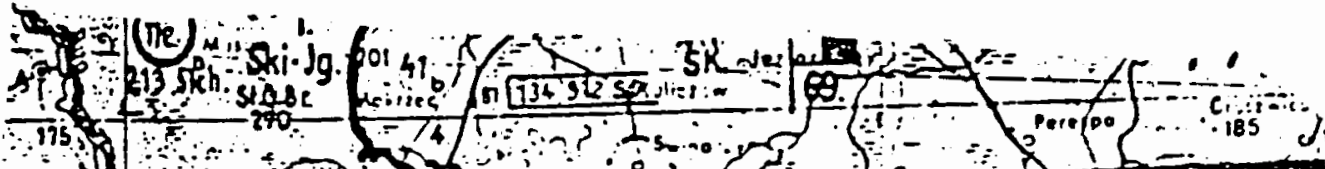

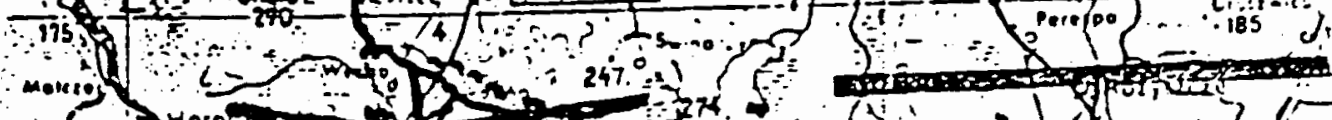

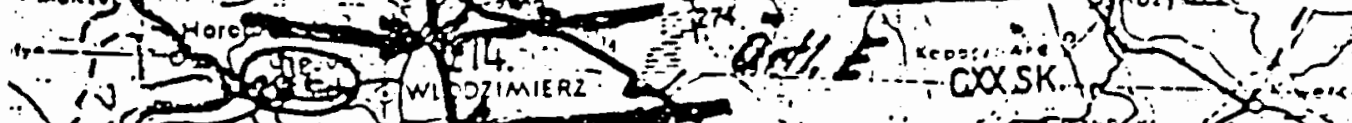

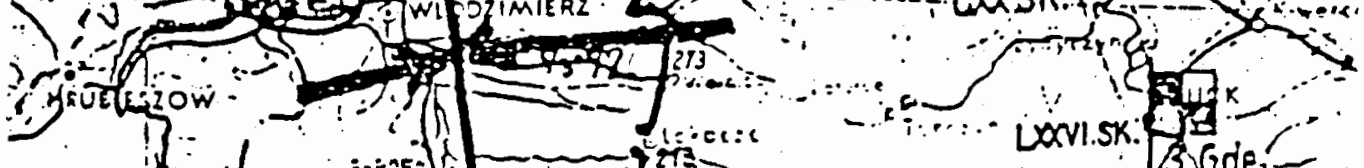

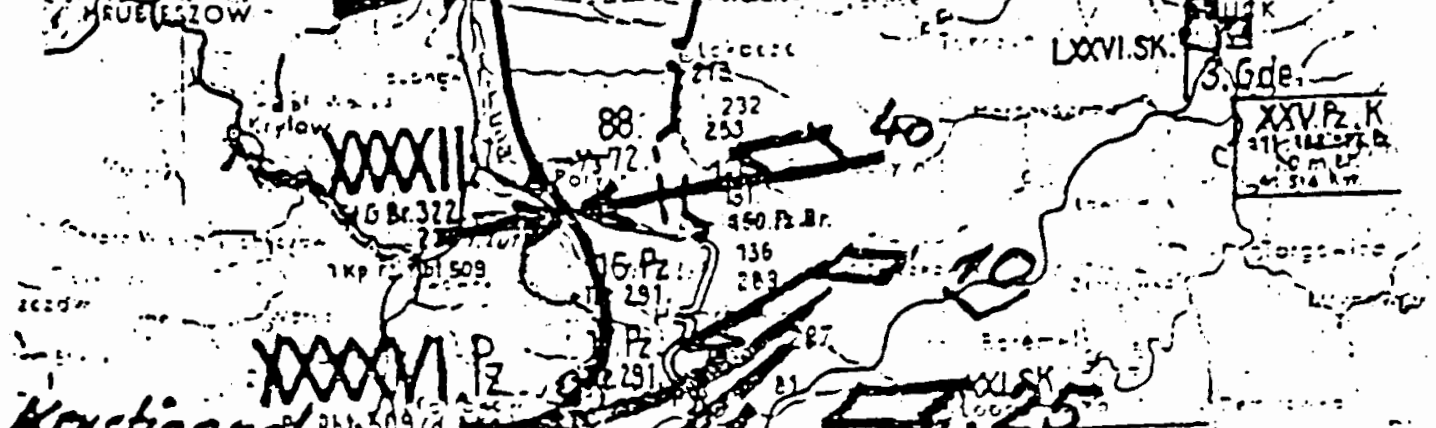

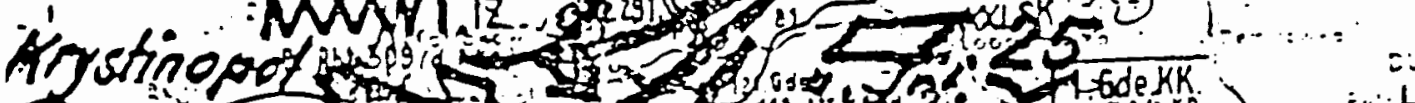

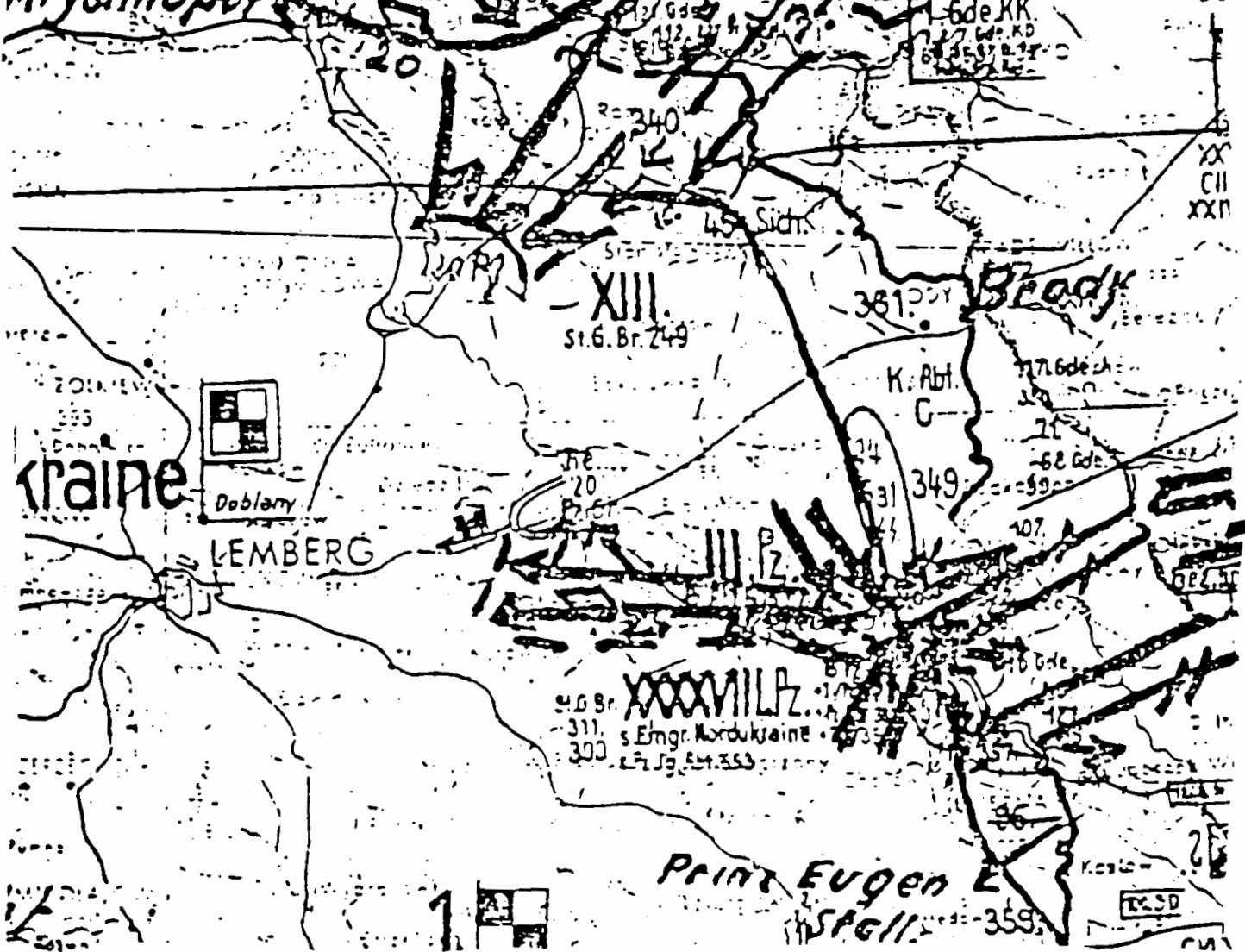

Figure 174. Soviet Attacks On The Flanks Of The XIII Army Corps, July 17, 1944. Source: OKH, Der Grosse Durchbruch Bei Hgr. Nordukraine U. Kaempfe am grossen Weichsel-Brueckenkopf v. 8.7. - 29.8.44 National Archives Microfilm Publication T-78, Roll 136. 


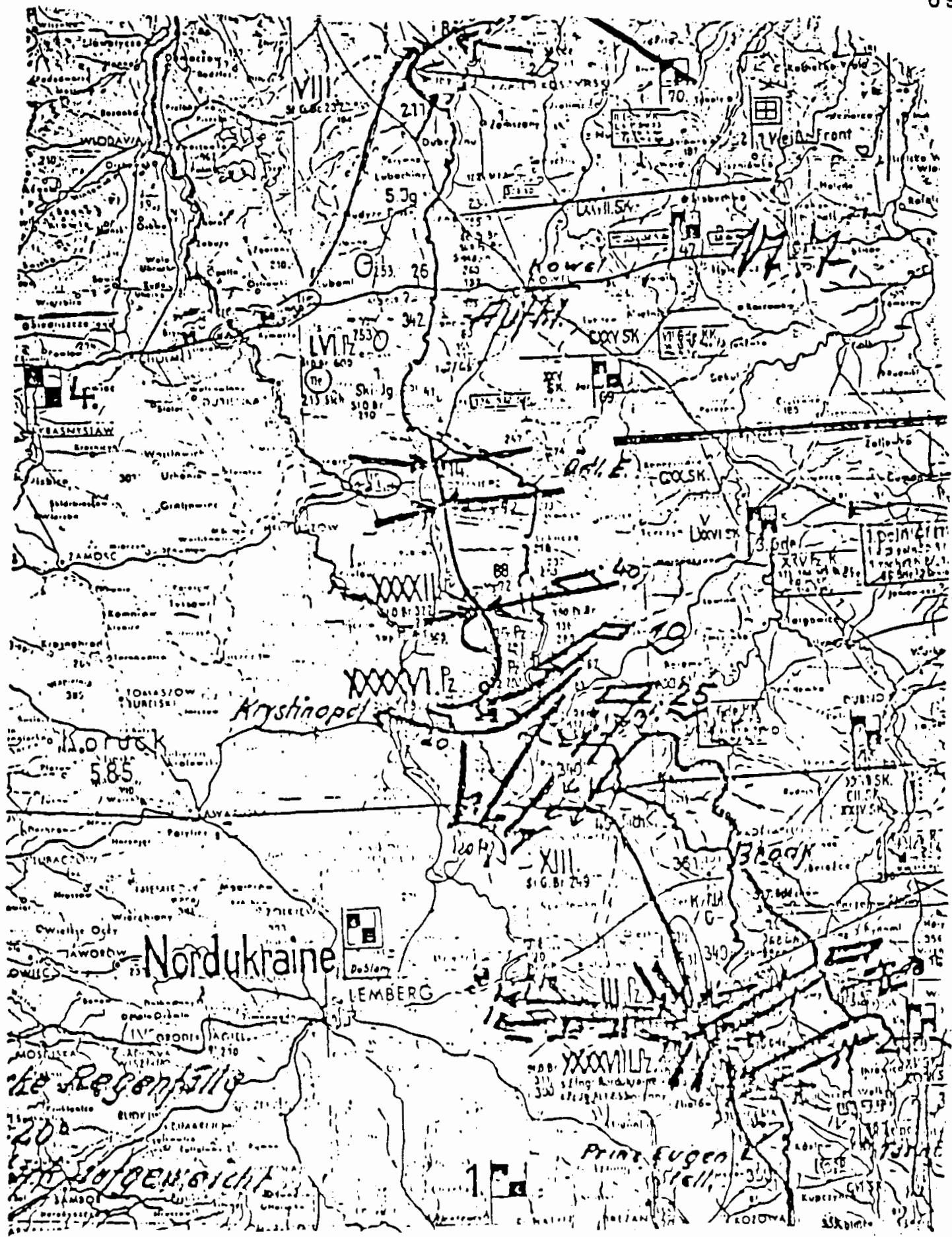

Figure 175. Army Group North Ukraine, July 17, 1944.

Source: OKH, Der Grosse Durchbruch Bei Har.

Nordukraine U. Kaempfe am grossen Weichsel-

Brueckenkopf v. 8.7. - 29.8.44 National Archives

Microfilm Publication T-78, Roll 136. 


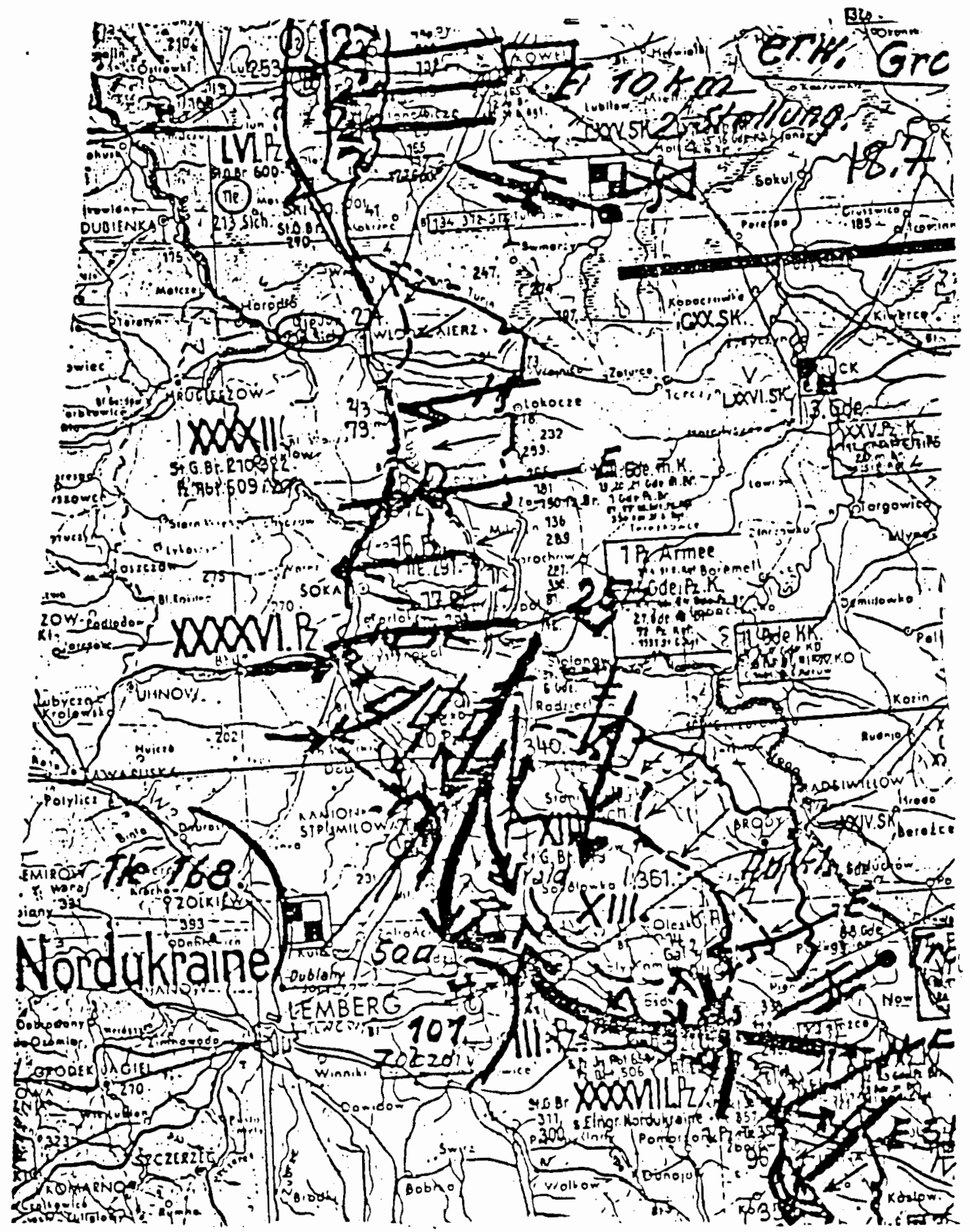

Eigure 176. The Encirclement Of The XIII Army Corps On July 18, 1944. Source: OKH, Der Grosse Durchbruch Bei Hor. Nordukraine u. Kaempfe am grossen WeichselBrueckenkopf v. 8.7. - 29.8.44 National Archives Microfilm Publication T.78, Roll 136. 


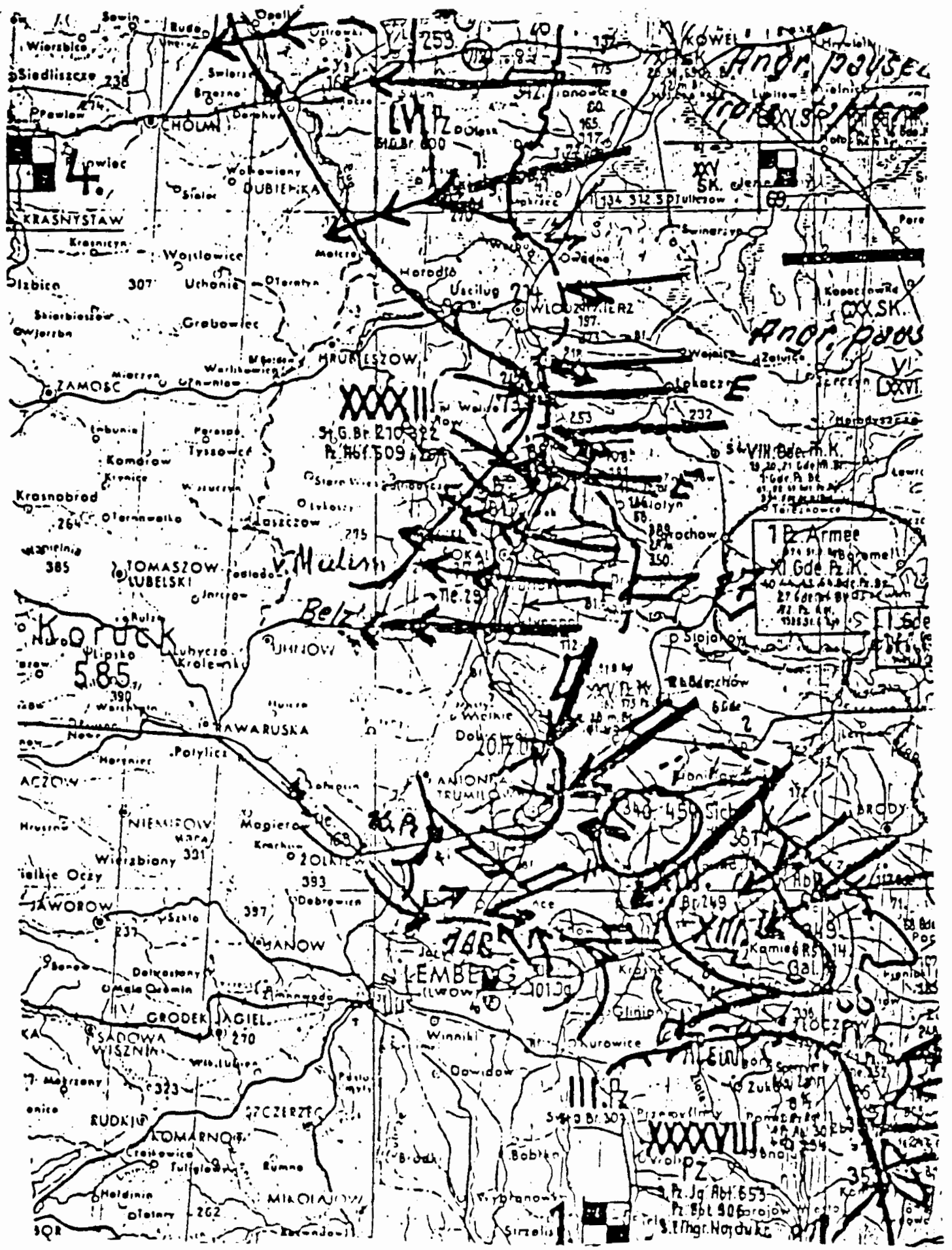

Figure 177. The 4th And 1st Panzer Armies, July 19, 1944. Source: OKH, Der Grosse Durchbruch Bei Har.

Nordukraine U. Kaempfe am grossen WeichselBrueckenkopf v. 8.7. - 29.8.44 National Archives Microfilm Publication T.78, Roll 136. 


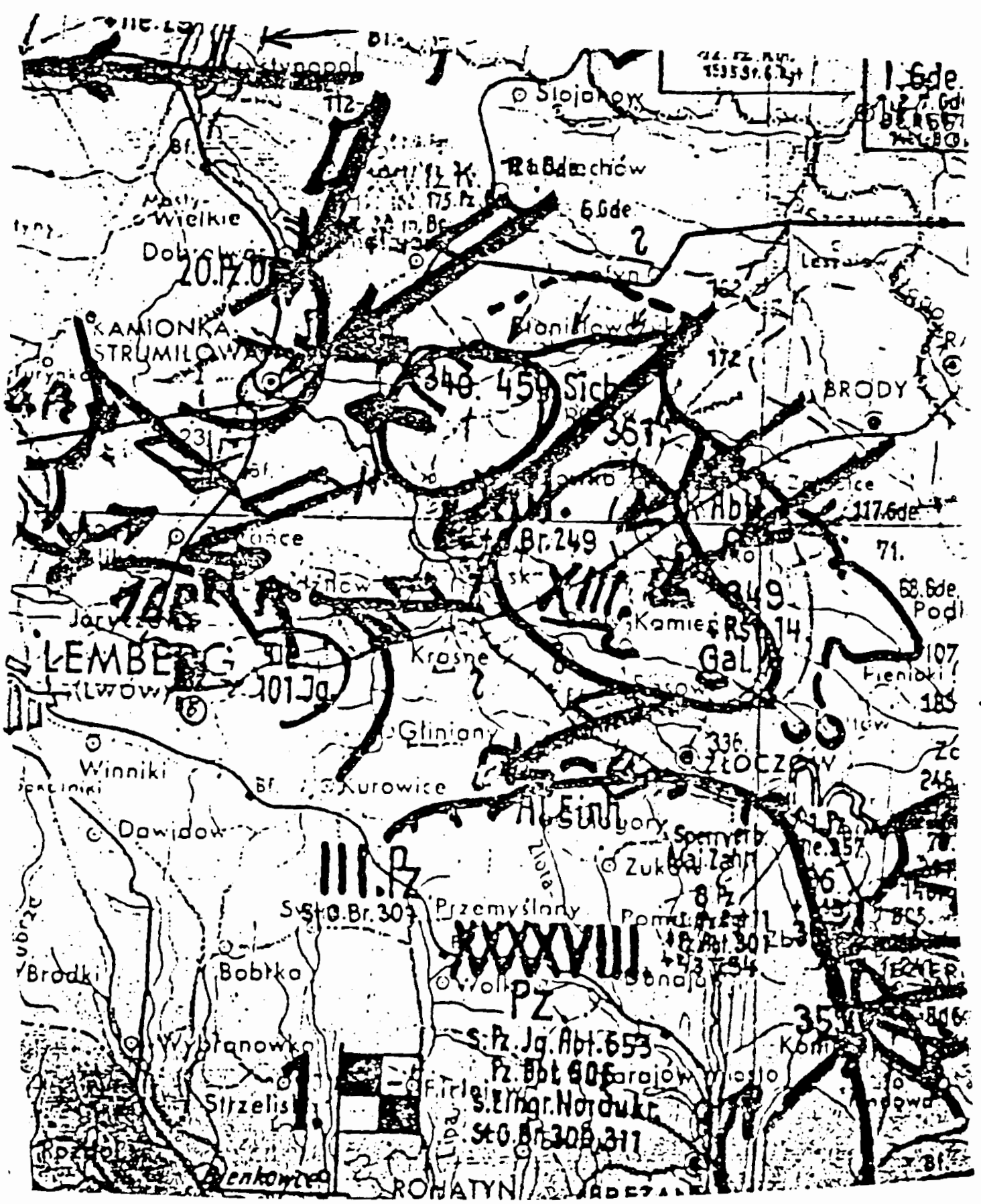

Figure 178. The Encircled XIII Army Corps, July 19, 1944. Source: OKH, Der Grosse Durchbruch Bei Hgr. Nordukraine $u$. Kaempfe am grossen WeichselBrueckenkopf v. 8.7. - 29.8.44 National Archives Microfilm Publication T-78, Roll 136. 


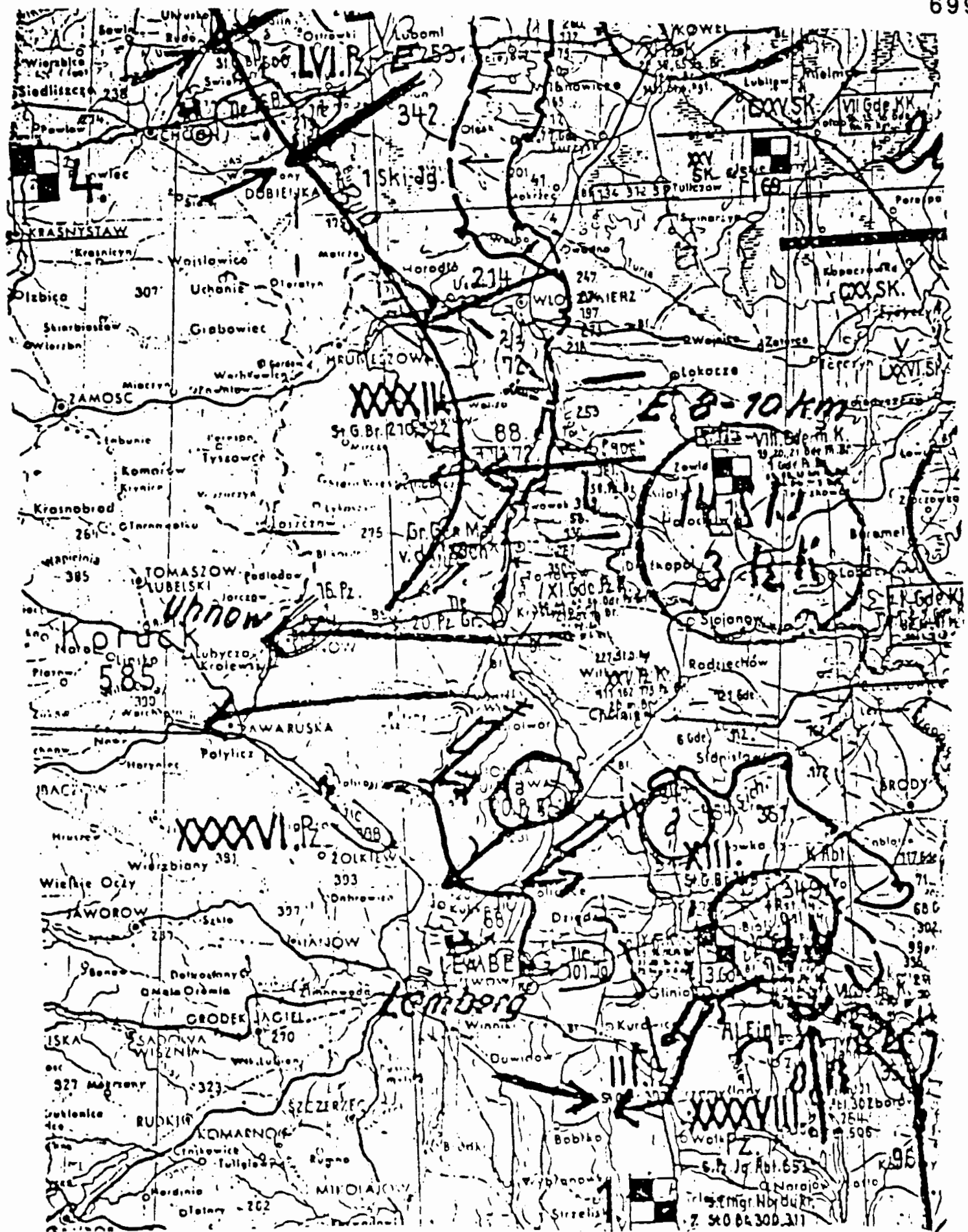

Figure 179. The 4th And 1st Panzer Armies, July 20, 1944. Source: OKH, Der Grosse Durchbruch Bei Har. Nordukraine U. Kaempfe am grossen WeichselBrueckenkopf v. 8.7. - 29.8.44 National Archives Microfilm Publication T-78, Roll 136. 


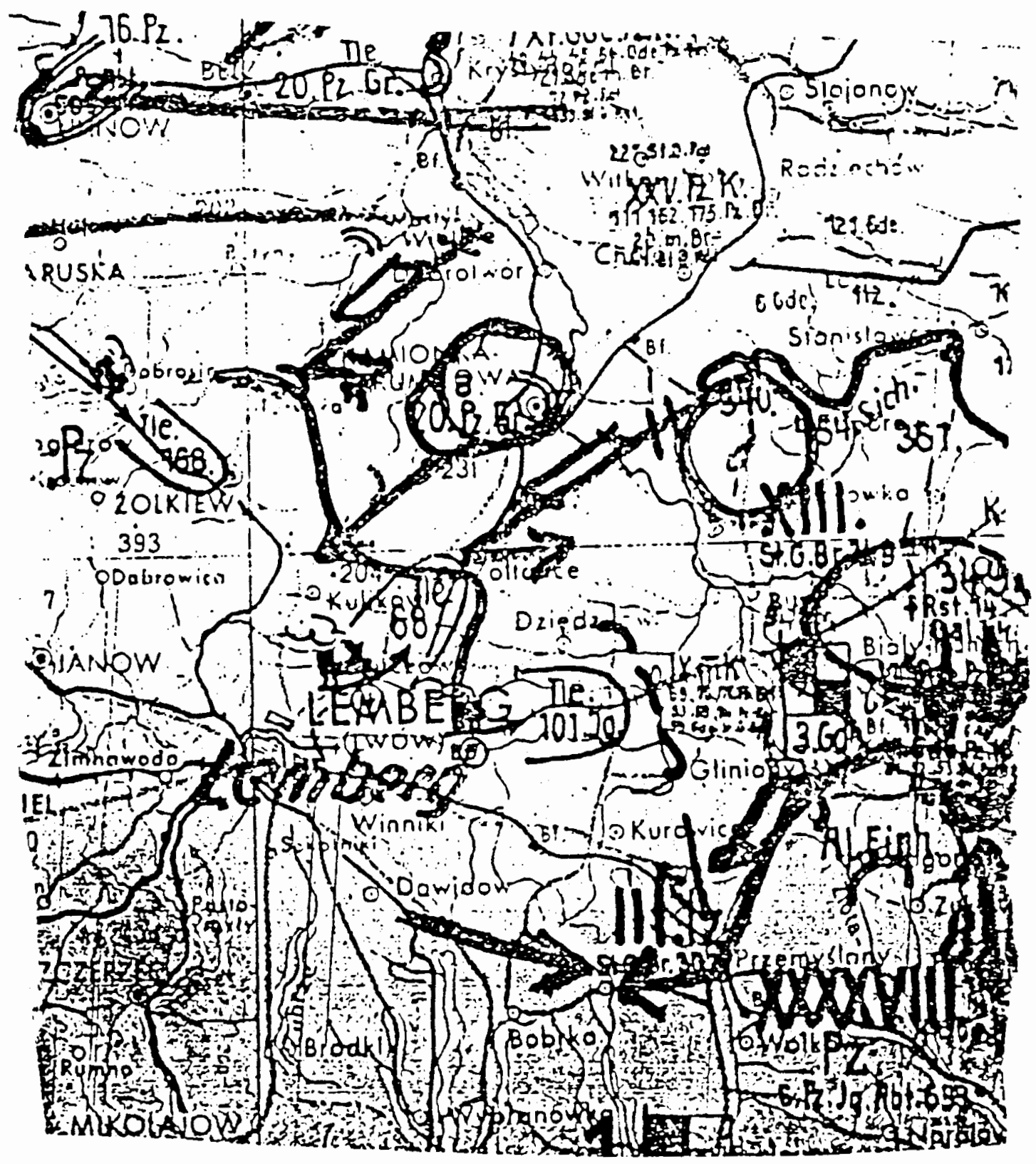

Figure 180. The Breakout Of The XIII Army Corps, July 20, 1944. Source: OKH, Der Grosse Durchbruch Bei Hgr. Nordukraine u. Kaempfe am grossen WeichselBrueckenkopf v. 8.7. - 29.8.44 National Archives Microfilm Publication T-78, Roll 136. 


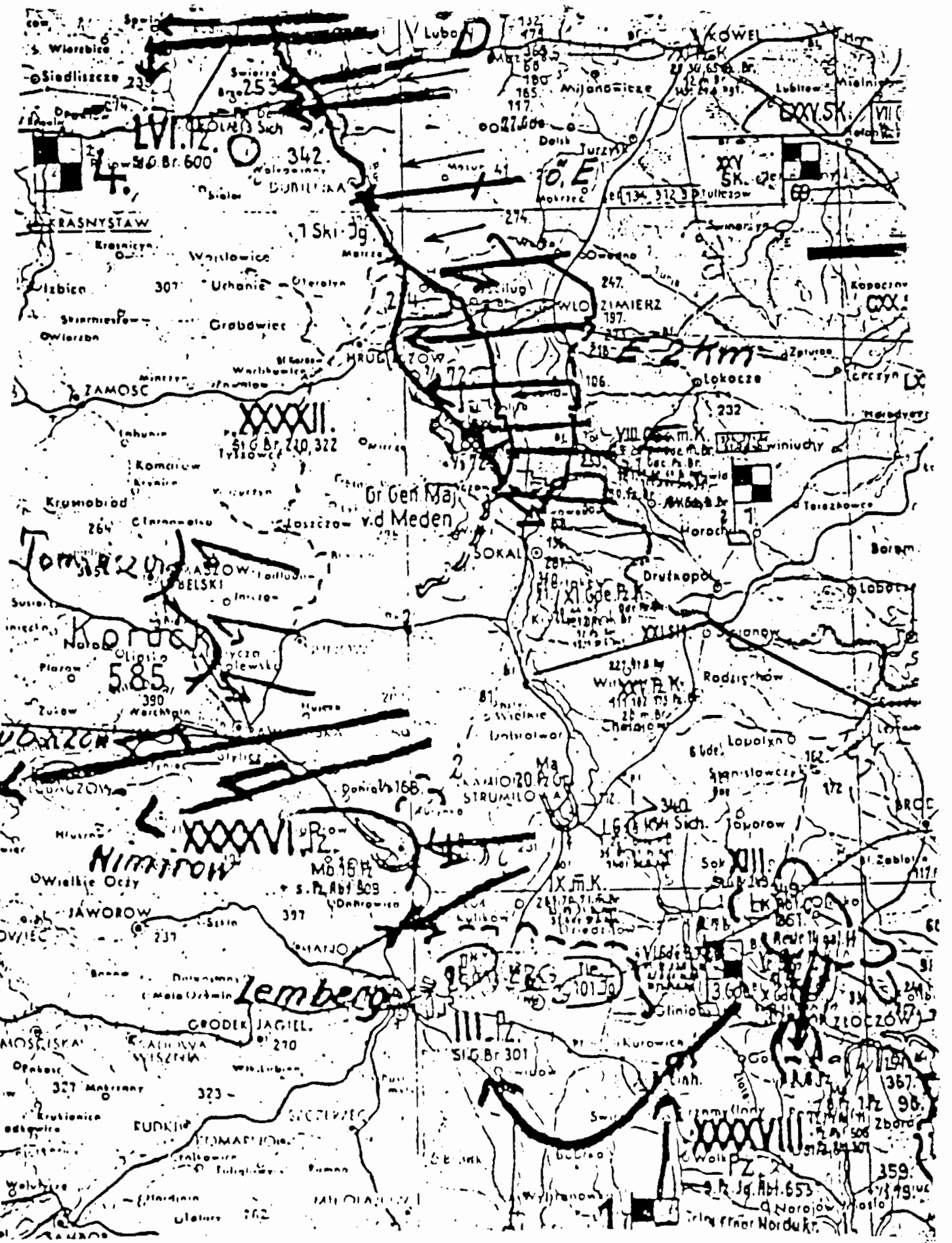

Figure 181. The 4th And 1st Panzer Armies, July 21, 1944. Source: OKH, Der Grosse Durchbruch Bei Har. Nordukraine 4. Kaempfe am grossen WeichselBrueckenkopf v. 8.7. - 29.8.44 National Archives Microfilm Publication T-78, Roll 136. 


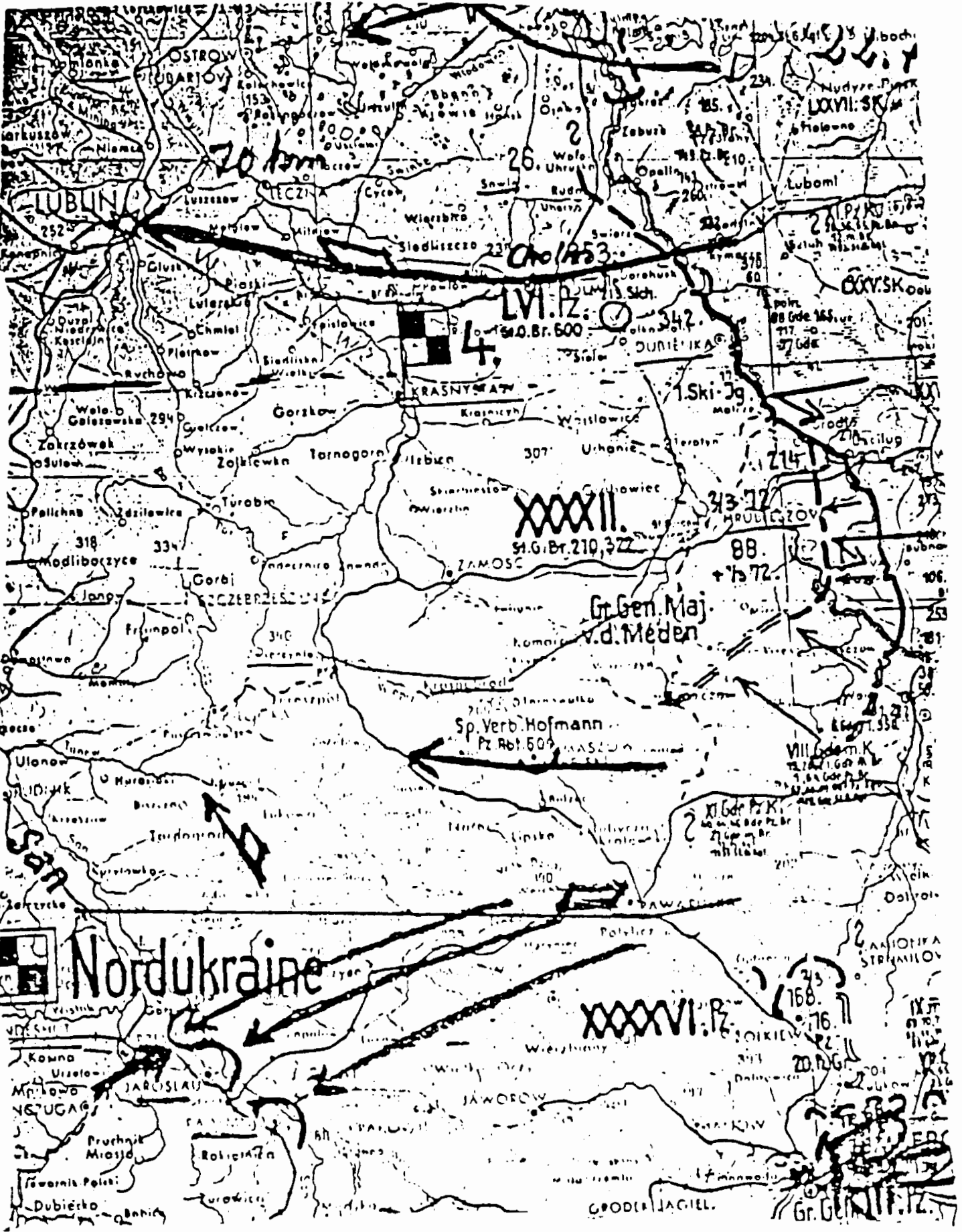

Figure 182. Army Group North Ukraine, July 22, 1944.

Source: OKH, Der Grosse Durchbruch Bei Hgr.

Nordukraine u. Kaempfe am grossen Weichsel-

Brueckenkopf v. 8.7. - 29.8.44 National Archives

Microfilm Publication T.78, Roll 136. 

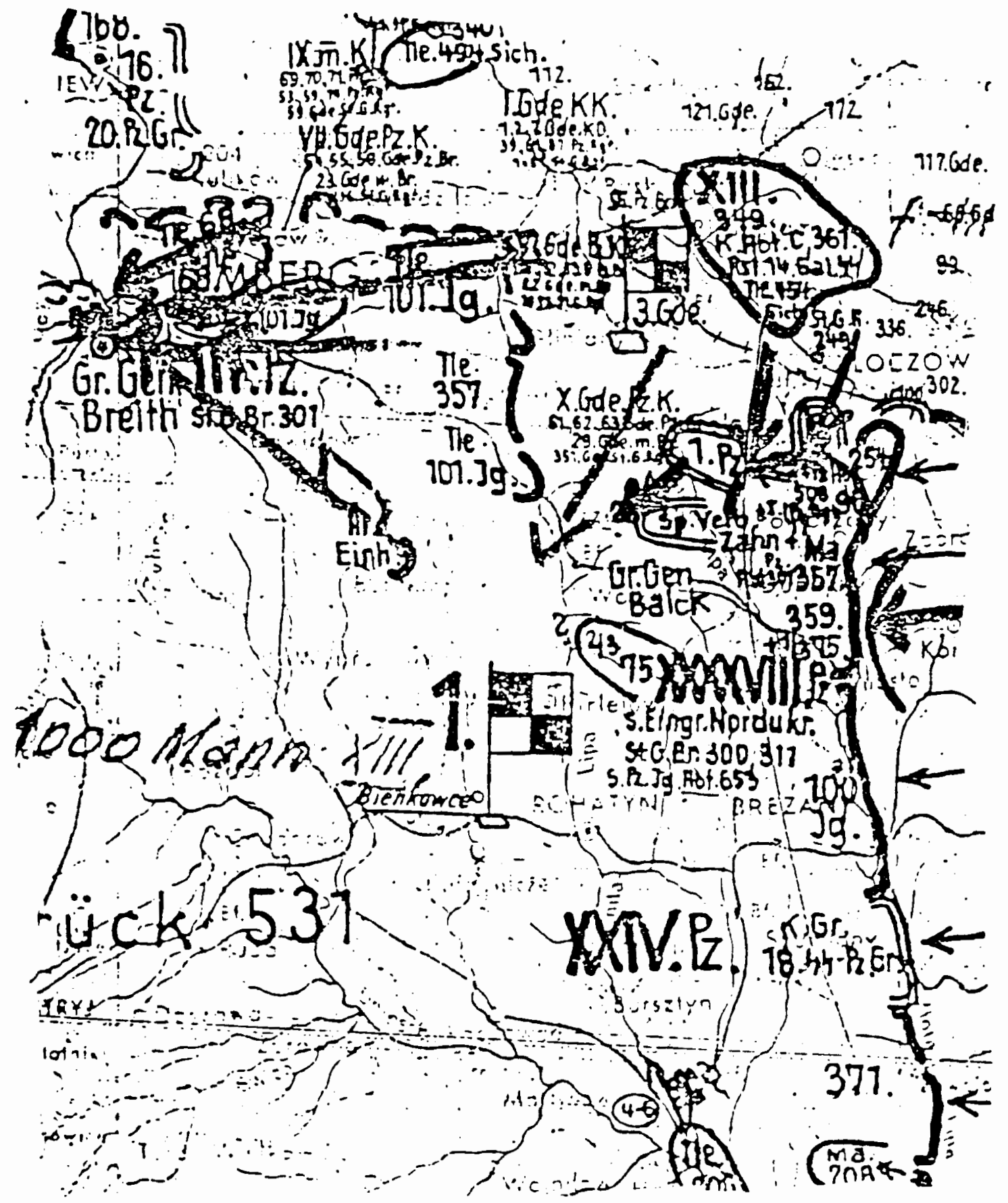

Figure 183. The XIII Army Corps, July 22, 1944.

Source: OKH, Der Grosse Durchbruch Bei Hor.

Nordukraine U. Kaempfe am grossen Weichsel-

Brueckenkopf v. 8.7. - 29.8.44 National Archives

Microfilm Publication T-78, Roll 136. 


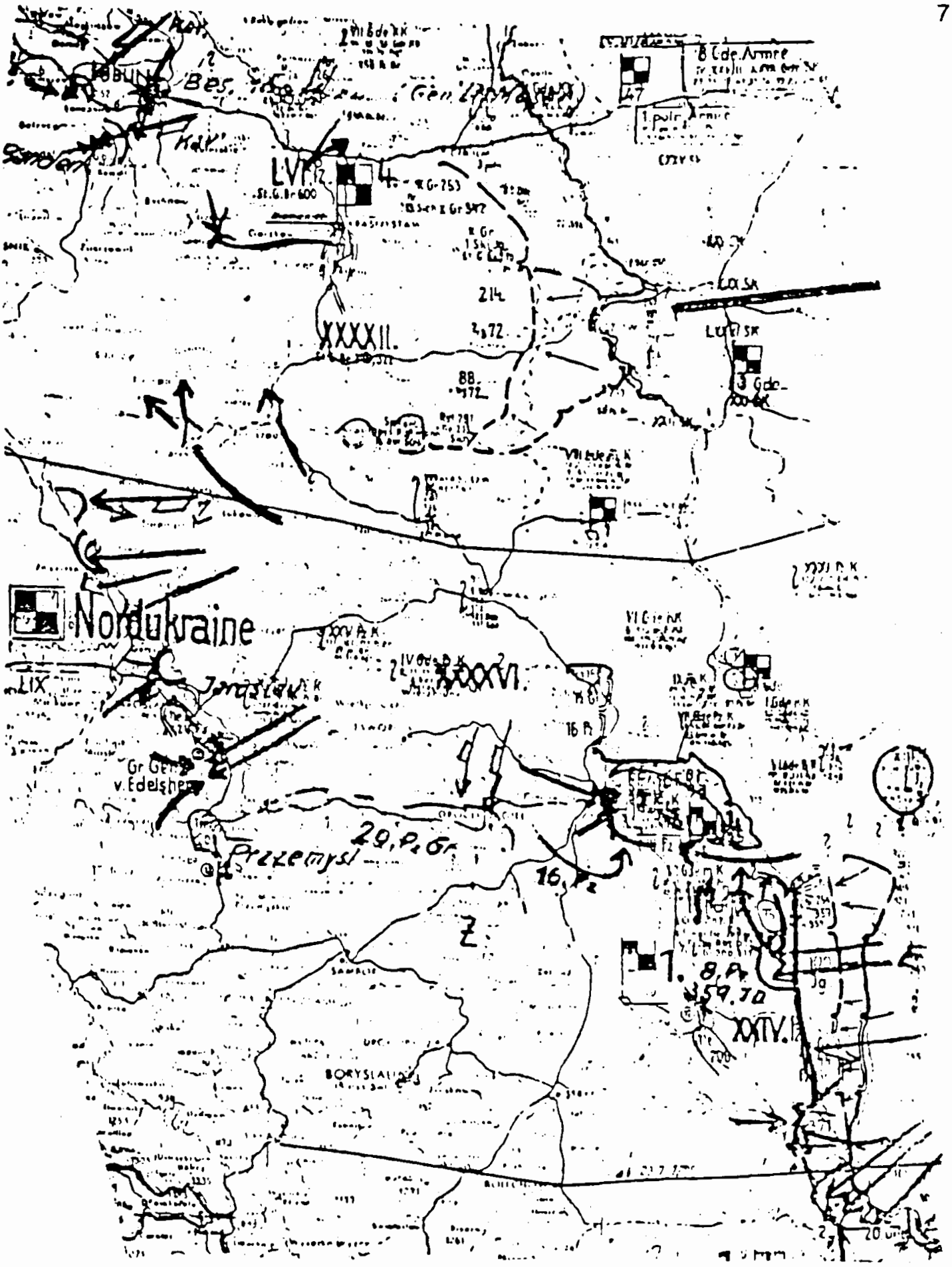

Figure 184. Army Group North Ukraine, July 24, 1944.

Source: OKH, Der Grosse Durchbruch Bei Har.

Nordukraine u. Kaempfe am grossen Weichsel-

Brueckenkopf v. 8.7. - 29.8.44 National Archives

Microfilm Publication T-78, Roll 136. 


\section{NOTES TO CHAPTER $X$}

${ }^{1}$ Colonel T.N. Depuy \& Paul Martell, Great Battles On The Eastern Front: The Soviet-German War 1941-1945 (New York: The Bobbs-Merrill Company Inc., 1982), p. 169.

2John Erickson, The Road To Berlin (Boulder, Colorado: Westview Press, 1983), p. 232.

3 ibid.

${ }^{4}$ Ibid.

5 Mehner, GHTBDW Vol. 10, p. 504.

6Dupuy, p. 167.

7ibid.

${ }^{8}$ Erickson, p. 231.

9lbid.

10Depuy, p. 167; Erickson, p. 232.

11 ibid.

12/bid.

13lbid.

${ }^{14}$ Erickson, p. 231.

15Oberkommando der 4. Panzer Army, Kriegstagebuch A.H.QU. 2. Juli 1944 NAMP T-313 ROLL 410.

16Ibid.

17 Ibid.

18/bid.

19 lbid.

201bid.

21 lbid. 
22 Ibid.

${ }^{23}$ General Oberst Harpe, Oberbefehlshaber der H.Gr. Nordukraine, Grosskampfgliederung. A.H.QU. 4.7.1944 NAMP T-313 ROLL 410.

24 Ibid.

25Mehner, GHTBDW VOL. 10, P. 340.

26 lbid.

27 Ibid., p. 343.

28 Ibid.

29 Ibid.

30 lbid.

${ }^{31}$ Rolf Stoves, Die 1. Panzer Division (Bad Nauheim: Verlag Hans-Henning Podzun, 1961), p. 620.

32Mehner, GHTBDW Vol. 10, p. 343.

33lbid.

${ }^{34}$ Stoves, p. 620.

35 Ibid.

36Mehner, GHTBDW Vol. 10, p. 346.

37 Ibid.

38 lbid.

${ }^{39}$ Ibid.

${ }^{40}$ Stoves, p. 621.

${ }^{41}$ Ibid.

42Mehner,GHTBDW VOL. 10, P. 346.

43/bid., p. 349. 
44 lbid.

45 Ibid.

46 lbid.

47Ibid.

48 lbid.

${ }^{49}$ Lt. General Lange, Korpsabteilung $C$ in der Kesselschlacht des XIII A.K. Suedwestlich Brody vom 13.-22. Juli 1944 NAMP T-78 Roll 139.

50 lbid.

51 Ibid.

52 Mehner, GHTBDW Vol. 10, p. 349.

53 Ibid., p. 352

54 Ibid.

55 Ibid.

56 Ibid

57 Ibid.

58 Lange

59 lbid.

60Richard Landwehr, Fighting For Freedom: The Ukrainian Volunteer Division Of The Waffen-SS (Silver Spring, Maryland: Bibliophile Legion Books, Inc., 1985), pp. 77-78.

61 Mehner, GHTBDW, Vol. 10, p. 355.

62 Ibid

63/bid.

64lbid. 
65Ibid.

66 ibid.

67/bid.

68 ibid.

69 lbid.

70 lbid.

71 Lange

72 bid.

73 bid.

74 lbid.

75 bid.

76 lbid.

77Landwehr, p. 79.

78Mehner, GHTBDW Vol. 10, p. 359

79 Ibid.

80 lbid.

81 lbid.

82 Ibid.

${ }^{83}$ Lange

${ }^{84}$ Ibid.

85 Ibid.

${ }^{86}$ lbid.

87Ibid. 
88 bid.

89 lbid.

90 lbid.

${ }^{9}{ }^{1}$ bid.

92/bid.

93/bid.

${ }^{94}$ Mehner, GHTBDW Vol. 10, p. 359.

95 lbid.

${ }^{96}$ |bid.

97Ibid., p. 362.

98 ibid.

99/bid.

100 Ibid.

101 lbid.

102Lange

103/bid.

104 /bid.

105 Ibid.

106 jbid.

107/bid.

108 Ibid

109ibid.

110 Ibid. 
111 Ibid.

112Mehner, GHTBDW Vol. 10, p. 362.

${ }^{113}$ Stoves, p. 625.

114 ibid., p. 624

115 lbid.

${ }^{116}$ Ibid.

117|bid.

118 Mehner, GHTBDW Vol. 10, p. 362.

119 Ibid.

120 lbid., p. 365

121 lbid.

122Ibid.

123/bid.

124 Ibid.

125/bid.

126Lange

127/bid.

128 Ibid.

${ }^{129}$ lbid.

130 tbid.

${ }^{131}$ Ibid.

132 Stoves, p. 625.

133Mehner, GHTBDW Vol. 10, p. 365 
134Lange

135/bid.

136/bid.

137/bid.

138 /bid.

${ }^{139}$ lbid.

140 lbid.

141 Ibid.

142 /bid.

143 lbid.

144 Ibid.

145/bid.

146/bid.

147/bid.

148 /bid.

${ }^{149}$ lbid.

150 Ibid.

${ }^{151}$ Ibid.

152 Ibid.

153/bid.

154 /bid.

155Mehner, GHTBDW Vol. 10, p. 365.

156/bid. 
157/bid., p. 368.

158 Ibid.

159 /bid.

$160 /$ bid.

161 Ibid.

162Ibid.

163/bid.

164Lange

165|bid.

166/bid.

167Landwehr, p. 83.

168 Ibid.

169/bid.

170 bid.

${ }^{171}$ Ibid.

172/bid.

173!bid., p. 84.

${ }^{174}$ Mehner, GHTBDW Vol. 10, p. 368.

175 Ibid.

176/bid., p. 371.

177/bid.

178 Ibid.

179 Ibid. 
180Lange

181 Ibid.

182 Ibid.

183/bid.

${ }^{184}$ Mehner, GHTBDW Vol. 10, p. 371.

185 Ibid.

186W.E.D. Allen and Paul Muratoff, The Russian Campaigns of 1944-45 (New York: Penguin Books, 1946), p. 159.

187P.N. Pospelov, p. 405.

188|bid.; Org. der Wehrmacht 2. OKW/Org. Abt. und Heerespersonalabt, Zusammenstellung der in diesem Kriege gefallenen, toetlich verunglueckten. Verstorbenen, Vermissten und in Gefangenschaft geratenen Generale. Flensburg 5 June 1945 NAMP T-77 Roll 785.

189 Ibid.

190Landwehr, p. 84.

${ }^{191}$ Alex Buchner, Ostfront 1944 (Friedberg: Podzun - Pallas - Verlag GMBH, 1988), p. 260. 


\section{CHAPTER XI}

\section{ARMY GROUP SOUTH UKRAINE AND THE DEBACLE IN RUMANIA}

Stavka issued the formal order for an attack on Rumania on August 2, 1944.1 Marshal Timoshenko was assigned by Stavka to coordinate the attack on Rumania by the 2nd and 3rd Ukrainian Fronts. ${ }^{2}$ The 2nd Ukrainian Front was commanded by General Malinovskiy and covered a $330 \mathrm{~km}$ sector stretching from Chernovtsy to Orgeyev (see Figure 185). The 3rd Ukrainian Front under the command of General Tolbukhin extended $260 \mathrm{~km}$ along the Dniester River from Orgeyev to the Black Sea (see Figure 185). ${ }^{3}$ Both fronts were to breakthrough on their respective sectors and by means of a double envelopment encircle the German 6th Army in the area of Kishinev by linking up together in the German rear. ${ }^{4}$ The 2nd Ukrainian Front was to breakthrough the German defenses northwest of lasi (Jassy) and seize the Pruth river crossings on the west bank depriving the Germans of a retreat route. The Soviets would also seize Bacau, Vaslui and Husi in the encirclement. 5 The 3rd Ukrainian Front was to breakthrough the German defenses south of Bendery taking Leovo and Tarutino while advancing toward Opachi and Husi where the encirclement would be completed from 
the southwest in conjunction with the 2nd Ukrainian Front. ${ }^{6}$ Once the encirclement was completed the 3rd Ukrainian Front was to advance south crossing the Danube and the 2nd Ukrainain Front was to move southwest taking Ploesti, Bucharest and the passes in the Carpathians and Transylvanian alps. ${ }^{7}$

The Soviets employed the same battle proven techniques that had been successful in White Russia. The Soviets established numerical superiority over Army Group South Ukraine and concentrated this superiority on narrow attack sectors to guarantee successful breakthroughs (see Table XXXXVII). The combined 2nd and 3rd Ukrainian Fronts contained 90 Infantry Divisions, 6 Tank and Mechanized Corps, 1 Cavalry Corps and numerous independent formations. ${ }^{8}$ This amounted to $1,250,000$ troops, 16,000 artillery guns and mortars, 1870 tanks and selfpropelled guns and 2,200 aircraft (see Tables XXXXVIII \& L). ${ }^{9}$

Army Group South Ukraine contained the German 6th and 8th Armies along with the Rumanian 3rd and 4th Armies. This amounted to 43 infantry divisions, 3 Panzer divisions, 1 Panzer Grenadier division and 5 infantry brigades (see Table XXXX|X). ${ }^{10}$ The German and Rumanian forces amounted to approximately 900,000 personnel (see Table L). The Rumanians accounted for 22 divisions and 5 brigades. ${ }^{11}$ The Germans had 25 divisions with about 360,000 troops stationed in Rumania. ${ }^{12}$ The Axis forces had 7600 artillery guns and mortars, 400 tanks and self-propelled guns and 810 combat aircraft (see Table L). ${ }^{13}$ 'Therefore, a comparison of Soviet to Axis forces reveals a substantial Soviet numerical superiority. 
The Soviets enjoyed a superiority of 1.4 to 1 in troops, 2.1 to 1 in artillery, 4.6 to 1 in tanks and self-propelled guns and 2.7 to 1 in aircraft (see Table L). ${ }^{14}$

Army Group South Ukraine was deployed along a $671.7 \mathrm{~km}$ front with an average divisional sector of $17.223 \mathrm{~km}$ (see Table LI). ${ }^{15}$ The 3rd Rumanian Army held a total of $121.5 \mathrm{~km}$ with an average divisional sector of $20.25 \mathrm{~km}$ (see Table LI). The German 6th Army held a total of $220.3 \mathrm{~km}$ with an average divisional sector of $13.76 \mathrm{~km}$. The German 8th Army held a total of $329.9 \mathrm{~km}$ of the front with an average divisional sector of $19.4 \mathrm{~km}$ (see Table LI). The weakest sectors of the front were held by the Rumanian troops on the flanks of German divisions. Rumanian divisions in Army Group Dumitrescu held $140 \mathrm{~km}$ out of $342 \mathrm{~km}$ of the front (see Table LII). Rumanian divisions in Army Group Woehler held 128 km. out of $330 \mathrm{~km}$ of the front (see Table LII). Therefore, the Rumanians held $268 \mathrm{~km}$ out of $672 \mathrm{~km}$ or $40 \%$ of the entire frontage held by the combined Army Groups Woehler and Dumitrescu (see Table LII).

Soviet strategy was to attack the Rumanian divisions on the flanks of the German divisions. The newly organized German 6th Army which replaced the 6th Army lost at Stalingrad was deployed along the front similiar to the old 6th Army at Stalingrad with Rumanian divisions holding its flanks and without adequate reserves. Soviet strategy was to concentrate its attack on the junction between neighboring German and Rumanian divisions. 16 The initial penetrations were to be made against Rumanian 
divisions on the flanks of the German 6th Army with the objective of driving deep into the German rear area and encircling it.

The Soviets concentrated their forces on narrow breakthrough sectors. The Soviets concentrated $73 \%$ of the 3rd Ukrainian Front's artillery to support the breakthrough sectors of the 57th, 37th and 46th Armies on an $18 \mathrm{~km}$ wide breakthrough sector. ${ }^{17}$ This permitted the Soviets to achieve a density of 250 guns, mortars and rocket launchers for each kilometer of the breakthrough sector. ${ }^{18}$ The 2nd Ukrainian Front's breakthrough sector was $16 \mathrm{~km}$ wide with 25 divisions assigned for the breakthrough (see Table XXXXVII). The 3rd Ukrainian Front had 24 divisions concentrated on its $18 \mathrm{~km}$ wide breakthrough sector (see Table XXXXVII). The Soviet formula of concentration of forces on narrow breakthrough sectors which had proven successful in Belorussia was once again employed in Rumania.

\section{GERMAN INTELLIGENCE FAILURE IN RUMANIA}

\section{Foreign Armies East}

Colonel Gehlen's intelligence organization which had failed to accurately predict the main Soviet offensive in Belorussia in June 1944 was also forecasting Soviet military activity opposite Army Group South Ukraine. Foreign Armies East (FHO) intelligence summary on July 30,1944 stated: 
Altogether the impression emerged that the Soviet High Command for the immediate future had dropped the ideas about a major offensive against the Army Group. ${ }^{19}$ However, FHO on August 7, 1944 noted an increase in Soviet reconnaisance efforts over the preceeding days which could serve as preparation for local attacks. 20 On August 8, 1944, FHO noted that the date of the possible Soviet attack could not be forseen with certainty, however, the situation permitted the Soviets to attack after only brief preparations. ${ }^{21}$ FHO on August 11, 1944 noted significant changes on the front. It recognized that for the last 10 days on Army Group South Ukraine's front from Tiraspol to the Carpathians that extensive Soviet regrouping was underway and the purpose was not yet definitely recognizable. Soviet forces were concentrating on both sides of the Pruth river, but the date of the attack had not yet been determined. 22 The assessment by FHO on August 15, 1944 reiterated the view that a major offensive against Army Group South Ukraine was unlikely. Soviet operations into the Balkans were viewed as limited, local attacks designed to prevent the transfer of German divisions to the central front where the major Soviet efforts were expected to continue (see Figure 186). Once again Foreign Armies East had predicted the wrong front for the next major Soviet operation.

FHO on August 16, 1944 noted that regrouping and departures of Soviet units were occurring on Army Group South Ukraine's front. Aerial reconnaisance indicated reinforcements in the area south of Tiraspol and in the area of Jassy. Attacks on a local scale to secure territory were probable. 23 The last three days preceeding 
the Soviet offensive against Army Group South Ukraine were filled with observations by FHO of Soviet preparations for an offensive. The FHO assessment on August 17, 1944 indicated that the preparations by the Soviets in the area south of Tiraspol could be expected to only result in local attacks. The stronger Soviet forces were noted to be assembling on the northern front of the Army Group in the sector of Jassy-Targul Frumos. However, FHO calculated that the amount of Soviet forces available for the attack was insufficent for operations with far ranging objectives. Therefore, strong local attacks were to be expected in the JassyTargul Frumos sector. Both attacks against Army Group South Ukraine were forecasted as local attacks and not a major offensive (see Figure 186). 24

FHO on August 18, 1944 continued to predict the main attack on the Dniester front in the area south of Tiraspol. Stronger Soviet attacks were expected soon to begin in the area of Jassy-TargulFrumos. Two Soviet tank corps were expected to participate in the attack in the Jassy area and the concentration of artillery was reaching levels of 150 guns per kilometer. ${ }^{25}$ Soviet activity on August 19, 1944 preceeding the major offensive was marked by numerous attacks against the entire front of Army Group South Ukraine which served to partly contain and distract German forces. In the area of Tiraspol and to the south and between the Pruth and Sereth rivers attacks were noted as preliminary before the anticipated stronger attacks. The Soviet 5th Air Army was noted to have regrouped in the area west of the Pruth river. The 
objective of the Soviets could only be estimated when a clearer picture of the employment of Soviet armored formations was available. ${ }^{26}$ In the area of Jassy-Targul Frumos and also on the east bank of the Pruth river attacks exceeding a local scope now had to be regarded as a greater possibility. ${ }^{27}$ Thus, on the day preceeding the major Soviet offensive FHO began to revise its forecast of Soviet intentions but this was already too late.

\section{RUMANIAN RELIABILITY}

Hitler and the German High Command overestimated Rumanian resolve to continue the war against the Soviet Union. False intelligence reports were transmitted through OKW concerning Rumanian loyalty to the Axis cause.28 The German minister to Rumania, von Killinger and Erik Hansen, Chief of the German Military Mission sent reports affirming Marshal Antonescu's loyalty to Hitler and the German cause. However, Antonescu's personal loyalty was confused with the loyalty of the Rumanian country to the continuation of the war.29 Foreign Minister von Ribbentrop, however, distrusted the reports he was receiving from Ambassador Killinger regarding the stability of the Antonescu regime and wanted a Panzer division stationed in Bucharest to guarantee the continued survival of the Antonescu government. 30 However, Colonel General Guderian could not make a panzer division available because of the continual crisis on the Eastern Front. ${ }^{31}$ Guderian 
instead wanted to send the 4th SS Polizei Division from Serbia to Rumania, but Jodl fobid it and Hitler did not act to overrule him.32 Therefore, a German combat division was not stationed in a strategic location in Bucharest to ensure Rumanian loyalty.

Colonel General Schoerner, Commander of Army Group South Ukraine, wrote Hitler on July 21, 1944 that the leadership in Rumania was wavering in its support of the continued war effort and Antonescu was loosing control.33 He recommended that Hitler personally interview Antonescu. Hitler apparently was displeased with Colonel General Schoerner's pessimistic attitude about Rumania and on July 23, 1944 he was transferred to the command of Army Group North. The High Command and in particular the new Chief of Staff of the Army, General Guderian was displeased with Colonel General Friessner's pessimistic attitude about the position of Army Group North in the Baltic area. 34 Therefore, The Commander of Army Group North, Colonel General Friessner was ordered to trade places with Schoerner and took over command of Army Group South Ukraine in a message received on July 23, 1944 from Adolf Hitler which stated:

Both Commanders of Army Group North and South Ukraine are to mutually change commands immediately. I promote General d. Inf. Friessner to Colonel General. ${ }^{35}$

Colonel General Friessner made the following annnouncement on July 26, 1944 to the soldiers of Army Group South Ukraine:

I have been appointed to the command of the Army Group with the confidence of the Fuehrer and I have assumed the command today. 
I expect from every soldier from the oldest General to the youngest Grenadier that as before he will do more than his duty at his post.

The apparent quiet on our front shall not deceive us. The war has entered its decisive stage. Any day the assault of the Bolshevik masses could begin against us. The unshakable belief in the Fuehrer and the Volk will give us the power to break the enemy in a fanatical battle of determination side by side with the brave soldiers of King Michael and the Marshal of Rumania.

In these decisive hours we look to the Fuehrer and promise him with immutable soldier's loyalty to follow him to the final victory. Long live the Fuehrer! 36

Colonel General Friessner on August 1, 1944 flew to Bucharest and was briefed by the German Ambassador von Killinger, Chief of the German Military Mission in Rumania, General d. Kav. Hansen, the commander of the German Luftwaffe in Rumania and Luftwaffe General Gerstenberg. General Gerstenberg in his briefing expressed his opinion that in case of unrest one German Flak battery would be sufficient to smash any putsch in Bucharest. ${ }^{37}$ Ambassador von Killinger informed Friessner that "Marshal Antonescu has the people and the government behind him. ${ }^{338}$ However, Friessner was not convinced and he asked von Killinger if the German government had prepared any measures in case of a governmental crisis. Von Killinger replied that "up to now none." "There is no governmental crisis to fear."39

Colonel General Friessner dissatisfied with the situation in Rumania sent Colonel Trotha with his personal letter by airplane to Hitler at the Fuehrer's Headquarters which stated: 
According to my earlier personal orientation at the front and in the rear territory since assuming command of Army Group South Ukraine and especially after the August 1st informational visit to the German and Rumanian Headquarters in Bucharest that occurred which confirmed the impression that the political and military circumstances in Rumania are not sufficiently secure to be able to lead the fighting troops without apprehension.

Subsequently, I am very disturbed on the basis of many rumors because of the uncertainty of the Rumanian troops and especially their higher commanders subordinate to my command, the German Ambassador and the German General with the Rumanian government in Bucharest claim to be informed about the political situation, but I have gained no reassuring impression. No one could give me a clear answer to my questions and minimized the insecure position of the Rumanian government. What happens when the many rumors already reported in the Army Group prove to be true and the Rumanian Government changes sides? The German Ambassador in Bucharest could not give me an answer to this question. It appears to me that to protect the troops under my command that it is an absolute necessity that the absolute security in the rear area be guaranteed. This can only be obtained by placing all German Headquarters, troops, and organizations under my command and allow me to operate our own intelligence service in the entire Rumanian area.

Should symptoms of insecurity of the Rumanian troops at the front be further confirmed, then, there must be an immediate withdrawal of the front behind the Pruth and the line Galatz-Focsani-edge of the Carpathians will be established. 40

Colonel Trotha reported to Friessner on August 8, 1944 the outcome of his visit to Hitler's Headquarters. He indicated that 
Colonel General Guderian instructions were that in event that further forces were withdrawn and particularily when the Rumanian troops became unreliable the present front was not to be held against Russian attacks; therefore when no reinforcements could be secured then a withdrawal to the First World War position of Danube-Sereth-Carpathians must occur and all preparations be in place. Guderian stated that he hoped, "when the situation developed in this direction that the Army Group could be given the necessary orders in time." 41

The concerns of Marshal Antonescu were relayed by Major General Garbea, Inspector of Rumanian Armored Forces to Colonel General Guderian on August 3, 1944 at 1840 hrs. 42 Major General Garbea expressed Antonescu's major concern about the withdrawal of numerous German formations from Rumania. However, Guderian attempted to alleviate Antonescu's concerns by reassuring Garbea that additional German formations would be sent to Rumania. The 20th Panzer Division had been transferred to Army Group South Ukraine and 6-8 assault gun units were to arrive in August. ${ }^{43}$ Major General Garbea informed Guderian that the new commander of Army Group South Ukraine, Colonel General Friessner had made a good impression in Bucharest. ${ }^{44}$ Garbea also announced the visit of Marshal Antonescu for August 5, 1944.45 The meeting between Hitler and Antonescu was positive. Field Marshal Keitel of OKW informed Army Group South Ukraine that Rumania was with Germany "Through thick and thin."46 Keitel dismissed Colonel Trotha with the following message to Friessner concerning his 
request for complete authority in Rumania: "You hold the front I will keep the rear area open." 47 German Ambassador von Killinger on August 10, 1944 reported to Foreign Minister Ribbentrop that "the situation was completely secure, King Michael guarantees the alliance with Germany."48 According to Colonel General Friessner his efforts were in vain:

Despite all reports and warnings from the Army Group to withdraw the front behind the Pruth or into the Carpathian border position permission was denied. My request for authority over the Wehrmacht in the rear area was also not imparted. 49

\section{THE STATUS OF GERMAN AND RUMANIAN FORCES PRIOR TO THE SOVIET OFFENSIVE ON AUGUST 20, 1944}

Army Group South Ukraine during the summer of 1944 had served as a reserve from which $\mathrm{OKH}$ pulled divisions to replace the losses by other Eastern Front Army Groups. The last transfer of a division from Army Group South Ukraine ocurred on August 13, 1944. Total transfers from Army Group South Ukraine since June amounted to 11 divisions or nearly one-third of the entire Army Group's strength.50 Army Group South Ukraine contained 25 German divisions and approximately 22 Rumanian divisions divided into two Army Groups: Army Group Woehler and Army Group Dumitrescu (see Figure 187). 51 
However, the quality of the German divisions had declined. The German divisions now contained only $15 \%$ combat seasoned troops while the other $85 \%$ had essentially no significant combat experience. 52 The infantry divisions also lacked motorization and depended on horses for movement (see Zustand der Divisionen der Heeresgruppe Suedukraine in Appendix C). The Rumanian divisions were also depleted and had serious morale problems. The combat readiness of Rumanian units was also low (see Zustand der Divisionen der Heeresgruppe Suedukraine in Appendix C). The Germans lacked armor on this front due to the withdrawal of panzer divisions to other Army Groups on the Eastern Front. The Rumanians had almost half of all the operational tanks in Army Group South Ukraine concentrated in the Rumanian Panzer Division "GrossRumaenien" (see Zustand der Divisionen der Heeresgruppe Suedukraine in Appendix ()). The German Luftflotte 4 contained only 232 combat operational aircraft: 60 reconnaissance aircraft, 43 bombers, 57 ground attack and night ground attack aircraft, 41 fighters and 31 night fighters. 53

The only additional support the German High Command had to offer was the traditional exhortations to the soldiers for discipline and sacrifice. Colonel General Friessner, Commander of Army Group South Ukraine, issued the following proclamation to all German and Rumanian Commanders on August 18, 1944:

1. In the coming days our front can also expect the beginning of major attacks that in seperate sectors will 
be accompanied by numerous deceptions and containing attacks.

we can brace for these attacks with resolute confidence shoulder to shoulder with our proven Rumanian comrades in the confidence of our training, our weapons and our good, improving defensive works.

The mission remains: Defense of the ordered main battle line with all available means. From responsible troop commanders to the last man, every penetration of his position must be defended to the last with grim determination. In the main battle line enemy breakthroughs are to be smashed in the counterstroke or counterattack.

2. It will depend in the coming days on continuously increased observation of reconnaissance probes and raids to determine where the main effort of the enemy's attack objectives are. We must make this point strong by considering the weakening of forces in the sectors which are not attacked.

I make in this context all commanders and troop leaders responsible for relevant, unvarnished and continuous reports. Invented reports will falsify the command's situation assessment. The forces will hereby be pulled from the true main points of attack, where every single man counts. 54

AUGUST 20, 1944

The Jassy-Kishinev operation commenced on the morning of August 20, 1944 in the area south of Tiraspol and in the area northwest of Jassy. 55 The Soviets achieved deep breakthroughs on both frontal sectors against Rumanian units which put up 
surprising little resistance. These breakthroughs were only partially sealed off by employing the available reserves en masse. The Kriegstagebuch of Army Group South Ukraine prophetically noted that the "burden of the battles in the days ahead were placed almost solely on the shoulders of German troops." 56

\section{Army Group Dumitrescu}

The Soviets attacked after 90 minutes of artillery preparation on both sides of the boundary between the 3rd Rumanian Army and the German 6th Army with infantry and armor supported by strong tactical air support. The attack succeeded and the front of the 4th Rumanian Moutain Division was broken through on a wide front and the division was routed (see Figure 188). 57 The 21st Rumanian Infantry Division after the loss of Rascaeti was thrown out of its positions along the entire length of its front (see Figure 188).58 A weak defensive line was established by evening with employment of reserves from the 9th Infantry Division, remnants of the 21st Rumanian Infantry Division and the 4th Rumanian Moutain Division. The line extended from Rascaeti to northwest of Festelita.

The main effort of the Soviet attack consisting of 4-5 rifle divisions and masses of armor was directed against the right wing of the XXX Army Corps where despite the employment of all reserves and tenacious defense the Soviets succeeded in the afternoon at Plopstiubei with a breakthrough by 50 tanks. 59 This 
forced a withdrawal of the front to the hills south of Popeasca and forced the abandonment of Carnateni.

The 13th Panzer Division on the right wing of the XXX Army Corps was employed to restore the situation east of Causenil (see Figure 188). The Soviet attack against the center and left wing of the 15th Infantry Division lead to a $6 \mathrm{~km}$ wide and $3 \mathrm{~km}$ deep penetration which was in the process of being liquidated. The Grenadier Regiment 81 of the 15th Infantry Division was overrun and an assault gun battery from the Assault Gun Brigade 239 was deployed to restore the situation (see Figure 188). 60

A Soviet attack in regimental strength against the center of the LII Army Corps west of Taslik was repuised with heavy Soviet losses. A limited penetration in the 14th Infantry Division's sector was in the process of being mopped up. Soviet breakthroughs at Redeni on the 106th Infantry Division's sector were being liquidated.

The situation of the German 6th Army was serious by 2005 hrs in the evening. The 21st Rumanian Infantry Division and the 4th Rumanian Moutain Division had completely disintegrated and no longer existed.61 However, the main Soviet attack against the right wing of the XXX Army Corps in the sectors of the 306th Infantry Division and the right wing of the 15th Infantry Division was pushed back. The 13th Panzer Division was employed in a counterattack at Popeascu against Soviet armor and had knocked out 17 Soviet tanks. Nevertheless, the situation remained serious 
with the loss of two Rumanian divisions and the breakthrough on the 306th and 15th Infantry Divisions' sectors (see Figure 188).

\section{Army Group Woehler}

The Soviets attacked with infantry and armor after 90-120 minutes of continuous artillery barrage fire and strong tactical air support northwest of Jassy between Rediu Mitropoliei and Erbiceni achieving very rapid, deep penetrations on the 7th and 5th Rumanian Infantry Division sectors because the Rumanians partly deserted their positions (see Figure 188). ${ }^{62}$ The 7th Rumanian Infantry Division during the course of battle lost Vultur and Rediul lui Tataru.63 The failure of the 3rd Rumanian Infantry Division to enter the battle except with small units enabled the Soviets to advance around Rediul lui Tataru to the south. The 5th Rumanian Infantry Division completely disintegrated when it was swept back by the Soviet offensive and the two most forward battalions of the 18th Rumanian Moutain Division were also swept away by the Soviet steamroller. The Commander of Army Group Woehler responded by forming an attack group from the 18th Rumanian Moutain Division, Artillery Brigade 959, Panzer Division "Grossrumaenien", formation Kessel and Assault Gun Brigade 286 to throw back the Soviets which had advanced south of Hoisesti. Meanwhile, the hole left on the 5th Rumanian Infantry Division's sector permitted the Soviets to enter the western part of Jassy where heavy street battles developed in which the population participated. The Commandant of Jassy encircled in the northern 
part of town was extricated by a counterattack from the north by a battalion with Assault guns.64 A counterattack succeeded northeast of Jassy and a new defensive front was built to the west to protect the 11th Rumanian Infantry Division and the 79th Infantry Division which were holding their positions. Directly west of Jassy the Soviets had crossed with their most forward elements to the south bank of the Bachluim sector and were met by the 10th Panzer Grenadier Division in a counterattack from the southwest of Jassy (see Figure 188).

The breakthrough area in the VI Rumanian Army Corps was a result of the failure of the 5th Rumanian Infantry Division which permitted the Soviets to advance very rapidly through the Bachluim sector to the area southeast of Podul lloaci. The Soviet breakthrough area was constricted by a counteratttack of the Panzer Division "Grossrumaenien" out of the area Popesti to the northeast. The 76th Infantry Division between the 7th Rumanian and 5th Rumanian Infantry Divisions was outflanked on both sides and had to withdraw to the hills south of Letcani and built a new defensive front on the line Cobiasca-Harpasesti (see Figure 188). The battle persisted between Jassy and the counterattacking Axis forces while the Soviets maintained strong frontal pressure to the south against the withdrawing 76th Infantry Division which was attempting to establish a defensive front along the rail line and southwest of it with elements of the 18th Rumanian Moutain Division. 
There were only local penetrations on the right wing of the $V$ Rumanian Army Corps. Nevertheless, a counterattack by the 1 st Rumanian Infantry Division to liquidate yesterday's penetration southwest of Belcesti did not succeed. The 1st Rumanian Moutain Division was locked into a seesaw battle around a hill $8 \mathrm{~km}$ west of Stranya.

The liquidation of the penetration in the I Rumanian Army Corps on the 6th Rumanian Infantry Division's sector was not successful. However, the Soviet penetration against the XVII Army Corps southwest of Solca was liquidated in a counterattack.

The situation on Army Group Woehler's front had become more critical by the evening. Contact with the 76th Infantry Division had not been restored and its request to withdraw to Voinesti had been denied. It was ordered to hold its forward positions to prevent the Soviets from reaching the Trajan line (see Figure 189).65 The Commanding General of Gruppe Kirchner reported at $2230 \mathrm{hrs}$ that the Panzer Division "Grossrumaenien" had been attacked in the rear and routed. The Commander of Army Group South Ukraine stressed that the Soviets under all circumstances must be prevented from reaching the Trajan line (see Figure 189) and likewise the hole to the VI Rumanian Army Corps must be closed.66 A withdrawal of the front to the Trajan line as proposed by the 4th Rumanian Army in Army Group Woehler was out of the question.

German fighter and ground attack aircraft made 300 sorties against the Soviets in the area of Jassy. ${ }^{67}$ Luftflotte 4 was advised that the main effort for tomorrow must again be directed 
to the support of Army Group Woehler. An attack against Jassy tonight was recommended to destroy important military installations within the city. Air support for the counterattack of the 13th Panzer Division would also be important.

\section{AUGUST 21, 1944}

\section{Army Group Dumitrescu}

The Soviets continued their attack around noon with new mobile forces and armor in the breakthrough area. Weak Soviet attacks were repulsed on the right wing of the XXIX Army Corps, but Soviet armored forces broke through the weakly occupied security line in the afternoon and after routing the 21st Rumanian Infantry Division and the 4th Rumanian Moutain Division advanced to the southwest and bypassed Grenadier Regiment 77 of the 153rd Field Training Division north of Volintiri (see Figure 190). 68 Then the Soviets after defeating Panzer Grenadier Regiment 66 of the 13th Panzer Division at Festelita advanced to the line Pauleni-Frumusica Veche-Nicolaeni. The 13th Panzer Division prevented one Soviet armored breakthrough only to be outflanked and forced back to the west in heavy fighting

Further north the Soviets made little headway against tenacious resistance by the XXX Army Corps and the 13th Panzer Division. A Soviet armored thrust west of Popeasca resulted in a heavy armored engagement and a Soviet armored breakthrough was prevented at Causanii Noui. However, the 13th Panzer Division 
suffered serious losses and was later pushed back to the hills west of Brezoaia by enveloping attacks. The Soviets later in the evening staged a breakthrough on the outermost right wing of the 15th Infantry Division and to the north broke through the remnants of the 306th Infantry Division into the wooded terrain southeast of Zaim and reached the Botha sector by the evening. 69 The southern part of Hadgimus was lost.

The Chief of Staff of the 6th Army reported that the situation in the south of the breakthrough area was developing very unsatisfactorily. Chizil, Adjiler, Marianca and Festilta were lost and the 13th Panzer Division was pushed back to the hills of Simionesti (see Figure 190). There was a large hole from the left wing of the 9th Infantry Division to the west (see Figure 190). ${ }^{70}$ The situation continued to worsen during the afternoon with the loss of Slobozla, Ganeasa, Siminnesti and Ursoaia. The 13th Panzer Division's losses were so heavy that it hardly had any tanks remaining. 50 Soviet tanks had reached Causanii Mari. The front of the 15th Rumanian Infantry Division was pushed back to Cara Hasan and from there to the west to connect with the 9th Infantry Division. The Soviet Air Force had achieved complete freedom of action on this front which caused numerous losses of vehicles and delayed all movement.

\section{Army Group Woehler}

The Soviets exploited yesterday's success in the breakthrough area at Jassy (lasi) during the early morning hours by breaking 
through the Trajan line to the south with strong infantry and armor forces. Meanwhile, the rapidly concentrated Kampfgruppe on the left wing of the VI Rumanian Army Corps succeeded in repelling Soviet attacks that were supported by more than 60 Soviet tanks (see Figure 190). The attack against the 101st Rumanian Moutain Brigade with 20 tanks resulted in 12 tanks being knocked out and the attack failed. However, the Soviets achieved a breakthrough into the Trajan line in the late afternoon with 30 tanks and mounted infantry south of Lungeni and penetrated the Trajan line east of Voinesti.71 The Soviets reacted rapidly by widening the breakthroughs to the south and southwest with 2nd echelon forces. Soviet armored spearheads advanced through Hadambul to the southeast, south and southwest on both sides of the VoinestiGarbesti road. Units from the Panzer Division "Grosssrumaenien" reinforced with one army engineer battalion moved to engage the oncoming Soviet armored spearheads. However, the attack of the Panzer Division "Grossrumaenien" was brought to a halt by a Soviet flank attack out of the area of Podul Iloaei-Cositeni and the division was routed. The 10th Panzer Grenadier Division launched an attack against the east flank of the Soviet breakthrough area and was brought to a halt by a Soviet counterattack supported by 100 150 tanks. Nevertheless, the 10th Panzer Grenadier Division during the afternoon managed to hold the following line: the south edge of Galata-west edge of Balciu-the hill terrain west of Dancasa and knocked out 40-50 Soviet tanks before being pushed back to the east during the evening hours along the Jassy-Vaslui road (see 
Figure 190). Similarly, the 11th Rumanian Infantry Division and 79th Infantry Division northeast of Jassy were thrown back to the the southeast in the Bachlui sector after the Soviets broke through their positions during the night. The Soviets attacked Targul Frumos on a broad front during the morning from the west flank of the breakthrough area with approximately the strength of a tank corps. Targul Frumos was bombed by 70 Soviet aircraft around noon. The Axis forces improvised an anti-tank line with units from the Assault Gun Brigade 286 and Kampfgruppe von Kessel. The Soviets were successfully blocked on the general line Sinestisouthwest of Crucea-Lugani-Baltati.

The Soviets achieved penetrations on the right wing and center of the 1st Rumanian Infantry Division. The Soviets attempted to widen their breakthrough on the 1st Rumanian Guards. Division's sector but failed. There were only Soviet company strength attacks against the 3rd Moutain Division in the XVII Army Corps sector.

\section{Army Group South Ukraine}

A report issued by the commanding general of Gruppe Mieth and the VI Rumanian Army Corps stated that the following units could no longer be counted as combat effective because of losses of men and material in the battles of August 20th and 21st: the 3rd, 5th and 7th Rumanian Infantry Divisions and most of the 5th Rumanian Cavalry Division. 72 
The Chief of Staff of Army Group Woehler recommended replacing the Rumanian tank crews in the Panzer Division "Grossrumaenien" and the 2nd Rumanian Panzer Division with German crews to make the units more effective. 73 The Panzer Division "Grossrumaenien" reported only 20 tanks and 10 assault guns available for action. A total of 5 Rumanian divisions had disintegrated in the last 24 hours. ${ }^{74}$ The Trajan line was ordered to be held under all circumstances. The situation had become more critical with Soviet armor attacking out of the breakthrough area on both sides of the Jassy-Targul Frumos road. The Soviets had even breached the Trajan line with 20 tanks south of Lungani.75 The German and Rumanian air forces had staged 500 sorties for August 21, 1944.

Marshal Antonescu met with Colonel General Friessner and conveyed to him that he was with the "Fuehrer and Germany to the end."76 Colonel General Friessner in his meeting with Marshal Antonescu on August 21-22, 1944 engaged him in the following discussion:

The present could still be overcome when the Rumanian troops and the Rumanian people with unshakeable, strong conviction were willing to see through through the common struggle and bring together the Rumanians and the Germans against the great danger that a predominant Soviet Russia represents for Europe.

We sit here together in a boat on a stormy sea. Whoever bails out brings not only himself and his nation into danger, but the entire European world. 77 
Marshal Antonescu responded to Friessner with an affirmation of loyalty:

I declare anew that despite all the Rumanian people out of complete conviction and as the sincerest and loyalist ally march at Germany's side and also will continue to march. 78

The parting words of Marshal Antonescu on August 21, 1944 indicated a sense of inevitable defeat when he declared to Friessner:

When the Russians cross over the line Galatz-Focsani, Rumania is lost for all time.79

Marshal Antonescu aware of the disappointing performance of the Panzer Division "Grossrumaenien" ordered the division to be divided into two groups. One group was to be commanded by the Rumanian General Corne and deployed at Voinesti and the other group was to go to Sinesti to Kampfgruppe von Kessel to be replaced by German crews. 80

\section{AUGUST 22, 1944}

\section{Army Group Dumitrescu}

The Soviets advanced from both sides of Volontiri to the southwest and west with motorized and armored forces and reached the area Paris-Tarutino-Leipzig-Taraclia-Cainari (see Figure 191). The 9th Infantry Division was pushed back $6 \mathrm{~km}$ to the southwest to Ivanesti Vechi. Meanwhile, the 13th Panzer Division repulsed the Soviets southwest of Causanii. German and Rumanian 
units held at Romanesti against the attacking Soviet armor. A defense line was under construction in the Cogalnicul sector southwest of Romanesti. The Soviets on the outermost left wing of the 6th Army broke through the 376th Infantry Division sector with infantry and armor forces and took Ungheni and the village $9 \mathrm{~km}$ northeast of Ungheni (see Figure 191).

\section{Army Group Woehler}

The Soviets continued their breakthrough of the Trajan line south of Lungani and east of Voinesti with infantry and armor. ${ }^{81}$ The breakthrough developed rapidly to the south and southeast resulting in a further breakthrough at Vasluiui pushing the German forces back.

Korpsgruppe Mieth continued to hold their positions southeast of Jassy against superior Soviet forces.

Gruppe Kirchner was thrown out of their positions directly east and northeast of Roman by a Soviet attack supported by armor. But the Germans managed to repulse weaker attacks against the Trajan line south and southwest of Targul Frumos (see Figure 191). A total of 32 Soviet tanks were in Negresti $30 \mathrm{~km}$ south of the Trajan line at 0925 hrs and 50 Soviet tanks had reached the area of Garbesti-Titanesti (see Figure 191). German antitank positions at Dragesti were smashed by Soviet aircraft and the Panzer Division "Grossrumaenien" was attacked by 80 Soviet tanks. Army Group Woehler reported that it now only had 45 tanks, 78 assault guns and 2 self-propelled howitzers available for action. 82 
Army Group South Ukraine

The Chief of Staff of Army Group Woehler stressed that the Soviet thrust to the southeast must be prevented and the Pruth river crossings must be held open. ${ }^{83}$ The Soviet armor had to be channeled. The Trajan line must be held as much as possible and the hole must be closed by an attack from the east and west.

Panzer Group Braun was dispatched from the Army Group in the direction of Vaslui to stop the Soviet armored thrust. Panzer Group Braun contained 30 tanks and 21 assault guns.

The main effort of Luftflotte 4 was to be directed against the Soviet armored breakthrough of the Trajan line which was advancing south in the sector of Army Group Woehler toward Vaslui (see Figure 191).84 Presently, 20 Soviet tanks were reported in Vaslui. The remainder of the aircraft were to be used against the Soviet armored spearheads in Army Group Dumitrescu's sector. Luftllotte 4 aircraft destroyed 16 Soviet tanks and 140 vehicles in the 6th Army sector (see Figure 191).

Soviet intentions were clear to the Germans by the end of the day. The Soviets continued their breakthrough operations in both breakthrough areas with the obvious objectives of capturing the Pruth river crossings and cutting off the German forces on both sides of Kischinew.85 Two Soviet assault groups were moving into the rear in the 6th Army sector. One assault group was moving west toward the Pruth river crossings and the other was advancing in the direction of Galatz. Two Soviet assault groups were also breaking through in the sector of Army Group Woehler (see Figure 
191). One assault group was advancing toward Husi and the other to the south. The 6th Army was to be pulled back into the Trajan line tonight and then tommorrow into the Stefan line when possible (see Figure 189). 86 The Soviets had also landed in the early morning hours in the area of Akkerman and pushed their way into the Axis defensive positions.

The Chief of Staff of Army Group South Ukraine sent the order to withdraw to the 6th and 8th Army which had been approved by the Fuehrer. The Fuehrer had approved the withdrawal of the 6th Army to the Ferdinand-Carol-Trajan line.87 Army Group Woehler was ordered to withdraw in conjunction with Army Group Dumitrescu. The withdrawal movement was to be conducted maintaining contact with the 376th Infantry Division and the west wing of the 6th Army to the Trajan line and the communication line southwest of Targul Frumos with contact at Harmaneasa to the old main battle line. 88 This order further stated:

It is of decisive importance that there is sufficiently strong mobile reserves available on the west wing to defend the general line Targul Frumos to Targul Neamt against a possible enemy breakthrough toward Roman. It must be clear to All troop leaders and every individual that the fate of their comrades east of the Pruth river is dependent upon their tenacity and resistance in holding this line. 89 
AUGUST 23, 1944

3rd Rumanian Army. Soviet armored spearheads from the breakthrough area south of Tiraspol and east of the Pruth river reached the area around and west of Comrat. Soviet units had turned south and seized Tatar Bunar and Furmanca. Consequently, the bulk of the III Rumanian Army Corps including the German 9th Infantry Division was encircled.90 These units were ordered to attack to the west and southwest in order to fight their way out of the encirclement. Soviet armored spearheads advancing to the southwest were halted at Cubei northeast of Bolgrad from advancing further by elements of the 13th Panzer Division.

6th Army. The withdrawal movement proceeded as ordered without notable Soviet pressure. Soviet armor was reported advancing southeast in the direction of Hancesti. Korpsgruppe General Mieth was placed under the command of the 6th Army as of noon on August 23, 1944 and was withdrawing in the line GrozestiCiortesti (30 km northwest of Husi). 91 The 10th Panzer Grenadier Division was currently engaged in battle with strong Soviet armor forces in the hills at Coadesti. The German defense line at Crassna repulsed attacking Soviet armor spearheads after the loss of Vaslui.92 A Soviet armored thrust against Barlad entered the town before it was repulsed with the loss of 9 tanks by Panzer Group Braun. Soviet attacks against Barlad were resumed in the evening with battalion strength infantry attacks. Soviet armor was reported west of Barlad moving south. Soviet armor reached the 
airport northwest of Barlad and Panzer Group Braun deployed on the northwest edge of Barlad to meet the Soviet tanks. The Battle Commandant of Barlad was Colonel von Parsival.

\section{Army Group Woehler}

The Soviets launched an attack supported by armor against the newly built line at Roman and also to the north of the town. The Soviet attack had forced its way into Roman from the northeast and the east by the afternoon. ${ }^{93}$ The 46 th Infantry Division defending the town was forced to withdraw to the west toward Trifesti. Similarly, the Soviets advanced north of Roman at Adjudeni over the Sereth river and pushed back the defending Rumanian troops to the west over the Moldau river. ${ }^{94}$ Soviet cavalry also crossed the Sereth river north of Roman at Comesti and enveloped the command bunker of the 6th Rumanian Infantry Division from the rear. 95

Colonel General Friessner informed Army Group Woehler of the following on August 23, 1944:

1. It is to be expected that large Soviet tank formations which broke through the Trajan line to the south have designated their main effort opposite and over the Vaslui-Husi line and through occupatioin of the Pruth river line down the river from Husi in coordination with Soviet armored fcices which broke through on the 6th Army sector the Dniester deployed divisions will be encircled for destruction. It must also be expected that elements of these Soviet tank formations will advance in a southern direction into the depth of the rear and further forces will advance to the south into the Sereth valley. 
2. The mission of Army Group Woehler is to construct a defensive front in close contact with the 6th Army in the general line north of Husi-Vaslui. Every action of these armored units against the Pruth river crossings and down the river from them is to be prevented. The west wing is to be retracted by pulling the front back behind the Moldau bridgehead position around Roman to the region of Bacesti to repulse the intended Soviet armored advance into the Sereth valley. 96

\section{Army Group South Ukraine}

The bulk of the III Rumanian Army Corps in the 3rd Rumanian Army sector with the German 9th Infantry Division burst out of the encirclement to the west and southwest. The German line was now at Falciu (30 Km south of Leova) to Leova. The 13th Panzer Division was at Leova on the Pruth river and the Pruth river crossing was occupied by an engineer battalion.

The German 6th Army withdrew in the general line: CimisliaCaracui-Zberoaia-Korpsgruppe Mieth. Army Group Woehler withdrew and halted on the west bank of the Sereth river and the Moldau river. Husi was reported under artillery fire as of 1105 hrs. 20 Soviet tanks were reported $30 \mathrm{~km}$ southeast of Leova at 1305 hrs. The Pruth river crossing at Cahul was occupied by the 153rd Field Training Division and the Pruth crossing at Reni was secured by the Army Weapons School of the 6th Army. The Pruth river bridge at Falciu was to be blown up.

The 4th Luftflotte received a small reinforcement with the arrival of Major Rudel and his ground support air group.97 


\section{Rumanian Political Situation}

The situation in Rumania reached catastrophic proportions with the fall of Marshal Antonescu and the Rumanians dropping out of the war. Marshal Antonescu and the Deputy Minister President of Rumania during the afternoon were taken to meet King Michael.98 The German Ambassador von Killinger was summoned by King Michael and informed that he wanted peace as soon as possible and he would not fight against the Germans. 99

The chief of Staff of Army Group South Ukraine was in direct contact with the German Ambassador by teletype. He was informed at $2225 \mathrm{hrs}$ that during the course of the afternoon that Marshal Antonescu was arrested. The German Ambassador had driven over to meet King Michael who informed him that Marshal Antonescu had resigned and that he was establishing a new government. This government was to seek an armistice. 100 However, a fight with the German Army was out of the question. 101 King Michael announced on radio that evening that Rumania had accepted an armistice from the allies and Rumanian troops were to cease fighting. 102 Ambassador Killinger reported that the German Headquarters in Bucharest had been surrounded by Rumanian troops. ${ }^{103}$

The change of the Rumanian political situation was relayed to the Commandant of Fortress Braila at 2300 hrs and the Chief of Staff for the Commander of Rear Operations in Rumania. All German units were put on complete alert but no active measures were ordered. 
The Commander of Army Group Woehler stated:

Colonel General Dumitrescu reported that he did not believe that Marshal Antonescu voluntarily resigned and he did not think the entire Rumanian Officer Corps would break their loyalty to Germany. He would also determine if the Rumanian Generals and their soldiers in our would continue to fight. 104

The Commander of Army Group Woehler expressed no great hope that the Rumanians would fight. A few officers may continue to fight but the troops would certainly not continue to fight. He expressed the view that there was no longer anything that could be done except get the German troops back to the Carpathians and block the Carpathian passes. ${ }^{105}$

\section{AUGUST 24, 1944}

\section{Army Group South Ukraine}

The 3rd and 4th Rumanian Armies and their subordinate units dropped out of the war because of the Rumanian betrayal on August 23, 1944.106 The Majority of Rumanian formations had abandoned their positions, some units departed in an orderly fashion while others disintegrated in the departure to the south and southwest. 107 The German attack to take possession of Bucharest ran into organized, strong resistance. The Soviets achieved great success today by occupying most of the Pruth river crossings as well as taking Barlad and Bacau. 108 
6th Army. The III Rumanian Army Corps was in retreat north of the mouth of the Danube river and crossed over at Ismail. The Soviets captured Kilia. The whereabouts of the German 9th Infantry Division was unknown. The weak German forces in the Ferdinand line were withdrawing into a compressed bridgehead in the sector Reni-Cahul. A bridgehead east of the Pruth river was built from Giurgiulesti to Cahul by the LXXII Army Corps Z.B.V. with the remnants of the 6th Army weapon School, alert units, remnants of Armored Reconnaissance Battalion 13 and the 153rd Field Training Division. 109 Elements of the 13th Panzer Division secured the town of Bolgrad. The withdrawal movement of the 4 corps of the 6th Army proceeded according to present reports without substantial Soviet pressure. The Soviets shifted armored forces followed by infantry to both sides of the Pruth river and the Pruth river crossings blocking the retreat routes of the 6th Army. 110 Tomai was occupied by an armored Soviet task force. Another Soviet group occupied the Pruth river crossing at Raseti and destroyed the bridge. Korpsgruppe Mieth was ordered to withdraw in the line Obinjany-Baltati.

Soviet armor and mechanized forces south of Korpsgruppe Mieth advanced from the northwest to the Pruth river crossings at Leova and Falciu. Soviet forces took Barlad and Soviet infantry reached a line $15 \mathrm{~km}$ southwest of Barlad. ${ }^{111}$ Soviets also occupied the crossing northeast of Husi. Korpsgruppe Mieth west of the Pruth river withdrew under strong Soviet pressure from the north 
and envelopment from the south to the line $20 \mathrm{~km}$ north of Husi to $10 \mathrm{~km}$ west of Husi.

8th Army. The Soviets advanced out of the area of Roman to the south with strong forces and took Bacau and threw the weak security forces back $6 \mathrm{~km}$ to the west in a bitter battle. The Soviets lost 21 tanks in this battle. The Soviets with part of their forces advanced from Bacau to the northwest and engaged the German forces at Roznov. Kampfgruppe von Kessel secured the area east and north of Piatra Neamt against Soviet forces advancing west from Roman. The Rumanian formations in the area along both sides of Targul Neamt abandoned their positions and withdrew to the southwest. Rumanian Border Regiment 3 commenced hostilities and attacked elements of the German 3rd Moutain Division on the Carpathian front.

\section{Army Group South Ukraine}

Hitler transmitted the order to Colonel General Friessner to crush the putsch in Rumania and arrest King Mlchael and his royal clique of advisors and reestablish a new government under a Rumanian general friendly to Germany in the event Marshal Antonescu was no longer available.112 Friessner assigned the execution of the Fuehrer's order to General der Flieger Gerstenberg who along with the German Ambassador and General d. Kavalry Hansen were surrounded in the German embassy by Rumanian tanks. ${ }^{113}$ General der Flieger Gerstenberg could not secure his freedom from the embassy so he directed SS Brigadefuehrer 
Hofmeier to execute the action against Bucharest. Hofmeier reported at $0300 \mathrm{hrs}$ from the assembly point outside Bucharest that the spearhead of the Kampfgruppe from Ploesti would arrive in approximately 90 minutes and then the attack would commence.114 General Hansen called Colonel General Friessner and informed him that the new Rumanian government had informed him that if the German measures against Bucharest were not stopped within an hour the Rumanian Army would take up arms against the German Army. 115 The Rumanian government made it clear that it wanted to be taken seriously and that this was no bluff by a small clique of traitors. It stressed that the Rumanian people and all the generals were behind the new government. General Hansen further stated that Ambassador von Killinger, General der Flieger Gerstenberg and Minister Clodium were unanimous in their opinion that the German forces assigned to occupy Bucharest and remove the new government were totally insufficient and that the German action was certainly expected to fail. ${ }^{116}$ Therefore, it was urgent to refrain from carrying out the ordered action. Colonel General Friessner asked if he was free to move and Hansen replied no to the question since he was still surrounded in the German Embassy. Friessner requested further instructions from the Fuehrer based on this information concerning the execution of the order to seize Bucharest. The Fuehrer's answer arrived at $0500 \mathrm{hrs}$ that the order was to be executed. The Fuehrer believed that General Hansen and the other people in Bucharest were unable to make free, 
independent decisions after they have been isolated for days which would impair and distort their judgement of the situation. ${ }^{117}$

General der Flieger Gerstenberg was released by the Rumanians to stop the German measures against Bucharest. ${ }^{118} \mathrm{He}$ arrived at the German assembly point outside Bucharest and informed the Chief of Staff of Luftflotte 4 at 0455 hrs that the new government consisted of only a small clique that were "filled with fear" and that Bucharest only had a thin screen of Rumanian troops. 119

The operation against Bucharest started at $0730 \mathrm{hrs}$ with appproximately 6,000 troops. 120 The 5th Flak Division was assigned to crush the putsch in Bucharest.121 General der Flieger Gerstenberg reported at $1130 \mathrm{hrs}$ that the operation against Bucharest had run into stiff resistance and troops had failed to enter the city and had only occupied the radio station.122 The assistance of the Luftwaffe was requested en masse. A request was sent to $\mathrm{OKW}$ for immediate air transport of infantry from the Southeastern Theater to Bucharest.

German instructions stated that the advance against the Rumanian King and the new government had nothing to do with the conduct of the Rumanian Army. No violent measures against the Rumanian Army were to be taken as long as it remained loyal. The Fuehrer ordered Colonel General Friessner, Commander of Army Group South Ukraine to assume command of all German military units thereby eliminating the Rumanian command of German 
units. ${ }^{123}$ German units that encountered hostile Rumanian units were to take the severest measures against the Rumanians. ${ }^{124}$ There was no Rumanian General prepared to continue the war on the German side.125 Even General Corne, Commander of Panzer Division "Grossrumaenien" would not side with the Germans. 126 Colonel General Friessner communicated with Colonel General Dumitrescu, Commander of the 3rd Rumanian Army. Dumitrescu stated that he had heard the proceedings on radio but had not received any orders from Bucharest. He intended to carry out his old orders until he received new orders. He personally regreted the actions of the Rumanian government and would resign his command of the 3rd Rumanian Army.127 However, he would not fight against his king. Friessner queried Corps General Steflea, Commander of the 4th Rumanian Army, as to his position. He responded that he . could not take any position since he had not received any orders from a higher Rumanian Headquarters. He indicated that he would relay any new orders so as not to surprise Army Group South Ukraine.

German instructions concerning Rumanian units which engaged in hostilities or sabotage against the German Army required that the Rumanian units be destroyed or disarmed. ${ }^{128}$ The order also stressed that the Wehrmacht was not to attack the Rumanian people or Rumanian troops but only the traiterous clique which had taken control of Marshal Antonescu's government. ${ }^{129}$ The Rumanians received an order from the Rumanian General Staff which raised the question of the armistice for the 3rd and 
Bacau since $0700 \mathrm{hrs}$ and the Germans after knocking out 12 Soviet tanks abandoned the town at 1045 hrs.

The German Luftwaffe had been employed during the morning to support the 6th Army against Soviet columns and armored spearheads advancing in the areas of Comrat, Husi, Vaslui, Barlad and Bacau. However, Luftwaffe support was shifted in the afternoon against the government buildings and the king's palace in Bucharest. ${ }^{135}$ Colonel General Friessner noted in his memoirs that the effect of Hitler's order to bomb Bucharest was catastrophic because it gave King Michael the pretext to declare war on Germany and order the Rumanian troops to attack the German soldiers of Army Group South Ukraine. ${ }^{136}$

\section{AUGUST 25, 1944}

The Soviets landed at St. Gheorghe in the Danube delta and advanced from Kilia in the direction of Tulcea. There was no Soviet pressure against the German Pruth river bridgehead between Reni and Cahul.

6th Army. The 6th Army report at noon reported that the XXX Army Corps had reached the area northeast of Sahaidac $(40 \mathrm{~km}$ south of Kischinew), the LII Army Corps reached the area of Hartop (12 km west of Sahaidac) and the XXXXIV Army Corps was in the area of Sarata Galbena (12 km southwest of Hancesti) (see Figure 192). ${ }^{137}$ The attack of the 106th Infantry Division in the VII Army 
Corps sector against the Pruth river crossing at Rasesti (12 km northeast of Husi) failed to breakthrough. However, the 370th and 376th Infantry Divisions advanced to the north of Rasesti and crossed over the Pruth river and united with Gruppe Mieth which was last reported in the area $15 \mathrm{~km}$ north of Husi with its front deployed to the north and west (see Figure 192). ${ }^{138}$ Soviet armor attacking from the east and west captured the bridge at Leova. Panzer Gruppe Braun and elements of the 10th Panzer Grenadier Division were employed in a northwestern direction to cover the bridgehead at Falciu. Soviet pressure increased against the garrisons of Tecuci and Adjud.

8th Army. The repeated enveloping attacks of strong Soviet armor and cavalry formations pushed Kampfgruppe Abraham which was under the Commander of the 76th Infantry Division out of the area west of Bacau approximately $18 \mathrm{~km}$ further to the west and southwest into the Trotus valley. ${ }^{139}$ Onesti was lost at 1600 hrs.

Concentrated Soviet attacks launched against the Piatraneamt Bridgehead were repulsed by the LVII Panzer Corps. There were only local attacks on the XVII Army Corps sector except for the defense of Paliligeni (20 km west of Targul-Neamt) against Soviet battalion strength attacks which were repulsed. Rumanian units now entered the battle against the Germans southeast of Gurahumorului ${ }^{140}$ There were no clear reports regarding the battle of Bucharest. The resistance there continued to be tenacious and bitter. However, in general there had still been no further combat 
engagements between German and Rumanian troops since the Rumanian declaration of war on Germany was reported.141

The order to hold the Galatz-Focsani line was not possible to maintain. The Buzau-Kronstadt road instead had to be held open for the 6th Army.

AUGUST 26, 1944

6th Army. The Soviets occupied the bridgehead at Cahul (see Figure 193). ${ }^{142}$ The divisions of the 6th Army were now completely encircled and under attack all day. The eastern group consisted of the remnants of XXX Army Corps, LII Army Corps and the XXXXIV Army Corps in the area of Mingir and the western group contained Gruppe Mieth and remnants of the VII Army Corps in the area south of Husi (see Figure 194). ${ }^{143}$

The Soviets advanced against the Sereth river position with strong armored forces concentrating their main effort in the direction of Focsani. 144 The Soviets penetrated the position east of Focsani and reached the region of Plainesti (see Figure 195). Kampfgruppe Philipp was employed from the area of Nanesti to meet these Soviet forces.

Meanwhile, in the Rumanian interior the hostile position of Rumanian troops toward German troops increased sharply. There were already several incidents of fire fights between German and Rumanian troops including Rumanian flak which had shot down 
German aircraft. There were no new reports on the situation around Bucharest. The 5th Flak Division in Ploesti was currently engaged in combat with Rumanian tanks (see Figure 195). ${ }^{145}$

The situation of the 6th Army in the area of Focsani and the encircled divisions on both sides of Husi continued to get worse especially due to supply difficulties. The LXXII Army Corps continued to hold the Reni Bridgehead and a weak defensive line was under construction from Braila to the junction of the Buzaul river with the Sereth river. Once Cahul was lost to superior Soviet armored forces the XXIX Army Corps withdrew with the remnants of the 153rd Field Training Division, 13th Panzer Division and 10th Panzer Grenadier Division to the Sereth river in contact with the LXXII Army Corps z.b.V.146 The Soviets captured Tecuci. The commandant of Fortress Foscani repulsed numerous Soviet attacks supported by armor from the northwestern and northern direction (see Figure 195). Nevertheless, a Soviet thrust east of Foscani could not be prevented from bypassing the town and the most foreward Soviet armored spearheads advanced $20 \mathrm{~km}$ south of Foscani (see Figure 195). Kampfgruppe Philipp coming from the east was employed in a counterattack against the Soviet armored spearheads emerging from the area of Maicanesti. Kampfgruppe Braun fought through southeast of Barlad to the south (see Figure 195).

The remnants of the XXX, LII and XXXXIV Army Corps were located on the east bank of the Pruth river $20 \mathrm{~km}$ east of Husi. 147 These corps were under attack from all sides by Soviet armor and 
were pushed back together and compressed into a tighter area west of the Pruth river (see Figure 194). Gruppe Mieth was currently located in the woods southwest of Husi. It was also encircled tightly by the Soviets and it attempted to breakout to the south (see Figure 194).

8th Army. The Soviets captured Adjud and advanced from here and Bacau toward Onesti where the Soviets had lost 18 tanks in the last two days as a result of defensive action by Gruppe Abraham (76th Infantry Division) which had been pushed back to the west edge of Ojtoz (see Figure 196). The Soviets advanced from Onesti toward the Ojtoz pass and Grozesti (see Figure 196). Soviet infantry and armor advanced from Darmanesti in the Uzul vally to the west over the Hungarian border to a point $12 \mathrm{~km}$ northeast of Feltiz (see Figure 196). ${ }^{148}$ The German defense line in the Trotus vally was pulled back to the west of Comanesti. The Soviets attacked Piatra Neamt in regimental strength in the LVII Panzer Corps sector and were repulsed (see Figure 196). The Soviets also attempted to push back the German defense line in the XVII Army Corps sector by an enveloping attack at Paliligeni from the south.

\section{Army Group South Ukraine}

The hostile attitude of Rumanian troops was increasing in the interior of Rumania. However, there had not been any incidents in the front lines but the Rumanians ceased supplying the area north of the Braila-Bucau line. The Rumanians increased the pressure in the area around Kronstadt by attacks against German 
administrative Headquarters. Rumanian moutain units had even occupied and blocked the Predeal pass. ${ }^{149}$ German troops crossing the Rumanian-Bulgarian border were being disarmed and other unfriendly acts were being taken by the Bulgarians. 150 Meanwhile, as the entire front was collapsing the Fuehrer ordered the GalatzFocsani line to be held with rear echelon and miscellaneous troops. ${ }^{151}$

\section{AUGUST 27, 1944}

6th Army. The remnants of the VII, XXXXIV, LII and XXX Army Corps were placed under the command of Gruppe Mieth and after combining received the mission to breakout to the Carpathian moutain passes (see Figure 197). ${ }^{152}$ The most forward elements on the west bank of the Pruth river had reached Hocenii at $1630 \mathrm{hrs}$ and the other elements were attacking Urlati while the rear guard troops were to hold the line Husi-Gragaseni-Gresteti. There were no further reports from the units east of the Pruth river. The Soviets had broken through the Galatz-Focsani line yesterday east of Focsani and today they seized Focsani by an enveloping attack of armored forces against bitter German resistance (see Figure 198). ${ }^{153}$ The German garrison of Focsani managed to withdraw to the south after having destroyed numerous Soviet tanks. The Soviets then advanced toward Ramnicul Sarat (see Figure 198). 
The XXIX Army Corps, units of the 153rd Field Training Division, remnants of the 13th Panzer Division, remnants of the 10th Panzer Grenadier Division and Kampfgruppe Braun received the mission to withdraw to the southeast Carpathians and block the Carpathian border from the area of Ploesti. ${ }^{154}$ Two parachute battalions were flown into the area of Buzau (see Figure 198).

8th Army. The Soviets moved against the southern wing of the army and increased the pressure against the Kampfgruppen blocking the Carpathian passes while the Soviets remained inactive on the XVII Army Corps front. Kampfgruppe Abraham consisting of units of the 76th Infantry Division had to withdraw from the continuously reinforced Soviet forces in the Ojtoz vally into the region $3 \mathrm{~km}$ southwest of Harja. The Soviets captured Poianna Sarata which was on the Hungarian side of the border. North of the Aklos pass the Soviets had advanced further to the southwest. Soviet cavalry formations advanced on the pass road DarmanestiPojana-Uzul over the border to the region southwest of Pojana Uzul (see Figure 199). A counterattack by Hungarian forces in cooperation with German alert units was making good progress. Gruppe Fessner withdrew from a Soviet attack to the heights of the pass $10 \mathrm{~km}$ southwest of Brusturoasa (see Figure 199).

The Soviets in the LVII Panzer Corps sector probed the combat outposts at Piatraneamt from the southeast and north (see Figure 199). The bulk of Kampfgruppe von Kessel withdrew to a defense position $8 \mathrm{~km}$ west of Piatraneamt. Soviet battalion 
strength attacks on the southern wing of the XVII Army Corps against the defensive position south of Pipirig were smashed.

\section{Army Group South Ukraine}

Kampfgruppe Stahel and the 5th Flak Division were engaged in heavy combat on all sides from attacking Rumanian infantry and armor forces north of Bucharest and in the area of Ploesti (see Figure 198). ${ }^{155}$ The 5th Flak Division located around Ploesti lost the city center and the oil refineries. ${ }^{156}$ The 5th Flak Division radioed that it could not spare any forces from Ploesti to reinforce Kampfgruppe Stahel at Bucharest (see Figure 198). The division stressed that it would hold to the last man. Lt. General Stahel radioed at $1640 \mathrm{hrs}$ that the battle at Bucharest had reached a turning point and he requested reinforcements. He demanded a new decision concerning the continuation of the battle no later than tomorrow. Lt. General Stahel, however, quickly changed his mind and informed the Army Group High Command at 1715 hrs that the battle for Bucharest had to be abandoned and requested permission to breakout toward Mizil tonight. $157 \mathrm{He}$ explained that his Kampfgruppe had suffered high casualties and it was now down to only 1900 men and was being attacked by a Rumanian armored force consisting of 26 German Panther tanks which had arrived north of the airport Otopeni and in the woods northwest of Baneasa (see Figures $198 \&$ 200). ${ }^{158}$ The Army Group instead ordered Kampfgruppe Stahel to withdraw to the area of Ploesti and 
stressed that it must be held under all circumstances (see Figure 200).

The following reinforcements were arriving for Army Group South Ukraine: 4th Moutain Division, 75th Infantry Division and 4 Panzer Jaeger Battalions.

The Luftwaffe conducted only weak reconaissance and fighter activity because of the fuel shortage. 159 Entire units of Luftlotte 4 after using up their last supply of fuel transferred to the east Hungarian area. 160 The air supply of Gruppe Mieth was no longer possible due to the shortage of fuel. 161

The war diary of Army Group South Ukraine noted on this day that the situation of the 6th Army was developing into a "complete catastrophe." 162

AUGUST 28, 1944

6th Army. Gruppe Mieth was still locked in battle in the area of Husi according to the last report. (see Figure 201). It was still attempting to fight its way out of the encirclement to the west.163 The Soviets attacked with armor along the Focsani-Buzau road and advanced after the capture of Ramnicul Sarat to Buzau. Buzau was lost to superior Soviet forces after a bitter battle (see Figure 202). ${ }^{164}$ The Germans managed to knock out 27 Soviet tanks during the course of the battle. No reports were received on the situation 
of German forces on the southern bank of the Sereth river and from Kampfgruppe Stahel and the 5th Flak division.

8th Army. The Soviets attacked the German forces blocking the roads in the moutain passes all day long in the sector of the LVII Panzer Corps. The Soviets attempted to penetrate the Ojtoz, Aklos and Gyimes Baekk passes and the Kronstadt area along the Kronstadt-Ditrau rail line (see Figure 202). 165 Gruppe Abraham near the Ojtoz pass was pushed back $3 \mathrm{~km}$ to the southwest edge of Pojana Sarata by a strong enveloping attack. Soviet Paratroops were landed south of Harja (see Figure 202). German forces continued to engage increasingly reinforced Soviet forces west of Darmanesti. A counterattack by units of the 76th Infantry Division and the 3rd Hungarian battalion failed to have any effect (see Figure 202). Therefore, the Soviets renewed their attack during the evening with 2 battalions supported by armor which broke through the German positions and advanced further to the west in the direction of Szt. Marton.

The battle in the area north of Feltiz near the Aklos pass continued with the Soviet infantry supported by armor. Gruppe Fessner at the Gyimes pass was attacked frontally and in the rear and after heavy casualties was withdrawn to the area west of Brusturoasa in the area of Palancu (see Figure 202). West of Piatra Neamt weak Soviet attacks were repulsed (see Figure 202). Meanwhile, the Soviets pressed foreward against the right wing of the XVII Army Corps in the area of Audia-Gura Largu and threatened from there the crossroads in the Bistrita valley. 
The German Luftwaffe employed Stukas against the Soviet spearheads and assembly areas at the Gyimes Buekk and Aklos pass roads. ${ }^{166}$ The radio station in Kronstadt was damaged.

Colonel General Friessner informed both the 6th and 8th Armies that the Balkan front would stand or fall depending on their holding of the Carpathian passes. 167 The commanding generals were ordered to defend the most important passes by establishing strong points and defending them like fortresses. 168 The Chief of Staff of the 6th Army stated, "that with the Soviets advancing on Ploesti that one could not have any illusions about holding the Carpathian passes because the available forces were far too weak." 169

AUGUST 29, 1944

6th Army. There were no new reports on the encircled units of the 6th Army in the area of Husi because of the breakdown in radio communications (see Figure 203). The breakthrough of the XXIX Army Corps with the remnants of the 13th Panzer Division, 10th Panzer Grenadier Division, 153rd Field Training Division, Panzer formation Braun and Gruppe Philipp along the Soviet occupied Buzau-Ploesti road toward the Carpathian Moutains to the northwest failed. 170 The breakthrough attempt was renewed on the night of August 29th-30th with infantry units attempting to reach the Carpathian Moutains to the northwest while motorized units 
moved west. The German forces that had been deployed in the western part of the Sereth line had retreated through Focsani and Ramnicul Sarat. These forces were now falling back along the Buzau-Kronstadt pass road and individual Kampfgruppen were located northwest of Buzau at Cislau, Nehoiuj and east of Teliul where the Rumanians west of the towns blocked the exits to the pass roads in the direction of Kronstadt (see Figure 204).171 The fuel shortage brought German motorized columns to a halt. A $50 \mathrm{~km}$ long German vehicle column was halted in the Buzau vally because of a lack of fuel.172 Soviet regimental attacks northwest of Buzau were repulsed (see Figure 204). Soviet armor advanced from Buzau to Ploesti and reached the edge of the city in the evening where units of the 5th Flak Division were locked into a difficult struggle against numerically superior Rumanian and Soviet forces (see Figure 204). The 5th Flak Division reported that Ploesti was lost at $1430 \mathrm{hrs}$ and only a strongpoint on the edge of the city was still holding. ${ }^{173}$ Kampfgruppe Stahel was $20 \mathrm{~km}$ south of Ploesti and was attempting to link up with the 5th Flak Division (see Figure 204). Lt. General Stahel was to take over the combined command of his Kampfgruppe and the 5th Flak Division once the link up had occurred. 174

8th Army. The German forces of the LVII Panzer Corps in the Ojtoz vally at Pojana Sarata were under an enveloping attack from both sides and were forced back to the town of Ojtoz and the pass (see Figure 204). Soviet attacks from the east and northeast were repulsed. The German counterattack in the area of Szt. Marton 
recaptured the wooded terrain $9 \mathrm{~km}$ northeast of the town. Further north the Soviets advancing from the Trotus vally through Soslelek had reached the hill terrain east of the Sepsiszentgoergy-Ditrau road at Csik Szt. Letek, Csomortan and Csik Szepiviz during the afternoon. A German counterattack pushed back the most forward units. The Soviets in the XVII Army Corps sector broke into the Bistrita vally northwest of Buhabuta and were pushed back again by a concentrated attack. Soviet air activity was weak on the southern wing of the 8th Army. The German Luftwaffe now directed its main effort against Soviet forces advancing over the Carpathian passes. ${ }^{175}$

Units of Gruppe Abraham located northeast of the Ojtoz pass were enveloped on both sides by a Soviet attack and thrown back to the pass where a battle was in process with Soviet paratroops which had landed east of the pass (see Figure 204). The 1st Regiment of the 4th Moutain Division was advancing toward the pass to reinforce the German units there (see Figure 204). Soviet forces captured Scepviz and the hill terrain $6 \mathrm{~km}$ east of the rail line and the road south of this town. However, German counterattacks at Scepviz recaptured the town. But German aerial reconnaissance reported 1000 Soviet vehicles were approaching Palanca. ${ }^{176}$ There was no significant combat activity reported at the Gyimesbuekk pass and west of Piatraneamt.

The Soviets on the right wing of the XVII Army Corps broke through on the Piatraneamt- Bistriz road at Hangul. However, the concentrated German counterattack repulsed the Soviets. The 
German 75th Infantry Division was being rushed to the area of Kronstadt and the Predeal pass. Kampfgruppe Stahel was to fall back to this pass when Ploesti could no longer be held. The Rumanian resistance in the Siebenbuergen was to be broken by arming the Volksdeutschen under the direction of the SS and the police. 177 The arriving 8th SS Cavalry Division "Florian Geyer" would also be employed to crush the Rumanian resistance.178

\section{AUGUST 30, 1944}

6th Army. There was no contact with Gruppe Mieth and aerial reconnaissance provided no new information. According to an intercepted Soviet radio message units of Gruppe Mieth consisting of the 370th Infantry Division, 282nd Infantry Division and the 106th Infantry Division with a total strength of approximately 20,000 men were located $48 \mathrm{~km}$ southeast of Husi. 179

There were also no further reports on the whereabouts of the XXIX Army Corps, Kampfgruppen Braun, Philipp and Stahel. The 5th Flak Division remained the entire day in the area of Ploesti in defensive battles with Rumanian infantry and Soviet tanks (see Figure 205). ${ }^{180}$ The 5th Flak Division was going to fight its way out through Valenii de Munte (see Figure 205). Kampfgruppe Stahel was apparently advancing from Berecszk to the north.

Gruppe Winkler was pushed back to the sector of Gura Aninoasei by enveloping attacks on both sides of the Buzau vally. 
Gruppe Winkler withdrew on the night of August 30-31, 1944 to a defensive position on both sides of Cislau (see Figure 205). A defensive line was under preparation with weak forces $10 \mathrm{~km}$ northwest of Star Chiojd on both sides of Clabucetui in a line to Nehoiuj and Plostina (see Figure 205). A Rumanian battalion strength attack north of Tartlau was smashed by a police battalion. 8th Army. The Kampfgruppe holding the Ojtoz pass repulsed several strong Soviet attacks (see Figure 206). ${ }^{181}$ Units of the 4th Moutain Division after clearing Berecszk were deployed on both sides of the Ojtoz pass where they encountered Soviet forces advancing on the flanks of the Ojtoz pass (see Figure 206). The German Luftwaffe was attacking Soviet vehicle columns northeast of the Ojtoz pass. The counterattack by units of the 4th Moutain Division north of Kastonjakabfalvar developed into a costly battle in difficult, moutainous terrain and gained only little ground.

The Soviets forced the north wing of the LVII Panzer Corps to withdraw to the region east of Bicaz by a series of enveloping attacks. Kampfgruppe von Kessel transferred units to Gruppe Fessner and now was no longer capable of countermeasures.

The Soviets achieved local penetrations northwest of Hangul on the southern wing of the XVII Army Corps which lead to the loss of some hills northeast of Bistricioara and a breakthrough southeast of the Aurel passes. The front was withdrawn behind the Bistrita in the region northeast of Bistricioara. A Soviet penetration $15 \mathrm{~km}$ north of this region was sealed off. 
AUGUST 31, 1944

6th Army. Aerial reconnaissance placed units of Gruppe Mieth (600-700 men and 70 vehicles) west of the Sereth river and approximately $25 \mathrm{~km}$ southwest of Bacau. ${ }^{182}$ There were no further new reports about Kampfgruppe Stahel. According to aerial reconnaissance units of the 5th Flak Division north of Ploesti were observed retreating to the north (see Figure 207). Gruppe Winkler repulsed several Soviet battalion strength attacks during the morning and then withdrew during the night of August 31st and September 1 st to the defensive position on both sides of Cisla (see Figure 207). Kampfgruppe Peters consisting of a police battalion, Flak Regiment 133 and 2 assault gun battalions had deployed on both sides of Sepsiszgyoergy on the Hungarian border and repulsed continuous attacks against the line Elopatak-llyefalya-KokosLisnyo by Rumanian troops since the early morning hours (see Figure 207). The Rumanians suffered heavy casualties.

8th Army. The Soviets continued heavy attacks in the LVII Panzer Corps sector against Gruppe Abraham in the Ojtoz pass. German troops after bitter battles managed to repulse the numerically superior Soviet force attacking the actual pass position. However, the town of Ojtoz was lost in the course of the battle (see Figure 207). 183

Gruppe Breith in the area northeast of Szt. Marton began its attack at $1300 \mathrm{hrs}$ and took both sides of the Aklos pass but failed to reach the controling heights north of Feltiz.184 This attack had 
to be suspended and units of the 4th Moutain Division were ordered to regroup on the south wing of the LVII Panzer Corps. German forces advancing out of the area of Szepviz made good progress advancing along the pass road to the Gyimes pass but encountered in the hills of the pass a strong Soviet force moving to the southwest (see Figure 207). The German force attacked the Soviets and pushed them partially back to the northeast. Meanwhile, a Soviet assault group advanced against the Hungarian defensive line and pushed it back at Felsolok. German forces were employed from the north to cut into the flank of the Soviet force.

The withdrawal movement of the 46th Infantry Division on the left wing of the LVII Panzer Corps went as planned into an intermediate position at Straja. The occupation of a bridgehead position at Bicaz was begun.

Soviet battalion to regimental attacks against the south wing of the XVII Army Corps were repulsed at Gura Hangului and north of Largu. Soviet units that had broken through the German front lines in Ostra were thrown back in a counterstroke and the hill terrain southeast of Stulpicani was also cleansed of Soviet troops. The Soviets attempted during the afternoon a new thrust southeast of Gura Hangului and were advancing west of the Pluton pass road to encircle units of the 3rd Moutain Division. A Soviet battalion strength attack $7 \mathrm{~km}$ northwest of Straja was successful.

The German Luftwaffe continued to support the defensive battles raging around the town of Ojtoz and the pass. 
Meanwhile, the Soviets took Ploesti and marched into Bucharest (see Figure 208). ${ }^{185}$ The Soviets entered Bucharest in the morning with the 6th Tank Army and 53rd Army along with the 1st Rumanian Volunteer Division "Tudor Vladimirescu."186 There was even more bad news with the Slovakian Army joining the Slovakian rebellion. ${ }^{187}$

\section{SEPTEMBER 1, 1944}

6th Army. There were no further reports concerning Gruppe Mieth, Gruppe Stahel and the 5th Flak Division. Intercepted Soviet radio messages indicated that a Kampfgruppe from Gruppe Mieth (approximately 5,000-6,000 men) were located on August 31, 1944 in battle in the region $20 \mathrm{~km}$ northwest of Barlad. ${ }^{188}$ The main body of Gruppe Mieth remained close to Barlad (see Figure 209). The commanding general of the XXIX Army Corps with his Chief of Staff and a few soldiers broke through to the north and reached German lines on foot through the Carpathian moutains arriving at the Command Post of the 6th Army. ${ }^{189}$ Kampfgruppe Winkler during the course of the day repulsed Soviet forces in the Buzau vally south of Valea Lupului that had attempted to envelope the Kampfgruppe from the east. The end of the German vehicle column was located $5 \mathrm{~km}$ north of Nehoiuj during the afternoon.

8th Army. The Soviets continued their attempt to envelope the Ojtoz pass position in the sector of the LVII Panzer Corps (see 
Figure 210). The Soviets shifted their forces from the northeast to the line Esztelnek-Kurtopatak. The Soviets with the onset of darkness renewed their attack against the Ojtoz pass position from the south and launched an attack on Berecszk from the south and on Lemheny from the north (see Figure 210). ${ }^{190}$ The 3rd Moutain Division repulsed Soviet company to battalion strength attacks west of Gura Hangului. However, Soviets managed to infilitrate the lines northwest of Straja.

The Soviets reinforced their position southwest of the Gyimes passes in the area east and west of the stretch of road between Santatelek-Felsolok. The Soviet attack enveloped the German Kampfgruppe Scholze from both sides at the Gyimes pass (see Figure 210) after the Hungarian battalion in the combined German Kampfgruppe had completely deserted their positions. ${ }^{191}$. Soviet forces south of the bridgehead Bicaz advanced to the west into the vally southwest of Cazaci by enveloping the northern regimental group of the 46th Infantry Division and engaged the weak German defensive line.

The Germans proceeded with the disarmament action against the 1st Slovakian Division. The Division Commander with his staff, 36 officers and 360 men were arrested in Szt. Andras $(6 \mathrm{~km}$ northwest of Szasz. Regen). ${ }^{192}$ Disarmament of the other units of the division were in progress.

The main effort of the Luftwaffe ground attack aircraft were directed against Soviet spearheads and columns advancing on the Ojtoz and Gyimes passes (see Figure 210). ${ }^{193}$ 
SEPTEMBER 2, 1944

6th Army. No further reports were available concerning Gruppe Mieth, XXIX Army Corps and Gruppe Stahel. Gruppe Von Scotti withdrew with the subordinate Kampfgruppen Winkler, Ludig, Schmidt and Malmeister to construct a defensive front along the line west of Sepsiszentgoergy-Illyefalya-Zagon-Zabola (see Figure 211).

The Rumanian forces advancing on llyefalya and Koekes crossed over the border but were thrown back. Rumanian reconnaissance forces were located on the east edge of the Geister Forest north of Sepsiszentgyoergy. Countermeasures were taken against Rumanian regimental attacks over the border at Barot that reached Bibarczfalva (see Figure 211).

8th Army. The Soviets advanced on the evening of September 1, 1944 into the towns of Ozsdola, Berevszk and Lemheny in the sector of the LVII Panzer Corps, but the Soviets were repulsed by counterattacks of Kampfgruppe Abraham (see Figure 211). The Soviets continued to attempt the Ojtoz pass at Ozsdola and Lemheny. Both of these Soviet attempts were frustrated. The Soviets in the area north of Lemheny were attacked in the flank by units of the 4th Moutain Division. Both sides of the Gyimes pass were repeatedly attacked by the Soviets and Gruppe Fessner repulsed these repeated attacks in hard fought battles (see Figure 211). Hungarian assault guns inflicted heavy losses on the Soviets during the evening along the pass road. The Soviets advancing on 
the left wing of the 46th Infantry Division to the west reached the Hungarian border $10 \mathrm{~km}$ south of Bicaz.

Several Soviet attacks were launched against the 3rd Moutain Division in the XVII Army Corps sector. The Soviet attacks were primarily directed at the bridgehead of Bistricioara and isolated attacks were made north of the Kimpolung-Suceava road (see Figure 212).

Rumanian troops which had occupied towns on the RumanianHungarian border west of the line Neumarkt-Szasz. Regen were mopped up by alert units so that there were no longer Rumanian troops located on Hungarian territory. ${ }^{194}$

\section{SEPTEMBER 3, 1944}

6th Army. The Rumanian forces that had advanced through Barot to the east on September 2nd were pushed back in a westward direction to the border by Kampfgruppe Hoffmann. Barot was retaken and the Germans advanced west to the HungarianRumanian border (see Figure 213). Soviet reconnaissance probes in the area northwest of Sepsikoeroespatak and west of Malnasfuerdo were repulsed. There were still no reports concerning Gruppe Mieth, Kampfgruppe Stahel and the 5th Flak Division.

8th Army. The Soviet main effort remained directed against the Ojtoz pass. The Soviets continued their attempt through an enveloping attack to take the Ojtoz pass without success (see 
Figure 213). The Soviets had entered Gelence and Ozsdola last evening but were repulsed once again. Strong Soviet assaults against Kezdimartanos and Berecszk were still in progress during the evening. The Soviets infilitrated German lines southeast of Bistricioasa and northwest of Brosteni. A Soviet battalion strength attack was repulsed east of Stulpicani. The disarmament of the 1st Slovakian Division proceeded. Earlier 126 officers and 3,525 troops had been disarmed.195

\section{Army Group South Ukraine}

The Army Group was suffering from a severe shortage of armored vehicles and reported that it had only 14 assault guns available. The 6th Army had 14 assault guns and 10 assault howitzers and the 8th Army had 54 assault guns available for action. 196

\section{SEPTEMBER 4, 1944}

Gruppe Siebenbuergen. The Soviets attacked during the evening after strong artillery preparation Mezoe Band (15 km west to northwest of Neumarkt)

6th Army. Kampfgruppe Gerecke was withdrawn out of the area of Sita Buzaului (35 km east of Kronstadt) to the Hungarian border bunker line north of Intorsura Buzaului. The German attack against the Soviets in the Geisterwald pushed the Soviets out of Szaraz Ajta. Moreover, Rakos and Koepecz were captured. The fate 
of Gruppe Mieth, Kampfgruppe Stahel and the 5th Flak Division remained unknown. ${ }^{197}$ A reconnaissance probe by a Soviet penal company southwest of Sepsiszentgyoergy was repulsed. Kampfgruppe Thams attacking from the area of Barot to the west, southwest and southeast pushed back the Rumanian troops (see Figure 213). The German defense line stood on the south edge of Vargyas.

8th Army. The Soviets attacked the south wing of the LVII Panzer Corps the entire day. Oszdola was lost again to the Soviets only to be recaptured. The Soviets pushed their way into Berecszk but were pushed out again to the south edge of the town and the road from the Berecszk to the Ojtoz pass was cleared of Soviet troops. The town of Eszteinek was cleared of Soviets and the encircled German Kampfgruppe in Kurtapatak was relieved. Further north a Soviet penetration in the area of Feltiz $1 \mathrm{~km}$ east of the Kezdiszentlelek-Ujfalu road was repulsed. Strong Soviet pressure was exerted against Lemheny and the road east of the town during the afternoon. Several weak Soviet thrusts were repulsed in the sector of the 4th Moutain Division.

The 2nd Hungarian Division launched local attacks to improve its position. Gruppe Fessner ran into a strong Soviet attack west of Felsoelok. The northern regimental group of the 46th Infantry Division in the Bicazul vally had its defensive position at Tikos Floaria enveloped by Soviet attacks of 1-2 regiments from the north and south. The Soviets advanced to the hills east of Domok (6 $\mathrm{km}$ south-southwest of Almasmezoe) and the hills north of 
Almasmezoe despite German counterattacks. Units of the XVII Army Corps were employed to secure the AlmasmezoeGyergyotoelgyes road and other units staged a successful counterattack southeast of Stulpicani.

The Volksdeutschen from the disarmed 1st Slovakian Division who were still willing to fight for the German Wehrmacht were organized into a battalion under the 8th Army and transferred to the Gruppe Siebenbuergen. 198 The remainder of the disarmed Slovakian troops were retained for the next two weeks for the construction of defensive positions in this region and roads. 199 Once this assignment was completed they were to be delivered to the rear.

The situation of Army Group South Ukraine had become desperate and Colonel General Friessner issued a statement to the. soldiers of Army Group South Ukraine on September 4, 1944:

...The danger that the loss of Rumania has brought to the Army Group can only be averted when everyone does his duty to the utmost. Whoever violates this command must and will be weeded out from our ranks! Everyone must know that fate has assigned us a hard trial which can only be endured by firm determination. This fate can only be mastered in Discipline, confidence and extreme readiness for action. It must be mastered for the sake of our people, our wives and children! It will be mastered when no one forgets this and everyone acts accordingly.

Let the Fuehrer's word be an admonition to us all: "God has in all times only blessed those that were ready to defend themselves." 200 
SEPTEMBER 5, 1944

\section{Army Group South Ukraine}

The 2nd Hungarian Army and Gruppe Siebenbuergen gained ground in an attack over the Hungarian/Rumanian border.

Meanwhile, the Soviets attacked the 8th Army at several positions and achieved several deep penetrations.

2nd Hungarian Army. The army began its attack at $0445 \mathrm{hrs}$ to the south with the 7th Hungarian Reserve Division, 9th Hungarian Reserve Division and the 2nd Hungarian Panzer Division reinforced with Assault Gun Battalion 1179 (see Figure 214).201 The attack was centered between Szasz Fenes and Szt. Gothard. The Rumanians were surprised by the attack. The assault group encountered only notable Rumanian resistance on both sides of the Klausenberg-Thorenburg road. The attacking spearhead of the 7 th Hungarian Reserve Division reached Burul-Thorenburg; the 9th Hungarian Reserve Division reached the region north of Campia Turzu; and the 2nd Hungarian Reserve Division arrived at Ludus (see Figure 214). The spearheads of the assault group had by $1800 \mathrm{hrs}$ reached the line of the river fork $9 \mathrm{~km}$ west of Cornesti-Cornestisouth of Thorenburg-Viiscara-Ludus and established a bridgehead at Thorenburg and Cornesti where the light bridges were taken intact. 202 The objectives of all assault groups were achieved. The Commander of the 20th Rumanian Infantry Division was taken prisoner and 6 batteries and two artillery tractors with equipment were captured on the route of Kolosz-Viisoara. 203 
Gruppe Siebenbuergen. Units of Gruppe Siebenbuergen joined the attack of the 2nd Hungarian Army out of the area southwest of Neumarkt (see Figure 214). The attack in the western direction made good progress without encountering significant Rumanian resistance and reached Lechinta and Ogra in the Mures vally. Reconnaissance units were deployed from Lechita toward Ludus to establish contact with the 2nd Hungarian Panzer Division. The attack in the southern direction ran into stiff resistance and only reached the hill terrain north of Gerghid and the line $2 \mathrm{~km}$ northwest and $1 \mathrm{~km}$ north of Supiac. The Rumanians responded with a regimental counterattack in the afternoon. A Hungarian tank platoon was put into action on the rail line from Ogra to the west. Units of the 8th SS Cavalry Division "Florian Geyer" took the hill terrain northeast of Capalna in an attack against tenacious Soviet resistance.

6th Army. German reconnaissance had determined on the right wing of Gruppe Gradel that the Soviets had occupied Bodogaja and Sakueni. The border town of Jimbor was captured by German forces and a Soviet force in the woods southwest of Vargyas was destroyed. Gruppe Thams along the road southwest of Barot took the towns of Koepecz and Miklosvar in an attack and continued advancing south during the evening. Weak Soviet infantry and cavalry forces probed Intorsura Buzaului in the sector of Gruppe General Scotti and pushed the German defense line back to the hills north of the town (see Figure 215). German reconnaissance forces east of Intorsura Buzaului advanced to the Hungarian-Rumanian 
border without meeting any Soviet or Rumanian units (see Figure 215).

8th Army. The Soviets conducted repeated attacks against the LVII Panzer Corps. Soviet frontal attacks with infantry and armor against the Ojtoz pass position which began in the early afternoon lasted into the evening hours (see Figure 215). Gruppe Breith and the 2nd Hungarian Replacement Division repulsed several Soviet company and battalion strength attacks with the main effort located east of Szt. Marton and southwest of Felsoe. The situation at the Gyimes pass where there was no contact remained uncertain. The Soviets advanced on the sector of the 46th Infantry Division through Horomkut to the west up to $5 \mathrm{~km}$ east of Gyergyoeszentmiklos (see Figure 215). German countermeasures were taken and a defensive line was built on the east edge of town (see Figure 215). Units of the 46th Infantry Division and the Brandenburg battalion were employed in a counterthrust northeast of Bekas at $1200 \mathrm{hrs}$.

The Soviets conducted numerous company and battalion strength attacks against the XVII Army Corps with the main effort northeast of Brosteni and south of Gurahomorului (see Figure 215). The Soviets achieved a deep penetration into the German strongpoint line northeast of Brosteni in battalion to regimental strength and by evening had advanced into the Bistrita valley southwest of Brosteni (see Figure 215). The Soviets advanced further north into the region northwest of Riana Micului in battalion strength into the German strongpoint line. 


\section{Army Group South Ukraine}

Army Group South Ukraine reported that it had the following numbers of armored vehicles available:

6th Army: 20 tanks, 30 assault guns and 14 antitank assault guns, type $38 \mathrm{t}$.

8th Army: 49 assault guns and 21 antitank assault guns, type 38t.204

\section{CONCLUSION}

The encircled corps and divisions of the 6th Army were designated as lost on September 5, 1944. There was no further hope that the encircled units would breakout. The war diary of Army Group South Ukraine noted that it was "the greatest catastrophe that had befallen the Army Group."205 Army Group South Ukraine reported that the 6th Army had lost 5 Army Corps Headquarters: IV, VII, XXX, XXXXIV and LII Army Corps in addition to 18 divisions: 9th, 15th, 62nd, 79th, 106th, 161st, 257th, 258th, 282nd, 294th, 302nd, 306th, 320th, 335th, 370th, 376th, 384th Infantry Divisions and the 153rd Field Training Division (see Table LIII). 206 Moreover, there were now only remnants that remained of the 10th Panzer Grenadier Division and the 13th Panzer Division. 207 The 76th Infantry Division was also nearly destroyed in addition to the divisions listed above in the war diary of Army Group South Ukraine.208 The following units were rebuilt immediately after the debacle in Rumania: 15th Infantry Division, 13th Panzer Division, 
10th Panzer Grenadier Division and the 153rd Field Training Division. 209

The Soviet High Command estimated the German losses in a report on September 13, 1944. German losses were listed at 256,000 with 150,000 killed and 106,000 taken prisoner.210 German material losses were listed at 330 aircraft, 830 tanks, 3500 artillery guns and 35,000 motor vehicles. 211 There was not one formation of the German 6th Army that was able to breakout of the Soviet encirclement. 212

It was clear to all the leading commanders that an effective defense by the German 6th Army was only possible based on the withdrawal of Army Group South Ukraine to a more defensible and shorter line. Marshal Antonescu in his August 5, 1944 meeting with Hitler proposed that Moldavia be evacuated and that the Army. Group be withdrawn to the Galatz-Focsani-Carpathian Moutain line. ${ }^{213}$ Colonel General Friessner agreed with the position of Marshal Antonescu and proposed to Hitler that the Front be withdrawn to the Galatz-Focsani-Carpathian Moutain line. Hitler, however, insisted that he must have positive proof of the Soviet's intention to attack before he would give his approval for a withdrawal. 214

However, Guderian in his memoirs leaves the issue of blame for the loss of the German 6th Army on Colonel General Friessner. Guderian states in Panzer Leader the following:

Although Hitler immediately authorized the withdrawal of the Army Group's front the troops attempted to hold 
out in places and to carry out a fighting retreat step by step. In order to avoid a complete collapse and consequent annihilation an immediate withdrawal and rapid seizure of the bridges over the Danube were essential. As this was not done the Rumanians reached that river before the Germans, closed the crossing places, and thus left their former allies at the mercy of the Russians. Sixteen German Divisions were completely destroyed, an irreplaceable loss in View of our already very difficult situation. These German soldiers fought valiantly to the bitter end; their military honor was unsullied. They were in no way responsible for their sad fate. The misfortune could only have been avoided if the decision to withdraw to the line Galatz-Focsani-the Carpathian Moutains had been implemented before the Russians launched their attack; the whole Russian plan would thus have been forstalled and we should have have been in possession of a line so shortened that we could have held it even without the assistance of the Rumanians. 215

Colonel General Friessner sets the record straight with a direct response to the assertions in Guderian's memoirs. Friessner refutes the claims of Guderian in Verratene Schlachten:

Army Group South Ukraine warned OKH repeatedly in written and verbal reports about the need for a timely withdrawal of the front.

But only on August 22nd was the permission granted after the Russian offensive had already been in progress 3 days. Furthermore, the troops east of the Pruth river had to face the complete collapse of the front as result of the loss of the Rumanians leaving 20 to $30 \mathrm{~km}$ wide holes in the front that caused the troops to have to fight their way back against Russian tanks which had flowed through the Rumanian holes in the front. 216

The Soviet History Of The Great Patriotic War supports the view of Colonel General Friessner: 
General Friessner only received the order to withdraw by the morning of August 22nd... However, the 6th Army could begin its retreat only with the onset of darkness, 13-14 hours after the order was received. 217

General Fretter-Pico, Commander of the German 6th Army supports the claims of Colonel General Friessner:

The early demand of the Army Group for freedom of action for a timely withdrawal of the projecting arc of the standing 6th Army far to the east beginning on the Pruth, then the Sereth sector and Carpathians was denied. Thereby the Army Group by the middle of August had all its reserves to conduct a defensive battle removed...The High Command retained for itself the order to withdraw with the consequence that it came too late like so often in the last world war. ${ }^{218}$

Therefore, Hitler alone bears the final responsibility for the failure to withdraw in time to save the German 6th Army. This failure was the result of his preoccupation with the "standing fast" doctrine and fighting for every foot of ground. 
TABLE XXXXVII

OPERATIONAL DENSITY OF SOVIET FORCES

AUGUST 20, 1944

\begin{tabular}{|c|c|c|}
\hline $\begin{array}{l}\text { Soviet } \\
\text { Formations }\end{array}$ & $\begin{array}{l}\text { Overall } \\
\text { Frontage }(\mathrm{Km})\end{array}$ & $\begin{array}{l}\text { Main } \\
\text { Attack Sector }(\mathrm{Km})\end{array}$ \\
\hline 2nd Ukrainian Front: & $330 \mathrm{Km}$ & $16 \mathrm{Km}$ \\
\hline
\end{tabular}

51 Divisions:

$6.5 \mathrm{Km} / \mathrm{Div}$

25 Divisions in Main

Attack sector:

$0.64 \mathrm{Km} / \mathrm{Div}$

3rd Ukrainian Front: $260 \mathrm{Km}$

$18 \mathrm{Km}$

37 Divisions:

$7.0 \mathrm{Km} / \mathrm{Div}$

24 Divisions in Main

Attack sector:

$0.75 \mathrm{Km} /$ Div

Armies:

$38-40 \mathrm{Km}$

$8-9 \mathrm{Km}$

Division:

5-6 Km

$1-1.5 \mathrm{Km}$

Artillery:

27 per $\mathrm{Km}$

240 per $\mathrm{Km}$

Tanks/Self-

propelled guns:

3 per $\mathrm{Km}$

14-17 tanks/30-

55 Self-propelled

guns per $\mathrm{Km}$

Source: Colonel T.N. Dupuy \& Paul Martell, Great Battles on the Eastern Front: The Soviet-German War 1941-1945 (New York: The Bobbs-Merrill Company, Inc., 1982), p. 189.

Major Scott R. McMichael, "The Battle Of Jassy-

Kishinev" Military Review Vol. 64 July 1985, p. 57. 


\section{TABLE XXXXVIII}

SOVIET ORDER OF BATTLE OPPOSITE ARMY GROUP SOUTH UKRAINE

\section{Soviet Formations}

2nd Ukrainian Front:

4th Guards Army

5th Air Army

6th Tank Army

7th Guards Army

18th Tank Corps

27th Combined Arms Army

40th Combined Arms Army

52nd Combined Arms Army

53rd Combined Arms Army

Gorshkov Cavalry-Mechanized Group

3rd Ukrainian Front:

4th Guards Mechanized Corps

5th Shock Army

7th Mechanized Corps

17th Air Army

37th Combined Arms Army

46th Combined Arms Army

57th Combined Arms Army

Black Sea Fleet

Danube River Flotilla

Source: Major Scott R. McMichael, "The Battle Of Jassy-Kishinev" Military Review Vol. 64 July 1985, p. 57. 
TABLE XXXXIX

ARMY GROUP SOUTH UKRAINE

ORDER OF BATTLE

AUGUST 15, 1944

Formations

Commanders

Army Group South Ukraine:

Col. General Friessner

Army Group Reserves:

10th Panzer Grenadier Division:

Lt. General Schmidt

153rd Field Training Division:

Artillery Brigade 959

Lt. General Bayer

Army Group Colonel General Dumitrescu:

Col. Gen. Dumitrescu

Army Group Reserves:

1st Rumanian Cavalry Division

9th Rumanian Infantry Division

304th Infantry Division:

Lt. General Sieler

3rd Rumanian Army:

Col. Gen. Dumitrescu

III Rumanian Corps:

2nd Rumanian Infantry Division

15th Rumanian Infantry Division

110th Rumanian Infantry Brigade

XXIX Army Corps:

Gen. d. Pz.Tr.

4th Rumanian Moutain Division

9th Infantry Division:

21st Rumanian Infantry Division

Brandenberger

Assault Gun Brigade 278

6th Army:

General d. Artillerie

Reserves:

Maj. Gen. Gebb

13th Panzer Division:

Fretter-Pico

Lt. General Troeger

XXX Army Corps:

Lt. General Postel

15th Infantry Division:

Major General Sperl

257th Infantry Division: 


\section{TABLE $X X X X \mid X$}

\section{ARMY GROUP SOUTH UKRAINE ORDER OF BATTLE AUGUST 15, 1944 (continued)}

Formations 302nd Infantry Division: 306th Infantry Division: Assault Gun Brigade 239

\section{Army Corps:}

161st Infantry Division 294th Infantry Division:

320th Infantry Division: 384th Infantry Division:

Assault Gun Brigade 243

XXXXIV Army Corps:

62nd Infantry Division 258th Infantry Division: 282nd Infantry Division: 335th Infantry Division: Assault Gun Brigade 911

VII Army Corps:

14th Rumanian Infantry Division 106th Infantry Division: 370th Infantry Division: Assault Gun Brigade 236
Commanders Maj. Gen. von Bogen Lt. Gen. Koehler General d. Infanterie Buschenhagen

Lt. Gen. Drekmann Maj. Gen. von

Eichstedt Colonel Schell Lt. Gen. de SalengreDrabbe

Lt. Gen Mueller Maj. Gen. Tronnier Lt. Gen. Bleyer Maj. Gen. Frenking Colonel Dr. Brechtel

Gen. d. Artillerie Hell Maj. Gen. v. Rekowski Maj. Gen. v. Huelsen 


\section{TABLE XXXXIX}

\section{ARMY GROUP SOUTH UKRAINE \\ ORDER OF BATTLE \\ AUGUST 15, 1944 \\ (continued)}

Formations

Commanders

Army Group General Woehler:

Gen. d Inf. Woehler

Army Group And 8th Army Reserves:

8th Rumanian Infantry Division

18th Rumanian Moutain Division

20th Panzer Division:

Panzer Division "GrossRumaenien":

Assault Gun Brigade 905

Lt. Gen. v. Kessel

Rum. Gen. Corne

8th Army:

Gen. d. Inf. Woehler

IV Army Corps (Gruppe Mieth):

Gen. d. Inf. Mieth

11th Rumanian Infantry Division

79th Infantry Division:

376th Infantry Division:

Lt. Gen. Weinknecht

Maj. Gen. Schwarz

IV Rumanian Army Corps:

3rd Rumanian Infantry Division

5th Rumanian Cavalry Division

7th Rumanian Infantry Division

102nd Rumanian Moutain Brigade

4th Rumanian Army:

Gen. d. Kav. Racovitza

VI Rumanian Army Corps:

5th Rumanian Infantry Division

76th Infantry Division:

Lt. Gen. Abraham

101st Rumanian Moutain Brigade

Assault Gun Brigade 325 
TABLE XXXXIX

ARMY GROUP SOUTH UKRAINE

ORDER OF BATTLE

AUGUST 15, 1944

(continued)

\section{Formations}

LVII Panzer Corps:

1st Rumanian Infantry Division

13th Rumanian Infantry Division

46th Infantry Division:

V Rumanian Army Corps:

1st Rumanian Guards Infantry Division

4th Rumanian Infantry Division

I Rumanian Army Corps:

6th Rumanian Infantry Division

20th Rumanian Infantry Division

VII Rumanian Army Corps:

103rd Rumanian Moutain Brigade

104th Rumanian Moutain Brigade

XVII Army Corps:

3rd Moutain Division:

8th Jaeger Division:

Rumanian Borderguard Units
Commanders

Gen. d. Pz Tr. Kirchner

Colonel Ewringmann
Gen. d. Geb Tr.

Kreysing

Maj. Gen. Klatt

Lt. Gen. Volckamer v.

Kirchensittenbach 
TABLE XXXXIX

ARMY GROUP SOUTH UKRAINE

ORDER OF BATTLE

AUGUST 15, 1944

(continued)

Formations

Luftflotten 4:

15th Flak Division with 4 Flak Regiments

I Fliegerkorps:

7 Reconnaissance squadrons

1 Bomb group

1 Ground Attack group

1 Antitank Squadron

2 Night Ground Attack Squadrons

3 Fighter groups

Total Aircraft:

Aircraft combat ready

on August 20, 1944:

60 Reconnaissance Aircraft

43 Bomber Aircraft

57 Ground Attack Aircraft

41 Fighter Aircraft

31 Night Fighter Aircraft

Total Combat Ready Aircraft: 232 Aircraft

Source: Mehner, GHTBDW Vol. 10, pp. 506-507; Alex Buchner, Ostfront (Friedburg: Podzun-Pallas Verlag GMBH, 1988), pp. 332-334; Oberkommando der Heeresgruppe Suedukraine, Zustand der Divisionen der Heeresgruppe Suedukraine Stand vom: 13.8.1944 NAMP T-311 Roll 266; Generaloberst Hans Friessner, Verratene Schlachten (Hamburg: HolstenVerlag, 1956), pp. 255-258. 
Axis Forces

25 German Divisions

22 Rumanian Divisions

5 Rumanian Brigades

Combat Personnel:

643,000

Artillery Tubes \& Guns:

7,600

Tanks \& Self-Propelled

Guns:

400

Aircraft:

810

Source: Major Scott R. McMichael, "The Battle OF Jassy-Kishinev" Military Review Vol. 64 July 1985, p. 57.
Force Ratios

90 Divisions

6 Tank/Mech Corps

929,000

$1: 1.4$

16,000

$1: 2.1$

1,870

$1: 4.6$

2,200

$1: 2.7$

Soviet Forces

Force Ratios

\section{TABLE L \\ SOVIET AND GERMAN COMPARISON \\ OF FORCES}


TABLE LI

ARMY GROUP SOUTH UKRAINE

DIVISIONAL FRONTAGE,

JULY 23, 1944

Formations

Frontage in Kilometers

Rumanian 3rd Army:

110th Rumanian Infantry Brigade:

33

2nd Rumanian Infantry Division:

15th Rumanian Infantry Division:

304th Infantry Division:

36

21

21st Rumanian Infantry Division:

5.9

4th Rumanian Moutain Division:

Total Rumanian 3rd Army Frontage:

15

10.6

$121.5 \mathrm{Km}$

6th Army:

306th Infantry Division:

5.8

15th Infantry Division:

257th Infantry Division:

15.5

302nd Infantry Division:

8

384th Infantry Division:

9

Corps Detachment A:

8.6

320th Infantry Division:

10.2

294th Infantry Division:

7.6

4th Moutain Division:

6.8

23.7

335th Infantry Division:

11.3

282nd Infantry Division:

15

258th Infantry Division:

Corps Detachment F:

14.2

14th Rumanian Infantry Division:

14

106th Infantry Division:

24

370th Infantry Division:

23.8

Total 6th Army Frontage:

22.8 
TABLE LI

ARMY GROUP SOUTH UKRAINE

DIVISIONAL FRONTAGE,

JULY 23, 1944

(continued)

Formations

8th Army:

376th Infantry Division:

11th Rumanian Infantry Division:

79th Infantry Division:

3rd Rumanian Infantry Division:

7th Rumanian Infantry Division:

76th Infantry Division:

5th Rumanian Infantry Division:

1st Rumanian Infantry Division:

46th Infantry Division:

4th Rumanian Infantry Division:

1st Rumanian Guards Division:

6th Rumanian Cavalry Division:

20th Rumanian Infantry Division:

104th Rumanian Moutain Brigade:

103rd Rumanian Moutain Brigade:

3rd Moutain Division:

8th Jaeger Division:

Total 8th Army Frontage:

Total Main Battle Line Frontage:

Average Divisional

Main Battle Line Frontage:
Frontage in Kilometers

24

16

4

5

5.8

6

14.5

13.8

7.8

8.2

10

16

12.8

11

14

86

75

$329.9 \mathrm{Km}$

$671.7 \mathrm{Km}$

$17.223 \mathrm{Km}$

Source: Oberkommando der Heeresgruppe Suedukraine, Zusammenstellung der Frontkilometer 23.7.44 NAMP T-311 Roll 266. 
TABLE LII

RUMANIAN DIVISION FRONTAGE

IN ARMY GROUP DUMITRESCU

AND ARMY GROUP WOEHLER

ON JULY 23, 1944

Formations

Army Group Dumitrescu:

2nd Rumanian Infantry Division:

4th Rumanian Moutain Division:

14th Rumanian Infantry Division:

15th Rumanian Infantry Division:

21st Rumanian Infantry Division:

110th Rumanian Infantry Brigade:

Total Rumanian Frontage:

Army Group Woehler:

1st Rumanian Infantry Division:

1st Rumanian Guards Division:

3rd Rumanian Infantry Division:

4th Rumanian Infantry Division:

5th Rumanian Infantry Division:

6th Rumanian Cavalry Division:

7th Rumanian Infantry Division:

11th Rumanian Infantry Division:

20th Rumanian Infantry Division:

103rd Rumanian Moutain Brigade:

104th Rumanian Moutain Brigade:

Total Rumanian Frontage:
Frontage in Kilometers

$342 \mathrm{Km}$

36

11

24

21

15

33

$140 \mathrm{Km}$

$330 \mathrm{Km}$

14

10

5

8

15

16

6

16

13

14

11 
TABLE LII
RUMANIAN DIVISION FRONTAGE IN ARMY GROUP DUMITRESCU AND ARMY GROUP WOEHLER ON JULY 23, 1944
(continued)

Formations

Total Army Group Frontage:

Total Rumanian Frontage:

Rumanian Percent of Total Frontage: $\quad 40 \%$

Rumanian Percent of Frontage in

Army Group Dumitrescu:

Rumanian Percent of Frontage in Army Group Woehler:

$41 \%$

$39 \%$
Frontage in Kilometers

$672 \mathrm{Km}$

$268 \mathrm{Km}$

Source: Oberkommando der Heeresgruppe Suedukraine, Zusammenstellung der Frontkilometer 23.7.44 NAMP T-311 Roll 266. 
TABLE LIII

THE DESTRUCTION OF ARMY GROUP SOUTH UKRAINE

\begin{tabular}{|c|c|c|}
\hline $\begin{array}{l}\text { Formations } \\
\text { Destroyed }\end{array}$ & $\begin{array}{l}\text { Reorganized Or } \\
\text { Disbanded Units }\end{array}$ & $\begin{array}{l}\text { Commanders } \\
\text { Killed Or Captured }\end{array}$ \\
\hline $\begin{array}{l}\text { 9th Infantry Division } \\
\text { 153rd Field Training } \\
\text { Division } \\
\text { IV Army Corps } \\
\text { (Gruppe Mieth) }\end{array}$ & $\begin{array}{l}\text { Reorganized } \\
\text { Reorganized }\end{array}$ & $\begin{array}{l}\text { Maj. Gen. Gebb } \\
\text { Prisoner } \\
\text { Lt. Gen. Bayer } \\
\text { Prisoner } \\
\text { Gen. d. Inf. Mieth } \\
\text { Killed }\end{array}$ \\
\hline $\begin{array}{l}\text { 79th Infantry Divison } \\
\text { 376th Infantry } \\
\text { Divison } \\
\text { VII Army Corps }\end{array}$ & $\begin{array}{l}\text { Reorganized } \\
\text { Disbanded }\end{array}$ & $\begin{array}{l}\text { Lt. Gen. Weinknecht } \\
\text { Prisoner } \\
\text { Maj. Gen. Schwarz } \\
\text { Prisoner } \\
\text { Gen. d. Art. Hell } \\
\text { Killed }\end{array}$ \\
\hline $\begin{array}{l}\text { 106th Infantry } \\
\text { Division }\end{array}$ & Reorganized & \\
\hline $\begin{array}{l}\text { 370th Infantry } \\
\text { Division } \\
\text { XXX Army Corps }\end{array}$ & Disbanded & $\begin{array}{l}\text { Lt. Gen. v. Huelson } \\
\text { Prisoner } \\
\text { Lt. Gen. Postel } \\
\text { Prisoner }\end{array}$ \\
\hline $\begin{array}{l}\text { 15th Infantry } \\
\text { Division }\end{array}$ & Reorganized & \\
\hline $\begin{array}{l}257 \text { th Infantry } \\
\text { Division }\end{array}$ & Reorganized & $\begin{array}{l}\text { Maj. Gen. Bluemke } \\
\text { Killed }\end{array}$ \\
\hline $\begin{array}{l}302 n d \text { Infantry } \\
\text { Division }\end{array}$ & Disbanded & $\begin{array}{l}\text { Maj. Gen. von Bogen } \\
\text { Prisoner }\end{array}$ \\
\hline $\begin{array}{l}\text { 306th Infantry } \\
\text { Division }\end{array}$ & Disbanded & \\
\hline XXXXIV Army Corps & & $\begin{array}{l}\text { Lt. Gen. Mueller } \\
\text { Missing In Action }\end{array}$ \\
\hline $\begin{array}{l}62 \text { nd Infantry } \\
\text { Division }\end{array}$ & Reorganized & $\begin{array}{l}\text { Maj. Gen. Tronnier } \\
\text { Prisoner }\end{array}$ \\
\hline $\begin{array}{l}258 \text { th Infantry } \\
\text { Division }\end{array}$ & Disbanded & \\
\hline
\end{tabular}


TABLE LIII

THE DESTRUCTION OF ARMY GROUP SOUTH UKRAINE (continued)

\begin{tabular}{|c|c|c|}
\hline $\begin{array}{l}\text { Formations } \\
\text { Destroyed }\end{array}$ & $\begin{array}{l}\text { Reorganized Or } \\
\text { Disbanded Units }\end{array}$ & $\begin{array}{l}\text { Commanders } \\
\text { Killed Or Captured }\end{array}$ \\
\hline $\begin{array}{l}\text { 282nd Infantry } \\
\text { Division }\end{array}$ & Disbanded & $\begin{array}{l}\text { Maj. Gen. Frenking } \\
\text { Prisoner }\end{array}$ \\
\hline $\begin{array}{l}\text { 335th Infantry } \\
\text { Division }\end{array}$ & Disbanded & \\
\hline LII Army Corps & & $\begin{array}{l}\text { Gen. d. Inf. } \\
\text { Buschenhagen } \\
\text { Prisoner }\end{array}$ \\
\hline $\begin{array}{l}\text { 161st Infantry } \\
\text { Division }\end{array}$ & Disbanded & \\
\hline 294th Infantry & Disbanded & Maj. Gen. von \\
\hline $\begin{array}{l}\text { Division } \\
320 t h \text { Infantry } \\
\text { Division }\end{array}$ & Reorganized & Eichstedt Killed \\
\hline $\begin{array}{l}\text { 384th Infantry } \\
\text { Division }\end{array}$ & Disbanded & $\begin{array}{l}\text { Lt. Gen. de Salengre- } \\
\text { Drabbe Killed } \\
\text { Lt. Gen. Troeger, } \\
\text { Commander 13th } \\
\text { Panzer Division } \\
\text { Prisoner }\end{array}$ \\
\hline Fortress Jassy & & $\begin{array}{l}\text { Commandant Maj. Gen. } \\
\text { Stingl Prisoner }\end{array}$ \\
\hline $\begin{array}{l}\text { Rear Army Territory } \\
593\end{array}$ & & $\begin{array}{l}\text { Commander Lt. Gen. } \\
\text { Burckhardt Missing in } \\
\text { Action }\end{array}$ \\
\hline F.K. 497 & & $\begin{array}{l}\text { Commandant Maj. Gen. } \\
\text { Boie Prisoner }\end{array}$ \\
\hline Fortress Kischinew & & $\begin{array}{l}\text { Commandant Maj. Gen. } \\
\text { von Dewitz Prisoner }\end{array}$ \\
\hline Fortress Galatz & & $\begin{array}{l}\text { Commandant Maj. Gen. } \\
\text { Seelig Missing in } \\
\text { Action }\end{array}$ \\
\hline
\end{tabular}


TABLE LIII

THE DESTRUCTION OF ARMY GROUP SOUTH UKRAINE (continued)

Formations

Destroyed

Total Corps Destroyed:

Total Divisions Destroyed: 18

Total Generals Killed,

Captured or Missing:
Reorganized Or Disbanded Units
Commanders Killed Or Captured

Source: Hauptmann Rabe, Kriegstagebuch des Oberkommandos der Heeresgruppe Suedukraine 20.8 - 5.9.1944 Band 4 Teil 1, NAMP T-311 Roll 158, pp. 150-151; Generaloberst Hans Friessner, Verratene Schlachten (Hamburg: HolstenVerlag, 1956), pp. 255-258; Organisation der Wehrmacht, OKW/Org. Abt. und Heerespersonalabt., Zusammenstellung der in diesem Kriege gefallenen, toetlich verunglueckten, verstorbenen, vermissten und im Gefangenschaft geratenen Generale stand 17.9.1944. Flensburg 5 June 1945 NAMP T77 Roll 785; Generalstab des Heeres, Organisationabteilung, Uebersicht ueber aufgeloeste Division 1944 NAMP T-78 Roll 410. 
Situation from 15 June to 20 August 1944

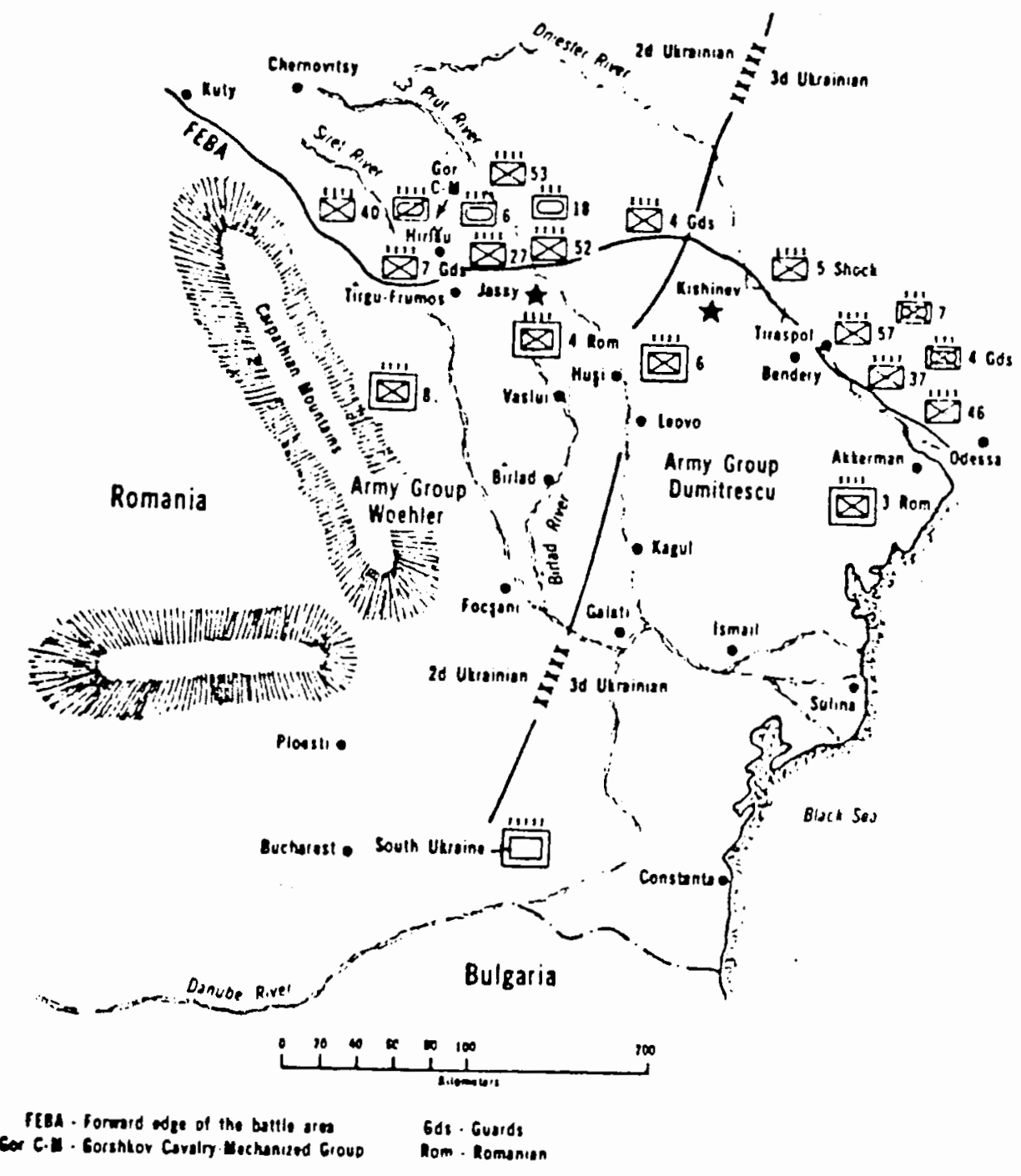

Figure 185. The Soviet And Axis Deployment In Rumania From June 15th To August 20, 1944. Source: Major Scott R. McMichael, "The Battle Of Jassy-Kishinev" Military Review Vol. 64 July 1985, p. 55. 


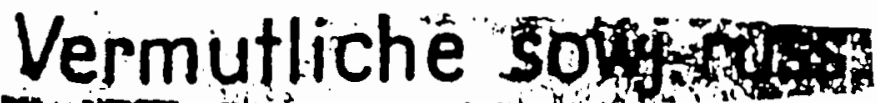

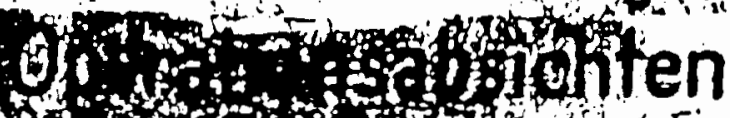

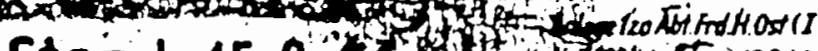

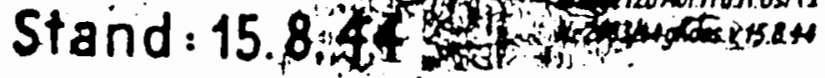

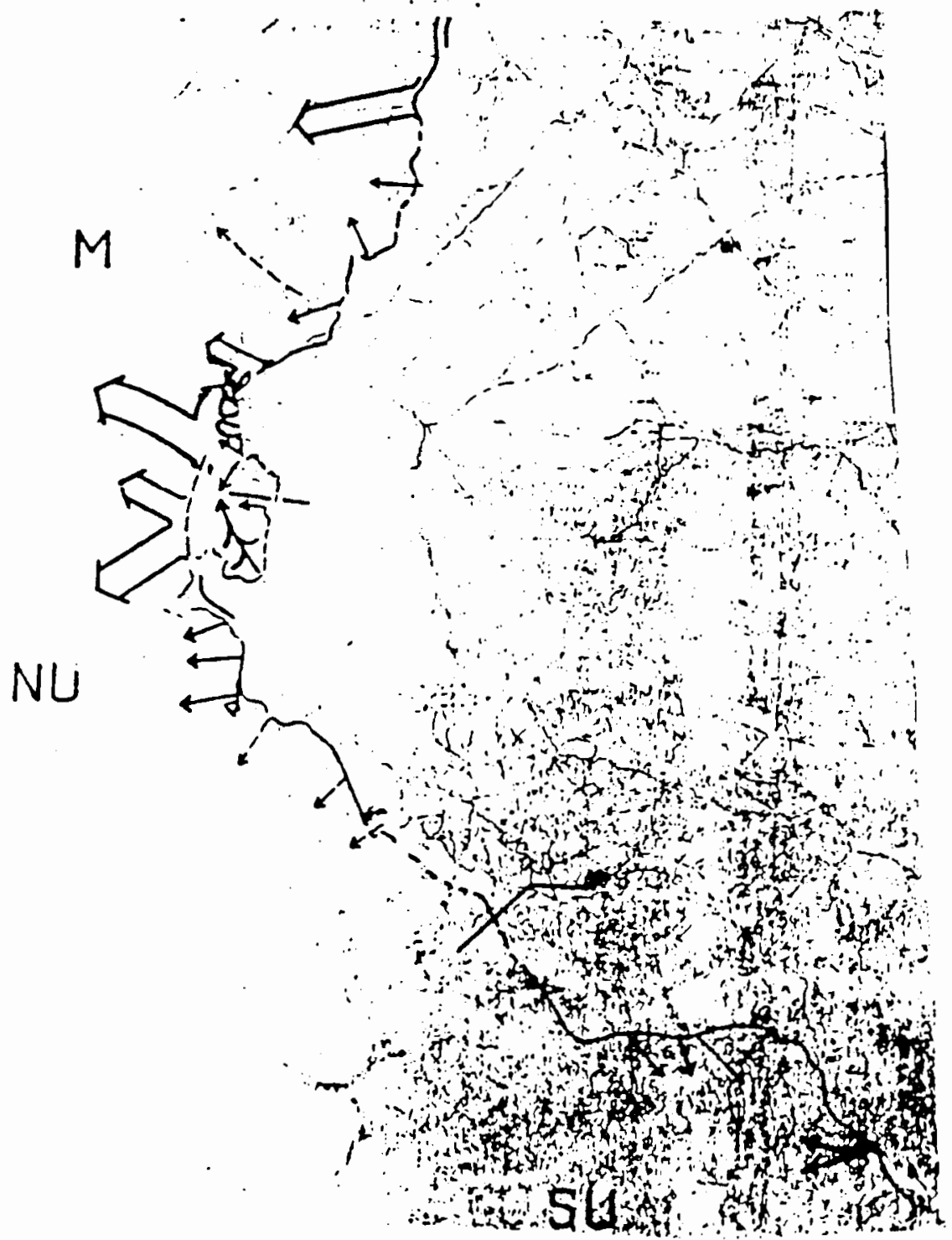

Figure 186. Possible Soviet Operational Objectives On August 15, 1944. Source: Fremde Heer Ost, Vermutliche Sowj. russ. Operationsabsichten Stand: 15.8.44 National Archives Microfilm Publication T-78 Roll 587. 


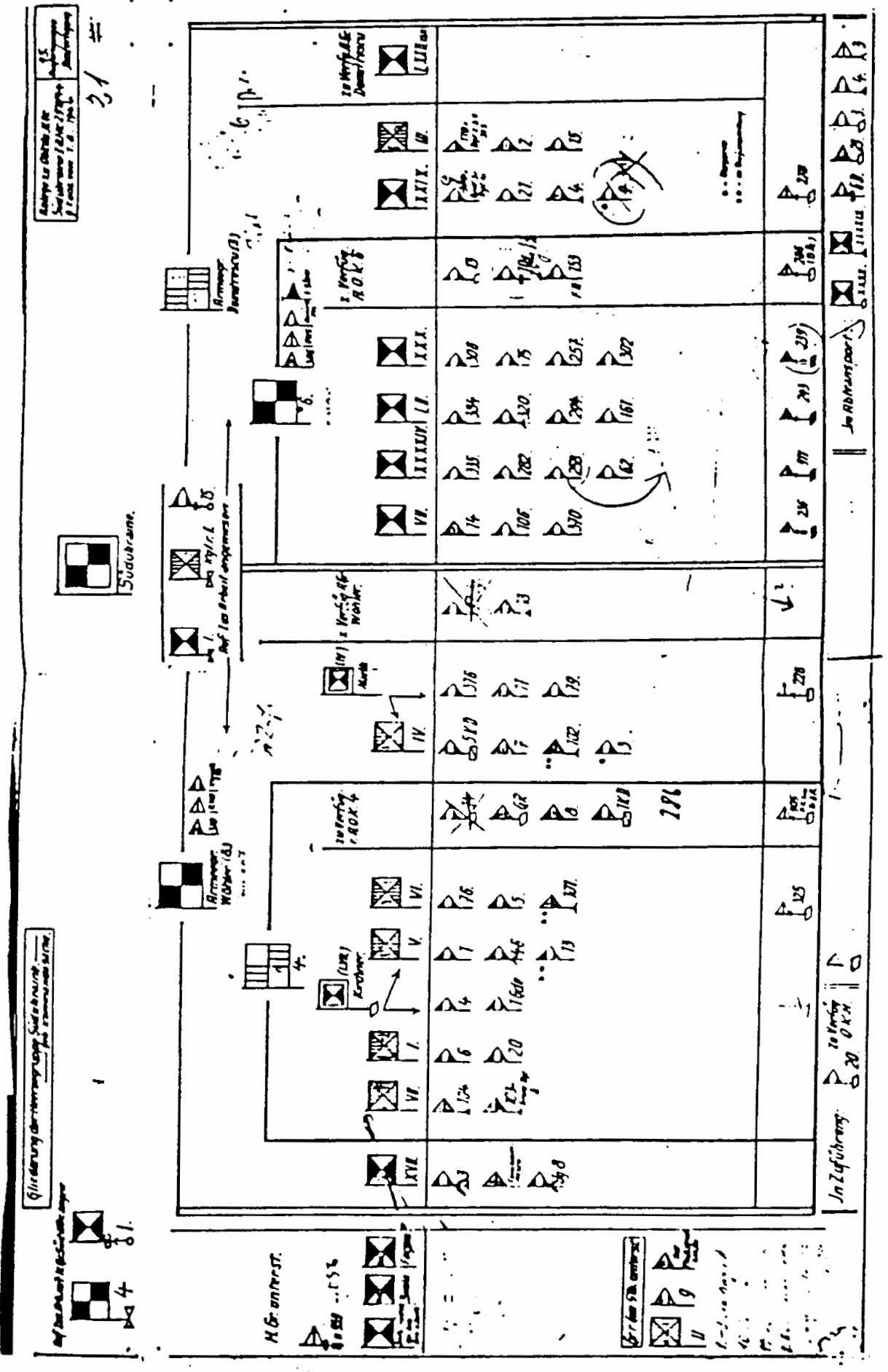

801

Figure 187. Army Group South Ukraine Order Of Battle, August 1, 1944. Source: Oberkommando der Heeresgruppe Suedukraine, Gliederung der Heeresgruppe Suedukraine 1.8.44 National Archives Microfilm Publication T-311 Roll 266. 


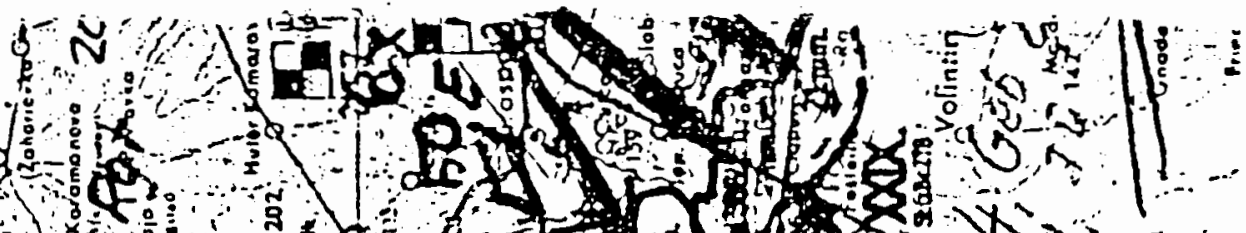

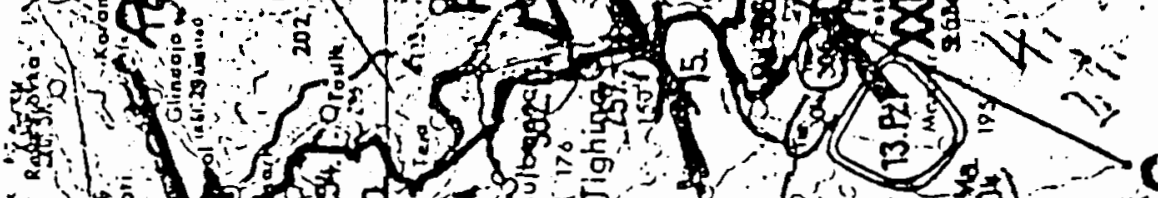

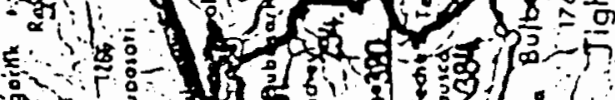

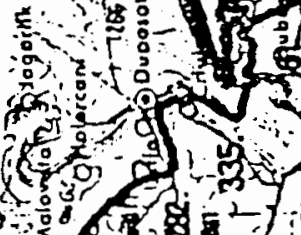

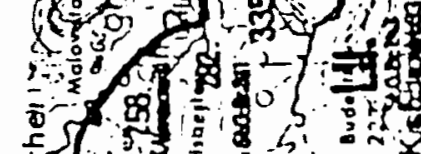

(1)

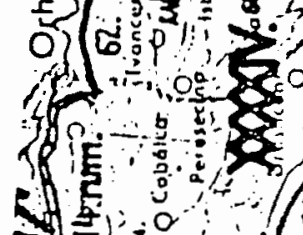

iा

1.

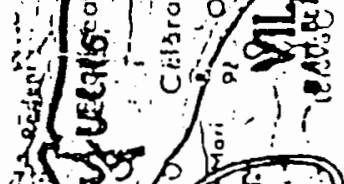

紧
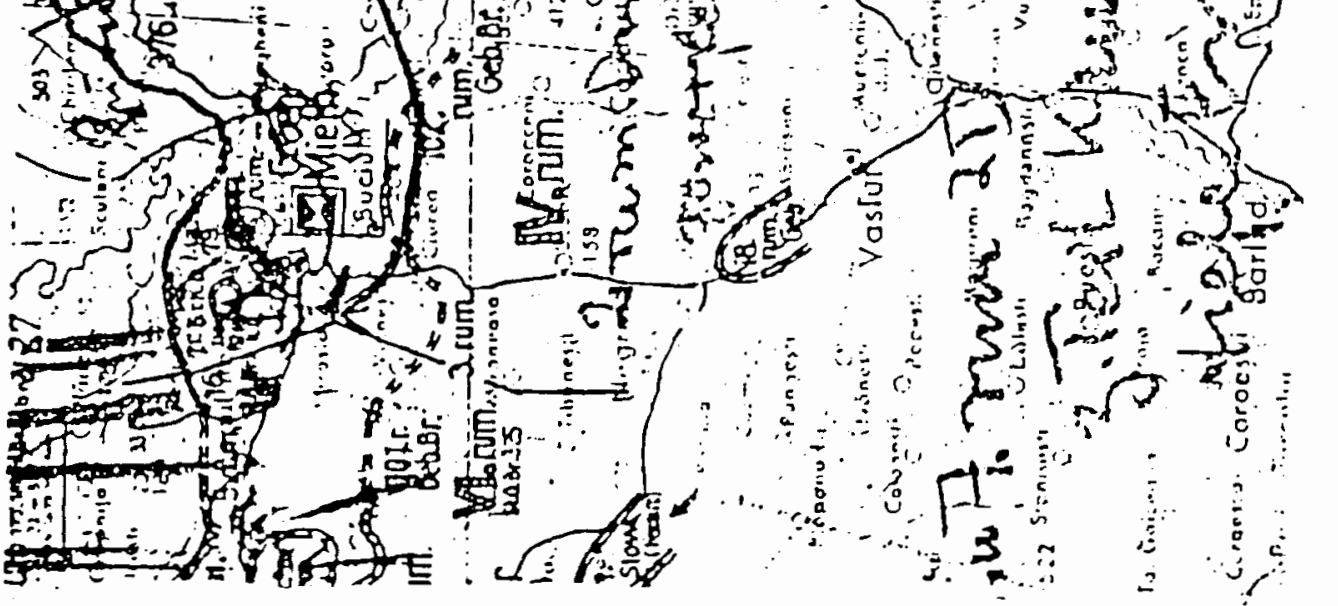

Figure 188. The Soviet Offensive Against Army Group South Ukraine On August 20, 1944. Source: OKH, Schlacht um Rumaenien u. den Beskiden v. 20.8.-29.9.44 National Archives Microfilm Publication T-78 Roll 136. 


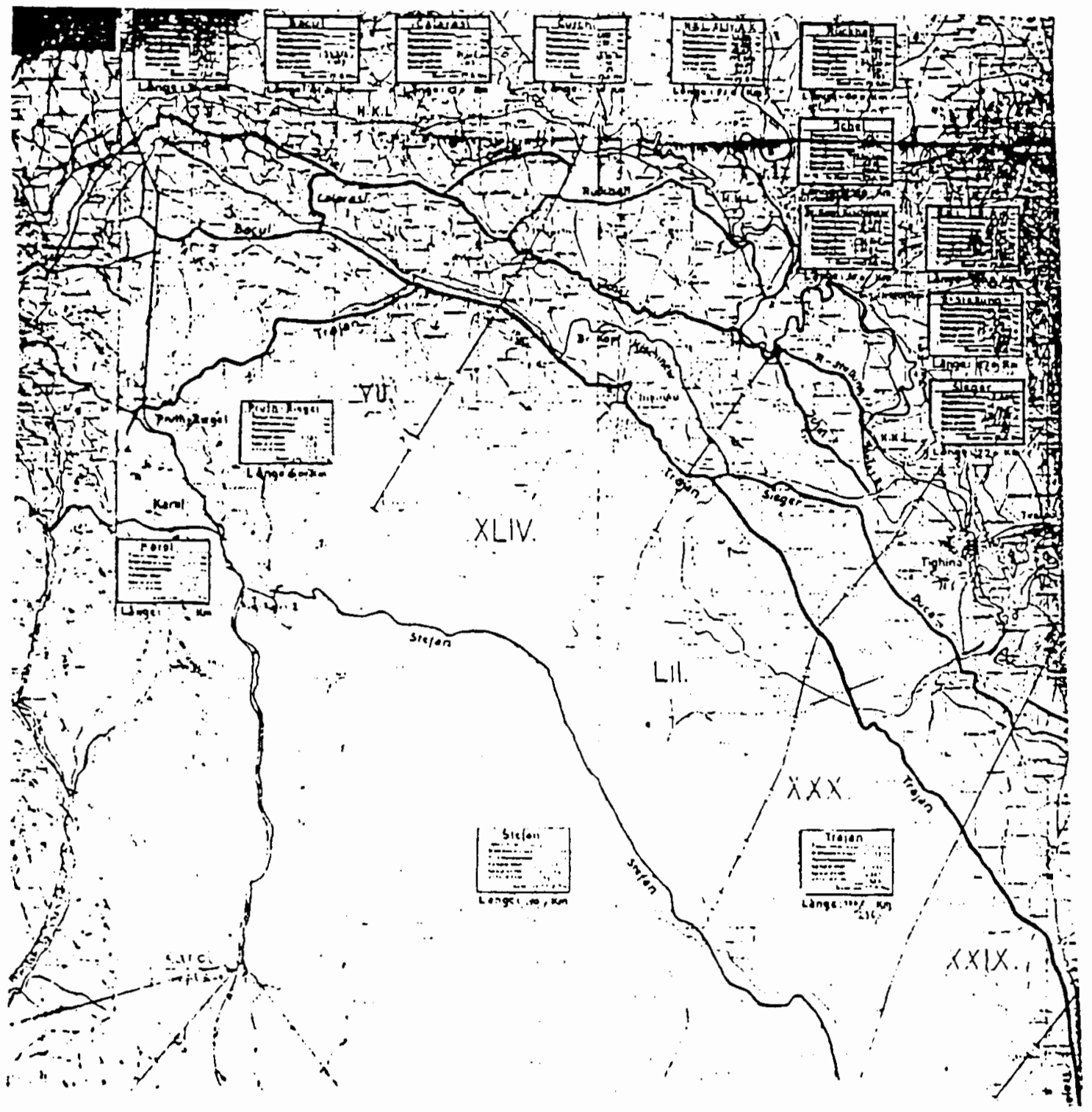

Figure 189. The German Defensive Lines In Rumania, August 10, 1944. Source: A.O.K. 6, Pendelkarte la. A.O.K. 6/A.Pi.Fue. Stand V. 10.8.44 National Archives Microfilm Publication T-312 Roll 1470. 
and

(1) (1)

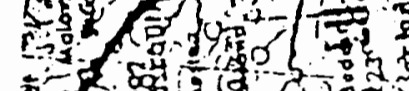

ब-5

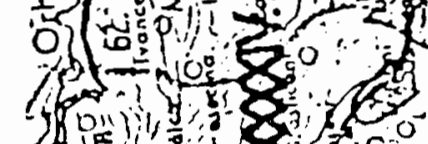

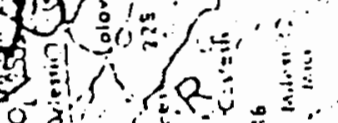
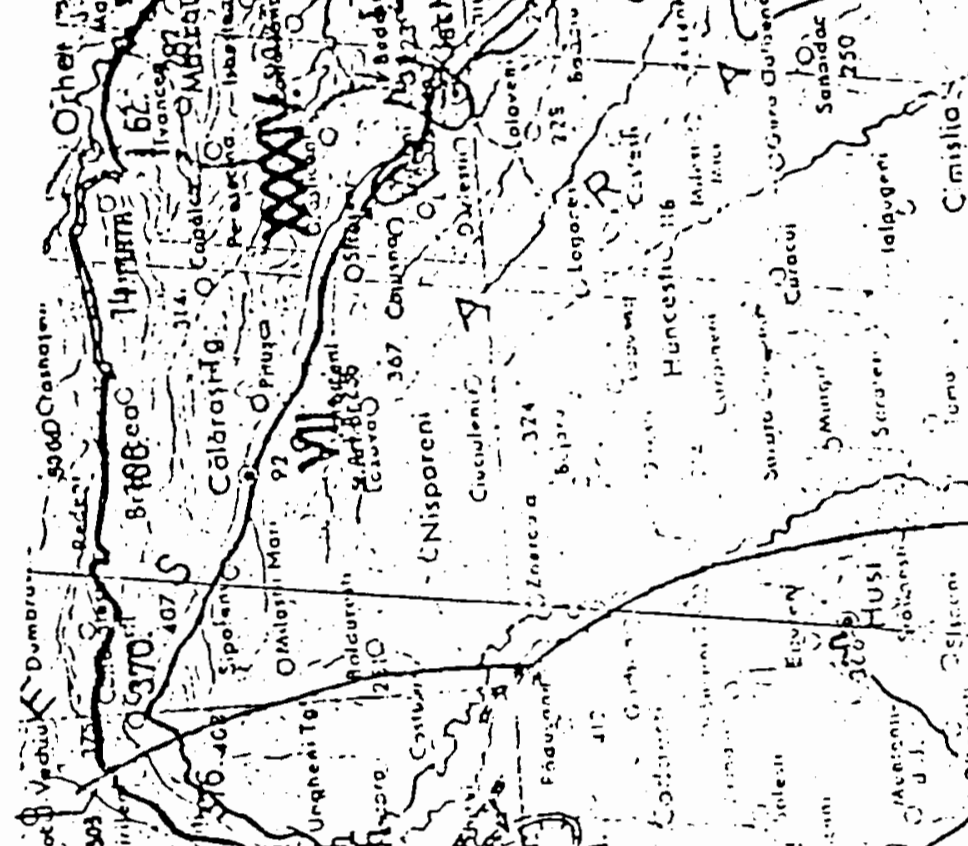


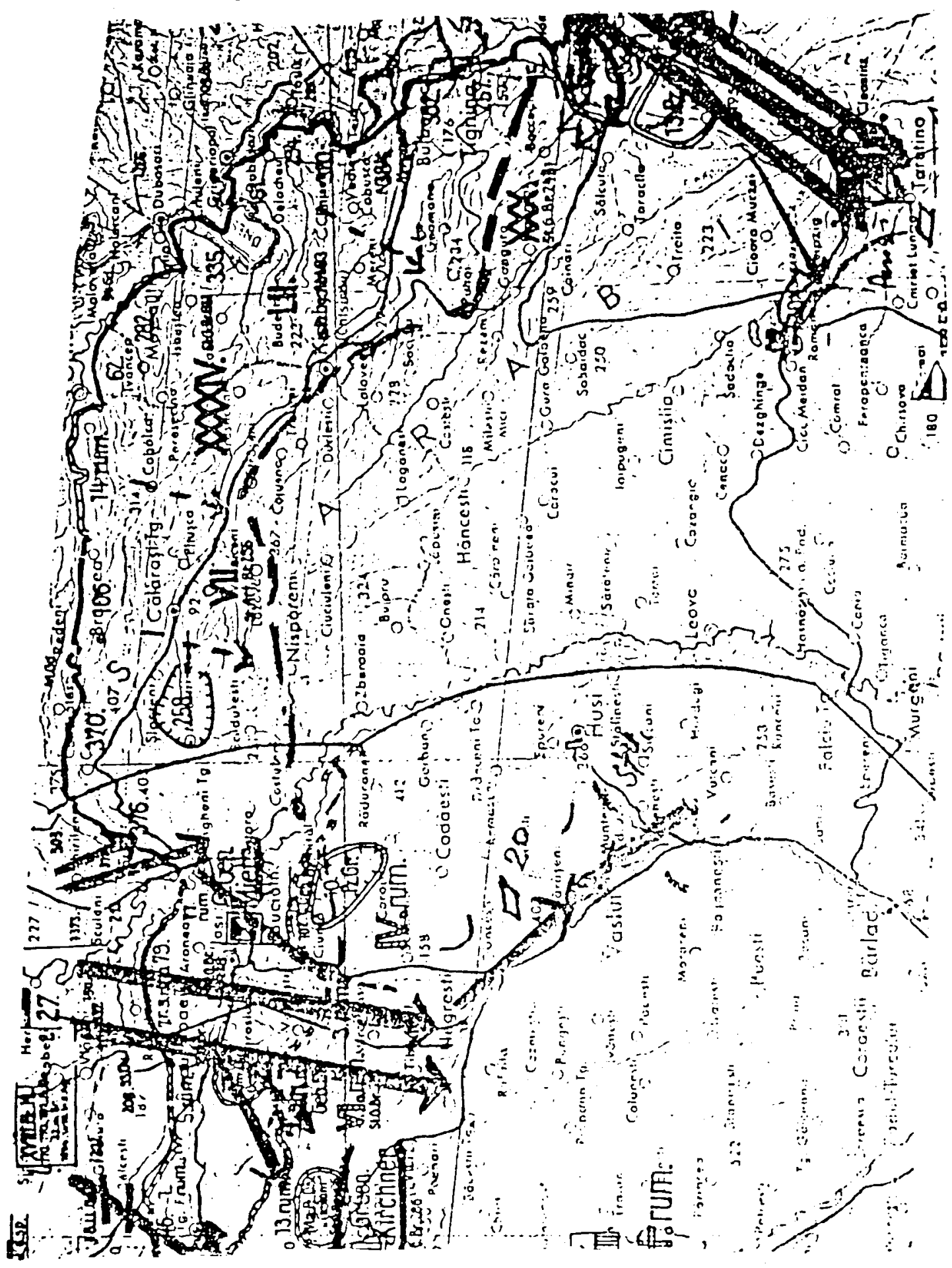

Figure 191. Army Group South Ukraine, August 22, 1944. Source: OKH, Schlacht um Rumaenien u. den Beskiden v. 20.8.-29.9.44 National Archives Microfilm Publication T-78 Roll 136. 


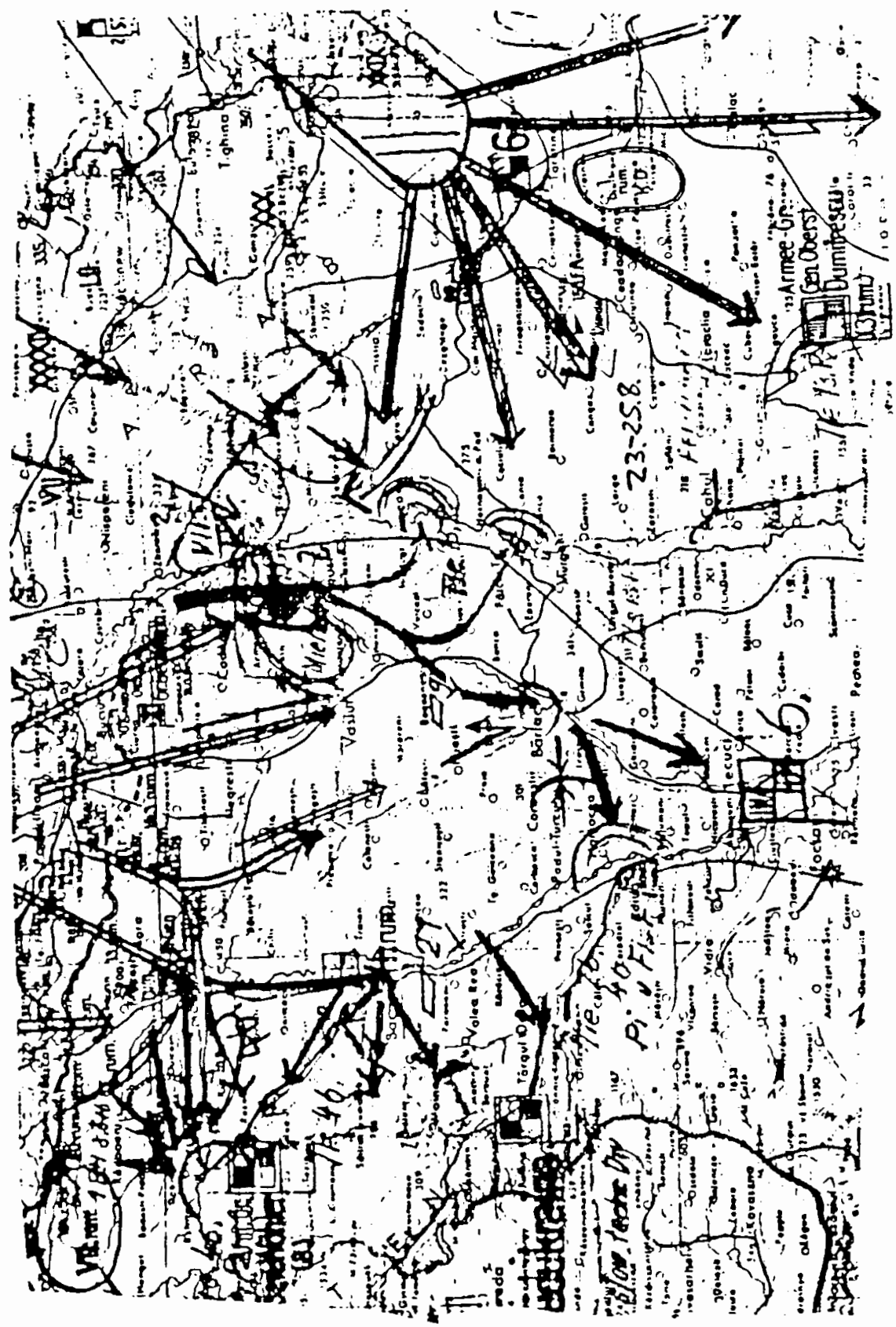

Figure 192. Army Group South Ukraine, August 23-25, 1944. Source: OKH, Schlacht um Rumaenien U. den Beskiden v. 20.8.-29.9.44 National Archives Microfilm Publication T-78 Roll 136. 


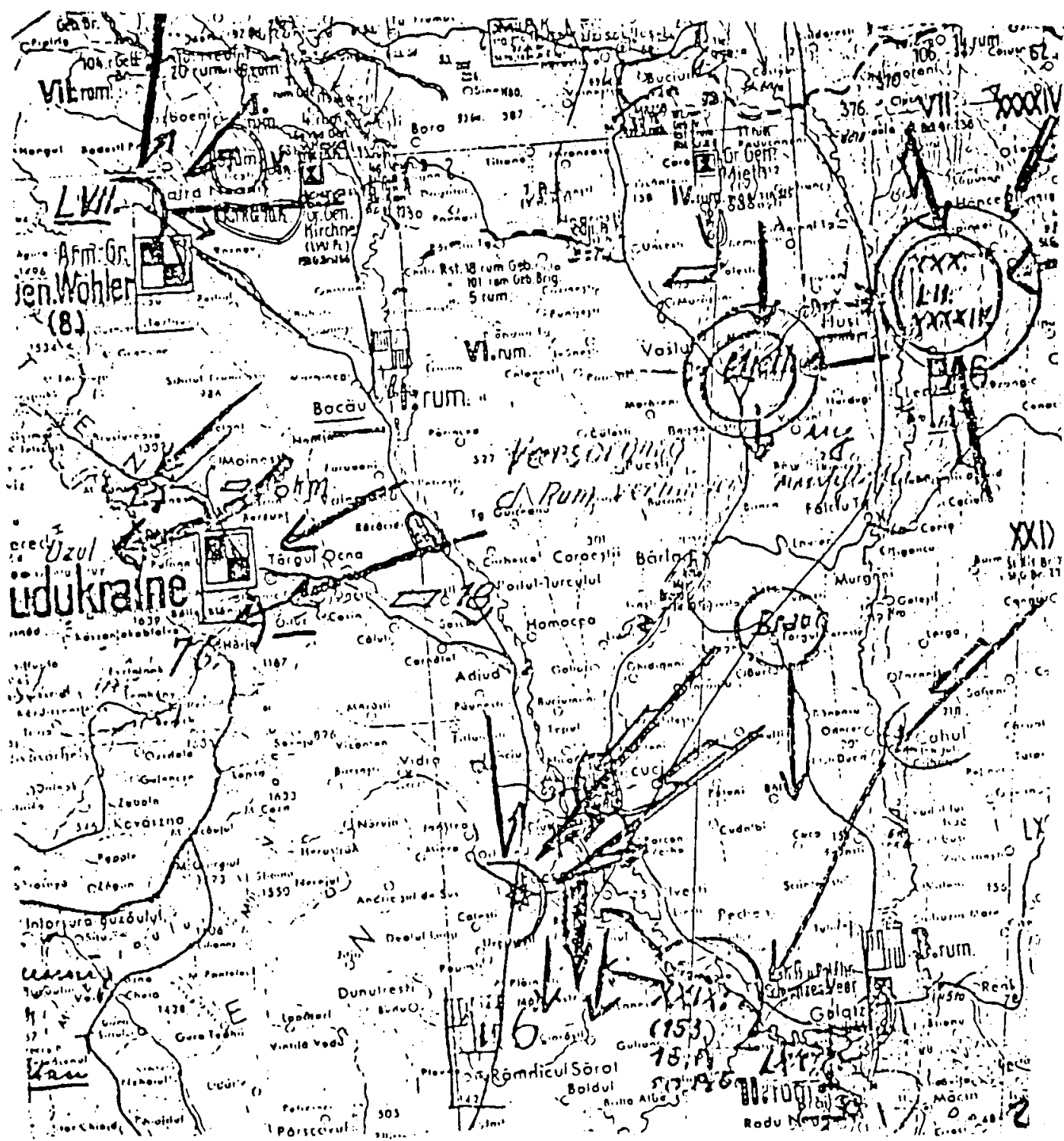

Figure 193. Army Group South Ukraine, August 26, 1944. Source: OKH, Schlacht um Rumaenien U. den Beskiden v. 20.8.-29.9.44 National Archives Microfilm Publication T-78 Roll 136. 


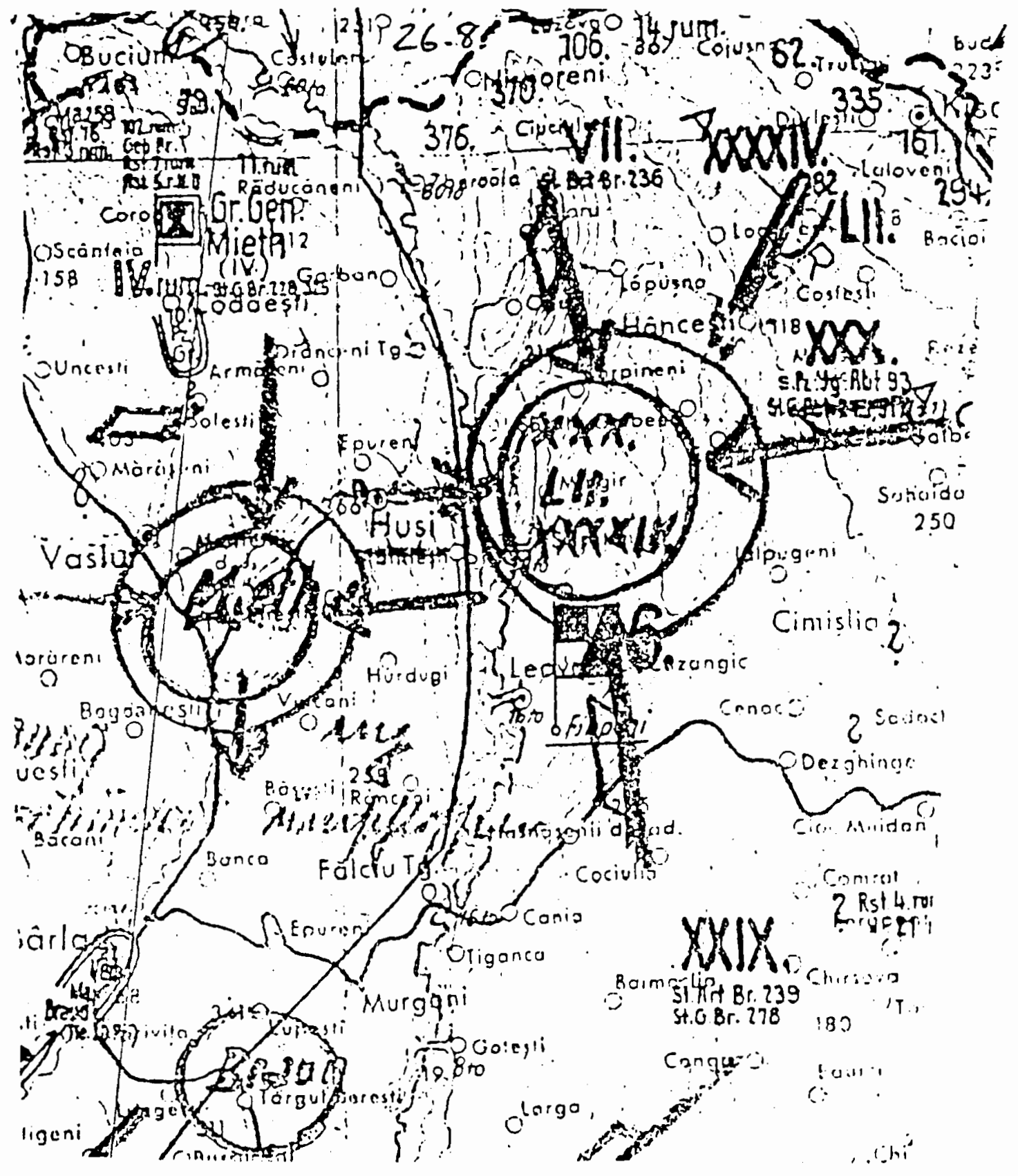

Figure 194. The Surrounded 6th Army, August 26, 1944. Source: OKH, Schlacht um Rumaenien u. den Beskiden v. 20.8.-29.9.44 National Archives Microfilm Publication T-78 Roll 136. 


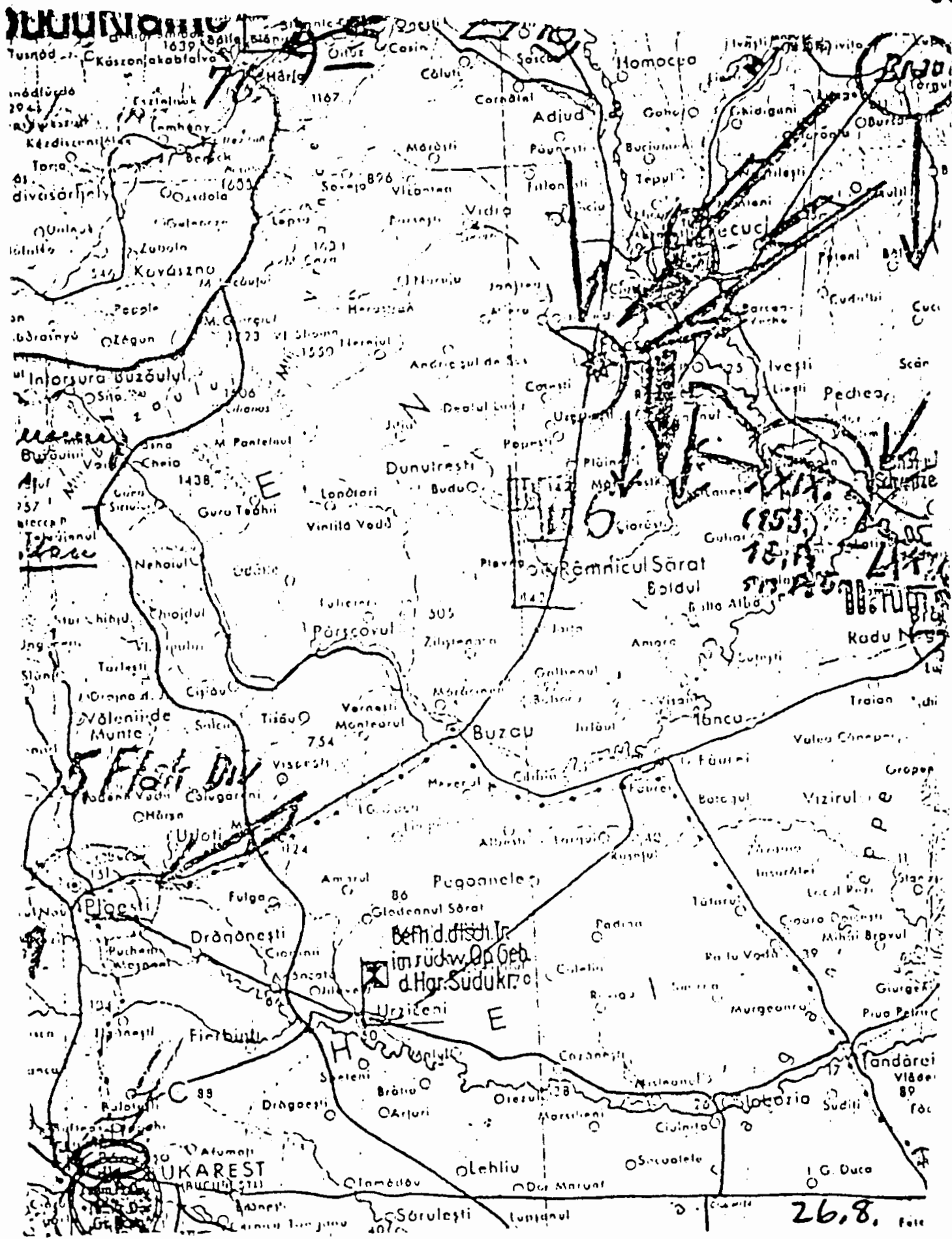

Figure 195. The Soviet Advance South Of Focsani And The Rumanian Armored Attack On Ploesti, August 26, 1944. Source: OKH, Schlacht um Rumaenien U. den Beskiden v. 20.8.-29.9.44 National Archives Microfilm Publication T-78 Roll 136. 


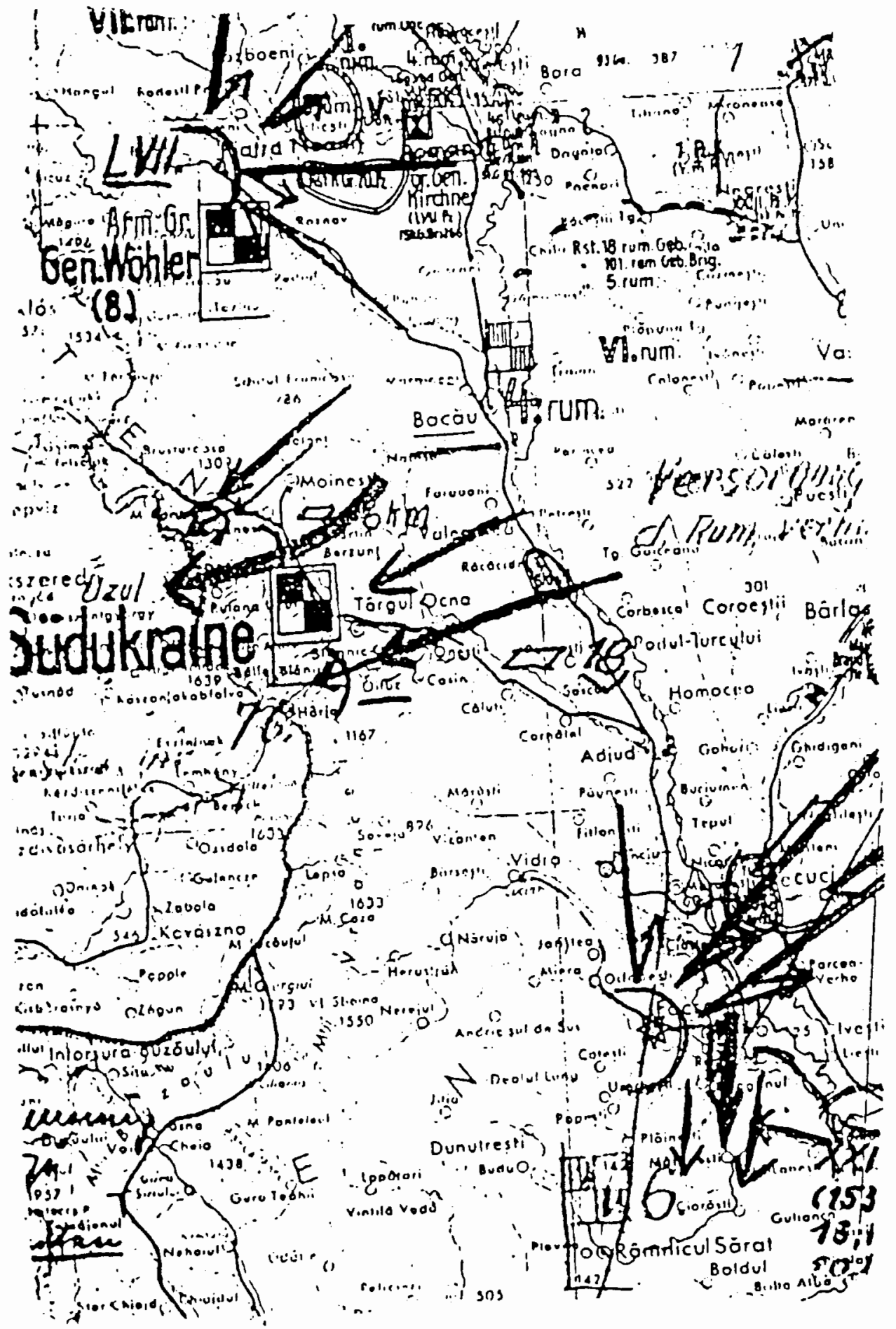

Figure 196. The Soviet Advance On The Ojtoz Pass And Toward The Carpathians, August 26, 1944. Source: $\mathrm{OKH}$, Schlacht um Rumaenien u. den Beskiden v. 20.8. 29.9.44 National Archives Microfilm Publication T-78 Roll 136. 


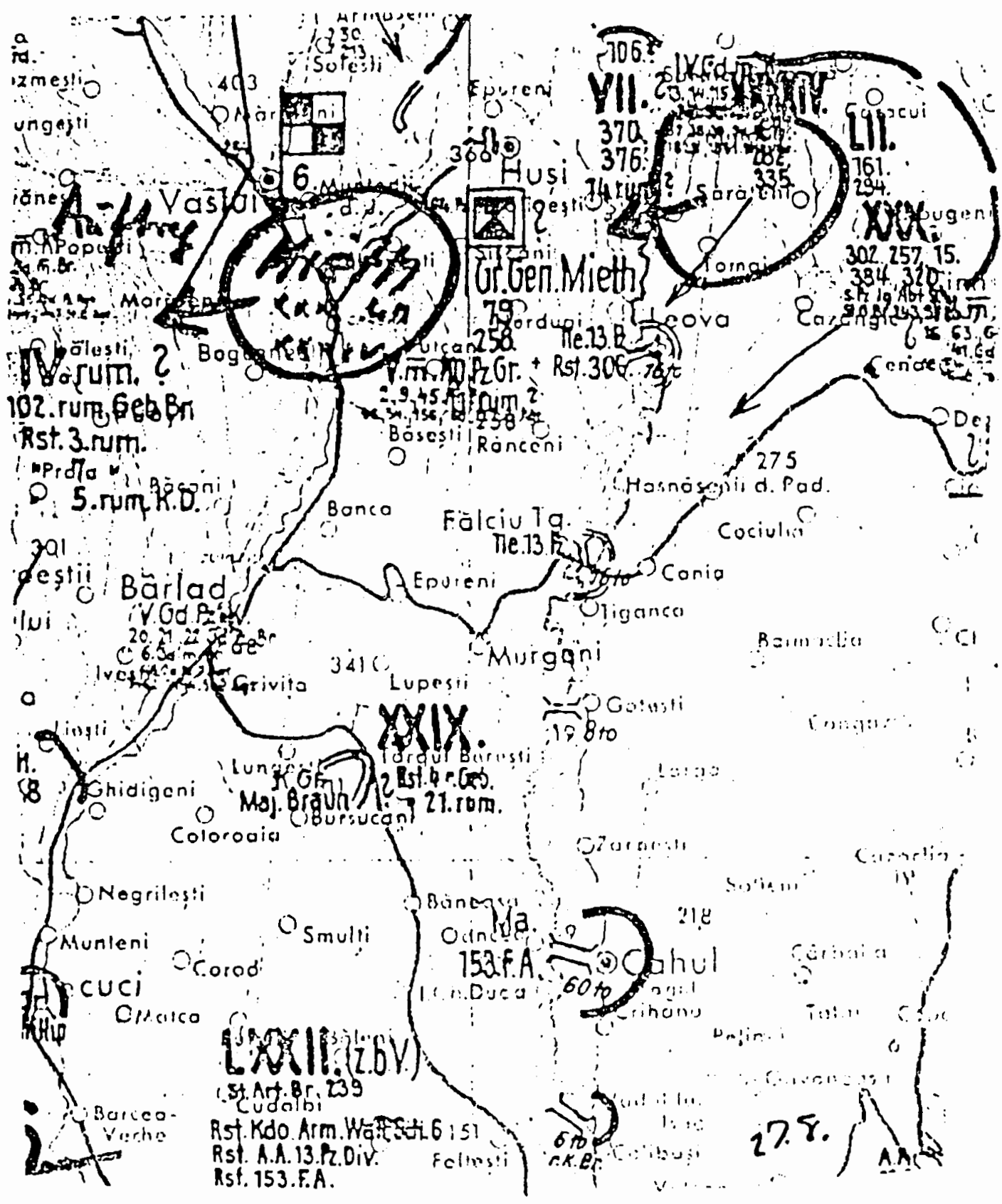

Figure 197. The encircled Elements Of The German 6th Army, August 27, 1944. Source: OKH, Schlacht um Rumaenien $u$. den Beskiden v. 20.8.-29.9.44 National Archives Microfilm Publication T.78 Roll 136. 


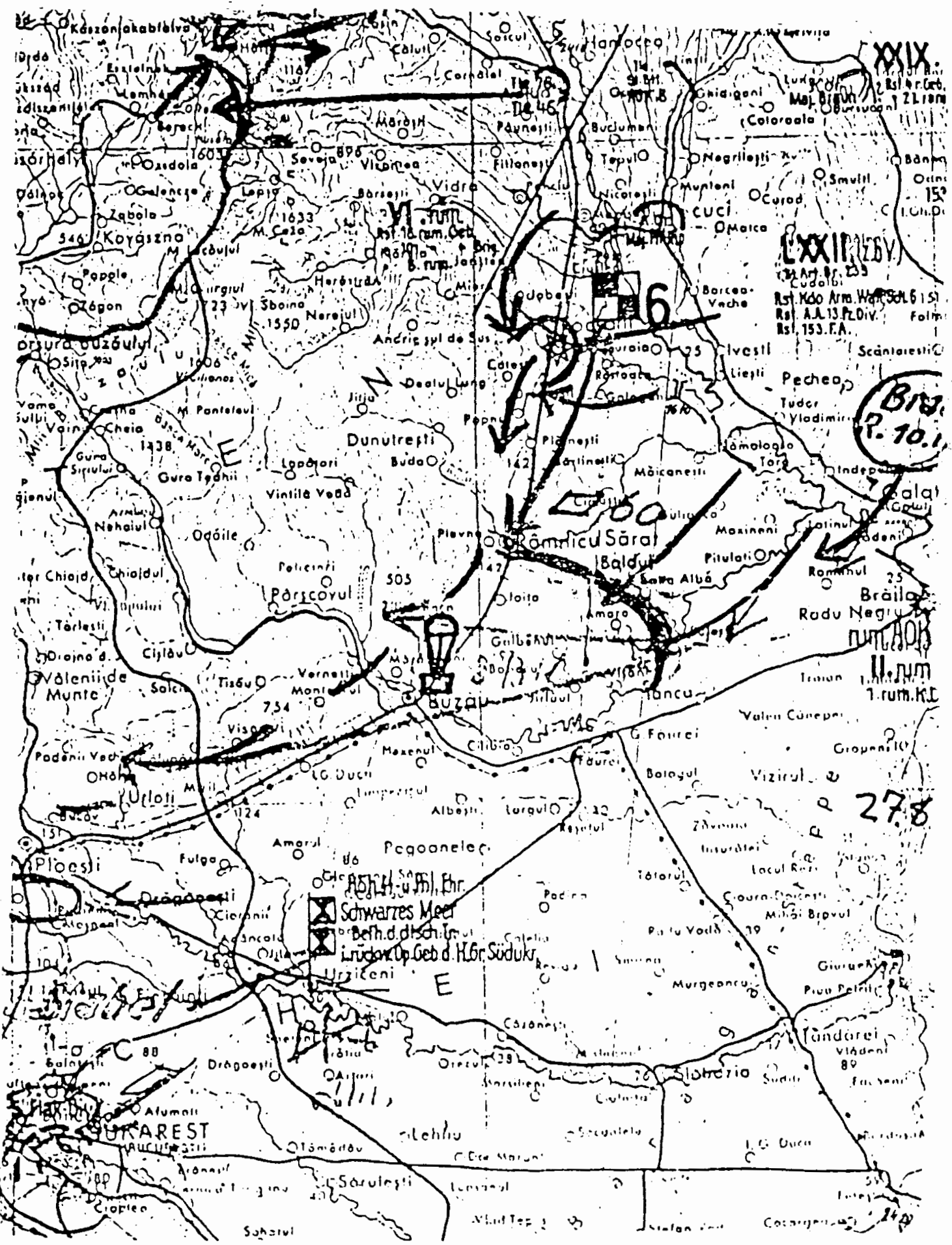

Figure 198. The Soviet Capture Of Focsani And The Drive South, August 27, 1944. Source: OKH, Schlacht um Rumaenien u. den Beskiden v. 20.8.-29.9.44 National Archives Microfilm Publication T.78 Roll 136. 


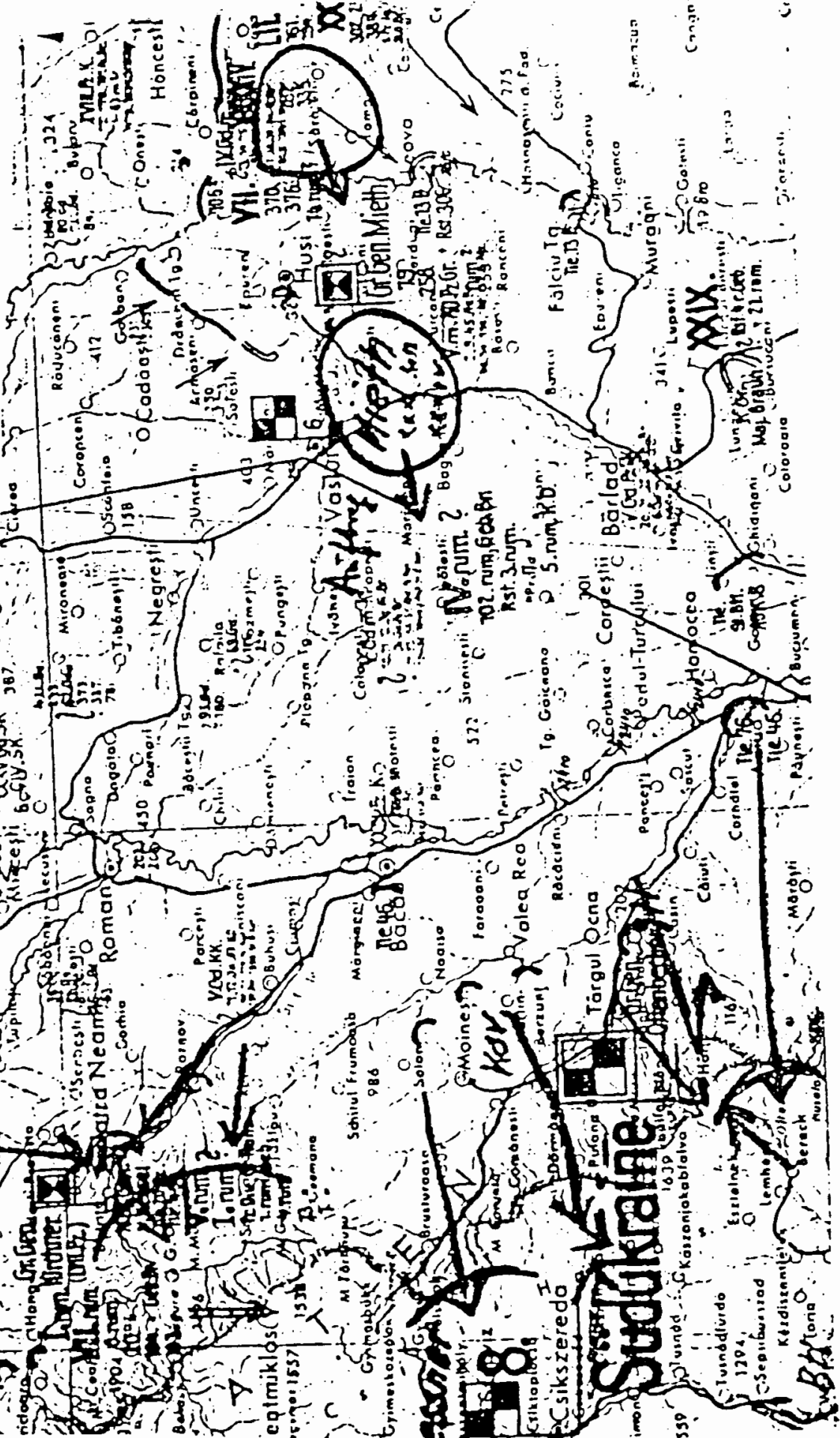

Figure 199. Soviet Attacks Against The German 8th Army, August 27, 1944. Source: OKH, Schlacht um Rumaenien u. den Beskiden v. 20.8.-29.9.44 National Archives Microfilm Publication T-78 Roll 136. 


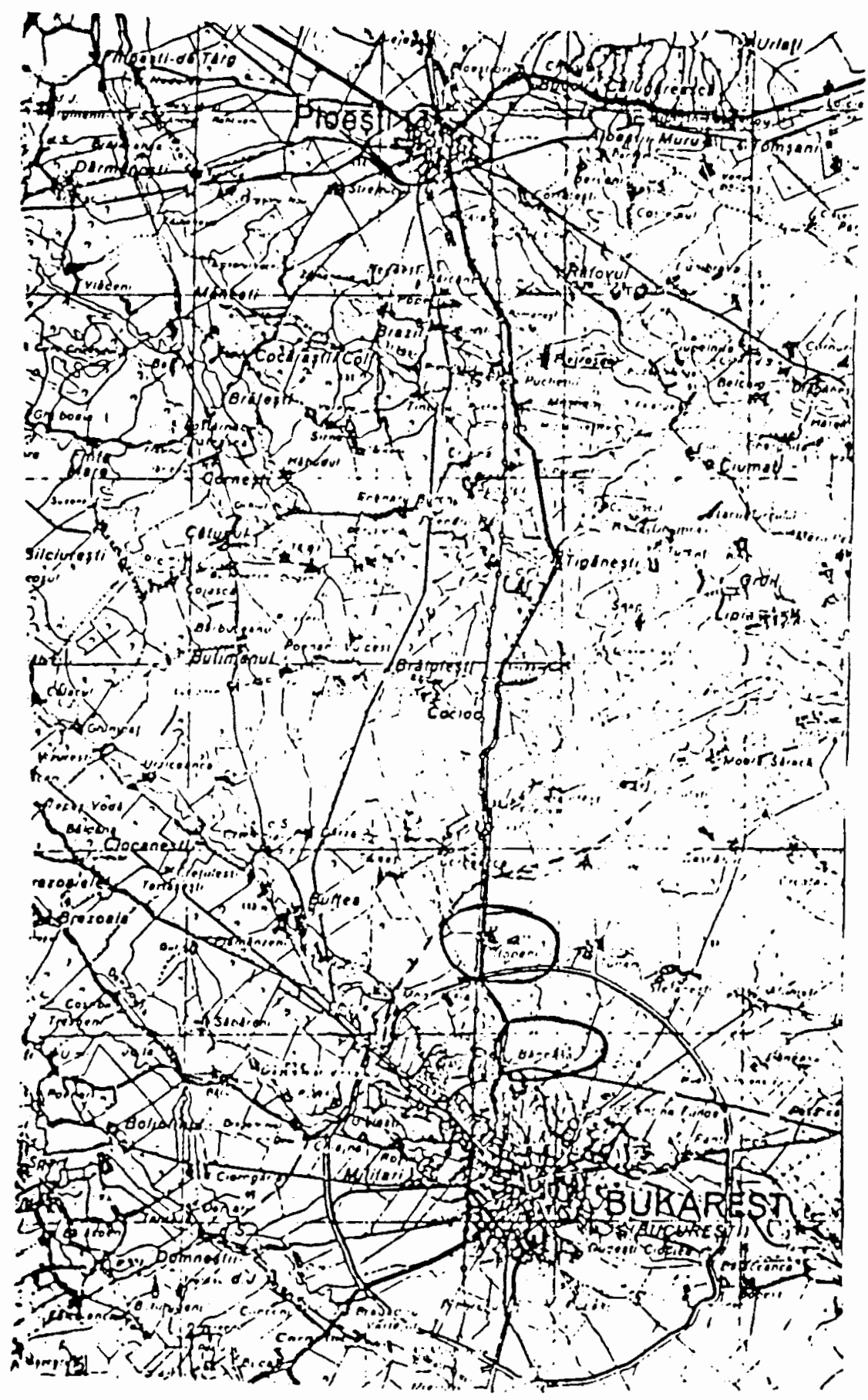

Figure 200. Rumanian Armored Reinforcements, August 27, 1944. Source: National Archives Microfilm Publication T-312 Roll 1470. 


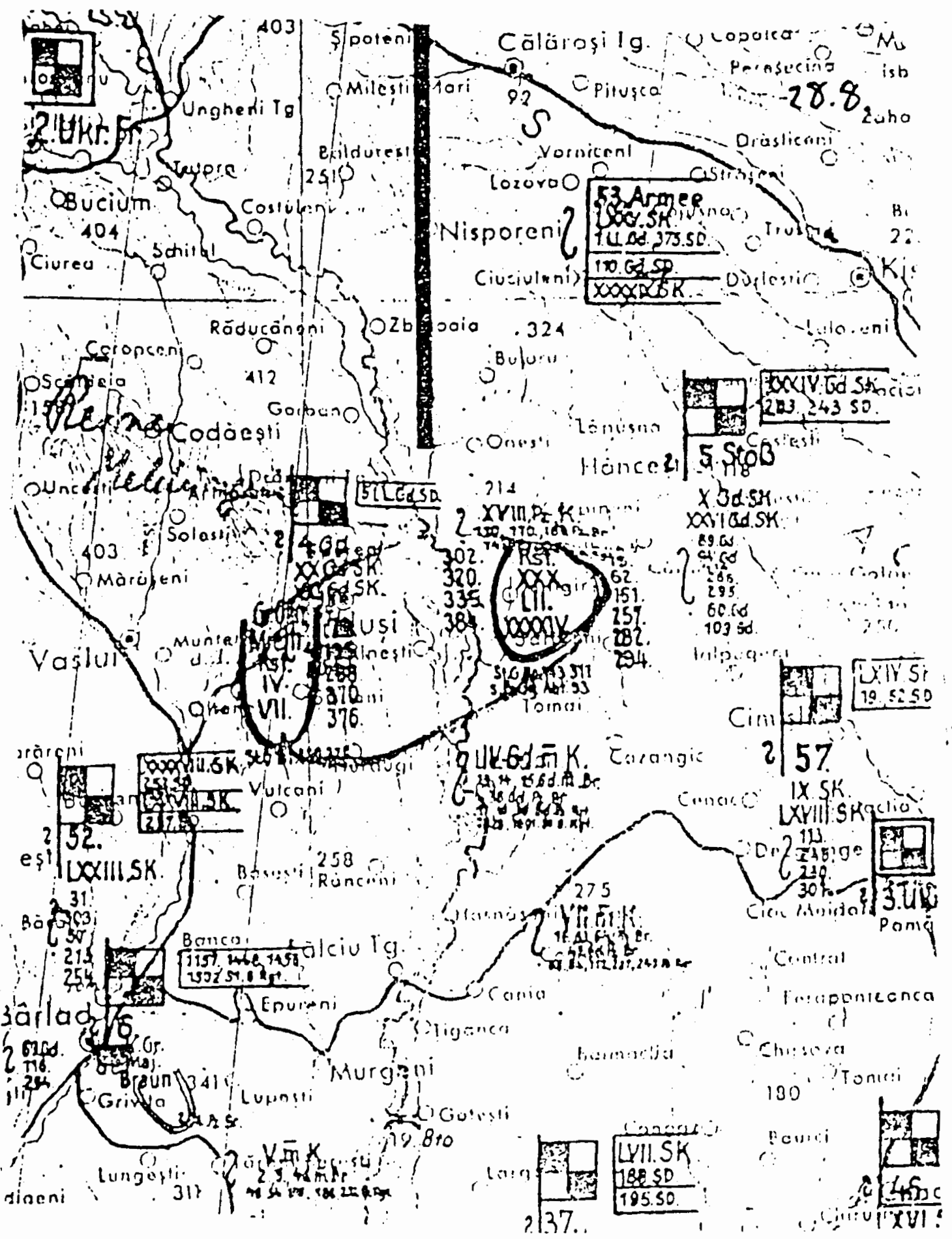

Figure 201. The Encircled Elements Of The German 6th Army, August 28, 1944. Source: OKH, Schlacht um Rumaenien u. den Beskiden v. 20.8.-29.9.44 National Archives Microfilm Publication T-78 Roll 136. 


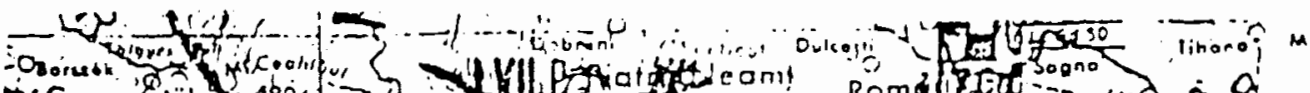

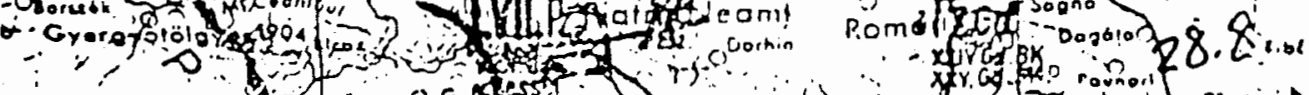

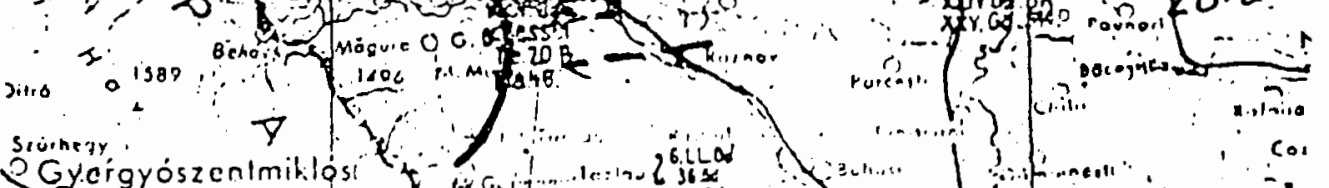
PGycigyószenlmiklosse

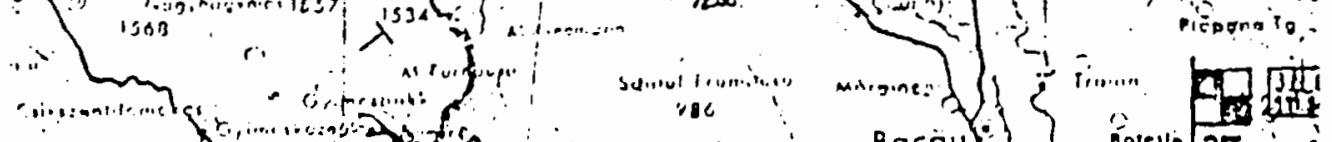

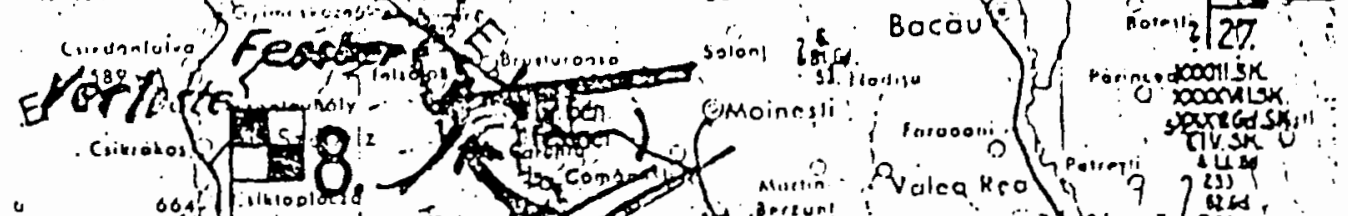

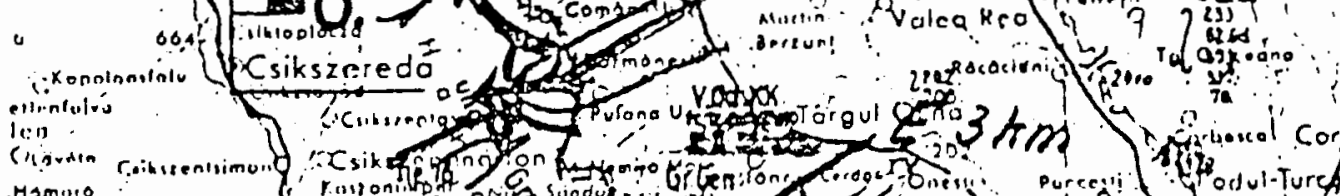
mamow

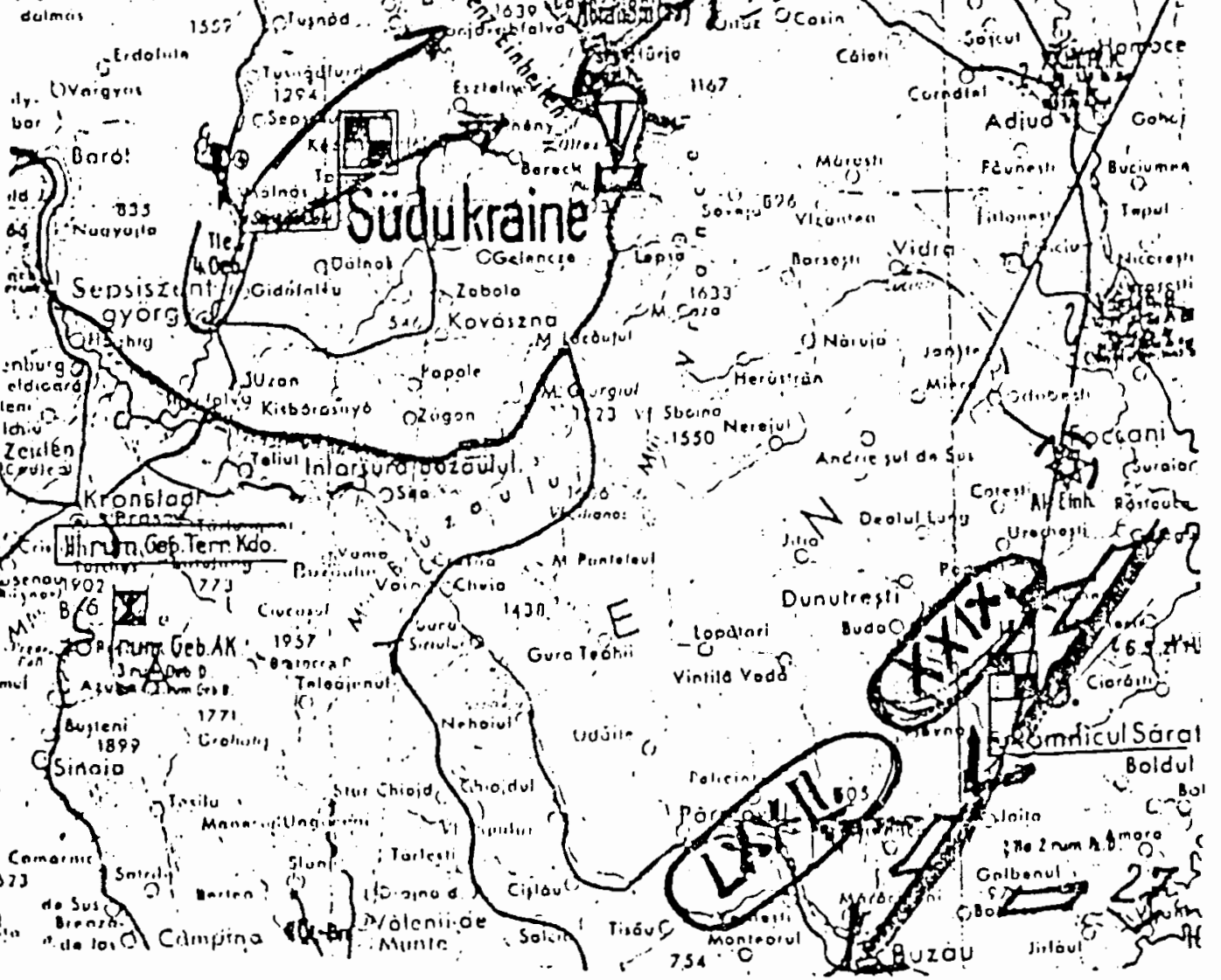

Figure 202. Soviet Attacks Against The German 8th Army, August 28, 1944. Source: OKH, Schlacht um Rumaenien U. den Beskiden v. 20.8.-29.9.44 National Archives Microfilm Publication T-78 Roll 136. 


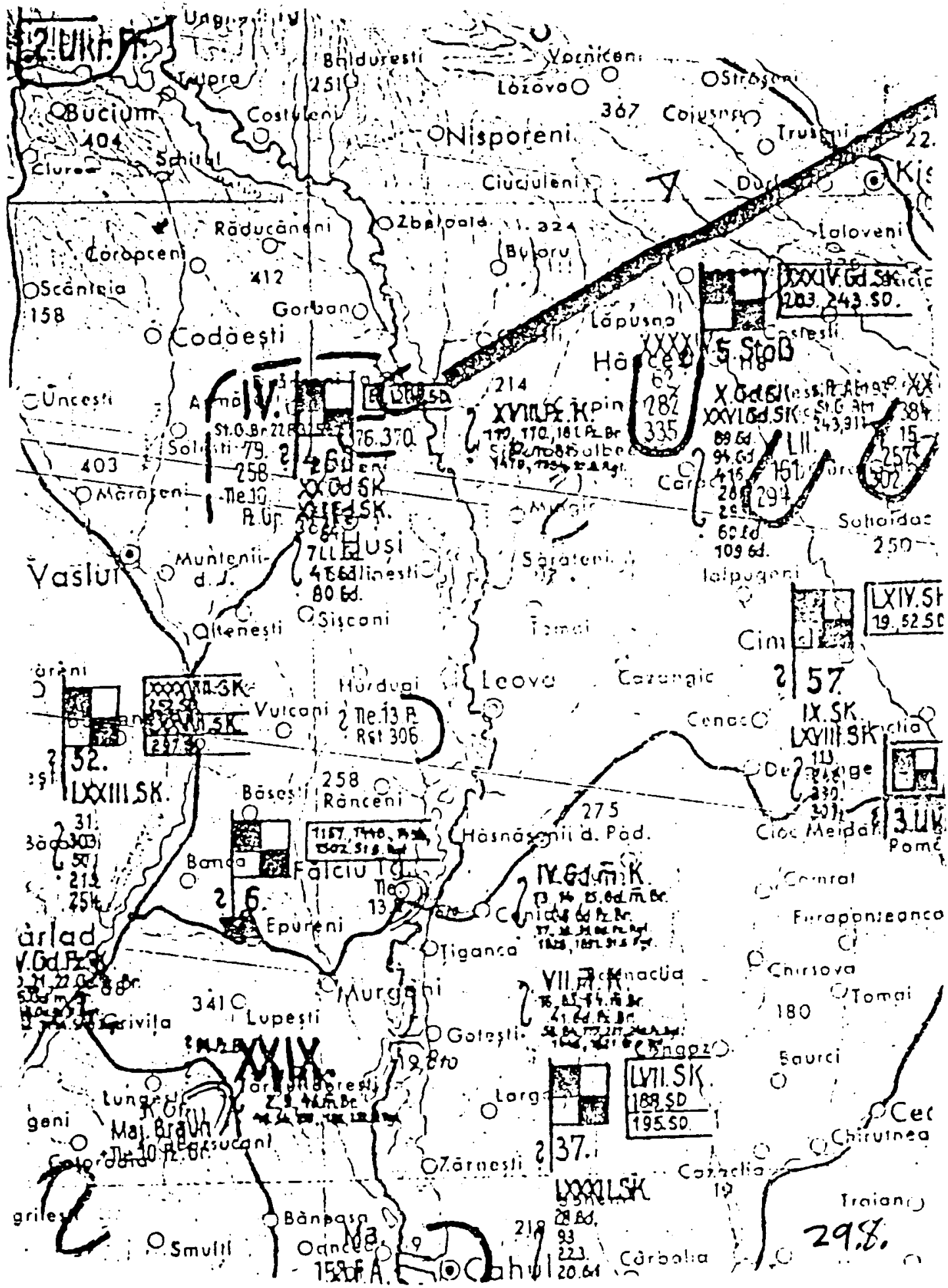

Figure 203. The Encircled Elements Of The German 6th Army, August 29, 1944. Source: OKH, Schlacht um Rumaenien u. den Beskiden v. 20.8.-29.9.44 National Archives Microfilm Publication T.78 Roll 136. 
oonte

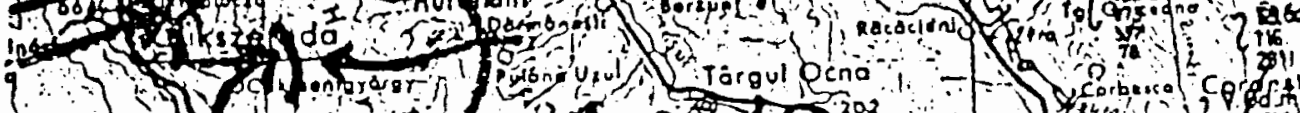

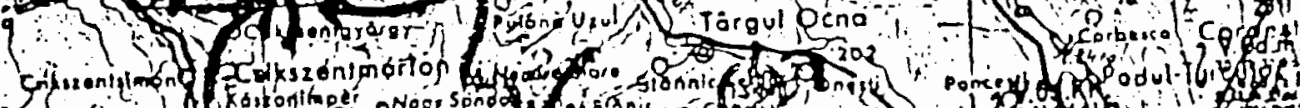

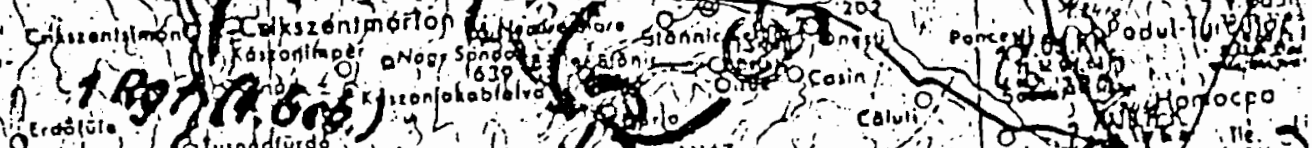

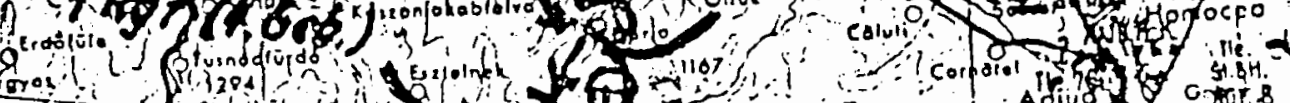
Safid-

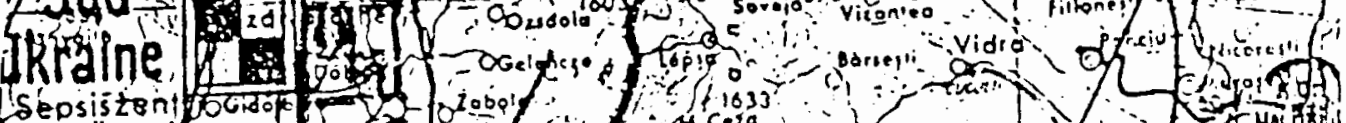

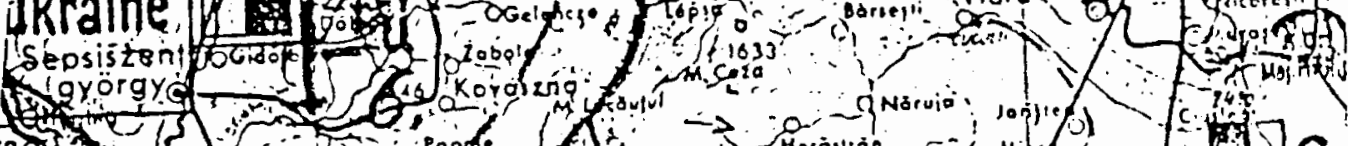
(A) 2 -

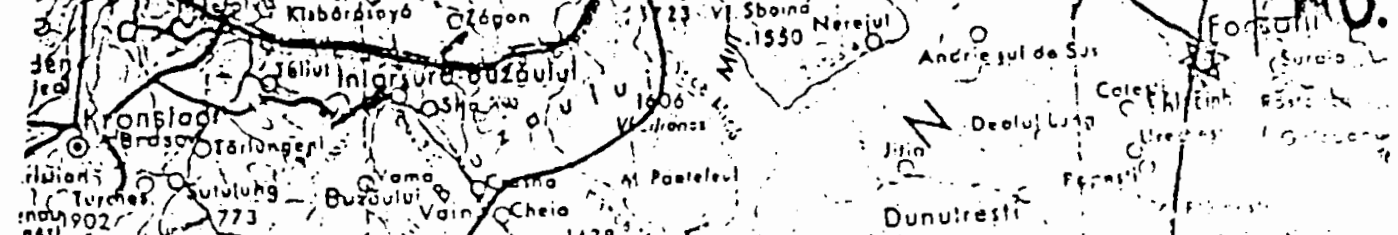

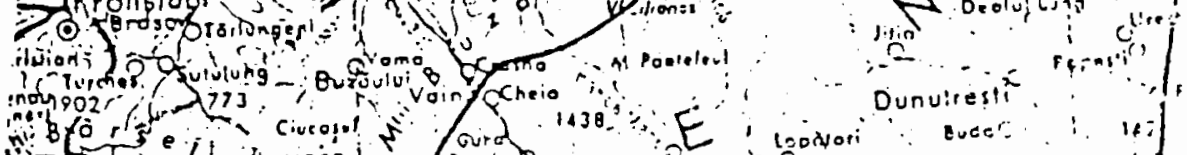

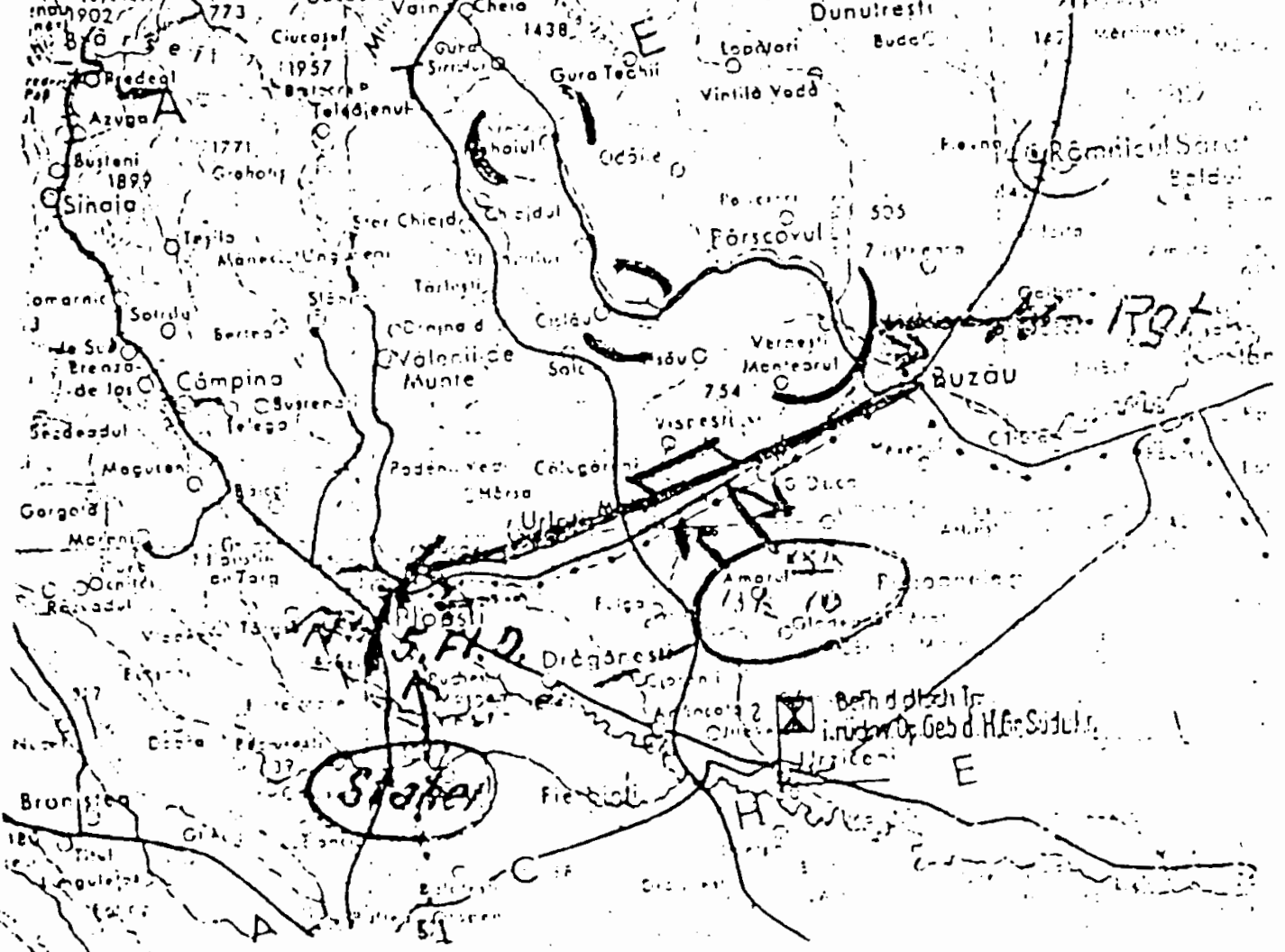

Figure 204. Army Group South Ukraine, August 29, 1944. Source: OKH, Schlacht um Rumaenien U. den Beskiden V. 20.8.-29.9.44 National Archives Microfilm Publication T.78 Roll 136. 


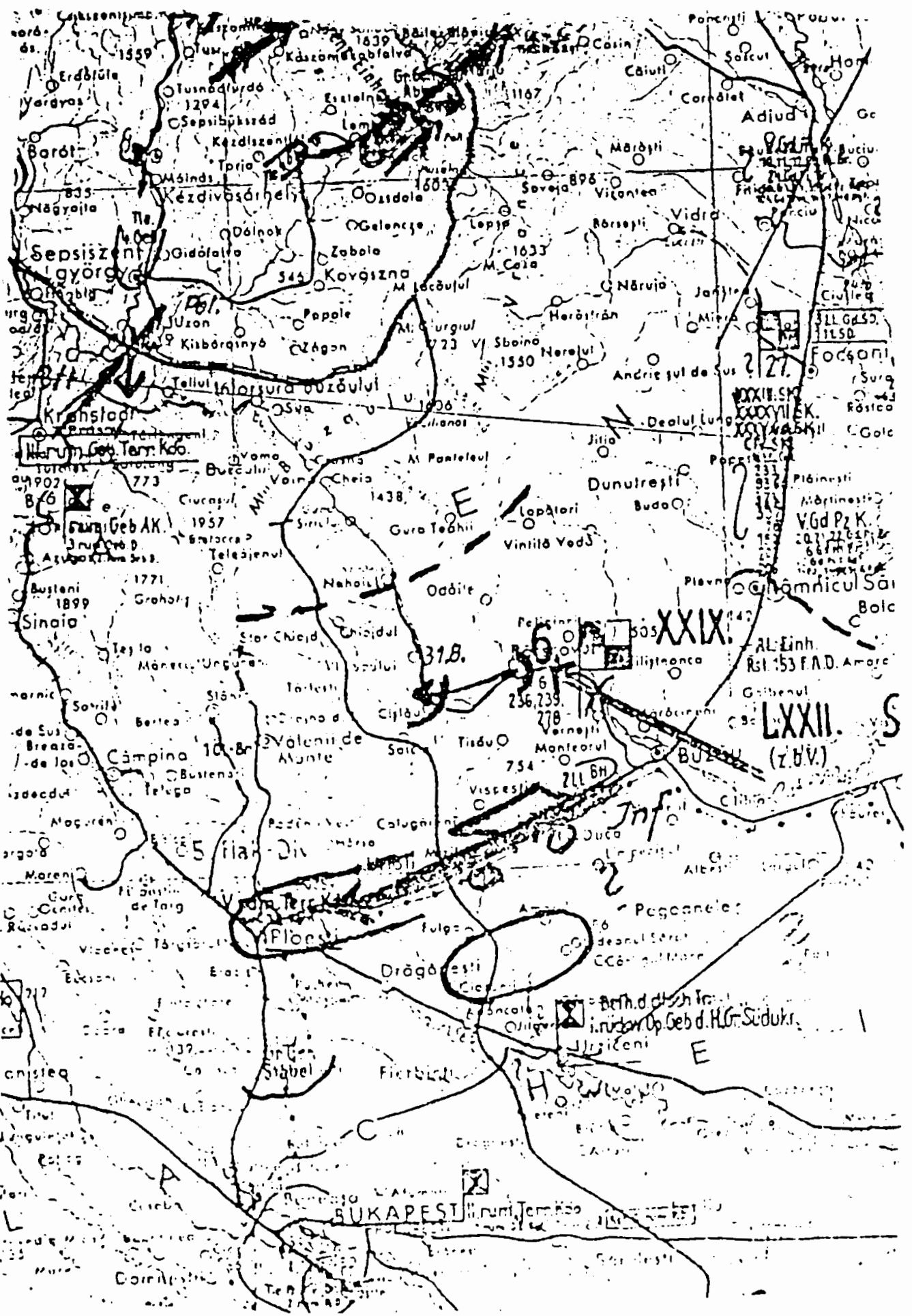

Figure 205. The 5th Flak Division And Kampfgruppe Stahel In The Area Of Ploesti, August 30, 1944. Source: OKH, Schlacht um Rumaenien u. den Beskiden v. 20.8.29.9.44 National Archives Microfilm Publication T-78 Roll 136. 


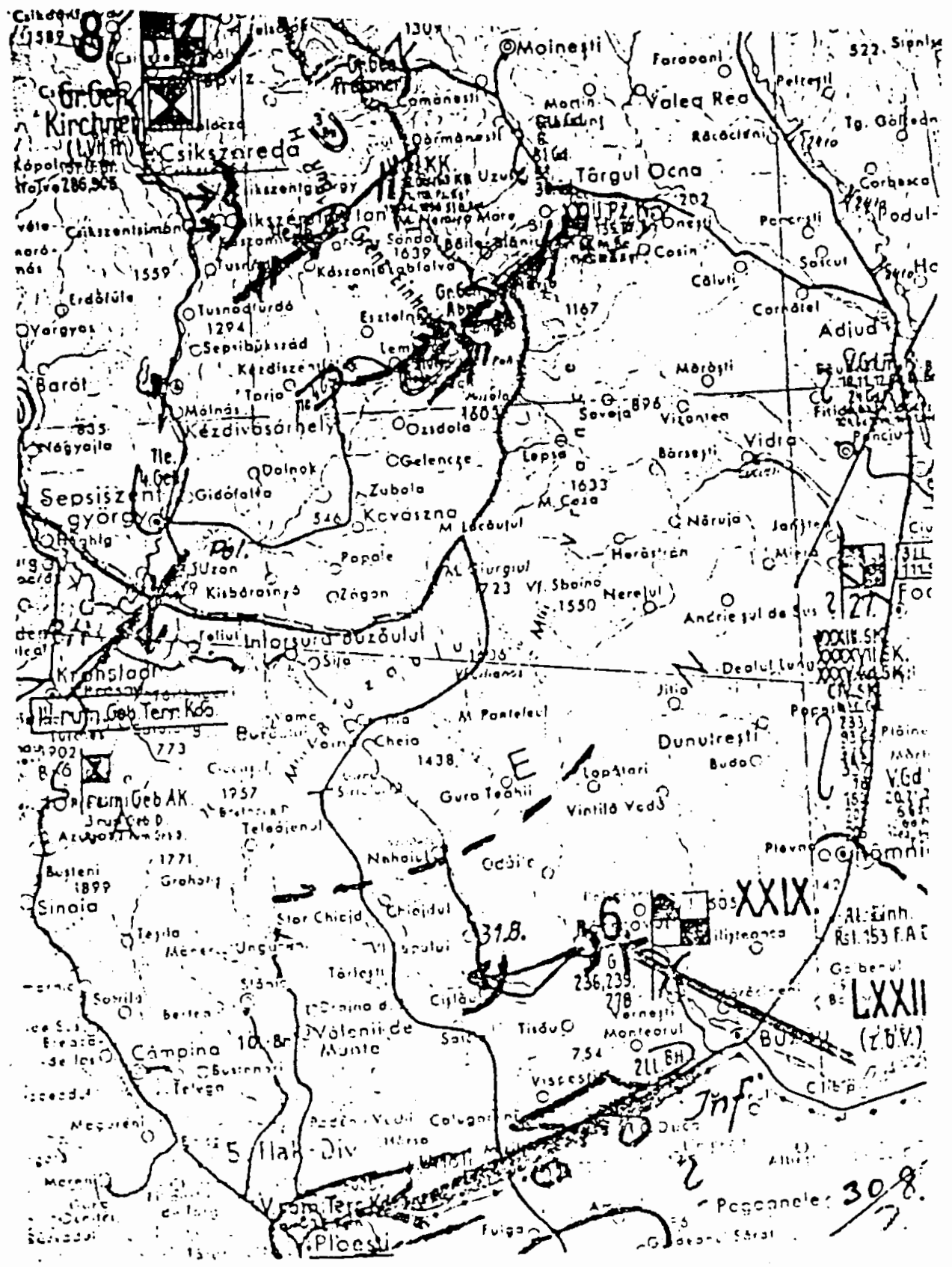

Figure 206. Army Group South Ukraine, August 30, 1944. Source: OKH, Schlacht um Rumaenien u. den Beskiden v. 20.8.-29.9.44 National Archives Microfilm Publication T-78 Roll 136. 


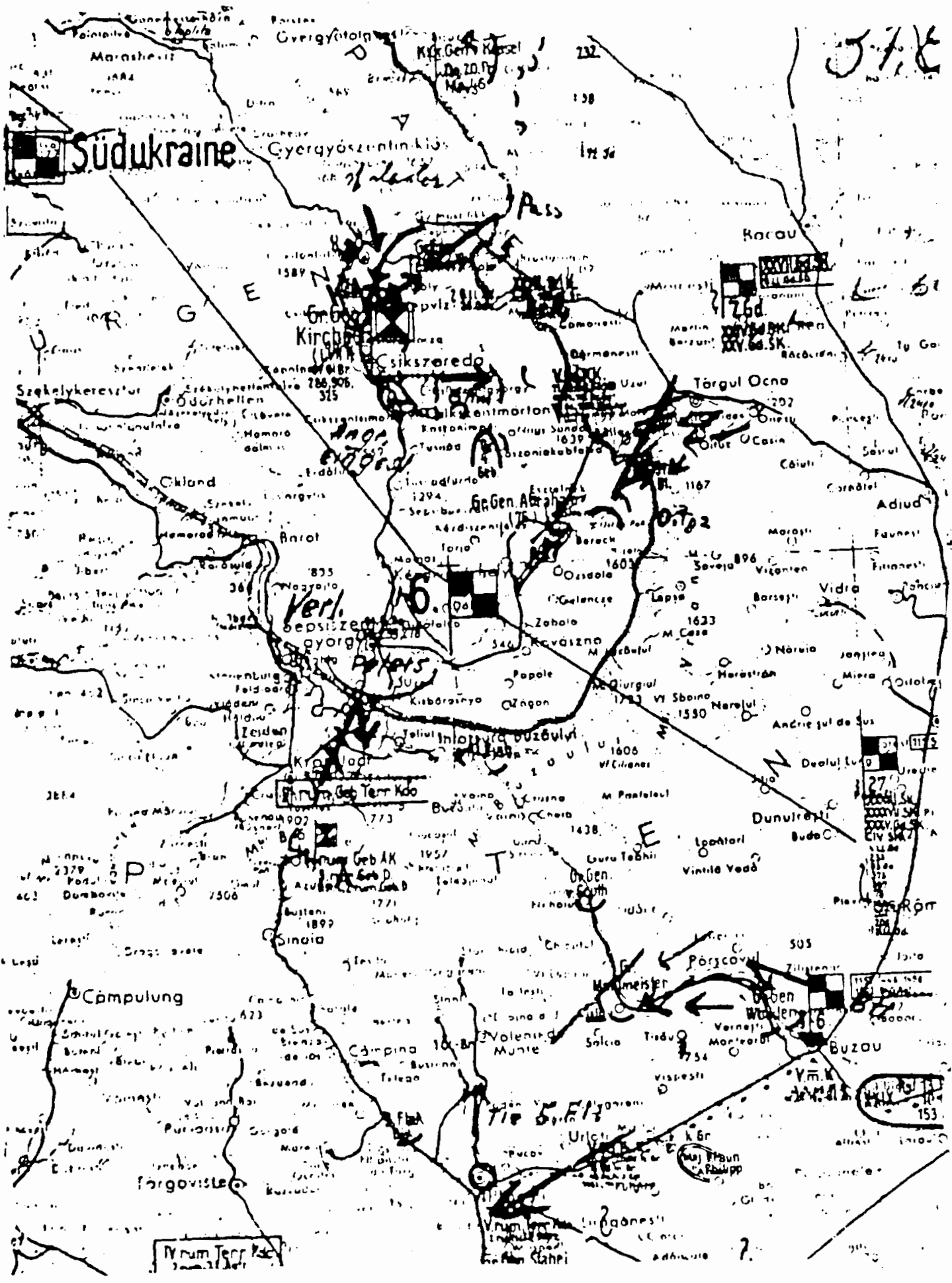

Figure 207. Army Group South Ukraine, August 31, 1944. Source: OKH, Schlacht um Rumaenien U. den Beskiden v. 20.8.-29.9.44 National Archives Microfilm Publication T-78 Roll 136. 


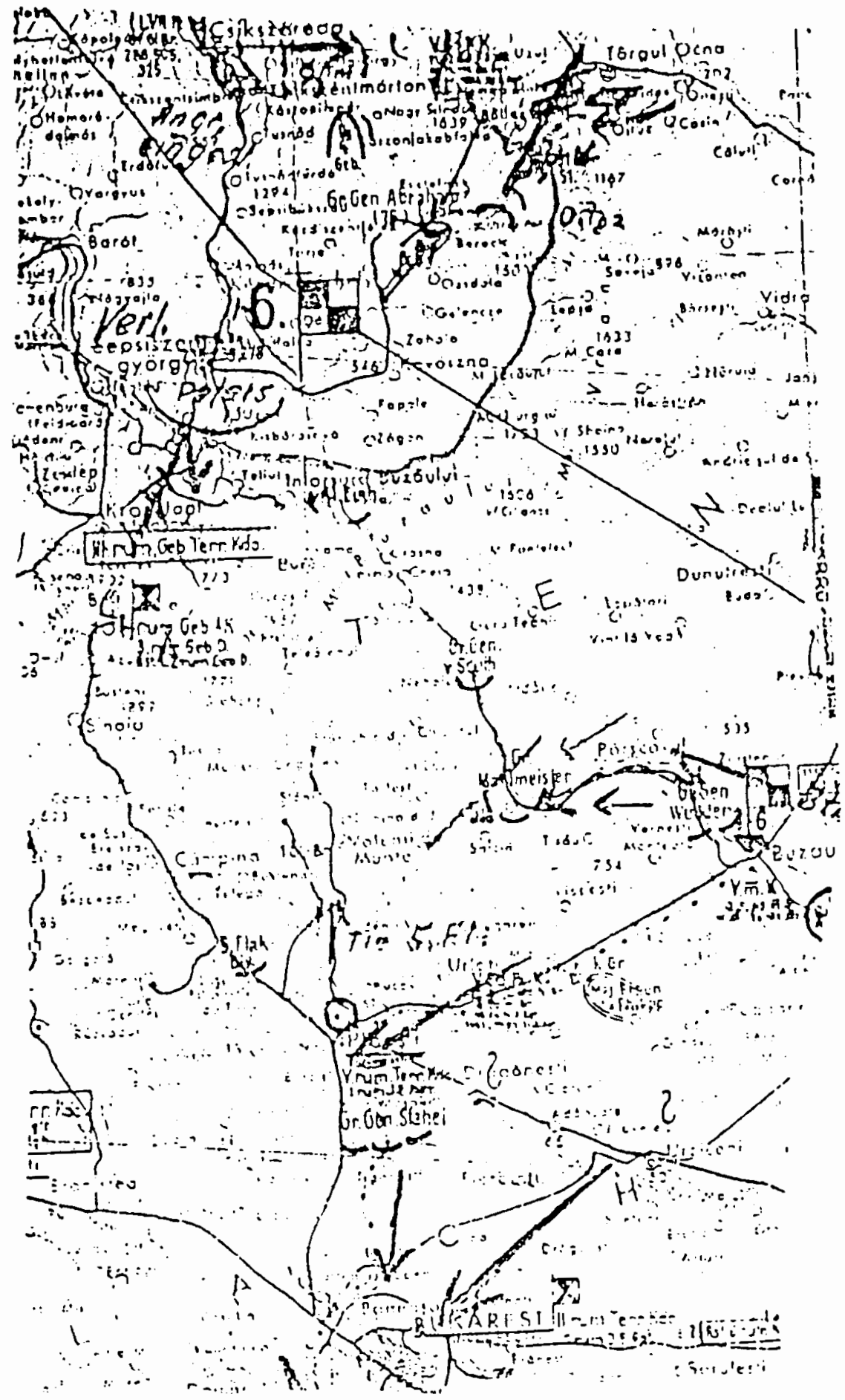

Figure 208. Kampfgruppe Stahel And The 5th Flak Division, August 31, 1944. Source: OKH, Schlacht um Bumaenien u. den Beskiden v. 20.8.-29.9.44 National Archives Microfilm Publication T-78 Roll 136. 


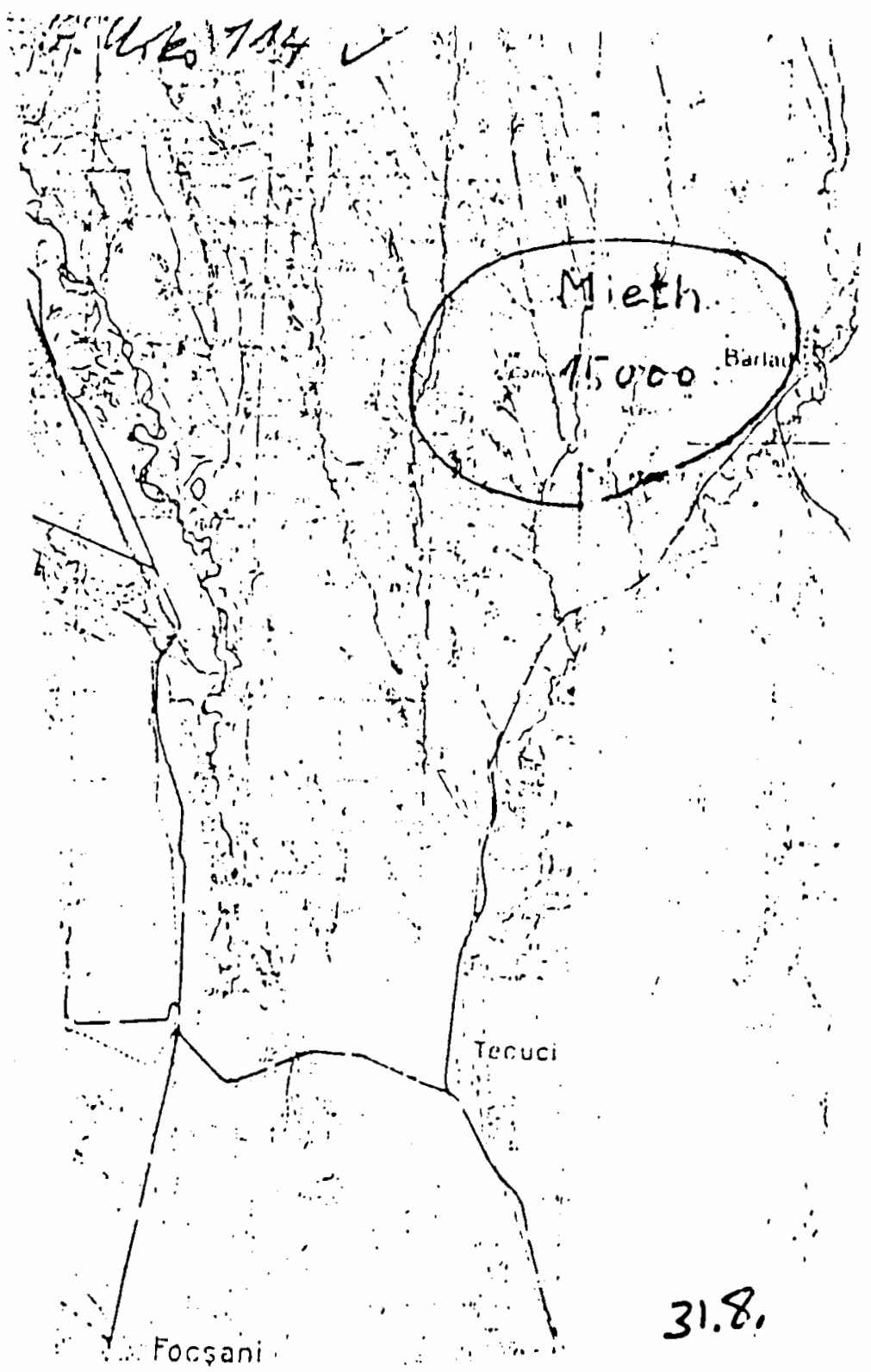

Figure 209. Gruppe Mieth, August 31, 1944. Source: A.O.K. 6, Lagekarte 31.8.44 National Archives Microfilm Publication T-312 Roll 1470. 


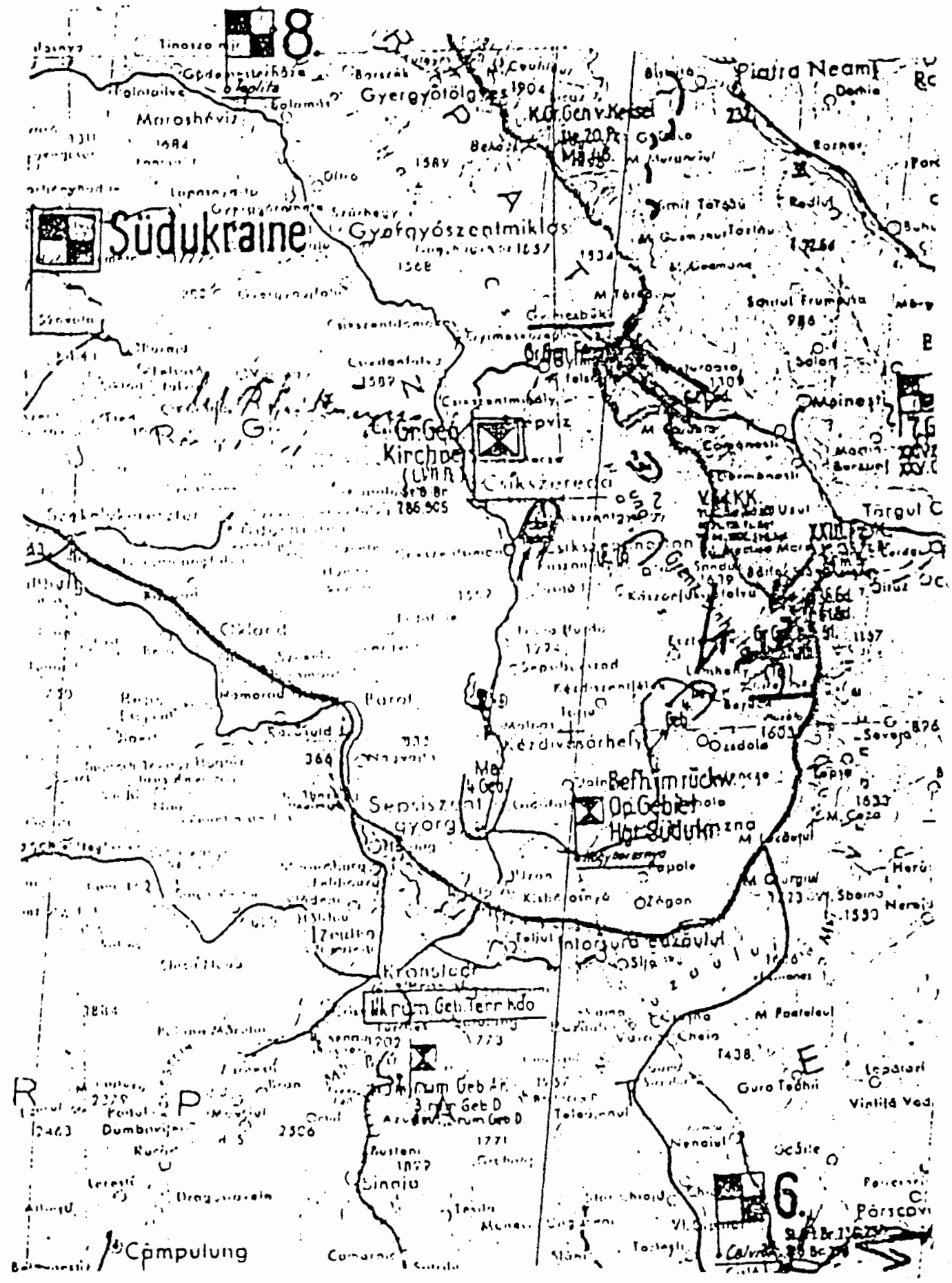

Figure 210. Army Group South Ukraine, September 1, 1944. Source: OKH, Schlacht um Rumaenien U. den Beskiden v. 20.8.-29.9.44 National Archives Microfilm Publication T-78 Roll 136. 


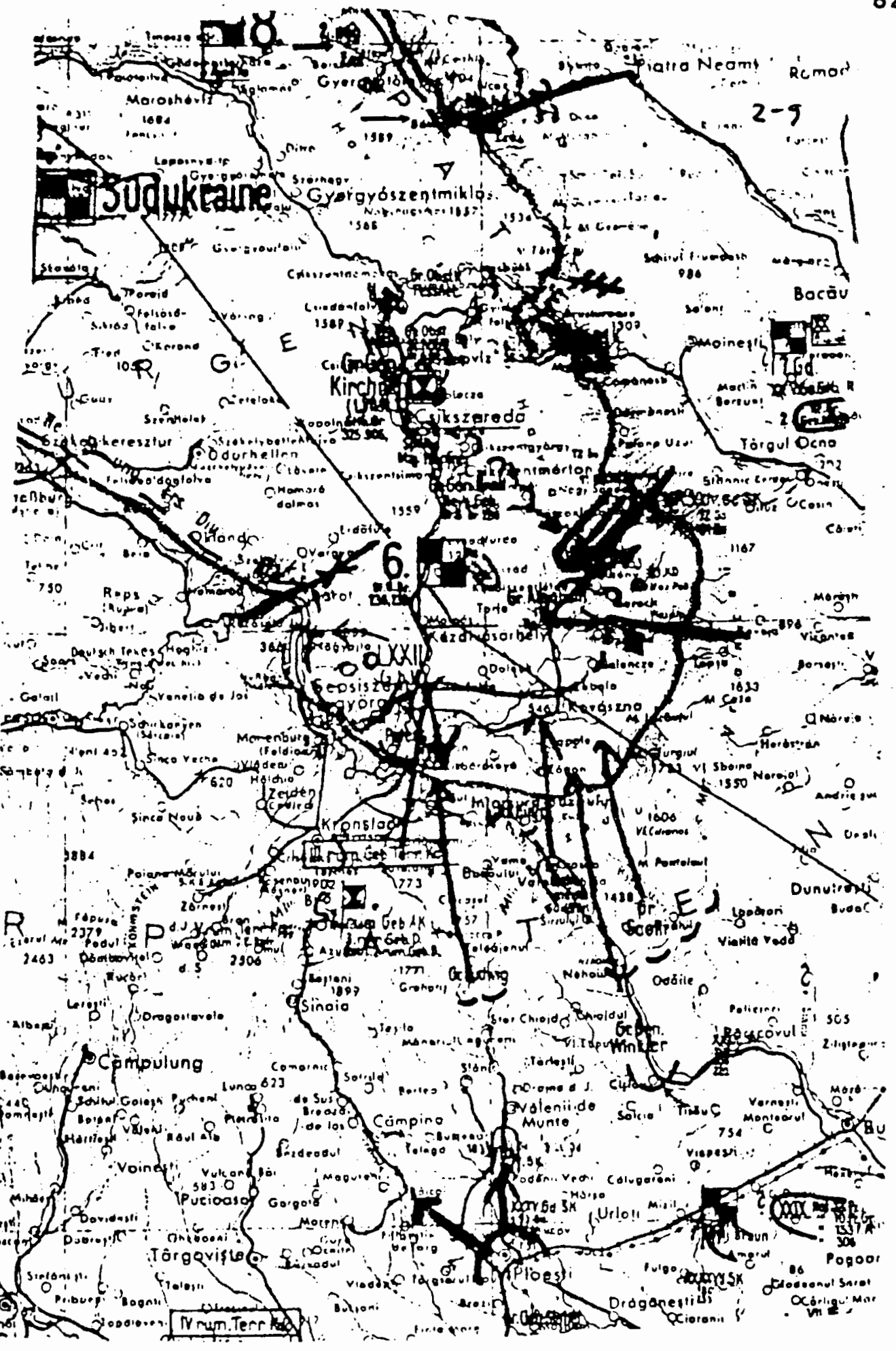

Figure 211. Army Group South Ukraine, September 2, 1944. Source: $\mathrm{OKH}$, Schlacht um Rumaenien u. den Beskiden v. 20.8.-29.9.44 National Archives Microfilm Publication T-78 Roll 136. 


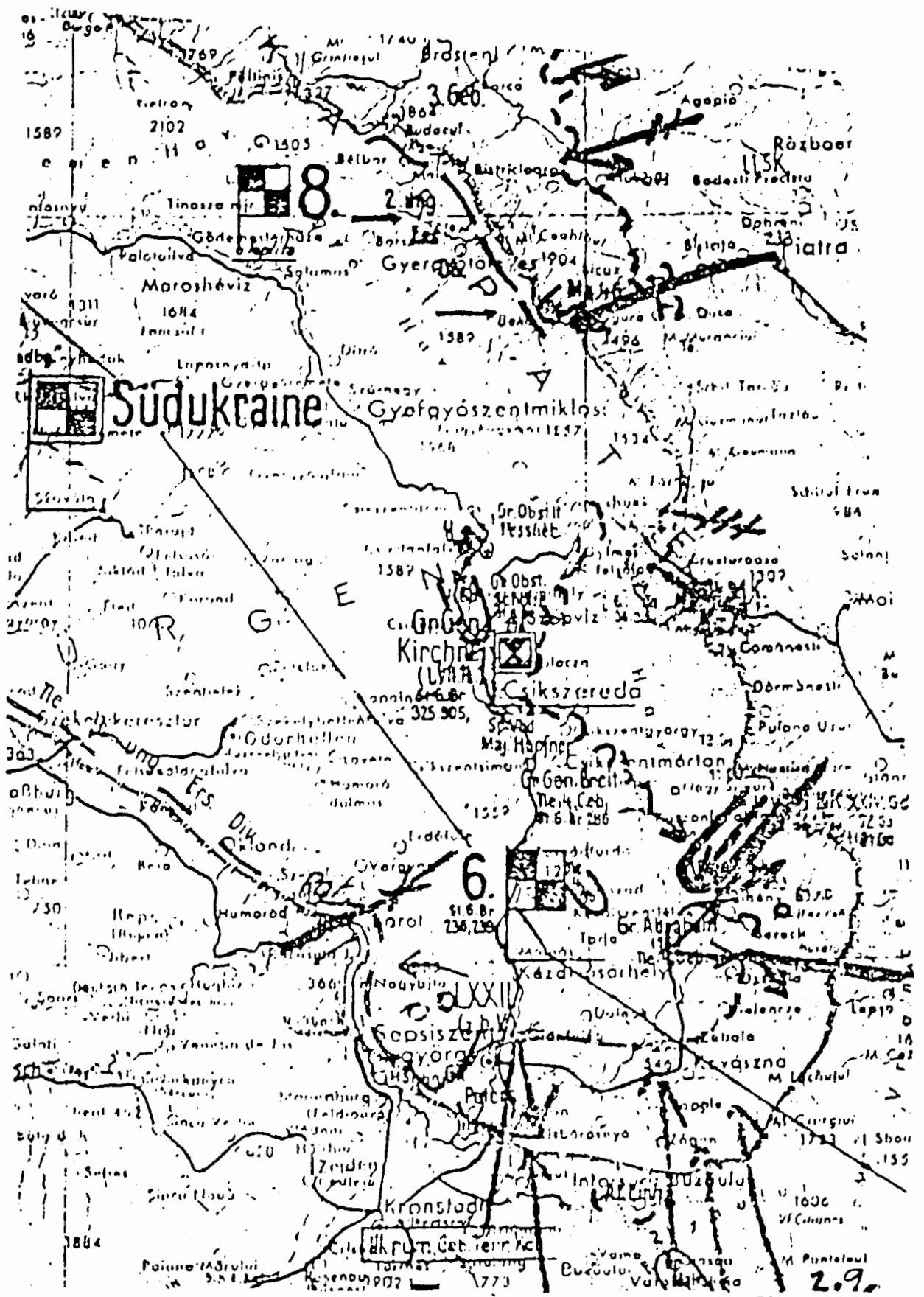

Figure 212. Soviet Attacks Against The German 8th Army, September 2, 1944. Source: OKH, Schlacht um Rumaenien u. den Beskiden v. 20.8.-29.9.44 National Archives Microfilm Publication T-78 Roll 136. 


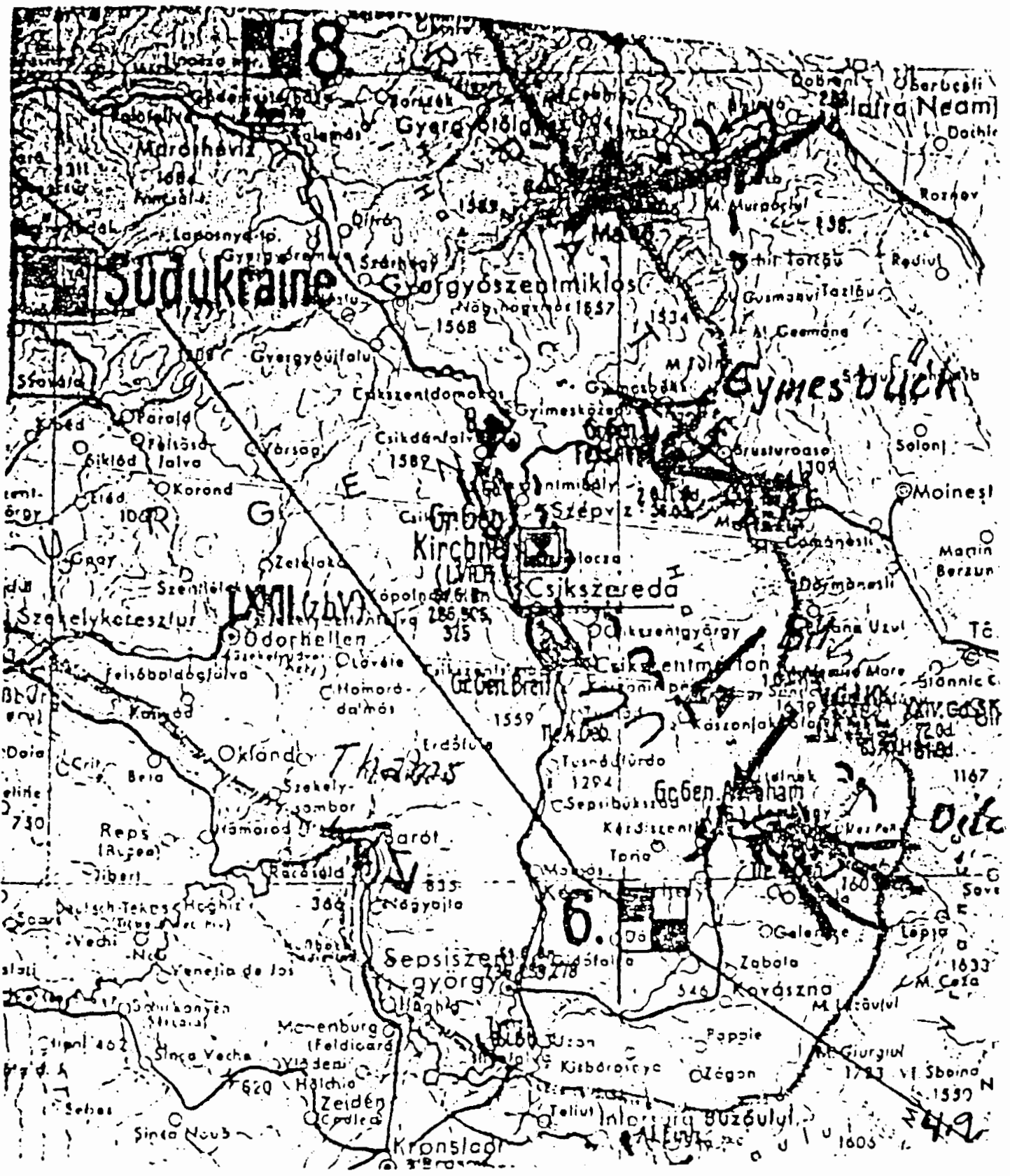

Figure 213. Army Group South Ukraine, September 4, 1944. Source: OKH, Schlacht um Rumaenien U. den Beskiden V. 20.8.-29.9.44 National Archives Microfilm Publication T-78 Roll 136. 


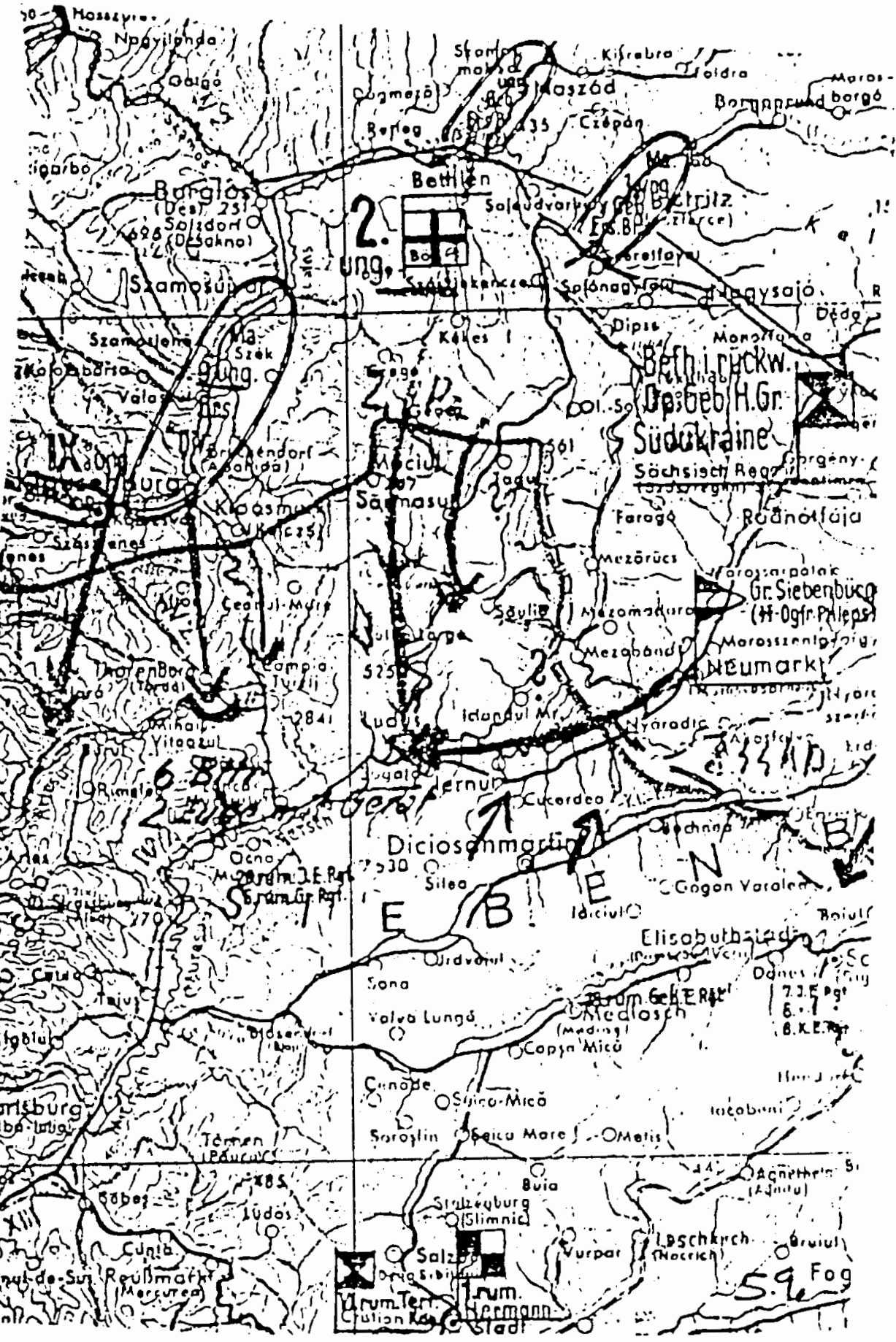

Figure 214. The Counterattack Of The 2nd Hungarian Army, September 5, 1944. Source: OKH, Schlacht um Rumaenien u. den Beskiden v. 20.8.-29.9.44 National Archives Microfilm Publication T-78 Roll 136. 


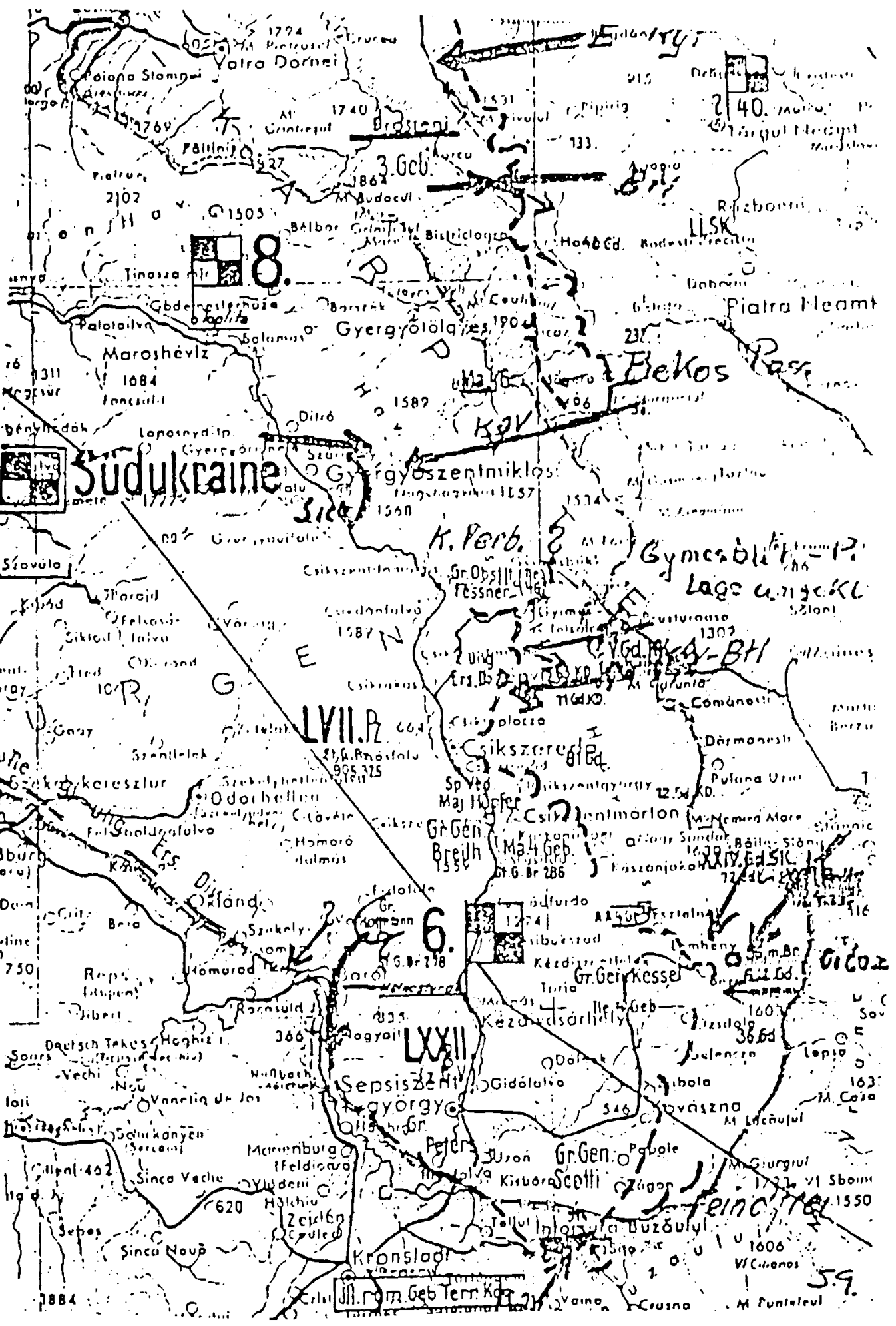

Figure 215. Army Group South Ukraine, September 5, 1944. Source: OKH, Schlacht um Rumaenien u. den Beskiden v. 20.8.-29.9.44 National Archives Microfilm Publication T-78 Roll 136. 


\section{NOTES TO CHAPTER XI}

1John Erickson, The Road To Berlin (Boulder, Colorado: Westview Press, 1983), p. 346; Major Scott R. McMichael, "The Battle of Jassy-Kishinev" Military Review Vol. 64, July 1985, p. 56.

2Earl F. Ziemke, Stalingrad To Berlin: The German Defeat In The East (New York: Dorset Press, 1968), p. 350.

${ }^{3}$ Colonel T.N. Depuy \& Paul Martell, Great Battles On The Eastern Front: The Soviet-German War 1941-1945 (New York: The Bobbs-Merrill Company Inc., 1982), p. 183.

${ }^{4}$ Albert Seaton, The Russo-German War 1941-1945 (New York: Praeger Publishers, Inc., 1971), p. 475.

5Dupuy \& Martell, p. 183; S.M. Shtemenko, The Soviet General Staff At War 1941-1945 Vol. 2 (Moscow: Progress Publishers, 1986), p. 125.

6lbid.

7 Seaton, p. 475.

8McMichael, p. 57.

9lbid.

10Mehner, GHTBDW Vol. 10, pp. 506-507.

${ }^{11}$ McMichael, p. 57.

12McMichael, p. 57; Dupuy \& Martell, p. 184.

13 McMichael, p. 57.

${ }^{14}$ Ibid.

15Oberkommando Heeresgruppe Sued Ukraine, Zusammenstellung der Frontkilometer 23.7.44 NAMP T-311 Roll 266.

${ }^{16}$ Erickson, p. 348.

${ }^{17}$ Chris Bellamy, Red God of War: Soviet Artillery and Rocket Forces (New York: Brassey's Defense Publishers, 1986), p. 64.

18 Ibid. 
${ }^{19}$ Fremde Heere Ost, Offensive Jassy-Tiraspol: Auszuege aus kurzer Feindbeurteilung vom 1.6. - 20.8.44.27.10.1944. NAMP T-78 Roll 494.

20 Ibid.

21 Ibid.

22Ibid.

23 Ibid.

${ }^{24}$ Ibid.

25 bid.

26 bid.

27|bid.

${ }^{28}$ Seaton, pp. $470-471$.

${ }^{29}$ Ziemke, p. 348.

${ }^{30}$ Heinz Guderian, Panzer Leader (Washington, D.C.: Zenger Publishing Co., Inc., 1979), p. 366.

31/bid.

${ }^{32}$ |bid.

33Ziemke, p. 346.

${ }^{34}$ Ibid., p. 336.

${ }^{35}$ Generaloberst Friessner, Verratene Schlachten (Hamburg: Holsten-Verlag, 1956), p. 29.

${ }^{36}$ Generaloberst Friessner, Soldaten der Heeresgruppe Suedukraine! H. Qu.. 26.7.1944 NAMP T-311 Roll 266.

${ }^{37}$ Friessner, Verratene Schlachten, p. 53.

38|bid., p. 54.

39 ibid. 
40Ibid., pp. 55-56.

${ }^{41}$ Ibid., p. 56.

42OKH, Besprechungsnotiz, Gen. Oberst Guderian-General Major Garbea, 3.8. 1840 Uhr NAMP T-78 Roll 366.

43 bid.

${ }^{44}$ Ibid.

45 Ibid.

${ }^{46}$ Hauptmann Rabe, Entwuerfe 1.-19.8.1944 Band III Teil II 8.8.1944 NAMP T-311 Roll 158, p. 3.

${ }^{47}$ Friessner, Verratene Schlachten, p. 57.

48 Ibid., p. 58.

49/bid., p. 59.

50 Ziemke, p. 349.

51 McMichael, p. 54; Gerhard Foerster, "Die Operation von lasi-Kischinjow und ihre Bedeutung fuer die Befreiung der Voelker Suedosteuropas" Militaer Geschichte $5 / 74$, p. 521.

52 Seaton, p. 412.

${ }^{53}$ Alex Buchner, Osttront 1944 (Friedberg: Podzun-Pallas-Verlag GMBH, 1988), P. 334.

54 Generaloberst Friessner, An alle deutschen und rumaenischen Kommandeure (bis einschl. Div.) H.Qu. 18.8.1944 NAMP T-311 Roll 266.

55Hauptmann Rabe, Kriegstagebuch des Oberkommandos der Heeresgruppe Suedukraine 20.8. - 5.9.1944 Band 4 Teil 1, NAMP T-311 Roll 158, p. 1.

56 Ibid.

57Ibid., p. 2.

58 Ibid. 
59 lbid.

60 Ibid., p. 7.

61 Ibid., p. 10.

62Ibid., p. 2.

63 Ibid.

${ }^{64}$ Ibid., pp. 7-8.

65Jbid., p. 9.

66lbid.

67 Ibid., p. 3.

68/bid., p. 13.

69Mehner, GHTBDW Vol. 10, p. 461.

70Hauptmann Rabe, Kriegstagebuch des Oberkommandos der Heeresgruppe Suedukraine 20.8.-5.9.1944 Band 4 Teil 1, NAMP T-311 Roll 158, p. 17.

$71^{\prime}$ Ibid., p. 14.

72Mehner, GHTBDW Vol. 10, p. 461.

73Rabe, p. 19.

74 Ibid., p. 20.

75 lbid.

76/bid., p. 21.

77Friessner, Verratene Schlachten, p. 75.

78Ibid., p. 80.

79 lbid.

801 bid.

81 Ibid., p. 25. 
82Ibid., p. 27.

83 Ibid., p. 31.

84 Ibid., p. 32.

85 bid., p. 25.

86/bid., p. 37.

${ }^{87}$ Chef des Generalstabes Heeresgruppe Suedukraine v. Grolman, Fernschreiben an Armeegruppe Dumitrescu 22.8.1944 NAMP T-311 Roll 266.

${ }^{88}$ Chef des Generalstabes Heeresgruppe Suedukraine v. Grolman, Fernschreiben an Armeegruppe Woehler 22.8.1944 NAMP T-311 Roll 266.

89 Ibid.

${ }^{90}$ Rabe, p. 39.

91 lbid.

92।bid.

93ibid.

94 Ibid.

95Ibid., p. 46.

${ }^{96}$ Generaloberst Friessner, Fernschreiben an Armeegruppe Woehler 23.8.1944 NAMP T-311 Roll 266.

97 Rabe, p. 48.

98 Ibid., p. 49.

99 Ibid.

${ }^{100}$ Ibid.

101 Ibid.

102 Ibid. 
103 Ibid.

${ }^{104}$ Ibid., p. 50.

${ }^{105}$ Ibid.

106Mehner, GHTBDW VOL. 10, p. 472.

107Rabe, p. 53.

108/bid., p. 52.

109ibid.

110Mehner, GHTBDW Vol. 10, p. 472.

${ }^{111}$ Rabe, p. 52.

112 Ibid., p. 55.

113/bid.

114 Ibid.

115 bid., p. 56.

116 lbid.

117 ibid., p. 57

118 ।bid.

${ }^{119}$ |bid.

120 lbid.

121 lbid., p. 59.

122 bid., p. 57.

123/bid., p. 58.

124 Ibid., p. 59.

125 Ibid. 
126/bid.

127 Ibid.

128/bid., p. 60; Generaloberst Friessner, Fernschreiben an Armeegruppe Woehler, 6. Armee, Beth. rueckw. Op.Geb. Suedukraine, Dt. General b. Obkd. d. Rum. Wehrmacht, Luftflotte 4, Admiral Schwarzes Meer, Komm.General und Befh. d.Dt.Luftwaffe in Rumaenien NAMP T-311 Roll 266.

129 lbid.

130 lbid.

131/bid.

132Ibid.

133|bid., p. 62.

${ }^{134}$ Ibid., p. 63

135/bid., p. 53.

${ }^{136}$ Friessner, Verratene Schlachten, p. 91.

137Ibid., p. 65.

138 Ibid.

${ }^{139}$ Ibid.

140Mehner, GHTBDW Vol. 10, p. 475.

141 lbid.

142Rabe, p. 69.

143 Ibid.

${ }^{144}$ Ibid.

145/bid.

${ }^{146}$ Mehner, GHTBDW Vol. 10, p. 478.

${ }^{147}$ Ibid. 
${ }^{148}$ Rabe, p. 69.

${ }^{149}$ Mehner, GHTBDW Vol. 10, p. 478.

${ }^{150}$ Rabe, p. 74.

151 lbid., p. 72.

152 Ibid., p. 75.

153/bid

${ }^{154}$ Mehner, GHTBDW Vol. 10, p. 482.

155Rabe, p. 75.

${ }^{156} \mid$ lbid.

157/bid., p 81.

158 Ibid.

159 lbid., p. 75.

160/bid.

161 lbid., p. 76.

162 Ibid., p. 78.

163 Ibid., p. 86.

164 Ibid.

165 Ibid.

166 Ibid., p. 87.

167 Ibid., p. 88; Generaloberst Friessner, Fernschreiben bezw. Funkspruch an 6. Armee, 8. Armee NAMP T-311 Roll 266.

168|bid.

${ }^{169}$ Rabe, p. 88. 
170 Ibid., p. 93.

${ }^{171}$ Ibid.

172/bid., p. 96.

173/bid., p. 93.

${ }^{174}$ Ibid.

175 Ibid., p. 94.

176/bid., p. 98.

177/bid., P. 99.

178 Ibid.

179 Ibid., p. 100.

180/bid., p. 101.

181 Ibid., p. 100.

182/bid., p. 106.

183/bid.

${ }^{184}$ Ibid.

185|bid., p. 116.

186P.N. Pospelov et al, History Of The Great Patriotic War Of The Soviet Union 1941-1945 Vol. 4 trans. Foreign Technology Division: Air Force Systems Command, (Moscow: Publishing House "Voyennoye," 1962), p. 527.

187Rabe, p. 111.

188Ibid., p. 113.

189 Ibid.

190 lbid.

191 Ibid. 
192/bid., p. 114.

193/bid.

194/bid., p. 199.

195/bid., p. 133.

196|bid., p. 129.

197/bid., p. 135 .

198|bid., p. 141.

199/bid., p. 142 .

200 Generaloberst Friessner, Soldaten der Heeresgruppe Suedukraine! 4 September 1944 NAMP T-311 Roll 266.

201Rabe, p. 144

202 Ibid.

203/bid.

${ }^{204}$ Ibid., p. 148.

205 Ibid., p. 150.

206/bid., pp. 150-151

207/bid.

208Von Hans Kissel, Die Katastrophe in Rumaenien 1944 (Darmstadt: Wehr und Wissen Verlagsgesellschaft MBH, 1964), p. 153.

${ }^{209}$ Chef des Generalstabes von Grolman, Fernschreiben an OKH/Gen St d H/Org.Abt. 22.9.1944 NAMP T-311 Roll 266.

210Kissel, p. 153.

211 Ibid.

212Pospelov et al, p. 513.

213Guderian, p. 365 . 
214/bid., p. 366.

$215_{\text {ibid., p. } 367 .}$

${ }^{216}$ Friessner, Verratene Schlachten, p.71.

217 Pospelov et al, pp. 506-508.

${ }^{218}$ General d. Artillerie Maximilian Fretter-Pico, Missbrauchte Infanterie (Frankfurt am Main: Verlag fuer Wehrwesen Bernard \& Graefe, 1957), p. 134. 


\section{CHAPTER XII}

\section{THE SOVIET FRONT IN PERSPECTIVE: COMPARISON OF LOSSES BETWEEN EASTERN AND WESTERN FRONTS}

The significance of the collapse of the German Army in the East in the Summer of 1944 can be determined by an analysis of German losses in the East compared to German losses in the West. A review of German losses will reveal that the Eastern Front was the most decisive front during the Summer of 1944. German losses in the East were far greater than in the West and the shipments of armored and non-armored vehicles to the East was greater than to the West. The following categories will be examined to reveal the actual losses and supplies to the Eastern and Western fronts during the Summer of 1944: (1) troop losses; (2) armored vehicle losses;

(3) armored vehicle deliveries; (4) non-armored vehicle losses;

non-armored vehicle deliveries; (6) aircraft losses; (7) German General losses; and (8) divisional losses.

The loss of troops is perhaps the strongest indicator of combat activity in a war zone. The total losses of German troops killed, wounded or missing for the period June-August 1944 amounted to $1,265,397$ (see Table LIV). The Eastern Front 
accounted for 908,806 and the Anglo-American Fronts for 356,591 troop losses (see Table LIV). Therefore, the Eastern Front accounted for $72 \%$ and the Anglo-American Fronts for $28 \%$ of the total German troop losses during the summer of 1944 (see Table LIV). The fact remained that most of the German troop losses were occurring on the Eastern Front even after the allied forces had landed in France.

The analysis of troop losses beyond the Summer of 1944 continues to demonstrate the predominance of the Eastern Front in German troop losses. The period of June-November 1944 shows a large increase in troop losses for the Anglo-American fronts during the period September thru November. The German troop losses on the Anglo-American fronts increased from 356,591 in August to 537,000 by November 1944 (see Table LV). Nevertheless, German troop losses for the June-November 1944 period remain predominately on the Eastern Front which accounted for $63 \%$ and the Anglo-American Fronts for $37 \%$ of all German troop losses (see Table LV).

German armored vehicle losses during the Summer of 1944 occurred mostly on the Eastern Front. The Anglo-American forces with the invasion of France on June 6, 1944 prior to the Soviet offensive against Army Group Center on June 22, 1944 inflicted greater armored vehicle losses on Germany in June of 1944 than the Soviet Union accounting for $83 \%$ of all German armored vehicle losses during the month of June (see Table LVI). However, once the Summer Soviet offensive had begun the armored losses shifted 
decisively to the Eastern Front. German armored losses in both July and August on the Eastern Front accounted for $80 \%$ of all German armored losses for both months (see Tables LVII \& LVIII). The overall German armored losses for the entire Summer of 1944 on the Eastern Front were $68 \%$ compared to $32 \%$ for the AngloAmerican Fronts (see Table LIX).

The analysis of German armor vehicle deliveries to the various theaters of operations reveals that the preponderance of German armor vehicles were shipped to the Eastern Front during the Summer of 1944. The Eastern Front received $75 \%$ and the AngloAmerican Fronts received only $25 \%$ of all armor shipments (see table LX). Thus, the Eastern Front received greater numbers of armored reinforcements during the Summer of 1944 .

German non-armored vehicle losses were greater on the Anglo-American Fronts after D-Day and prior to the start of the Soviet Summer offensive with the result that $81 \%$ of all nonarmored vehicle losses in June 1944 occurred on the AngloAmerican Fronts (see Table LXI). However, in July 1944 the Eastern Front accounted for $91 \%$ of all German non-armored vehicle losses (see Table LXII). A shift occurs again in August 1944 with the Anglo-American Fronts accounting for $59 \%$ of German non-armored vehicle losses (see Table LXIII). Nevertheless, by the end of August 1944 the Eastern Front still accounted for more non-armored vehicle losses than the Anglo-American Fronts even though losses on the Anglo-American Fronts in June and August had been greater than the Eastern Front. The German non-armored vehicle losses for 
the three month period reveal that $52 \%$ of all German non-armored vehicle losses occurred on the Eastern Front (see Table LXIV).

The deliveries of non-armored vehicles to the German theaters of operations reveals that the Eastern Front received priority in the shipments of non-armored vehicles during the Summer of 1944. The Eastern Front received $63 \%$ of all German non-armored vehicles delivered to the operational theaters (see Table LXV).

Luftwaffe aircraft losses was the only area where losses on the Anglo-American Fronts completely surpassed all losses in the air on the Eastern Front. The Anglo-American air war over Germany and the rest of Western and Southern Europe inflicted tremendous losses on the German Luftwaffe. The Anglo-American Fronts accounted for $75 \%$ of all Luftwaffe losses and the Eastern Front only accounted for $25 \%$ of German aircraft losses (see Table LXVI). Therefore, the Anglo-American "Second Front" was most successful in the air against the German Luftwaffe.

The Summer of 1944 marked a turning point in the war for Germany which can be measured by the fact that Germany lost more generals during the Summer of 1944 than in the preceeding 12 months of the war. ${ }^{1}$ The losses of generals during the Summer of 1944 exceeded even the previous disaster periods of the Wehrmacht at Stalingrad and in Tunisia. ${ }^{2}$ The Anglo-American Fronts accounted for the loss of 26 German generals (see Table LXVII) compared to the Eastern Front where 64 German generals were lost (see Table LXVIII). Therefore, the Eastern Front was responsible 
for $71 \%$ of all German general losses compared to $29 \%$ for the Anglo-American Fronts during the Summer of 1944.

The Summer of 1944 also marked a turning point in the war because of the vast number of precious German divisions that were destroyed on both the Eastern Front and the Anglo-American Fronts during the Summer. German divisional losses on the AngloAmerican Fronts amounted to 32 divisions (see Table LXIX). The Eastern Front accounted for 52 destroyed German divisions or $62 \%$ of all German divisional losses for the Summer of 1944 (see Table $L X X)$.

The Eastern Front based upon the analysis of troop losses, armored vehicle losses, armored vehicle deliveries, non-armored vehicle losses, non-armored vehicle deliveries, German generals lost and the number of German divisions destroyed was the most decisive front and made the greatest contribution to the defeat of Nazi Germany during the Summer of 1944. The Anglo-American Fronts made significant contributions during this period but were in fact not the most decisive fronts causing the greatest destruction to the German Wehrmacht. The Anglo-American contribution in the air war against Germany was the most decisive operation of the Western powers inflicting severe damage on the infrastructure of Germany and more losses on the Luftwaffe than the Soviet Union. The Soviet Union's successful ground operations expelling the Germans from most of the Soviet Union and Rumania and the resulting destruction of German Armies were the most 
significant contributions toward the defeat of Nazi Germany during the Summer of 1944. 
TABLE LIV

COMPARISON OF TROOP LOSSES BETWEEN

THE EASTERN AND WESTERN FRONTS

FROM JUNE-AUGUST 1944

\begin{tabular}{lllll}
\hline Dead & June & July & August & Totals \\
\hline Eastern Front & 10,853 & 31,351 & 30,880 & 73,084 \\
Western Front & 4,973 & 10,839 & 7,205 & 23,017 \\
Italian Front & 3,551 & 3,238 & 1,423 & 8,212 \\
Total Dead & 19,377 & 45,428 & 39,508 & 104,313 \\
\hline Wounded & June & July & August & Totals \\
\hline Eastern Front & 42,700 & 135,469 & 153,567 & 331,736 \\
Western Front & 14,631 & 38,824 & 13,605 & 67,060 \\
Italian Front & 10,281 & 12,877 & 5,527 & 28,685 \\
Total Wounded & 67,612 & 187,170 & 172,699 & 427,481 \\
\hline Missing & June & July & August & Totals \\
Eastern Front & 73,931 & 238,474 & 191,581 & 503,986 \\
Western Front & 15,848 & 55,135 & 127,633 & 198,616 \\
Italian Front & 16,193 & 9,210 & 5,598 & 31,001 \\
Total Missing & 105,972 & 302,819 & 324,812 & 733,603 \\
\hline Total Losses & June & July & August & Totals \\
\hline Eastern Front & 127,484 & 405,294 & 376,028 & 908,806 \\
Western Front & 35,452 & 104,798 & 148,443 & 288,693 \\
Italian Front & 30,025 & 25,325 & 12,548 & 67,898 \\
Total Losses & 192,961 & 535,417 & 537,019 & $1,265,397$ \\
\hline
\end{tabular}

* Eastern Front includes Geb AOK 20 (Finland) 
TABLE LIV

COMPARISON OF TROOP LOSSES BETWEEN

THE EASTERN AND WESTERN FRONTS

FROM JUNE-AUGUST 1944

(continued)

\section{Dead}

Eastern Front

Anglo-American Front

Comparison of Troop Losses on the Eastern and Anglo-American

Fronts for the three month period, June-August 1944:

Dead:

Eastern Front-70\%

Anglo-American-30\%

Wounded:

Eastern Front-78\% Anglo-American-22\%

Missing:

Eastern Front-69\% Anglo-American-31\%

Total Losses:

Eastern Front-72\% Anglo-American-28\%

Source: Der Heeresarzt im Oberkommando des Heeres, Personelle blutige Verluste des Feldheeres, Berichtigte Meldung fuer die Zeit vom 1.6.1944 bis 10.1.1945 NAMP T-77 Roll 826. 
TABLE LV

GERMAN LOSSES BY FRONT

FROM JUNE-NOVEMBER 1944

\begin{tabular}{ll}
\hline Operational Area & Losses \\
\hline Ob. West & 440,000 \\
Ob. Suedwest & 97,000 \\
Ob. Suedost & 17,000 \\
H.Gr. Sued & 243,000 \\
H.Gr. A & 117,000 \\
H.Gr. Mitte & 435,000 \\
H. Gr. Nord & 94,000 \\
Geb. AOK 20 & 14,000 \\
Total Losses & $1,457,000$ \\
& \\
Eastern Front Losses & \\
Anglo-American Front Losses & 537,000 \\
. & $37 \%$ \\
\hline
\end{tabular}

Source: Organisationsabteilung, Betrag: Aufschluesselung der unwiederbringlichen Verluste Juni - November 44 nach Kriegsschauplaetzen. H. Qu. den 2.12.44 NAMP T-78 Roll 411. 
TABLE LVI

COMPARISON OF ARMORED VEHICLE LOSSES

BETWEEN THE EASTERN FRONT AND

THE ANGLO-AMERICAN FRONTS,

JUNE 1944

\begin{tabular}{|c|c|c|c|c|}
\hline Type & East & West & S.West & Totals \\
\hline \multicolumn{2}{|l|}{ PzKpfWg II } & 1 & & 1 \\
\hline \multicolumn{2}{|l|}{ PzKofWg II Mun. } & & 9 & 9 \\
\hline \multicolumn{2}{|l|}{ PzKpfWg III L42 } & & 6 & 6 \\
\hline \multicolumn{2}{|l|}{ PzKpfWg III L24 } & & 27 & 27 \\
\hline \multicolumn{2}{|l|}{ PzKpfWg III L60 4} & & 4 & 8 \\
\hline \multicolumn{5}{|l|}{ PzKpfWg III Flamm } \\
\hline \multicolumn{2}{|l|}{ PzKpfWg IV L24 } & 1 & 7 & 8 \\
\hline \multicolumn{5}{|l|}{ PzKpfWg IV L43 } \\
\hline PzKpfWg IV L48 & 10 & 124 & 109 & 243 \\
\hline \multicolumn{5}{|l|}{ StuPz IV $15 \mathrm{~cm}$} \\
\hline PzKpfWg V L71 & 17 & 76 & 40 & 133 \\
\hline & 11 & 17 & 61 & 89 \\
\hline PzBefWg Gross & & & 3 & 3 \\
\hline \multicolumn{5}{|l|}{ PzBefWg III L42 } \\
\hline \multicolumn{2}{|l|}{ PzBefWg III L60 } & 1 & 7 & 8 \\
\hline \multicolumn{2}{|l|}{ PzBefWg V L71 } & 4 & 1 & 5 \\
\hline \multicolumn{2}{|l|}{ PzBefWg VI L56 } & 2 & 1 & 3 \\
\hline \multicolumn{5}{|l|}{ StuGesch L24 } \\
\hline \multicolumn{5}{|l|}{ StuGesch L43 } \\
\hline StuGesch L48 & 70 & 27 & 80 & 177 \\
\hline StuHaub 42 leFH 18 & 9 & & 7 & 16 \\
\hline PakSf $7.5 \mathrm{~cm} \mathrm{pz} \mathrm{II}$ & 2 & 5 & 1 & 8 \\
\hline PakSf $7.5 \mathrm{~cm} \mathrm{pz} \mathrm{38t}$ & 11 & 15 & 30 & 56 \\
\hline PakSf $7.5 \mathrm{~cm}$ Lorraine & 2 & 9 & & 11 \\
\hline PakSf $7.62 \mathrm{~cm} \mathrm{pz} \mathrm{II}$ & & & 1 & 1 \\
\hline PakSf $7.62 \mathrm{~cm} \mathrm{pz} \mathrm{38t}$ & & & 17 & 17 \\
\hline PakSf $8.8 \mathrm{~cm} \mathrm{pz} \mathrm{IV}$ & 36 & & 11 & 47 \\
\hline PakSf $8.8 \mathrm{~cm} \mathrm{pz} \mathrm{VI} \mathrm{(P)}$ & & & 4 & 4 \\
\hline Beob. Pz III & 1 & & 11 & 12 \\
\hline ArtSf leFH $18 \mathrm{pz} \mathrm{II}$ & 1 & 2 & 22 & 25 \\
\hline
\end{tabular}


TABLE LVI

COMPARISON OF ARMORED VEHICLE LOSSES

BETWEEN THE EASTERN FRONT AND

THE ANGLO-AMERICAN FRONTS,

JUNE 1944

(continued)

\begin{tabular}{lllll}
\hline Type & East & West & S. West & Totals \\
\hline ArtSf SFH 18 pz IV & & & 7 & 7 \\
ArtSf SIG 33 pz 38t & & 1 & 8 & 9 \\
le. Pz. Sp. Wg. M.G. & 1 & 7 & 5 & 13 \\
le. Pz. Sp. Wg. 2cm & 5 & & 6 & 11 \\
S. Pz. Sp. Wg. 2cm & 2 & 7 & 5 & 14 \\
S. Pz. Sp. Wg. 7.5cm & & 7 & 2 & 9 \\
S.Pz.Sp.Wg. Luchs 7.5 & & & & \\
le. Pz. Fu. Wg. & 3 & & 1 & 4 \\
S. Pz. Fu. Wg. & & & 1 & 1 \\
le. Schtz Pz. Wg. & 8 & 29 & 17 & 54 \\
le. SchtzPzWg 2cm & & 12 & 1 & 13 \\
le. SchtzPzWg 3.7cm & & & 2 & 2 \\
m. SchtzPzWg & 17 & 70 & 51 & 138 \\
m. SchtzPzWg 7.5cm & 1 & 13 & 14 & 28 \\
m. SchtzPzWg 3.7cm & 1 & & 2 & 3 \\
Pion. PzWg & 3 & 28 & 19 & 50 \\
Krk. PzWg & 1 & 3 & 5 & 9 \\
Kde. PzWg & 1 & & & 1 \\
Beob. PzWg & 2 & 6 & 8 & 16 \\
Mun. PzWg & 3 & & & 3 \\
Fla. PzWg 251/16 & 1 & 2 & 2 & 5 \\
PzKpWW III Mun. & & & 1 & 1 \\
PzKpWW IV Mun. & & 1 & 4 & 5 \\
PzKpfWg V Berge & 1 & & & 4 \\
\hline Total Losses: & 224 & 471 & 641 & 1.336 \\
\hline
\end{tabular}


TABLE LVI

COMPARISON OF ARMORED VEHICLE LOSSES

BETWEEN THE EASTERN FRONT AND

THE ANGLO-AMERICAN FRONTS,

JUNE 1944

(continued)

Type East

West

S.West

Totals

German Armor Losses by Front:

Eastern Front:

$17 \%$

Western Front:

$35 \%$

Southwestern Front:

$48 \%$

Source: OKH, Kraftfahrzeuge (gepanzert) Heer-Westen, Ob. Suedwest, Osten NAMP T-78 Roll 145. 


\section{TABLE LVII}

COMPARISON OF ARMORED VEHICLE LOSSES

BETWEEN THE EASTERN FRONT AND

THE ANGLO-AMERICAN FRONTS,

JULY 1944

\begin{tabular}{|c|c|c|c|c|}
\hline Type & East & West & S.West & Totals \\
\hline PzKpfWg II & 57 & 1 & 3 & 61 \\
\hline $\begin{array}{l}\text { PzKpfWg II Mun. } \\
\text { PzKpfWg III L42 }\end{array}$ & 8 & 6 & & 14 \\
\hline PzKpfWg III L24 & 5 & & & 5 \\
\hline $\begin{array}{l}\text { PzKpfWg III L60 } \\
\text { PzKpfWg III Flamm } \\
\text { PzKpfWg } 38 \mathrm{t}\end{array}$ & & & 4 & 4 \\
\hline $\begin{array}{l}\text { PzKpfWg IV L24 } \\
\text { PzKpfWg IV L43 }\end{array}$ & & 1 & $\begin{array}{l}7 \\
27\end{array}$ & $\begin{array}{l}8 \\
27\end{array}$ \\
\hline $\begin{array}{l}\text { PzKpfWg IV L48 } \\
\text { StuPz IV } 15 \mathrm{~cm}\end{array}$ & $\begin{array}{l}256 \\
5\end{array}$ & 149 & $\begin{array}{l}28 \\
52\end{array}$ & $\begin{array}{l}433 \\
57\end{array}$ \\
\hline PzKpfWg V L71 & 219 & 121 & 7 & 347 \\
\hline $\begin{array}{l}\text { PzKpfWg VI L56 } \\
\text { PzBefWg Gross }\end{array}$ & 164 & 13 & 14 & 191 \\
\hline PzBefWg III L42 & 15 & & & 15 \\
\hline PzBefWg III L60 & & 2 & 1 & 3 \\
\hline PzBefWg V L71 & 22 & 4 & & 26 \\
\hline $\begin{array}{l}\text { PzBefWg VI L56 } \\
\text { StuGesch L24 }\end{array}$ & 2 & 1 & 1 & 4 \\
\hline StuGesch L43 & & & & \\
\hline StuGesch L48 & 808 & 68 & 38 & 914 \\
\hline StuHaub 42 leFH 18 & 79 & & 1 & 80 \\
\hline PakSf $7.5 \mathrm{~cm} \mathrm{pz} \mathrm{II}$ & 49 & & & 49 \\
\hline PakSf $7.5 \mathrm{~cm} \mathrm{pz} \mathrm{38t}$ & 264 & 10 & & 274 \\
\hline $\begin{array}{l}\text { PakSf } 7.5 \mathrm{~cm} \text { Lorraine } \\
\text { PakSf } 7.62 \mathrm{~cm} \mathrm{pz} \mathrm{II} \\
\text { PakSf } 7.62 \mathrm{~cm} \mathrm{pz} 38 \mathrm{t}\end{array}$ & 6 & 5 & & 11 \\
\hline PakSf $8.8 \mathrm{~cm}$ pz IV & 34 & & & 34 \\
\hline PakSf $8.8 \mathrm{~cm}$ pz VI (P) & 23 & & & 23 \\
\hline Beob. Pz III & 24 & 2 & & 26 \\
\hline ArtSf leFH 18 pz $\|$ & 43 & 8 & 1 & 52 \\
\hline
\end{tabular}


TABLE LVII

COMPARISON OF ARMORED VEHICLE LOSSES

BETWEEN THE EASTERN FRONT AND

THE ANGLO-AMERICAN FRONTS,

JULY 1944

(continued)

\begin{tabular}{lllll}
\hline Type & East & West & S.West & Totals \\
\hline ArtSf SFH 18 pz IV & 70 & 8 & & 78 \\
ArtSf SIG 33 pz 38t & 23 & 2 & 1 & 26 \\
le. Pz. Sp. Wg. M.G. & 22 & 2 & 1 & 25 \\
le. Pz. Sp. Wg. 2cm & 33 & 1 & 4 & 38 \\
S. Pz. Sp. Wg. 2cm & 39 & & 1 & 40 \\
S. Pz. Sp. Wg. 7.5cm & 6 & & & 6 \\
S.Pz.Sp.Wg. Luchs 7.5 & & & & \\
le. Pz. Fu. Wg. & 9 & & & 9 \\
S. Pz. Fu. Wg. & 3 & & 1 & 4 \\
le. Schtz Pz. Wg. & 173 & 14 & 23 & 210 \\
le. SchtzPzWg 2cm & 24 & 3 & & 27 \\
le. SchtzPzWg 3.7cm & 4 & & & 4 \\
m. SchtzPzWg & 205 & 47 & 8 & 260 \\
m. SchtzPzWg 7.5cm & 25 & 5 & 3 & 33 \\
m. SchtzPzWg 3.7cm & 7 & 1 & & 8 \\
Pion. PzWg & 60 & 21 & & 81 \\
Krk. PzWg & 12 & 1 & 1 & 14 \\
Kde. PzWg & 4 & 1 & & 5 \\
Beob. PzWg & 32 & 1 & 2 & 35 \\
Mun. PzWg & 29 & & & 29 \\
Fla. PzWg 251/16 & 20 & 8 & & 28 \\
PzKpfWg III Mun. & 10 & & 2 & 12 \\
PzKpfWg IV Mun. & 15 & & 4 & 19 \\
PzKpfWg V Berge & 10 & 1 & 1 & 12 \\
\hline Total Losses: & 2,918 & 506 & 202 & 3,626 \\
& & & & \\
\hline
\end{tabular}


TABLE LVII

COMPARISON OF ARMORED VEHICLE LOSSES

BETWEEN THE EASTERN FRONT AND

THE ANGLO-AMERICAN FRONTS,

JULY 1944

(continued)

Type

East

West

S. West

Totals

German Armor Losses by Front:

Eastern Front:

$80 \%$

Western Front:

$14 \%$

Southwestern Front:

$6 \%$

Source: OKH, Kraftfahrzeuge (gepanzert) Heer-Westen, Ob. Suedwest, Osten NAMP T-78 Roll 145. 
TABLE LVIII

COMPARISON OF ARMORED VEHICLE LOSSES

BETWEEN THE EASTERN FRONT AND

THE ANGLO-AMERICAN FRONTS,

AUGUST 1944

\begin{tabular}{|c|c|c|c|c|}
\hline Type & East & West & S.West & Totals \\
\hline PzKpfWg II & 2 & & & 2 \\
\hline $\begin{array}{l}\text { PzKpfWg II Mun. } \\
\text { PzKpfWg III L42 }\end{array}$ & 3 & 4 & & 7 \\
\hline PzKpfWg III L24 & 5 & & & 5 \\
\hline $\begin{array}{l}\text { PzKpfWg III L60 } \\
\text { PzKpfWg III Flamm } \\
\text { PzKpfWg } 38 \mathrm{t}\end{array}$ & 2 & & & 2 \\
\hline PzKpfWg IV L24 & 3 & & & 3 \\
\hline PzKpfWg IV L43 & 3 & & & 3 \\
\hline PzKpfWg IV L48 & 309 & 49 & 4 & 362 \\
\hline StuPz IV $15 \mathrm{~cm}$ & & 14 & 2 & 16 \\
\hline PzKpfWg V L71 & 239 & 36 & 3 & 278 \\
\hline $\begin{array}{l}\text { PzKpfWg VI L56 } \\
\text { PzBefWg Gross } \\
\text { PzBefWg III L42 }\end{array}$ & 75 & 13 & 3 & 91 \\
\hline PzBefWg III L60 & 5 & 1 & & 6 \\
\hline PzBefWg V L71 & 7 & 5 & & 12 \\
\hline PzBefWg VI L56 & 1 & 2 & & 3 \\
\hline StuGesch L24 & 3 & & & 3 \\
\hline StuGesch L43 & & & & \\
\hline StuGesch L48 & 254 & 98 & 13 & 365 \\
\hline StuHaub 42 leFH 18 & 39 & & 5 & 44 \\
\hline PakSf $7.5 \mathrm{~cm} \mathrm{pz} \mathrm{II}$ & 7 & & & 7 \\
\hline $\begin{array}{l}\text { PakSf } 7.5 \mathrm{~cm} \text { pz } 38 \mathrm{t} \\
\text { PakSf } 7.5 \mathrm{~cm} \text { Lorraine }\end{array}$ & 44 & & 3 & 47 \\
\hline $\begin{array}{l}\text { PakSf } 7.62 \mathrm{~cm} \mathrm{pz} \mathrm{II} \\
\text { PakSf } 7.62 \mathrm{~cm} \mathrm{pz} 38 \mathrm{t}\end{array}$ & & 24 & & 24 \\
\hline PakSf $8.8 \mathrm{~cm}$ pz IV & 7 & & 13 & 20 \\
\hline PakSf $8.8 \mathrm{~cm}$ pz VI (P) & 2 & & & 2 \\
\hline Beob. Pz III & 9 & & & 9 \\
\hline ArtSf leFH $18 \mathrm{pz} \|$ & 7 & & 1 & 8 \\
\hline
\end{tabular}


TABLE LVIII

COMPARISON OF ARMORED VEHICLE LOSSES

BETWEEN THE EASTERN FRONT AND

THE ANGLO-AMERICAN FRONTS,

AUGUST 1944

(continued)

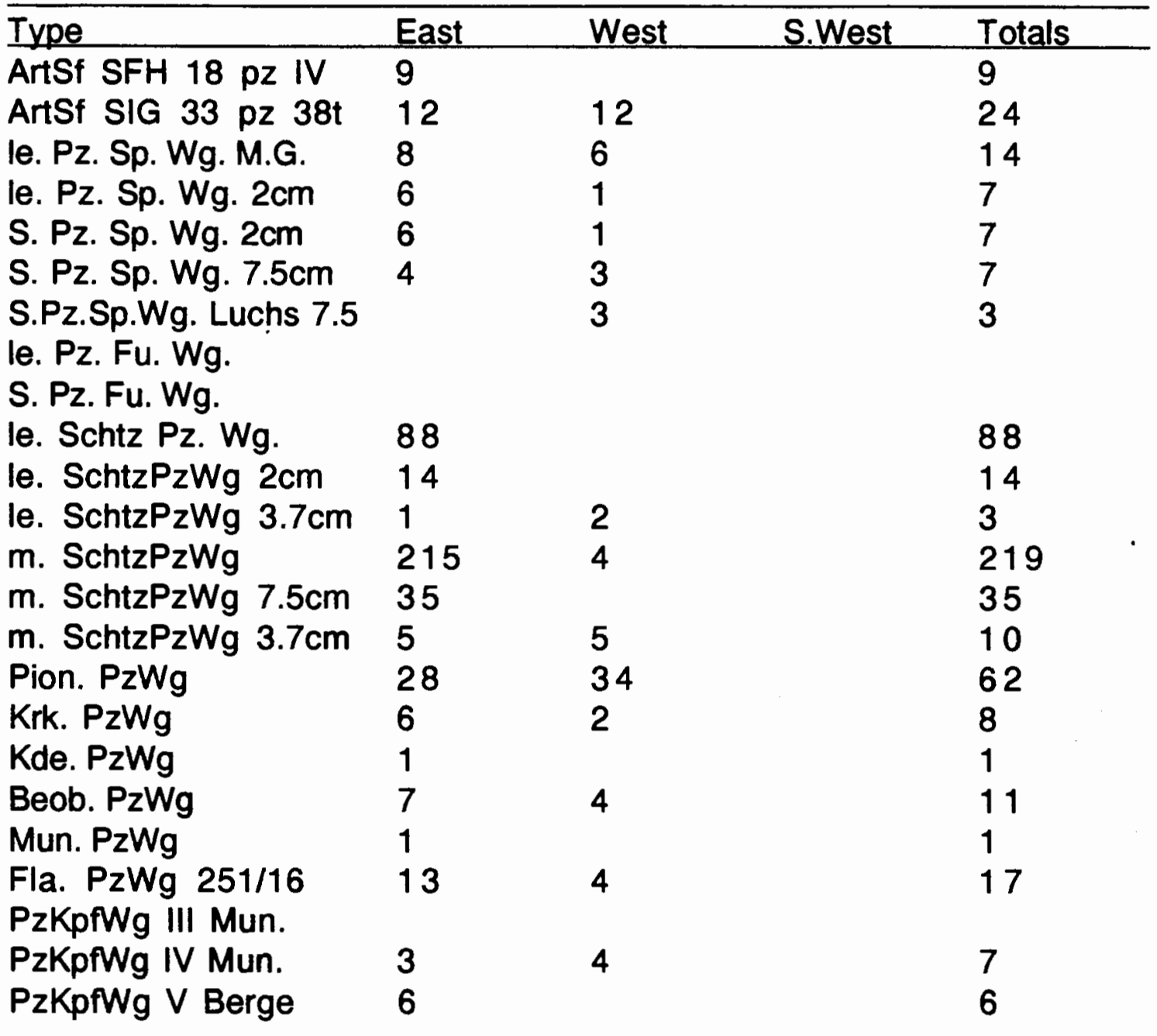


TABLE LVIII

COMPARISON OF ARMORED VEHICLE LOSSES

BETWEEN THE EASTERN FRONT AND

THE ANGLO-AMERICAN FRONTS,

AUGUST 1944

(continued)

Type

East

West

S.West

Totals

German Armor Losses by Front:

Eastern Front:

$80 \%$

Western Front:

$18 \%$

Southwestern Front:

$2 \%$

Source: OKH, Kraftfahrzeuge (gepanzert) Heer-Westen, Ob. Suedwest, Osten NAMP T-78 Roll 145. 
TABLE LIX

COMPARISON OF ARMORED VEHICLE LOSSES

BETWEEN THE EASTERN FRONT AND

THE ANGLO-AMERICAN FRONTS, JUNE-AUGUST 1944

\begin{tabular}{|c|c|c|c|c|}
\hline Type & East & West & S.West & Totals \\
\hline PzKpfWg II & 59 & 2 & 3 & 64 \\
\hline $\begin{array}{l}\text { PzKpfWg II Mun. } \\
\text { PzKpfWg III L42 }\end{array}$ & 11 & 10 & $\begin{array}{l}9 \\
6\end{array}$ & $\begin{array}{l}30 \\
6\end{array}$ \\
\hline PzKpfWg III L24 & 5 & & 27 & 32 \\
\hline $\begin{array}{l}\text { PzKpfWg III L60 } \\
\text { PzKpfWg III Flamm } \\
\text { PzKpfWg } 38 \mathrm{t}\end{array}$ & 6 & & 8 & 14 \\
\hline PzKpfWg IV L24 & 3 & 1 & 7 & 11 \\
\hline PzKpfWg IV L43 & 3 & & 19 & 22 \\
\hline PzKpfWg IV L48 & 575 & 322 & 141 & 1,038 \\
\hline StuPz IV $15 \mathrm{~cm}$ & 5 & 14 & 54 & 73 \\
\hline PzKpfWg V L71 & 475 & 233 & 50 & 758 \\
\hline PzKpfWg VI L56 & 250 & 43 & 78 & 371 \\
\hline PzBefWg Gross & & & 3 & 3 \\
\hline PzBefWg III L42 & 15 & & & 15 \\
\hline PzBefWg III L60 & 5 & 4 & 8 & 17 \\
\hline PzBefWg $\vee L 71$ & 29 & 13 & 1 & 43 \\
\hline PzBefWg VI L56 & 3 & 5 & 2 & 10 \\
\hline StuGesch L24 & 3 & & & 3 \\
\hline StuGesch L43 & & & & \\
\hline StuGesch L48 & 1,132 & 193 & 131 & 1,456 \\
\hline StuHaub 42 leFH 18 & 127 & & 13 & 140 \\
\hline PakSf $7.5 \mathrm{~cm}$ pz II & 58 & 5 & 1 & 64 \\
\hline PakSf $7.5 \mathrm{~cm} \mathrm{pz} 38 \mathrm{t}$ & 319 & 25 & 33 & 377 \\
\hline PakSf $7.5 \mathrm{~cm}$ Lorraine & 8 & 14 & & 22 \\
\hline PakSf $7.62 \mathrm{~cm} \mathrm{pz} \mathrm{II}$ & & 24 & 1 & 25 \\
\hline PakSf $7.62 \mathrm{~cm} \mathrm{pz} 38 \mathrm{t}$ & & & 17 & 17 \\
\hline PakSf $8.8 \mathrm{~cm}$ pz IV & 77 & & 24 & 101 \\
\hline PakSf $8.8 \mathrm{~cm}$ pz VI (P) & 25 & & 4 & 29 \\
\hline Beob. Pz III & 34 & 2 & 11 & 47 \\
\hline ArtSf leFH $18 \mathrm{pz} \|$ & 51 & 10 & 24 & 85 \\
\hline
\end{tabular}




\section{TABLE LIX}

COMPARISON OF ARMORED VEHICLE LOSSES

BETWEEN THE EASTERN FRONT AND

THE ANGLO-AMERICAN FRONTS,

JUNE-AUGUST 1944

(continued)

\begin{tabular}{|c|c|c|c|c|}
\hline Type & East & West & S.West & Totals \\
\hline ArtSf SFH $18 \mathrm{pz} \mathrm{IV}$ & 79 & 8 & 7 & 94 \\
\hline ArtSf SIG $33 \mathrm{pz} 38 \mathrm{t}$ & 35 & 15 & 9 & 59 \\
\hline le. Pz. Sp. Wg. M.G. & 31 & 15 & 6 & 52 \\
\hline le. Pz. Sp. Wg. $2 \mathrm{~cm}$ & 44 & 2 & 10 & 56 \\
\hline S. Pz. Sp. Wg. $2 \mathrm{~cm}$ & 47 & 8 & 6 & 61 \\
\hline S. Pz. Sp. Wg. $7.5 \mathrm{~cm}$ & 10 & 10 & 2 & 22 \\
\hline S.Pz.Sp.Wg. Luchs 7.5 & & 3 & & 3 \\
\hline le. Pz. Fu. Wg. & 12 & & 1 & 13 \\
\hline S. Pz. Fu. Wg. & 3 & & 2 & 5 \\
\hline le. Schtz Pz. Wg. & 269 & 43 & 40 & 352 \\
\hline le. SchtzPzWg $2 \mathrm{~cm}$ & 38 & 15 & 1 & 54 \\
\hline le. SchtzPzWg $3.7 \mathrm{~cm}$ & 5 & 2 & 2 & 9 \\
\hline m. SchtzPzWg & 437 & 121 & 59 & 617 \\
\hline m. SchtzPzWg $7.5 \mathrm{~cm}$ & 61 & 18 & 17 & 96 \\
\hline m. SchtzPzWg $3.7 \mathrm{~cm}$ & 13 & 6 & 2 & 21 \\
\hline Pion. PzWg & 91 & 83 & 19 & 193 \\
\hline Krk. PzWg & 19 & 6 & 6 & 31 \\
\hline Kde. PzWg & 6 & 1 & & 7 \\
\hline Beob. PzWg & 41 & 11 & 10 & 62 \\
\hline Mun. PzWg & 33 & & & 33 \\
\hline Fla. PzWg 251/16 & 34 & 14 & 2 & 50 \\
\hline PzKpfWg III Mun. & 10 & & 3 & 13 \\
\hline PzKpfWg IV Mun. & 18 & 5 & 8 & 31 \\
\hline PzKpfWg V Berge & 17 & 2 & 3 & 22 \\
\hline Total Losses: & 4,63 & 1,308 & 890 & 6,829 \\
\hline
\end{tabular}


TABLE LIX

COMPARISON OF ARMORED VEHICLE LOSSES

BETWEEN THE EASTERN FRONT AND

THE ANGLO-AMERICAN FRONTS,

JUNE-AUGUST 1944

(continued)

Type East

West

S. West

Totals

German Armor Losses by Front:

Eastern Front:

$68 \%$

Western Front: $19 \%$

Southwestern Front:

$13 \%$

Source: OKH, Kraftfahrzeuge (gepanzert) Heer-Westen, Ob. Suedwest, Osten NAMP T-78 Roll 145. 
TABLE LX

COMPARISON OF ARMORED VEHICLE SHIPMENTS

TO THE EASTERN FRONT AND

THE ANGLO-AMERICAN FRONTS,

JUNE-AUGUST 1944

\begin{tabular}{|c|c|c|c|c|}
\hline Type & East & West & S.West & Totals \\
\hline PzKpfWg II & 11 & & & 11 \\
\hline $\begin{array}{l}\text { PzKpfWg II Mun. } \\
\text { PzKpfWg III L42 }\end{array}$ & 4 & 7 & & 11 \\
\hline PzKpfWg III L24 & & & 16 & 16 \\
\hline $\begin{array}{l}\text { PzKpfWg III L60 } \\
\text { PzKpfWg III Flamm } \\
\text { PzKpfWg } 38 t \\
\text { PzKpfWg IV L24 } \\
\text { PzKpfWg IV L43 }\end{array}$ & 2 & & & 2 \\
\hline $\begin{array}{l}\text { PzKpfWg IV L48 } \\
\text { StuPz IV } 15 \mathrm{~cm}\end{array}$ & 524 & $\begin{array}{l}163 \\
45\end{array}$ & $\begin{array}{l}107 \\
31\end{array}$ & $\begin{array}{l}794 \\
76\end{array}$ \\
\hline PzKpfWg V L71 & 429 & 347 & 38 & 814 \\
\hline PzKpfWg VI L56 & 173 & 104 & 43 & 320 \\
\hline $\begin{array}{l}\text { PzBefWg Gross } \\
\text { PzBefWg III L42 }\end{array}$ & 2 & & & 2 \\
\hline PzBefWg III L60 & 19 & 8 & & 27 \\
\hline PzBefWg V L71 & 31 & 21 & & 52 \\
\hline $\begin{array}{l}\text { PzBefWg VI L56 } \\
\text { StuGesch L24 }\end{array}$ & 7 & 6 & 2 & 15 \\
\hline StuGesch L43 & & & & \\
\hline $\begin{array}{l}\text { StuGesch L48 } \\
\text { StuHaub } 42 \text { leFH } 18\end{array}$ & $\begin{array}{l}1,454 \\
221\end{array}$ & $\begin{array}{l}130 \\
9\end{array}$ & $\begin{array}{l}85 \\
21\end{array}$ & $\begin{array}{l}1,669 \\
251\end{array}$ \\
\hline PakSf $7.5 \mathrm{~cm} \mathrm{pz} \mathrm{II}$ & 20 & & & 20 \\
\hline PakSf $7.5 \mathrm{~cm} \mathrm{pz} \mathrm{38t}$ & 96 & 3 & 10 & 109 \\
\hline $\begin{array}{l}\text { PakSf } 7.5 \mathrm{~cm} \text { Lorraine } \\
\text { PakSf } 7.62 \mathrm{~cm} \mathrm{pz} \mathrm{II} \\
\text { PakSf } 7.62 \mathrm{~cm} \mathrm{pz} 38 \mathrm{t}\end{array}$ & 1 & & & 1 \\
\hline PakSf $8.8 \mathrm{~cm}$ pz IV & 40 & & & 40 \\
\hline PakSf $8.8 \mathrm{~cm} \mathrm{pz} \mathrm{VI} \mathrm{(P)}$ & 4 & 18 & & 22 \\
\hline Beob. Pz III & 7 & 9 & & 16 \\
\hline ArtSf leFH $18 \mathrm{pz} \mathrm{II}$ & 48 & 18 & & 66 \\
\hline
\end{tabular}




\section{TABLE LX}

COMPARISON OF ARMORED VEHICLE SHIPMENTS

TO THE EASTERN FRONT AND

THE ANGLO-AMERICAN FRONTS,

JUNE-AUGUST 1944

(continued)

\begin{tabular}{|c|c|c|c|c|}
\hline Type & East & West & S.West & Totals \\
\hline ArtSf SFH $18 \mathrm{pz} \mathrm{IV}$ & 42 & 27 & & 69 \\
\hline ArtSf SIG $33 \mathrm{pz} 38 \mathrm{t}$ & 74 & 12 & 2 & 88 \\
\hline le. Pz. Sp. Wg. M.G. & 34 & 1 & 6 & 41 \\
\hline le. Pz. Sp. Wg. $2 \mathrm{~cm}$ & 43 & 1 & 1 & 45 \\
\hline S. Pz. Sp. Wg. $2 \mathrm{~cm}$ & 9 & 1 & 1 & 11 \\
\hline $\begin{array}{l}\text { S. Pz. Sp. Wg. } 7.5 \mathrm{~cm} \\
\text { S.Pz.Sp.Wg. Luchs } 7.5\end{array}$ & 3 & & & 3 \\
\hline le. Pz. Fu. Wg. & 3 & & & 3 \\
\hline S. Pz. Fu. Wg. & 1 & & & 1 \\
\hline le. Schtz Pz. Wg. & 334 & 59 & 8 & 401 \\
\hline le. SchtzPzWg $2 \mathrm{~cm}$ & 50 & 16 & 1 & 67 \\
\hline le. SchtzPzWg $3.7 \mathrm{~cm}$ & 1 & & & 1 \\
\hline m. SchtzPzWg & 921 & 231 & 11 & 1163 \\
\hline m. SchtzPzWg $7.5 \mathrm{~cm}$ & 132 & 20 & & 152 \\
\hline m. SchtzPzWg $3.7 \mathrm{~cm}$ & 1 & & & 1 \\
\hline Pion. PzWg & 240 & 66 & 2 & 308 \\
\hline Krk. PzWg & 50 & 6 & & 56 \\
\hline Kde. PzWg & 5 & & 1 & 6 \\
\hline $\begin{array}{l}\text { Beob. PzWg } \\
\text { Mun. PzWg }\end{array}$ & 38 & 10 & & 48 \\
\hline $\begin{array}{l}\text { Fla. PzWg 251/16 } \\
\text { PzKpfWg III Mun. }\end{array}$ & 89 & 17 & & 106 \\
\hline PzKpfWg IV Mun. & 7 & & & 7 \\
\hline PzKpfWg V Berge & 40 & 25 & 2 & 67 \\
\hline Total Shipments: & 5,210 & 1,380 & 388 & 6,978 \\
\hline
\end{tabular}




\section{TABLE LX}

COMPARISON OF ARMORED VEHICLE SHIPMENTS

TO THE EASTERN FRONT AND

THE ANGLO-AMERICAN FRONTS,

JUNE-AUGUST 1944

(continued)

Type

East

West

S.West

Totals

German Armor Vehicle Shipments To The Front:

Eastern Front:

$75 \%$

Western Front:

$20 \%$

Southwestern Front:

$5 \%$

Source: OKH, Kraftfahrzeuge (gepanzert) Heer-Westen, Ob. Suedwest, Osten NAMP T-78 Roll 145. 
TABLE LXI

COMPARISON OF NON-ARMORED VEHICLE LOSSES

BETWEEN THE EASTERN FRONT AND

THE ANGLO-AMERICAN FRONTS,

JUNE 1944

\begin{tabular}{|c|c|c|c|c|}
\hline Type & East & West & S.West & Totals \\
\hline Motorcycles & 863 & 663 & 2,452 & 3,978 \\
\hline Cars & 962 & 919 & 2,648 & 4,529 \\
\hline Trucks & 1150 & 1649 & 3820 & 6,619 \\
\hline Command Cars & 24 & 27 & 79 & 130 \\
\hline Ambulances & 47 & 54 & 150 & 251 \\
\hline Maultier & 43 & 39 & 26 & 108 \\
\hline Wheeled Tractors & 27 & 29 & 148 & 204 \\
\hline $\begin{array}{l}\text { Tracked Tractors } \\
\text { RSO }\end{array}$ & $\begin{array}{l}22 \\
68\end{array}$ & $\begin{array}{l}2 \\
88\end{array}$ & $\begin{array}{l}69 \\
205\end{array}$ & $\begin{array}{l}93 \\
361\end{array}$ \\
\hline $\begin{array}{l}\text { Half-Track Motorcycle } \\
\text { Heavy Army Tractors } \\
\text { Half-Track Mover }\end{array}$ & 29 & 109 & $\begin{array}{l}68 \\
-\end{array}$ & 206 \\
\hline $\begin{array}{l}1 \text { ton } \\
\text { Half-Track Mover }\end{array}$ & 38 & 5 & 88 & 131 \\
\hline $\begin{array}{l}3 \text { ton } \\
\text { Half-Track Mover }\end{array}$ & 6 & 10 & 92 & 108 \\
\hline $\begin{array}{l}5 \text { ton } \\
\text { Half-Track Mover }\end{array}$ & 5 & 2 & 10 & 17 \\
\hline $\begin{array}{l}8 \text { ton } \\
\text { Half-Track Mover }\end{array}$ & 17 & 27 & 125 & 169 \\
\hline $\begin{array}{l}12 \text { ton } \\
\text { Half-Track Mover }\end{array}$ & 6 & 1 & 17 & 24 \\
\hline $\begin{array}{l}18 \text { ton } \\
\text { Trailers }\end{array}$ & $\begin{array}{l}1 \\
74\end{array}$ & $\begin{array}{l}2 \\
129\end{array}$ & $\begin{array}{l}13 \\
553\end{array}$ & $\begin{array}{l}16 \\
756\end{array}$ \\
\hline Total Losses: & 3,382 & 3,755 & 10,563 & 17,700 \\
\hline
\end{tabular}




\section{TABLE LXI}

COMPARISON OF NON-ARMORED VEHICLE LOSSES

BETWEEN THE EASTERN FRONT AND

THE ANGLO-AMERICAN FRONTS,

JUNE 1944

(continued)

\section{Type}

East

West

S.West

Totals

German Non-Armored Losses by Front:

Eastern Front:

$19 \%$

Western Front:

$21 \%$

Southwestern Front:

$60 \%$

* The data has a margin of error due to a lack of reports from several Army units.

Source: OKH, Kraftfahrzeuge (ungepanzert) Heer-Westen, Ob. Suedwest. Osten NAMP T-78 Roll 145. 
TABLE LXII

COMPARISON OF NON-ARMORED VEHICLE LOSSES

BETWEEN THE EASTERN FRONT AND

THE ANGLO-AMERICAN FRONTS,

JULY 1944

\begin{tabular}{|c|c|c|c|c|}
\hline Type & East & West & S.West & Totals \\
\hline Motorcycles & 5001 & 13 & 569 & 5,583 \\
\hline Cars & 5,443 & 25 & 590 & 6,058 \\
\hline Trucks & 9,689 & 57 & 764 & 10,510 \\
\hline Command Cars & 211 & 3 & 77 & 291 \\
\hline Ambulances & 459 & 1 & 28 & 488 \\
\hline Maultier & 574 & - & 5 & 579 \\
\hline Wheeled Tractors & 119 & 20 & 30 & 169 \\
\hline $\begin{array}{l}\text { Tracked Tractors } \\
\text { RSO }\end{array}$ & $\begin{array}{l}120 \\
1566\end{array}$ & $\begin{array}{l}- \\
-\end{array}$ & $\begin{array}{l}10 \\
36\end{array}$ & $\begin{array}{l}130 \\
1602\end{array}$ \\
\hline Half-Track Motorcycle & 200 & - & 9 & 209 \\
\hline $\begin{array}{l}\text { Heavy Army Tractors } \\
\text { Half-Track Mover }\end{array}$ & 5 & - & - & 5 \\
\hline $\begin{array}{l}1 \text { ton } \\
\text { Half-Track Mover }\end{array}$ & 275 & 3 & 13 & 291 \\
\hline $\begin{array}{l}3 \text { ton } \\
\text { Half-Track Mover }\end{array}$ & 163 & - & 20 & 183 \\
\hline $\begin{array}{l}5 \text { ton } \\
\text { Half-Track Mover }\end{array}$ & 87 & - & - & 87 \\
\hline $\begin{array}{l}8 \text { ton } \\
\text { Half-Track Mover }\end{array}$ & 122 & - & 8 & 130 \\
\hline $\begin{array}{l}12 \text { ton } \\
\text { Half-Track Mover }\end{array}$ & 60 & - & - & 60 \\
\hline $\begin{array}{l}18 \text { ton } \\
\text { Trailers }\end{array}$ & $\begin{array}{l}21 \\
1314\end{array}$ & 23 & 82 & $\begin{array}{l}21 \\
1419\end{array}$ \\
\hline Total Losses: & 25,429 & 145 & 2,241 & 27,815 \\
\hline
\end{tabular}


TABLE LXII

COMPARISON OF NON-ARMORED VEHICLE LOSSES

BETWEEN THE EASTERN FRONT AND

THE ANGLO-AMERICAN FRONTS,

JULY 1944

(continued)

German Non-Armored Losses by Front:

Eastern Front: $\quad 91 \%$

Western Front: $\quad 1 \%$

Southwestern Front: $\quad 8 \%$

*The data has a margin of error due to a lack of reports from several Army units.

Source: OKH, Kraftfahrzeuge (ungepanzert) Heer-Westen, Ob. Suedwest, Osten NAMP T-78 Roll 145. 
TABLE LXIII

COMPARISON OF NON-ARMORED VEHICLE LOSSES

BETWEEN THE EASTERN FRONT AND

THE ANGLO-AMERICAN FRONTS,

AUGUST 1944

\begin{tabular}{|c|c|c|c|c|}
\hline Type & East & West & S.West & Totals \\
\hline Motorcycles & 4,373 & 7,515 & 252 & 12,140 \\
\hline Cars & 4,612 & 8,384 & 248 & 13,244 \\
\hline Trucks & 7,066 & 7,469 & 300 & 14,835 \\
\hline Command Cars & 168 & 226 & 4 & 398 \\
\hline Ambulances & 512 & 659 & 13 & 1184 \\
\hline Maultier & 613 & 683 & 1 & 1297 \\
\hline Wheeled Tractors & 65 & 272 & 27 & 364 \\
\hline Tracked Tractors & 40 & 231 & 14 & 285 \\
\hline RSO & 809 & 310 & 17 & 1136 \\
\hline Half-Track Motorcycle & 170 & 224 & - & 394 \\
\hline $\begin{array}{l}\text { Heavy Army Tractors } \\
\text { Half-Track Mover }\end{array}$ & - & - & - & - \\
\hline $\begin{array}{l}1 \text { ton } \\
\text { Half-Track Mover }\end{array}$ & 281 & 369 & 7 & 657 \\
\hline $\begin{array}{l}3 \text { ton } \\
\text { Half-Track Mover }\end{array}$ & 138 & 155 & 3 & 296 \\
\hline $\begin{array}{l}5 \text { ton } \\
\text { Half-Track Mover }\end{array}$ & 60 & 35 & - & 95 \\
\hline $\begin{array}{l}8 \text { ton } \\
\text { Half-Track Mover }\end{array}$ & 145 & 314 & 5 & 464 \\
\hline $\begin{array}{l}12 \text { ton } \\
\text { Half-Track Mover }\end{array}$ & 51 & 50 & - & 101 \\
\hline $\begin{array}{l}18 \text { ton } \\
\text { Trailers }\end{array}$ & $\begin{array}{l}16 \\
764\end{array}$ & $\begin{array}{l}57 \\
912\end{array}$ & 41 & $\begin{array}{l}73 \\
1,717\end{array}$ \\
\hline Total Losses: & 19,883 & 27,865 & 932 & 48,680 \\
\hline
\end{tabular}


TABLE LXIII

COMPARISON OF NON-ARMORED VEHICLE LOSSES

BETWEEN THE EASTERN FRONT AND

THE ANGLO-AMERICAN FRONTS,

AUGUST 1944

(continued)

Type

East

West

S.West

Totals

German Non-Armored Losses by Front:

Eastern Front:

$41 \%$

Western Front:

$57 \%$

Southwestern Front:

$2 \%$

*The data has a margin of error due to a lack of reports from several Army units.

Source: OKH, Kraftfahrzeuge (ungepanzert) Heer-Westen, Ob. Suedwest, Osten NAMP T-78 Roll 145. 
TABLE LXIV

COMPARISON OF NON-ARMORED VEHICLE LOSSES

BETWEEN THE EASTERN FRONT AND

THE ANGLO-AMERICAN FRONTS,

JUNE-AUGUST 1944

\begin{tabular}{|c|c|c|c|c|}
\hline Type & East & West & S.West & Totals \\
\hline Motorcycles & 10,237 & 8,191 & 3,273 & 21,701 \\
\hline Cars & 11,017 & 9,328 & 3,486 & 23,831 \\
\hline Trucks & 17,905 & 9,175 & 4,884 & 31,964 \\
\hline Command Cars & 403 & 256 & 160 & 819 \\
\hline Ambulances & 1,018 & 714 & 191 & 1,923 \\
\hline Maultier & 1,230 & 722 & 32 & 1,984 \\
\hline Wheeled Tractors & 211 & 321 & 205 & 737 \\
\hline $\begin{array}{l}\text { Tracked Tractors } \\
\text { RSO }\end{array}$ & $\begin{array}{l}182 \\
2,443\end{array}$ & $\begin{array}{l}233 \\
398\end{array}$ & $\begin{array}{l}93 \\
258\end{array}$ & $\begin{array}{l}508 \\
3,099\end{array}$ \\
\hline Half-Track Motorcycle & 399 & 333 & 77 & 809 \\
\hline Heavy Army Tractors & 5 & - & - & 5 \\
\hline Half-Track Mover & & & & \\
\hline $\begin{array}{l}1 \text { ton } \\
\text { Half-Track Mover }\end{array}$ & 594 & 377 & 108 & 1,079 \\
\hline $\begin{array}{l}3 \text { ton } \\
\text { Half-Track Mover }\end{array}$ & 307 & 165 & 115 & 587 \\
\hline $\begin{array}{l}5 \text { ton } \\
\text { Half-Track Mover }\end{array}$ & 152 & 37 & 10 & 199 \\
\hline $\begin{array}{l}8 \text { ton } \\
\text { Half-Track Mover }\end{array}$ & 284 & 341 & 138 & 763 \\
\hline $\begin{array}{l}12 \text { ton } \\
\text { Half-Track Mover }\end{array}$ & 117 & 51 & 17 & 185 \\
\hline $\begin{array}{l}18 \text { ton } \\
\text { Trailers }\end{array}$ & $\begin{array}{l}38 \\
2,152\end{array}$ & $\begin{array}{l}59 \\
1,064\end{array}$ & $\begin{array}{l}13 \\
676\end{array}$ & $\begin{array}{l}110 \\
3,892\end{array}$ \\
\hline Total Losses: & 48,694 & 31,765 & 13,736 & 94,195 \\
\hline
\end{tabular}




\section{TABLE LXIV}

COMPARISON OF NON-ARMORED VEHICLE LOSSES BETWEEN THE EASTERN FRONT AND

THE ANGLO-AMERICAN FRONTS, JUNE-AUGUST 1944

(continued)

Iype East West S.West Totals

German Non-Armored Losses by Front:

Eastern Front:

$52 \%$

Western Front:

$34 \%$

Southwestern Front:

$14 \%$

*The data has a margin of error due to a lack of reports from several Army units.

Source: OKH, Kraftfahrzeuge (ungepanzert) Heer-Westen, Ob. Suedwest, Osten NAMP T-78 Roll 145. 
TABLE LXV

NON-ARMORED VEHICLE SHIPMENTS

TO THE EASTERN FRONT AND THE

ANGLO-AMERICAN FRONTS,

JUNE-AUGUST 1944

\begin{tabular}{|c|c|c|c|c|}
\hline Type & East & West & S.West & Totals \\
\hline Motorcycles & 7,504 & 1,488 & 3,020 & 12,012 \\
\hline Cars & 11,033 & 3,775 & 4,197 & 19,005 \\
\hline Trucks & 17,248 & 5,479 & 4,428 & 27,155 \\
\hline Command Cars & 361 & 220 & 110 & 691 \\
\hline Ambulances & 1,159 & 417 & 371 & 1,947 \\
\hline Maultier & 1,277 & 123 & 87 & 1,487 \\
\hline Wheeled Tractors & 199 & 77 & 122 & 398 \\
\hline Tracked Tractors & 98 & 27 & 38 & 163 \\
\hline $\begin{array}{l}\text { RSO } \\
\text { Half-Track Motorcucle }\end{array}$ & $\begin{array}{l}1,487 \\
577\end{array}$ & $\begin{array}{l}107 \\
138\end{array}$ & $\begin{array}{l}310 \\
88\end{array}$ & 1,904 \\
\hline Heavy Army Tractors & 95 & - & 00 & 95 \\
\hline Half-Track Mover & & & & \\
\hline $\begin{array}{l}1 \text { ton } \\
\text { Half-Track Mover }\end{array}$ & 342 & 24 & 82 & 448 \\
\hline $\begin{array}{l}3 \text { ton } \\
\text { Half-Track Mover }\end{array}$ & 212 & 17 & 71 & 300 \\
\hline $\begin{array}{l}5 \text { ton } \\
\text { Half-Track Mover }\end{array}$ & 116 & 4 & 1 & 121 \\
\hline $\begin{array}{l}8 \text { ton } \\
\text { Half-Track Mover }\end{array}$ & 455 & 69 & 136 & 660 \\
\hline $\begin{array}{l}12 \text { ton } \\
\text { Half-Track Mover }\end{array}$ & 121 & 6 & 3 & 130 \\
\hline $\begin{array}{l}18 \text { ton } \\
\text { Trailers }\end{array}$ & $\begin{array}{l}168 \\
2,354\end{array}$ & $\begin{array}{l}98 \\
596\end{array}$ & $\begin{array}{l}6 \\
613\end{array}$ & $\begin{array}{l}272 \\
3,563\end{array}$ \\
\hline Total Shipments: & 44,806 & 12,665 & 13,683 & 71,154 \\
\hline
\end{tabular}


TABLE LXV

NON-ARMORED VEHICLE SHIPMENTS

TO THE EASTERN FRONT AND THE ANGLO-AMERICAN FRONTS,

JUNE-AUGUST 1944

(continued)

Type

East

West

S.West

Totals

German Non-Armored Shipments To The Front:

Eastern Front:

$63 \%$

Western Front:

$18 \%$

Southwestern Front:

$19 \%$

Source: OKH, Kraftfahrzeuge (ungepanzert) Heer-Westen, Ob. Suedwest. Osten NAMP T-78 Roll 145. 
TABLE LXVI

LUFTWAFFE FRONTAL AIRCRAFT LOSSES

(TOTAL LOSSES AND DISABLED AIRCRAFT)

ON THE EASTERN FRONT AND THE

ANGLO-AMERICAN FRONTS,

JUNE-OCTOBER 1944

\begin{tabular}{llll}
\hline Aircraft Type & $\begin{array}{c}\text { Anglo-American } \\
\text { Fronts }\end{array}$ & $\begin{array}{l}\text { Eastern } \\
\text { Front }\end{array}$ & Total \\
\hline Close Recon Aircraft & 191 & 341 & 532 \\
Long Range Recon Aircraft & 249 & 133 & 382 \\
Single-Engine Fighters & 6,099 & 1,058 & 7,157 \\
Night Fighters & 1,271 & 73 & 1,344 \\
Twin-Engine Fighters & 313 & 7 & 320 \\
Ground Attack Aircraft & 224 & 1,119 & 1,343 \\
Night Ground & 125 & 191 & 316 \\
Attack Aircraft & 1,548 & 289 & 1,837 \\
Bomber Aircraft & 598 & 159 & 757 \\
Transport Aircraft & 32 & 10 & 42 \\
Sea Planes & & & \\
Liaison, Communications, & 532 & 270 & 802 \\
and other Aircraft & 5,182 & 3,650 & 14,832 \\
\hline Total Aircraft Losses & 11,18 & & \\
\hline
\end{tabular}

Luftwaffe Aircraft Losses by Front:

Anglo-American Fronts: $\quad 75 \%$

Eastern Front: 25\%

Source: Olaf Groehler, "Staerke, Verteilung und Verluste der Deutschen Luftwaffe im Zweiten Weltkrieg," Militaer Geschichte No. 3, 1978, p. 333. 


\section{TABLE LXVII}

GERMAN GENERALS KILED, MISSING OR TAKEN PRISONER

ON THE ANGLO-AMERICAN FRONTS

DURING THE SUMMER OF 1944

\section{WESTERN FRONT GENERALS}

1. Gen. d. Art. Marcks, Commander LXXXIV Army Corps, Killed 6.12.44

2. Lt. Gen. Falley, Commander 91st Jaeger Division, Killed 6.6.44

3. Lt. Gen. Hellmich, Commander of 243rd Jaeger Division, Killed 7.16.44

4. Maj. Gen. Ritter und Edler v. Dawans, Chief Panzer Grenadier Command West, Killed 6.11.44

5. Maj. Gen. Stegmann, Commander 77th Jaeger Division, Killed 6.17.44

6. Lt. Gen. v. Schlieben, Commander of Cherbourg and Commander 709th Jaeger Division, Prisoner June 1944

7. Maj. Gen. Sattler, Deputy Commander of Cherbourg, Prisoner June 1944

8. Lt. Gen. v. Drabich-Waechter, Commander 326th Infantry Division, Killed 8.1.44

9. Lt. Gen. Kraiss, Commander 352nd Infantry Division, Killed 8.3.44

10. Lt. Gen. Spang, Commander 266th Jaeger Division, Prisoner 8.14.1944 


\section{TABLE LXVII}

GERMAN GENERALS KILLED, MISSING OR TAKEN PRISONER

ON THE ANGLO-AMERICAN FRONTS

DURING THE SUMMER OF 1944

(continued)

\section{WESTERN FRONT GENERALS}

11. Gen. d. Inf. Neuling, Commander LXII Reserve Corps, Prisoner 8.20.44

12. Lt. Gen. Menny, Commander 84th Infantry Division, Missing in Action 8.20.44

13. Gen. d. Inf. von Choltitz, Commanding General of Greater Paris, Prisoner 8.29.44

14. Lt. Gen. Klfeldt, Commander LXẌXIV Army Corps,

Prisoner 8.29.44

15. Lt. Gen. Schaefer, Commander 244th Infantry Division, Prisoner 8.31.44

16. Maj. Gen. Richter, Commander 198th Infantry Division, Prisoner 8.31.44

17. Maj. Gen. Schramm, Commandant F.K. 533, Missing in Action 9.5.44

18. Gen. d. Inf. Vierow, Commander of District Northwest France, Prisoner 9.3.44

19. Gen. d. Pz. Tr. Eberbach, Commander 5th Panzer Army, Prisoner 9.3 .44

20. Lt. Gen. Badinski, Commander 276th Infantry Division, Missing in Action 8.21.44 


\section{TABLE LXVII}

GERMAN GENERALS KILLED, MISSING OR TAKEN PRISONER

ON THE ANGLO-AMERICAN FRONTS

DURING THE SUMMER OF 1944

(continued)

\section{WESTERN FRONT GENERALS}

21. Maj. Gen. Suschnig, Commandant to the Military Command in France, Missing in Action August 1944

22. Maj. Gen. Schuberth, Commandant F.K. 792, Missing in Action August 1944

23. Maj. Gen. Bieringer, Commandant F.K. 800, Missing in Action 8.18.44

24. Lt. Gen. Seyffardt, Commander 348th Infantry Division, Prisoner 9.9.44

25. Maj. Gen. von Felbert, Commandant F.K. 560, Prisoner 9.10.44

26. Lt. Gen. Heinrichs, Commander 89th Infantry Division, Killed 9.10.44

Total Generals Killed:

Total Generals Missing:

Total Generals Captured:

Total Generals Lost To Enemy Action: 26

Source: Organisation der Wehrmacht, OKW/Org. Abt. und Heerespersonalabt.; Zusammenstellung der in diesem Kriege gefallenen, toetlich verunglueckten, verstorbenen. vermissten und im Gefangenschaft geratenen Generale, Flensburg 5 June 1945 NAMP T-77 Roll 785. 


\section{TABLE LXVIII}

GERMAN GENERALS KILLED, MISSING OR TAKEN PRISONER

ON THE EASTERN FRONT DURING THE SUMMER OF 1944

\section{EASTERN FRONT GENERALS}

1. Lt. Gen. Richter, Former Commander, 263rd Infantry Division, Killed 6.3.44

2. Gen. d. Art. Martinek, Commander XXXIX Panzer Corps, Killed 6.28.44

3. Gen. d. Art. Pfeiffer, Commander VI Army Corps, Killed 7.1.44

4. Lt. Gen. Philip, Commander 134th Infantry Division, Killed 6.27.44

5. Lt. Gen. Schuenemann, Commander 337th Infantry Division Killed 6.27.44

6. Maj. Gen. Hamann, Commandant of Bobruisk, Prisoner 6.30.44

7. Gen. d. Inf. Gollwitzer, Commander LIII Army Corps, Prisoner

8. Lt. Gen. Bamler, Commander 12th Infantry Division, Prisoner

9. Lt. Gen. Hitter, Commander 206th Infantry Division, Prisoner

10. Maj. Gen. v. Erdmannsdorff, Commandant Mogilev, Prisoner

11. Maj. Gen. Mueller-Buelow, Commander 246th Infantry Division, Prisoner 


\section{TABLE LXVIII}

GERMAN GENERALS KILLED, MISSING OR TAKEN PRISONER ON THE EASTERN FRONT DURING THE SUMMER OF 1944 (continued)

\section{EASTERN FRONT GENERALS}

12. Lt. Gen. Mueller (Vincenz), Commander XII Army Corps, Prisoner

13. Maj. Gen. Klammt, Commander 260th Infantry Division, Prisoner

14. Maj. Gen. Schmidt (Aurel), Commander Army Engineers, Prisoner

15. Maj. Gen. Trowitz, Commander 57th Infantry Division, Prisoner

16. Lt. Gen. Traut, Commander 78th Sturm Division, Prisoner

17. Lt. Gen. Hoffmeister, Commander 383rd Infantry Division, Prisoner

18. Maj. Gen. v. Steinkeller, Commander Panzer Grenadier Division "Feldherrnhalle," Prisoner

19. Maj. Gen. Gihr, Commander 707th Infantry Division, Prisoner

20. Maj. Gen. Conrady, Commander 36th Infantry Division, Prisoner

21. Lt. Gen. v. Luetzow, Commander XXXV Army Corps, Prisoner 
TABLE LXVIII

GERMAN GENERALS KILLED, MISSING OR TAKEN PRISONER

ON THE EASTERN FRONT DURING THE SUMMER OF 1944

(continued)

\section{EASTERN FRONT GENERALS}

22. Lt. Gen. Heyne, Commander 6th Infantry Division, Prisoner

23. Maj. Gen. Michaelis, Commander 95th Infantry Division, Prisoner

24. Gen. d. Inf. Voelckers, Commander XXVII Army Corps, Prisoner

25. Lt. Gen. Peschel, Commander 6th Luftwaffe Field Division, Missing in Action

26. Lt. Gen. Pistorius, Commander 4th Luftwaffe Field Division, Killed 6.28.44

27. Maj. Gen. Hahne, Commander 197th Infantry Division, Missing in Action

28. Lt. Gen. Drescher, Commander 267th Infantry Division, Killed 8.13.44

29. Maj. Gen. Engel, Commander 45th Infantry Division, Prisoner

30. Lt. Gen. Franek, Commander 73rd Infantry Division, Missing in Action 6.29.44

31. Gen. d. Inf. Hauffe, Commander XIII Army Corps, Killed July 1944 


\section{TABLE LXVIII}

GERMAN GENERALS KILLED, MISSING OR TAKEN PRISONER ON THE EASTERN FRONT DURING THE SUMMER OF 1944 (continued)

\section{EASTERN FRONT GENERALS}

32. Lt. Gen. v. Kurowski, Commander 110th Infantry Division, Prisoner July 1944

33. Lt. Gen. Moser, Commandant Lublin, Prisoner July 1944

34. Lt. Gen. Ochsner, Commander 31st Infantry Division, Prisoner July 1944

35. Lt. Gen. Wuestenhagen, Commander 256th Infantry Division, Missing in Action July 1944

36. Lt. Gen. Zutavern, Commander 18th Panzer Grenadier Division, Killed July 1944

37. Maj. Gen. Beutler, Commander 340th Infantry Division, Killed July 1944

38. Maj. Gen. Lindemann, Commander 361st Infantry Division, Prisoner July 1944

39. Maj. Gen. Nedtwig, Commander 454th Security Division, Prisoner July 1944

40. Maj. Gen. Franking, Commander 282nd Infantry Division, Prisoner 8.29.44

41. Maj. Gen. Tronnier, Commander Corps Detachment F, Prisoner 8.28.44 


\section{TABLE LXVIII}

GERMAN GENERALS KILLED, MISSING OR TAKEN PRISONER ON THE EASTERN FRONT DURING THE SUMMER OF 1944 (continued)

\section{EASTERN FRONT GENERALS}

42. Lt. Gen. von Bogen, Commander 302nd Infantry Division, Prisoner 8.28.44

43. Lt. Gen. Postel, Commander XXX Army Corps, Prisoner 8.28.44

44. Maj. Gen. Eichstedt, Commander 294th Infantry Division, Killed 8.28.44

45. Lt. Gen. Drubbe de Salengre, Commander 384th Infantry Division, Killed 8.28.44

46. Maj. Gen. Gebb, Commander 9th Infantry Division, Prisoner 8.29.44

47. Gen. d. Inf. Leux, Commander 16th Army, Died from Wounds 9.2.44

48. Gen. d. Inf. Mieth, Commander IV Army Corps, Killed 9.2.44

49. Maj. Gen. Boie, Commandant F.K. 497, Prisoner 8.29.44

50. Gen. d. Art. Hell, Commander VII Army Corps, Killed 9.1.44

51. Lt. Gen. Weinknecht, Commander 79th Infantry Division, Prisoner 9.1.44 


\section{TABLE LXVIII}

GERMAN GENERALS KILLED, MISSING OR TAKEN PRISONER

ON THE EASTERN FRONT DURING THE SUMMER OF 1944

(continued)

\section{EASTERN FRONT GENERALS}

52. Maj. Gen. Stingl, Commandant Jassy,

Prisoner 8.30.44

53. Lt. Gen. Burckhardt, Commander Rear Army territory 593, Missing in Action 9.11.44

54. Gen. d. Inf. Mueller, Commander XXXXIV Army Corps, Missing in Action 9.4.44

55. Gen. d. Inf Buschenhagen, Commander LIl Army Corps, Prisoner 9.4.44

56. Maj. Gen. von Dewitz, Commandant Kischinew Prisoner 9.4.44

57. Maj. Gen. Seelig, Commandant Galatz, Missing in Action 9.4.44

58. Lt. Gen. Troeger, Commander 13th Panzer Division, Prisoner 9.4.44

59. Maj. Gen. Bluemke, Commander 257th Infantry Division, Killed 9.4.44

60. Lt. Gen. von Hulsen, Commander 370th Infantry Division, Prisoner 9.4.44

61. Lt. Gen Bayer, Commander 153rd Field Training Division, Prisoner 9.4.44 
TABLE LXVIII

GERMAN GENERALS KILLED, MISSING OR TAKEN PRISONER ON THE EASTERN FRONT DURING THE SUMMER OF 1944 (continued)

\section{EASTERN FRONT GENERALS}

62. Lt. Gen. Schwarz, Commander 376th Infantry Division, Prisoner 9.4 .44

63. Gen. d. Kav. Hansen, Chief of the German Army Mission in Rumania, Prisoner, End of August 1944

64. Maj. Gen. Spalcke, Military Attache to the German Embassy in Bucharest, Prisoner, End of August 1944

Total Generals Killed:

Total Generals Missing:

Total Generals Captured:

Total Generals Lost To Enemy Action:
16

7

41

Source: Organisation der Wehrmacht, OKW/Org. Abt. und Heerespersonalabt.; Zusammenstellung der in diesem Kriege gefallenen, toetlich verunglueckten, verstorbenen, vermissten und im Gefangenschaft geratenen Generale, Flensburg 5 June 1945 NAMP T-77 Roll 785. 
TABLE LXIX

\section{GERMAN DIVISIONS DESTROYED ON \\ THE ANGLO-AMERICAN FRONTS \\ DURING THE SUMMER OF 1944}

\begin{tabular}{ll}
\hline German Divisions Destroved & Reorganized or Disbanded \\
\hline Panzer Lehr Division & Reorganized \\
5th Parachute Division & Reorganized \\
16th Luftwaffe Field Division & Reorganized \\
17th Luftwaffe Field Division & Disbanded \\
17th SS Panzer Grenadier Division & \\
"Goetz von Berlichingen" & Reorganized \\
18th Luftwaffe Field Division & Reorganized \\
47th Infantry Division & Reorganized \\
64th Infantry Division & Disbanded \\
70th Infantry Division & Disbanded \\
77th Infantry Division & Disbanded \\
85th Infantry Division & Reorganized \\
91st Air Landing Division & Disbanded \\
92nd Infantry Division & Disbanded \\
242nd Infantry Division & Disbanded \\
243rd Infantry Division & Disbanded \\
244th Infantry Division & Disbanded \\
266th Infantry Division & Disbanded \\
271st Infantry Division & Reorganized \\
272nd Infantry Division & Reorganized \\
275th Infantry Division & Reorganized \\
276th Infantry Division & Reorganized \\
277th Infantry Division & Reorganized \\
326th Infantry Division & Reorganized \\
331st Infantry Division & Disbanded \\
343rd Infantry Division & Disbanded \\
344th Infantry Division & Reorganized \\
348th Infantry Division & Disbanded \\
352nd Infantry Division & Reorganized \\
362nd Infantry Division & Reorganized \\
363rd Infantry Division & Reorganized \\
462nd Infantry Division & Disbanded \\
& \\
\hline & \\
&
\end{tabular}


TABLE LXIX

GERMAN DIVISIONS DESTROYED ON

THE ANGLO-AMERICAN FRONTS

DURING THE SUMMER OF 1944

(continued)

German Divisions Destroyed

708th Infantry Division

709th Infantry Division
Reorganized or Disbanded Reorganized

Disbanded

Total Divisions Destroyed:

32 Divisions

Source: Generalstab des Heeres, Organisationabteilung, Uebersicht ueber aufgeloeste Division 1944 NAMP T-78 Roll 410; Abwicklungs und Betreuungstab/Rudolstadt/Prinz Eugen Kaserne, Uebersicht der abzuwickelnden Verbaende Stand per 15.l.1945 NAMP T-78 Roll 141; Mehner, GHTBDW Vol 10, pp. 499-508; Mehner, GHTBDW Vol. 11, pp. 337-339; Samuel W. Mitcham, Jr., Hitler's Legions: The German Army Order of Battle. World War II (New York: Stein and Day Publishers, 1985), pp. 75-459. 
TABLE LXX

\section{GERMAN DIVISIONS DESTROYED ON \\ THE EASTERN FRONT \\ DURING THE SUMMER OF 1944}

\begin{tabular}{ll}
\hline German Divisions Destroyed & Reorganized or Disbanded \\
\hline Corps Detachment C & Disbanded \\
Corps Detachment E & Disbanded \\
4th Luftwaffe Field Division & Disbanded \\
6th Luftwaffe Field Division & Disbanded \\
6th Infantry Division & Reorganized \\
9th Infantry Division & Reorganized \\
12th Infantry Division & Reorganized \\
13th Panzer Division & Reorganized \\
14th SS Division "Galizien" & Reorganized \\
15th Infantry Division & Reorganized \\
18th Panzer Grenadier Division & Reorganized \\
20th Panzer Division & Reorganized \\
25th Panzer Grenadier Division & Reorganized \\
31st Infantry Division & Reorganized \\
36th Infantry Division & Reorganized \\
45th Infantry Division & Reorganized \\
57th Infantry Division & Disbanded \\
60th Panzer Grenadier Division & \\
"Feldherrnhalle" & Reorganized \\
62nd Infantry Division & Reorganized \\
78th "Sturm" Division & Reorganized \\
79th Infantry Division & Reorganized \\
95th Infantry Division & Reorganized \\
106th Infantry Division & Reorganized \\
110th Infantry Division & Disbanded \\
134th Infantry Division & Disbanded \\
153rd Field Training Division & Reorganized \\
161st Infantry Division & Disbanded \\
197th Infantry Division & Disbanded \\
206th Infantry Division & Disbanded \\
246th Infantry Division & Reorganized \\
256th Infantry Division & Reorganized \\
& \\
&
\end{tabular}


TABLE LXX

GERMAN DIVISIONS DESTROYED ON

THE EASTERN FRONT

DURING THE SUMMER OF 1944

(continued)

\begin{tabular}{ll}
\hline German Divisions Destroyed & Reorganized or Disbanded \\
\hline 257th Infantry Division & Reorganized \\
258th Infantry Division & Disbanded \\
260th Infantry Division & Disbanded \\
267th Infantry Division & Disbanded \\
282nd Infantry Division & Disbanded \\
294th Infantry Division & Disbanded \\
296th Infantry Division & Reorganized \\
299th Infantry Division & Reorganized \\
302nd Infantry Division & Disbanded \\
306th Infantry Division & Disbanded \\
320th Infantry Division & Reorganized \\
335th Infantry Division & Disbanded \\
337th Infantry Division & Reorganized \\
340th Infantry Division & Reorganized \\
361st Infantry Division & Reorganized \\
370th Infantry Division & Disbanded \\
376th Infantry Division & Disbanded \\
383rd Infantry Division & Disbanded \\
384th Infantry Division & Disbanded \\
454th Security Division & Disbanded \\
707th Infantry Division & Disbanded \\
\end{tabular}




\section{TABLE LXX}

GERMAN DIVISIONS DESTROYED ON

THE EASTERN FRONT

DURING THE SUMMER OF 1944

(continued)

German Divisions Destroyed

Reorganized or Disbanded

Total Divisions Destroyed: 52 Divisions

Source: Generalstab des Heeres, Organisationabteilung, Uebersicht ueber aufgeloeste Division 1944 NAMP T-78 Roll 410; Hauptmann Rabe, Kriegstagebuch des Oberkommandos der Heeresgruppe Suedukraine 20.8. - 5.9.1944 Band 4 Teil 1, NAMP T-311 Roll 158, pp. 150-151; Generaloberst Hans Friessner, Verratene Schlachten (Hamburg: HolstenVerlag, 1956), pp. 255-258; Abwicklungs und Betreuungstab/Rudolstadt/Prinz Eugen Kaserne, Uebersicht der abzuwickelnden Verbaende Stand per 15.I.1945 NAMP T-78 Roll 141; Mitcham, Jr., Hitler's Legions: The German Army Order of Battle World War II, pp. 45-475; Mehner, GHTBDW Vol. 10, pp. 502-508; Mehner, GHTBDW Vol. 11, pp. 337-342; Carell, pp. 508-509; Kriegstagebuch (KTB) Heeresgruppe Mitte, Fuehrungsabteilung, Kriegsgliederungen NAMP T-311 Roll 228; Hinze, Das Ostfront Drama 1944: Rueckzugskaempfe Heeresgruppe Mitte, p. 426; Teske, p. 216; Generalstab des Heeres, Organisationabteilung, Uebersicht ueber die grossen Verbaende des Heeres, der Waffen-SS und der FallschirmTruppen, Stand 30.7.44 NAMP T-78 Roll 413; Burkhart Mueller-Hillebrand, Das Heer 1933-1945 Vol. 3, p. 241; $\mathrm{OKH}$ Allgemeines Heeresamt, Abwicklungsstab, $\mathrm{H}$ 41/7-H 41/12 NAMP T-78 Roll 139. 


\section{NOTES TO CHAPTER XII}

1Organisation der Wehrmacht, OKW/Org.Abt. und Heerespersonalabt., Zusammenstellung der in diesem Kriege gefallenen, toetlich verunglueckten. verstorbenen, vermissten und in Gefangenschaft geratenen Generale Flensburg 5 June 1945 NAMP T-77 Roll 785.

2Ibid. 


\section{CHAPTER XIII}

\section{CONCLUSION}

The failure of Foreign Armies East to forecast the beginning of the Soviet main offensive against Army Group Center set the stage for the subsequent collapse of the German Army on the Eastern Front during the summer of 1944 . The Wehrmacht in the East needed accurate intelligence about the direction of Soviet offensive operations for the summer of 1944. Foreign Armies East in April 1944 forcast two possible offensives. One possible offensive was directed toward Rumania and into the Balkans. The other offensive was predicted in the line Kovel-Warsaw. German intelligence leaned toward the Balkan scenario until May 10, 1944 when serious offensive preparations were noted in the KovelTernopol area. Foreign Armies East in June 1944 predicted that attacks against Army Group Center were viewed as preliminary and secondary to the main attacks against Army Group North Ukraine. This failure to identify the main axis of Soviet offensive operations was disastrous for the Wehrmacht in the East.

The deployment of the armored and mobile reserves in the East was primarily in Army Group North Ukraine and South Ukraine leaving Army Group Center stripped of armored and mobile 
reserves. The armored "Fire Brigades" were not deployed where they were needed for the summer of 1944 and the failure of German intelligence was directly responsible for this situation. The failure to deploy the armor and mobile reserves behind Army Group Center resulted in the collapse of the Army Group and the destruction of 28 German divisions which unhinged the entire Eastern Front.

Foreign Armies East was also responsible for the German intelligence failure in Rumania which as late as August 15, 1944 noted that a major offensive against Army Group South Ukraine was unlikely. The assessment by Foreign Armies East on August 17, 1944 indicated that only local attacks were to be expected on the Rumanian front. German intelligence also failed to accurately assess Rumanian reliability and the combination of both intelligence failures resulted in a catastrophe for Army Group South Ukraine and the destruction of the German 6th Army and 18 German divisions. Therefore, the intelligence failures of Foreign Armies East were a central cause of the collapse of the German Army in the East during the summer of 1944. Accurate intelligence could have played a key role in preventing disasters on the scale of the collapse of Army Group Center and Army Group South Ukraine. Hitler's defensive doctrine of "standing fast" prevented local commanders from exercising initiative to prevent Soviet breakthroughs and executing withdrawals to save German units. Hitler's interference with local commander's decisions also prevented the implementation of an elastic defense which would 
have absorbed the Soviet offensive much better than holding onto a rigid defensive line. However, Hitler was obsessed with the notion of "will" and the defensive recovery made by the Wehrmacht during the winter of 1941-42 by adhering to his "standfast" doctrine. Hitler clung to the belief of "standing fast" after the usefulness of this idea was negated by Soviet advances in mobility. The Red Army achieved a significant increase in motorization and mechanization since the winter of 1941 and this greater mobility rendered Hitler's "standfast" strategy obsolete. Fortresses served little purpose given the increased mobility and firepower of the Red Army. The medieval notion of establishing fortresses was an anachronistic idea that continued to appeal to Hitler. His establishment of cities as fortresses on the Eastern Front created further restrictions on local commanders in defending territory against Soviet advances. Precious reserves were as a result tied down holding stationary positions. Thus, Hitler was directly responsible for a defensive doctrine which may have been effective in 1941 but it was no longer an effective strategy in 1944. The opportunity to conduct an elastic defense based on rivers was available to Army Group Center and Army Group South Ukraine. Field Marshal Busch proposed two alternatives for conducting an elastic defense in Belorussia. The first proposal was adjusting defensive lines rearward behind the Dnieper river. The second proposal was for a more extensive withdrawal behind the Berezina river. A combination of both plans based on timely withdrawals could have absorbed the shock of the Soviet summer offensive more 
effectively. However, Hitler forbid any plan establishing an elastic defense and instead promulgated "Fuehrerbefehl Nr. 11" which established fortresses at Bobruisk, Mogilev, Vitebsk and Minsk which had to be defended with no options for withdrawal.

The situation on Army Group South Ukraine's Front offered the possibility of conducting an elastic defense. The defensive front was overextended running from the Carpathians to the Black Sea. Colonel General Friessner upon assuming command of Army Group South Ukraine was not satisfied with the Rumanian political situation and wanted authorization to withdraw the front behind the Pruth river and into the Carpathian moutains. This withdrawal would have permitted a more flexible and stronger defense against Soviet offensive operations. Hitler, however, was not convinced and did not authorize a withdrawal to the more defensible terrain. Therefore, Hitler was directly responsible for the Wehrmacht's failure to conduct an elastic defense in the East and this resulted in withdrawals which were too late resulting in the needless encirclement and destruction of German divisions.

The loss of air superiority by the Luftwaffe on the Eastern Front was the direct result of fighting a two front war. The Luftwaffe's forces were fragmented by having to fight in several theaters of operation. The Italian/Balkan Front, Western Front and air defense of the Reich consumed the majority of the Luftwaffe's aircraft. The Luftwaffe maintained only $44 \%$ of its aircraft on the Eastern Front compared to $56 \%$ on the Anglo-American Fronts in June 1944. The Luftwaffe suffered $75.4 \%$ of its losses on the 
Anglo-American Fronts and $24.6 \%$ on the Eastern Front between June and October 1944. The Anglo-American air campaign significantly altered the balance of power in the air making it impossible for the Luftwaffe to deploy greater numbers of aircraft in the East. This lack of aircraft in the East did not allow the Germans to engage in strategic warfare by bombing the sources of aircraft and armor production which would have significantly affected the strength of the Red Army and Soviet Air Force. Thus, the Soviet Air Force managed to develop numerical superiority being opposed by less than half the German Air Force.

Consequently, the Soviet Air Force had achieved a superiority of at least 6:1 in operational aircraft over the Luftwaffe by the summer of 1944. Soviet air power played an increasing role in assisting the Red Army to achieve its objectives on the ground. Therefore, the loss of air superiority by the Luftwaffe in the East and the simultaneous rise of Soviet numerical air superiority created an untenable situation for the German Army on the defensive in the summer of 1944. The Luftwaffe had formerly served as a "fire brigade" for the Wehrmacht when it was in trouble and now it was no longer capable of meeting the numerous Soviet breakthroughs in the East during the summer of 1944 .

Lend-Lease aid to the Soviet Union provided significant supplies which enabled the Red Army to launch offensives with far greater endurance and mobility to exploit the initial breakthroughs. The first component of the Red Army was the infantryman and he was better prepared to fight as a result of Lend-Lease aid. The 
U.S.S.R. had received 6 million pairs of boots by 1944 and over the course of the war Lend-Lease aid provided at least one pound of concentrated rations for 6 million soldiers each day for the length of the war. The combination of food and clothing undoubtedly increased the fighting potential of the Red Army. In fact, LendLease food aid prevented a civilian caloric drop by an estimated one-third. Lend-Lease food supplies, therefore, helped maintain the physical strength of the U.S.S.R.'s industrial workers that produced the armaments.

The highly successful, widely separated and far-reaching breakthroughs achieved by the Red Army during the summer of 1944 can be directly linked to the high degree of motorization and mechanization achieved by the Red Army by the summer of 1944 . Lend-Lease aid played a crucial role in the Red Army achieving a superior mobility compared to the Wehrmacht in the East. The Red Army received approximately 430,000 vehicles by 1944 in LendLease aid. The vast number of trucks provided motorization for the Red Army on an unprecedented scale. The Soviet infantry could finally follow the Soviet armor in exploitation of the initial penetration and then into the extension of the breakthrough. The four and six wheeled trucks permitted supplies to be carried overland and therefore Soviet supply trains were not tied to the roads and rail lines when conducting offensives. The vast number of trucks gave the Red Army superior mobility compared to the Wehrmacht. Lend-Lease supplies also permitted the Soviets to concentrate their production on armor and aircraft which 
facilitated their armaments production. Therefore, the Soviets were able to produce approximately 112,952 tanks and assault guns compared to the 46,742 vehicles produced by Germany. Thus, LendLease aid facilitated the long range Soviet offensives conducted during the summer of 1944 and thereby played a critical role in the collapse of the German Army on the Eastern Front.

The lack of German mobile reserves in the East during the summer of 1944 was a direct result of the Anglo-American second front. The German Army stationed $51 \%$ of its mobile formations in the West to counter Anglo-American offensive operations. The German mobile formations consisted of their most elite units and the fact that half of these formations were tied down in the West was of significant assistance to the Red Army during the summer of 1944. Additionally, the West tied down $42 \%$ of German nonmobile divisions consisting primarily of infantry divisions. The total military deployment in the West amounted to 128 divisions. If the Anglo-American second front had not been a reality the number of divisions available to reinforce the East would have been substantially greater and the scope of Soviet breakthroughs would have been reduced.

The defense of Belorussia by Army Group Center during the winter of 1943-44 was successful as the result of the use of a combination of tactics. Army Group Center employed concentrated artillery fire and the shifting of reserves along roads and rail lines. Mobile reserves consisting of armor units, assault gun battalions and motorized antitank units were shifted to the threatened 
sectors of the front to block any imminent Soviet breakthrough. This German strategy worked during the winter battles, but the Soviet High Command changed their tactics for the summer offensive.

The Soviets recognized a need to achieve a greater level of numerical superiority, more coordination of artillery in the breakthrough zones and the need to establish several breakthrough areas simultaneously to tie down German reserves preventing effective German counterattacks. The Soviet plan for the summer offensive incorporated all these changes. The number of divisions in the breakthrough areas was increased from 77 to 97 divisions. The number of aircraft and artillery was substantially increased. Ammunition supplies were increased to permit the Soviets to fire massive artillery barrages for days without stop while the Germans had to conserve their more limited supply of artillery ammunition and could not effectively engage in counter battery fire. Six breakthrough sectors were planned which effectively dismembered the German defensive front. The depth of the operation was also extended further to the west which was effective in disrupting German supplies, artillery support and the movement of reserves. This combination of Soviet tactics proved highly successful in destroying Army Group Center. Army Group South Ukraine and the XIII Army Corps in Army Group North Ukraine were destroyed by a similiar combination of tactics.

The German Army at the operational and tactical level in Army Group Center made errors which facilitated the Soviet plan to 
destroy the Army Group. Field Marshal Busch failed to seize the initiative and withdraw his divisions once the situation had become hopeless and encirclement was inevitable. Busch also failed to prepare the Berezina river as a secondary defense line. Field Marshal Busch would have had to exercise command in such a way as to circumvent Hitler's orders to have preserved his Army Group and the necessary actions would have been necessary prior to the beginning of the Soviet offensive on June 22, 1944.

Field Marshal Busch failed to plan for the potential retreat of his Army Group and build sufficient bridges across the Berezina river to facilitate a rapid withdrawal. More ferrys were also necessary but not acquired to facilitate a rapid retreat across the river. Field Marshal Busch failed to act in the best interest of his troops and instead followed Hitler's orders without regard to the preservation of his Army Group. Busch would even support Hitler's demands to leave entire divisions in compliance with "Fuehrerbefehl Nr. 11" surrounded without attempting to circumvent his orders.

The German High Command made errors by hesitating to move reserves in time and in sufficient numbers to reinforce Army Group Center before it was too late to prevent a disaster. Furthermore, the High Command failed to provide the infantry in Army Group Center with sufficient quantities of anti-tank weapons such as the Panzerfaust and Panzerschreck. The troops instead were burdened with cumbersome anti-tank mines which were ineffective compared to the Panzerfaust and Panzerschreck. Therefore, the 
combination of Soviet strengths and German weakness and errors resulted in the destruction of 28 German divisions and the loss of 31 generals in Army Group Center. These losses were replaced by the transfer of 29 divisions and 7 brigades to Army Group Center to fill in the huge hole in the Eastern Front. Consequently, this transfer of divisions weakened the other Army Groups on the Eastern Front and set the stage for the successive defeat and retreat of the remaining Army Groups.

Army Group North Ukraine was weakened with the collapse of Army Group Center by having to transfer significant mobile reserves to Army Group Center consisting of the following divisions: 3rd Panzer Division, 23rd Panzer Division and 24th Panzer Division. This transfer of divisions occurred prior to the Soviet offensive against Army Group North Ukraine on July 13, 1944. Therefore, when the 1st Ukrainian Front attacked Army Group North Ukraine and broke through in the three planned sectors there were insufficient mobile reserves to stop the main Soviet breakthroughs. The primary Soviet advances breaking through on the flanks of the XIII Army Corps were successful and the Corps was encircled and essentially destroyed. The Germans lost 5 divisions at the Battle of Brody and the losses of Army Group North Ukraine were replaced mostly by transfers of divisions from Army Group South Ukraine which weakened this Army Group for the next round of Soviet offensive operations.

Army Group South Ukraine had served as a reserve pool for Army Group Center and North Ukraine during the summer of 1944. A 
total of 11 divisions or nearly one-third of the entire Army Group's strength had been transferred since June 1944. Consequently, this Army Group was also depleted of mobile reserves. Army Group South Ukraine's front extended from the Carpathians to the Black Sea which meant that it was overextended and lacked sufficient reserves to block Soviet breakthroughs in strength and depth. The average divisional sector was 17 kilometers, but the lack of mobile reserves made it impossible to contain any large scale breakthroughs once this divisional sector had been penetrated.

Colonel General Friessner had wanted to conduct a defense from behind the Pruth river and at the edge of the Carpathian moutains which would have been much more defensible and permitted a more elastic defense but Hitler and the High Command would not allow this operational withdrawal until it was too late.

Colonel General Guderian, Chief of OKH failed to place a Panzer Division in Bucharest to back up Marshal Antonescu's regime despite requests from the German Foreign Minister in Berlin. This proved critical because the Antonescu regime was to collapse on August 23, 1944, and within two days Rumania was to change sides in the war and declare war on Germany. The placing of Rumanian divisions on the flanks of German divisions was risky and once the Rumanians began dropping out of the war the flanks of German formations were wide open. Soviet motorized units drove deep into the German rear area. The German 6th Army reconstituted after Stalingrad now suffered the same fate a second time. The Rumanian units on the flanks of the German 6th Army melted away 
and the Soviets encircled the 6th Army and compressed it until most of the 6th Army had been destroyed or capitulated. Army Group South Ukraine reported the loss of 18 divisions and 5 Army Corps Headquarters from the 6th Army. There were also three other divisions that were mostly destroyed in the collapse of Army Group South Ukraine. Essentially, 21 German divisions were destroyed in the Rumanian debacle.

Finally, the significance of the collapse of the German Army in the East during the summer of 1944 can be determined by comparison of losses between the East and the Anglo-American Fronts. The number of German troops killed, wounded or missing on the Eastern Front from June-August 1944 was 908,806 compared to 356,591 on the Anglo-American Fronts. Therefore, the Eastern Front accounted for $72 \%$ and the Anglo-American Fronts $28 \%$ of total German troop losses. German armored losses in the East during the summer of 1944 were 4,631 vehicles which amounted to $68 \%$ compared to 2,198 or $32 \%$ on the Anglo-American fronts. Nonarmored vehicle losses in the East were 48,694 or $52 \%$ compared to 45,504 or $48 \%$ in the West. German armored shipments to the East consisted of $75 \%$ of all armored reinforcements while only $25 \%$ were sent to the Anglo-American Fronts. Non-armored vehicle shipments by contrast were almost equally split between the East and West with $52 \%$ to the East and $48 \%$ to the West. Therefore, the bulk of armored and non-armored vehicles were sent to the East to reinforce the crumbling front. A total of 64 German generals were lost in the East compared to 26 generals in the West during the 
summer of 1944. German divisional losses in the East amounted to 52 divisions or $62 \%$ compared to 32 divisions or $38 \%$ in the West during the summer of 1944 . The Germans only suffered greater losses in the West from the Anglo-American air campaign. The Luftwaffe lost $75 \%$ of its aircraft in the West compared to $25 \%$ in the East.

Therefore, the collapse of the German Army in the East was the most decisive military event during the Summer of 1944 based upon the military losses suffered by the German Army and was the result of the following factors: German Intelligence failures; German defensive doctrine; loss of German air superiority; LendLease aid to the Soviet Union; German mobile reserves committed in the West; Soviet numerical superiority; and Soviet offensive doctrine and tactics. The lack of attention given to the Soviet contribution to the defeat of Nazi Germany during the Summer of 1944 in the history textbooks in the West has been an act of omission which has lead to a lack of understanding by people in the West of the significant contributions made by the Soviet Union during the period of the Allied invasion of France. However, Soviet historiography, likewise, has neglected an examination of the Anglo-American contributions which directly facilitated its defeat of the German Army in the East during the Summer of 1944. The end of the Cold War will hopefully produce an environment where more objective and balanced history can be written in the West and East about the contributions of both the Soviet and Anglo-American Allies in the defeat of Nazi Germany. 


\section{REFERENCES}

\section{Unpublished Documents}

Combined Chiefs of Staff. "Red Army Action to Facilitate

Overlord," 3 April 1944, (Reel 2:0021). Records of the Joint

Chiefs of Staff Part I: 1942-1945, The Soviet Union.

Frederick, M.D.: University Publications of America, Inc., 1981.

Deane, General John. "Red Army Offensive Action to Facilitate Overlord," (Reel 2:0012), Records of the Joint Chiefs of Staff Part 1: 1942-1945. The Soviet Union. Frederick, M.D.: University Publications of America, Inc., 1981.

Joint Chiefs of Staff, Postwar Economic Policies and Capabilities of the U.S.S.R.. November 1, 1945. Frederick, M.D.: University Publications of America, 1977.

Joint Intelligence Committee Memorandum for Information, Number 74. "Developments on the Eastern Front and their Implications for Overlord," 25 May 1944. (Reel 10:0719). Records of the Joint Chiefs of Staff Part I: 1942-1945. The European Theater. Frederick, M.D.: University Publications of America, Inc., 1981.

O.S.S.. "Relative Capabilities on the Eastern Front, May 1, 1944" O.S.S./State Department Intelligence and Research Reports, part VI: The Soviet Union, 1941-1949. Frederick, M.D.: University Publications of America, 1977. 
U.S. Department of State, Protocol and Area Information Staff of the U.S.S.R. Branch of the Division of Research and Reports. "Report on War Aid Furnished by the United States to the U.S.S.R." Foreign Economic Section, Office of Foreign Liquidation. Department of State. November 28, 1945.

U.S. National Archives, Records of Headquarters, German Armed Forces High Command (Oberkommando der Wehrmacht/OKW). Microcopy No. T-77 Rolls: 785, 826, 856.

---.--Records of Headquarters, German Army High Command (Oberkommando des Heeres/OKH). Microcopy No. T-78 Rolls: $113,136,139,140,141,145,366,410,411,413,421,432$, $466,494,497,579,581,582,587,588$.

-----Records of German Field Commands: Army Groups. Microcopy No. T-311 Rolls: 158, 217, 219, 225, 228, 229, 230, 234, 266, 298, 299.

-----Records of German Field Commands: Armies. Microcopy No. T-312 Rolls: 244, 252, 339, 1318, 1325, 1365, 1366, 1470.

-Records of German Field Commands: Panzer Armies.

Microcopy No. T-313 Rolls: 73, 74, 291, 309, 316, 317, 318, $409,410,413,415$.

-..---Records of Headquarters of the German Air Force High Command (Oberkommando der Luftwaffe/OKL). Microcopy No. T-321 Roll: 9.

\section{Published Documents}

Commission For The Publication Of Diplomatic Documents Under the Ministry Of Foreign Affairs Of The U.S.S.R.. Correspondance Between The Chairman of The U.S.S.R. And The Presidents of The U.S.A. And The Prime Ministers Of Great Britain During The Great Patriotic War Of 1941-1945. Vols. 1-2. Moscow: Foreign Languages Publishing House, 1957. 
Deichmann, General der Flieger a. D.. German Air Force Operations in Support of the Army. USAF Historical Studies: No. 163. New York: Arno Press, 1968.

Department of the Army, German Defense Tactics Against Russian Breakthroughs. Washington D.C.: Department of the Army, October 1951.

-.----Rear Area Security In Russia: The Soviet Second Front Behind The German Lines. Washington D.C.: Department of the Army, July 1951.

-----Russian Combat Methods In World War II. Washington D.C.: Department of the Army, 1950.

Groeben, Generalmajor Peter von der. "Collapse of Army Group Center and its Combat Activity until Stabilization of the Front" MS\#T-31 World War II German Military Studies. Vol. 16. New York: Garland Publishing Inc., 1979.

Hoeffding, Oleg. Soviet Interdiction Operations, 1941-1945. United States Air Force Project Rand Report. Santa Monica, California: Rand Corporation, 1970.

Howell, Edgar M. The Soviet Partisan Movement 1941-1944. Washington D.C.: Department of the Army, August 1956.

Mehner, Kurt. Die Geheimen Tagesberichte der Deutschen Wehrmachtfuehrung im Zweiten Weltkrieg 1939-1945. Vols. 8-11. Osnabrueck: Biblio Verlag, 1985.

Morzik, Generalmajor a.D. Fritz. German Air Force Airlift Operations. USAF Historical Studies: No. 167. New York: Arno Press, 1968.

Murray, Williamson. Strategy For Defeat The Luftwaffe 1933-1945. Washington D.C.: U.S. Government Printing Office, 1983.

OKW. Die Wehrmachtberichte 1939-1945. Vols 1-3. Koeln: Gesellschaft Fuer Literatur und Bildung mbH, 1989. 
Plocher, Generalleutnant Hermann. The German Air Force Versus Russia, 1943. USAF Historical Studies: No. 155. New York: Arno Press, 1968.

Royal Air Force Historical Branch. The Rise and Fall of the German Air Force 1933-1945. New York: St. Martin's Press, 1983.

Schwabedissen, Generalleutnant a. D. Walter. The Russian Air Force in the Eyes of German Commanders. USAF Historical Studies: No. 175. New York: Arno Press, 1968.

Suchenwirth, Richard. Command and Leadership in the German Air Force. USAF Historical Studies: No. 174. New York: Arno Press, 1970.

Historical Turning Points in the German Air Force War Effort. USAF Historical Studies: No. 189. New York: Arno Press, 1968.

Uebe, Generalleutnant a.D. Klaus. Russian Reactions to German Airpower in World War II. USAF Historical Studies: No. 176. New York: Arno Press, 1968.

U.S. General Services Administration, National Archives and Records Service. Guides to German Records Microfilmed At Alexandria. VA. 84 vols. Washington, D.C.: The National Archives, 1958-1989.

U.S. President, Reports to Congress on Lend-Lease Operations. No. 16. Washington D.C.: Government Printing Office, 1943-45.

U.S. President, Report on Operations of the Foreign Economic Administration. Washington D.C.: Government Printing Office, 1944.

United States Strategic Bombing Survey. German Motor Vehicles Industry Report. Munitions Division, January 1947.

-..---Tank Industry Report. Munitions Division, January 1947. 
U.S. War Department, Military Intelligence Division. German Military Intelligence, 1939-1945. Frederick, Maryland: University Publications of America, Inc., 1984.

United States War Department. Handbook On German Military Forces. Washington D.C.: U.S. Government Printing Office, 1945.

Wray, Timothy A. Standing Fast: German Defensive Doctrine on the Russian Front During World War II. Washington D.C.: U.S. Government Printing Office, 1986.

\section{Unpublished Dissertations}

Dalecky, Major William J. "Battlefield Air Interdiction by the Luftwaffe at the Battle of Kursk-1943." Master's Thesis. U.S. Army Command and General Staff College, Fort Leavenworth, Kansas, 1980.

Rately III, Lonnie O. "A Comparison of the USAF Projected A-10 Employment in Europe and the Luftwaffe Schlachtgeschwader Experience on the Eastern Front in World War Two." Master's Thesis. Naval Postgraduate School, Monterey, California, March 1977.

Thach, Jr., Joseph E. "The Battle of Kursk, July 1943: Decisive Turning Point on the Eastern Front." Ph.D Dissertation. Georgetown University, Washington D.C., 1971.

Van Tuyll, Hubert Paul. "Lend-Lease And The Great Patriotic War, 1941-1945." Diss. Texas A\&M University, December 1986.

\section{Memoirs}

American:

Deane, John. The Strange Alliance. New York: The Viking Press, 1946.

Stettinius, Jr., Edward R. Lend-Lease. New York: The Macmillan Company, 1944. 
German:

Fretter-Pico, General d. Artillerie. Missbrauchte Infanterie.

Frankfurt am Main: Verlag fuer Wehrwesen Bernard \& Graefe, 1957.

Friessner, Generaloberst. Verratene Schlachten. Hamburg: Holsten-Verlag, 1956.

Gackenholz, Hermann. "The Collapse of Army Group Centre in 1944." Decisive Battles of World War II: The German View. ed. H.A. Jacobsen and J. Rohwehr. New York: G.P. Putnam's Sons, 1965.

Gehlen, General Reinhard. The Service. New York: World Publishing Company, 1972.

Guderian, General Heinz. Panzer Leader. Washington D.C.: Zenger Publishing Co., Inc., 1979.

Manstein, Field Marshal Erich von. Lost Victories. Novato, California: Presidio Press, 1982.

Mellenthin, Major General F.W. von. German Generals Of World War II As I Saw Them. Norman: University of Oklahoma Press, 1977.

Panzer Battles. Norman: University of Oklahoma Press, 1956.

Niepold, Gerd. Battle For White Russia: The Destruction Of Army Group Centre June 1944. London: Brassey's Defense Publishers, 1987.

-.-----Mittlere Ostfront Juni' 44. Herford: Verlag E.S. Mittler \& Sohn, 1985.

Schramm, Percy Ernest. Hitler: The Man And The Military Leader.

Chicago: Quadrangle Books, 1971. 
Kriegstagebuch des Oberkommandos der Wehrmacht 19441945. Muenchen: Bernard \& Graefe Verlag, 1982.

Teske, Hermann. Die Silbernen Spiegel. Heidelberg: Kurt Vowinckel Verlag, 1952.

Tippelskirch, Kurt von. Geschichte des Zweiten Weltkriegs. Bonn: Athenaeum-Verlag, 1956.

Warlimont, Walter. Inside Hitler's Headquarters 1939-45. New York: Frederick A. Praeger, Publishers, 1964.

Westphal, Lieutenant General Siegfried. "The End Draws Near." The Fatal Decisions. ed. William Richards and Seymour Freidin. London: Michael Joseph LTD, 1956.

Soviet:

Bagramian, Marshal Ivan KH. "The Liberation of Byelorussia (Operation Bagration)." Soviet Generals Recall World War II. ed. Igor Vitukhin. New York: Sphinx Press, Inc., 1981.

Rokossovsky, Marshal K. A Soldier's Duty. Moscow: Progress Publishers, 1985.

Shtemenko, S.M. The Soviet General Staff At War 1941-1945. Vols. 1-2. Moscow: Progress Publishers, 1985.

Stalin, Joseph. The Great Patriotic War Of The Soviet Union. New York: International Publishers, 1945.

Zhukov, Marshal G. Marshal of the Soviet Union G. Zhukov

Reminiscences And Reflections. Vols. 1-2. Moscow: Progress Publishers, 1974.

-Marshal Zhukov's Greatest Battles. ed. Harrison E.

Salisbury. Theodore Shabad trans. New York: Harper and Row, Publishers, 1969. 
Zhukov, Konev, Malinovsky, Rokossovsky, Rotmistrov, Chuikov et al. Battles Hitler Lost. New York: Richardson \& Steirman, Inc., 1986.

Other:

Anders, General Wladyslaw. Hitler's Defeat in Russia. Chicago: Henry Regnery Company, 1953.

\section{Journal Articles}

Akhromeyev, S. "Soviet Military Science And Art Of Warfare--A Key Factor In The Victory In The Great Patriotic War." International Affairs. May 1985, pp. 73-86.

Arnold, Major Joseph C. "Current Soviet Tactical Doctrine: A Reflection of the Past." Military Review. Vol. 57. July 1977, pp. 16-24.

Blumentritt, General Guenther. "Strategic Withdrawals." Military Review. Vol. XXXIII No. 6, September, 1953, pp. 24-34.

Boldyrev, Colonel P. "The Bobruisk Operation." Krasnaya Zvezda (Red Star) 28 September 1944 as translated in Military Review. Vol. 24. No. 12, March 1945, pp. 105-108.

-.-.-.-."Notes on the Preparation of Breakthrough Operations." Krasnaia Zvezda (Red Star) 16 November 1944 as translated in Military Review. Vol. XXV No. 3, June 1945, pp. 90-93.

-..-.-.-"The Art of Pursuit." Krasnaya Zvezda (Red Star) 18 October 1944 as translated in Military Review. Vol. XXV No. 1, April 1945 , pp. $115-118$.

Chibisov, Brigadier General N.E. "Military Doctrine of the Red Army." Krasnaia Zvezda (Red Star) 12 November 1944 as translated in Military Review. Vol. 25. No. 5, August 1945, pp. 89-92. 
Creveld, M. Van. "War Lord Hitler: Some Points Reconsidered." European Studies Review. Vol. 4. No. 1, January 1974, pp. 5779.

Dobrev, Colonel-General Kh. "The Decisive Role of the Soviet Union in the Victory Over the Fascist-Militarist Bloc." International Affairs. April 1985, pp. 78-83.

Fitzgerald, Lt. Colonel Charles G. "Operation Bagration." Military Review. May 1964, pp. 59-72.

Foerster, Gerhard. "Die Operation von lasi-Kischinjow und inre Bedeutung fuer die Befreiung der Voelker Suedosteuropas." Militaer Geschichte. 5/74, pp. 517-529.

Gackenholz, Hermann. "Zum Zusammenbruch Der Heeresgruppe Mitte Im Sommer 1944." Vierteliahreshefte fuer Zeitgeschichte. (July 1955), pp. 317-332.

Galkin, Major J. "Notes on German Field Fortifications." (Tekhnika Molodezhi) April 1944 as translated in Military Review. Vol. XXV No. 4, July 1945, pp. 102-105.

Glabisz, Major General Kazimierz. "Causes of the German Defeat in the 1941-1945 Russo-German Campaign." Military Review. Vol. XXX No. 10, January 1951, pp. 32-41.

Goerlitz, Walter. "The Battle for Stalingrad 1942-3." Decisive Battles of World War II: The German View. ed. H.A. Jacobsen and J. Rohwer. New York: G.P. Putnam's Sons, 1965.

Groehler, Olaf. "Juni 44: Die Errichtung der Zweiten Front in Frankreich." Militaer Geschichte. 3/84, pp. 270-272.

"Militarische Ursachen fuer die Niederlage des Faschistischen Deutschlands im Zweiten Weltkrieg." Militaer Geschichte. 4/77, pp. 443-455.

-"Staerke, Verteilung und Verluste der Deutschen Luftwaffe im Zweiten Weltkrieg." Militaer Geschichte. 3/78, pp. 316336. 
Grozanov, Professor G. "The Second Front In Europe: Fact And Fiction." International Affairs. June 1984, pp. 96-104.

Guderian, General Heinz. "The Experiences of the War in Russia." Military Review. July 1957, pp. 90-97.

Hennicke, Otto. "Zu den Menschenverlusten der Faschistischen deutschen Wehrmacht im Zweiten Weltkrieg." Zeitschrift fuer Militaergeschichte. 2/67. p. 196.

Kahn, David. "An Intelligence Case History: The Defense of Osuga." Aerospace Historian. Vol. 28 No. 4 (1981), pp. 242-252.

-"Codebreaking in World Wars I and II: The Major Successes and Failures, their Causes and their Effects." The Historical Journal. Vol. 23 No. 3 (1980), pp. 617-639.

Loshchagin, Colonel N. and Colonel A. Melnichuk. "Employment of Operational Reserves in the German Army." Krasnaya Zvezda (Red Star) 17 June 1944 as translated in Military Review. Vol. XXIV No. 9, December 1944, pp. 85-87.

Mason, Noel F. "Observing the Russians at War." Military Review. Vol. 28, May 1948, p. 101.

McMichael, Major Scott R. "The Battle of Jassy-Kishinev." Military Review. Vol. 64, July 1985, pp. 52-65.

Mueller, Norbert. "Juni 1944: Der Zusammenbruch der Heeresgruppe Mitte Beginn der Agonie der faschistischen Kriegfuehrung im Osten." Militaer Geschichte. 3/1984, pp. 267-270.

Munting, Roger. "Lend-Lease and the Soviet War Effort." Journal of Contemporary History. Vol. 19. No. 3, (July 1984), pp. 495510.

Orlov, A. "Attempts To Falsify The Hisory Of The Second World War." International Affairs. January, 1985, pp. 65-72. 
Ratley III, Captain Lonnie O. "A Lesson for Today? Air Power at Kursk." Military Review. Vol. 58, April 1978, pp. 54-62.

Rhoden, General Hans-Detlef Herhudt von. "The Last Great Attack of the German Bombers in the Eastern Theater of Operations." Military Review. Vol. 31, September 1951, pp. 73-77.

Rokossovsky, Marshal K. "Operation Bagration." Soviet Military Review. No. 6. 1969, pp. 46-60.

Rzheshevsky, Professor O. "The Truth About the Second Front." International Affairs. April 1985, pp. 83-87.

Saulin, Major D. "The Battle of Orsha." Krasnaya Zvezda (Red Star) 11 October 1944 as translated in Military Review. Vol. 25. No. 2. May 1945, pp. 121-124.

Shimanskiy, Colonel A. "1944 Summer-Fall Campaign On The Eastern Front." Joint Publications Research Service. No. 46237 (20 August 1968), p. 1-11.

Shishkin, Colonel S. "The Vitebsk Operation." Krasnaia Zvezda (Red Star) 25 October 1944 as translated in Military Review. Vol. 25. No. 4, July 1945, pp. 93-97.

Slayton, Major Barney F. "War in the Ether: Soviet Radio-Electronic Warfare." Military Review. Vol. 60, January 1980, pp. 56-67.

Tiberi, Colonel Paul. "German Versus Soviet Blitzkrieg." Military Review. Vol. 65 No. 9, September 1985, pp. 63-71.

Tikhomirov, Major General P. "Preparation of Troops for Breakthrough Operations." Krasnaia Zvezda (Red Star) 7 October 1945 as translated in Military Review. Vol. XXVI No. 3, June 1946, pp. 103-105.

Vernon, Colonel Graham D. "Soviet Combat Operations in World War II: Lessons for Today? Part I." Military Review. Vol. 60 No. 3, March 1980, pp. 31-40. 
"Soviet Combat Operations in World War II: Lessons for Today? Part II." Military Review. Vol. 60 No. 4, April 1980, pp. 42-50.

Woithe, Gerhard. "Neue Tatsachen und Gedanken zur Belorussischen Operation." Zeitschrift Fuer Militaergeschichte. 2/1965, pp. 217-223.

Zeitzler, Colonel General Kurt. "Withdrawals of the German Army on the Eastern Front." Military Review, Vol. XL No. 5, August 1960, pp. 73-84.

"Men And Space In War: A German Problem in World War II." Military Review. Vol. XLII No. 4, April 1962, pp. 86-96.

\section{Books}

Allen, W.E.D. and Paul Muratoff. The Russian Campaigns Of 1944-45. New York: Penguin Books, 1946.

Andrianov, V.N., Z.A. Bogatyr' et al. History Of The Great Patriotic War Of The Soviet Union 1941-1945: Results Of The Great Patriotic War. Vol. 6 trans. Foreign Technology Division: Air Force Systems Command. Moscow: Publishing House "Voyennoye," 1962.

Armstrong, John A. Soviet Partisans In World War II. Madison: University of Wisconsin Press, 1964.

Assmann, Kurt. Deutsche Schicksalsjahre. Wiesbaden: Eberhard Brockhaus, 1950.

Baumbach, Werner. Broken Swastika. London: Robert Hale Ltd., 1960.

Bellamy, Chris. Red God of War: Soviet Artillery And Rocket Forces. New York: Brassey's Defense Publishers, 1986.

Bender, Roger James and Hugh Page Taylor. Uniforms, Organization And History of The Waffen-SS. Vol. 3. San Jose, California: R. James Bender Publishing 1972. 
Boog, Horst. Die Deutsche Luftwaffen-Fuehrung 1935-1945.

Stuttgart: Deutsche Verlags-Anstalt, 1982.

Boyd, Alexander. The Soviet Air Force Since 1918. New York: Stein and Day Publishers, 1977.

Breuer, William B. Death Of A Nazi Army. New York: Stein and Day Publishers, 1984.

-----Hitler's Fortress Cherbourg. New York: Stein and Day, Publishers, 1984.

Buchner, Alex. Ostfront 1944. Friedburg: Podzun-Pallas-Verlag GMBH, 1988.

Carell, Paul. Scorched Earth: The Russian-German War 1943-1944. New York: Ballantine Books, Inc., 1966.

Clark, Alan. Barbarossa: The Russian-German Conflict 1941-1945. New York: William Morrow and Company Inc., 1965.

Clausewitz, Carl Von. On War. Princeton, N.J.: Princeton University Press, 1976.

Collins, Jr., Brigadier General James L. The Marshall Cavendish lllustrated Encyclopedia of World War II. Vol. 14. New York: Marshall Cavendish Corporation, 1972.

Cooper, Matthew. The German Army 1933-1945: Its Political and Military Failure. New York: Bonanza Books, 1984.

-The German Air Force 1933-1945: An Anatomy of Failure. New York: Jane's Publishing Inc., 1981.

The Phantom War: The German Struggle Against Soviet Partisans 1941-1944. London: Macdonald and Jane's Publishers Limited, 1979.

Cooper, Matthew and James Lucas. Panzer The Armoured Force of the Third Reich. New York: St. Martin's Press, 1976. 
Dahms, Hellmuth Guenther. Geschichte des Zweiten Weltkriegs.

Tuebingen: Rainer Wunderlich Verlag, 1965.

Detwiler, Donald S., Charles Burdick and Juergen Rohwehr. World War II German Military Studies. Vol. 16. New York: Garland Publishing, Inc., 1979.

Dupuy, Colonel T.N. and Paul Martell. Great Battles On The Eastern Front: The Soviet-German War 1941-1945. New York: BobbsMerrill Company, Inc., 1982.

Erickson, John. The Road To Berlin. Boulder, Colorado: Westview Press, 1983.

Erickson, John, Lynn Hansen and William Schneider. Soviet Ground Forces: An Operational Assessment. Boulder, Colorado: Westview Press, Inc., 1986.

Faber, Harold. Luftwaffe: A History. New York: The New York Times Book Company Inc., 1977.

Flower, Desmond and James Reeves. The War 1939-1945. London: Cassel \& Company Ltd, 1960.

Gilbert, Felix. Hitler Directs His War. New York: Octagon Books, 1982.

Fuller, Major-General J.F.C. The Second World War 1939-45. New York: Duell, Sloan And Pearce, 1949.

Hardesty, Von. Red Phoenix. Washington D.C.: Smithsonian Institution Press, 1982.

Hart, B.H. Liddell. History of the Second World War. Vols. I-II. New York: Capricorn Books, 1972.

-..---The German Generals Talk. New York: William Morrow \& Co., 1948. 
------The Red Army. New York: Harcourt, Brace And Company, 1956.

Haupt, Werner. Die Schlachten der Heeresgruppe Mitte 1941-1944. Friedburg: Podzun-Pallas-Verlag GmbH, 1983.

Hermann, Carls Hans. Deutsche Militaergeschichte. Frankfurt am Main: Bernard \& Graefe Verlag fuer Wehrwesen, 1968.

Herring, Jr., George C. Aid To Russia 1941-1946. New York: Columbia University Press, 1973.

Hesse, Erich. Der sowjetrussische Partisanenkrieg 1941 bis 1944. Goettingen: Musterschmidt Verlag, 1969.

Higham, Robin and Jacob W. Kipp. Soviet Aviation and Air Power. Boulder, Colorado: Westview Press Inc., 1977.

Hinze, Rolf. Das Ostfront Drama 1944. Stuttgart: Motorbuch Verlag, 1987.

-.-.---Der Zusammenbruch der Heeresgruppe Mitte im Osten 1944. Stuttgart: Motorbuch Verlag, 1980.

---.--Hitze. Frost und Pulverdampf: Der Schicksalsweg der 20. Panzer Division. Bochum: Heinrich Poeppinghaus Verlag, 1981.

Hogg, lan V. German Order of Battle 1944. New York: Hippocrene Books Inc., 1975.

Hubatsch, Walther. Hitlers Weisungen fuer die Kriegfuehrung 1939-1945. Frankfurt Am Main: Bernard \& Graefe Verlag Fuer Wehrwesen, 1962.

Irving, David. Hitler's War. New York: The Viking Press, 1977. Jacobsen, H.A. and J. Rohwehr. Decisive Battles of World War II: The German View. New York: G.P. Putnam's Sons, 1965. 
Jacobsen, Hans-Adolf and Hans Dollinger. Der Zweite Weltkrieg In Bildern und Dokumenten. Koeln: Buch und Zeit Verlagsgesellschaft MBH, 1965.

Jones, Robert Huhn. The Roads to Russia: United States Lend-Lease to the Soviet Union. Norman: University of Oklahoma Press, 1969.

Keegan, John. The Second World War. New York: Viking Penguin, Inc., 1989.

Kilmarx, Robert A. A History of Soviet Air Power. New York:

Frederick A. Praeger, Inc., 1962.

Kissel, Von Hans. Die Katastrophe in Rumaenien 1944. Darmstadt: Wehr und Wissen Verlagsgesellschaft MBH, 1964.

Kozhevnikov, M.N. The Command and Staff of Soviet Army Air Force in the Great Patriotic War 1941-1945. Moscow: Nauka Publishing House, 1977.

Kuehner, Otto-Heinrich. Wahn und Untergang 1939-1945.

Stuttgart: Deutsche Verlags-Anstalt, 1956.

Kuehnrich, Heinz. Der Partisanenkrieg in Europa 1939-1945.

Berlin: Dietz Verlag, 1968.

Kurowski, Franz. Luftwaffe ueber Russland. Rastatt: Verlag Arthur Moewig GmbH, 1987.

Landwehr, Richard. Fighting For Freedom: The Ukrainian Volunteer Division Of The Waffen-SS. Silver Spring, Maryland: Bibliophile Legion Books, Inc., 1985.

Madej, W. Victor. German Army Order of Battle 1939-1945. Vols. I, II, Supplement. Allentown, Pennsylvania: Game Marketing Company, 1981.

-German War Economy: The Motorization Myth. Allentown, Pennsylvania: Game Marketing Company, 1984. 
Hitler's Dying Ground: Description And Destruction of the

German Army. Allentown, Pennsylvania: Game Marketing Publishing Company, 1985.

Russo-German War: Summer 1944. No. 33. Allentown, Pennsylvania: Valor Publishing Company, 1987.

-..---.-Southeastern Europe Axis Armed Forces Order of Battle.

Allentown, Pennsylvania: Game Marketing Company, 1981.

-.-.-.-The War Machine--German Weapons and Manpower, 1939-

1945. Allentown, Pennsylvania: Game Marketing Company, 1984.

Majdalany, Fred. The Fall Of Fortress Europe. Garden City, New York: Doubleday \& Company, Inc., 1968.

Minasyan, M.N. et al. Great Patriotic War Of The Soviet Union 19411945: A General Outline. Moscow: Progress Publishers, 1974.

Mitcham, Jr., Samuel W. Hitler's Legions: The German Army Order of Battle. World War II. New York: Stein and Day Publishers, 1985.

Mueller-Hillebrand, Burkhart. Das Heer 1933-1945. Vol. 3.

Frankfurt am Main: Verlag E.S. Mittler \& Sohn G.M.B.H., 1969.

Murphy, Paul J. The Soviet Air Forces. Jefferson, North Carolina: Mcfarland \& Company Inc., 1984.

Natkiel, Richard. Atlas Of Battles. New York: Crown Publishers Inc., 1984.

Nicolsen, Nigel. Napoleon. New York: Harper \& Row Publishers, 1985.

Poirier, Robert G. and Albert Z. Conner. The Red Army Order of Battle in the Great Patriotic War. Novato, California: Presidio Press, 1985. 
Pospelov, P.N. et al. History Of The Great Patriotic War Of The Soviet Union 1941-1945. Vol. 4 trans. Foreign Technology Division: Air Force Systems Command. Moscow: Publishing House "Voyennoye," 1962.

Price, Alfred. Luftwaffe Handbook 1939-1945. New York: Charles Scribner's Sons, 1977.

Rehm, Walter. Jassy. Neckargemuend: Kurt Vowinckel Verlag, 1959.

Roebling, Karl. Great Myths Of World War II. Fern Park, Florida: Paragon Press/Dynapress, 1985.

Rzheshevsky, Oleg. World War II: Myths and the Realities. Moscow: Progress Publishers, 1984.

Seaton, Albert. The Fall Of Fortress Europe 1943-1945. New York: Holmes \& Meier Publishers, Inc., 1981.

-..---.-The Russo-German War 1941-45. New York: Praeger Publishers, Inc., 1971.

Schuman, Wolfgang and Olaf Groehler. Deutschland im Zweiten Weltkrieg. Vol. 6. Berlin: Akademie Verlag, 1988.

Sokolovskii, Marshal V.D. Soviet Military Strategy. Englewood Cliffs, New Jersey: Prentice-Hall, Inc., 1963.

Sorge, Martin K. The Other Price of Hitler's War. New York: Greeenwood Press, 1986.

Staff of Strategy \& Tactics Magazine. War In The East: The RussoGerman Conflict, 1941-45. New York: Simulations Publications Incorporated, 1977.

Stoves, Rolf. Die Gepanzerten und Motorisierten Deutschen Grossverbaende 1935-1945. Friedburg: Podzun-PallasVerlag GmbH, 1986. 
------Die 1. Panzer Division. Bad Nauheim: Verlag Hans-Henning Podzun, 1961.

Trevor-Roper, H.R. Hitler's War Directives 1939-1945. London:

Pan Books Ltd, 1966.

Werth, Alexander. Russia At War 1941-1945. New York: Carroll \& Graf Publishers, Inc., 1964.

Whaley, Barton. Stratagem: Deception and Surprise in War. (1969), p. A-393.

Whiting, Kenneth R. Soviet Air Power. Boulder: Westview Press, 1986.

Wilhelm, Hans-Heinrich and Louis De Jong. Zwei Legenden aus dem Dritten Reich. Stuttgart: Deutsche Verlags-Anstalt GmbH, 1974.

Wilmot, Chester. Struggle For Europe. New York: Caroll \& Graf Publishers, Inc., 1986.

Young, Brigadier Peter. World War 1939-45. New York: Thomas Y. Crowell Company, 1966.

Young, Brigadier Peter and Richard Natkiel. Atlas Of The Second World War. New York: Berkley Publishing Corporation, 1977.

Zaleski, E. Stalinist Planning for Economic Growth 1932-52. Chapel Hill, 1980.

Zaloga, Steven J. and James Grandsen. Soviet Tanks And Combat Vehicles of World War Two. London: Arms and Armour Press, 1984.

Ziemke, Earl F. Stalingrad To Berlin: The German Defeat in The East. New York: Dorset Press, 1968. 


\section{APPENDIX A}

\section{GERMAN MILITARY FORMATIONS}

SOURCE: Staff of Strategy \& Tactics Magazine, War In The East: The Russo-German Conflict. 1941-45. New York:

Simulations Publications, Incorporated, 1977. 
KEY TO SYMBOLLOY

USED IN THE DIAGRAMS

IN SECTIONS IV AND $V$

$\triangle$ intentir

[Dechanized Intantry (Panzerorenadier)

(5) Aumor or tenk (Panzer)

[2] Amored Reconnaikence

[ covalis

$\square$ Antittery

D Selt-propelled Artillery

D. Anti-Tonk

8 Anti-Aircraft (Flak)

$\Rightarrow$ Aockat Artitlery

(T) Enoineer

D Signal

$\infty$ Aviation

[D Tremsport

$\square$ supoly

ORGANIZATIONAL SIZE SYMBOLS

-ee Platoon

1 Company or Battery

II Battalion

III Regiment

$x \quad$ Brigede

$x \times \quad$ Oividion

$x \times x \quad$ Corpo

$x \times x \times$ Army 

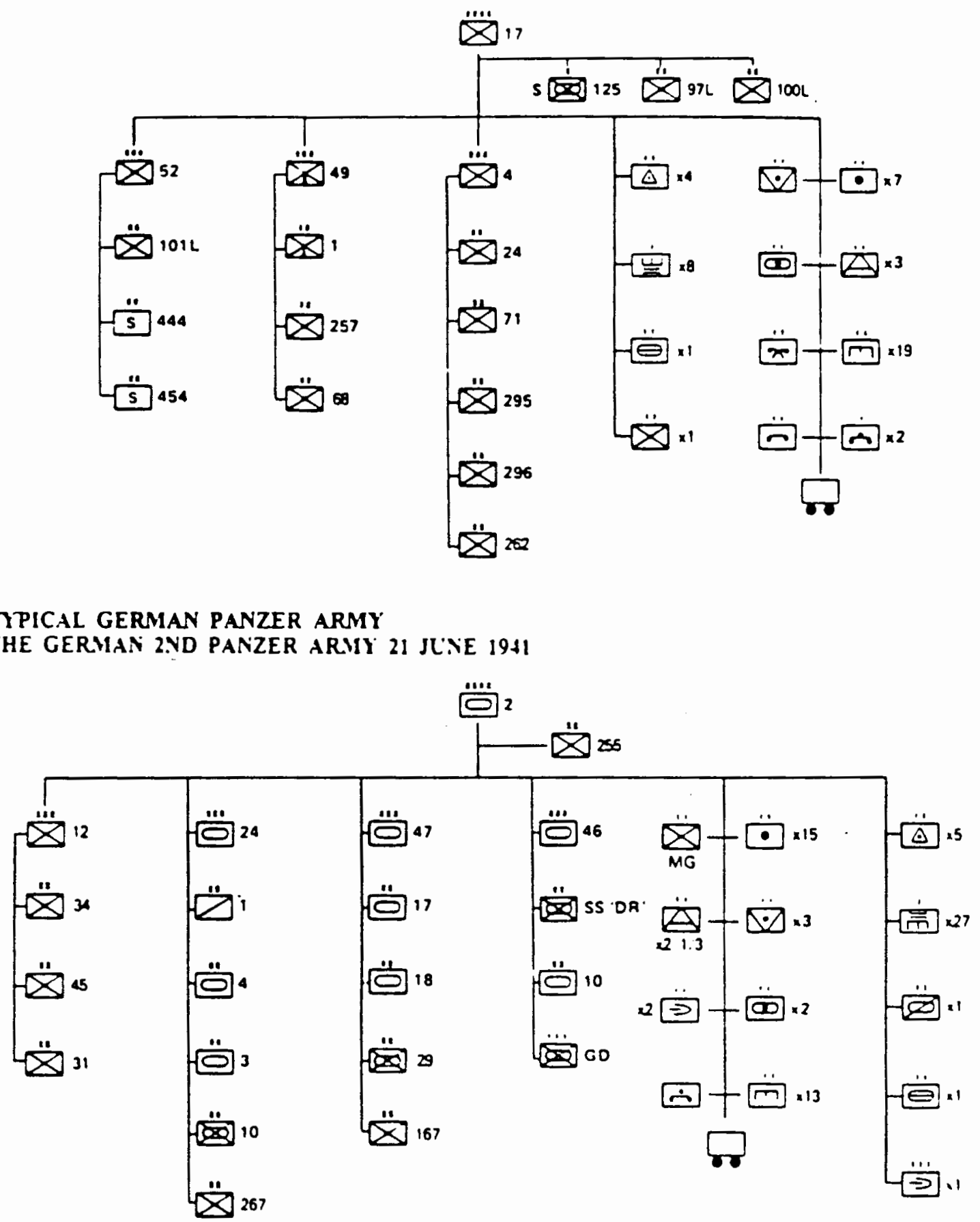


\section{H GERILAN INFANTRY DNISION}

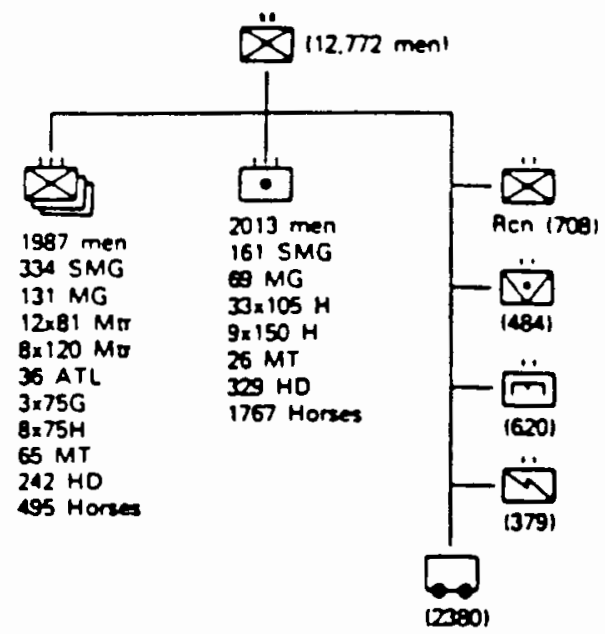

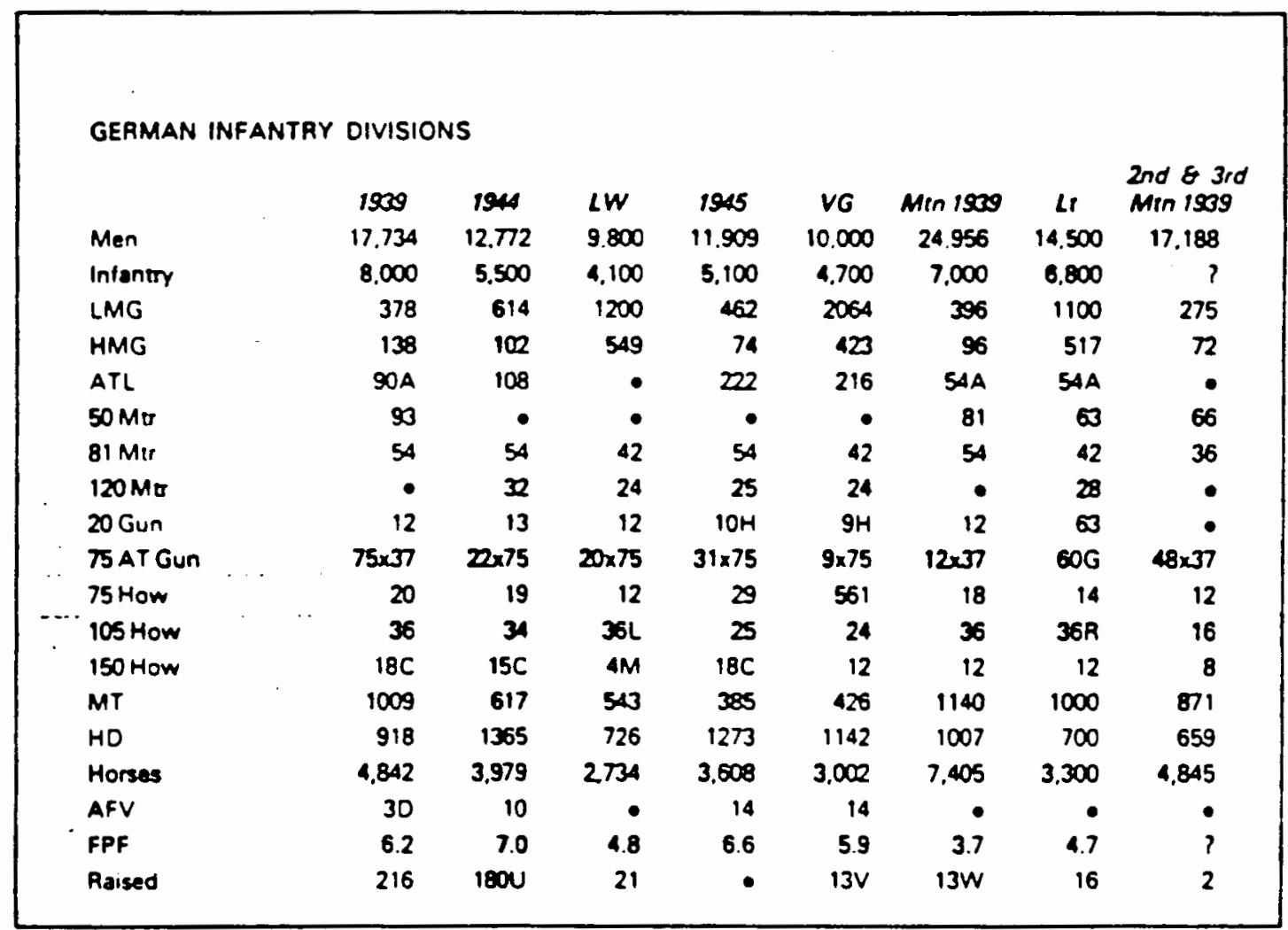

\section{ABBREVIATIONS:}

Men = toral "psper" (fuln strength of unit: Intantry = all men in intaniry. reconnaissance. and engineer bor. calions: $L W=$ Lutrwatte intoniry: $V G=$ volksgrenedier: Min = mountoin intoniry: $L \mathrm{l}$ = light intanir: $F J=1 \mathrm{all}$. schirmyoget loarochute light intoninl: $P G=$ ponzer. grenadier: Ariv = erillerv: $50 \mathrm{mts}$ (81. $1201=50 \mathrm{~mm}$ $181 \mathrm{~mm}, 120 \mathrm{~mm} \mid$ mortar: 20 gun $=20 \mathrm{~mm}$ anel aurcrstt gun: 88 gun $=88 \mathrm{~mm}$ gun: 75 AT gun $=75 \mathrm{~mm}$ ant rank gun: 75 How 1105,150$)=75 \mathrm{~mm} 1105 \mathrm{~mm}, 150 \mathrm{~mm} \mid$ howitzer; FPF = fire power foctor; $\%$ of Div larty) = per. cent of divisional fire power generared by artillen regiment: $M G(L M G . H M G)=$ machinegun $\mid$ light, heavl. ATL = ant 1 tank rocket launchers: SMG = submachine. gun: $\quad F T=$ flame thrower: $A F V=$ ormored fighing benicle: $A G=$ assaull gun: $A C=$ armored car; Pz $I I I I I V . V$. $V I I=$ Panzer $I I \mid I V . V$. VIl rank: $M T=$ moror transport behicle: $\mathrm{HO}=$ horse-drawn vehicle 


\section{GERMAN INFANTRY REGIMENT}

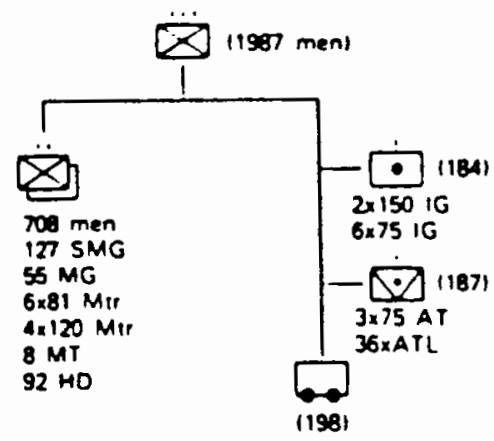

INFANTRY REGIMENTS

Pzon Mot Div PzDiN PzDiN PGOiN

lame IMor LAMmd IMot lMot

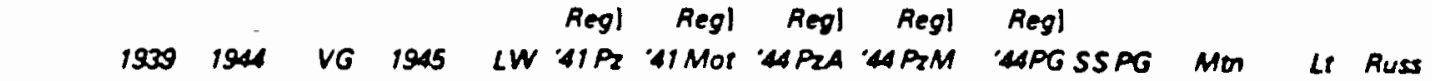

$\begin{array}{lllllllllllllll}\text { Men } & 3060 & 1987 & 1854 & 1849 & 2645 & 2200 & 3250 & 2294 & 2258 & 3020 & 3242 & 3650 & 3650 & 2474\end{array}$

$\begin{array}{lllllllllllllllll}\text { LMG } & \cdots & 85 & 107 & 597 & 79 & 251 & 172 & 151 & 336 & 235 & 316 & 413 & 142 & 232 & 650\end{array}$

$\begin{array}{lllllllllllllll}\text { HMG } & 26 & 24 & 95 & 16 & 202 & 150 & 130 & 250 & 170 & 237 & 322 & 174 & 174 & 207\end{array}$

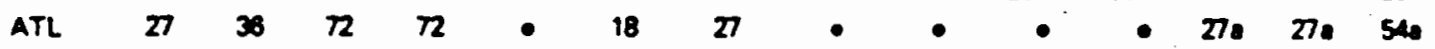

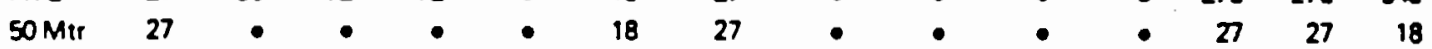

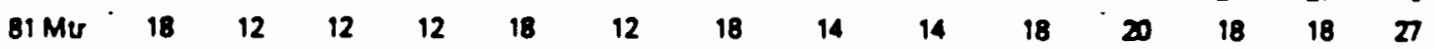

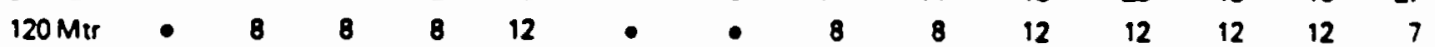

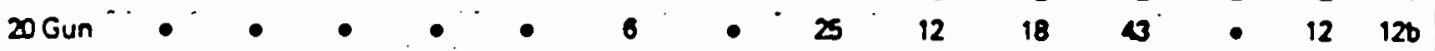

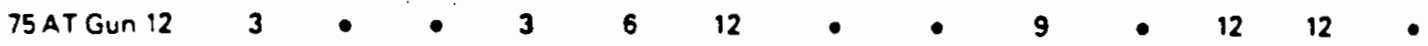

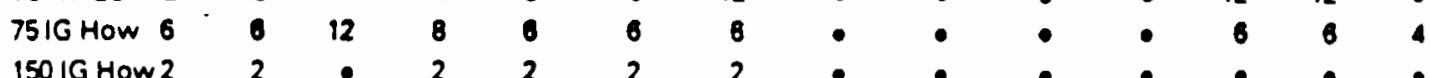

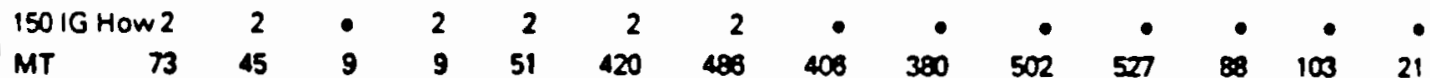

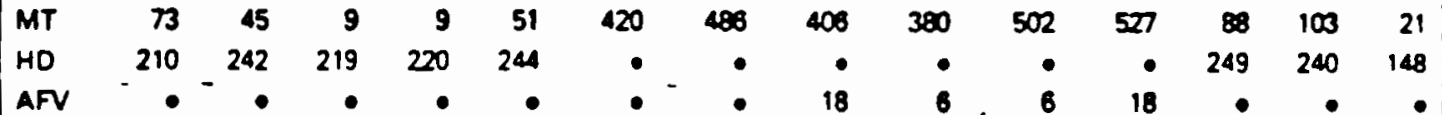




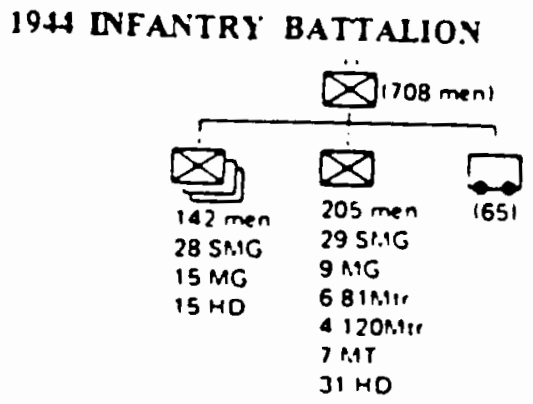

\begin{tabular}{|c|c|c|c|c|c|c|c|c|c|c|c|c|c|}
\hline GERMAN & $\begin{array}{l}\text { INFANT } \\
1939\end{array}$ & $\begin{array}{l}\text { AY BA } \\
1944\end{array}$ & TALI & $\begin{array}{l}\text { NS } \\
\qquad W\end{array}$ & 1945 & Min & $\angle r$ & $\begin{array}{c}A 1 \\
P G A \\
\left|P_{2}\right|\end{array}$ & $\begin{array}{c}11 \\
P G M \\
\text { (MOP) }\end{array}$ & $\begin{array}{c}4 \\
P G A \\
\left|P_{z}\right|\end{array}$ & $\begin{array}{c}\text { PGM } \\
\text { (MOI) }\end{array}$ & $\begin{array}{c}A t \\
P G M \\
\left(P_{X}\right)\end{array}$ & Russ \\
\hline Men & 850 & 780 & $6+2$ & 668 & 644 & $8 \pi$ & $8 \pi$ & 910 & 850 & 867 & 868 & 955 & 619 \\
\hline SMG & $Q$ & 127 & 253 & 107 & 256 & 71 & 71 & 82 & 2 & 179 & 91 & 97 & 145 \\
\hline MG & 48 & 55 & 38 & 57 & 38 & 52 & 52 & 145 & 48 & 127 & 72 & 72 & 69 \\
\hline $50 \mathrm{Mtr}$ & 9 & - & $\bullet$ & - & $\bullet$ & 9 & 9 & $\bullet$ & 9 & $\bullet$ & - & - & 6 \\
\hline 81 MiP & 6 & 6 & 6 & 6 & 6 & 6 & 6 & 6 & 6 & 6 & 6 & 6 & 9 \\
\hline $120 \mathrm{Mt}$ & - & 4 & $\bullet$ & 4 & - & 4 & $\bullet$ & $\bullet$ & $\bullet$ & 4 & 4 & - & $\bullet$ \\
\hline 75 How & $\bullet$ & $\bullet$ & 4 & - & 4 & 2 & 2 & 4 & $\bullet$ & $\bullet$ & - & 4 & $\bullet$ \\
\hline 20 Gun & $\bullet$ & $\bullet$ & - & - & - & $\bullet$ & $\bullet$ & $\bullet$ & $\bullet$ & 18 & 6 & 6 & 2 \\
\hline 75 Gun & 9 & - & $\bullet$ & $\bullet$ & $\bullet$ & - & $\bullet$ & 21 & $\bullet$ & $\bullet$ & - & 12 & - \\
\hline AFV & - & - & $\bullet$ & $\bullet$ & $\bullet$ & $\bullet$ & - & $\bullet$ & - & 12 & $\bullet$ & $\bullet$ & $\bullet$ \\
\hline$M T$ & 11 & 8 & 2 & 6 & 2 & $\bullet$ & 16 & 130 & 125 & 158 & 143 & 140 & $\bullet$ \\
\hline HD & 104 & 92 & 70 & 82 & 70 & 211 & 97 & - & - & $\bullet$ & $\bullet$ & $\bullet$ & 27 \\
\hline Horses & 177 & 165 & $1: 5$ & 139 & 125 & 271 & 182 & - & - & - & $\bullet$ & - & $\cdot 43$ \\
\hline
\end{tabular}


1944 GERMAN ARMORED DIVISION

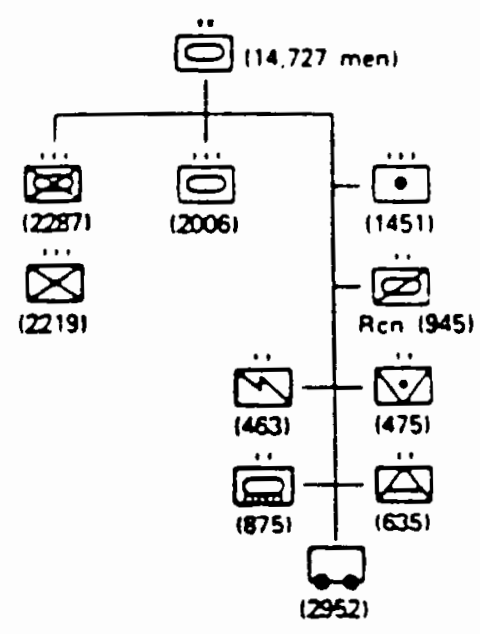

TANK REGIMENTS

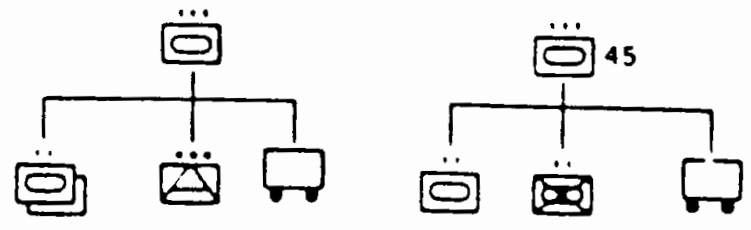

GERMAN TANK REGIMENTS

$1942-43 \quad 1944$ SS 1945 Russ

$\begin{array}{llllll}\text { Men } & 3000 & 2006 & 1771 & 1361 & 1306\end{array}$

$\begin{array}{llllll}\text { SMG } & 182 & 279 & 245 & 37 & 1260\end{array}$

$\begin{array}{llllll}\text { MG } & 307 & 363 & 296 & 172 & 410\end{array}$

20 Gun $12 \quad 24 \quad 6 \quad 33$ •

37 Gun $\quad$ P 848 .

PzIII 54 - 54

$\begin{array}{lllll}P_{Z} I V & 54 & 89 & 64 & \bullet\end{array}$

PIV $\quad * \quad 79 \quad 62 \quad 54 \quad 65$

$A G \quad 31 \quad \bullet \quad \bullet \quad \bullet \quad \bullet$

$\begin{array}{lrrrrr}A C & 6 & \bullet & \bullet & \bullet & \bullet\end{array}$

$\begin{array}{lrrrrr}\text { MT } & 537 & 654 & 313 & 250 & 156 \\ \text { AFV } & \bullet & 12 & \bullet & 49 & \end{array}$ 


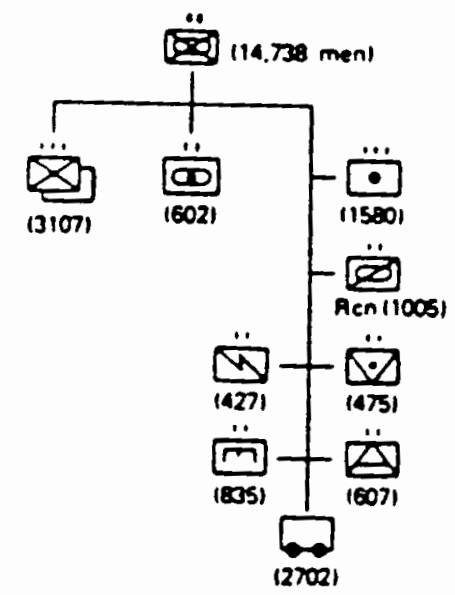

\begin{tabular}{|c|c|c|c|c|c|c|c|c|c|c|}
\hline \multicolumn{11}{|c|}{ GERMAN MOTORIZEO OIVISIONS } \\
\hline & f) & $P G|9|$ & PG Igne & $A(901)$ & Pि & Alies & SSA & an & Am & Tont \\
\hline Men & 15976 & 16000 & 1413 & 15600 & 14727 & 11022 & 11200 & 10900 & 900 & 11900 \\
\hline Intoniry & 100 & 1100 & 2000 & 300 & 5200 & $\$ 700$ & 7100 & $\approx 0$ & $\infty$ & 300 \\
\hline LMG & 3026 & $=10$ & 818 & eso & 1250 & $2+\infty$ & 2050 & 1101 & 2200 & 2961 \\
\hline HMG & 1010 & 712 & 100 & 1008 & $\pi$ & 650 & 1565 & 613 & M) & S17 \\
\hline ATt & 250 & 0. & - & 150 & - & $\omega$ & - & - & 2122 & $201 \mathrm{r}$ \\
\hline SO Mt & - & 57 & - & - & - & - & - & - & 0 & - \\
\hline $81 \mathrm{Mu}$ & 125 & 36 & 6 & 30 & 52 & 36 & 58 & 6 & $\mathbf{o r}_{r}$ & S2r \\
\hline $120 \mathrm{Ms}$ & $\infty$ & - & $\pi$ & - & 10 & $x$ & 24 & 4 & 21 & 4 \\
\hline$x$ Gun & 3 & 12 & $x$ & 14 & 102 & 109 & 152 & 54 & • & $16 \mathrm{r}$ \\
\hline TSAT Gun & 21 & $\infty$ & 19 & 150 & 13 & נy & 12 & 12 & $\mu_{z}$ & $M_{2}$ \\
\hline 75 How 16 & 20 & 14 & - & 18 & - & - & - & - & - & - \\
\hline 105 How & 36 & 36. & 41 & 360 & $\boldsymbol{\theta}$ & 34 & $42 n$ & S6) & $12 x$ & $n$ \\
\hline 105 How & 12 & 12 & 20 & 160 & 26 & 16 & $30 \mathrm{k}$ & $\infty$ & - & - \\
\hline MT & 2141 & $2+\infty$ & $\pi 4$ & 200 & 2427 & 2171 & פשn & 2520 & 100 & 1810 \\
\hline HO & - & - & - & - & - & - & - & - & G12 & - \\
\hline Morren & - & - & - & - & - & - & - & 1800 & 8 & $?$ \\
\hline AFV & 14 & 0 & 105 & 165 & 5003 & 10 & 231 & 23 & - & 240 \\
\hline FPF & .7 & 71 & 9.1 & 26 & 100 & 8.1 & 142 & 130 & 40 & 2.3 \\
\hline mared & - & 16. & 15 & 27 & 25 & 0.11 & 7 & 1 & 790 & 20 \\
\hline
\end{tabular}




\section{9\$3-44 GERMLAN ARTLLERY DTISION}

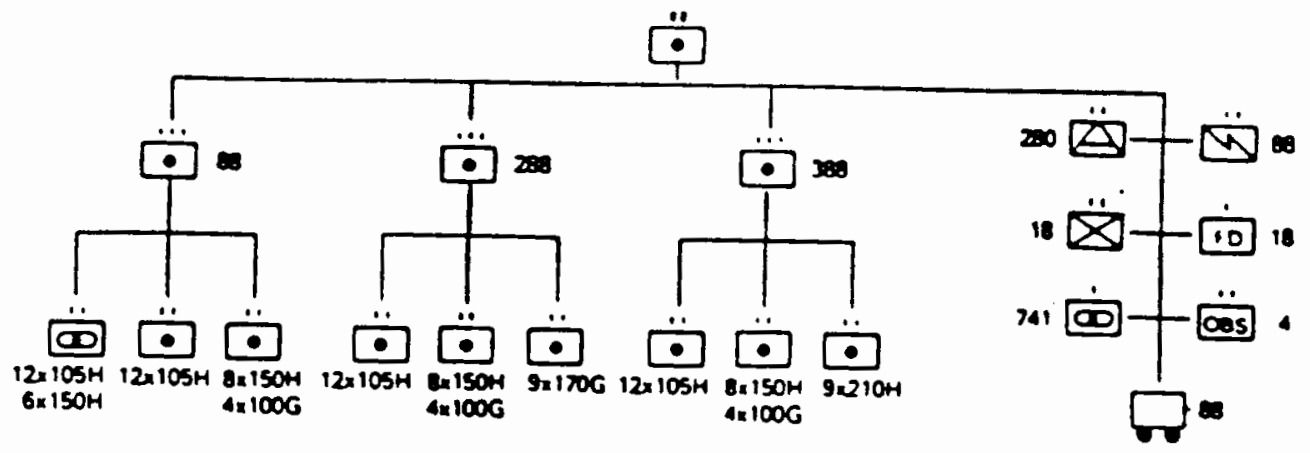

CERMAN ARTILLERY REGIMENT

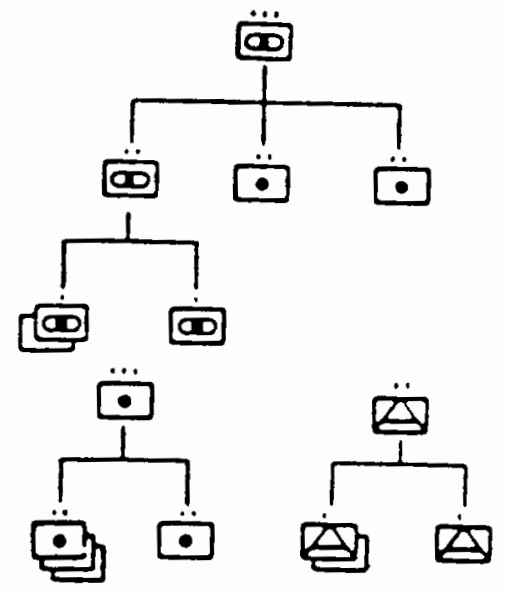

GERMAN ARTILLERY AEGIMENTS

\begin{tabular}{|c|c|c|c|c|c|c|c|c|c|}
\hline & 1900 & 194 & LW & $v G$ & $M E n$ & $t$ & $\triangle A$ & 100 & $M A$ \\
\hline Men & 3172 & 2013 & 175 & 174 & 2750 & 2500 & 2000 & 2550 & 1451 \\
\hline SMG & $\bullet$ & 161 & 103 & II & 100 & 120 & 10 & 147 & 158 \\
\hline MG & 30 & 6 & $\omega$ & As & 24 & $\mathbf{x}$ & s & $\mathbf{x}$ & $\omega 6$ \\
\hline 105 How & 30 & $\mathbf{D}$ & $\mathbf{3}$ & 24 & 26 & - & 2 & 24 & 24 \\
\hline 105 Gun & - & - & $\bullet$ & - & 36 & - & 4 & 4 & $\bullet$ \\
\hline $150 \mathrm{How}$ & 12 & 9 & $\bullet$ & 12 & 12 & 1 & $\mathbf{e}$ & 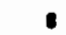 & 14 \\
\hline $75 \mathrm{Gun}$ & $\bullet$ & $\bullet$ & $\bullet$ & 10 & 10 & $\bullet$ & $\bullet$ & $\bullet$ & - \\
\hline MGun & $\bullet$ & $\bullet$ & 12 & $\bullet$ & - & - & - & $\bullet$ & $\bullet$ \\
\hline MT & 158 & 21 & 0 & 99 & 42 & 217 & 10 & SAI & 300 \\
\hline HO & 26 & 30 & 10 & 2.5 & $x$ & $\infty$ & $\bullet$ & $\bullet$ & - \\
\hline Morse & 2200 & 1167 & 10 & 1062 & 2100 & 1214 & - & $\bullet$ & - \\
\hline FPF & 3.87 & 3.98 & 2.00 & 200 & 116 & 150 & 3.2 & 32 & 4.0 \\
\hline ol oiv & 625 & est & 580 & 40 & 313 & us & $\mathbf{4} .2$ & 4.5 & 43 \\
\hline
\end{tabular}


GERMAN BATTLEGROUPS (KAMPFGRUPPEN)
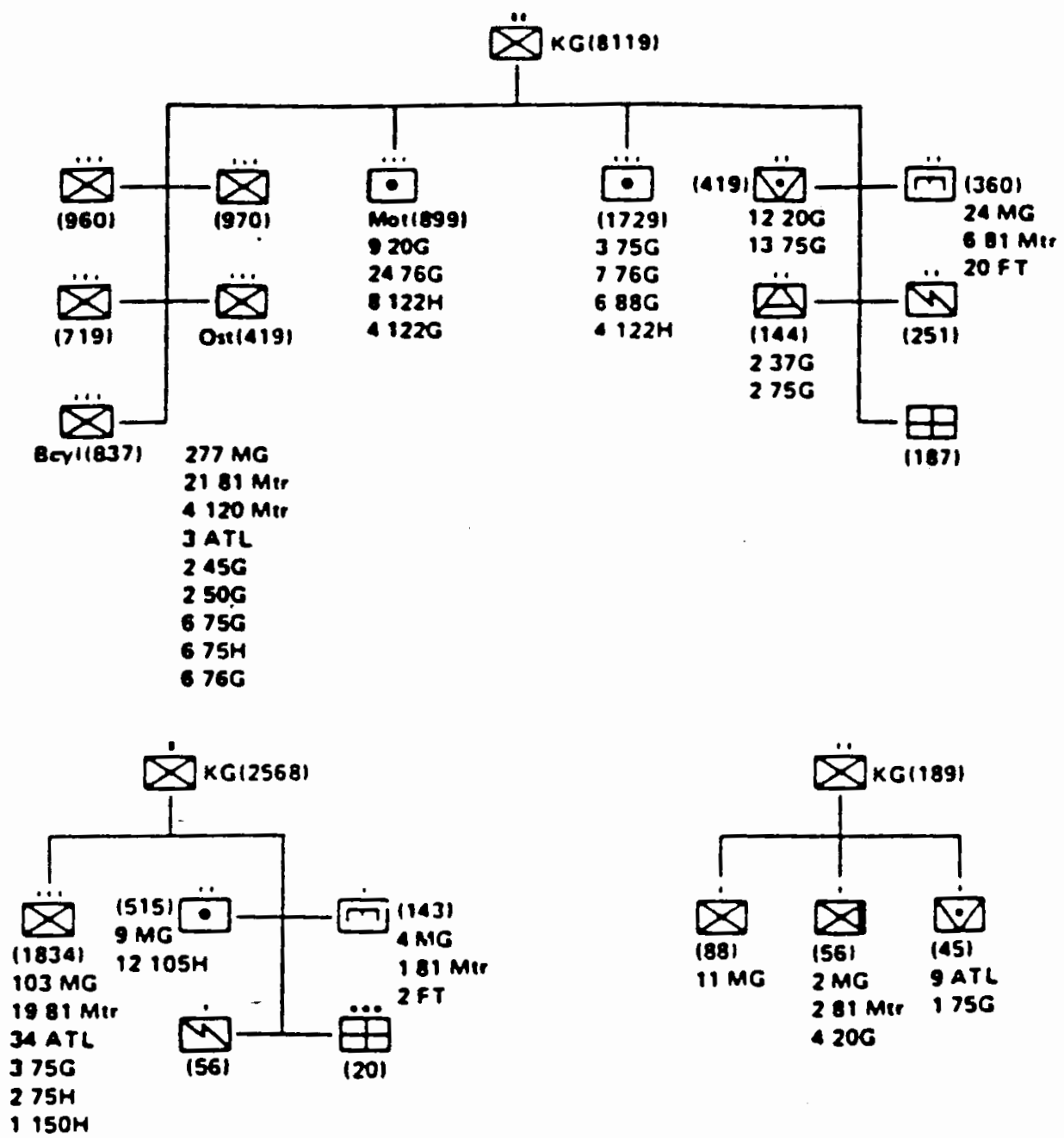


\section{RECONNAISSANCE BATTMLIONS}

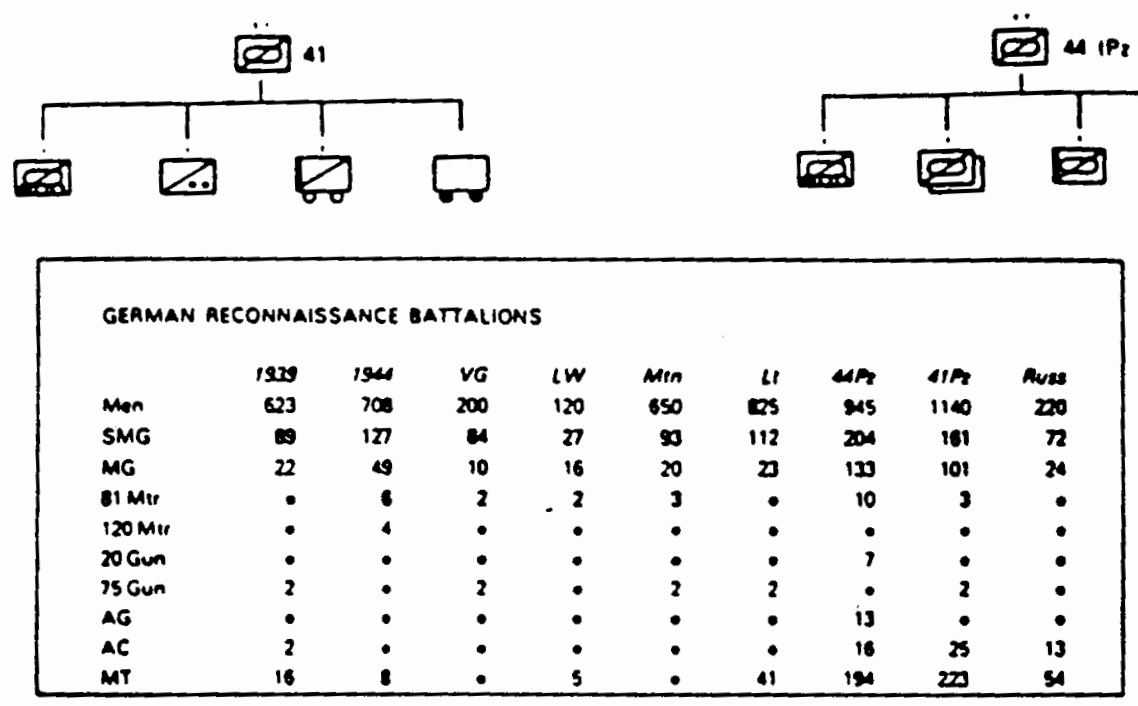

ENGLEER BATTALIONS

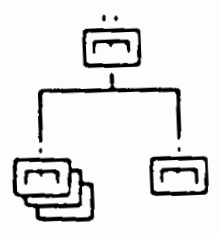

ENGINEER BATTALIONS

\begin{tabular}{|c|c|c|c|c|c|c|c|c|c|c|c|}
\hline & 1920 & 1944 & vo & ew & Mrn & $t_{1}$ & Alf & $\triangle I A G$ & $M A$ & $55 P$ & $\begin{array}{l}\text { Muss } \\
\text { 17042 }\end{array}$ \\
\hline Men & 779 & 620 & 42 & 397 & 1050 & 0 & 958 & n & 974 & $\operatorname{sen}$ & 164 \\
\hline SMG & 12 & $n$ & 11 & 2 & 2 & $\boldsymbol{x}$ & 31 & 35 & 102 & 102 & is \\
\hline MG & 27 & y) & 2 & 20 & 34 & 31 & 67 & 61 & 102 & 105 & $\bullet$ \\
\hline $11 \mathrm{Mt}$ & $\bullet$ & 6 & $\bullet$ & 4 & $\bullet$ & $\bullet$ & $\bullet$ & - & $\bullet$ & 6 & - \\
\hline$x$ Gun & - & $\bullet$ & - & $\bullet$ & - & - & $\bullet$ & $\bullet$ & 3 & 6 & $\bullet$ \\
\hline$F$ & 20 & 20 & 12 & 14 & 20 & $\boldsymbol{x}$ & 20 & 20 & 20 & 2 & - \\
\hline Dridges & $\bullet$ & $\bullet$ & $\bullet$ & $\bullet$ & $\bullet$ & $\bullet$ & - & $\bullet$ & $\bullet$ & $\bullet$ & - \\
\hline MT & $n$ & 17 & 12 & 3 & 4 & 100 & 194 & 90 & 174 & 212 & 4 \\
\hline MD & 19 & 52 & 33 & 35 & 10 & $\bullet$ & $\bullet$ & - & $\bullet$ & $\cdot$ & 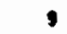 \\
\hline Mor set & 52 & 97 & 6 & $\theta$ & 30 & $\bullet$ & $\bullet$ & $\bullet$ & - & $\bullet$ & - \\
\hline
\end{tabular}


GERMAX TANK BATTALIONS

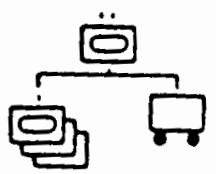

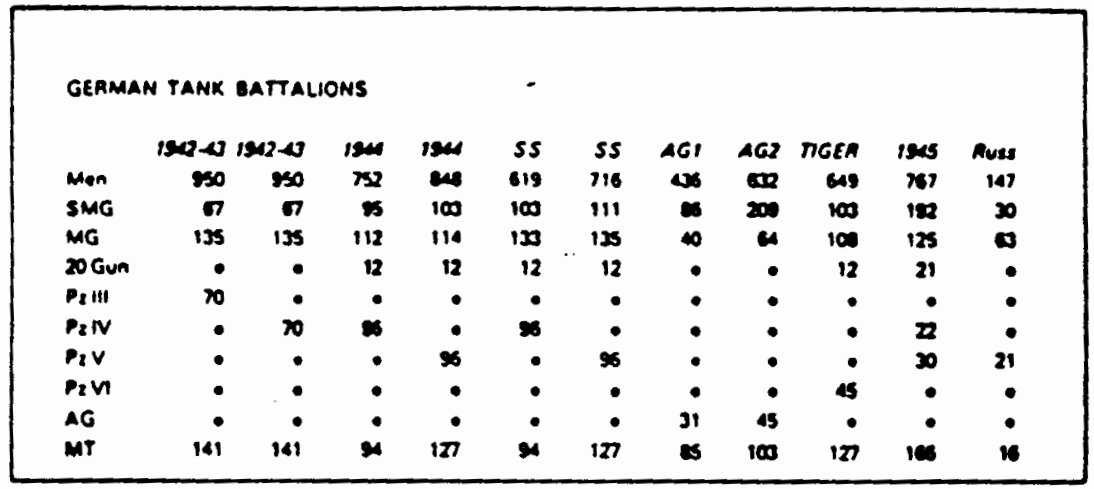

ANTI.TANK BATTALIONS
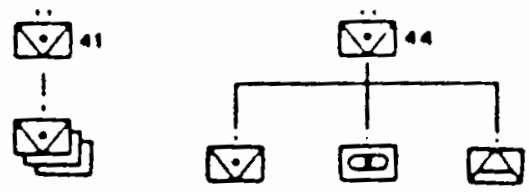

\begin{tabular}{|c|c|c|c|c|c|c|}
\hline \multicolumn{7}{|c|}{ ANTI-TANK BATTALIONS } \\
\hline & $\begin{array}{l}1039 . \\
1903\end{array}$ & Iss & $V G$ & ew & $M P_{z}$ & Tiger \\
\hline Men & 551 & 484 & 460 & 350 & 475 & 915 \\
\hline SMG & 47 & 81 & 26 & 39 & 59 & 127 \\
\hline NIG & 6 & 29 & 30 & 17 & 37 & 60 \\
\hline 20 Gun & 12 & 48 & 9 & 12 & - & 12 \\
\hline 75 Gun & 36 & 12 & 9 & 14 & 12 & $\bullet$ \\
\hline AG & - & 10 & 10 & - & 21 & - \\
\hline$P_{2} V_{I}$ & - & - & - & - & - & 45 \\
\hline MT & 114 & 113 & 100 & 88 & 102 & 192 \\
\hline
\end{tabular}




\section{APPENDIX B}

\section{SOVIET MILITARY FORMATIONS}

SOURCE: Staff of Strategy \& Tactics Magazine, War In The East:

The Russo-German Conflict. 1941-45. New York:

Simulations Publications, Incorporated, 1977. 
KEY TO SYMBOLIOGY

USED IN THE DIAGRAMS

IN SECTIONS IV AND $V$

$\square$ miteniry

[82) Mechenized Infentry (Ponzergrenadier)

D Nmor or tank (Panzer)

[0] Armored Reconnaisence

[D cevaliry

- Nitllory

(D) Self.propelled Artillery

D) Anti-Tonk

$\Delta$ Anti-Aircrafl (Flak)

$\$$ Rocket Artillery

I7) Engineer

$M$ signal

- Avition

(D) Trensport

$\square$ Supply

ORGANIZATIONAL SIZE SYMBOLS

-ee Pistoon

1 Company or Battery

II Bortalion

III Reciment

$x \quad$ Brigede

$x \times \quad$ Division

$X \times X \quad$ Corps

XXXX Amy 


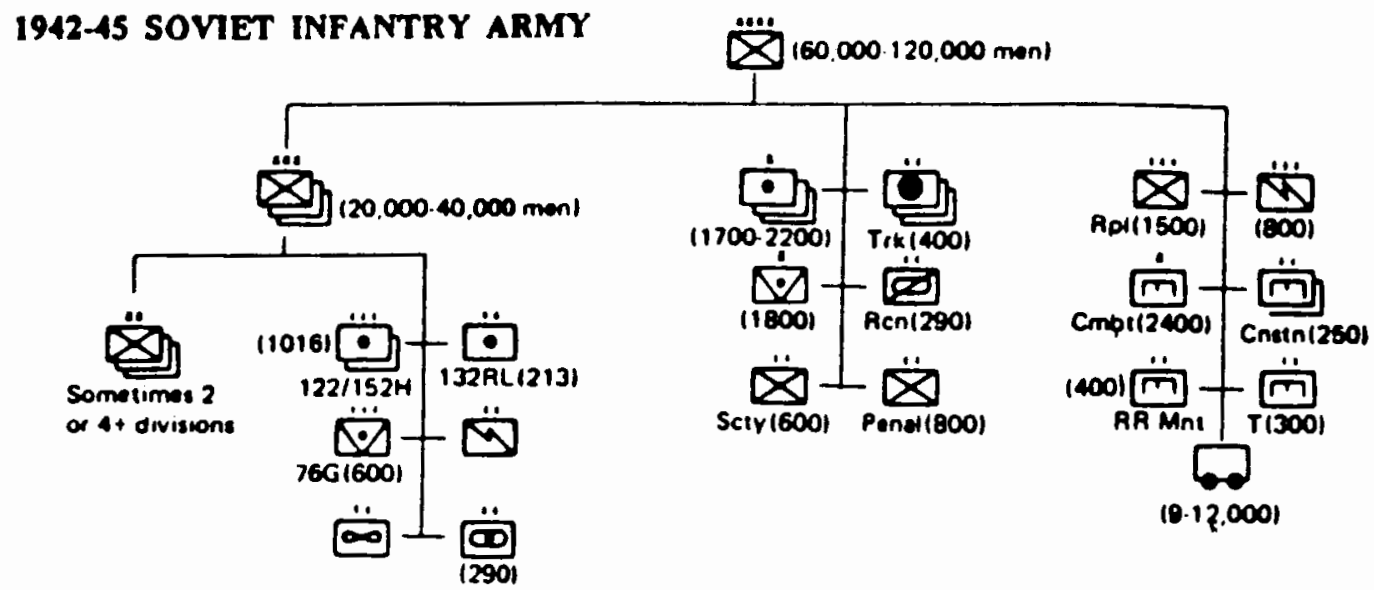

1942.45 SOVIET TANK ARMY

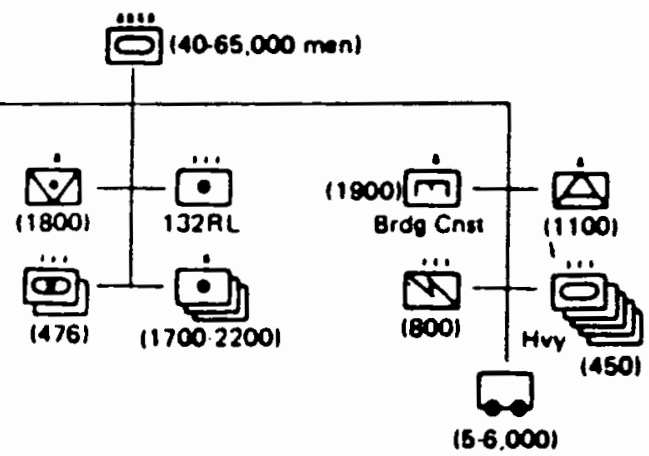


1942-45 SOVIET TANK CORPS
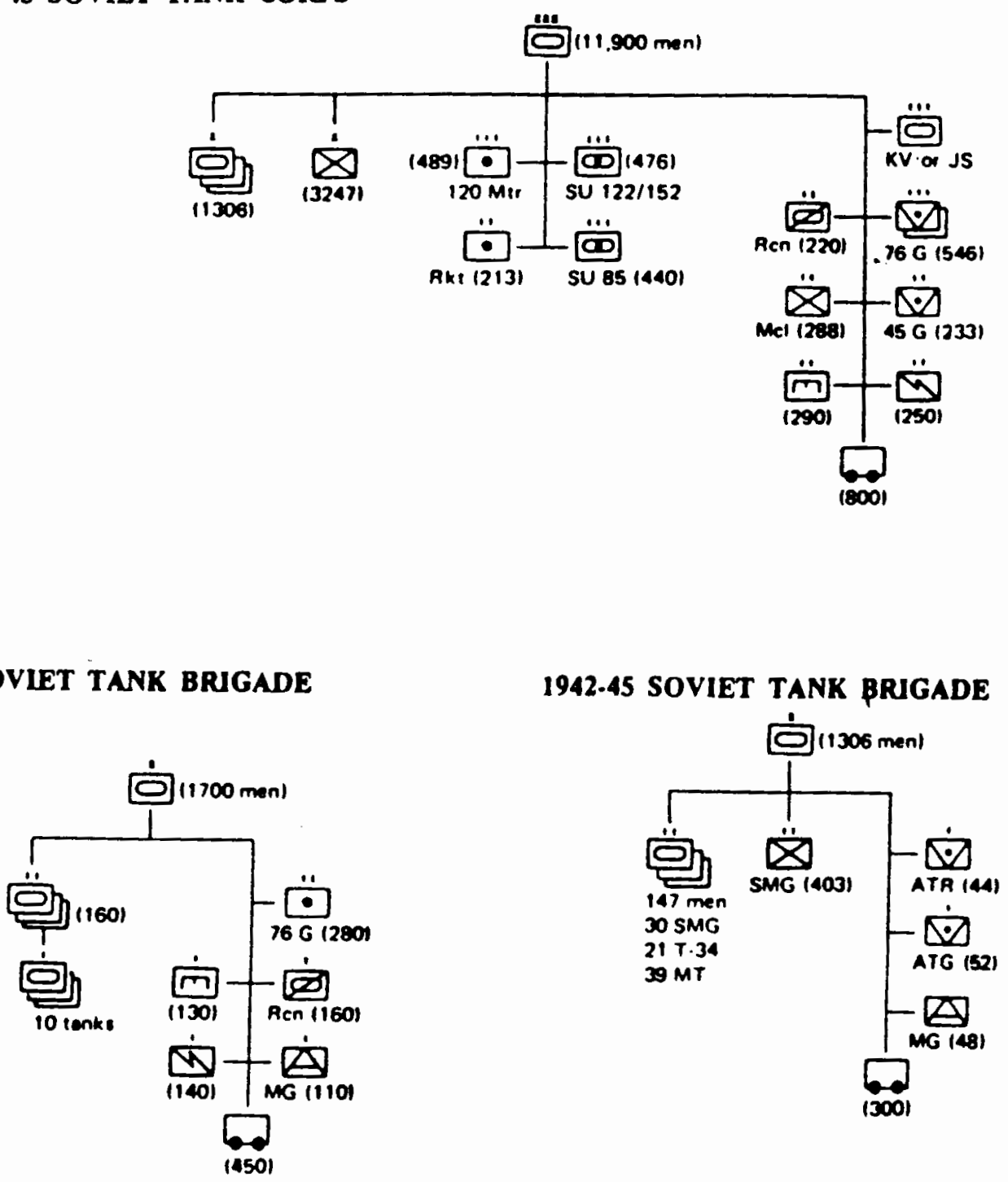
艾(17.400 men)

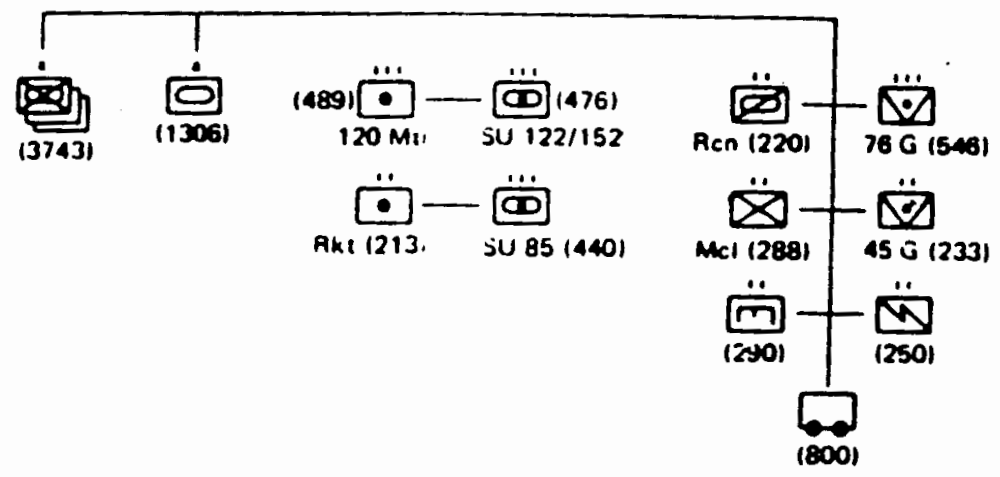

1942-45 SOVIET

MOTORIZED RIFLE BRIGADE

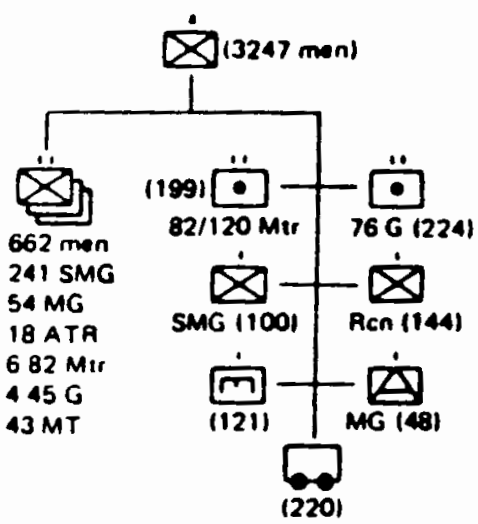

1942.45 SOVIET

MOTORIZED RIFLE BATTALION

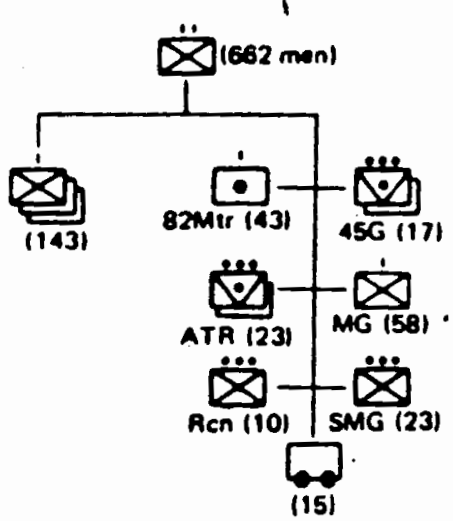


9/39 SOVIET RIFLE DIVISION

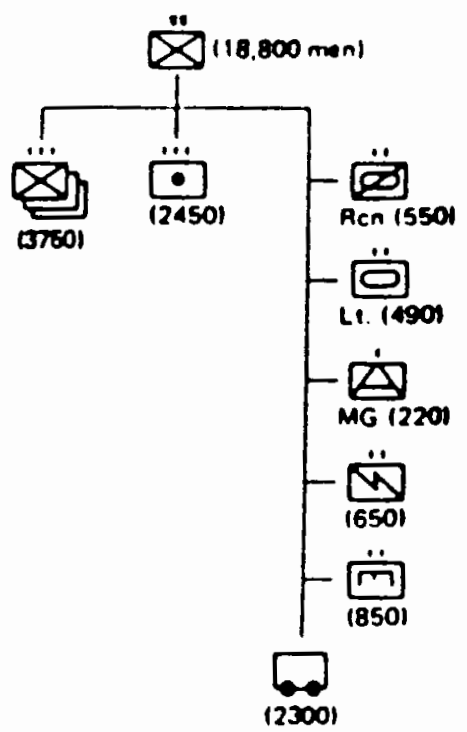

12/42 SOVIET RIFLE DIVISION

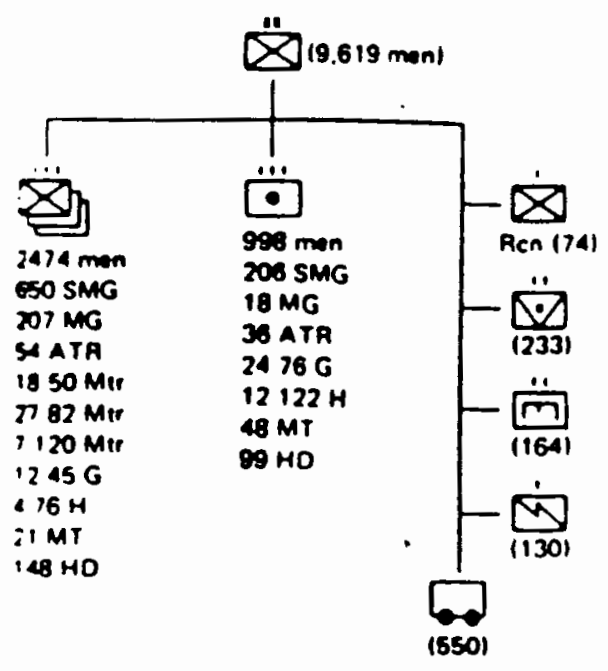

12/42 SOVIET RIFLE REGLMENT

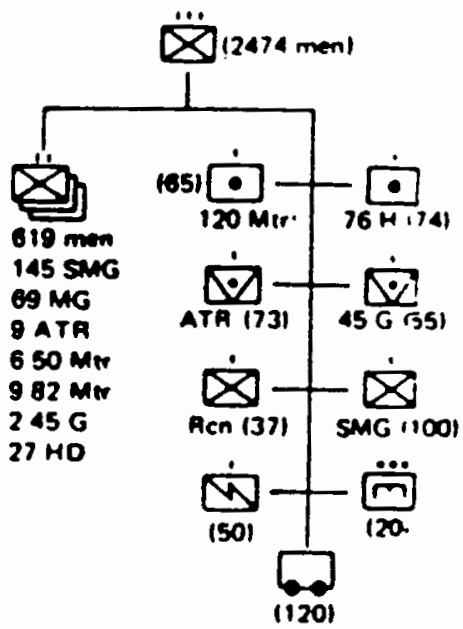


1942-45 SOVIET CAVALRY CORPS

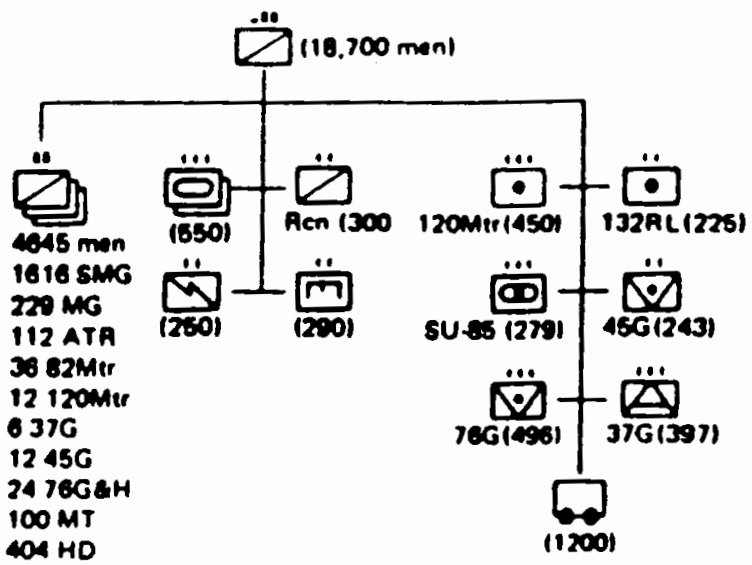

1942-45 SOVIET CAVALRY DTVISION

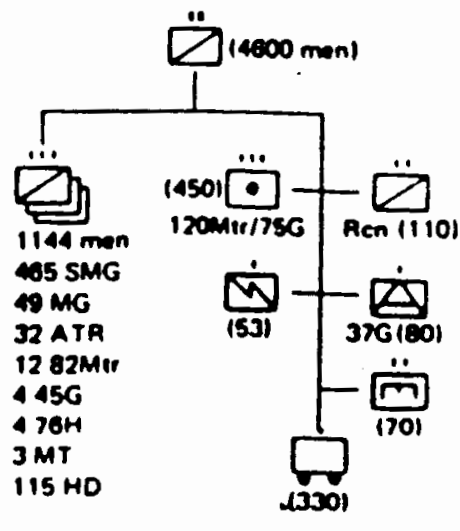

1942.45 SOVIET

RECONNAISSANCE BATTALION

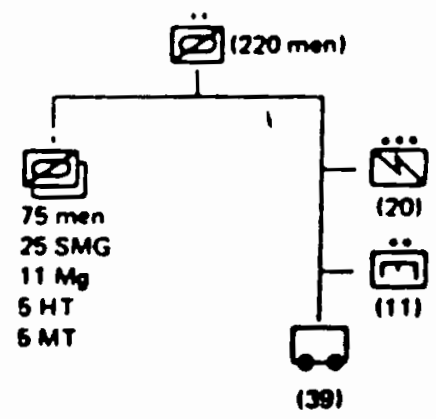

139
1942.45 SOVIET

MOTORCYCLE BATTALION

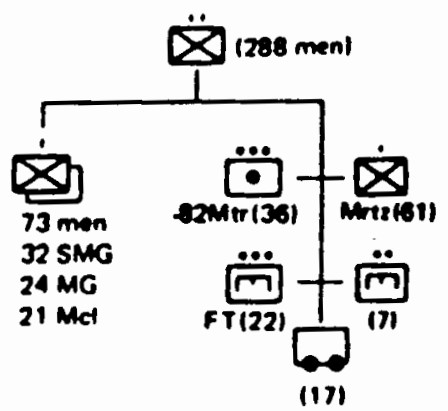


1942-45 SOVIET ARTILLERY DIVISION

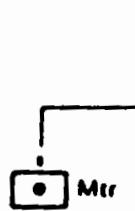

1705 man 135 SAMG

57 MG

10: ATR

108 120Mtr

$303 \mathrm{MT}$

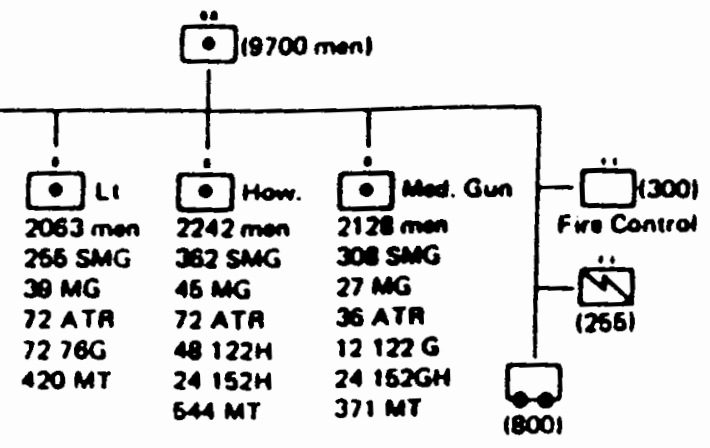

1942-45 SOVIET ROCKET

LAUNCHER (M-13) BRIGADE

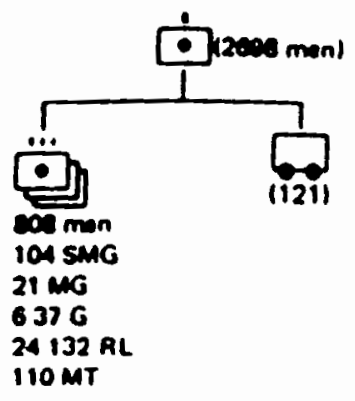

1942.45 SOVIET SELF.PROPELLED

ARTILERY REGIMENT

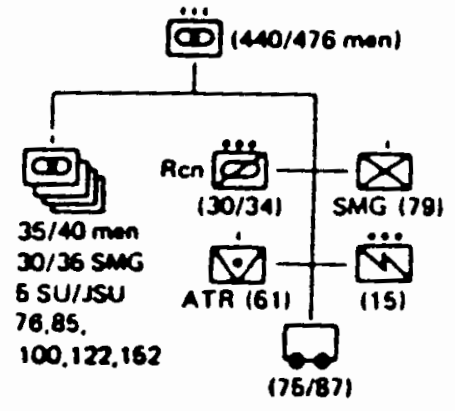


1942-45 SOVIET

ANTI.AIRCRAFT ARTULERY DIVSION

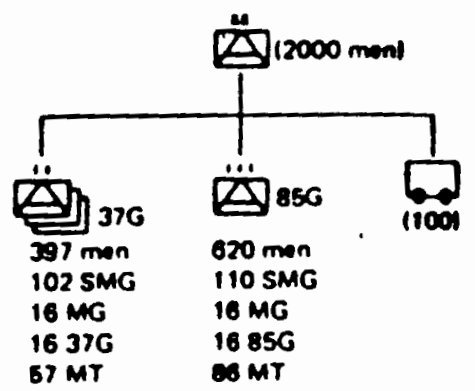

1942.45 SOVIET

MOTORIZED ANTI-TANK BRIGADE

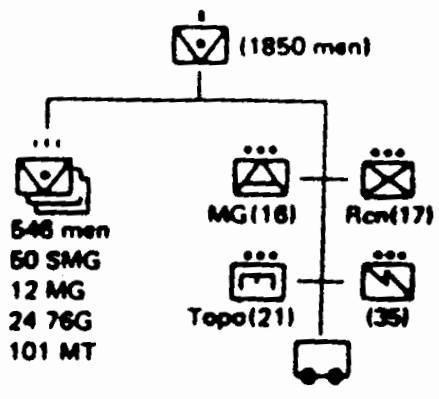

(123)
1942-45 SOVIET MOTORUZED

SUBMACHINEGUN BATTALION

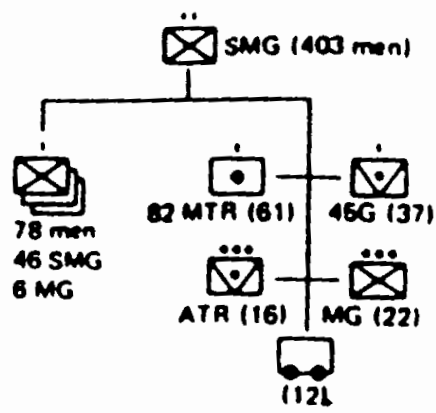

1942.45 SOVIET

MOTORIZED ANTI-TANK REGIMENT

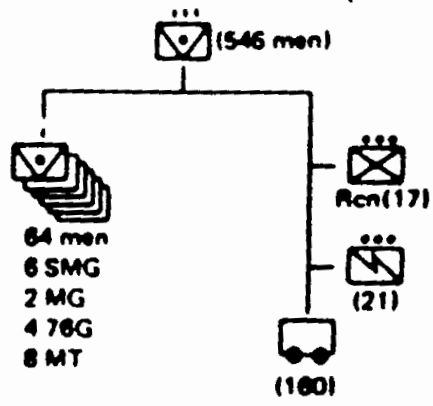


1941.45 SOVIET RIFLE BRIGADE

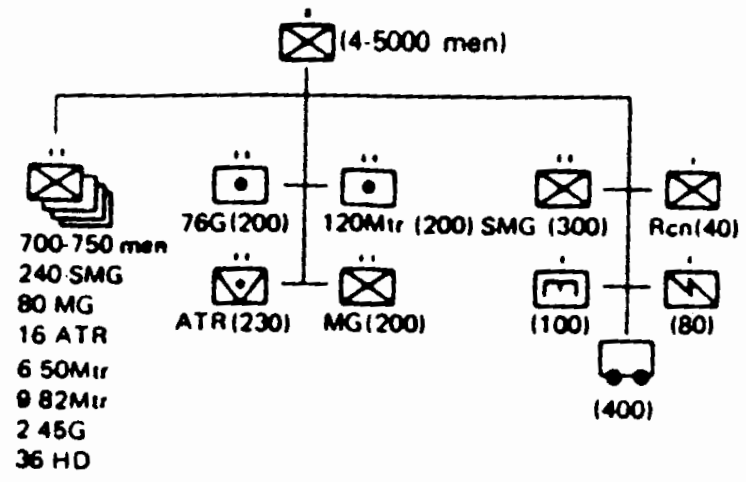

12/42 SOVIET GUARDS RIFLE REGMEENT

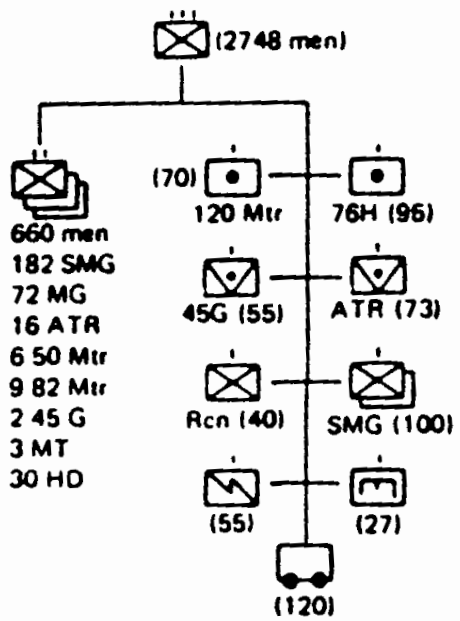




\section{2/42 SOVIET RIFLE BATTALION}
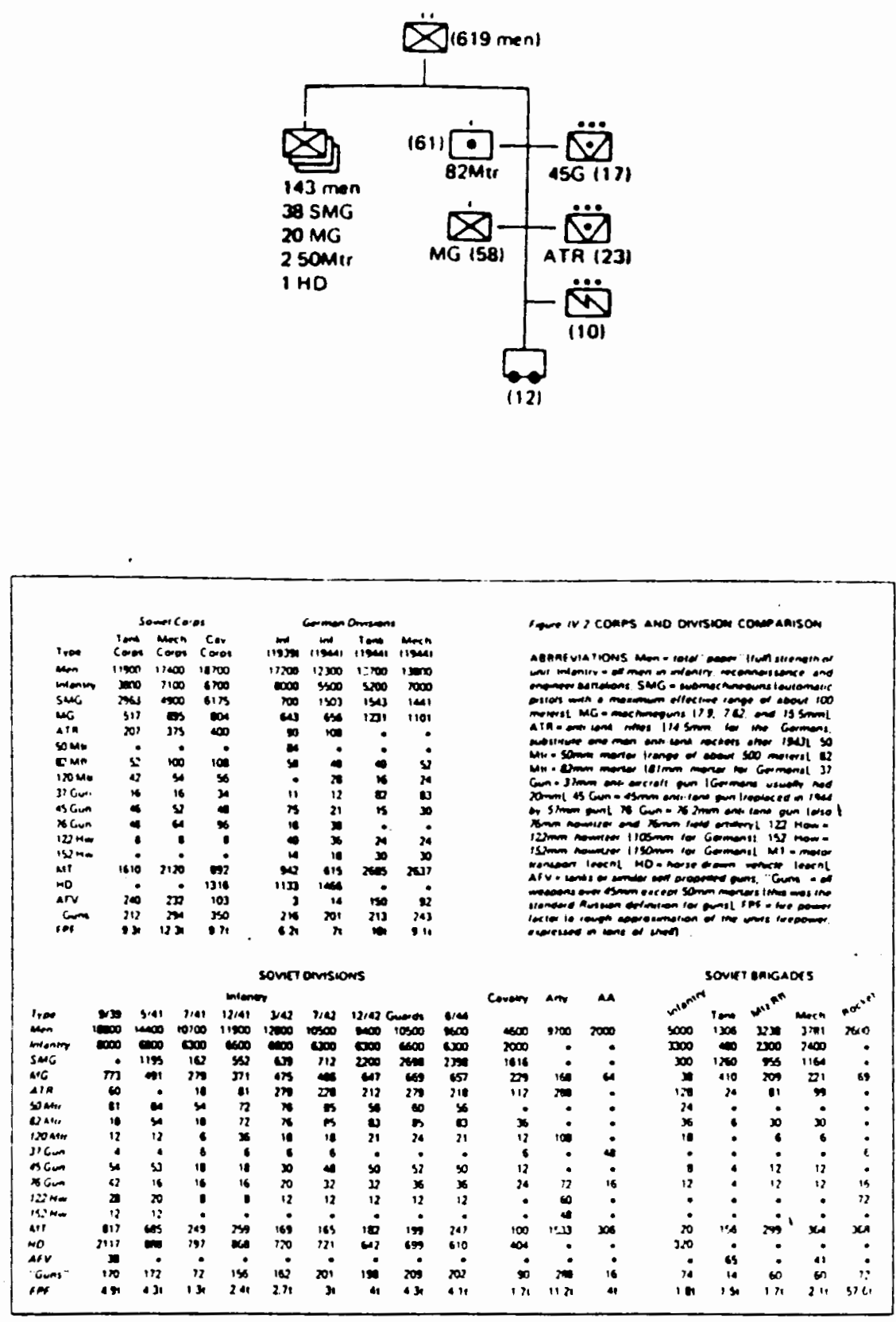
APPENDIX C

DOCUMENTS 
Oberkommando der Heeresgruppe Mitte H.Qu., den 11.3.1944 An Armeen, Befh.i.Weissruthenien

Fuehrer Order No. 11

(Commandants of Fortified Areas and Battle Commandants)

1. A distinction will be made between "Fortified Areas" [festen Plaetzen], each under a "Fortified Area Commandant", and "Local Strong-points"[Ortsstuetzpunkten], each under a "Battle Commandant".

The "Fortified Areas" will fulfil the function of fortresses in former historical times. They will ensure that the enemy does not occupy these areas of decisive operational importance. They will allow themselves to be surrounded, thereby holding down the largest possible number of enemy forces, and establishing conditions favorable for successful counterattacks.

"Local Strong-points" are strong-points deep in the battle area, which will be tenaciously defended in the event of enemy penetration. By being included in the main line of battle they will act as a reserve of defense and, should the enemy break through, as hinges and corner-stones for the front, forming positions from which counter-attacks can be launched.

2. Each "Fortified Area Commandant" should be a specially selected, hardened soldier, preferably of General's rank. He will be appointed by the Army Group concerned. Fortified Area Commandants will be personally responsible to the Commander-inChief of the Army Group.

Fortified Area Commandants will pledge their honor as soldiers to carry out their duties to the last.

Only the Commander-in-Chief of an Army Group in person may, with my approval, relieve the Fortified Area Commandant of his duties, and perhaps order the surrender of the fortified area.

Fortified Area Commandants are subordinate to the Commander of the Army Group, or Army, in whose sector the fortified area is situated. Further delegation of command to General Officers commanding formations will not take 
place.

Apart from the garrison and its security forces, all persons within a fortified area, or who have been collected there, are under the orders of the Commandant, irrespective of whether they are soldiers.or civilians, and without regard to their rank or appointment.

The Fortified Area Commandant has the military rights and disciplinary powers of a Commanding General. In the performance of his duties he will have at his disposal mobile courts martial and civilian courts.

The staff of Fortified Area Commandants will be appointed by the Army Group concerned. The Chiefs of Staff will be appointed by High Command of the Army, in accordance with suggestions made by the Army Group.

3. The garrison of a fortified area comprises:

the security garrison, and the general garrison.

The security garrison must be inside the fortified area at all times. Its strength will be laid down by Commander-in-chief Army Group, and will be determined by the size of the area and the tasks to be fulfilled (preparation and completion of defenses, holding the fortified area against raids or local attacks by the enemy).

The general garrison must be made available to the Commandant of the fortified area in sufficient time for the men to have taken up defensive positions and be installed when a fullscale enemy attack threatens. Its strength will be laid down by Commander-in-Chief Army Group, in accordance with the size of the fortified area and the task which is to be performed (total defense of the fortified area).

4. The "Battle Commandant" comes under the orders of the local forces commander. He will be appointed by him, will be subordinate to him, and will receive operation orders from him. His rank will depend upon the importance of the position in the battle area and the strength of the garrison. His duties call for specially energetic officers whose qualities have been proved in crisis. 
5. The strength of the garrisons of a "Local Strong-point" will be determined by the importance of the position and the forces available. It will receive its orders from authorities to which the Battle Commandant is subordinate.

6. The duties of "Fortified Area Commanders" and "Battle Commandants" as well as a list of fortified areas, and of reports on them submitted by Army Groups, are contained in the appendices.

7. All previous orders concerning Battle Commandants are hereby cancelled.

signed: ADOLF HITLER

Source: Adolf Hitler, Fuehrerbefehl Nr. 11, 8.3.44. NAMP T-311 Roll 228. 
Zustand der Divisionen der Heeresgruppe Südukraine stend rom 1301044

\section{Armeegruppe Dumitrescu}

\begin{tabular}{|c|c|c|c|c|c|}
\hline 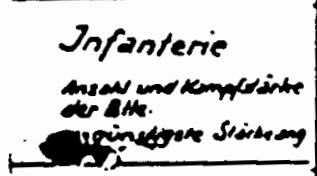 & 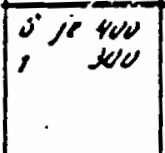 & 910200 & $7 j 300$ & 6 je 300 & $\therefore j 300$ \\
\hline unterstert & & & & & \\
\hline \multicolumn{6}{|l|}{ odgastier } \\
\hline 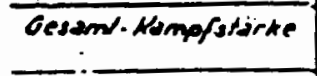 & $\begin{array}{r}2700 \\
126001 \\
\end{array}$ & $\begin{array}{l}3800 \\
138001\end{array}$ & $\begin{array}{l}2100 \\
190001\end{array}$ & $\begin{array}{l}2200 \\
124001\end{array}$ & 1220001 \\
\hline$F E B$ & $4001400)$ & $\dot{-}$ & $400(400)$ & $200(200)$ & 40014001 \\
\hline Aioniene & 30011001 & $400(400)$ & 50013001 & $300(300)$ & $2001200)$ \\
\hline$H A L \mathrm{~km}$ & $23 \quad(23)$ & $26(25)$ & $14(14)$ & $14(14)$ & $18(1.7)$ \\
\hline Mampekm & $! \prime(n)$ & $740^{\circ}$ (152) & $150(135)$ & $157(1+1)$ & 12218291 \\
\hline Adillerix & $\begin{array}{l}\text { solersoles) } \\
\text { 6s. (6s.) }\end{array}$ & 406 l. 140 led & $\begin{array}{l}34 \text { le }(34 / e) \\
4 \text { s. (4.s) }\end{array}$ & 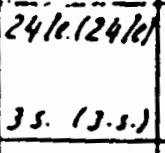 & $\begin{array}{l}25 \text { (el25ie) } \\
2 \text { s. (2.ses }\end{array}$ \\
\hline Ask & 21/s. (3/s.) & 155.1155 .1 & 20.2 .1125$. & ros. (10.5) & ris.riss. \\
\hline \begin{tabular}{cc} 
& $v$ \\
Ponzer & $v$ \\
$a$ & $v$ \\
\hdashline
\end{tabular} & & & & & \\
\hline \multicolumn{6}{|l|}{ Sturingesctúne } \\
\hline Govider compinithtrit & $\begin{array}{r}\operatorname{mox} 10 \% \\
60.100 \% \\
\end{array}$ & $\begin{array}{l}\text { mor. } 75 \% \\
6000.100 \% \\
\end{array}$ & $\begin{array}{l}\operatorname{mot} 35 \% \\
\text { oxys } 100 x \\
\end{array}$ & $\begin{array}{l}\operatorname{mot} 10 \% \\
6 \times 0 \\
0 \times 00 \%\end{array}$ & 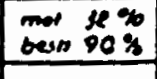 \\
\hline Hampfivert & Ul & IV & III & 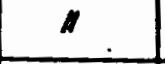 & 1 \\
\hline
\end{tabular}


Zustand der Divisionen der Heeresgruppe Südukraine Srand ram: 13 8 1044

\section{Armeegruppe Dumitrescu}

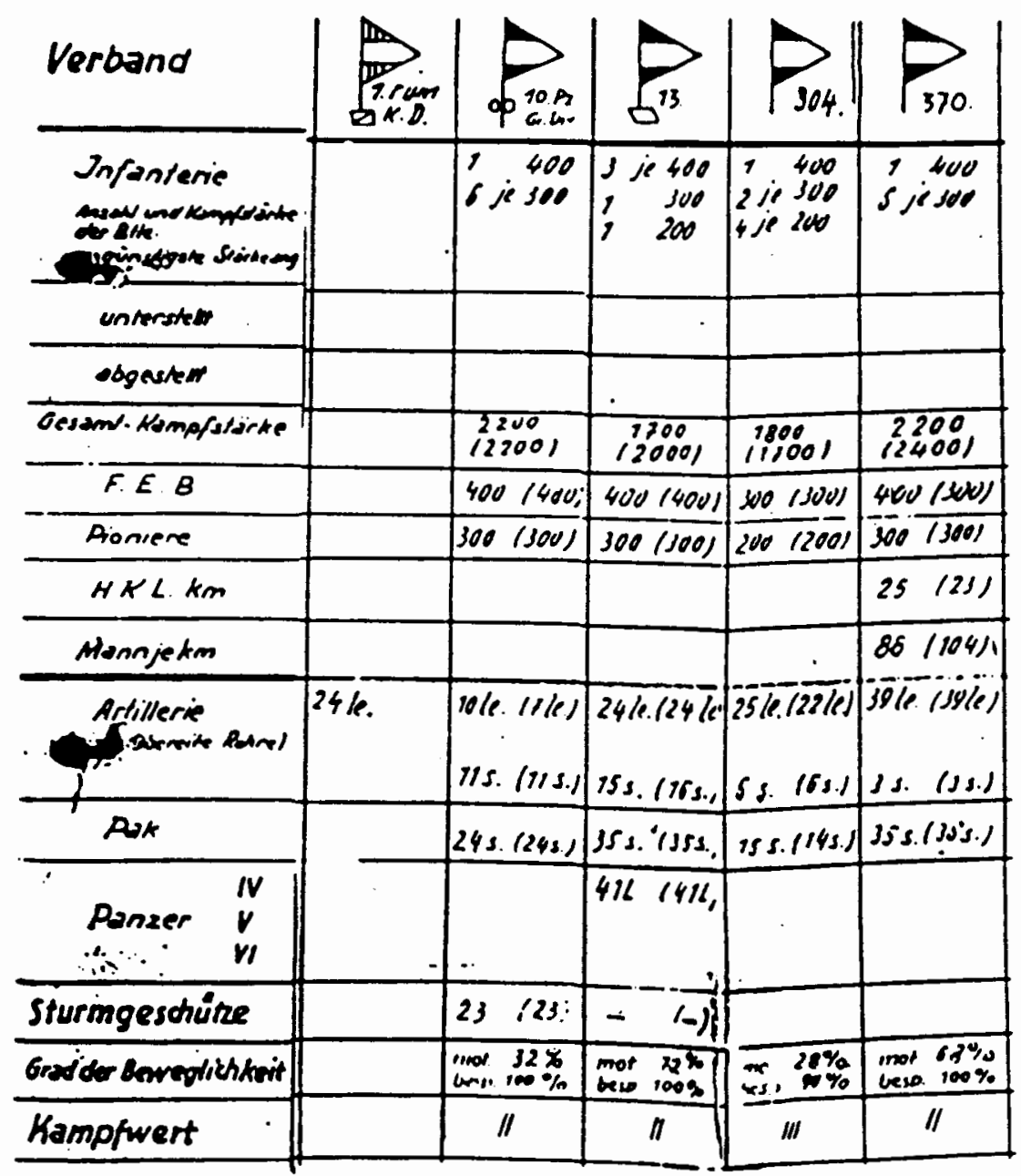


Zustand der Divisionen der Heeresgruppe Süduknaine Sreand nom: 13 o rot4

\section{Armeegruppe Dumitrescu}

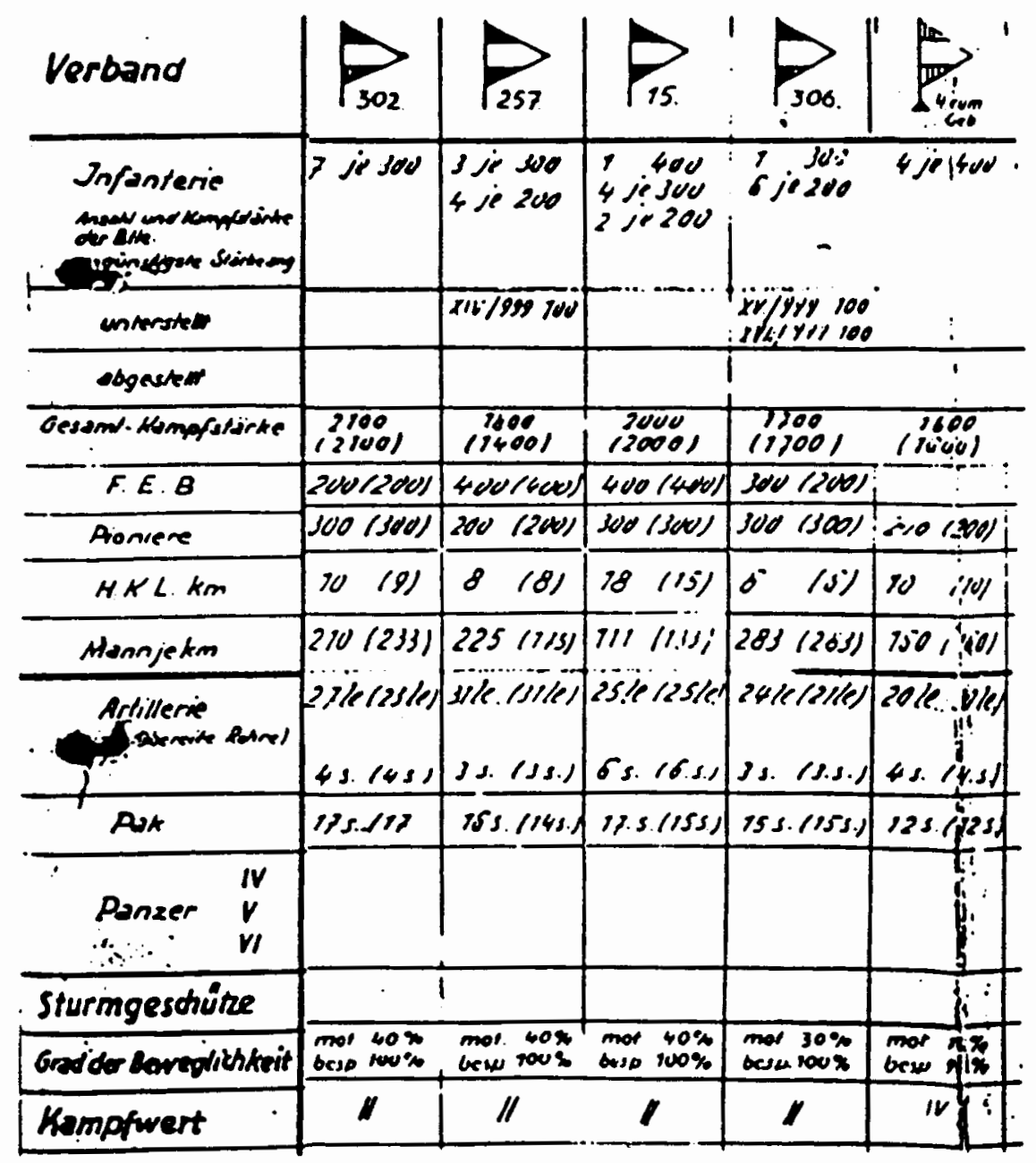


Zustand der Divisionen der Heeresgruppe Südukraine stand ram: 19 o so64

\section{Armeegruppe Dumitrescu}

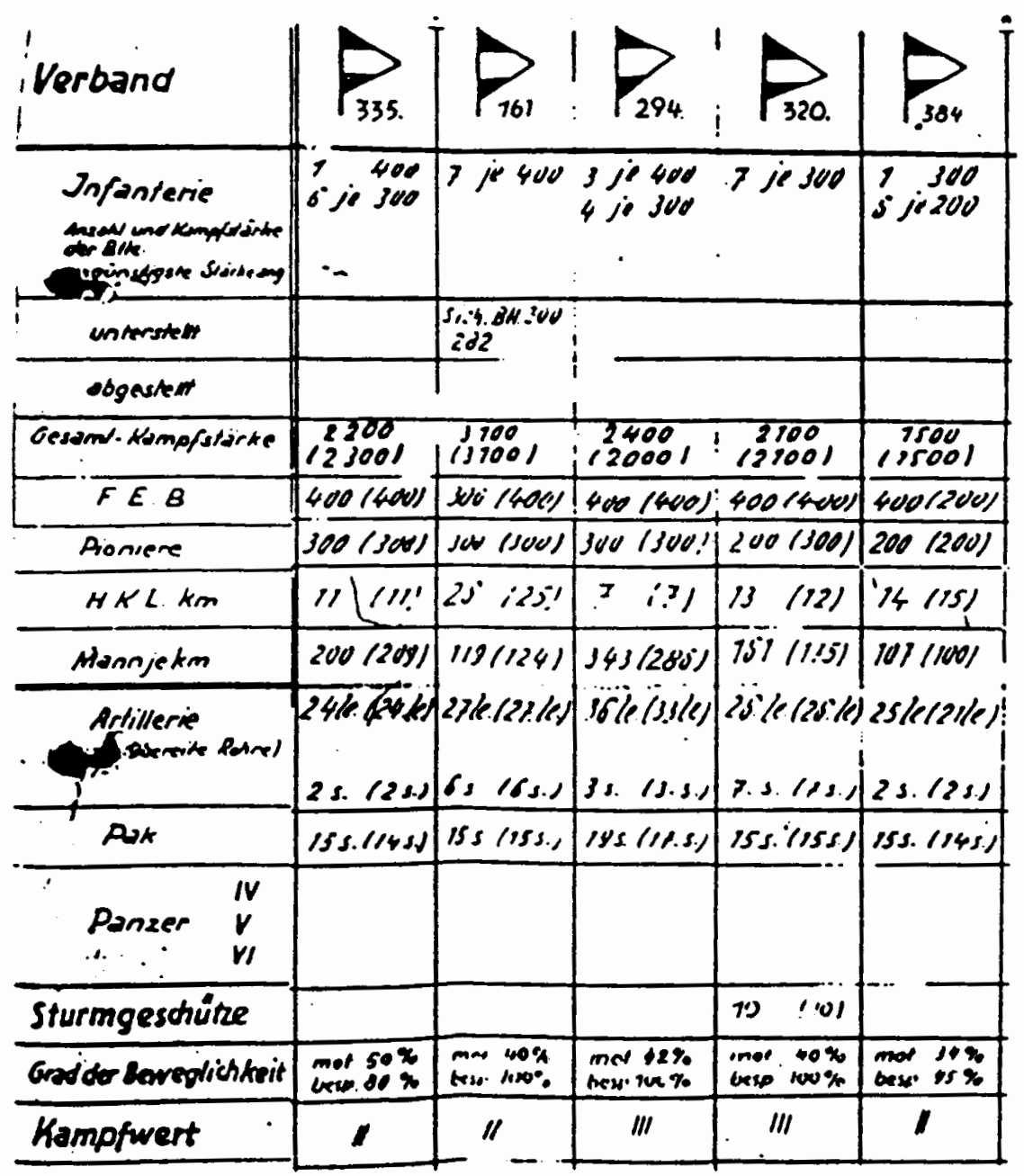


Zustand der Divisionen der Heeresgruppe Süduhraine siand rom: 13 g polt

Armeegruppe Dumitrescu

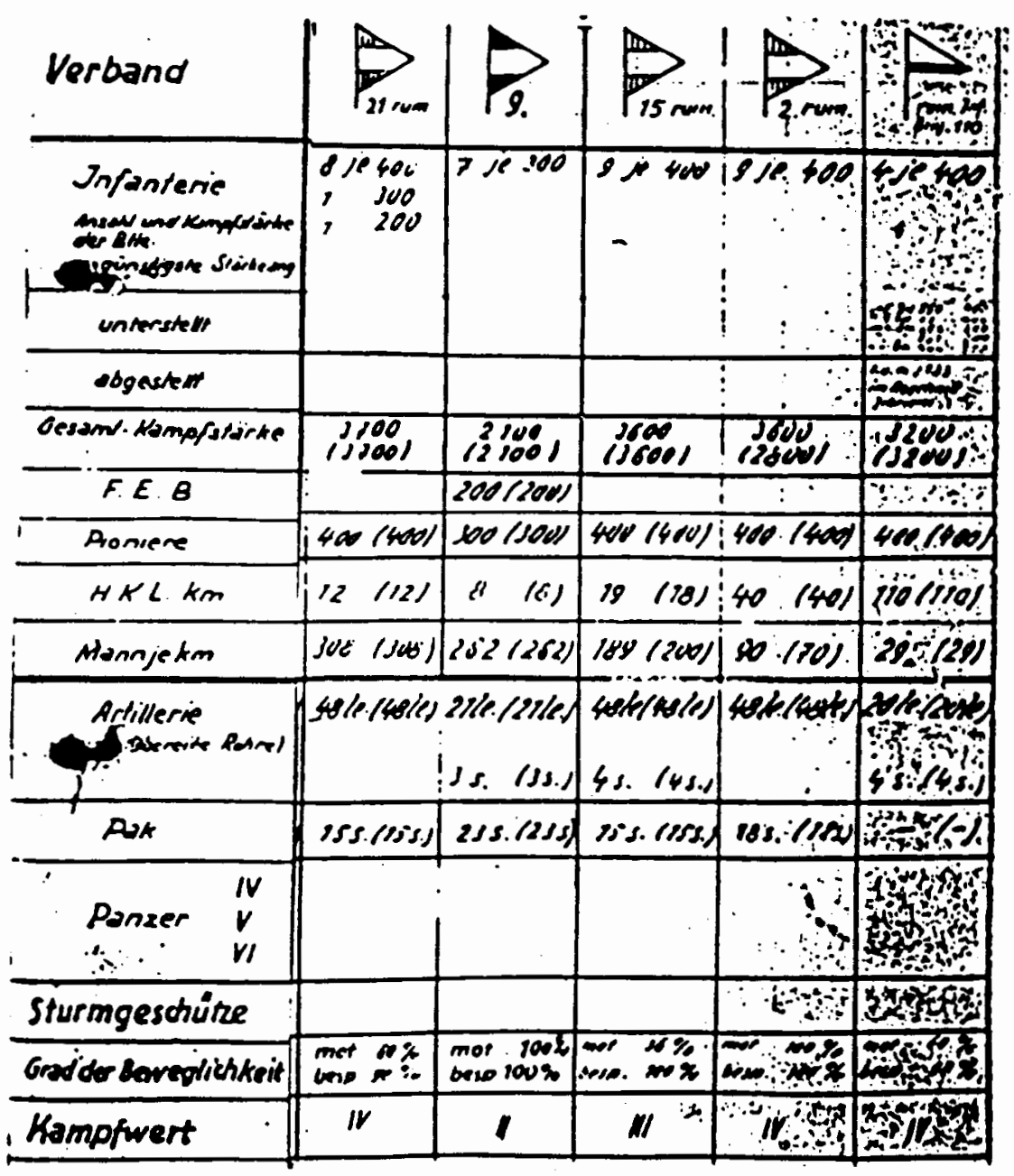


Zustand der Divisionen der Heeresgruppe Südukraine siond rom: 13 \& 1064

Rrmeegruppe Wöhler

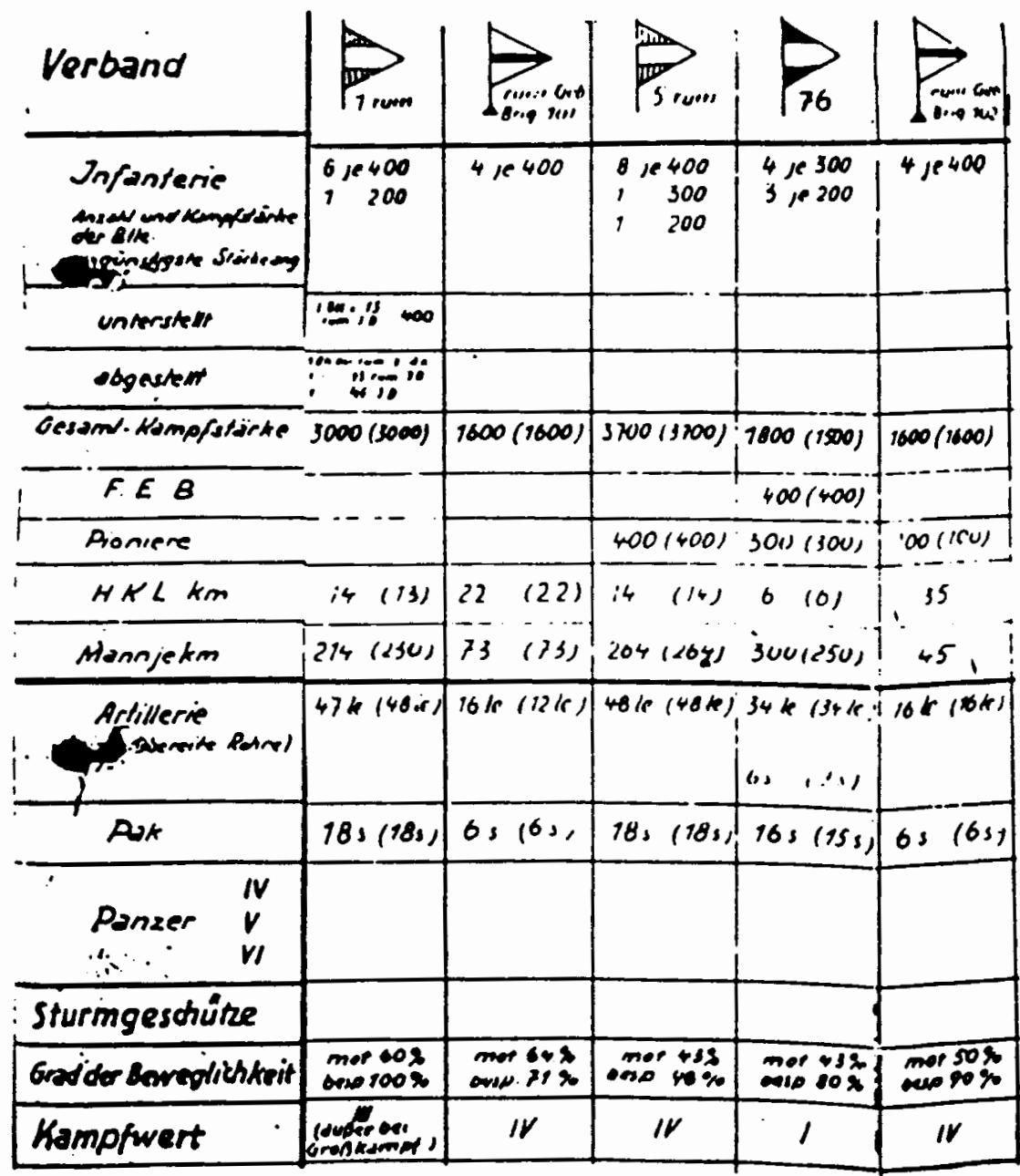


Zustand der Divisionen der Heeresgruppe Südukraine Seend rom: 19 $\theta$ ro4 4

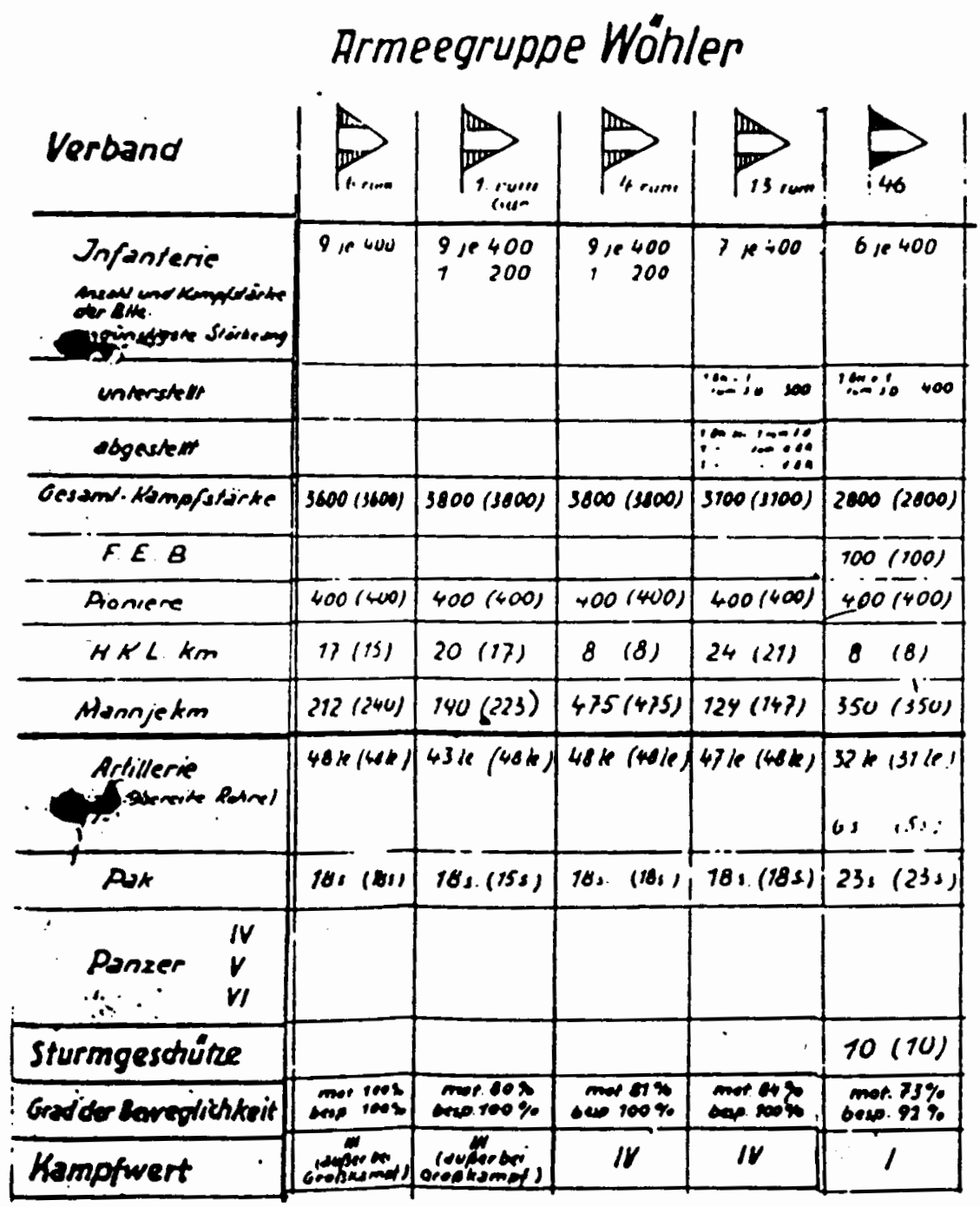


Zustand der Divisionen der Heeresgruppe Südukraine srend rom. 138 gos 4

Armeegruppe Wöhler

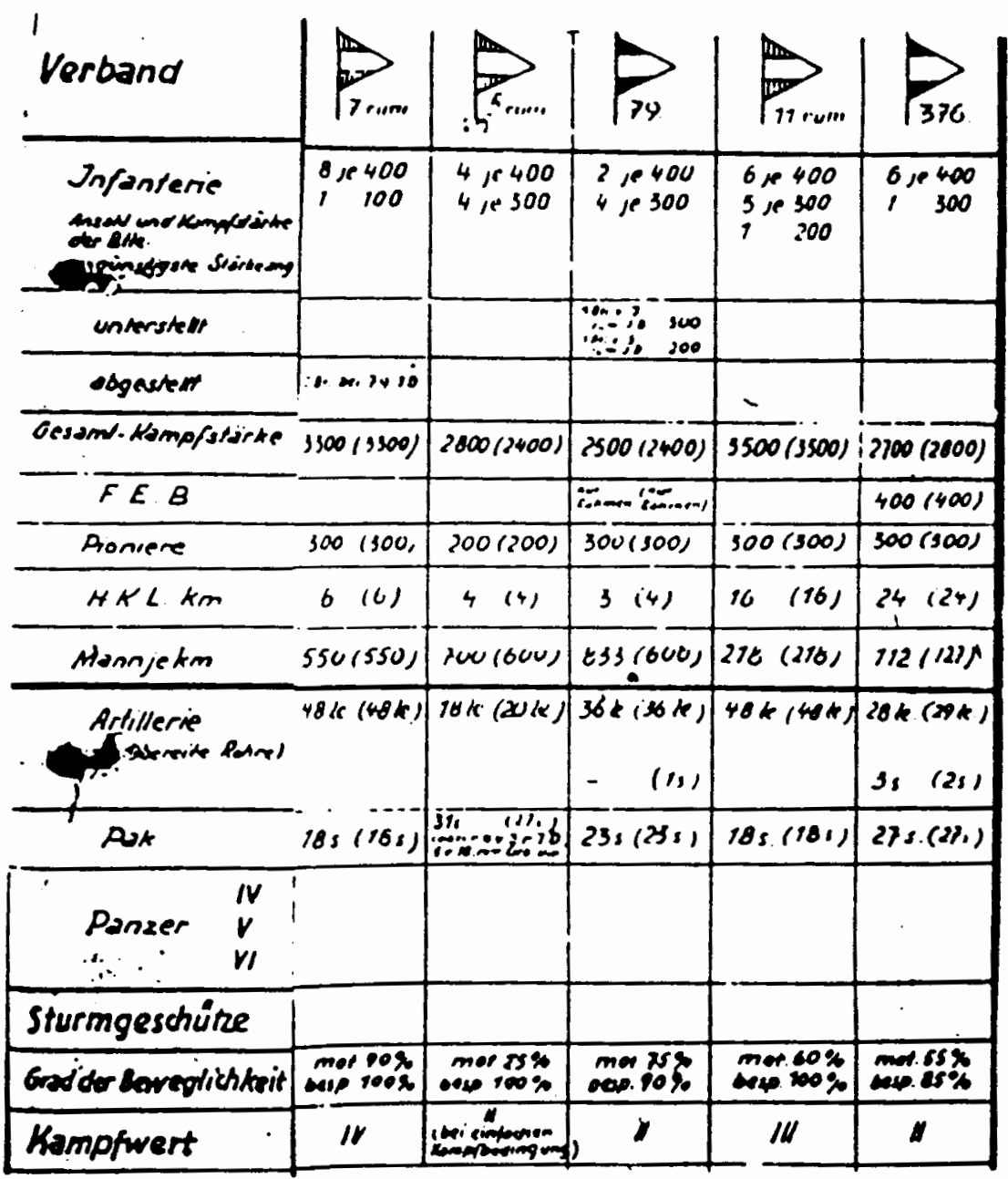


Zustand der Divisionen der Heeresgruppe Südukraine siand rom. $19 \theta 1946$

\section{Armeegruppe Wöhler}

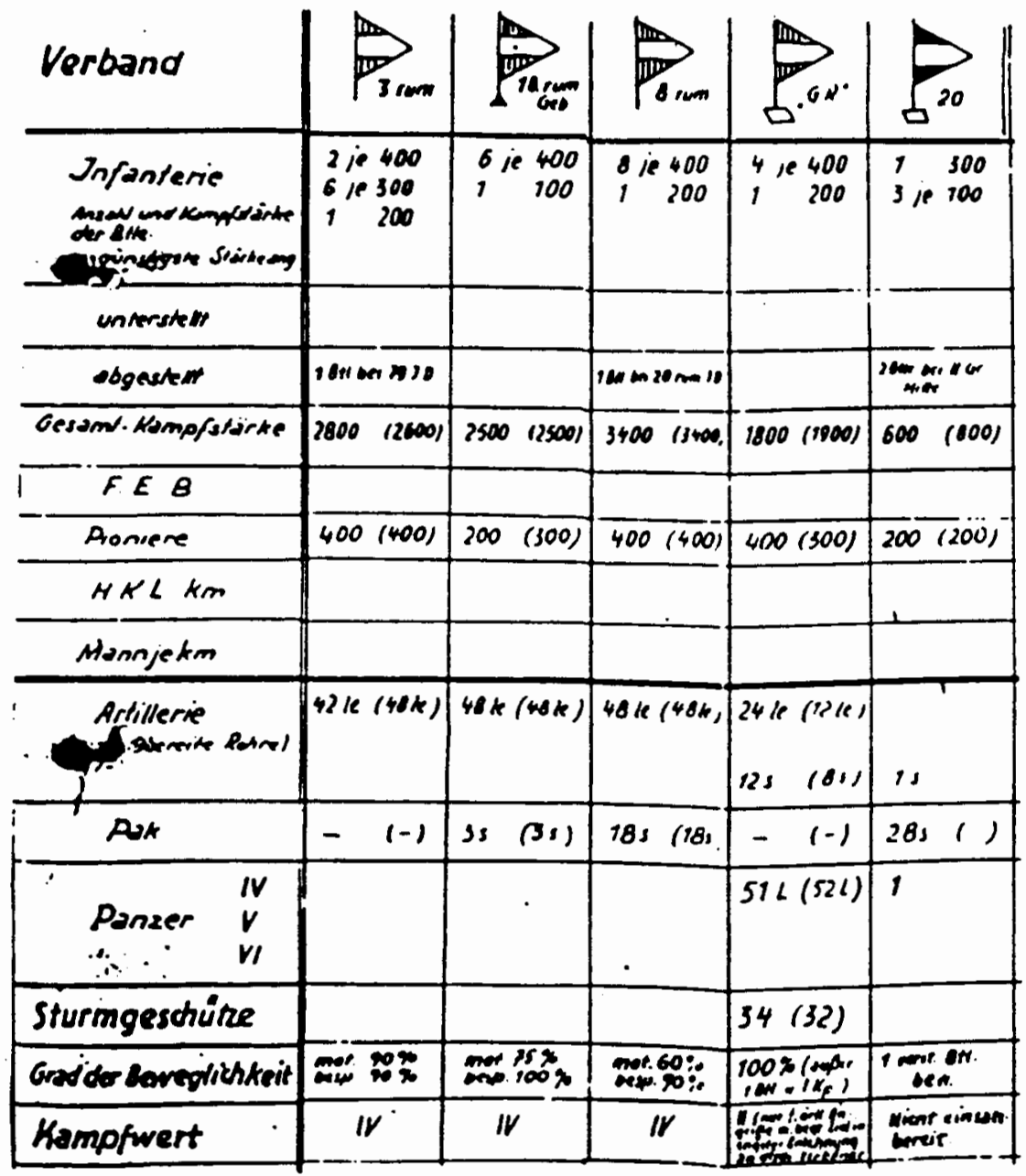


Zustand der Divisionen der Heeresgruppe Südukraine Srend ram. 98 yot4

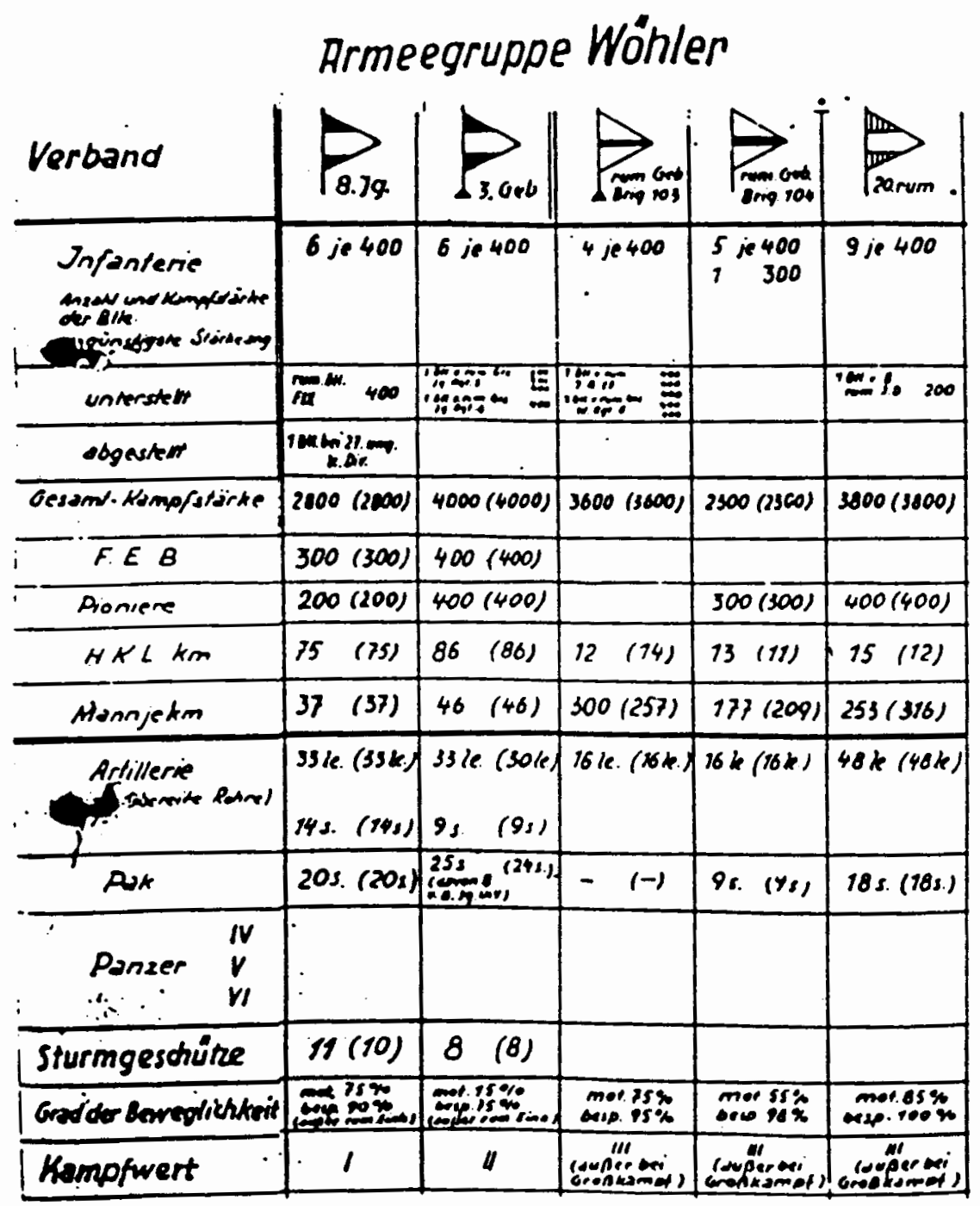

